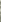

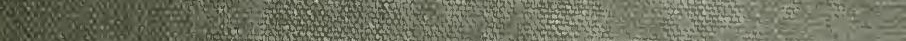

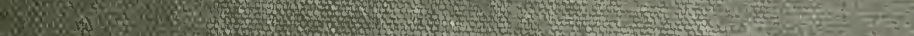

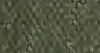

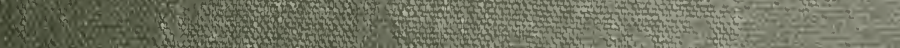

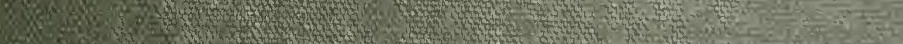

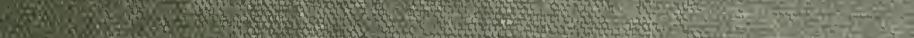
Q

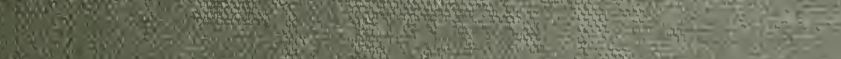

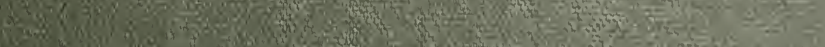

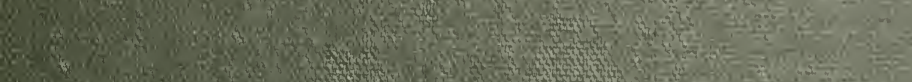

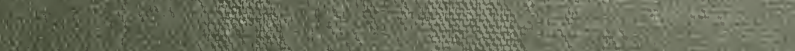

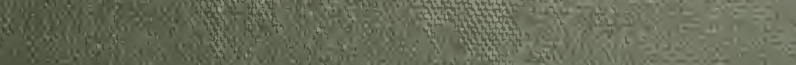
Q. Mrip of a

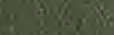

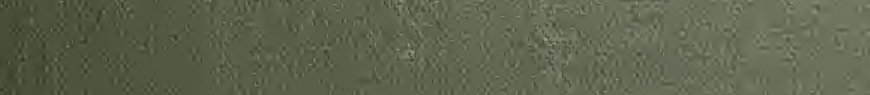

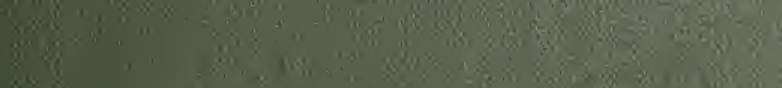

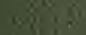
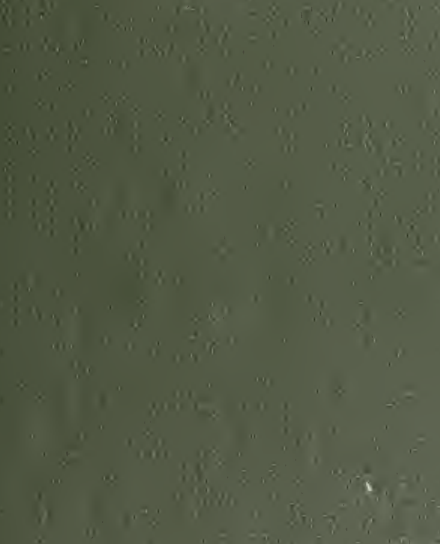

$1 \mathrm{~W}$

\title{
Q3
}

$\therefore$

:-

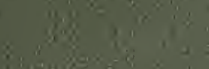

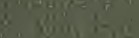

Q

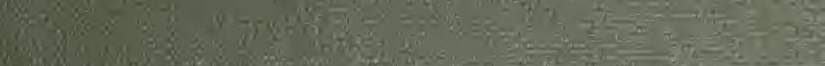

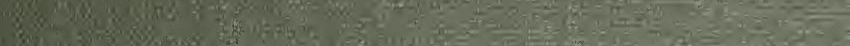

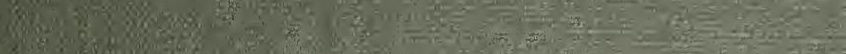
3.

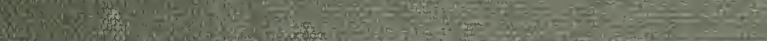

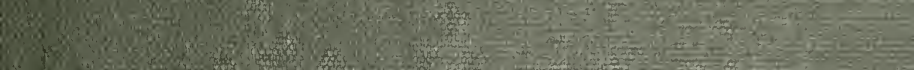










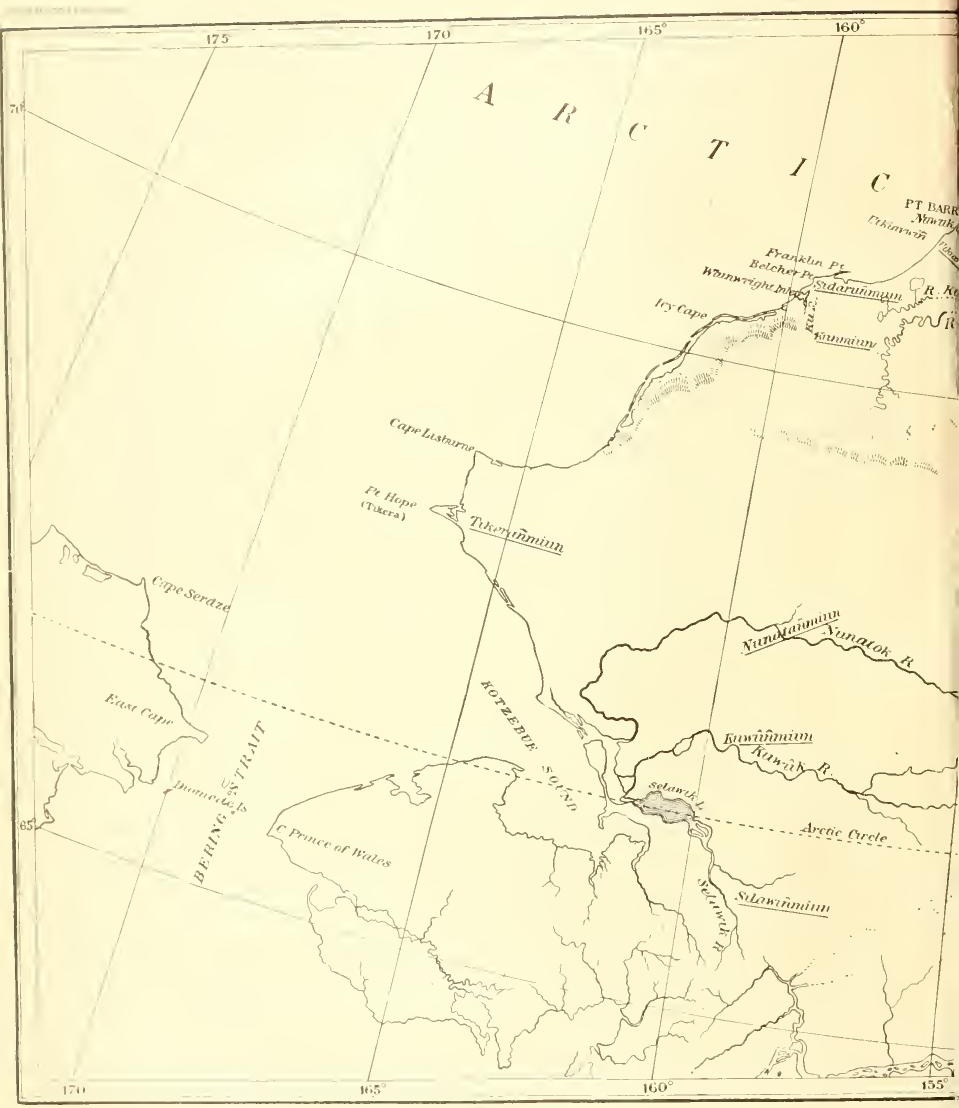





\section{ETHNOLOGICAL RESLTTS}

(1) $\mathrm{THF}$

\section{POINT' BARROII EXI'EDITION.}

BY

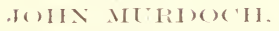

Vaturalist and obserrer. Intermational Polar Fispedition to

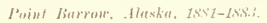





\section{CONTENTS.}

Introduction

List of works eonsulterl.

situation and surronudmes.

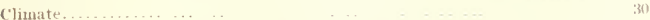

People.......................

Physical characteristies. ... .....

Pithologr ............. $3: 4$

Psychisal characteristics. .... (1)

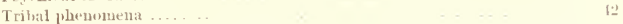

focial surroumblings. ....... . . . . . .

Contact with nuejvilized people'.

(1) ther Eskimo ............ 1:

ludians

Contact with eivilizent people...

Natural resnures. ................. . . . .

Animats ..........................

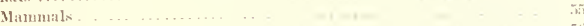

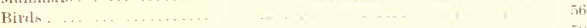

Fishes

Instrets and ot her invertebrates......

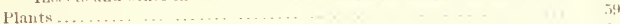

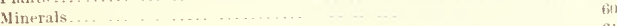

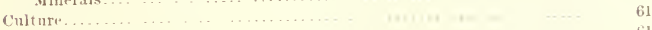

Yeaus of subsistence................. til

Food .

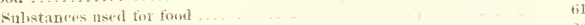

Metins of prejatring foot. ........

Time and trequeney of eating . -

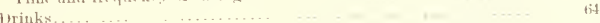

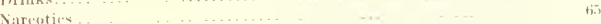

Hahitations........................

The winter louse -........ - .....

Arraugement in villages. ... ....

Snow honkex $\quad \times 1$

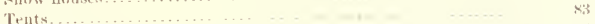

Houscholil ntemsils.................... ...

for holding aml carryiug tood, water, etc ....

Canteens.......................

Willets, pte

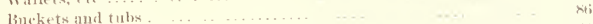

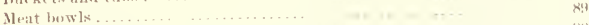

For prepitring fond ......................

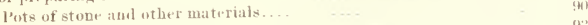

Bone erushe1s..................

For kerring and eating food .........

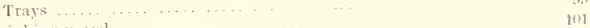

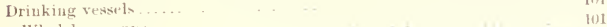

Whalebone cups .. 
[1]

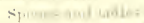

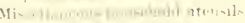

1 lothising

II:11, mit

Sish +e:-11, so

11. wi phothes

$13+. .6=$

11. 11 h.

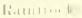

Armilinthese

M111,11

(ilies:

berp and towt , lathon:

lirewe hew

1:a11taluem

Stowholues

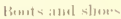

Part-ut dres

Iiviti

Ornament

Peтsonal :ulormutut

Skin (1) namentatim

Tattoutug

Painting ..........

10.1

1(n)

110

112

113

121

122

1,3

123

124

125

125

126

129

129

135

135

$13 x$

$13 x$

138

Heas ornaments ...

Jlethenl of wearing the latis

lik

140

He:al hands

Ear rings .........

Lizlorets

Neck ornimustuts.

Oruaments of the liublo

brimen-lett:

Fingere ringe

Miscellatmenus ornituents Beads

Toilet artivies...

Implements of gremeral nse, teto

Touls.

Knives. ... ........

Atizes. . . . .....

(hisels .....................

Whatelone shaves......

S:I

1rills and horers

II:munuers

Files

Whetstames

Timol buxes and bagk ....

Wripous

Firwtirme

Whatum gums . . . . . . . .

Beow- 
C'ulture- I methened

Betir irtoiye-

Bow tased ant yoser -

Brituers.

Birel darts

Si:al dirt

11:arjwon-

Thrustiug we whese-

Harpouni

Lanwe's

Throwing weilpure

Flipper tougles....

H:rpenu boxes....

Nets ...........

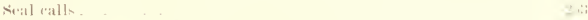

Sist rattlen. .... . .

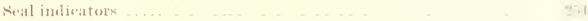

Sualiug -tools. ... $=$.

Sietil drilgs ..............

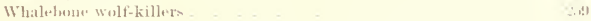

Traps ............ . .

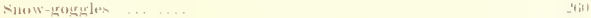

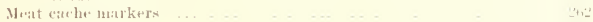

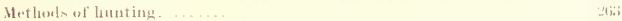

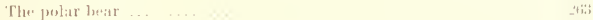

The woll ........... _...

Tlu fox ....... ....... 2il

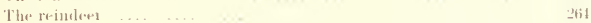

The seal ... .... .......

The watrus (........

Tha whitle . . . . .

Fowl ... . . . The

Implements for tishing. ......... $27 \times$

Howks and lines. .... -Ts

Nets ... ........ ...

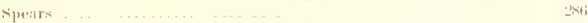

Flint workin.

Fire makiug ... .... ............

Dills

Flut aud sterl ....

Kimllingx ..... _........

Buw atul arrow making... _.......

The matrline spiki.

The twistorx

The featlee sutter

skin workin! .... . . . .

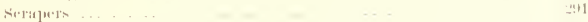

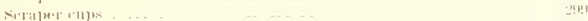

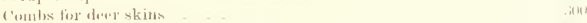

y:aunfieture of lines of thoms

Builders tools. ..............

For "xatrating _.........

Tools for suow and ice working

sute kutes 
['ulture. ('omtiname

snow -ivereits

le, pintis

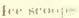

fmplement - for promring and preparing food.

30

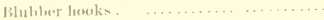

Fisli oritur

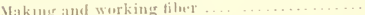

Twistiug and bratuling ...................... .

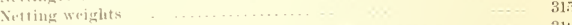

Wi:11 H114. 311

Mans of locomotion and transportation..... . . . .

Traveling by water.

Kaiaks and patdles

linialix and fittinger

Traveling on foot

snowslises...

statt.

Lind conseyanes

Slediges.

bours and Larness

Huntime sioves.

Games ind pastimes.

(itmblingr.

Fintivals.

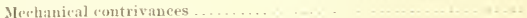

Duseription of fistivals

Toys and sunts fir ehililren and others.

Playthings

1) lells.

Juvenile implements

Gaunes and sports

Mnsis

Musionl instrmuents.

('haracter and frespency of mnsie

Art ...........

Domestir lite

Narriagu

stanling and troatment of women.

('hildren .... ........

Riglits and wromers.

Social life and customs.

P'ersomal hal hits and rleanliness.

Silutiation

Healing ...

('ustoms conceruing the dead.....

Mlistentions

Mannel of disposing of the dead.

(ioverument

In the fimily

In the village.

latligrom

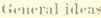

Amulvets 


\section{ILIU:TR.IIIONS}

PL. 1. Map of Nortliwestern Alaskia.

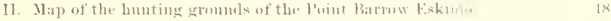

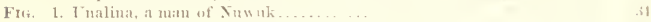

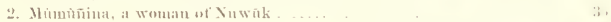

3. Ahalyiana, a youth ot' l'tkiavmin̂.....

4. Pukat, a young man of l'tkiavwiñ

5. Wom:ul stret. hing skim-...........

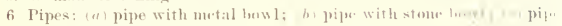
witl bowl of antler or ivery.

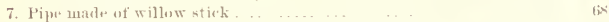

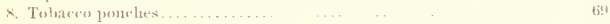

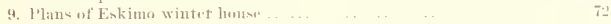

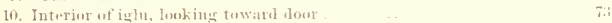

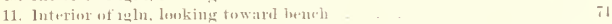

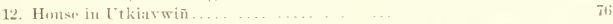

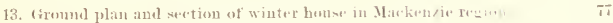

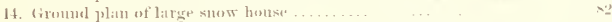

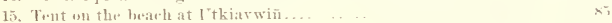

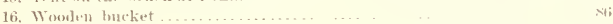

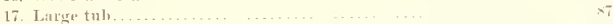

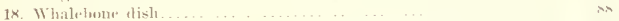

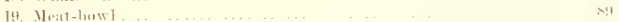

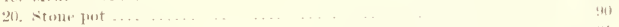

21. Sutall stome jut . . .

2.2. Fraguetits of pottiry.... .... ...

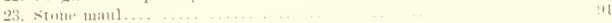

24. Stome maul ..... ... ... . ... ...

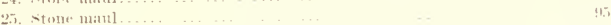

2ti. Stout 10anl t...

-27. Stmu manl

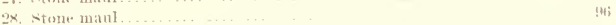

29. Bone matu] ..... ...

30. Bon+ manl ... ...............

31. Bund manl .............. Is

3.. lione minl ....... is

33. Mr:at-1]ish .... [997

34. ()bloner muat-dish. [net

35. () blomer meat-1lish, very old

36. Fish dish ............. 1611

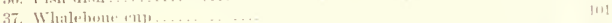

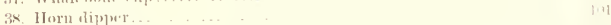

39. Horn dipper....... . . . . 1 H2

40. Dipler of fossil ixory .... - 10. 


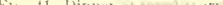

1113

4:- Wosha

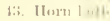

1.f. 13an- 1 ind

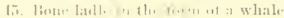

4ti. Houtu Iikl|,

47. Stome hanse-1.tus

tr. Samistone- lamin

(4). Traveling lamp'

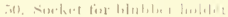

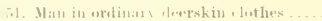

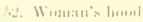

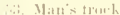

if Patterm of it.mi-deretsin frock

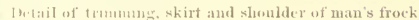

104

104

104

105

105

106

107

Iox

$10 \mathrm{~s}$

110

111

113

113

sti. M:m warme plam, havy frock . . . . . . . . . . . . .

114

57. M:m's frock of monntain sherpskin, front and back

ax. Mn's frow of ermine skins ..................

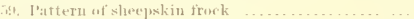

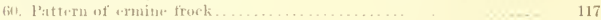

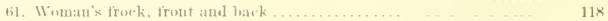

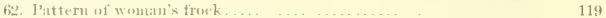

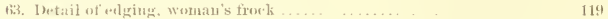

tit. Hetails of trimming, woman's frock. . ............

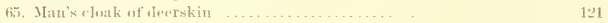

66. Patteru of matu's rleak .................. 121

67. Dererskin mittens ..................... 123

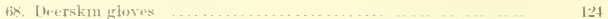

69. Mon's hreeches of derskin ............ ... 125

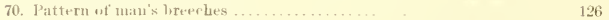

71. Trimming of man's hre thes. ............... 126

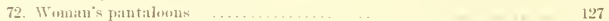

73. Patterus of womath's pantaloons ... ....... . . .

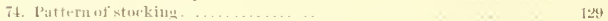

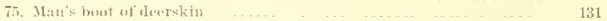

76, Pattern of deerskin lumt ..... .......... . 131

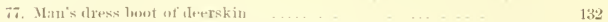

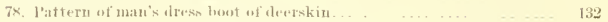

79. Nan's dress bout of skin of momutain sheep . .... 133

xo. Pair of man's alress loosts of der.rskin ........... 134

$x t$. Womats's watriprout stalskin boot..............

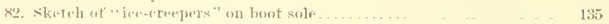

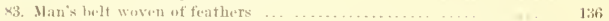

4. Diagram sluwing method of fastaning the ends of feathers in belt . 137

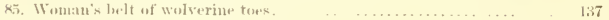

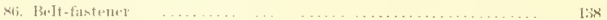

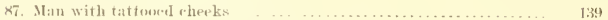

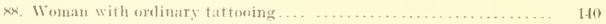

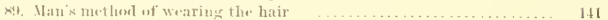

(k). Earriugs. . . . . . . . . . . . . . . . . . . . . . . . . . 143

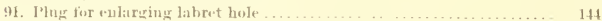

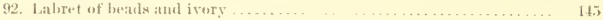

93. Blue and white labret from Andersou River. . . . . . . . . . . . . . . . 146

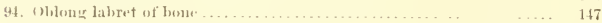

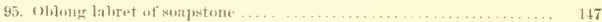


Fig. (H). AH. Am t roter

Y'anis

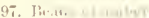

9x. 11:111 yourle

99. Slati, Hasic

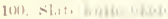

101. slatiol ain

1112. Slatw wath

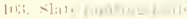

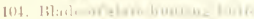

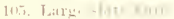

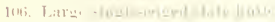

107. [Hitu], .

10s. Pesiotian thri Lith

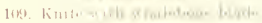

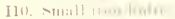

11]. Sinull gong Inome

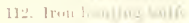

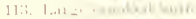

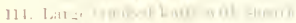

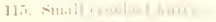

116. I'2nektis herro

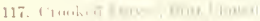

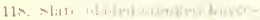

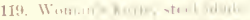

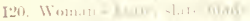

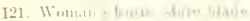

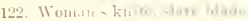

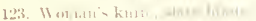

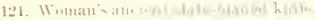

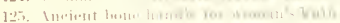

12hi. Lanere knolent vat.

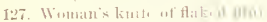

I2x. Hateber hatiterl as an wlis

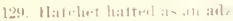

1301. Mix-luent ut i:mli

131. Aels-limatel ot jable

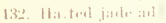

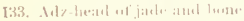

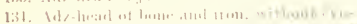

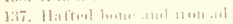

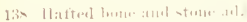

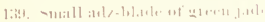

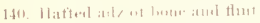

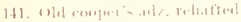

112. Nol, with lioser litwe

|13. Inther intal ....

14. Anther: lital

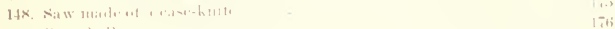

11!1. Inom dinll

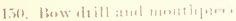


Fu. 1.31. Bow trill

152. Irill how

153. Irill how =

154. Npleced ilrill low

1\%i, Drill mouthpioce with iron acket

1:it. Jull menthpiese without wings. .

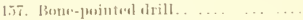

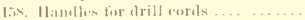

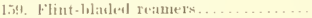

16i). Flint-hlakled reamer's

16it. $A \amalg 1$

16it. Jink whetsterust

16i3. Iatele whetstomes.

161. Nomien toul-troxes

16is. Large woorlen toml-lowes

liti. T(w)]-hag of wolverinu skin

16i.. T(я)l-bay of wolverint skin

lix. brills low longing to the torl-bate.

16:4. ('wnl, for deerskins in the tool-bag

170. Bang hanclies

171. Bay of leatler.

172. 1,ittle lunul-reluh

173. Slungklet mitld of walrus jaw

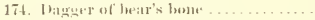

175. Bow digurers

176. So-eallesl diagger of hon

177. Buy's bow from l'tkiavwiñ

17x. Lerop at rucl of howstring

179. Large low from Nuwík

180. Larä how from sirlaru.

181. Featlering of the Exkimo arrow....

182. Flint-headed arrow (kukiksadmon)

183. Longr tlint pilo. . . .

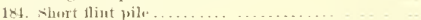

18.i. Heart-shajeel flint pile

186. (a) Arrow with ":aft.r pile" (ipmullegalliñ); (b) arrow with irom pile (savichñ); (c) arrow with irot jile (satiallñ); (d) arrow with

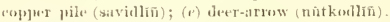

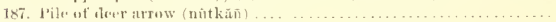

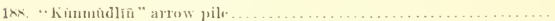

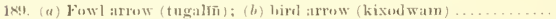

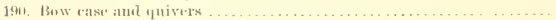

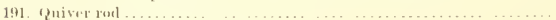

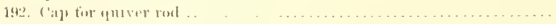

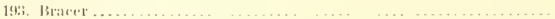

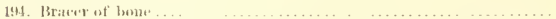

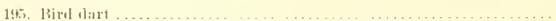

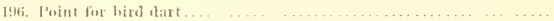

197. In ient point for linel dart . …

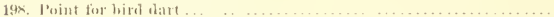

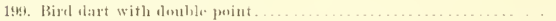

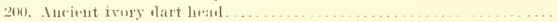

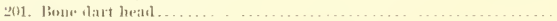

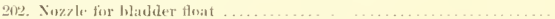

20) sial dart.... 


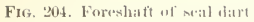

205. Throwing board tir alart

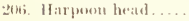

2077. H:เгрини hu:at

20k. Ancient bone baspoon ha:

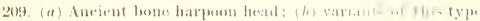

210. Bome harpoun heal

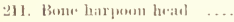

212. H:arpoot betel, lume and stome

213. Harpoon ha:al, lane and stome.

214. Walrus hatpums. ......

215. Typicat walrum-harpoun heatio

216. Typicall walme-hanpent heals

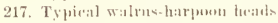

218. Walrus-hatpon heid, with "leater."

219. Walrux-h:urpen heitl, with line

220. Walrus-harpoom hesul, with liuw

221. Walrus-hampon lewad, with lime

22. Fureshat of walrus harpou

223. Harponin lesad for laree seals

224. Retrieving sath harpow ....

225. Whetails of retrieviug sit:al haspum

226. Jaule blade tire seal hingrom .... . . .

227. Seal harpuou for thrusting .

$22 \times$. Niagram of lashing on shat th

229. Motel of a se:at harpenem

230. Large morlet of whald harpuos

231. Modtel of what he hrpuon, with thats.

232. Flint blate for whale harpoon -... . .

233. Slate blate for whale harpoon

231. Body of whale harpoon head ......... . . .

235. Whale harpoom heads

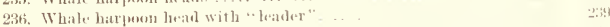

237. Formshatt of whale laryoum ...........

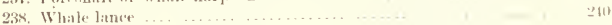

239. Flint heal of whale lanw. .... ........

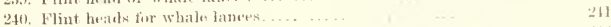

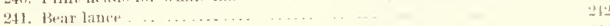

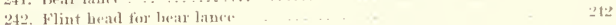

243. Deer lauw .............. 213

244. Part of dere bawe with thint lwad ... ..... 213

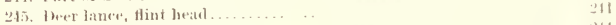

246. Flint head for ther lines. ....... ...

247 . Birc bolas, Joped up for earrying. 35

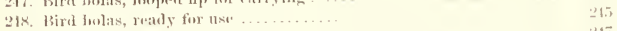

24t, sialskin float ....................

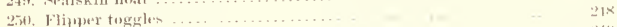

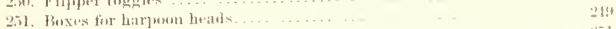

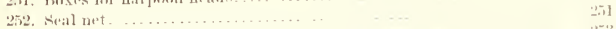

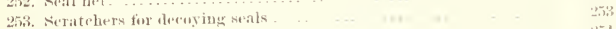

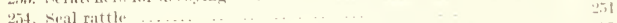

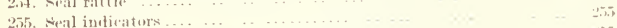

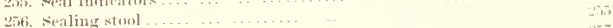

257. Neal drig and hambles. ...... . .

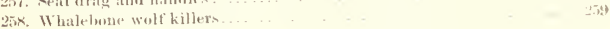




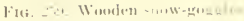

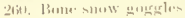

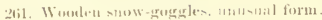

26;. Marker for meat rathe

26:3. Marker for meat carele.

261. Tackle for shote fisling

20. Kuof of line nuto hook.

2633

2fiti. Smitll tikh-heoks.....

2tiī. Horks for river fisling ..

2tix. Tarkle for river tishing

$2 \times()$

2649. Burlost lowok, tirst patterti.

2ख(1)

2ĩo. Burlest lowk, secoud pattern .

$2 \times 1$

271. Burbot look, made of cod hook...

$.3 \times 1$

27.2. Burlust takkle, luited ..........

$2 \times 1$

$2 \times 1$

273. Ivory sinkr.r.

2x:

27). lvory jiger for polat eod...

$2 \times 2$

27i. Section of whatebene net .....

$2 \times 1$

27i. Mesh of sine we net

$2 \times 5$

277. Fish triaj?.

$27 x$. Fish spent.

27!. Flint flaker

$2 \times 0$. Haft of tlint tlaker

$2 \times 5$

$2 \times 6$

$2 x x$

$2 \times x$

2xi. Plint flaker, with lone blate... 2xy

282. Fire trill, with nouthpiece and stock............ 2x!9

$2 \times 3$. Set of bow-ind-arrow tools .......... 241

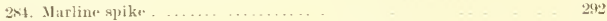

$2 \times 5$. Varline spike. .......... 292

286. "Twister" fir working siuew bateking of how. _. _..... 293

287. "Feather settr.r" .......... . . . . . . . . . 29.

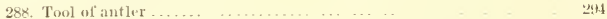

$2 \times 9$. Nkin seralper ............. 29.

290. Nkin seraperx-handles only............... 295

291. Kkin serapers . . . . . . . . . . . . . . . . . . . . . . . .

292. Skin serajer ... . . . . . . . . . . . . . . . . . .

293. Peculiar moditication of acraper............ .

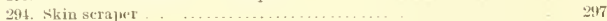

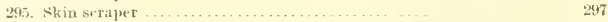

246. Skin seraper . . . . . . . . . . . . . . . . . . . . . 297

297. Flint blatle for skin seraper. ........................

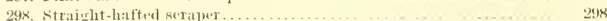

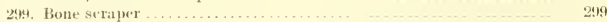

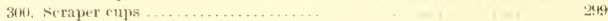

301. Combe for cletuing de+r-skins. . . 301

302. "Double slit" splice fur rawhide lines

303. Mattock of whitle s rib ...................... $310^{3}$

304. Pickax-he'tuls of lone, ivory, and whate's rib. 303

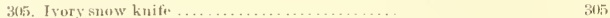

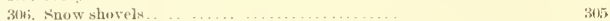

307. Snow shovel mate of at whale seipula ....... 307

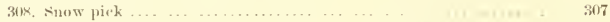

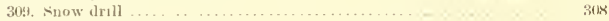

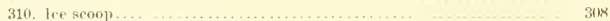

311. Lone lilubler look ........................

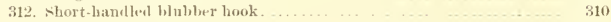

313. Fish sealex ...................... 311 
Fiti. 314. Ivory shimale

315. Detting unew tha

3†6. Ylosh stirk

317. Notting mentive

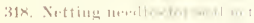

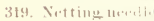

3261. Mesh stivh =

321. Nutine wetshit-

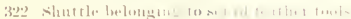

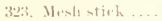

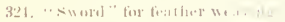

325. Q Q

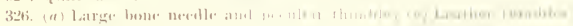
with lome meralles.

327. Xectlle cisas with lwit howh-

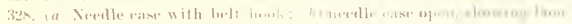
needles

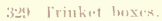

3330. Funket loseres.

331. In⿴ri laws.

332. Bone lax .

333, Little tlask wi ivory.

334. Box in shape of there

335. sumill basket .........

336. suall basket ....

337. suall hasket

33x. Katiak ...

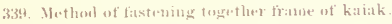

340. Thulble kaialk patalu.

311. Moulel katak atut pathlly.

312. Frame of muiak

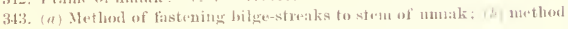
of fratuiug rib to gumwale, r.te. . . .

341. Metherl of slinging the oar of umiak...

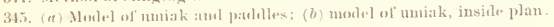

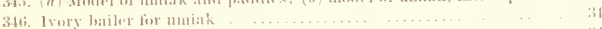

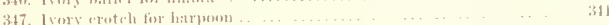

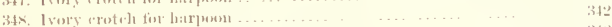

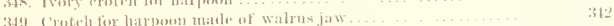

350.

351 Kuot in suow

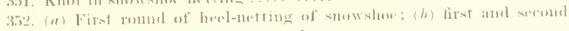

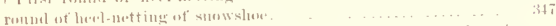

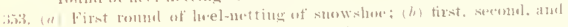

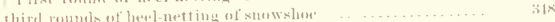

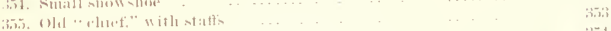

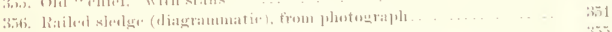

35 . Flat slutere

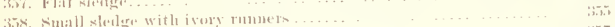

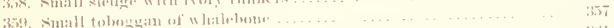

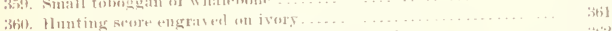

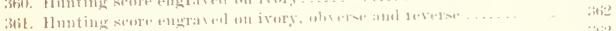

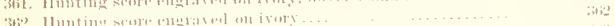

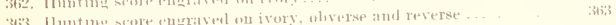


Fic. 3tit. Ciame of fox and greese from Plover Bay...

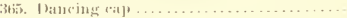

:36it. Moorlen misk

3ii. Winglen mask and dancing gormet

Btix. ()]d ntotentut makk

itist. Rumle mask of worn

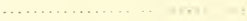

37i). Wolf mask of woos

$\ldots \ldots \ldots \ldots+\cdots+\cdots$

371. Very murinut small mask

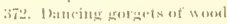

373. Voutlo daneing to the aurora

371. Whirlinges...

375. Tivetotum

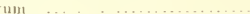

3iti. 1:uz\% toy .....

37\%. Whizzing stick

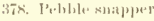

374. farving of Jimu:u hetad

380). Merelatical doll-ilrum-platyer

$3 \times 1$. Mrellanimal toy-kitiak paduller...

3x2. Kaitk carved foum block of wood

$3 \times 3.11 \mathrm{rum}$.

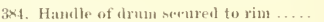

3xi. 1hum handlis...

3xti. Ivory drumsticks

$3 \times 7$. Aneient rarving-human heasl ..................

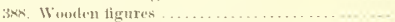

38:), C:Arving-tace of Eskimo man.

340. tirotesque sonaptone imatge " "walrus man"

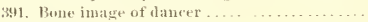

39. Hone image of man

393. Hrotesyme bone inature.

3!4. Bone imate-sitting man.

34.. Human figure "arvel from walrus ivory

34ti. Ivory rarvitu-throe homan heads

397. Rute lonmatu lesul, farsed from a walrus tooth.

39x. Nlaborate ivory varving

349. Bear earverl of keapstome

4001. Bear flaktel froun tlint.

401. (a) buar carvel fiom bune; (b) bear's head .

402. Jvery figures of lotals.

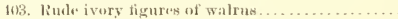

104. Hurges of seal-wood and home.

10: Whift whale couved from gypsum

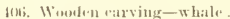

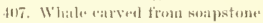

fux, limle that inage of whale.

4t) fot. fory intage of whale

410. Ivory imatge of whale.

111. Pair of little ivory whales

412. Soapotone image of inatrinary aninal

113. lvory carving, neal with fish's head.

411. Ivory carrintr, tan-legared beis . .

115. lvory rarving, griant holuliug whales.

416. Datble-healed animal earved frou antler

417. Ivory carving-log . 
FIs. $41 \times$. (a) Piece of ivory, engraved with tignres; (b) desolmonom if

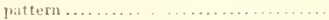

419. (a) Similar engraved ivory: $(b)$ development of pattern.

420. Ivors dell ................................

421. Whale flaked from glass...

42. Whale tlaked from red jasjur $\mathrm{r}$

424. Amnlet of whalingr-stuticul mod wit.

425. Amulet consisting of ancient jade adz

126. Little box containing ammlet tor whaling

427. Amulet tor catching tow $\mathrm{with}$ bolas.

428. Box of dried hees-amulet.

(1) ЕTH—- 


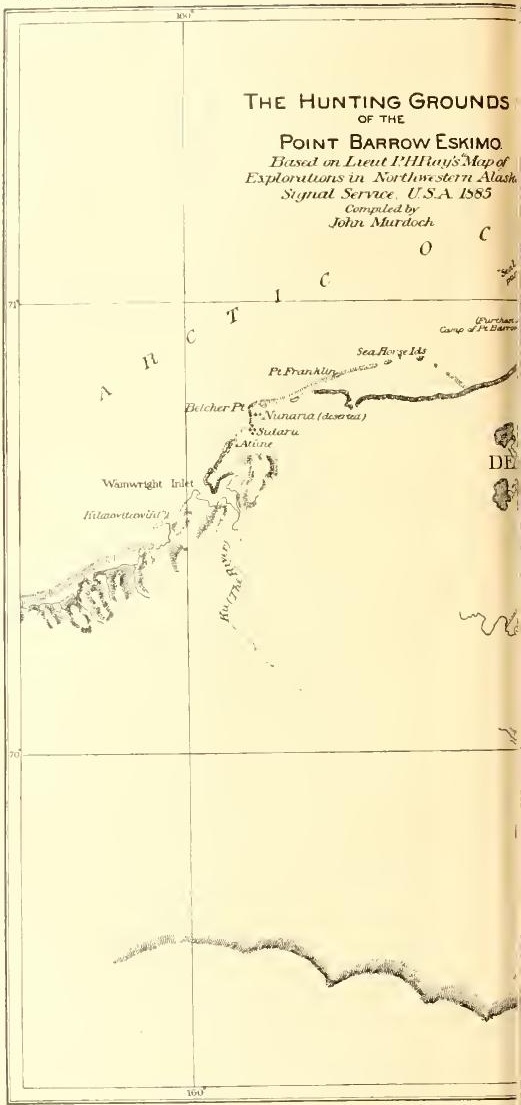




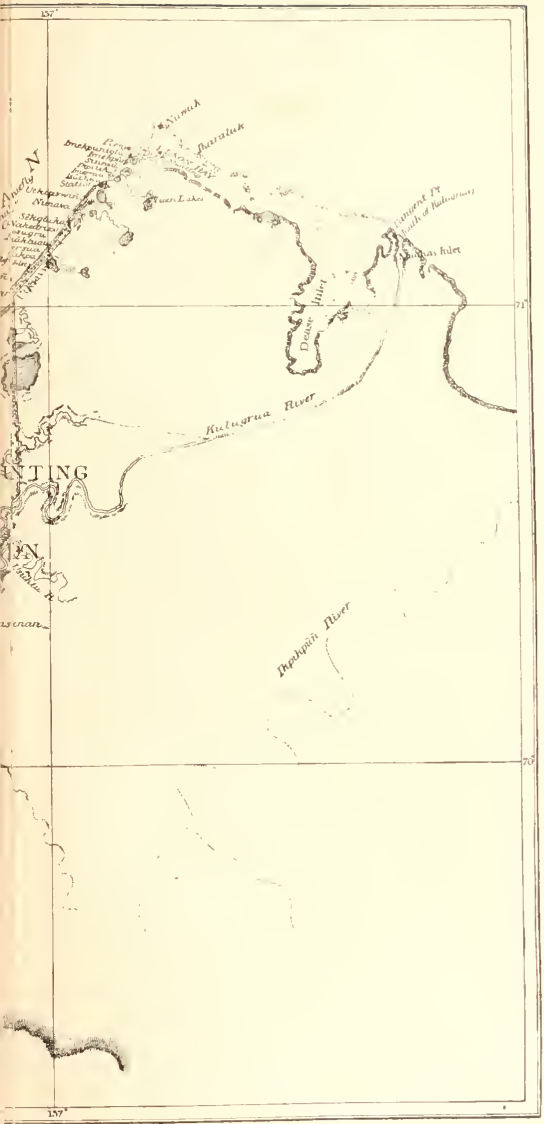





\title{
ETHNOLOGIAL RESTITS OF THE POINT B.MRROII E.PPIITIOX.
}

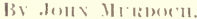

\section{INTRODUCTION}

The International Polar Expolition to l'oint Barrow, Mlaskial, Was

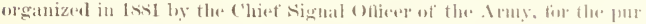
pose of eooperating in the work of riremumpelate olsatration proposed ly the International Polar conteremere. The experlition, which was

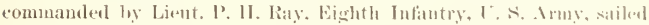
from San Franciseo July 1s, 1sist, and reanluel ('ape singth, 11 mites sonthwest of leoint liarow, on siptember $x$ of the sane year. llere a permanent station was established, whele the panty memilued nutil

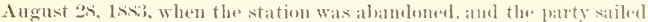
for Sath Franciseo, arriving thete (), tober 7.

Though the main ohject of the "xpeclition was the prosention of the observations in terrestrial magnetism and meteorology, it was pessible. to obtain a larede collection of artieles illustrating the ants and industries of the Eskino of the pegion, with whom the most friendly relatims were early established. Tearly all of the colle et ien was made ly barter. the natives bringing their weapons, elothing, and of hed objects to the station for sale. Frull notes an the lathits and (astoms of the Eskimes also were collected by the different members of the party, esperially

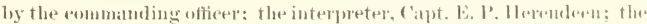

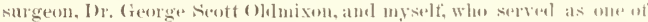
the naturalists and observers at the expedition, It tell to my shame to take eharge of and atalogue all the eolleetions ande hy the expenti

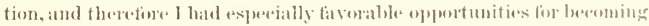

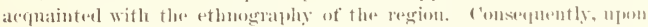
the return of the axperlition, when it was tound that the e.thondengieal

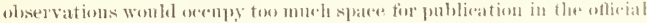
report, ${ }^{1}$ all the collections and notes were intrasted to me for that purpose

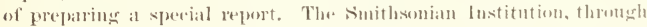

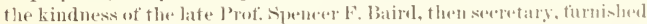

\footnotetext{
'Report of the International Polar Expedition to Point Barrow, Aluska, loy Licut. I' II Fis Whith
} ington, 1885 . 
a room where the work of studying the collection eould be earried on, and allowed me aresess to its libraries and to the extersive collextions of the National Musenu for the purposes of comparison. The birector of the Burean of Ethuology, Ma j. .J. W. P'ewell, kintly agreed to furnish the illustrations lor the work and to publish it as part of his anmal report, while the ('hief signal ofiteer, with the greatest ronsideration, permitted me to remain in the employ of his Burean until the completion ot the work.

T'wo yeas were spent in a detailed analytical stmly of the artieles in tha collection, until all the information that pould low gathered from the objects themselves aud from the notesof the eolleeters had been recorded. Careful eomparisons were made with the arts and industries of the Eskimo race as illustrated by the collections in the National Musemu and the writings of varions axplorers, and these frepuently resulted in the eluedation of obseme peints in the history of the Point Barrow Eskino. In the form in wheh it is presisnted this work contains, it is believed, all that is known at the present day of the ethmograply of this interesting jeople.

Mueh linguistio material was also collected, whieh 1 hope some time to be able to prepare for publication.

The observations ale arranged ateording to the plan proposed by Prof. otis T. Mason in his "Ethnologiral Directions, ete.," semewlat modified to suit the cirenustames. In writing Eskimo words the alphabet given in Powell's " Introduetion to the Situdy of' Indian Lauguatges" has been 11 sed, with the addition 1 for an obsene a like the final " in

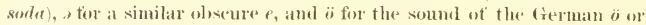
French eu.

I desire to express my gratitule to the late Prof. spenere F. Baird, Secretary of the smithonian Institution, to the late (ien. William B. Hazen, Chief Sigual Offixer of the Army, aud to Maj. I. W. Powell, lid rector of the Burean of Ethuology, for their kinduess in mabling me to carry on these investigations. Grateful ankowled grment is due for valu. able assistame to various members of the sejentifie stafl' of the National

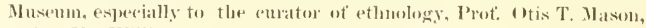
and to Mr. Willian 11. Dall. Vahable suggestions were reseiverl tiom Mr. Lucien 1l. Tumer, Mr. Framz Boas, the late Hr. Emil Bessels, and 1)r. 11. link, of ('hristiania.

LINT () WORKK ('NXILTED.

The following list is not intended tor a complete bibliography of what has been written on the ethography of the Eskimo, lout it is believed that it contains most of the important works by autlors who latre treated of these peoplo fiom gersomal observation. Sule of the lexis important works have been included as contain any relerenees bearing upon the sulpject of the study.

As it has bere my object fo go, whenever possible, to the original somres of information, compilations, whether seientific or popnlar, have 


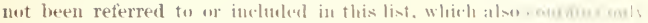
the editions referted to in the taxt.

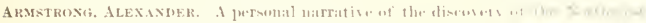

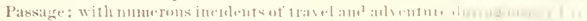

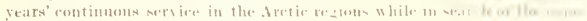

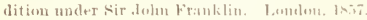

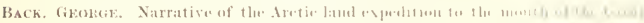

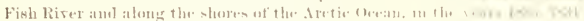

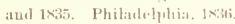

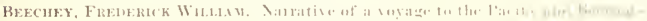

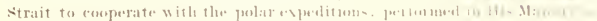

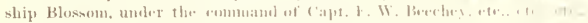

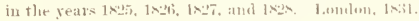

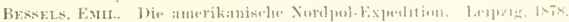

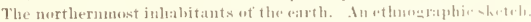

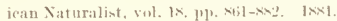

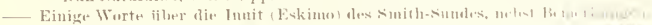

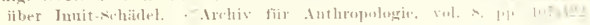
Brannoulimeig, $1 \times 75$.

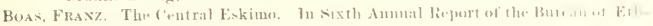

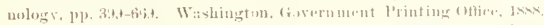

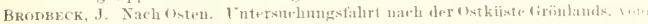

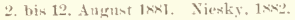

Chappli, E. (Lielut., R. X.). Narrative of a voyage to lludson's Bay in llim Majesty's ship Rosamond, containing some accomint of the northeatern coast of Auerica, and of the tribus inhahiting that remote region. Lemulem. 1817 .

Choris, L. Vorage Pittoresym antum du Momlu, awe des purtraits ales saurages

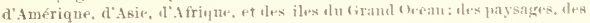
vues maritimes, ot plusienrs ehjets ahistoire naturelle: accompagne de deseriptions far M. le baron Curier, et M. A. de. C'hamiseo, A.t d'observations

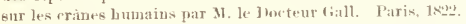

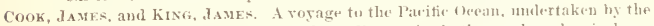
command of His Majusty for making diseoveries in the nerthern hemisphere. to determine the position and estent of the west sitle of Nurth Imeriea: its

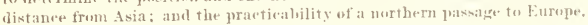
in the rears $1766,1777,177 \times, 1779$, and 17x0. Luthen, 17x4. 3 vols, commally vallud "( cook's Thirel Voyage."

"Corwis." ('ruise of the revenne steimer f'urwin in Alaska mu the $\mathrm{X} . \mathrm{W}$. Aretic Oenan in lNe1. Notes and menoranda. Medionl and antleropologicat: hetan-

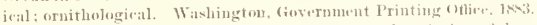

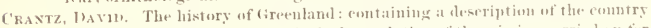
and its inhabitants: amo particularly a rolation of the mission earried on tor

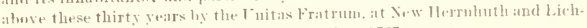
tenfels, in that emintry. I volumes. Lomblou, Iitio.

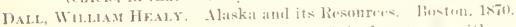

on masks, labrets, ant mertain abriginal enstoms. with an impuirs into the

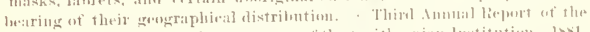

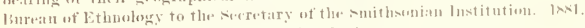
Wishimgton, fowernment l'rinting ithim. Ixxt.

Tribes of the extreme northwest. C Contributions to Xorth Inerienn Eethol

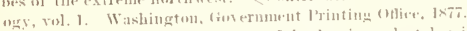

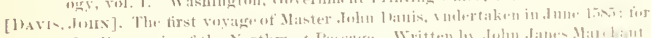

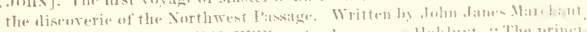
seruant tu the worshipfull M. William simulerkou. 11:akhyt, "The prinet

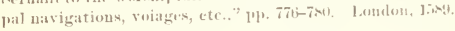




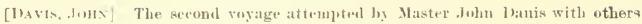
for the aliscoverie of the Northwest pissiget, in Anno linti, <Hakluyt, " The prineipal navigations, voiages, ete.." ple. Fst-7ot. Lonelon, 15xt.

The third royagr Xorthwestward, wate by fohn Danis, fintleman, as thiefe C'aptains and l'ilet grenerall, for the discoverie of a prosage to the Isles of the

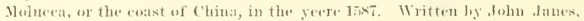
Aeruant to the af foresayd M. William fanclersu. <Hakluyt, "The princi-

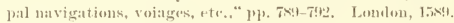

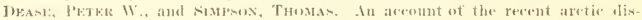

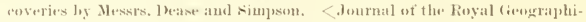

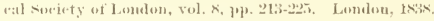

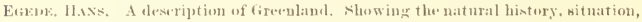
boundaries, and liate of the count ry ; the nat nu' of the soil ; the rise aud prog-

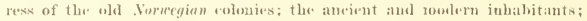
their genius and way of life, and predues of the soil; their plants, beasto, fislues, ete. Trauslated trom the Thanish. London, 1745.

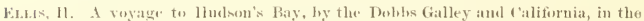
years 1746 and 1717 , for discovering a northwest passage. London, $174 x$.

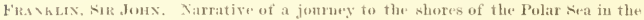

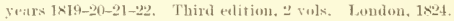

- Namative of a secomel expeclition to the sheres of the l'olar sea in the years 1825 , $1 \times 26$, and $1 \mathrm{~N}^{2} 2$. In-huling an accomnt of the progress of a detachment to the castward, by Joln Richardisn. Lomelon, 1K2x.

[Fuonsmin, MARTIx]. The first voyage of M. Martine Frobisher to the Northwest for the searels of the straight or passage to ('hina, written ly ('loristopler Hall, and made in the yere of our Jord 1.76. Nakluyt. "The principal navi-

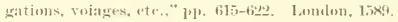

- 'The' second vorage of Master Martin Frobisher, made to the West aud Nortlowest

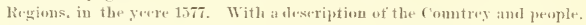
Written by Dionike Settle. < llakluyt. "The principal navigations, voi-

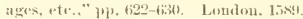

The third and last voyage inte Sleta Ineognita, mate lyy M. Martin Frobisher, in the year 157x. Writtin l,y Thomas Ellis. <Hakluyt, "The prineipal

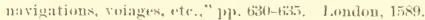

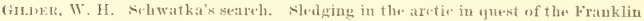
resorts. Xiw York, $1 \times \times 1$.

Gksan. W. A. (Capt,). Sarrative ot an +xpulition to the east coast of Greenlabd, sent by oreler of the King of lenmark, in seareb of the lest colonice. Frimslated from the Danikh. Loudan, $1 \times 37$.

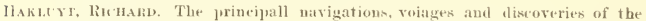
Englixh nation, made by Sea or over Latnd, to the most remote and firthest Jistant Quarters of the earth at any time within the eompasse of these 100 verise. Loudon, $15 \times 9$.

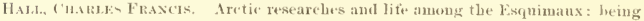
the narrative of an "xpmlition in searels of sir foln Franklin, in the vears INtill, 1N61, and 18ti2. New Vork, 1kits.

_ Xarrative of the sesond aretic expedition male by ('harles $\mathrm{F}$. Hall: his voyage to lieprulse bay. sledge jomrneys to the strats of Fury and llecla and to king

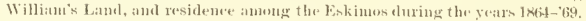

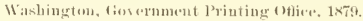

HFan, M. A. Report of the eruise of the resenne mane steamer for in in the

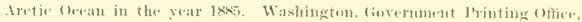
$\operatorname{lnxt}$.

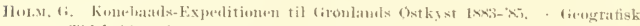

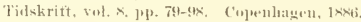




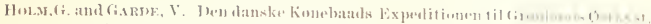

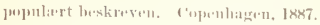

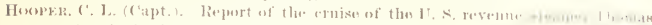

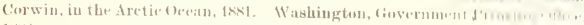
$1 \times \times 4$.

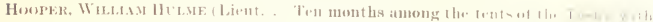

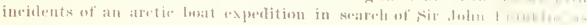

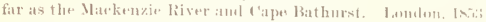

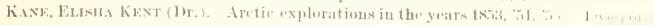
Philahluphial, 1xiti

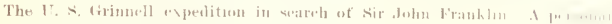
nartative. New Jork. $1 \times, 2,3$.

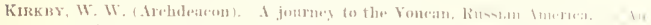

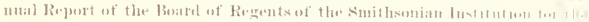

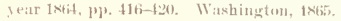

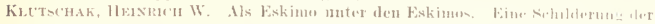

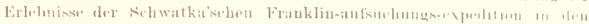
Jahren $1 \times 7 x-s 0$. Wien. Pist, Jeipzig, $1 \times 81$.

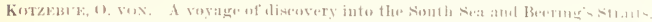

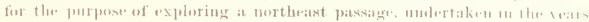

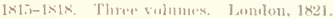

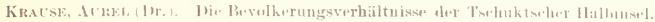

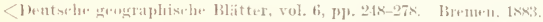

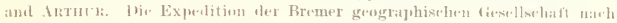

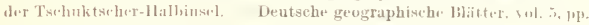
1-3:5, 111-1323. Br+m1-11, 1Xx-2.

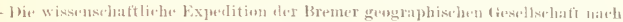

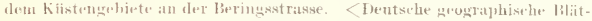
tor. vol. 4. [1]. 245-2x1. Brimen, $1 \times \times 1$.

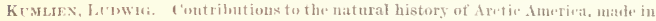

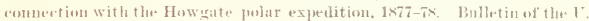

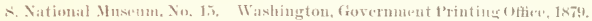

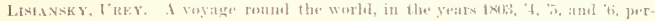

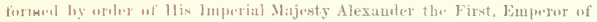
Russia, in tlu. ship Novit. Lomilus, Ja14.

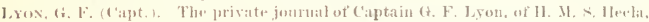
during the reent vositg of discovery under C'ajetain Parry. Beston. 1824.

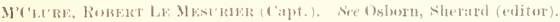

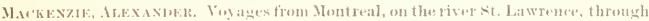
the antinent of North Ameriva, to the Frozen and Pacific Ocesius, in the years $17 \times 9$ and 1793 . Lomdon, $1 \times 02$.

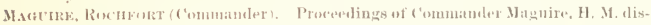

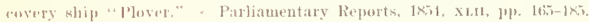
Lenulon, 1xil.

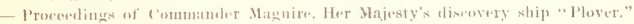
Further pilpers relative to the recent antic: expedition in seareh of sir

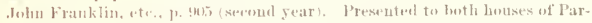
lianent, damtars, 1x:s. Jemton.

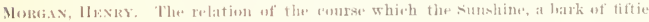

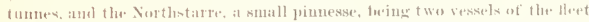

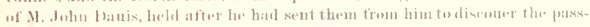

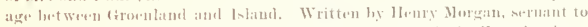

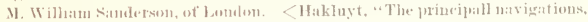

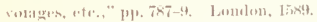

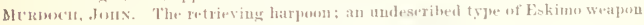
$<$ Auerican Naturalist, vol. 19, 1885, pp. 423-425. 
Mrmoch, Junx. (In the Siberian origin of some customs of the western Eskimos. <American Anthropologist, rol. 1, pp. 325-336. Washingtou, 1888.

A study of the Eskimo bows in the U. S. Nutional Musenm. < Smithsonian Report for 18xt, pt. II, pp. 307-316. Washington, Government Printing Office, 1885 .

Nordexskiöld, Anolf Eric, The voyage of the Vega romul Asia aud Enrope. Translated l,y Alexander Leshe. 2 vols. London, $18 \times 1$.

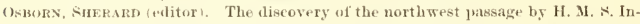
restigator, Cajt. R. M'Clure, 1 $\times 50,1 \times 51,1852,1 \times 53,1 \times 54$. Ellited bs Commander sherard (b)boru, from the logs and jouruals of Cajt. Robert Le M. M'lure. Appentix: Narrative of Commanter Magnire, wintering at Point Barrow. Lontom, 1856 .

1'anz: W11.tam EDWam (Nir). Jourual of a voyage for the discovery of a northwest passage from the Athantic to the Pacifie; pertormed in the years $1 \times 19-^{2} 20$, in 1 is llajesty's ships Hecla and (rriper. Fecond edition. Londom, $1 \times 2 y$ 1.

__ Jourual of a sucond royage for the discovery of a northwest passage from the Atlantic to the Pacifie; performed in the years 1821-22-23, in His Majest $\Gamma^{\prime}$. ships Fury and Hecla. London, 1\%24.

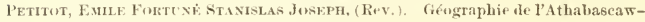
Matkenzie. <Bulletin the la Societe do (Héographir, [6] vol. 10, 1'p. 5-12, 126-1 $1 \times 3,242-240$. Paris, 1875.

Vocabulaire. Frawais-Escuiman, dialecte des Trhiglit des bouches dn Mackenzie et de l'Anderson. précédé d'une monographie de pette tribu tet de notes grammaticales. Vol. 3 of Pinart's . Bibliotheque de linguistique et d' Ethnographie Amérienines."

Petroff, WAx. Riport on the popnlation, industries, and resourees of Alaska. $<$ Truth C'eusus of the I. S. Washington, Government Printing Oftice. $1 \times \times 4$.

Powell, Joseph S. (Lient.). Report of Lient. Joseph \&. Powell: Relief expedition to Point Barrow, Alaska. <Signal Servic Notes, No, V, pp. 13-23. Washington, office of the Chief Signal Officer, $1 \times \times 3$.

RAE, Jorn (Dr.). Narrative of an expedition to the shores of the Aretic sea in 1846 and 1847. Londan, 1850 .

RaY. Patrick Hexry (Lient.). Report of the International Polar Expedition to Point Barrow, Alaska. Washington, Govermuent Printing oftice, 1885.

- Report of lient. F'. Henry Ray: Work at Point Barrow, Alaska, from Neptember 16, 1881, to Anguit 25, 1882. <signal service Note8, No, V, pp, 35-40.

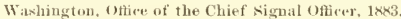

Rochandox, Joнs (Nir.). Aretic searching expedition: A journal of a boat voyage throngh Rujert's Land and the Aretic Sea, in seareh of the discovery ships under command of Xir John Franklin, 2 volmmes. Londow, $1 \times 51$.

- Eskimos, their geographical distribution. <Elinburgh New Philosophical Jomrual, vol. 52. pj. 322-323. Edinburgh, 16,32.

The polar regions. Edinburgh, 1861 .

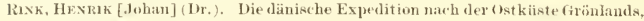

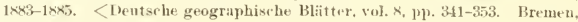
$1 \times \times 5$.

Danish (ivernland. its people and its products. London, 1877.

The Eskimo tribes. Their distribution and churacteristies, especially in regard to langratge. Meddeleloer on Gronland, vol. 11. Copenbagen. $1 \times 87$.

- loi Ostgrönlanter in ihrem Verhältnisse zu den uhroge. Exkimost Bwntse geographische Blïtter, vol. 9, pp. 228-239. Bremen, 1×86.

- Ostgroulipuderne i detes Forhold til Vest gronlanderne og de ovrigu Exkimostammer. < (ieografisk Tilskrift, vol. $\times$, pp. 139-145. Copenhagen, 1×xt. (Nearly the same as the above.) 


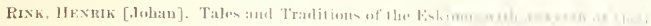

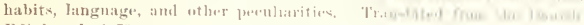
Elinburgh, $1 \times 75$.

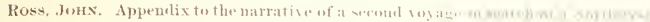

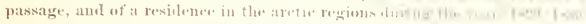

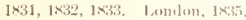

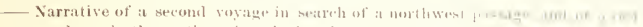

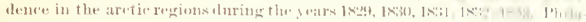
1telphia. 1835.

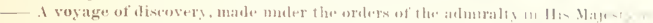

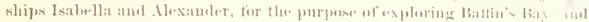

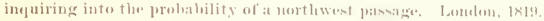

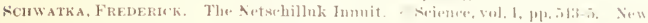
York, $1 \times \times 4$.

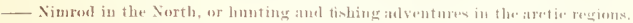
New York, $18 \times 5$.

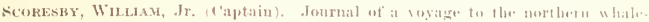

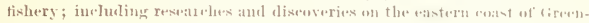
land, mate in the summer of 182.2, in the ship lattin, of liverpose. Eilin. burgh, $1 \times 23$.

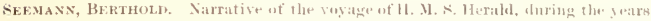

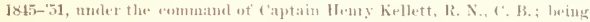

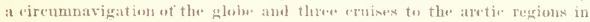

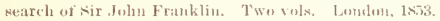

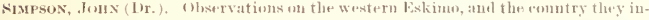
labloit; trom notes taken during two years at Point Barrow. <A selectiou of

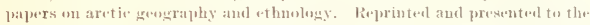

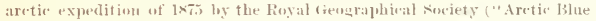
Beok"), p1, 233-275. Losulon, 1K75. (Rejerinted trom "Further papers," etc.. Parl. Rep., 1855.)

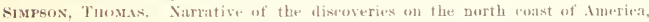

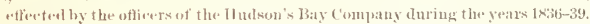
l.ondon, 1843 .

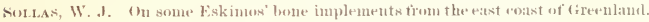
<.onrnal of the Anthropologival Institute of Great Britain and Irelaul, vol. 1t. pl. 329-336. 1.ondon, $1 \times 3 \times 1$.

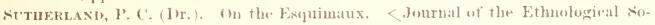

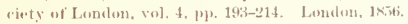

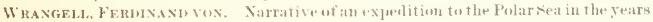
1820, 1821, 1822, and 1823. Edited lis Maj. Eilwaral sabiuc. Lomrlon, 1840. 


\section{SITUATION AND SURROUNDINGS.}

The perple whose arts and industries are repursented by the collese tion to be deseribed are the liskino of the northwestern extremity of the continent of Xorth Ameriea, who make germatent homes at the two villages of Suwnk and Ithiavwion. Sull enotributions to the collecetim were olstained from natives of Wainwright hulet and from people of the Inland liver (Numatanminu) who visited the northern villages.

Nuwnk, "the Point," is situated on a slightly elevated knoll at the extremity of Point Barrow, in lat. $71023^{\prime} \mathrm{X}$., long. 15to $17^{\prime} \mathrm{W}$., and

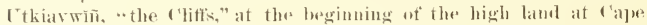
Suyth, 11 miles sentlewest from Nowntk. The name T thiarwin wasexplained as meaning " the high place, whenee one ran look ont," and was said to be eqpivivalent to ilkpilk, a cliff. This name appeats on the various maps of this region under sereral corrupted forms, doe to earelessuess

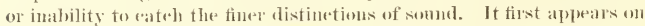
Capt. Magnipes map) as "()t-ki-at-wing," a form of the word very neal" the Eskimo pronmuciation. On IMr. Simpson's mapre it is changed to ".()t-ke-a-vik," which on the adminalty rhart is misprinted "()tkiwik." Petroff on his map" ealls it "ootiwakl," while lee gives an imaginasy village " Gotkaiowik, Aretic ()eant," of his inhahitants, in his census of the Aretie lovision (ope eit., p. 4), which does not appear upon his map.

Our party, 1 regret to say, is responsible for the name "o (oglaamis" or "I glaamie," which hasappeared on many mapsincenreturu. Strictly. speaking this name slonkt be nered only as the official name of the [nited States signal station. It arose from a misumlerstanling of the name as heard the day after we arrived, and was even alopted by the batives in talking with us. It was not motil the seconel year that we learnet the eorrect form of the word, whieh has lesen carefully verified.

The inlabitants of these two villages are so widely separated from their neighbors-the mearest fermanent villages are at P'oint Beleher' and Wainwright Inlet, 7.5 miles sontlewest, and Inemadration Point, 350

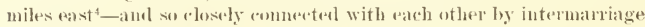
and common interests, that they may be considered as a single people. In their lonting and traling "xperlitions they habitually range from the

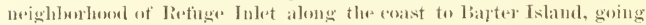
inland to the nyper waters of the large rivers whicle flow northward

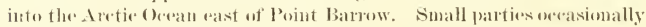
travel as far as Wainwerght lnlet and more rarely to Point Hope, and

1Parl. Reporta, 1854, vol.4:3. p. 1 86

${ }^{2}$ Further Papery, Ar, ]'arl. Firl, (1855)

${ }^{3}$ Report on the population, ete , of A laska.

¿Capt. E. E. Sinith who in command of a steam whaler penetratel as far east as Return Reef in the Bummer of 1685, eaye that the natives told him there was no permanent village west of Herschel Island. 


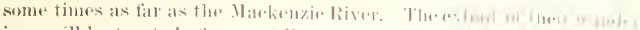

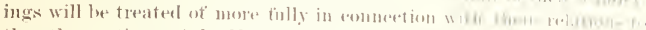

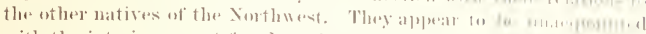

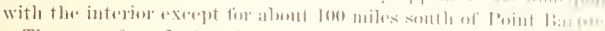

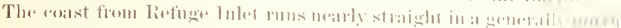

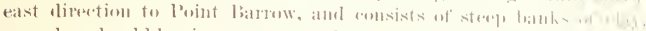

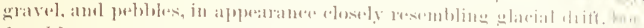

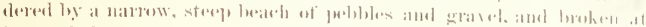

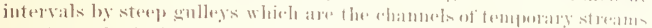

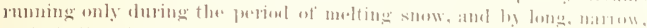

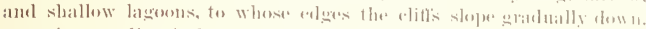

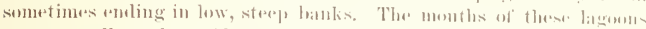

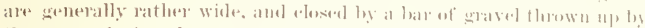

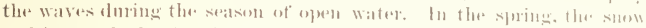

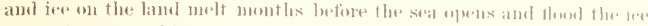

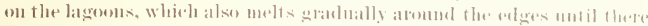

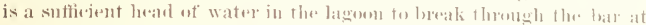

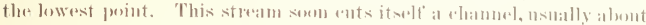

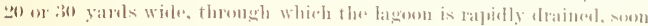

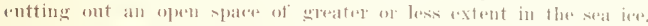

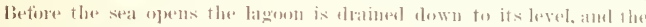

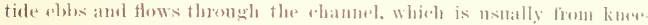

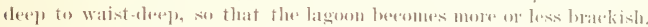

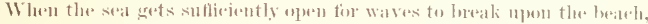

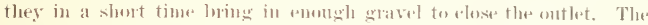

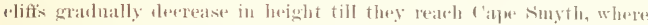

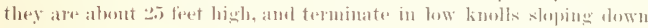

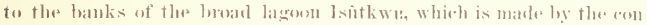

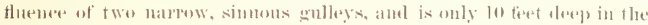
derpest part.

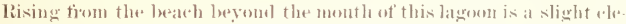
vation, 12 fent above the seta level, whiele was ameiently the site ot at

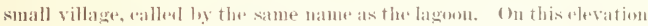

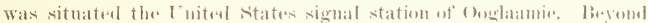
this the lame is level with the tepe of the loweh, which is broas and waty flat, raiserl into a slight rielere on the ontere edere. Abent half a mile

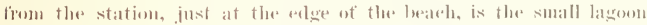

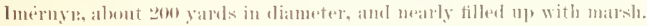
From this point the lamel slopes down to Elson laty, a shallow body

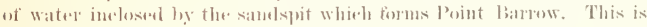
a entimation of the line of the beach, varying in brealth fiom 200 to

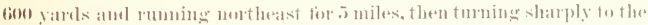

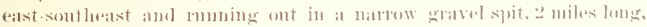

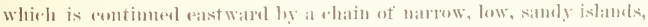
whielt ratend as far as Point Tangent. It the angle of the point thet laul is sliglitly elevated into irvesular tenterorered knolls, on which the 
village of Nuwnk is situaterl. It varions points along the bearh are healps of grawe sometimes jor ti feet in beight, which are raised by the

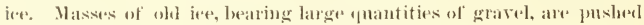

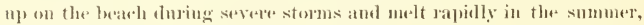
lepositing their loald of gravel and probles in a larap. These masses are often proshed np out of reach of the wares, so that the heaps of gravel are lett thementorth mulisturberl.

Between lmerny? and Elsom Bay (Ta'syotk) is a series of large shat

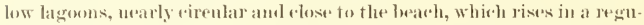
lar sea-wall. All have bow steep banks on the band side, bordered with a narrow beath. The first of these, l'kpiliñ ("that which has ligh lanks"), breaks ont in the spring though a narow rhamel in the beach in the manne already deseribed, and is salt or barkish. The next is fresh aml comnected with Ikpoin by a small stream rumning along lee

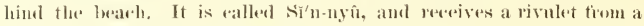
small fresh-water lake $30 x+$ miles inland. The thircl, Imék kpôn ("great water"), is also foesh, and has meither tributary mor ontlet. The fourth, Imêk pu'niglu, is lnakish, ant empties into Elson Bay by a small stream. Between this stream and the beath is a little fresh-water pond close to

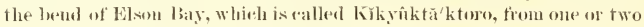

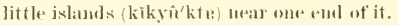

Bark from the slum the land is but slightly elevated, and is marshy and juterspersed with many small lakes and ponds, sometimes romnerted by ineonsiderable streams. This marsh passes gramblly into a somewhat higher and trier folling plain, stretehing bark inkand from the elift's and growing gradnally higher to the sentle. Dr. Simpsom, on the anthority of the Point Barrow natives, deseribes the eomutry as "nuiformly low, and tull of small lakes or pools of tresh water to a dis-

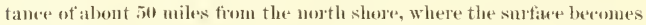
undulating and hilly, amol, farther sonth, moutanous." This deseription lats been substantially verified by Lient. lioy's explorations. South of the usual teer-huntiug gromul of the natives he found the land dectulwly lowken and hilly, aut rising grablually to a considerable range of monntains, rmoning approximately past anl west, which conld be seen from the farthest point le mached. ${ }^{2}$

The natives also speak of high rouky lamd "a loug way off to the east." which some of them have visited the the pur onse of humting the mountain slexep. The low solling plain in the immediate vicinity of I'oint Barrow, which is all of the comitry that anlel be visited by our party when the land was clear of snow, presents the general alpearance of a commtry overspreat with glacial drift. The landseape is strikingly like the jolling drift hills of ('ape ('od, and this resemblamed

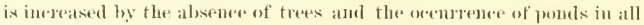
the depressious. There are no rocks in sitn visible in this region, and 


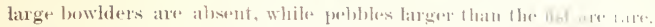

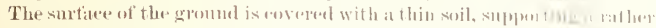

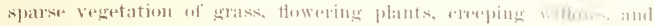

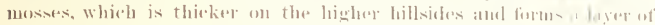

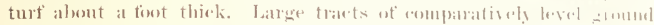

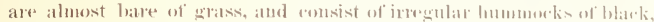

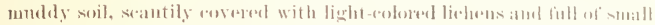

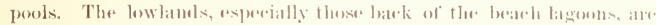

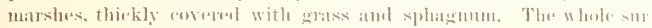

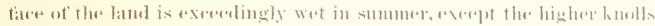

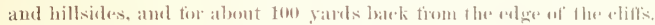
The thawing, howerele axtends down only atout a fout or aighteren

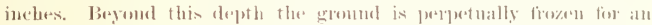

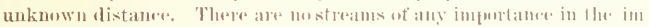
mediate neighborhood of l'oint barrow. On the other hatul, howe of

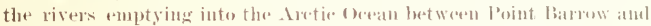
the Colville, which lor. Simpsom speak of as " small and hambly known

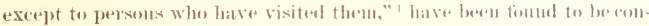
siderable streans. Two of these were visitesl Jy lient. lial in his ax-

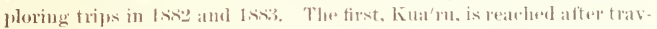

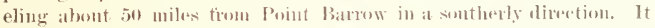

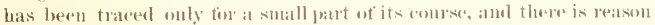
to betiese, frem what the natives saty, that it is a tributary of the sees ond named river. Lient. Ray visited the uperer pant of the seseond

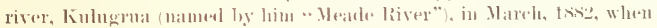

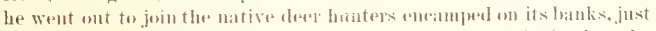
on the edere of the hilly comotry. (1) his return he visited what the natives assured him was the montlo of this river, and obtaned observa

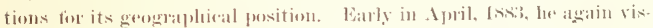

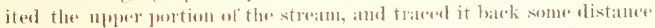
into the hilly romotry. The intermediate fortion has never been sule. veyed. It the time of each of his visits the river was, of eomese, frozen

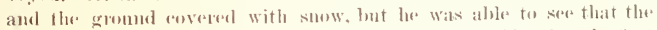

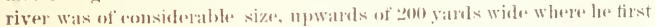

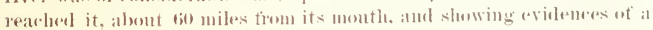
large volume of water in the spring. It receives saveral tributaries. Isee maps, P's. 1 : mol 11.$)$

The thid river is kunwn only ly hearsay thom the natives. It is called I'kpikpuni (tomat ('liff'), and is abont to miles (estimated from day"s jomruegs) east of Kulu'griat. It is aleseribed as being a larger and more lalpid streallu than the other two. and so desp that it does not

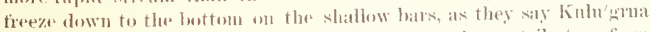
does. Not far form its month it is said to receive a trilutary from

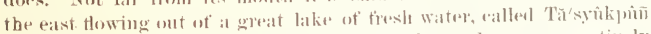
(Great bake.) This lake is selparated from the sea ly a romparatively

$$
\text { 10p. rit, 1. } 233 .
$$


narow strip of land, and is so larese that a man standing on the northeru shore "an not see the "very higli" lamel on the sontlieru. It takes all umiak a day to travel the leogth of the lake umber sail with a fair wind, and when the Ninntañmin foming from the south first saw the lake they satid "Taxaio!" (the stat).

()n ('apt. Haguine's map' this lake is laid down by the name "Tasolijod," "fiom native report." It is represented as lying between Smith bay and Itarrisen bay, and comected with each by a stream. Magnire semens to hatve heard nothing of Ikpikpatu. This lake is not mentioned in the lyoly ot the report. Wr. Simpson, lowerer, ${ }^{2}$ speats of it in the following words: "They [i. r., the trading parties when they reach Smith Baylenter a river which romluets them to a iake, or rather series of lakes, and deserend anotleer strean which joins the sea in Harrison Bay." They are well acpuainted with the Colville River, whieh in their intereomise with us they nsmally ealled *the river at Nígalèk,"

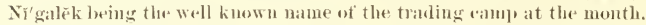
It was also sometimes speken of as the "river of the Numataunimu." The Markenzie River is known as “ Kuphñ " (great river). We fomul them also actuainted with the large nuexplored river alled "Kok" on the maps, which flows into Wainwright Inlet. They ealled it " $\mathrm{Ku}$ " (the river). The river "('ingrna," whieh is laid down on the charts as emptying into Peard Bay, was never mentioned by the Point Barmow natives, but we were intorued ly ( apt. Gifford, of th" whaler Inemiel Webster, who traveled along the coast fiom Point Barow to (ape Lisburne after the loss of lis vessel in Issi, that it is quite a eousiderable stream. He had to asemel it for abont a day's jomrney-20 miles, aceording to Capt. Hooper -betore he found it shallow womgh to ford.

\section{CLIMATE.}

The climate of this region is thoromghly aretic in charates, the mean annual temperature lwing $\&$ E., ranging trom 6.5 to - izo F. Such temperatures as the last mentioned ane, lowever, rare, the ordinary winter temperature beiug between - 20 and - 30 F., rarely rising during December, January, Felmoury, and Mareb as high as zero, and still more rarely pasing beyoul it. The winter merges insensibly by klow degrees into sumuer, with oreasional "cold slatis," and trosty nights begin again by the tst of sejotemlere.

The smo is antirely leetow the herizen at l'oint barrow for re days in the winter, beginning November [5, thongh visible by retiation a day or two later at the beginumge of this periond and a day or two earlier at the embl. The midilay darkmess is never eomplete even at the winter solstion, as the sun is sueh a short distane below the horizon, but the time suitable for ontelore employments is linited to a short twilight

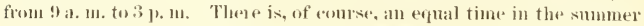




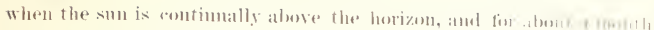
before and ater this perioul the twilight is sol bright atl uight that an stars are visible.

The suowtall during the winter is comparatively small. There a probably not more than a tiont of snow on a level any where on the latul,

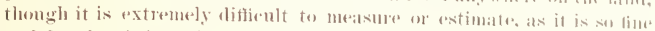
and rly that it is easily moved by the wimel and is romstantly in motion,

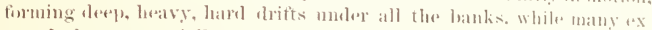

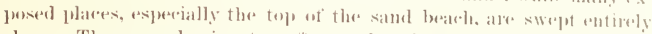
elean. The snow lesgins to sotten and melt about the first worek in

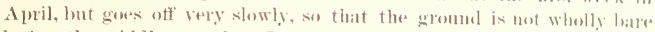

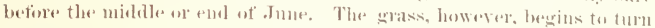

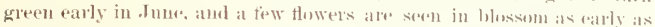
Julle 7 or $s$.

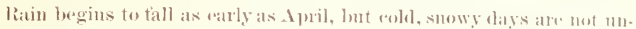

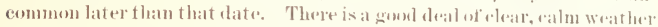
during the winter, atud extremely low temperatures are selelom atesonpanied by high wind. liolent stomes are not mucommon, however,

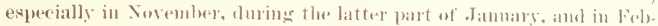

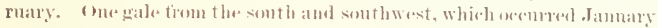

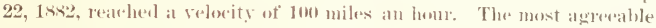

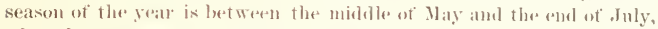

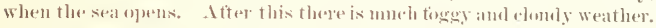

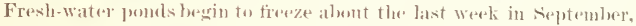

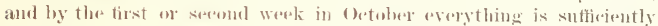
fiozen for the natives to travel with sledges to tish themgle the joe of the inland rivers. Melting begius with the thawing at the show, but the

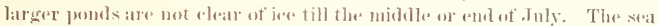
in most seasoms is permanemtly closed by tirezing and the moving in of

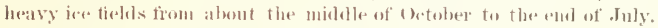

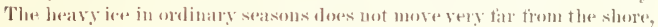

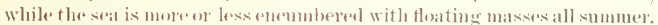

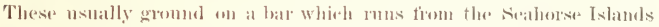
alomer the shore patallel to it and about 1,000 yalels alistant, forming a

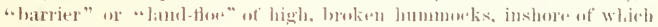

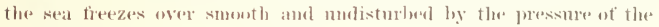
onter park.

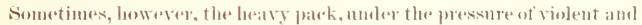
long-eontimed westerly winds, pushes across the bar and is finced up on the beach. The ies sometimes eomes in with great rapidity. The nativesintermed us that a year or two betore the station was astablisherl

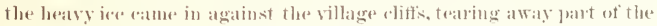
bank and destroying a homse on the edges of the rliff so smoldenly that one of the inmates, a lalrefe, stout man, was muable to escape themgh the trap-rloos and was arushed to death. (Hutside of the latud-flow the jee is

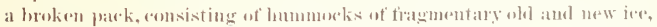

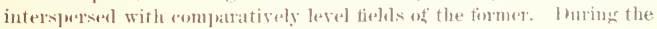


farly part of the winter this park is most of the time in motion, some. times moring notheastwad with the provailing anrent and grinding alonge the edere of the barries, sometimes moving off to sea before an ofishore wind, leaving " leads" of open water, which in ralm weather are

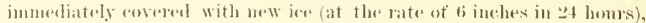
and again coming in with greater or less violence against the edges ot thisum ice, rushing and ermpling it up against the barrier. Portions of the lami-floe exent fleat off' ame move a way with the park at this seasom.

The westerly gales of the later winter, hewrever, bring in great 'puantities of ine, which, presings against the land-floe, are pushed up into

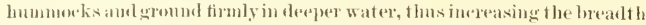
of the fixed lamd-flese mutil the line of separation between the land-floe and the moving park is for 5 or sometimes even 8 miles trom land. The hummorks of the laud the shew a temelency to arrange themselves in limes parallel to the shore, and if the pressure las not been too great there are often fields of in of the season not over 4 feet thick hetween the ranges of lommonoe ks, as was the ease in the winter of 1881-92. In the following geat, howerer, the pressure was so great that there were bo suld fields, and even the level iee inside of the barrier was crushed into hummorks in many plates.

After the wales are over there is generally less motion in the pack, until alout the middle of April, when easterly winds nsually eanse leads to open at the edge ot the laud-floe. These leads now continne to ofene and shat, varying in size with the direction and force of the wint. As the seasom advanees, esperially in July, the melting of the iee on the surface loosens portions of the lamb-floe, which float off and join the patk, lninging the leads nearer to the shore. In the meantine the level shore ice has been eut awa trom the bearlo by the warm water romming down firom the land and has grown "rotten" and tinll of holes firom the heat of the sum. By the time the outside jee has moved away so as to leaveouly the floes gromeded on the bar the inside ios brealis uj into loose masses, moving up and down with wind and current and ready to move off through the first loreal in the barrier. Pontions of the re maiuing barrier gradually break off and at last the whole finally floats and moves ont with the patk, sometimes, ats in 1sis - a very remarkable season-moving out of sight from the land.

This final departme of the iec may take plater at any time between the middle of July ant the mifllle of Angust. East of Point liarrew We had opportmoities only for hasty anel superfieial observations of the state of the ices. The land flos apjesars to form some distance outside of the sambly islands, and firm the aceonut of the matives there is mueh open water along show earty in the seasen, (ansed by the breaking up of the rivers. 13. Nimpen learned from the natives that the trading parties which lett the Point about the 1 st of July fomml open water at Dease Inlet. This is more definite information than we were able to obtain. We omly leamed that they comnted on fimding open water a few tays' journey rast. 
THE PEOPLE.

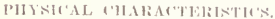

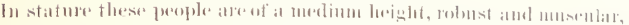

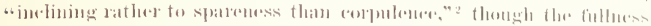

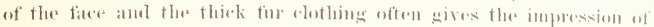
the latter. There is, howerer, ansiderable individual ratiation anome then in this respert. The women are as a rule sherter than the men.

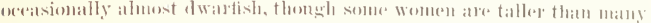

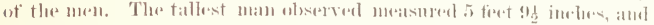

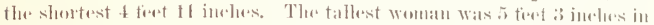

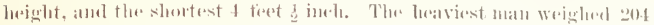

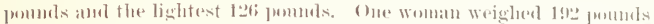

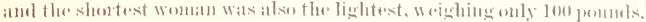

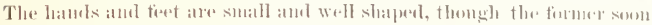

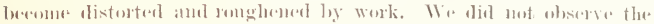

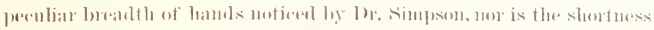

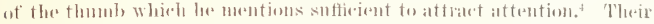

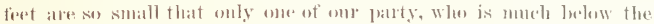
orelinary size, was able to wear the bouts mald lye the natives for theme

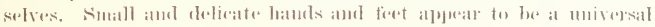

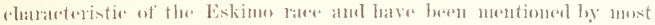

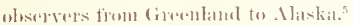

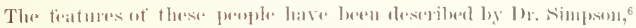

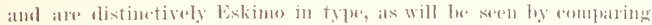

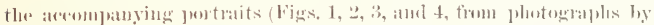

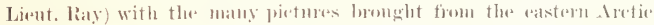

10 p. cit., p. 264 .

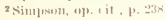

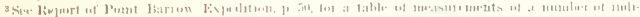

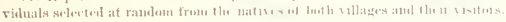

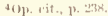

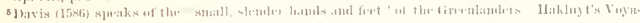

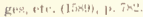

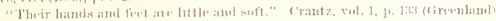

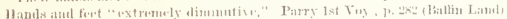

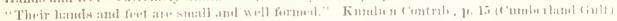

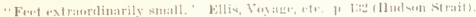

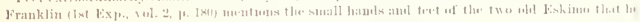

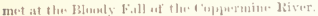

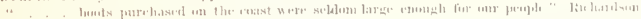

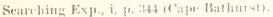

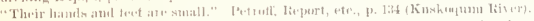

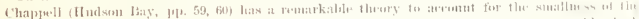

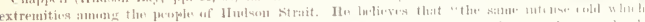

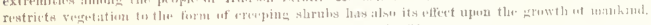

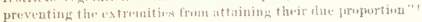

${ }^{6} \mathrm{O}_{1}$. cit., 1. 2ain.

\section{(9) Ети-3}




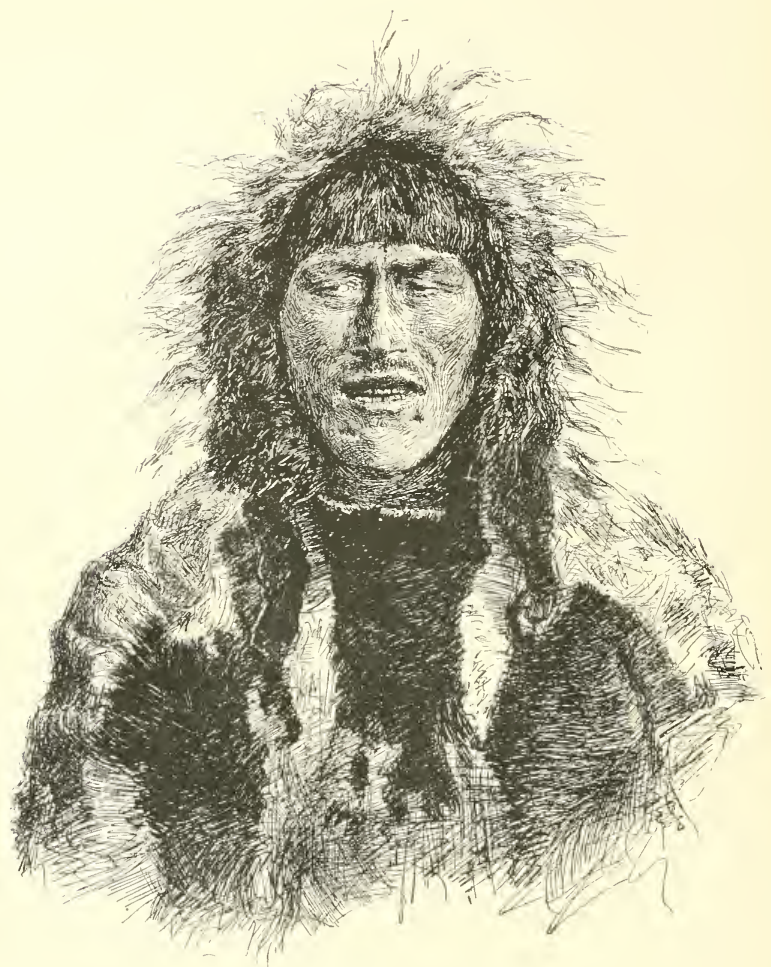

Fut. 1.- Dnalinat, a mal of Nuwük. 


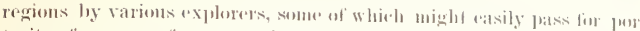

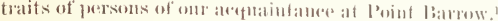

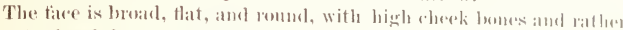

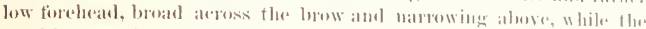
heal is some what pointed towarl the arown. The peraliar shape of the

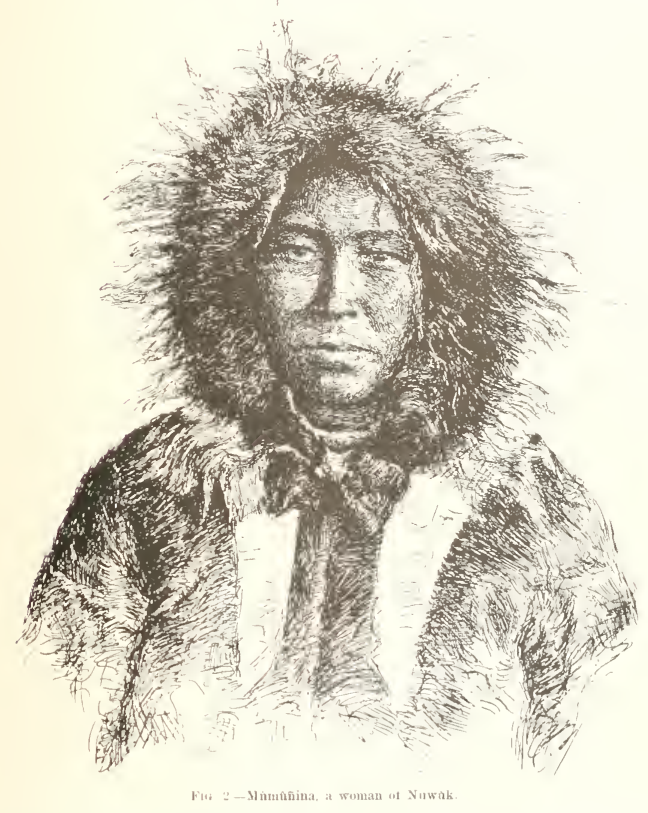

head is somerwhat masked ly the way of wearing the hair, and is best

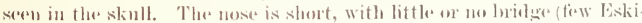
mo were able to wear our spring eye-glassess), and broul, esperially

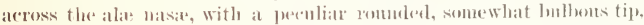

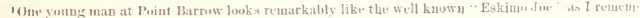
ber him in Boston in the winfer of $1862-63$. 
and lange nostrik. The eyes ane horizontal, ${ }^{1}$ with rather full lids, and

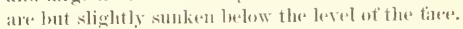

The month is large ans the lips full, espeetally the under one. The teeth are natually large, and in pouth are white and generally regular, but by midele age they are gemerally wormelown to tlat erowned stmmes, as is usual among the Eskimo. The color ot the skin is a light yethowish

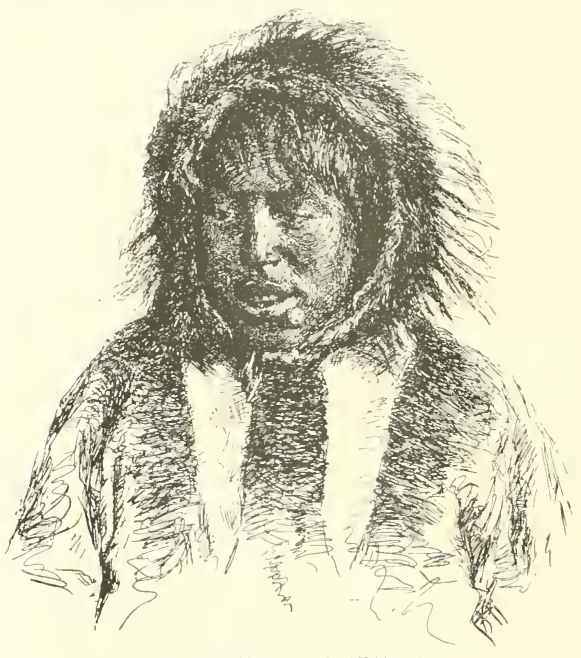

FIG. 3-A kabiama, a youth of I'thiavwนกี

brown, with often eonsiderable meldy color on the cheeks and lips. There appears to be mueh natumal variation in the complexion, some women being nearly as tair as Europeans, while other individnals seem to have maturally a coppery colon. ${ }^{2}$ In most ases the complexion appears dacker than it really is thom the effects of exposure to the weather. All sumburn very easily, especially in the spring when there is a strong reflection from the snow.

The expression of obliquity in the ryes, meutioned by Dr. Simpson (op). cit., p. 239), Aeems to me to have arben from the shaje of the cheek looses. I uay be mistaken, however, as no careful compariNons were made on the syot.

${ }^{2}$ Frobisher says of the people of Battin Land: "Their ecolvur is not much unlike the supburut countrie man." Hakluyt's Voyages, etc. (15*9), p. 627. 


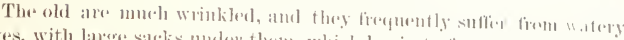

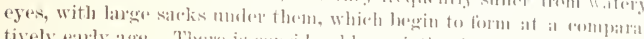

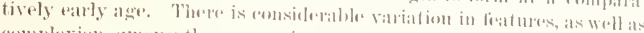

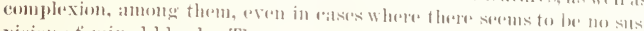

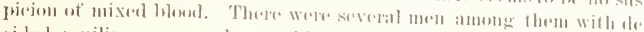

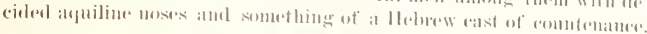

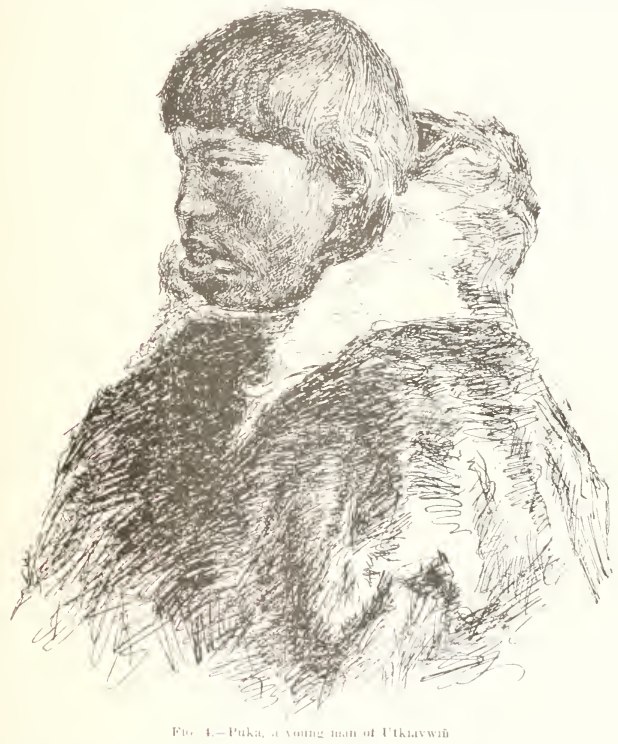

The eges arr of varioms sharles of dark hrown-two pairs of light hazel

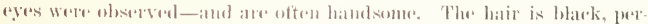

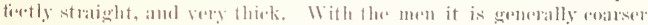
than with flue women, whe sometimes have very lome and silky hair,

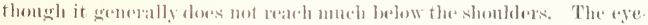

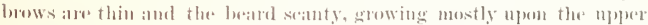

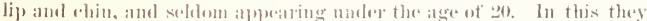
resemble most Eskimo. liack, howerest, spealis of the "luxuriant 
beards and flowing mustaches" of the Eskimo of the Great Fish River. some of the older men have ratler heary blace mustaehes, but there is much valiation in this respeet. The uperer part of the body (as mued is commonly "xposed in the lomse) is remarkably tree from lair. The general exprexsion is good homored and attartive.

The males, aven when very youmg, are remarkalse for their graceful and dignified eariage. The boly is ledel erest, with the shoulders sipuare and ehest wall thrown wht, the knees straight, and the feet firmly plated outhe gromel. In walking they move with long swinging elas tie strides, tlo tow well tomed ont and the arms swiuging.

I can not agred with I)r. Simpson that the turning out of the toes gives "a certain jecendiatrity to their gait difficult to describe." I shemld say that they walled like weel built athletic white men. The women, wii the other hand, although possessing gexol plysicfues, are singularly ungrantul in their movements. They walk at a solt of slonfling laalf trot, with the toes turned iu, the body leaning forward, and the arms latuging a wkwardly?

A noticalble thing abont the women is the remarkable flexibility of the lowly and limls, and the great length of time they ean stand in a stonping posture. (Sore Fig. J tor a posture often assumed in working.)

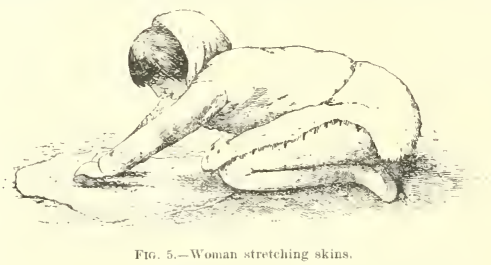

Both men and wouen have a very firir share of musenlar strength. Some of the women, especially, showed a power of earying leary loads sujerior to most white men. We were able to make no other cemparisoms of their streugth with ours. Their power of enduranee is very great, and both sexes are capalse ot making long distances on toot. Two unen sometimes spend 24 lomrs tramping thromgh the rongle iee in seareh of seals, and we knew of instances where small parties made jomeneys of 50 or 75 miles on foot without stoppring to slerejt.

The women ane not prolifie. Althomgh all the alults are or have been married, many of them are childless, aud tew lave more than two chil drem. One woman was known to have at least four, lont investigations of this sort were rembered extremely difficult ly the miversal eustom

$$
\text { Iop. eit., p, 238. 2 Cf. Simpson, op, cit., p. } 240 .
$$




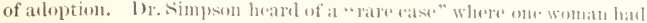

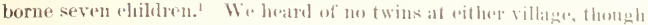
we obtained the liskino worl low twins. 1t wats imposilole to learu

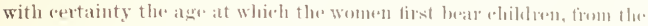

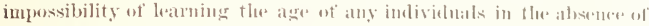
any fixed methed of reskoning time. Ine simpente states that they do

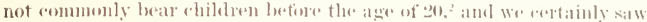

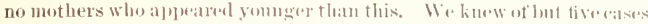

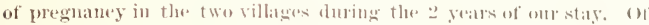
these, one suffered miscanciage, and of the other foms, muly two of the infants lived more than a slent time. It is axereclingly diftionlt, tere the reasons stated above, to form any extimate of the age to whirh these people live, thomglo it is natmal to suppose that the arduoms and ofters

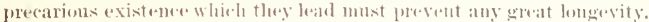

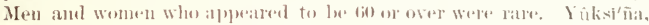

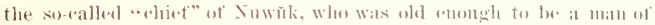
considerathe influene at the time the Plorer winteresl at P'oint barrow

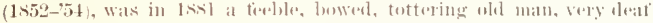

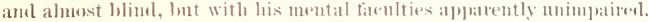
Gray hair appeatre mommons. Even the oldest are, as a rule, but slightly gray.

\section{P.ITHOLOTYY.}

Diseases of the respiratory and digestive organs are the most freguent

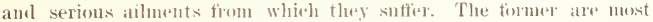
prevalent towatel the alu of summer and early in winter, and are lowe

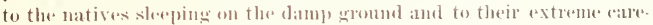
lessness in exposing themselves to slatits of wind when orerletated.

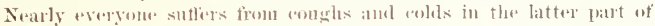

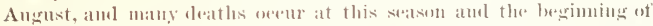

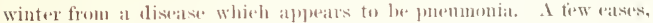

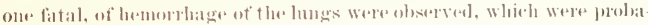
bly atgaravated by the nuiversal habit of inhaling tobaren smoke. The

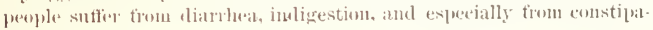
tionl.

Gonorrhea appear's common in both sexes, hut syphilis seems to be unkuown in spite of the promisenoms intereonse of the woment with the

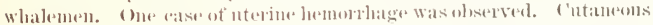

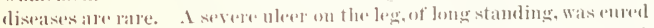

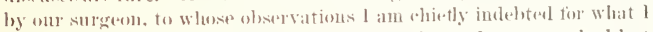

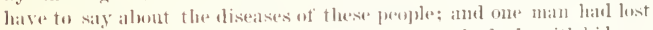
the eartilalue of his nose and was matked all oree the lody with hideous

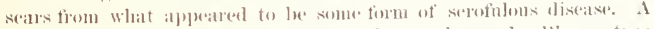
single rase of tmuor on the deltojel musele was observed. lihematism

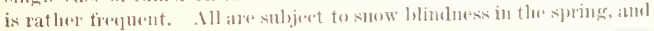

$$
\text { upp.cit., p. } 254 . \rightarrow \quad{ }^{2} \text { Op.e.24. p. } 254 .
$$


sores on the far from ueglected frost bites are common. Many are blind in one rye from what appears to be rataract or leneoma, lnit only

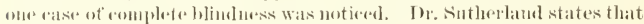
he does not recollest a single instance of total blindness amomg the

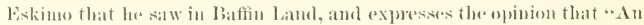
indivilual in such at state would be equite untit tor the life of toil and lamelipip to which the hardy Esennimanx is exposed. The neghet consefpent upon this helpless condition most probably ents of its afflicted objecets. $" 1$

This sesms cfuite reasonable on a priori gromods, lut nevertletess the bliml man at caje. smyth had lived to midule age in very eomtortable rireumstaures, and thomgle supperted to a great extent by his relatives he was nevertheless able to do a rertatin share of work, and hat the reputation of being a gored paddler tor a whaling momiak.

lnjuries are rare. Our matn lad lost both fiet at the ankle and moved

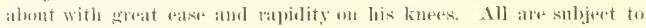
blecoling at the mose and usually phig the bleeding nostril with a lomedh of demer latir. ${ }^{2}$

This habit, as it has been termed, of viearions hemorrhage serms to be alatareteristie of the Eskimo rane wherever they lave been met with, and has been snpposed to be a process of nature tor relieving the finlluess of the cireulatory system ramsed by their exclusively animal eliet. ${ }^{3}$

Natural deformities and ahormalities of strueture are mneommon, except stralsismms, which is common and often, at least, mongenital. One boy in Ltkiavwion lat his formlead twisted to one side, probaloly trom

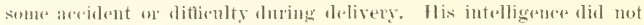
serem to be impared. The people are, as a role, right handed, but that

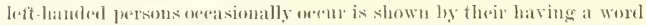
for a lefthameler mam. We also collected a "rooked kuite," fitted tor use witls the left hand.

\section{PSYGIIGAL 'ILARAGTERISTIE'}

As a rule they are quick-witted and intelligent, and show a great

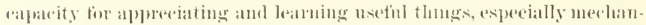
iral arts. In disposition they are light-hearted and rheertul, not casily ast down by sorrow or misfortume, and thomgl sometimes quick-tempererl, their anger seldom lasts long.s They later a very keen sense of lumor, and are foncl of practical jokes, which they take in good part,

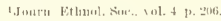

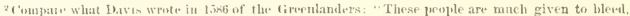

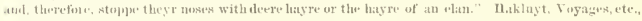
1.ik!1, p. $7 \times 2$.

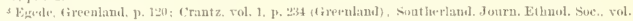

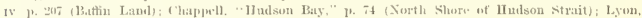

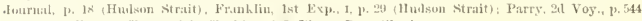

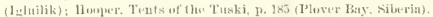

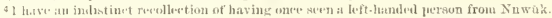

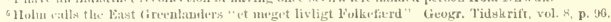




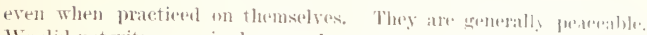

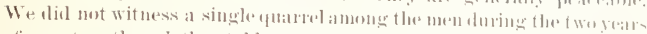

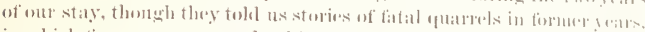

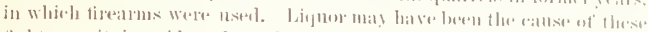

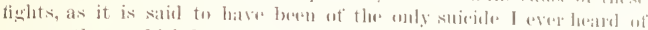
amonge them, which 1 am intirmed by (apt. E. E. Sunth, the whalling

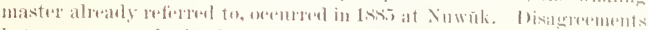

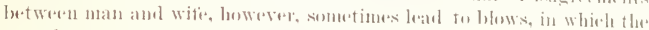
man dees not al ways get the leset of it.

When the station was first estadslisherl miny of the natives lewan

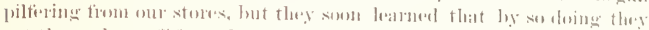
cut themselves off forn the privilege of visiting the station and enjoging

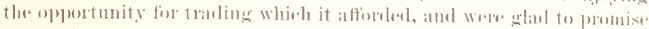

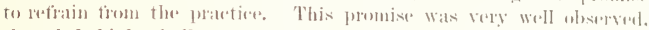
though I think wholly form terelings ot selt-intelest, as the thieres when

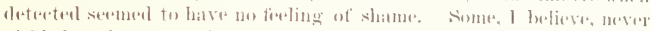
yieleled to the temptation. There was selelom any dithenlty in obtaining

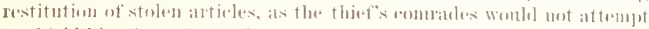

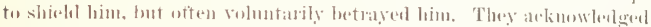

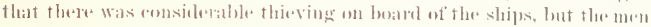

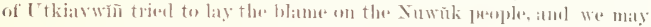

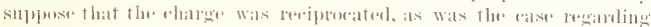

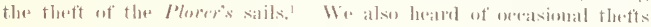

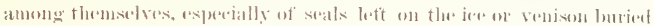

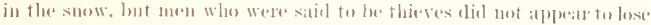
ally ser.ial (o) sidelation.

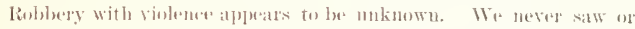

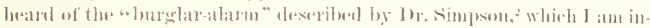

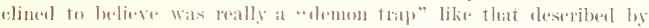

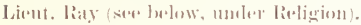

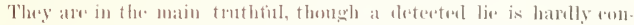

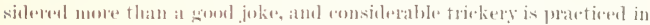
traling. For iustatuen, som after the station was extablishol they

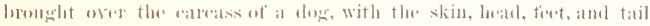

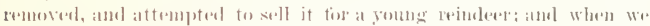

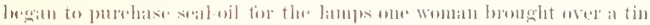

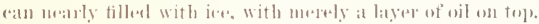

Clothing and other anticles mate espertally tar sile to lts were often

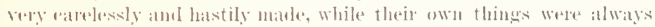
airnfinlly tinislied.

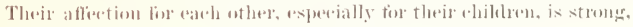


thomgh they make little khow of griet tor hereavement, and their minds are easily diverted by amusements. I am inclined to believe, however,

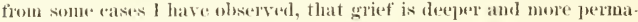
nent than superficial appearaness would indieate.

Their ruriosity is unbounded, and they have no hesitation in gratifying it by unlimited rpestioning. All who have read the adeounts of the Eskimo eharacter given by explorers in other partsof the Aretie regions will recognize this as a familiar trait. We also fomed the habit of begging at first guite as offensive anomg some of these jeeple as other travelers have foumd it, but as they grew better acquanted with us they ceased to beg except tor trifling things, sneh as a dhew of tobacen or a matelh. Some of the better dasis nerer begged at all. Some of them seremed to feel truly gratetul for the benefits and gifts received, and endeavored ly their general behavior, as well as in more substantial ways, to make some adequate return. (Others appeared to think only of what they might receive.

IIospitality is a miversal virtue. Many of them, from the beginning of om aecpuantane with them, showed the greatest triendliness and willinguess to assist us in every way, while others, espreially if there were many of them together, were inclined to be insolent, and knives were oreasionally drawn in sndelen fits of passion. These "ronghs," lowever, soon leared that behavior of this sort was pmisded by jompt ostracism and threats of severer discipline, and before the first nine months were past we hat established the most friendly redations with the whole village at (ape simyth. Some of those who were at first most insolent berame atterwards on best triends. Iiving as these people do at peace with their neighlors, they would not be expecterl to exhibit the fieree matial anrage of many other savages, but bold whalemen aud venturons iee-lnuters can not be said to lawk bravery.

In their dealings with white nen the rieher and nore influential anoug them at least ronsider themselves their eyuals if not their superiors, aud they do not appreciate the attitude of arrogant superiority adopted ly many white men in their intereomre with so-ralled savages. Many of them show a graee of mamer and a natural delisacy and polite. ness which is quite smprising. I lave known a young Eskimo so polite that in eonversing with Lient. Ray lo would take pains to misprenounee his words in the same way as the latter did, so as not to hurt his feelings by eorrecting him bluntly.

TRIBAL PIIENOMENA.

We were unable to discover amomg these people the slightest trace of tribal organization or of division into gentes, and in this onr observations agree with those of all who have studied the Eskimos elsewhere.

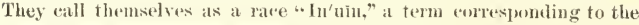

'Compare Fega, vol 1. 13. $\$ \times 9$. The ('lukches were "so courta-ous as not to correct but to adopt the mintakes in the pronunciation or meaning of words that were mide on thes Vega." 


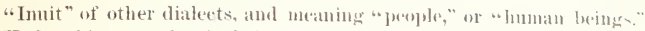

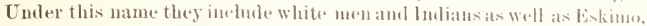
as is the ease in Grendind and the Hatengis River distriet, and prot, ably also everywhere else, though many writers have supjosed it to be applied by them only to their own race.

They have however special hames tor the former fwo rates. The jeople of any village are lonow as " "the inhabitants of suel and suels

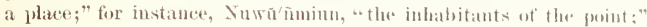

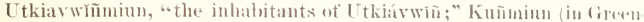
landie "Kungmint"), "the preople who live on the rivere" The [x+opte.

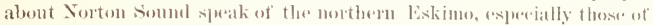

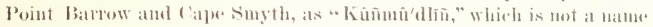
derived from a location, lut a solt of nicklome, the meaning of which was not aseretained. The Point barrow natives do not eall themselves by this name, but apply it to those people whose winter village is at

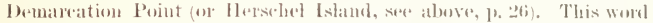
appears in the corrmpted form "Kokmullit," ats the name of the village at Nuwük on Petroff's maj). Petroft' derived his information regateding the morthern roast at seconel-hamd from people who had obtained their knowledge of names, etr., firom the natives of Nortou somd.

The perple of the two villages under consideration frepuently go barkward and forward, sometimes lemoving permanenty fom one village to the other, while strangeres trom distant villages sometimes winter here, so that it was not metil the end of the serond year, when we were intimately aefpuinted with everylody at Lthiawiñ, that wa comld form anything like a correst estimate of the population of this village. This we found to be alont 1 to souls. As well as we eould judge, there

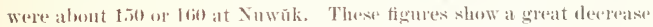

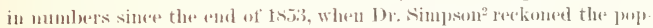

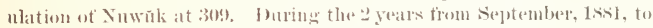

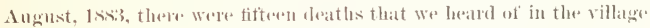

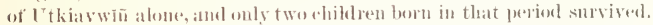
With this ratio betweren the number of births and deathe, even in a

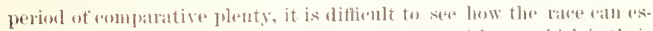
eapes sperly extinction, unless by acessions from without, which in the isolated situation they are not likely to receive. ${ }^{3}$

SUTAL STRRUTDINGS.

$$
\text { COXTUCT WITH INCIVILES PEOPLE. }
$$

Other Eskimo.-The nearest ueighbors of these people, as has beem stated alove, ale the Eskino living at Demareation Point (or Herselhel

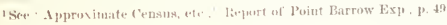

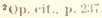

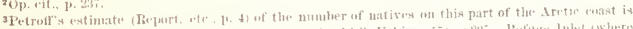

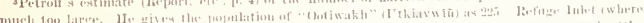

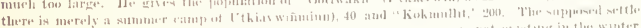

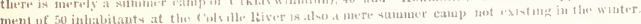


Island), wastwarl, and those who inhabit the small villages between

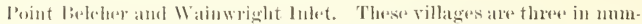
ber. The nearest to Peint lielelese, Nomatria, is now deserted, and its

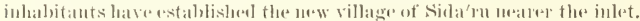

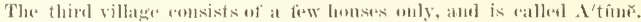
The preple of these villages alde so closely commeded that they are some-

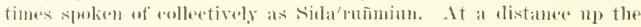
river, which flows into Wainwright lnlet, live the Kn'ñmim, "the peo-

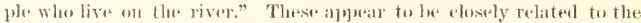

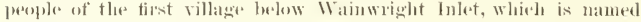
Kilanwitawrio. At any late, a jalty of them who rane to Capes smyth in tle spring of Iss:3 were spolen of indiflerently as Kunmin or Kil-

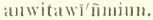

Sinall parties trom all the villages oesasionally visit Point Barow louing tles winter tor the purjose of trate and anmsement, traveling

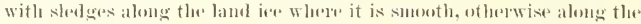
atger of the eliffs; and similar parties fiom the two northern villages

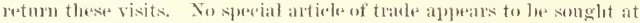
either village, though perhapes the sontheren villages have a greater smplyly of skins of the bearderl seal, fit for making mmiak coters, ats I

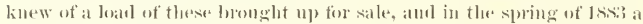
party went down to the inlet in searely of snclt slins. Niugle families aud small partios like that from Kilauwitawin, mentioned alowe, sometimess spend the whaling season at Point Barrow, joining some of the whaling cress at the morthern villages. The perople that we saw from these seftlements were very like the northeren Exkimos lant many of them spole a peresptibly harsher dialect, somoding the final comsonants distinetly:

The jeople at Pont Ifope are known as Tíkera'ñminn "inhabitants of the foretinger (Point llopes), and their settlement isoreasionally visited by strageling parties. No natives from Point llope rane north during tle "2 years of our stay, but a palty of them visited the Plorer

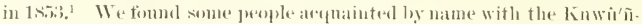
mim and Silawionnim of the kinwik (Kowak or "Plutuam") aund silawik liver's emptying into Ilotham lulet, and one man was familiar with the name of Sisualiñ, the great tralling (amul at Kotzelome somel. We

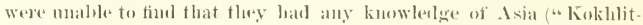
mma,") or the Siberian Eskimo, Int this was probably dhe to lark of properly diresterl infuiries, ats they seen to have been well informed on tles sulyowt in the Plorer's time.?

Witli the people of the No'natak (Inland) Biver, the Nunatanmim, they are well aryuainted, as they mos them erery summer for purposes of trading, and a family or two of Numatañmin sometimes spent the

\footnotetext{
1 Maguiru, XW. Passage, p, itst.

${ }^{2}$ It is to la merrettul that the expedition was not supplieal with a copy of Dr. Simpson's exeellent paper, as much valuable information was missed for lack ol suggestions as to the direction of inquiries.
} 
winter at the mentlern villages. One lismily winterest at Numbli in

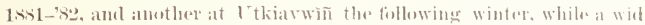
ower of this "tribe" was also settled? thete for the same wintere having

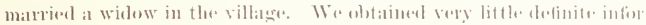

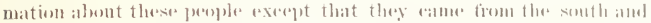

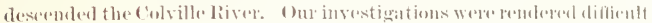
by the engrosing nature of the work of the station, and the fremshe

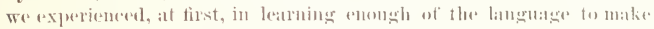

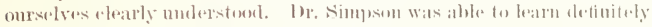
that the homes of these presple are on the Numatak and that some of them visit Kotzelne semel in the smmmer, while trading parties make a portage between the Sumatik ame colville, deseromeling the latter

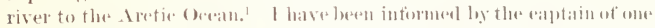
of the Ameriean whalers that he has, in ditherent seasems, met the same

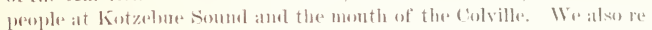
ecived articles of siberian tame reinderer skin fiom the east, which must

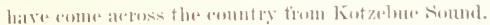

These people atitier from the morthern natives in some habits, which will be deseribed latere and spatk a harsher dialert. We were informerl

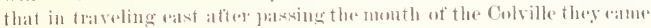
to the Kûnut'd

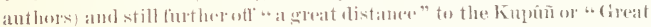

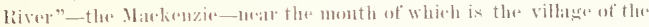

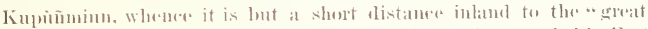

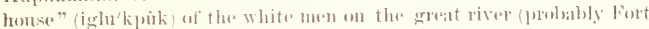

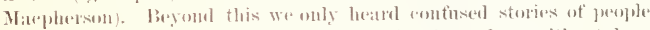
withent posteriors and of sledges that run lye themselves withent dogs

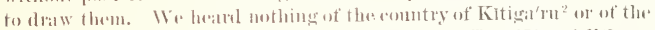
stone lamp comutry mentioned by br. Simpson. ${ }^{3}$ The Kinñmulliñ are pobahly, as 1)1. Simpson believes, the people whose winter houses were

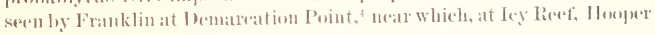
also salw a low homsess.s

As alrealy stated, (ablt. E. li. Smith was informed ly the natives

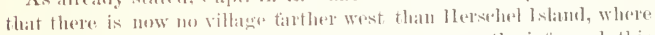

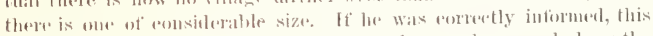
unst be a new village, sime the older explorers who passerl along the

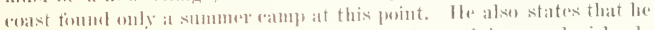

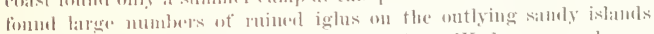

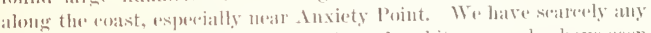
information alount these proplele, as the only white men who have seen them had little intereomse with them in passing aloug the coast. ${ }^{6}$ The

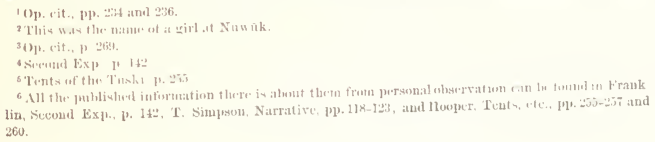


Point barrow people have but slight acquaintance with them, as they see them only a short time each summer. Captain Smith, however, informs ne that in the summer of tistis one boat loal of them rame larek with the Point Barrow tratlers to Point Barrow, where he saw them on boatrl of his ship. There was a man at Jtkiavwiñ who was called "the

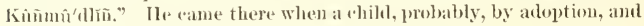
was in no way distinguishable from the other pesple.

father Petitot appears to include these people in the "Tapeopment"

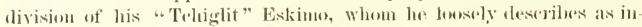
habiting the coast from Herseluel Istand to Liverponl Bay, inclubling the delta of the Iarkenzie, without loeating their fremanent villages. In anotler plate, howarer, he exchules the "Tapienoment" firom the "Trhiglit," saving, " Dans l'omest, les Tehiglit rommmoniquaient avee

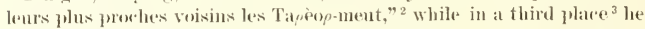
gives the country of the ". Trlighlit" as extending form the coiplermine River to the Colville, and on his mal in the same volume, the "Tareor-

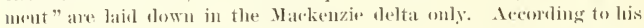
own areount, lowever, he had no jersmat knowledge of any Exkimo west of the Mardingie delta. These people molombtedly have a lowal nam. derived from that of their winter village, lut it is yet to he larmed.

It is possible that they do consider themselves the sane people with the Eskimo of the Matekenzie delta, and eall themselves by the gereral name of "Ta/sopment" (= Taxaiomim in the toint Barlow dialest), "those who live by the sea." That they do not "all themselves "Kiñmuntliñ" or "kammali-enyum "or " kimgmaligment" is to my mind

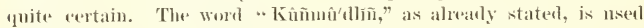
at Nortom Somul to desiguate the perople of Point Barrow (1 was

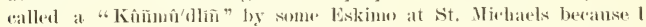
spolse the Point barmo dialect), who do not resognize the name as belomging to themsedves, but have transtiered it to the people muler con-

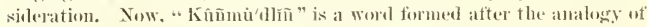
many Eskimo words from a noun kînme and the athix liñ or allin (in (irenlandic lik), "one who has a __." The radical nom, the meaning of which I can mot ascertain, wonld become in the Markenzie dialect koagmak (using Petitot's orthograjhy), which with lik in the phural would make kpagmalit. (Areording to Petitot's "Grammaire" the plural of -lik in the Mackenzie dialest is -lit, and mot - grdlit, as in Green lanchic). This is the name given by Petitot on lis maje to the people of the Anterson liver, ${ }^{4}$ while lue ealls the Anterson River itself Kaganalik. ${ }^{5}$ The father, however, had but little jersomal knowledge of the matives of the Anderson, havisg mate lust two, apparently brief, visits to their village in 1865 , when lie first made the acenaintame of the Eskimo. Ile afterwarels became farly intimate with the Exkimo of the Mackeuzie

\footnotetext{
1 Monographie, p. x1.

${ }^{2}$ Ibid, p. xvi.

${ }^{3}$ Burll. de la société de Geographio, 6r nér., vol. 10, p. 256

s Sern also Mlonographie, etc., p. xi, where the name is spelied $\mathrm{K}$ pamatit

${ }^{2}$ Vocabulaire, otct p. 76 .
} 
delta, parties of whom spent the summers of listig and lsio with him. From these parties he appears to have obtained the greatere pant of the

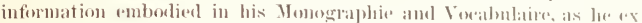
plicitly states that he bromglit the last party to linet fimol llope

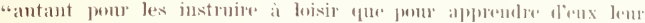
jeliome." 1 Nothing serems to me more probable than that he learmed from these Marekenzie people the mames of their urighbors of the Amber sem, which he had tailed fo olotain in his tying visits.j years betione, andel

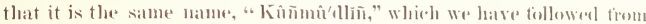
Sorten somol and tomul always applied to the people just loyoud us. Combl we learu the meaninge of this word the puestion might be setthel.

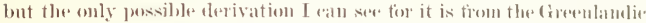
Karmak, a wall, which throws no light apon the suljeet. Peditot malls the prople of Caje liathurst Koagmaliveit, which alphars to mean

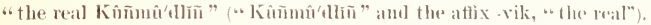

The Kupañminu alpear to inhahit the permanent villages which latve beren seen near the western menth of the Markenzie, at slomgle Point ${ }^{2}$ and Point sabine, with an ontlying village, supjosed to be desertend, at Point Kity. They are the matives deseribed by Petitot in his Monesgraphie as the Taresement avision of the Telighlit, to whem, from the

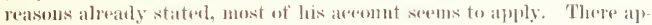

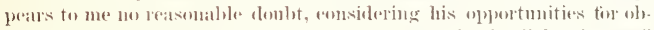

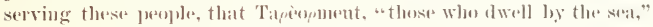

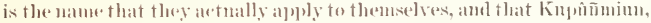
or Kopaymut, "those who live on the (Heat River," is a name bestowerl upon them by their meighlors, perlaps their western moghloms alone, sines all the refereneses to this name serem to be traceable to the authority of 101 . Simpsom. Sleould they apjly to themselves a name of similate meaning, it would problably be of a different timm, as, according to

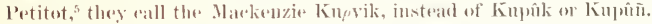

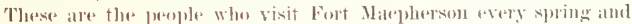
sunumer, ${ }^{6}$ and ale woll kuewn to the lludson bay traders as the Mate-

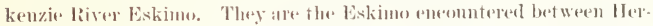
sche] Islant and the mont lo of the Markenzie lyg Franklin, by Dease and Simpono, and ly llogere and Pullen, all of whom have published brief notes rencerining theme.

We are still somewhat at a loss for the projere local names of the last

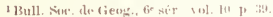

'T. Simpmon, Xirrative, v. 112

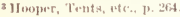

41bid, p. :-5is.

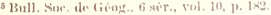

6. Potitot, Monographis, ote, pp. vvi ind $x x$.

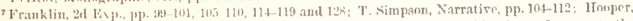

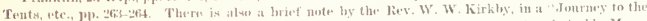

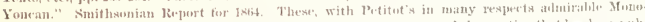

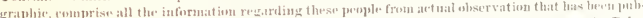

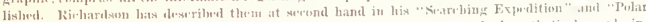

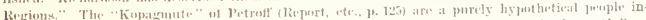
vented to till the space between "the cost pojle iu the north and the $\Delta$ thabascans in the south." 
labret-wearing Ekimo, those, namely, of the Anderson River am Cape Bathust. That they ane not eomsidered hy tlee Tapiedyment as belonging to the same "tribe" with themselores is evident from the names

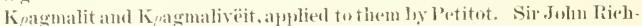
ardson, the first white man to eneomiter them (in 1s:6), says that they ralled themselves "Kittr-gatrue-the," and the Point Barrow jeople told 1). Simpsom of country ralled "Kit-te-ga'-su" beyond the Mate-

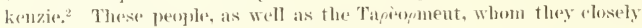
resemble, are lescriber in t'etitot's IIomographie, and brief notires of them ane given by sir Joln Rirhardson," Mrelure, Armstrung, and Jlonerer. ${ }^{6}$ The arts and industries of these people from the Markenzie to the Anderson, esporcially the latter regriom, are well reprexented in the National Mnsemu by the collections of Messis. Kemieott, Ross, amel

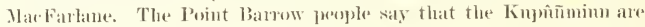
"bal;" but notwithstanding this small parties from the two villages oreasionally travel east to the Markenzie, and spend the winter at the kupinminn village. Whence they visit the "great house," retmrning the following season. Sinele a party lett Point Barrow June 1.5, 1sine, lowaring their intention of going all the way to the Markenzie. They returned Angust 25 or $26,1 \times 4,3$, when we were in the midst of the confusum of elosing the station, so that we learnesl no details of their jomrney. I letter with whish they were intrusted to be tiorwarded to the

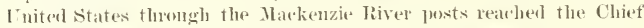
Signal Officer in the stummer of $1 \times 53$ by way of the Rampart llouse, on the Porenpine River, whence we received an answer by the bearer from the faretor in eharge. The Eskino probably sent the letter to the Ram. part tlouse by tha Indians who visit that post.

The intereourse between these people is purely commereial. Dr. Simp. son, in the paper so wt ten quoted, gives an execllent detailed deseription of the course of this trade, which agrees in the main with om observations, thomgh we did not learn the particnlars of time and distance as areurately as le did. There bave bern some important ehanges, low ever, since his time. A small party, perbajes five or six fimilies, of " Nunatañminn" now come every summer to Point Barow about the end of July, or as soon as the shallow bays along shore are open. They estab. lish themselves at the smmmer eamping glomm at Pernys, at the south. west corner of Elson Bay, and stay two or three weeks, trading with the natives and the slips, dameing, and sheoting dueks. The eastward-bound parties seem to start a little earlier than formerly (July 7, 18,5, July

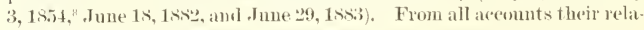

1 Franklin, 2d Exp., p. 2u:

z 1biai, 17. 269.

3. Fraklin, 2d Esp., pp. 193, 203 and 230; Starehing Esp., and Polar Regions, 1. 300.

4 N. W. Pasiage, pl. Xit.

I'tramal Sarrative, p. 176.

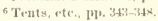

7 ('ompare what Petitat has to say-Monograplie, ete., p. xili and passim-abont the turbnlent and

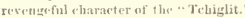

${ }^{5}$ Ur, simpson, op, cit. p. 264 


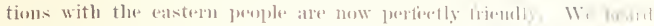

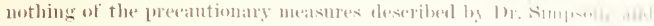

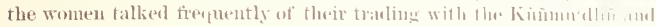

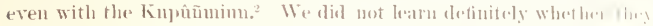

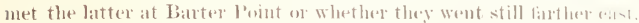

Some of the l'oint barrow parties do not go cast of the ('olville. The

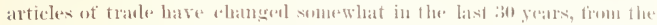

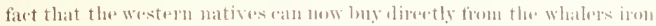

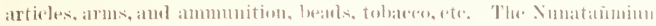

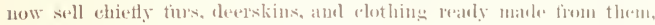
wonklenware (burkets and tubs), willow poles tin setting nets, and some. times fossil ivory. The doublededged siberian kuves are no longer in

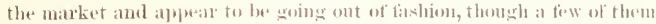
are still in use. liealy-mate stone articles, likit the whetstomes mentioned by lor. Simpsom, ale ramely, it ever, in the market. We disl mel

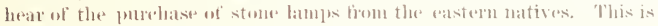
probably due to a cessation of the demand tor them at loint barmo. owing to the falliug off in the proululation.

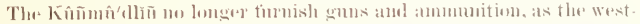

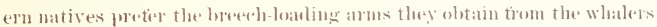
to the flintlock guns sold by the lludson liag ('ompany. The trate with these people serms to le almost entirely tor furs and skins, notally black and reel tox skins and wolverine skins. Skins of the nawhal or belugal are no longer mentioned ats important articles of trade.

In returu tor these things the western natives give seatlokins, ote. especially oil, as formerly, thomgh 1 believe that very little. it any, whalde bone is now rarried east, sine the natives pretin to sare it tor tranling with the ships in the hope of gerting lichor, or arms ancl ammunition, and valions articlesof Aneriean manutiuture, heals, kettles, ete. I was told by an intelligent native of I thiavwiñ that brass kettles were highly prized by the Kuptum ine skins, there blateli foxskins, or five leyl ones. Hhe woman was anxions

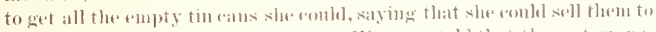

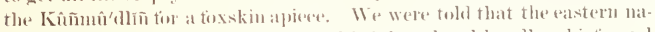
tives ware glat to buy gum thints ame bright-rolored handkerehiofs, and that the Nonatanumin wanted hlambets anul playingeands.

Indions.-They informed us that east of the C'olville they sometimes met "Itkathliñ," people with whon they could not converses, but who were frisully and trated with them. luying oil for tox skms. They

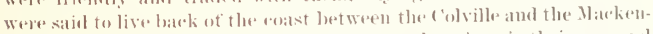
zie, and were described as wearing no labrets, but rings in their eats and boses. They wear their hat lowg, do wot tomstore the erown, and are dresset in jackets of skin with the hair removerl, without lowels, and

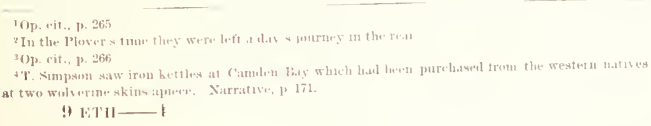


ormamented with beads and fringe. We saw one or two such jackets in Ttkiaviñ apparently male of meose skin, and a few pomelese of the same material, highly ormanented with beark. They have long flintlock guns, white man's woolen pipes, which they value highly, and axes-not adzes- with which they "break many trees." W. casily mulerstond trom this descliption that ludians were meant, and since war geturn I have been able to iclentity one or two of the tribes with tolerable entainty.

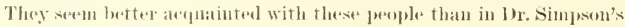
time, and know the word "kütehin," peeple, in which many of the tribal namesend. We did not lear the names Ko'fukan or Itkalya'ruin which 10r. Simpson heamed, alparently from the Numatañmim.' I hearel one natu s]erak of the Kunteha Kutchin, who inhabit the "Yukon fiom the Birch River to the Kot lo River on the east and the Poreupine liver on the north, ascendiug the littere a short distance."

()ne of the tribes with which they have lealings is the "Rat Indians" of the Hulson Bay men, probably the Vuuta' Kätehin, from the faet that they visit Fort Yukno. These ane the people whom (anpt. Masuire met on his unsmeessful sledge jomrney to the east ward to communieate with Collinson. The Point Barrow people tolul us that "Magwa" went east to see "Colli'k-sina," but dol not see him, only saw the Itkûlliin. Collinson, suealking of Maguire's second winter at Point Barrow, says: "In attempting to prosecute the searde easterly, an armed body of lmelians of the Kognkun tribe were met with, and were so hostile that he was compelled to return." Waguire himselt, in his ofticial report, speaks of mesting fon Indians who had tollowed his party for several days. He says nothing of any lostile demonstration; in fict, satys they showed sigus of disappointment at his having nothing to trate with them, but his Eskimo, he says, called the'n lioynkm, which he knew was the tribe that had so barbanom momelesed Lient. Barnard at Nulato in 1s.51. Moreover, earh Ludian hat a musket, and he had ouly two with a party of eight men, so he tlonght it sater to turu back. However, he seems to have distributed among them printed "information slips," which they inumediately earried to Fort Yukon, and returning to the coast with a letter from the elerk in chatge, delivered it to Capt. Collinson on board of the Enterprise at Barter Islaud, July 18, 15.5. The letter is as tollows:

Fort Yoleon, June 27, 1854.

The printed slips of pruper delivered hy the officers of H. Y. S. Plover on the 25 th of April, $1 \times 54$, to the Rat Indans were reretvert on the 27 th of June, 1854, at the Hutson Bay Company's establishment, Fort Yoncon. The Rat lnelians are in the

\footnotetext{
1... The inland Eskimo also call them Ko'yu-kan, and divide them into threesections or tribes. * * One is called I't-ka-lyi [apparently the plural of ltkfullin], * * the second It-kal-ya'-ruin [different or other Itkidliñ ], " op. cit., p. 269.

${ }^{2}$ 1 all. Cont, to N. A. Ethn. vol. 1. p. 30, where they are identitied with lthalyarnin of simpson.

${ }^{3}$ Ibikl., $\mathrm{p}, 31$.

4 Aretie Papert. 13. 119

s Further pitpers, ete... 10p, 905 et secy.
} 


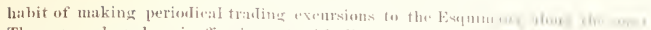

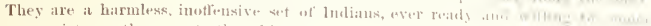
any assistance they can to the whites.

Wis. Lation Hation

l lith nownons.

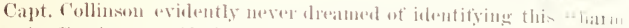
less, inoffensive set ot luelians" with " all armed borly of Indians of the Kogukun tribe." It is impurtant that his statement, quoted above,

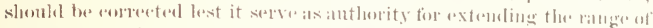

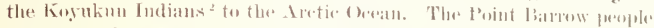

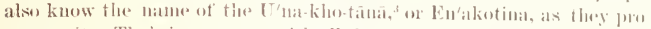

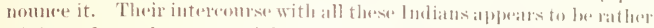

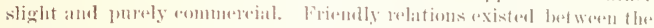

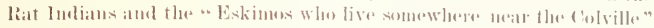

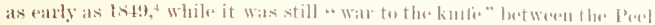
River Lndians and the Kun

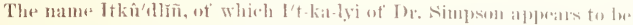

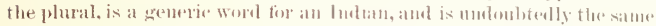

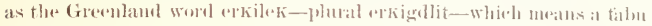

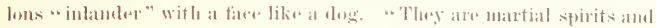
inhmman foes to mankind: lowerert, they only inhabit the ast side of

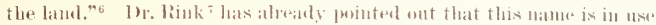

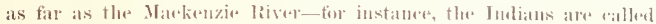

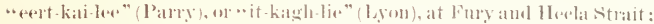

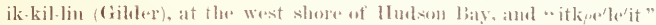

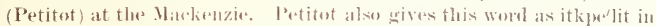

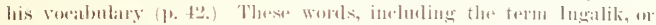
In-ka-lik, alppliod by the natives of Sorton Somel to the Indians, and

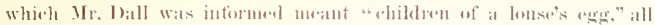

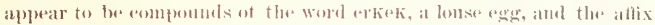
lik. (I suspert elkilak, from the firm of its plural, to be a cormption

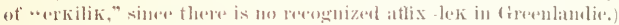

Petitot ${ }^{9}$ gises an interesting trantion in reaghel to the origein of this

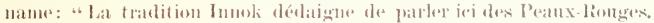

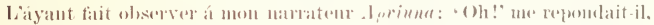

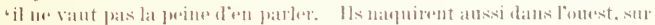

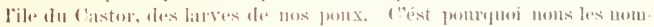
mons ltke'le'it."

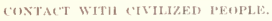

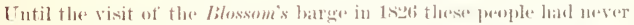

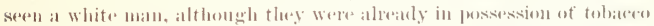

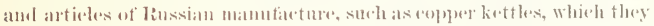

\footnotetext{
Aretic Patuers. 1. 1.14

4'inutz, wi 1, j, sho

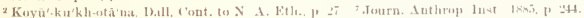

3 Ibid., 1, $2 k$.

4 Hooper, Tents, atc., 1), 276.

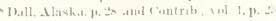

yougraphe, p. xxy.

- Ibili., 1. 273 .
} 
hat olotained from siberia by way of the Diomedes. Mr. EIson's party

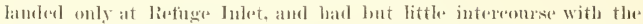

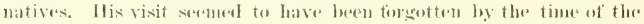
Plocers stay at Point liarow, thomgh 10r. simpson found people who rerelleeted the visit of Thomas simpsom in 1s:3. The latter, atter he had left the boats and was proseding on fiest with his party, first net the Nuwñnmim at l'oint Tangent, where there was a small party en-

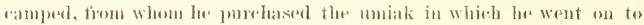

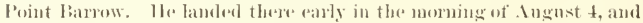

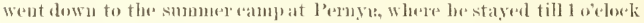
ju the afternoon, trading with the natives and watehing them danee. (1) lis return to Point Tangent some of the natives atoompanied him to loat lixtereme, where he parted from them Ingust 6, so that his whele intereomse with them was continesl to kess than a week. ${ }^{2}$

The next white nen who lanted at leoint lamew were the party in the Plorer's boats, under Lients. P'ullen and llooper, on their way to the Markenzie, and the erew of Mr. Sheddom's yatht, the Nancy Inerson, in the summer of ts 19 . The boats were from duly 29 to Anghat 3 getting from Cape smyth past Point banow, when the rems were ashore for a aouple of days and did a little trading with the matives, whom they found very friendly. "They afterwads had one or two skimishes with evil-disposerl partics of Nowñmiun retuming fiom the east in the neighbohlowd of Return Roef. The "xphoring ship Enterprise and Investiyutor also had casmat meetings with the natives, who reariven tobaceo, ite., tirom the ships.

The depot ship Plorer, Commander Maguire, spent the winters of

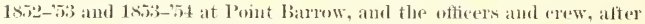
some mismulerstamdings and skirmishes, estallished very triendly and soriable relations with tles natives. The ouly pullished areomisof the Plorer's stay at l'oint Barrow are Commander Magnire's ofticial reports,

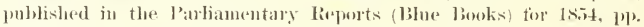

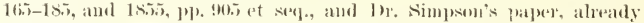
mentioned. Maguire's report of the first winter's procesedings is also published as an appendix to sherard (1shorme's " Diseovery of the North. West l'assage."

We foumd that the elder natives rememberes Magnim, whom they called " Magwa," very well. They gavens the manes of many of his peo-

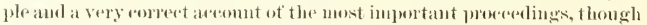
they did not make it clear that the death of the man mentioned in his report was aroidental. They described "Magwa" as short and fat, with a very thiek mese and all seemed very much inmessed with the height of his first lientenant, "Ejo'ana" ( lemon,) who had "lots of gums,"

It was diftienlt to see that the Plorer's visit had exerted any permanent influenes on these people. In tiet. Br. Simpson's areount of their habits and enstoms would serve very well tor the present time, except 


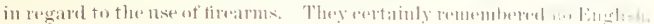

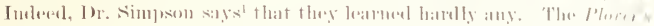

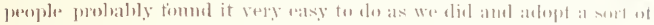

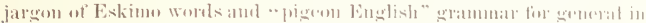

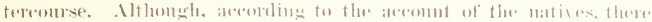

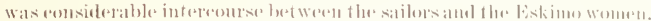

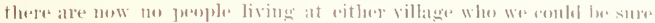

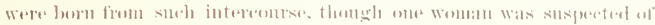
being half English. She was remarkahle only tor lore large huild. anul

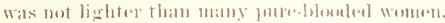

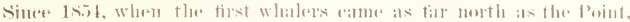

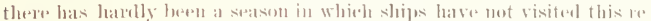

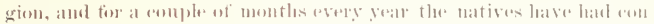
siderable interoutese with the whites, going oft to the shipe to trate.

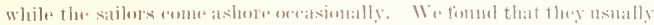

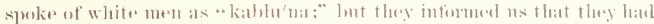

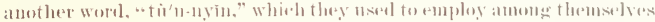
when they saw a ship. Ir. Simpson salys that they learmel the word

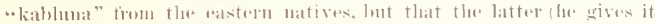

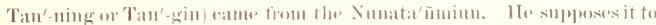
apply to the laussiaus, whe had regulat bath days at their posts, and

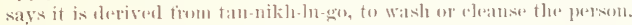

The ehiet elange pesulting trum their intereourse with the whites has

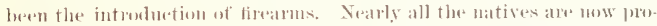

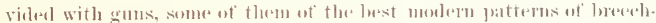

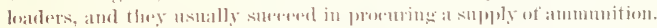

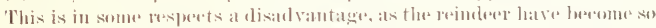

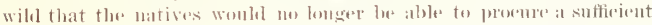
mumber of them for fout and r hothing with their former appliances, and

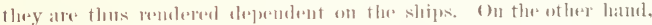
with a plentiful supply of ammunition it is asier for them to procure

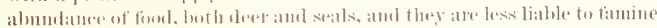
than m fimmer timus.

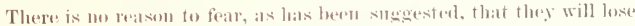
the ant of making any of their own wallons exerpt in the case of the low. With firearms alone they would le unable to ohtain any seals, a muele more inpertant somes of foed than the reinderes and their awn

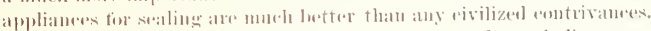
Althengh they have plenty of the most improved mostern whaling geatr,

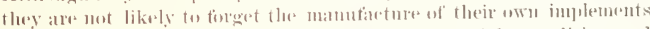
fir this purpeses, as this important fishery is ruted by tratition and

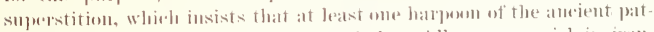

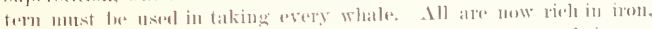
eivilized tonls, eanvas and wreek wowl, and in this respert their condition is imporenl. 
They have, lowerer, arlopted very tew rivilized habits. They lave contracted a tasto for eivilized food, especially bard bread and flomr, lnut this they are mable to olytain for 10 months of the year, and they are thes obliget to adhere to their tomerer habits. Jn fiact, exeept in regarl to the use of firearms amd meehanies' tools, they struek me as exisentially a conservative people.

letroff' makes the assertion that in late years their movements have been guided e hidetly by those of the whaless. As far as we could observe they late not elhanged the comse or time of their jomrnegs since br. Sinposu's time, rxeept that they have given up the autumu whaling, possibly on aceount of the presenes of the shipe at that season. Of consese, men who are rieh in whatebone now stay to trade with the ships, while those who have plenty of oil go east. They are not absolutely dependent on the ships for anything exept ammmition, and "sen during the short time the ships are with them they hardly neglest their own pursuits.

The one munitigated evil of their interomre with the whites has been the introluetion of spirits. Apart from the direet injury which lignor does to their health, their passionate fonduess for it leads them to barter away valuable artieles which shenld have served to proeure ammunition or other things of permanent wse. It is to be loped, how ever, that the liquor trathe is dereasing. The vigilanes of the revenue enter prevents regular whisky tralers from reaching the Aretie Ocean, and public opinion among the whaling eaptains serms to be growing in the right direction.

Another serions evil, which it wonld he almost impossible to cheek, is the unlinited intereourse of the sailors with the Eskimo womeu. The whites ean hardly be said to have introduced laxity of sexnal morals, hut they have eneouraged a natural savage tendeney, and have tanglit them frostitution for gain, which has bronght about great excesses, fortunately confined to a short season. This may lave something to de with the want of fertility among the woment.

()ur two sears of frimuly relations with these people were greatly to their advantage. Not only were on house and om doings a eonstant somere of amosement to them, lont they lamed to respect and trust

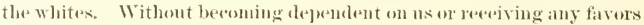
without some adequate return either in work or goods, they were able to obtain tobareo, hard breat, and many other things of use to them, all thromgh the year. Onr presenes prevented their proming more than

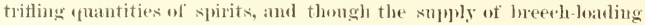
ammnnition was juretty well ent off, they conld get plenty of peweles and shot tor their muzze loaders. The abuudance of ejvilized food was modoubterlly good for them, and ons surgeon was able to give them at great deal of help in sickuess.

In all their untereourse with the whites they have learmed very little. 
English, ehiefly a few antlis and exclannations like ". (int onf of here," and the words of such somgs as " little lirown the" and "slum fily."

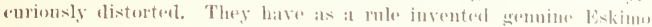

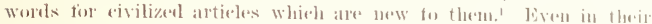
intimate relations with us they learneel but few more phrases and in most eases without a knowledge of their meaning.

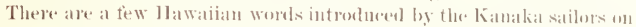
the whaleships, which are muiversally emplogenl betweren whifes and Eskimo along the whole of the Iretie eoast, and oeselsionally al leatst

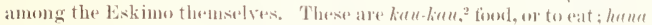

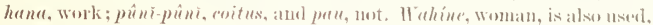
but is less cemmon. Another toreign word now moiversally employed among them in their interomese with the whites, and even, I believe, amony themselves, is " knuin?" tor woman or wife. They themselses

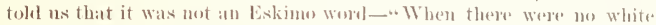
men, there was no kunin"-and some of the whalemen who hat bren at Iludsen Bay salicl it was the ". (x)entanel" worel for woman. It wats

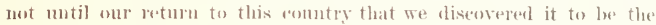
Danish worl kour, woman, which in the corrupted form "coony" is in common use among the eastern Exkino generally in the jargon they employ in thealing with the whites. Kunip is "oomy" with the suffix of the third person, and therefore means "his wite". It is sometimes nsed at loint barrow ton either of a married (on worel "spouse."

\section{NATURAL RESOURCES.}

\section{ANIMALS.}

These people are atopuainterl with the following animals, all of which are more or less hunted, and serve some useful prispose.

Hemmals,-The woll, amaxo ( 'anis lupus griseo-albus), is not meommon in the interion, but rarely if aver reawes the coust. Red and black foxes, kaiáktôk (Vulpes tulvus tulvus and argentatus), are chietly known from their skins, whiels are common artioles in the trade with the eastern matives, and the same is true of the wolverine, ka'rwiñ (Gnlo hosens), and the marten, kabweatya (Mustela amerieana). The aretic fox,

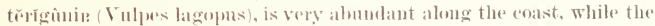
ermine (Putorius arminea) and P'ary's spermophile (Spermophilus

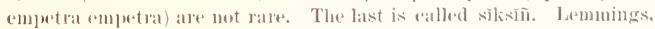
a'viño, of two spereses ('unieulus torquatus and Myodes obensis) are

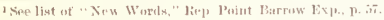

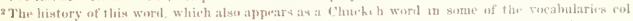

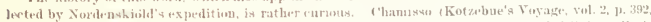

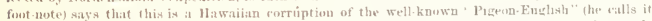

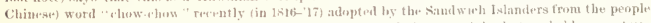

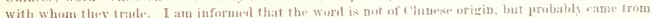

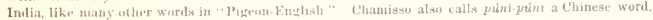

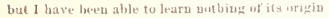


very abundant some yeal's, and they recognize a tiny shrew monse (Sorex forsteri). This little animal is called ngrune, a word corresponding to the name ugsenugnak given to the same animal in Labrador, which. areording to Kleinselumidt, ${ }^{1}$ is an ironieal application of the name of the largest seal, ngssuk (ugru at Point Jarrow), to the smallest mammal known to the Exkimo. The same name is also applied at Point barrow to the forsil ox, whose bones are sometimes found. The most abmolant

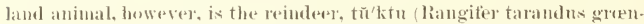
landiens), which is tomel in winter in great hads along the mperer waters of the rivers, oreasionally moming down to the east, and attords a very important supply of tiond.

The moose, tō'ktuwñn, or "big reindere" (Alee maelhlis), is well known from the aremuts of the Numatañmin, who bring mose skins to trade. Some of the natives have beren east to lonut the momntain sheep, i'mnêe (1) vis ranadensis dalli), anul all are familiar with its skin, lorus, and teeth, whirh they buy of the wastern natives. The musk ox, mminman (1) vilos moseluatus), is known only fiom its bones, which are sometimes found wh the tundra. Inland, near the rivers, they also find a large brown bear, atkqlak, which is probably the barren ground bear, while on the ice-park, the polar bear, nä'nn (Thalassaretos maritimus), is not mocommon, sometimes making ratids on the provision storehonses in the villages.

The most important sea animual is the little rongl seal, nĕty̆í (Phora fortida), which is very abmulant at all stasoms. Its flesh is the great staple of fored, while its blubber supplies the Exkimo lamps, and its skin servescomotless usetul purjosis. The great bearded seal, ígru (Erignathus bathatus), is less common. It is espectally valued for its hide, which serves for covering the lange loots and making steut harpoon lines. Two other speries of seal, the harbor seal, kasigía (Ploon vitulina), and the beautiful ribbon seal, kaixóliñ (Phoca fastiata), are known, lut both are morommon, the latter very rare.

ILerds of walrus, a'bwek (1)dobenus obesus), pass along the eoast in the open season, generally resting on cakes of floating ice, and are pursued for their hides and ivory as well as their flesh and blubber. Whales, alibwek, of the sjecies Balena mysticetus, most pursued for its oil and whalebone, travel along the coast in the leads of open water alowe deselibed from the middle of A pril to the latter part of Jnne in large numbers, and return in the antumn, appearing abont the end of Angust. White whales, kilelua (1) lyhimapterus sp.), are not uncommon in the smmmer, and they say the narwhal, tugáliñ (Monodon monoceros), is oreasionally seen. They are also ateqnainted with another cetacean, which they eall axlo, and which alpears from their deseription to be a species of oreal.

Birds.-In the spring, that is during Ifay and the early part of June, vast flowks of migrating duckis pass to the northeast, close to the shore, 


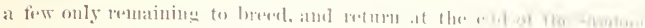

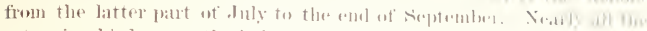

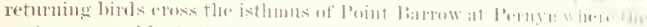
natives assemble in barge numbers for the purpose of takmo them

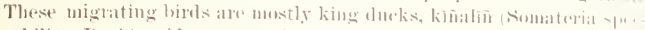

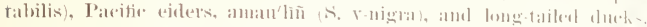
a'dygía, a'ballin ('langula hyomalis), with sulaller numbers of the

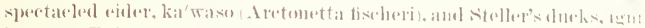

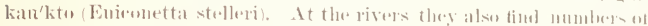

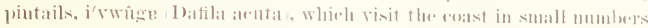
during the migrations. Cimese of these speries. the . Inerioan white.

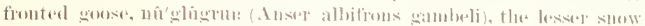

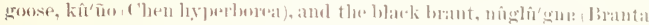

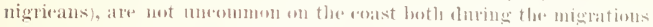

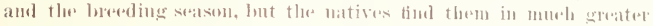

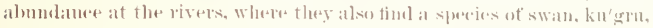
probably (Olor wolnublanus. which rately visits the coast.

Next in importanes to the natives are the enlls, of which the l'oint

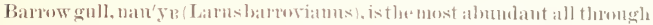

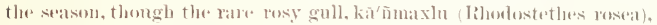
appears iu maltitudes late in the antumu. The irory gull (iavial allai).

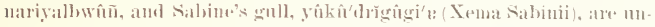

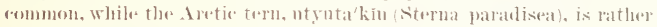

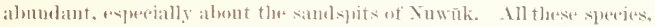

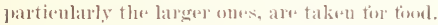

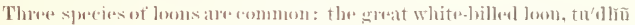

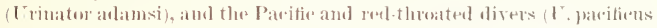

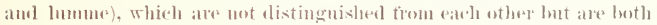
called katkinl. They also oreasionally see the thiek-billed guillemot

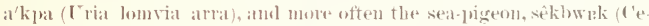

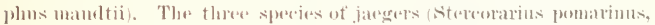
parasitiens, and longicanlus) an not distiugnishul from wn another but are all ealled ismun. They paly but little attention to the momereses

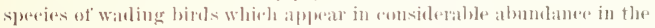

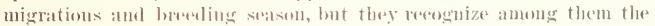

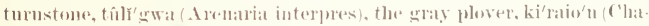

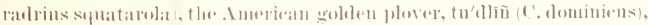

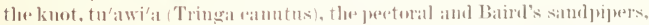

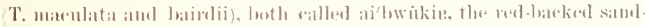

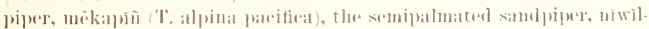

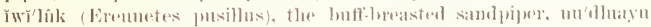

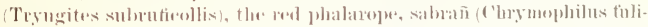

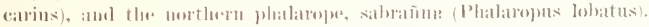
The last is relle at l'oint batrow, but they see many of them near the

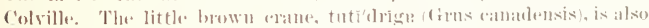
rare at the l'oint, but they sily they fiml many of them at the montlo of Kinlu'gruit. 
of land birds, the most familiar are the little snow bunting, amanlige? (Plectrophenax nivalis), the first bird to artive in the spring, the Lapland longspur, nössan'dlige: ('alcallins lapponicus), and two species of gromse, the willow grouse (Lagopus lagepus) and the rock ptarmigan (1. rupestris), which are both ralled akit'digin. These two birals do not migrate, but are to be seen all winter, as is alse the well known snowy

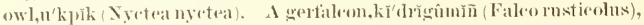
is alse sometimes sen, and skins and tieathers of the golden eagle, tín mipkpuk, "the gloat him" (A'puila chrysetos), are bromght from the east for eharms and oruanents. The raven, tulno (Corvus worax $\sin$ natux), Was not seen at l'oint barrow, but the natives are familiar with it ancl have many of its skins for ammlets. Several species of small land hirds also orene in small numbers, hut the natives are not faniliar with them and eall them all "sûtksaxí." - This naur appears to mean "wauderer" or "flutterer," and probalbly belongs, I believe, to the different species of redpolls (degiothus).

Fishers-A tew speries only of fish are fomml in the salt water. Ot these the most abmudant are the little polar cod (Boreogarlus saida), which is plentiful through the greater part of the year, and is often an

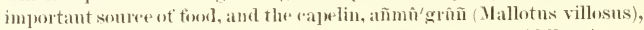
which is found in large schools alose to the bearh in the midalle of summer. There are also (aught sometimes two sjeseies of seulpins, kúnaio (Cottus quadrionrnis and decastrensis). and two speecies of Lyoudes, kí. grame. (L. turnerii and roceinens). In the gill nets at Elson Bay they also eatch two species of salmon (Onchorhynehus gorbuscha and nerka) and a whitefish (Coregonts lanettio) in suall numbers, and oceasiom. ally a large trout (salvelinus mahma). The last-named fish they find sometimes in great numbers, near the month of the Colville.

The greatest quantities of tish are taken in the rivers, especially Kuaru and knhgrua, by fishing though the ior in the winter. They say there are no fish taken in Ikpikpuñ, and aecount for this by rxplain. ing that the former two rivers freeze down to the lottom on the shallow lars inclosing derelp pook in which the tish are held, while in the latter the las never tomehes the lottom, so that the fish are time to mu down to the sea. The species ranght are the small coresomms lamettae, two large whitefish (C. lemicottii aud nelsomi), and the burbot, tita'liñ (Lota maculosa). They speak of a fish, sulnkpan'gal (which appeats to mean "wing-fin" and is applied in (ireenland to a species of Selnastes). that is eanght with the hook in Kulngrua aplatently only in summer, and seems from the description to be Bark's grayling (Thymallus signitrer). In the river Ku is ('anght a smelt, ithoa'niñ (osmerus dentex).

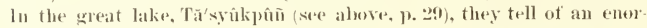
mons fish "as loig as a kaiak." They qave it no name, hut describe it as laving a red lelly and white thesh. One man said he had seen one 15 teet long, but another was more moderate, giving about 3 feet as the length of the longest he had seren. 


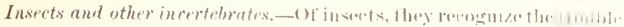

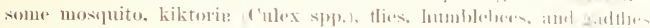

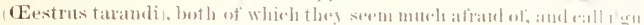

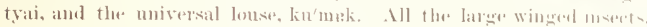

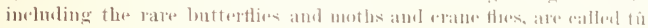

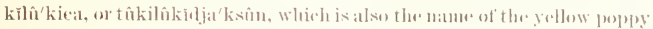

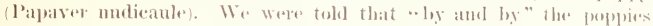

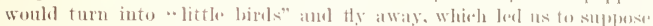
that there was some yellow lontertly which we should tind atumelant in the later summer, but we saw mone aithere seasom. 1 small spidler is

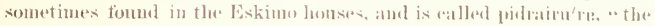

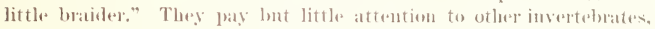

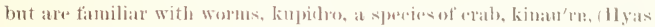

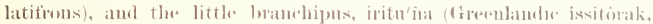

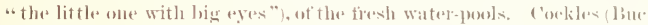
cinum, etre) are ralled siutigo (

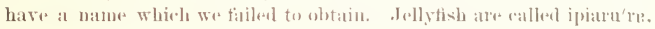
"like bags." They saly the " Kinñmmdliñ" "at them!

\section{PLAXTS.}

Few plants that are of any servier to man grow in this region. The willows, n'kpik, of varions speetes, which near the coast are nothing

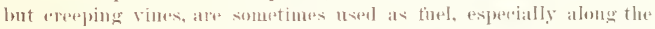
rivers, where they grow into slumbs of 6 feet high. Their catkins are

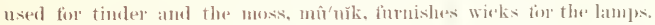

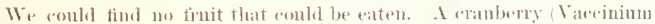

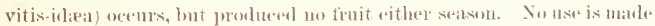

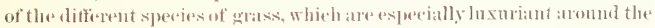
houses at Ithiarwin, where the groumd is riebly mamued with rarious

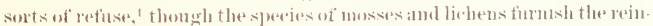

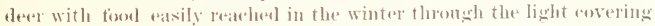
of snow. Litfle attention is paid to the numerous and sometimes showy, Howering plants. We learod lut two names of Howers, the

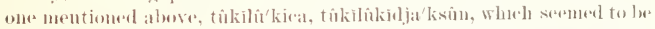

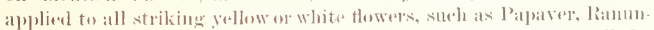
rulus, and loraba, and mai'sun, the hright pink Pediendaris. All the worsl used in this region, exeept the ready-made woolenwate and the willow poles obtainel from the Xunatanmim, comes from the drift on the beareh. Wost of this on the beath west of looint Barrow appears to cone from the sonthwest, as the prevaling roment alomg this shome

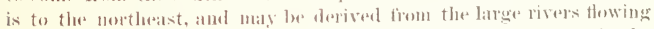
into Kotzelou. Somul, since it shows signs of having bren long in the water. The lriftwod, which is reported to be aloumlant atst of Point

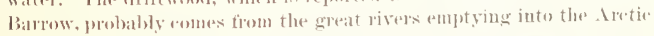

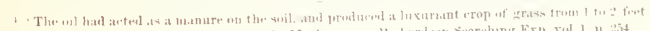

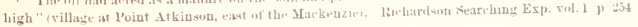


(Mean. This wool is suthieidntly abundant to furnish the natives with

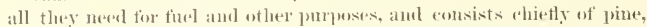
spruce, and wottonword, mostly in the form of water-worn logs. often of large size. (1) late years, also, mueh wood of the different kiuds ned in shipbuilding has drifted ashore from wreelks.

MINEI:ALS.

The people of this region are anduanted with tew mineral substances, exrluding the metals whirh tley ohtain from the whites. The most important are flint, slate, soapstone, jacle, and a peeruliar form ot massive pertolite, first atescribed hy Prof. F. W. C'larke' from specineus brought homm by our party. Flint, amma, was formerly in great demaut for arrow and spear heark and other implements, and atorting to Ior. Simpson was obtained from the Nunataummim. It is generally black or a slightly translue grat gray. hit we collerted a number of arrowbeads, ete., made of jasper, mel or variegated. A tew rystals of transpareut quartz, sometines smoky, were also sern, anul appearest to be used as amulnts. Slate, ulu'kip, ". material tor a round knife," was used, as its name nuports, for making the woman's rome knife, and for larpoon blacles, pto. It is a smoeth clay slate, varying in hardness, and light green, red, purple, dark gray, or black in color. All the pieces of soft gray soapstone, tmuăkte, which are so mommon at looth villages, are jorbably fragments of the lamps and kettles obtained in former years from the eastern natives. The jade is often sery beantifinl, varying from a pale or bright translueent green to a dark olive, almost black, and was formerly nset tor making arlzes, whetstones, aud oecasionally other implements. The pectolite, generally of a pale greeuish or bluish rolor, was only fomd in the form of oblong, more or less eylindrical masses, nsed as hammerheads. Buth of these minerals were called kat'dlo, aut were said to come "from the east, a long way off." from ligh rocky gromul, but all that we eould learn was very indefinite. 1) r. Simpson was intiomed that the stones for making whetsteues were lorought from the Kuwilk liver, so that this jacte is probably the same as that whieh is said to form Jade Monntain, in that region.

Bits of porphyry, sypuite, and similar rocks are used for making labrets, and large pebbles are nsed as hammers and net sinkers. They havealso a litfle irom lyrites, both massive aud in the form of spherimal coneretions. The latter were said to come from the montlo of the Colville, and are believed by the uatives to have fallen from the sky. Two other kinds of stoue are bronght from the veighborloogl of Nu'zsŭknan, partly, it appears, as couliosities, and partly with some ill defined mystical notious. The first are botryoidal masses of brown limonite, resemb. ling bug irom ore, and the other sort murims rouretions, looking like the fimiliar "elay stomes," but very heary, ant apparently eontaining a 


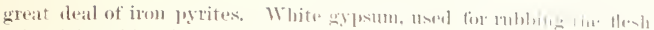
side of deerskins, is obtained on the seastome at a place called Tulye, "one sleep" east from l'oint biurow.

Bituminons coal, alu'al, is well knowe, thomgle not used lim find.

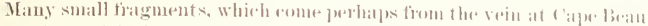

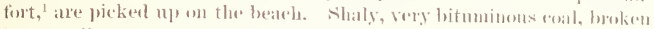
into small senare fragments, is rather alumbant on the hats of kinh

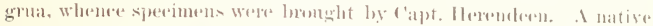
of Wainwright Inlet gate us to mulerstamel that abal existod in a regu lar vein neate that plawe and told a story of a lmoning hill in that

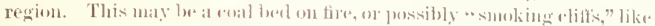

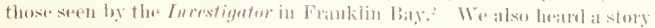

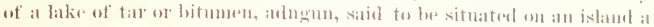

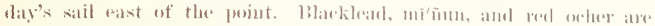
almudant and used as pigments, hat we did not learl whele they were

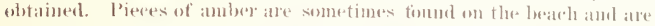

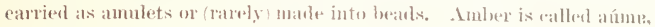
a wort that in other Eskimo dialests, and probathy in this also, meins "a live eoal." Its application to a lump of antrer is quite a striking tigne of sjererh.

\section{CULTURE.}

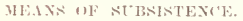

Finit).

Substanees used for food. - The food of theser people consists a honst entirely of animal substaness. The staple article of fiend is the theslo of the rough seal, of which they obtain mose than of any other meat. Xext

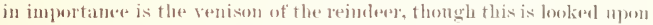
as a kind of dainty. Wany well develuped fietal remulere are bought lome fiom the syning dere hunt and ane sald to be excellont rating.

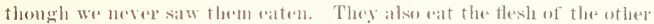
three species of seal, the walrus, the polar leat, the "bowhead" whale, the white whale, and all the larger kinds of birds, geese, dueks, wulls, and grouse. All the etiflerent kinds of fish alpease to be eaten, with the

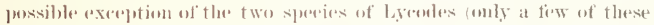

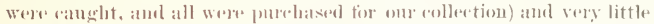
of a fish is wasted exiept the hardest parts. Walrus hide is sometimes cooked and eaten in times of searity. Mallusksof any kind are ranely eaten, as it is dificult to prome them. Atter a beary gale in the

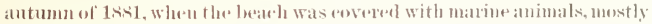
lamellibaneh mollusks with their shells and softere parts broken ofl by

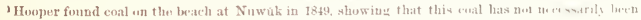
thrown over from ships Trufa uf the 'Tuski, p. 201

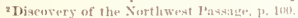

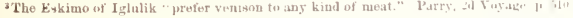


the violenes of the smrt, we saw one woman collect a lapinl of these "tam heads," which she satid she was going to eat. The "blackskin" (epidermis) of the whald is comsidered a great delieacy by them, as by all the other Eskimo who are able to procore it, and they are also very fomd of the tomgh white skin or gnm romel the roots of the whalebome.

We saw and heard nothing of the habit so geuerally noticed amomg

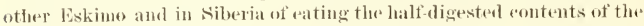
stomach of the reinderer, lout we found that they were fond of the tiees. taken from the rectum of the dees. I find that this curions habit has been noticed among Eskimo only in two other places-fireenlaud in former times and Boothia Felix. The (ireenlanders ate "the Demg of the liein-deer, taken ont of the (ints when they elean them; the Entrails of Partridges and the like Ont "ast, pass for Dainties with them." ${ }^{2}$ The dung of the musk ox amb reinder when fresh were considered a delicacy ly the Boothians, acourding to .J. 1'. lioss. The entrails of fowls are also ronsidered a great delieacy and are carefolly cooked as a separate dish. ${ }^{+}$

As far as our observations go these people eat little, if any, more fat than civilized man, and, as a rule, not by itself. Fat may oceasionally be eaten (they are foud of the fiat on the inside of duck skins), but they do not habitually eat the great quantities of blubber spoken of in some other places ${ }^{5}$ or think oil, as the IJudsum bay Exkimo are said to flo by lIall, or use it as a sance tor dry fool, like the natives of Norton Somnel. It is usmally supposed and generally stated in the popenlar accomnts of the Eskimo that it is a physiologioal neressity for them to eat enormous equantities of blublere in order to obtain a sufficient amount of (arbus to enable them to maintain their animal heat in the cold climate which they inhabit. A carceful comparison, however, of the reports of aetual olservers shows that an excessive eating of fat is not the rule, and is perhaps confined to the territory near Boothia Felix.

liggs of all kinds, exerpt, of eomrse, the smallest, are eagerly songht for, but the smaller birds are seldom eaten, as it is a waste of time and ammunition to pursue them. We saw this people eat no vegetable sub. stances, though they intormed ns that the buds of the willow were sometimes eaten. (Of late years they have anduired a fondmess for many kinds of eivilized food, expecially bread of any kind, flour, sugar, and molasies, and some of them are learning to like salt. They were very

\footnotetext{
ICompare Hooper, Tents, ete. "This, which the Tuski call their sugar," p. J74; and Hall, Aretic Regearches, p, 132 (Baftin Land).

${ }^{2}$ Egede, Greenlaud, p. 136.

${ }^{3}$ Aplendix to Tusa's al Toyag", p. xix.

4Compare the passage from Eycele, just quoted, and also Kumlien. Contributions, vte, p. 30, at Cum berlant Golf.

${ }^{5}$ Fer instance, Schwatka says that the Nètcillk of King William Land devour enormous quantities ef seal blubber. "noticeably nore in summer tban the other tribes," viz, thuse ef the western shores of 11 uson's Bay ( irience, vol. 4, p. 54t. Parry speaks of the natires of the Savage Islands, Hud sen's Strait, enting raw blubber aud sucking the oil remaining on the skins the had emptied (2d Toy. age, p. 14 .

G.ee for example Eirede's fireenlinu, p. 134; Crantz, History of tireenland. vol, 1, D. 1H; Dall, Alaska. passim: Hoofw. Tents of the Tuski, p. 170: Nordenskiold. Vega, p. 110.
} 


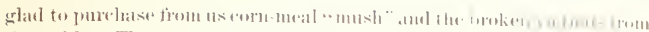

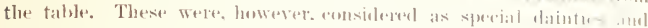

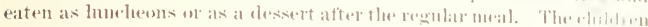
and exen some of the women were always on the watele for the rende

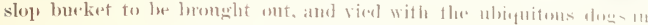

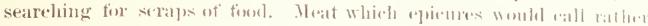

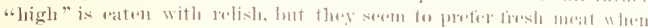
they can get it.

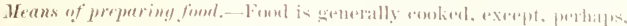

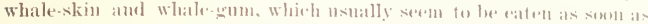

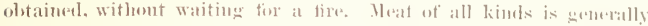

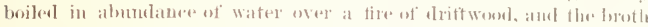

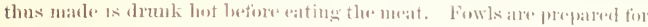

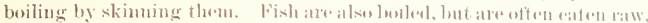

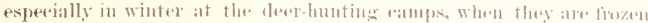

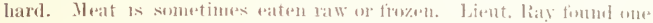

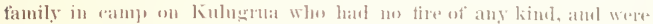

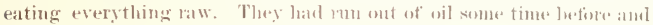

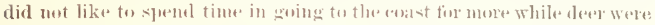
plentitil.

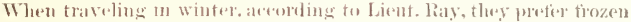

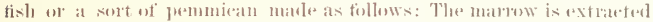

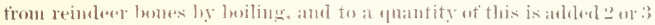

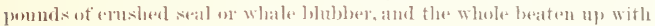

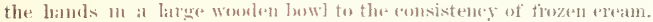
Into this they stir hite of hoileel venison, gemerally the fromer portions of the meat selayed oft the ]

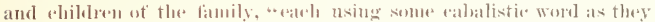

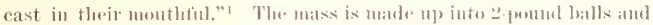

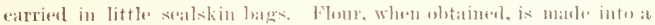

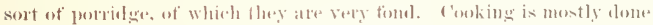

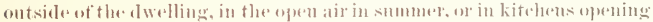

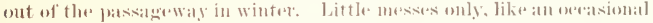

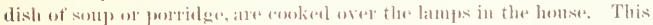

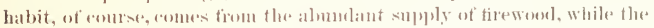

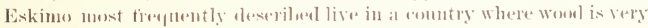

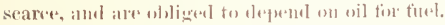

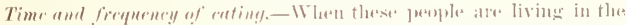

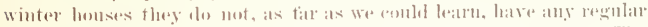

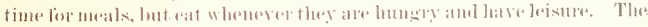

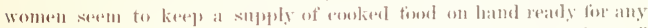

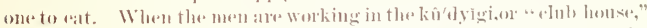
or when a mumber of them ale ancampert together in tomts, as at the

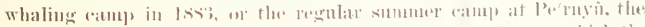
women at infervals thengh the day prepare dishes of meat, which the 


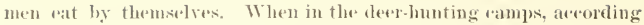
to Lient. Ray, they wat but little in the morning, and ran really be said to take no more tham one full meal a day, which is eaten at night when the daty's work is done.' When on the mareh they usually take a few moutlifuls of the pemmiean alowe dexeribed betore they start out in the morning, and rancly tomeh food again till they go into camp at night.

When a fimily returns fiom the spring deer hunt with phenty of venison they usnally keep open house for a day or two. The women of the homsehold, with sometimes the assistanee of at neighbor of two, keepl the pot antimuatly losiling, sending in dishes of moat at intervah. while the house is full of guests who stay for a short time, pating, smoking, and chatting, and then retire to make rom for others. Messes are sometimes sent ont to invalids who ("an uot aome to tle feast. One household in the spring of 1 sis', ansumed in this way two whole reindeer in 24 lowrs. They use ouly their hands and a knife in eating meat, usually filling the month and entting or biting off the menthful. They are large eaters, some of them, esperially the women, eating all the time when they have plenty, but we never sid them gorge themselves in the manner described ly 1)r. Kane (2d (irinumll Exp., passion) and other writers.

Therr habits of hospitality prevent their laying wp any large supply of meat, though blubler is rarefully saved for commereial use, and they depend for sulsistemed, almost from day to day, on their sureses in hunting. When encanped, however, in small parties in the summer they oftentake more seals than they ran consmme. The eareasses of these, stripped of their skins and bubber, are buried in the gravel edose to the camp, and dug up and brought home when meat beomes seares in the winter.

Dinhat.

The habitual drink is water, which these people comsume in great glantities when they an ohtain it, and like to have very eold. In the winter there is always a lump of elean snow on a lat k elose to the lamp, with a tub umber it to atele the water that drips from it. This is replaced in the smmmer ly a loucket of fresh water from some poucl or lake. When the men are sitting in their open air elubs at the summer "amps there is always a bucket of firesh water in the middle of the eirele, with a dipper to drink from. 11ardly a native ever passed the stafion without stoppling tor a drink of water, often drinking a cquart of cold water at a time. When tramping about in the winter they eat large fluntities of ios and snow, and on the mareh the women eary small rantens of sealskin, which they fill with snow and arry inside of their jackets, where the heat of the body melts the smow and keeps

1"They have un set Time for Meals, hut every one wats when he is hungry, except when tbey go to Mea, and then their chief Rrpast is a supper after they are come home in the Evening." (Egede, Greenland, p. lis. Compare also, Crantz, vol. 1, p. 145.) 


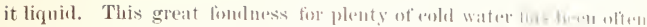

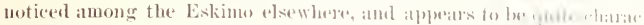

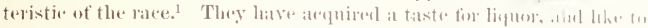
get enough to produre intoxication. As woll ats wa sombl julese, thes

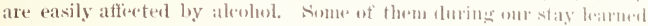

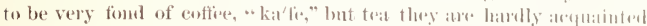
with, though they will drink it. I hatve motiond that they sometime-

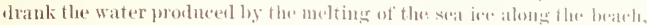
and prononed it exeetlent when it was so bratekish that I fomm if quite undrinkable.

\section{SAISUTIC:}

The only nareotic in ase anomg these prople is tobareo, which they obtain dimestly or indirectly from the whites, and whieh has beren in ust among them from the araliest time when wo have any knowlesher of them. When Mr. Elson, in the IBlossomes harese, visiterl Point latrow, in

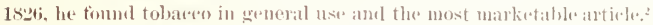

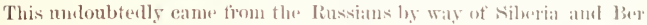
ing Strait, as Kotzente limel the natives of the somed whele luan his name, who were in communition with the Asiatie roast by way of the Diomedes, already addireted to the use of tobaure in 1sib. It is not

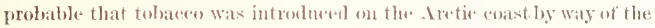

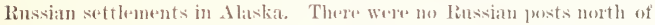
Bristol Baty until 1s;3, when St. Mirhatel's limeloubt was built. When Capt. Cook visited Bristol bay, in 177. for timmel that tobaces was not userl there, while in Norton somm, the sime year, the natives "laad

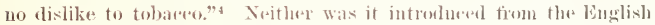

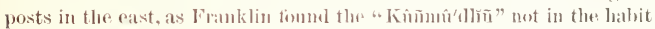
of using it-"The western lisfuimanx use tohateo, and seme of our

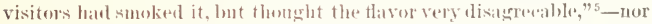
hat they alopted the lathit in 1 .

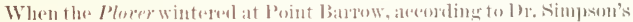

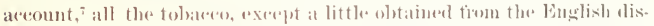
covery ships, rame from A Ait and was hrought ly the Nunatañmimn.

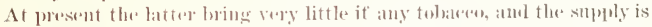

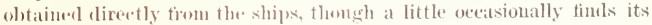
way we the earat from the sonthwest.

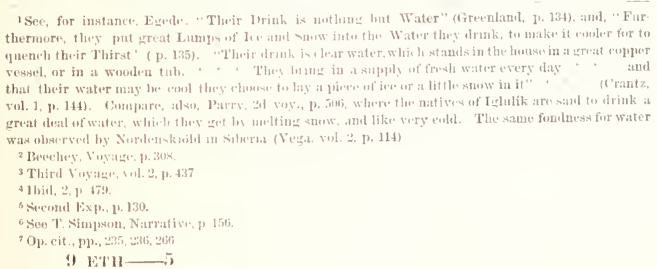


They use all kinds of tolnaces, but reatily distinguish and desire the sorts rousidered leeter by the whites. For instane, they were eager to get the exeellent atuality of "Navy" tobaten furnislocl by the commiskary bepartment, while one of om party who had a large quantity

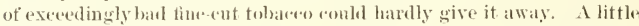
of the strong yellow "C "ireassian" tobaee nsel by the Russians for trading is oecasionally loromght up from the sonthwest, and perlatps also by the Nonatanmim, and is very highly prized, probalbly besamse it was in this form that they first satw tohatero. Snuff seems to be muknown; tobate is used only for clewing and smoking. The habit of elewing tobaceo is ahmost universil. Men, women, and even children, thongh the latter be but 22 or :3 years old and unweaned, ${ }^{1}$ when tobacen is to be obtained, keep a "whew," often of anormons size, eonstantly in the mouth. The juice is not spit ont, but swallowel with the saliva, without prodneing any signs of nansea. The tobaces is rhemed by itself and not sweetened with sngar, as was olserved by llooper and Nordenskiöld among the "Chukeles." 1 knew lunt two adnlt Eskino in Ttkiarwin who did not elew tobaceo, and one of these adopted the habit to a certain extent while we were there.

Tobaceo is smoked in pipes of a peenliar pattern ealled kui'nye, of which the eollection contains a series of teus spereimens.

Of these, No. siscis [70.5], figured in Ray's l'oint Barrow lieport, Ethology, P'l. I, Fig. 1, will serve ats a type. The bowl is of brass, neatly inlaid on the mples surface with a namow ring of eopper close to

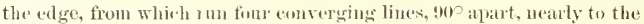
center. liownd the moler surtare are also three coneentrice rings of copperer. The woolen stem atpears to be willow or birch, and is in two longitudinal seetions, held together by the lashing of sealskin thong which serves to attatel the lowl to the stem. This bashing was evidently put on wet and allowed to shrink on, and the ands are secured by tueking under the turns. The whipping at the montlupiece is of fine sinew thread. A piekes of steed for cleaning sut the bowl is attached to the stem hy a pice of seal thong, the "mol of whieh is wordgeal under the turns of the lashing. The remaining pipes are all of the same general jattern, but vary in the naterial of the bowl and in details of exeration. The stems are always of the same naterial and put together in the same way, but are sometimes lozenge-shaped insteat of elliptieal in seetion. The lashing is sometimes of thresply sinew braid. The bowl slows the greatest varjation, both in form and material.

Fig. 6o (No, 56737 [10], from Ttkiavwrī) has an iron lowl, noticeable for the ornamentation of the shank. The metal work has all been done with the dike "xeept the fitting of the samere to the shank. This has evidently been heated and shrmk on. Three pipes have bowls of

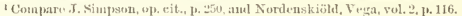

2'Tints, vete, p, k3; Vegn, vol, 2, p, 11ti,

${ }^{3}$ The numbers first givet are those of the National Masemin; the numbers in brackets are those of the collector. 


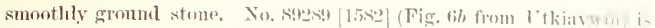

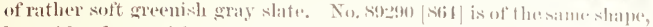

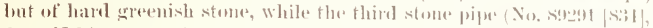

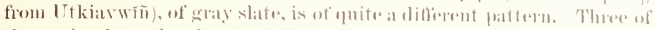
the series have bowls of reimbere antler, lined with thin shot bass,

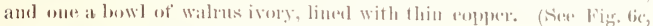

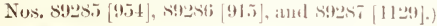

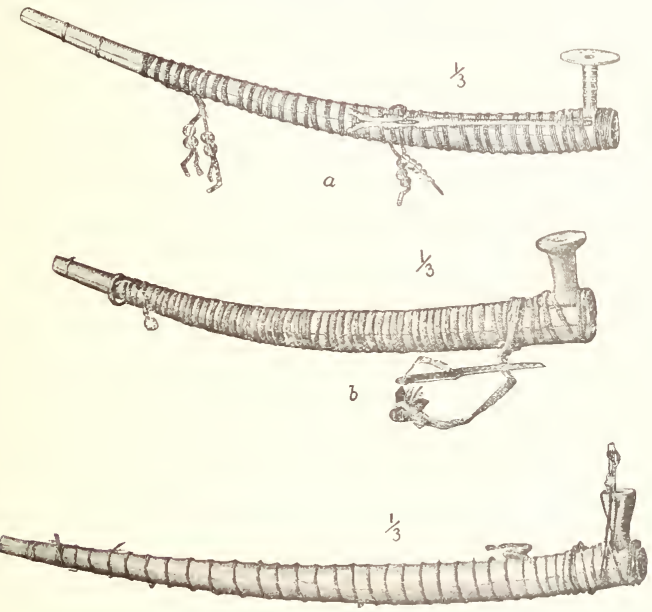

$c$

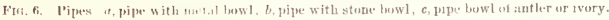

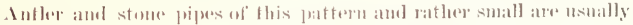

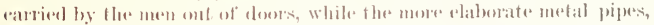

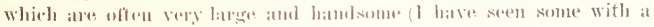

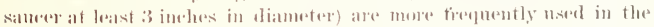
homse and by the women. Tho stem is msmally 1 finot or $1: 3$ imeles long,

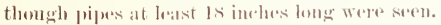

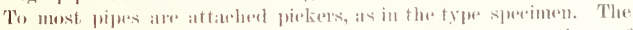
pirker is in all cases of metal, nsmatly iron or stopl, but sometimes of

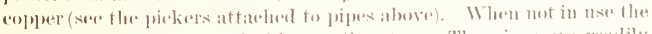
point is torked under the latshing on the stem. The pipes ane readily taken apart for cleanimg. 


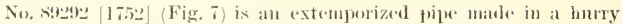
by a man who wished to smoke, but hat no pipe.

tt is simply a rongh willow stiek, slightly whittled into shapes split and hollowed ont like a pipestem. It is leeld together ly a whippong of sinew threal and a lashing of dearkin thong, tastened by a slip-

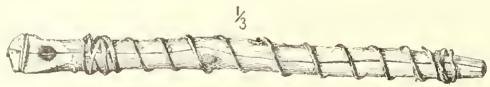

F10. 7. Pipe made of willow stick.

knot at one enul, the other being turked in as usual. A small funnet. shaped hole at one and serves tor a bowl, and slows by its eharred

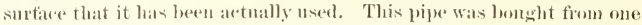
of thr. "Nonatañmin," who were in ramp at Pernŷn in 18.4.3, and shows its inland onigin in the use of the deerskin thoug. A coast native would hase used seal thong.

The pipe is carriol at the girde, either with the stem thrust inside

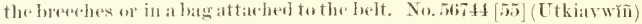

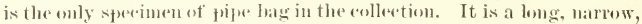
"ylindre bas, masle of tome white mones skins, with two hind legs and

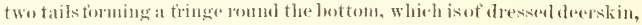
in one piese, tlesh side out. The band romed the month is of gray deerskin, rumbingonly two-thindsot the way romul. The piede which fills the renaining thind rmos ant into the strate for fistening the batg to the belt. The ornamental strigs on two of the longitulinal seams and round the bottom alle of deerskin. The seams are all sewed "aroer and over" on the "wrong" sirle with sinew threarl. This is an unusually handsome bage.

Tolbaces is atried in a small pouch of for attached to the girdle, and turked insirle ot the breselues, of sometimes worn under the jacket, slung womel the neck by a string or the neeklace. The collection contains thres of these, of which No, s98003 [sigg] (Fig. sa) will serve as a tyjuical specimen.

It is made ly sewing fogether two preses of wolverine for, hair ont, of the same shape and size, and romed the mouth of this a band of slortJatired lightotoloment deerskin, also hair out, with the ends merting at one sire in a seam rorresponding to one of the seams of the wolverine fur: The nomtl is ormamented with a narow hand of wolverine fur, the flesh sirle, which is coloned red, tumed ont. It is rlosed by a piece of sal thoug about 5 ind hes long, oue end of which is sewed to the

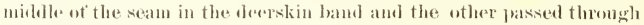
a litree blus glass beat and knotted. This string is womel two the thee times round the neek of the bag, and the bight of it tueked under the 


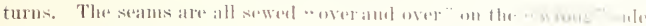
witla sinew threat.

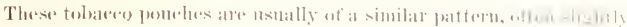

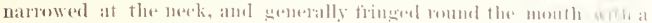

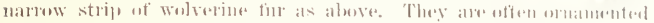

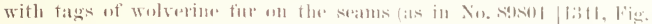

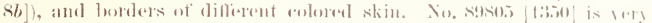
elaberately whamented. It is male of bown derskin, trimmed with

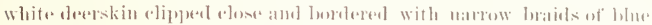

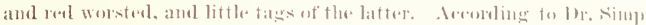

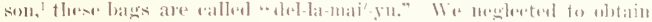

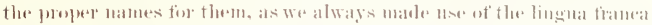

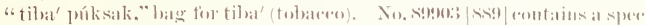

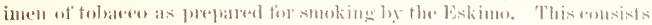
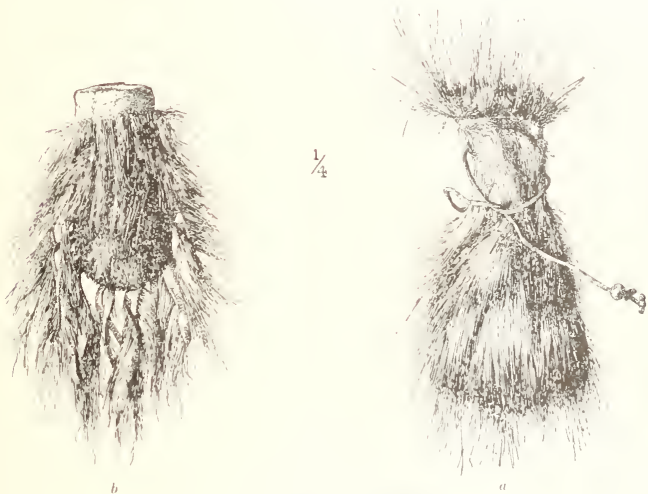

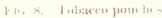

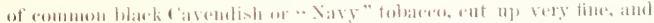

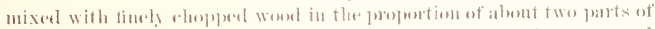

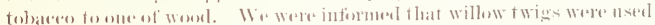
for this purpere. Perlates this may have sume slight aromatie flaver,

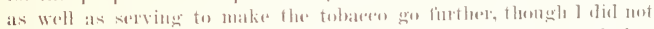

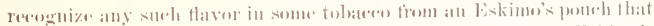

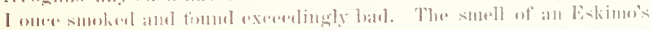


pipe is different from any ot her tobaces smokn and is very disagreeable. It has some lexemblane to the smell of some of the rheaper bramels of North farolina tobateo which are known to be alulterated with other

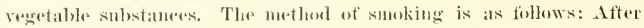
Clearing out the bowl with the pieker, a litfle wall of dere hair, plueked from the elothes in some ineons pienous place, generally the font skirt of the inner jacket, is rammed down to the bottom of the bowl. This is to prevent the tiur tolbaces from getting inte the stem and elogrging it up. The bowl is then filled with tobareen, of which it only holls a rery small guantity. The mouthpiese is placed between the lips, the tobareo irnitod, and all smoked ont in two or thee strong inlabations. The smoko is very dereply inlabed and allowed to pass ont slowly from the mouth and nostrils, hinging tears to the eyes, often produeing giddimess, and almost always a violent tit of coughing. I have seen a man almost plostrated from the efferets of a single pipefinl. This method of smoking has been in vogue since the time of omr first acpuaintane with these people.'

Though they smoke little at a time, they smoke frectuently when tobacoo is plentiful. Oflate years, sine tolberolasbecomeplentiful, some have alopted white men's pipes, which they snoke without inlualing, and they are glanl to get eigars, and, sine ont visit, eigarettes. In conversation with us they usually ealled all means for smoking "pai'pa," the children sometimes specifying "pai'pa-sigya'" (eigar) or "môkpara-

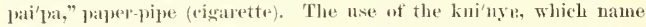
appears to be ajplied only to the native pipes, seems to be confined to the adults. We knew of no children ow ning them, though their parents mate no objection to their ehewing tobace or owning or using elay or wooden jipes which they ohtained from us. They carry their fonduess for tolaceo so tar that they will even ant the foul oily refuse from the bottom of the bowl, the smallest portion of which wonk produe nausea in a white man. This habit has been observed at Plover Bay, Siberia. ${ }^{2}$ Tobareo ashes are also eaten, probaloly tor the sake of the potash they (ontain, as one of the men at 1 thiavwiñ was fond of carbonate of soda, which les tolel the doctor was just like what he got from les pipe. Pipes of this type, diflering in details, but all agreeing in having very small bowls, frepunently of metal, and some contrivance for opening the stem, are need by the Eskimo from at last as far sonth as the Yukon delta (as shown by the collections in the National Musenm) to the An-

\footnotetext{
1.4e T. Simpson: "Not antent with chewing and smoking it, they swallowid the fumes till they beame sick, and sremed to revel in a nomentary intoxiention." Point Barrow (1k37), Narrative, p. 156.

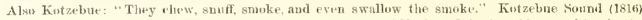

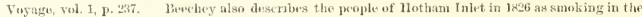
nanner above deseribed, olutaining the har from a strip of dogskin ted to tho pipe. Their tobaceo was mixud with wout. Voynge, p. 300. Putitot (3lonograplie, ete, p. xxix) discribes a preesely similar methut of smoking among the Mtukenzie Eskimus. Their tobaceo was "melange a de la raclure d. sanle " and the pipe was callovl "kwiüepk, "(Vocthulatre, p. 54).

${ }^{2}$ See Hooper, Tents, etc. p. 177, and Iall, Alaska. p. 81.
} 


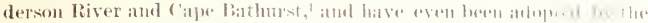

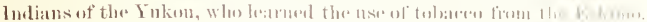

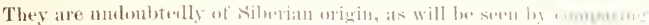

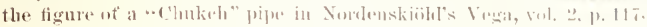

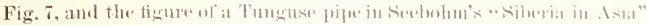

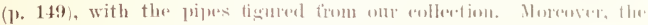

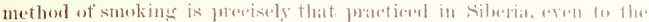
propertion of woud mixed with the teshatens.

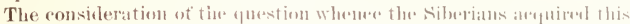

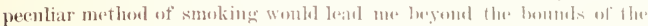

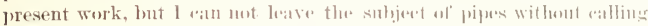

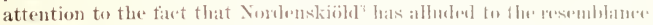

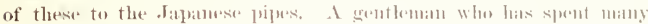
years in ('hina also intoms me that the ('hinese pijus ane of a very

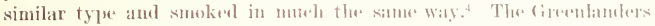

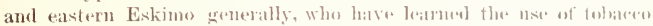

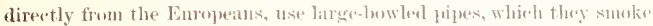
in the ordinary manner. In talking with us the josple ol l'oint Barrow

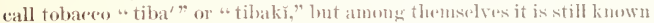
as $\mathrm{ta}^{\prime}$ wak, whieh is the word tomal in wase anomg them by the entiost explorers. "Tiba" was "viulently learued trom the Amerisan whaters, as it was not in nse in 1)x. Simpsom's time. It is merely an attempt to

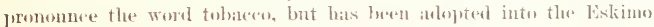

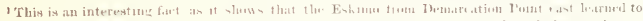

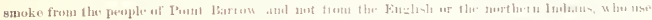

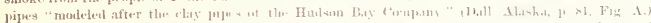

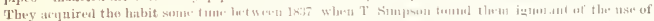

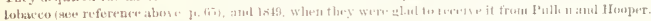

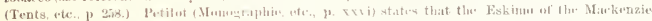

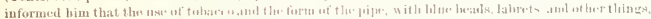

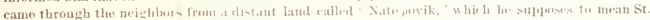

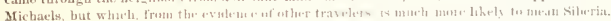

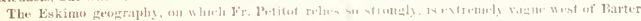

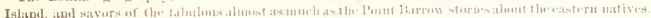

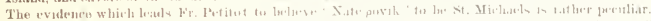

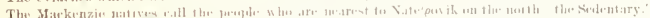

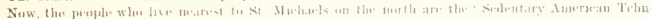

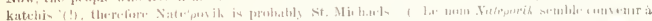

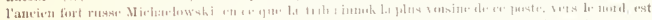

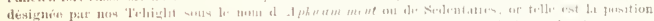

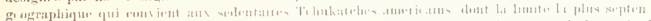

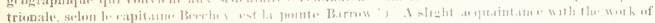

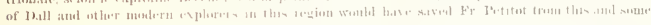
other errork.

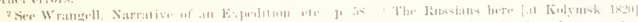

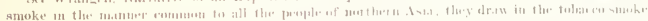

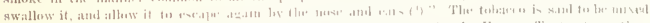

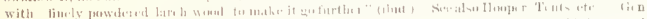

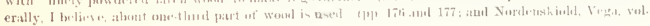
2. I 110 ,

3 Yetat, +ul. :2, 116

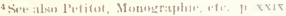

o

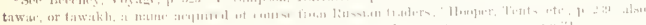

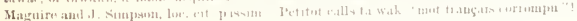




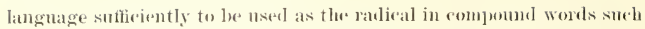

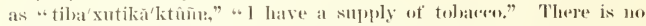
evidence that anything else was smoked before the introduetion of tobaceo, and no pipes seren or allected appear older than the tiuse when we know them to have hat tobaceos.

\section{IIABITATIONS.}

The exinter house (i'glu).-The permanent winter homses are luilt of

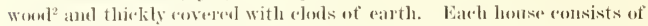

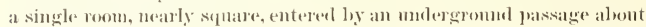
25 teet long and 4 to $4 \frac{1}{2}$ teet high. The sloping nomel of earth which

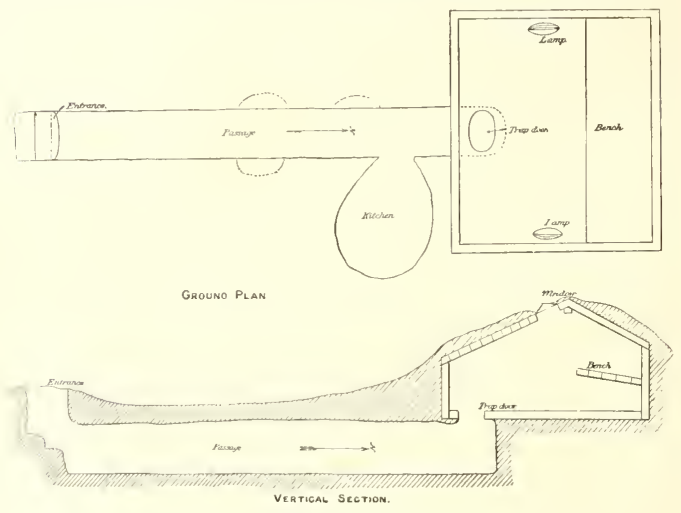

Fig. 9.-Plans of Eskhnu winter house.

"overs the house, grating off insemsibly to the level of the gromul, gives

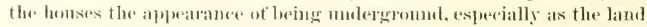
on which they stand is irregular and hilly. Without very careful masmements, which wo were mable to make, it is imposible to tell whether the floor is above or below tha surface of the ground. It is rertainly not very far either way. I am inelined to think that a space

\footnotetext{
I Since the ahove was written, the wort for pipe. "kningr," lans been found ts be of Siberian origin. Niw the writer's article "On the Silerian origin of some enstums of the Western Eskimos" (Amer isan Inthropolugist, vol. 1, pp. 325-336t.

In mum af the older houses, the ruins of which are still to be seen at the sonthwest end of the vil lage of litkiavwī̄, whales' bones were nsed for timhers. fompare Lyon Jumrnal, p. 171, where the

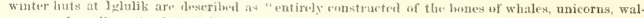
rumes, aud smaller animals." with the anterstices tilled with earth and moss.
} 


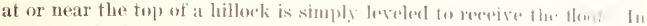
this case the bark of the house on at hill sicle, like some in l'thiarwin. would be mulergromel.

The passage is entered at the farthere and hy at rertionl shalt about a

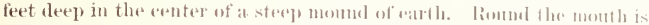

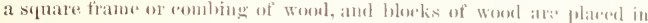

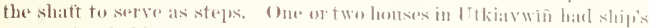

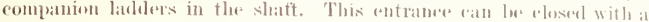
piece of walrus hide or a woolen cover in severe weather or when flat

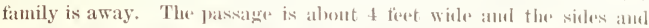

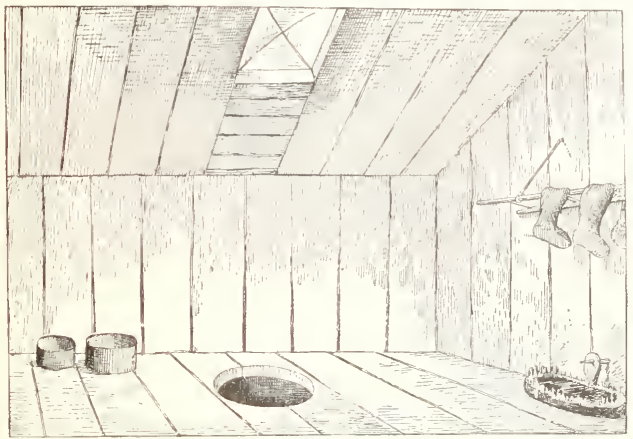

Fic, jo Intırior of inlı, fouking towaral tour.

roof are supported by timbers of whalelome. (1) the right hand near the inner end is a good-sized room opening from the bassage, whioh lats

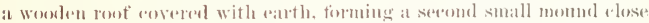
to the lonte, with a smoke hole in the middle, and serves as a kitehen,

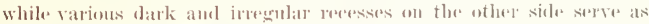
storeroums. The passatge is alwats iry and alark.

At the inner end of the passige a rirenkar trapelerer in the thoor opens into the main reom of the loouse, chose to the wall at the midelle of one encl. The there is at such a beiglit from the bottom of the tummel that a matn standing ereet in the tomel las bis lead and shomlelers in the reom. These rooms vary somewhat in dimensions, lont atre generally about 12 or 14 teet long and so or lo thet wide. The flowe, walls, and roof are miule of thick planks of drittwood, dresiod smooth and neatly

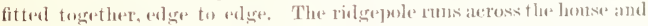

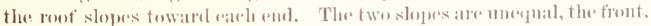
or that towards the entranere being enusiderably the longer. The walls 
ane vertical, those at the ends lowing between 3 and 4 feet high, while the silles run up to 6 or 7 feet at the ridgepole. The wall planks mo up and down, and those of the roef from the ridge to the ends of the house, where there is a stout horizontal timber. In some honses the walls are nade of paneled bulkhads fom some wrecked whaler.

In the front of the hows over the trapklom there are no planks for a space of about 2 fiest. The lower part of this space is filled in with short transwerne beams, so as to leave a sifuare lole elose to the ridge. This lole has a stout transverse beam at the foj and bottom and serves as a window. When the homse is orenpied it is eovered by a tramslueent momlone made ot strips of seal entrail sewed together and stretched

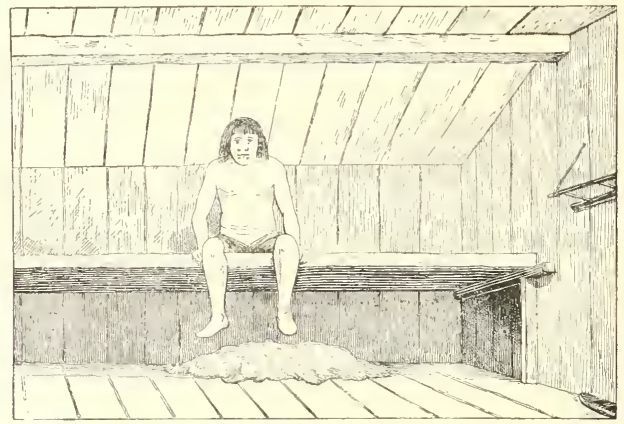

Fiv. 11-Interior of iglu. looking toward bench.

over f wo arehed stieks of light wood-whalebone was used in Dr. Simpson's timer-ruming diagonally across from cormes to corner. The window is alosed with a woolen shutter when the house is shut up in winter, lut both apertures are left open in summer. Just above the winlow, close to the ridgepole, is a little aperture for ventilation. Across the back of the rom rums a platform or banquette, about 30 inches high in front and sloping lowek a little, which serves as a sleeping and lonnging place. It is about 5 feet wide, and the front edge comes nearly under the ridgepole. It is made of thick plankis ruming aeross the house, and supported at atrle sul by a horizontal beam, the end of which projerts somewhat beyoud the bench and is supported by a round post. Af each side of the homse stands a lamp, and over these are suspended racks in

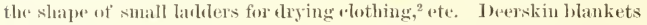

\footnotetext{
(1) 1. eit., p. 256 .

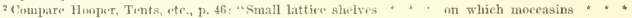
ari put to elry." Ploser Bay. See also plate to face 1, 160 T'arry'a hiecond Voyage.
} 


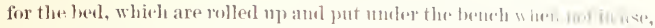

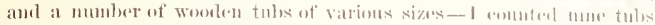

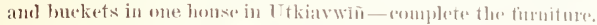

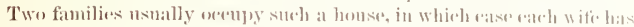
her own end of the room and here own hamp, netre which on the How sle usually sits to work. Somo homses romtain lut one family and ot fores

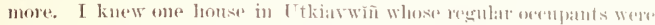
thirteen in number, namely, a fatleer with his wite and ablopterf langhtor.

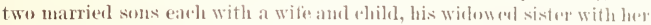
son and his wite, and one little girl. This homse was also the favorite

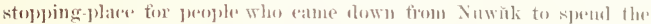
night. The furniture is always arranged in the same way. There is only one raek on the right sirle of the lowese and two on the loft. (1)

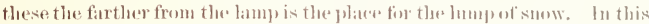

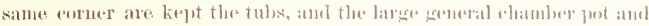

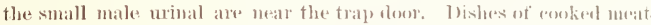
are also kept in this esmers. This leaves the other comer of the homs vaeant for women visitors, who sit there and sew. Male visitors, as well as the men of the honse when they have nothing to do, nsually sit om the edge of the bampuntte.

In slepping they ustally lie across the lanquette with their feet to the wall, but sometimes, when there are firw people in the lowse, lie lengthwise, and ofeasionally sleep on the floor muler the banguette.

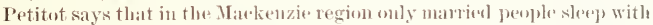

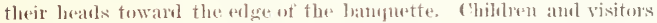

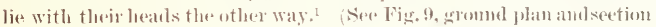
of lonse, and Figs. 10 and 11, interion, from skutehes by the writer. For outside ser. Fig. 12, from a photograph by Lient. Ray).

At the back of the homse is a high oblong seaftobling, made by set. ting up tall poles of driftwoul, four, six, or eight in number, and fisten-

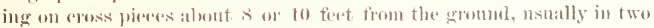
tiers, of which the fower supports the frames of the katiaks and the

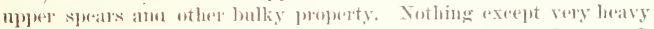

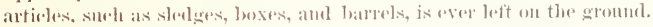

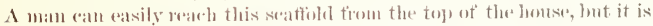

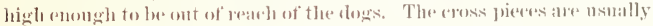
sujpertorl ou crotrhes male by lashing the lower jaw of a wallus to

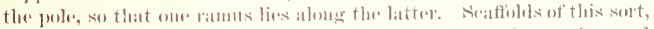

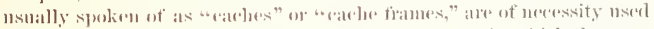
among the Eskimos generally, as it is the only way in which they an protecet their lublky pounerty.?

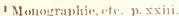

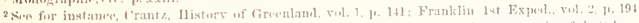

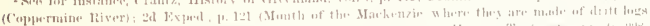

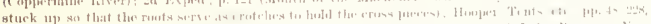

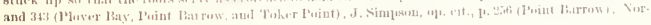
denskiöld, Fega, vol. ㄴ, 1.92 (Pillekaj).
} 
Arome Forlon Somel, however, they use a more elaborate structure, consistimg of a rexular little homse fo foet square, raised fi to 10 feet from the gromud on tour posts.

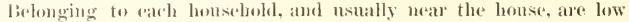

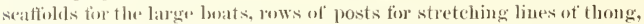
and onc or more smatl wellajs or underground rooms framed with whales' bones, the skull being fireguently nach for a root; which serve as storelomses for blublor. The maty be ealled "blubber rooms."

These winter honses an only bo ocoupied when the weather is cold enough to keep the gromen hand tiozen. Doung the summer the pas. sageways are full of water, which freezes at the beginning of winter

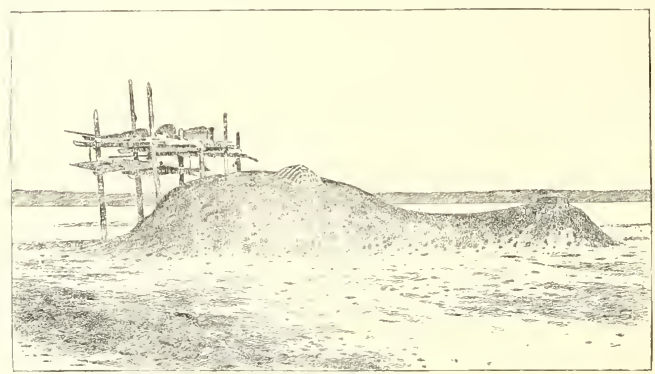

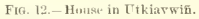

and is doug ont with a pirkax. The prople of Litkiarwion began to come to us to borrow onr piekax to clean ont their iglus about september 24 , 15t2, and all the houses were racated before July 1 , loth seasons.

This pautienlar torm of winter loowse, though in general like those built by ofluer Eskimo, nevertheless difters in many respeets from any described elsewhere. For instane, the fivenland house was an oblong that-roofed building of turf and stomes, with the passageway in the mildle of one side instead of one end, and not mulergrome. Sitil, the foor aud windows were all on one side, and the bamquette or "brix" only on the side opposite the entrane. The windows were formerly made of seal chtraik, and the passage, though not molergomnd, was still lower than the floor of the house, so that it was necessary to step up at wach pul.?

I detailed deseription of the perenliar eommmal house of the East

1):all. Alaska, p. 1:

${ }^{2}$ Eigede, cireenland, 1. 114; Crautz, History of Gireenland, vol. 1, 1, 1:39, Jiuk, Tales aud Traditions, p. 7 . 


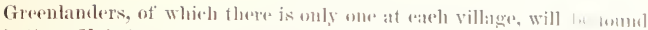

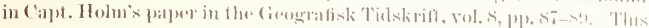
is the long house of West (imenlanel. still further worgated till it will

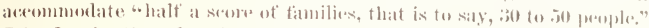
John Inavis (15isi) describes the homses of the Gimenlanders "nowere the Sea side," which were male with piowes of work on lofle silles, and

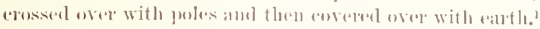

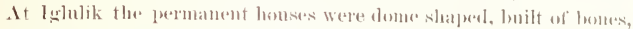

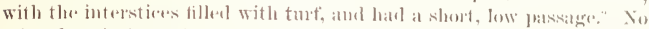
other deseriptions of purmanent homses are fo be fond until we reas h the

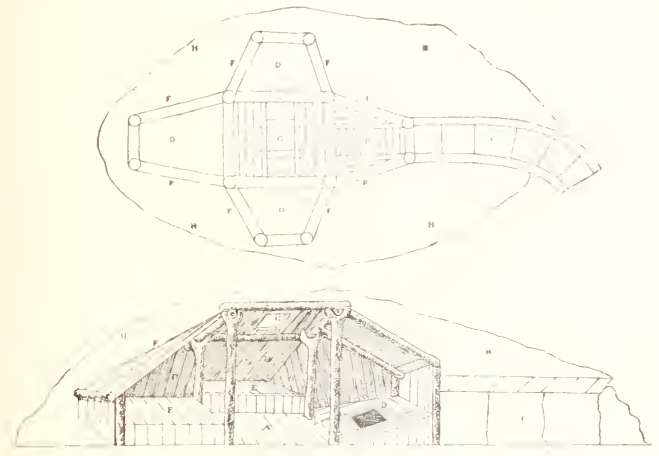

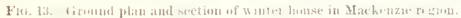

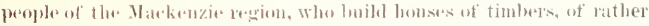

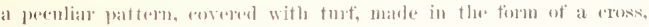

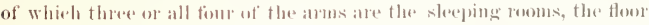

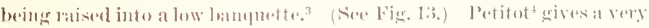
execellent detailed deseription of the lomses of the Anderkon Rivere people.

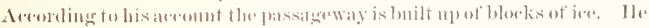
mentions one lumse with a single alcove like those at Point batrow.

We have mo deseription of the homses at the villages hetween l'oint

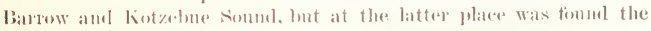

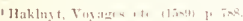

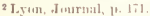

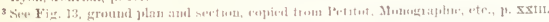

4 Munographis, ete., 1. Xxi.

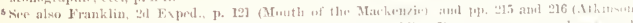

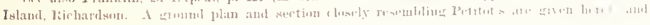
Hooper, Tents, ete., 1. 24s (2uker Toint). 
large triple house deseribed by l)r. Simpsom, and eompared by him with that deseribed hy Richamlson, though in soms resperets it more closely resembles those seren ly Ilomeser. ${ }^{1}$ This louse really has a tireplace in the midlle, and in this apdnoathes the houses of the sonthern Eskimo of Alaska. Acencling to 1 r. Simpson, "a modification of the last form, built of undressed timber, and sometimes of rery small dimensions, with two repsses oplosite each other, and raised a toot above the middle spane, is very common on the shores of Kotzebue somel," but he does unot make it plain whether houses like those used at Point barrow are not used there also.

This form of house is very like the large snow homes setn ly Limt. Ray at hunting camps on Kolugrna. Ir. Simpson deseribes less permanent strutures which are used on the pivers, eomsisting of small trees split and laid "inclining inward in a pyramilat form towards a rude sfruare fiame in the eenter, supported by two or more upright posts. Upon these the smaller branches of the felled trees are placed, and the whole, except the apertnre at the top and a small opening on one side, is eovered with earth or onty suow." These bildings, and especially the temporary ones descriled by l)r. Simpson, nsed on the Numatak, probably gave rise to the statement we hearl at Point Barrow that "the people sonth hal no iglus and lived only in tents." The houses at Norton Sommd are quite different from the leoint Barow form. The floor, which is not planlitel, is 3 or 4 feet under gromel, and the passage enters one side of the lomse, insteal of aming up through the floor, and a small shed is lonilt over the outerentrane to thes passage. The fire is louit in the minllle of the homse, moler the aperture in the roof which serves for chimusy and window, and there is seldom any hanguette, but the two ends of the room are finced off by logs laid on the gromel, to serve as slceping pliwes, straw and spruce boughs being laid down and covered with grass mats. ${ }^{3}$

The lonses in the Kuskokwim region are quite similar to those just deseribed, but are said to be bnilt above gromul in the interior, though they are still covered with serks. There are no pulblished aceomts of the houses of the St. Lawrence islanders, but they are known to inhabit subterranean or partly melergremed earth-rovered honses, luilt of wood,

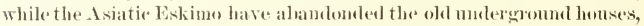
which werestill in use at the end of the last century, and have adopted the domblo-skin tent of the C'hnkrless. ${ }^{5}$ In adlition to the rases quoted by Dall, ('apt. Cook speaks of funding the natives of St. Lawrence bay in 17 is living in partly malergronud earth-eovered houses. ${ }^{6}$

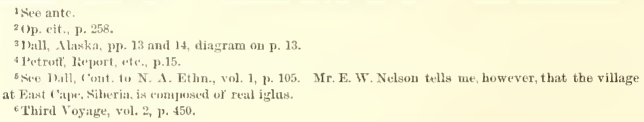




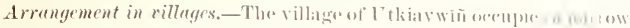

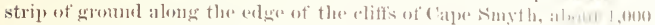

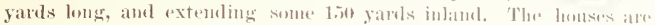
seattered among the hillorks without any attemel at regularity and at different distames from eaclo ot lere, sometimes alone, and sometimes in

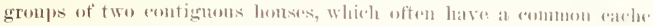

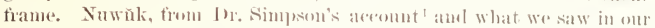
homried visits, is satteresl in the same way osere the linolls of l'oint Barrow, but has its greatest extension in an east and west direstion.

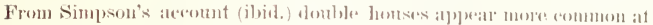

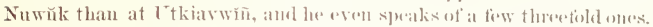
All the houses agres in faring senth. This is mulombterlly to anlmit the greatest amount of light in winter, and serms to be it tolerably general custom, at least among tlu mortherm liskimo."

The eustom of having the dwelling faces sonth appesus to be a decply rooted one, as crent the tents in smmer all fare the same way."

The tents on the saudspit at l'lorer bay all face west. The same was observed by the Kranse lnothers at bast c'ape." It Lthiavmin there

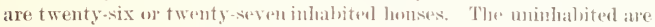
mostly ruins and are chicfly at the sonth west and of the village, thongh the breaking awaty of the elifts at the othere end has axposed the mins of a fow othere old houses. Near these alle also the rums of the buildings

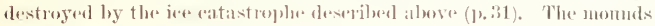
at the site of the United States signal station are alse the ruins of old iglus. We were toled that " loug ago," hefore they had any iron, tive families who "talked like doge" inhaliterl this villatese. They

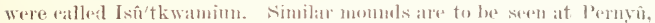

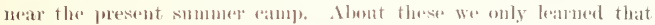

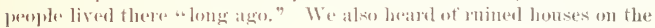
bankis of Kulngrua.

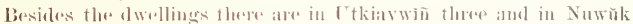

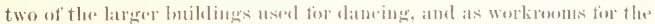
men, so often spolien af : among ot her liskimo.

D). Simpen states that they and nominally the property of some of

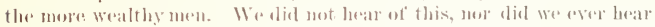

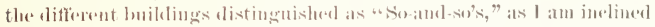

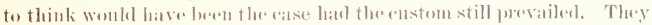

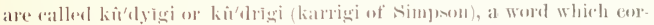
responels, mutatis mutaudis, with the (iresenlandie latgese, which means, first, a cirele of hills roumd at suall deet valley, and then at eirele of

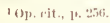

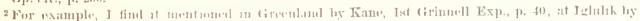

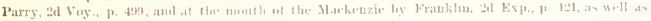
by Dr. Sinp

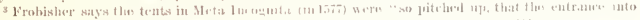

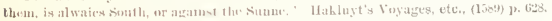

stieographiscloo Blitter, vel. 5, 1). 27.

'Up. cit., p. 259. 
preople: who sit elose together (and then, "mionsly enomgh, a brothel). At I'tkiavwiñ they are situated abent the middle of the village, one dose to the bank and the others at the ot laer edge of the village. They are built like the other homses, but ane lowader than lomg, with the riflgerele in the midhle, so that the two slopes of the roof are equal, and are not covered with turt, like tles d werlings, lwing unly partially banked up witl earth.

The one visited by lient. Ray on the ocedsion of the "trese danee" was 16 by 20 feet and i fiet high muler the ridge, and held sixty people. In the tall and suriug, when it is wam enough to sit in the ku'dyigi without fire and with the wiudow ofen, it is moel as a general lomgeng place or elubrom by the men. Those who have carpentering and similar work to do hring it there and others anot simjly to lomenge and gossip and heas the latest news, as the lumters when they come in genmally repair to the kitelygi as som as they have put away their equipments.

They are so tomd of this general resont that when uearly the whole village Was encamped at Imekpriñ in the sjring of $18 \times 3$, to le near the whaling gromol, they extemporizsd a elub homse ly artanging four timbers large enough for seats in a hollow squar war the mildle of the eamp. The men take tmos in catering for the chob, cach man's wife furnishing and reoking the forl fin the assembled party when her husband's tmm cones. The rlub homse, however, is not used as a sleepring place for the men of the villages, as it is said to be in the troritory south of IBering Strait, ${ }^{1}$ nor as a lootel for visitors, as in the Norton Sound region. ${ }^{2}$ Visitors are rither entertained in some dwellings or build temporary snow huts for themselves.

The ku'dyigi is uot used in the winter probably on account of the dithulty of warming it, exrept on the oreasions of the danees, festivals, or romjung eeremmies. Creviees in the walls are then covered with blockis of smow, a slab of transparent ice is fitted into the window, and the house is lightad and heated with lanpos. Buildings of this sort and used for essentially the same pmroses lave been observed among nearly all known Eskimo, exrept the Greenlanders, who, however, still retain the tratition of sueh struetures. ${ }^{3}$ Even the Siberian Eskimo, who have abandoned the ighn, still retained the kin'dy̆gi until a rexent date at loast, as IIonjer saw at Oong-wr-sac a jerformance in a "large tent, apparently erested for and levoted to pulliv pmowes (posibly as a romucil rom as woll as a theater, for in plase of the

'Petroff, Report, ete., p. 132,

${ }^{2}$ Dill, Alaska, 1. 16

${ }^{3}$ Sien link, Takes and Traltions, p. 8; also Geografisk Tiłskrift, rol 8, p. 141. Speaking of boild

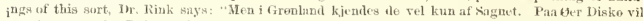
man have parist Ruinen af en satem Bygning, som besynderlig nok sierlig sagdes at have vieret benyttet til Festligheder af erotisk Natur." Boas, "Thn f'ental Eskimo," passim; Lyen, Journal, p. 325 (1gtulik): Richartoon, in Franhlin's 2d Exp. Pp. 215-216 (1tkinson Island); Pet tot, Monograpbie,

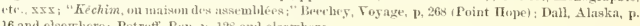
16 and elsewhere; Petrott, Rup. J, 12h and elsewherc. 


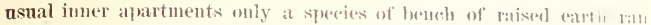

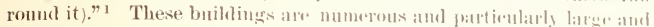
much used sonth of Bering sitrait, where they are also uscel is strat bath houses. ${ }^{2}$

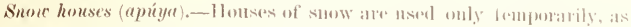
for instance at the hunting gromels on the fivers, and oceasionally ly

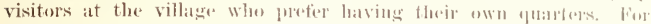

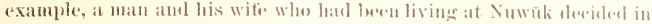
the winter of 1s:the woman's parents livenl. Instean of going to one of the lumses in the village, they built themselves a sum homse in which they spent

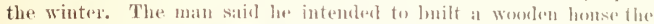

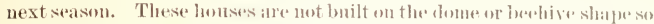

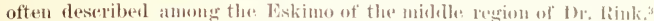

The idea maturally suggests itselt that this fom of louilding is really a snow tupek or tent, while the form userl at l'oint latrow is simply the iglu built of smow insteat of worl. Whos built on hacl groumb, as in the villater, the smow honse ameists of all oblong room about 6 feet by 12 , with walls mate of hlocks of smew, and high ranough for a person to stand np inside. Beams or polas are latid acrosis the top, and orer these is stretehed a roof of ramvas. At the somth and is a low narrow covered passage of smow about 10 thet long leading to a low door not over 'st foet high, above which is the wimlow, masle, as before deseriber, of seal entrail. The oprening at the miter end of the passage is at the top, so that one elimls over a low wall of smow to enter the house.

At the right side of the passatge, elose to the homse, is a small fire. place about $2 \frac{1}{2}$ feet sflutere and built of slabsot smow, with a smoke hole in the top and a stick sturk areross at the proper height to hang a pot on. When the first fire is built in such a tireplace there is comsich rable melting of the surfares of tha suow, hut as soon as the fire is allowed to go out this freezes to a latrel glaze of ice, which attorwarls melts only to a trifling extent. (D)presite to the lloor of the hemse, which is

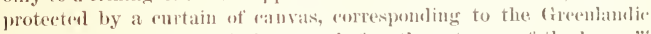
ubknak, "a skin whichs is loumen metore the entrance of the hense," the fleor is ratised into a bampuette about 18 incles high, on which are

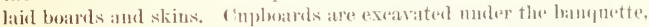
or in the walls, and jeges ane driven into the walls to hang things on.

1 Tents, etc.., P. 136

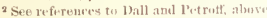

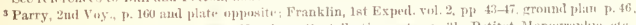

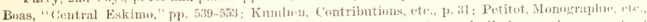
p. xvii (a full deseription with a gromul plan and section on p. sis), and all the popular acoumisut the Eskino.

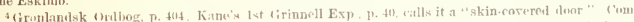

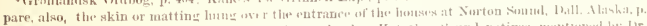

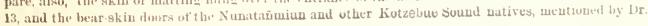
Simpson, op. eit., 1, 259

\section{9 $\mathrm{ETH}-6$}




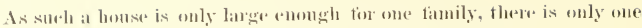
lamp, which stands at the right-haud side of the house.

At the leunting grounds, or on the real thither in the wiater, a place is selecterl for the lonse where the suow is deeply drifted under the adge of some bank, so that most of the hemse can be marle by exearation.

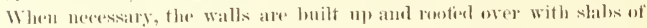
suow. Surb a honse is very sperelily built. The first party that goese over the roat to the louting gromel usmably builds honses at the end of earch clay's mareh, and these serve for the parties onning later, who

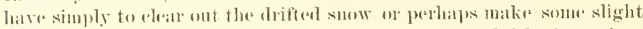
repais. On arriving at the humting sround they establish themselves in larger and nore comtortal) le homses of the same sort; generally for two fimilis:s. liont. liay, who visited these tamps, has drawn the plan represented in lig. 14. There is a bancuette, a, at eareh end of the room,

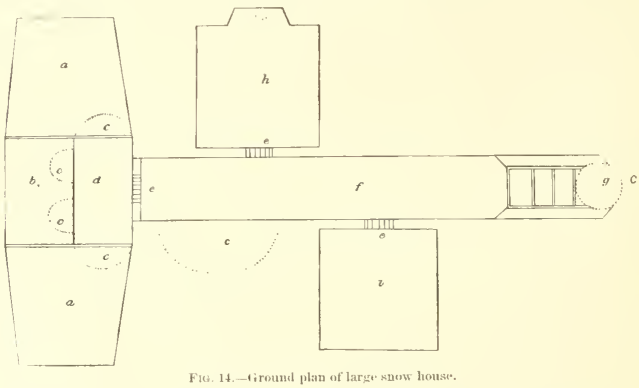

which is moch broater than long (compare the form of lieuse common

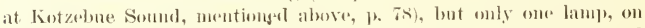

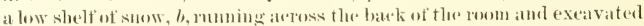
below into a sort of enphoard. There are also similar cupluaterls, e, at different places in the walls, and a long funnel, $f$, with the usmal storeroems,

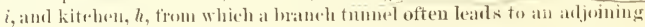

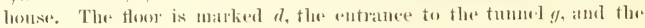
doer e. The lonse is lighted by the seal-gut winelows of the iglu brought from the village.

(1) going into tanp the railed sled is stuek points down into the snow and net-poles, or iov-picks, thrust thengh the rails, making at temporary cache tram ${ }^{2}$ on which are lume bulky articles-smowshoes and

\footnotetext{
1 Compare Dr. Simpkon's deseription. "11, cit. T. 959.

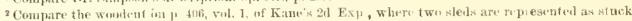
np on end with their "'npstanders" meeting to form a platforin-simith Sound.
} 


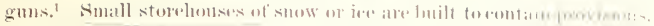

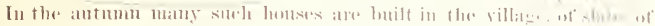

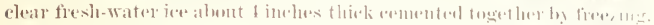

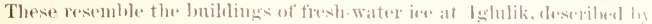
(atut. Lyom.

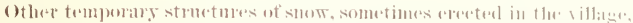

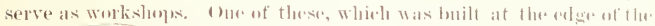

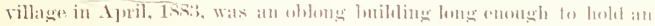

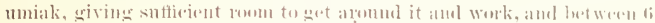

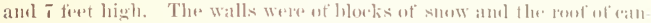

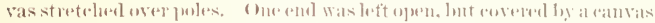

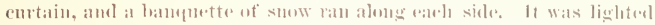

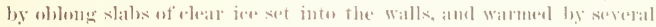

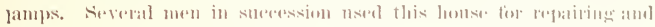
rigging up their mulaks, and others who haw whittling to do houglot their work to that same plawe.

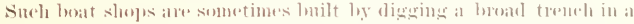

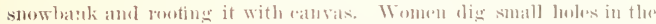
smow, whish they root orer with ranvas and use for work-rooms in which to dress seal skins. In sulh wases there is frolably smo snperstitions

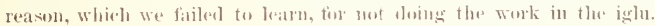

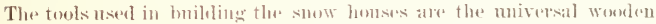
snow-shovel and the ivory snow-knite. for anting and trimming the

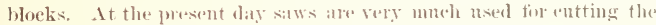
blocks, and also large iron knives (whalements " boarding kuives," ete.) oltained from the ships.

Tents (tuperi).-l)uring the summer all the natives live in tonts,

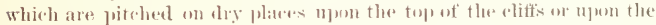
gravel luach, usmally in small ampes of fom or five tents rach. A tisw fimilies ge no farther than the dly hauks just soutlowest of the villiger, while the rest of the inhabitants who haye not gene castwat traling or to the rivers loming reindere are strmes along the const. The first eamp below l thiavwin is just beyoul the domble lagenen of Nomava, about 1 miles a way, and the rest at intervals of "2 or : 3 miles, usmally at

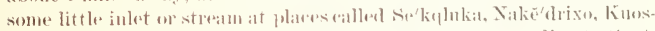

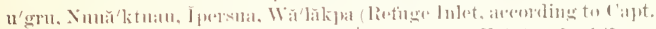

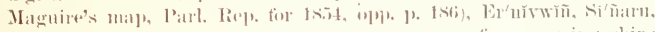

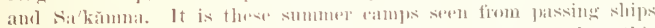
which have given rise to the ateonuts of mumerous villages alome this

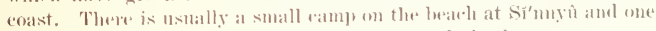

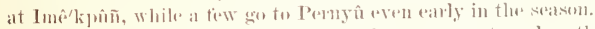

As the sta

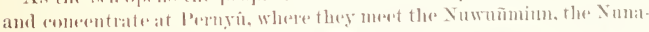

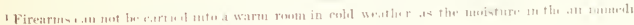

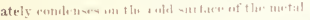

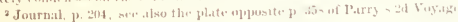


tanmiun traders, and the whalemen, and are joined later in the seatson by the trading farties retuming from the east, all of whom stop for a few days at Pernyô. On retmrning to the village alses, in September, the tents are pitrhed in dey plares among the homses and ocenpied till the latter are dry emough to live in. Trents ane used in the antumal

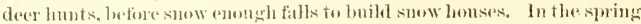

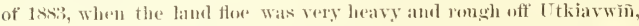
all who were going whaling in the ltkiavwiñ boats went into camp with their timilies in tents piteles on the erown of the beach at lmek

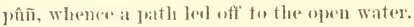

The tents ane nowalays al ways made of cloth, either saleloth obtained from wreass or dhilling, which is purrhased from the ships. The latter is prefored as it makes a lighter tent and both dark blue and white are used. Reindere or sual skins were used for tents as lately as 1sist. Elson saw tents of sealskin lined with reindere skin at Relinge lnket, and Heoper mentions sealskin tents at Cape sinyth and Point Barow. ${ }^{2}$ Dr. Simpen gives a dexeription of the skin tents at Point Barrow. ${ }^{3}$ Indeed, it is probable that canvas tents were not eommon mutil after the great "wreek seasums" of 1871 and 1866 , when so many whateships were lost. The Nunatañmin at Pernyô had tents of deerskin, and I remember ako seeing one soalskin tent at the same place, which, it is my impression, belonged to a nan fom Itkiarwin. loceskin tents are used by the Anderson River matives, ${ }^{4}$ while sealskins are still in use in Greenland and the east generally. ${ }^{5}$ The matives sonth of Kotzebue Somul do not use tents, but have smmmer homses erected above gromed and deseribed as "generally log strmetures roofed with skins and open in front." That they have not always been ignomant of tents is shown by the nse of the word "topere" for a dwelling at Nortom Somd."

Tle tents at Point Barrow are still constructed in a manner very similar to that descrilsed by I r. Simpon (see reference above). Four or five poles about 12 fert long are fastened togrether at the top and spread ont so as to form a eone, with a base abont 12 feet in diameter. Insirle of these about 6 f foet liom the groum is lasherl a large hom, upon which are bid shorter peles (sometimes spuss, umiali oars, ete.). The eanvas cover, which is now made in one piece, is wrappred spirally romet this

\footnotetext{
'Buelhey's Foyage, p. 315.

${ }_{2}$ Tents, ote, py. 216, 225.

sop. cit, p. 260 .

${ }^{4}$ MacFarlane Misi. and Prtitot, Munographie, etc. p.xx, "des tentes coniques (tuppepk) en peaux te renne."

"Sce Rink, Tales, tf., p. $T$ ("gkins" in this passage undonbtedls means scalskins, as they are more plentiful than decrskins among the Greenhadirs, and were nsw fur his purpose in Egede's time-Green, land, p. 117: and Kamlien, op.eit., p. 33.). In east Grvenland. aceording to Holm, "Om Sormmereubo Angs.

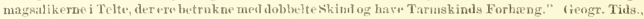
vol. 8, p. 89. In Frohisher's olseription of Meta lueognitu (in 1577), he sacg: "Their housed are tents male of acale skins, pitehed up with 4 Firre quarters, forre square, meeting at the topp: and the skinnes sewed together with sinewes, aud lagd therempon." 11:klnyt's Voyages, ete. (1589), p. 628. See also Boas, "Contral Eskimo."

"Petroti, op. cit., p. I28.

'Dall, Mlaska, p. 13.
} 


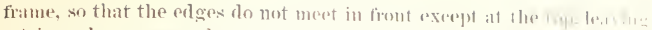

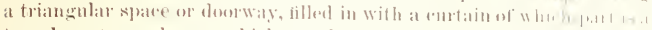

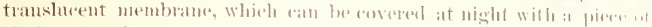

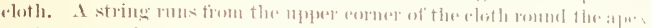

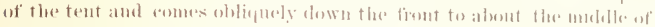

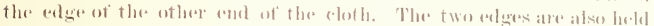

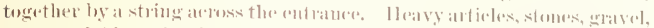

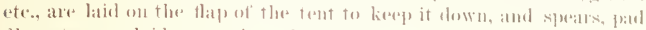

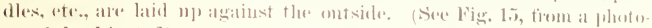
giatph by lixut. liay.)

Inside of the tent there is much lese fimniture than in the ighn, as flue

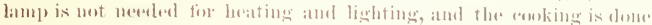

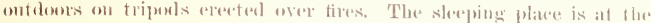

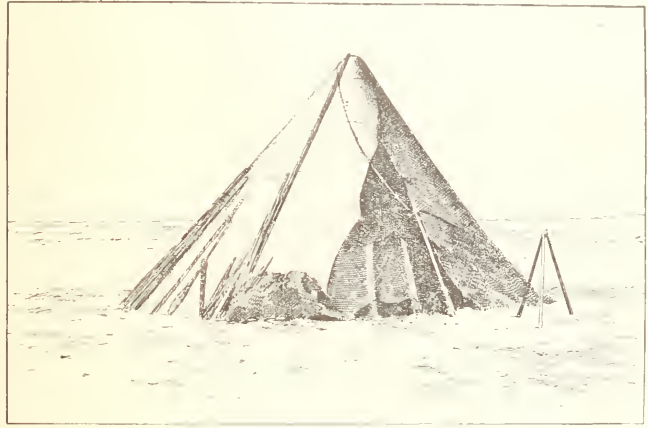

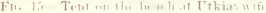

bawk of the tent, and is msually matred off by laying a loge across the

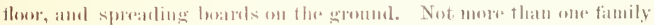

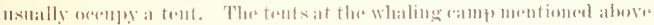
were, af first, titterl ont with sllow passages and tireplawes like at surow lunt, and many had a low wall of sunw aromed them, but these hatl all

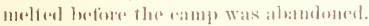

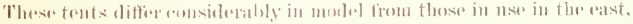

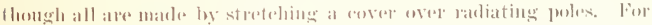

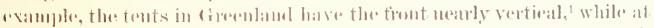

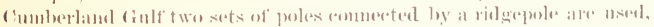

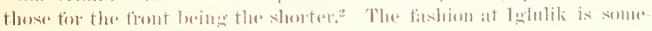

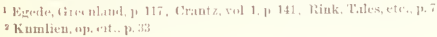


what similar. Small rude tents ouly large plough to hold one or two perplu are used as labitations tor women during continement, and for sewing rooms when they are working on dereskins in the antmmn. Tonts tor tla latter purpose axe called "su'dliwiñn," the place for working.

\section{HOLNEHOLD ITENSILS.}

FOR HWLDING AND CARRYXi Jog1, WATER, ETC.

Conteens (i'mutin). - Nome of the eantrens, the use of which has been clescribes alove (under "Irinks"), were obtained for the collection. They were seen only by Lieut. lay and tapt. llerendern, who made winter journeys with the matives. They describe them as made of seal skius and of small size. I find no pulblisluel mention of the use of such

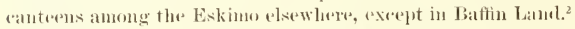

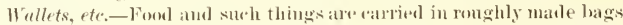
of skin or eloth, or sometimes merely wallperl 11 in a piece of skin or entrail, or whatever is consenient. Sprecial bags, however, are used for loringing in tha small fish which are eaught thromgh the ice. These are Hat, about 1s inclues or '2 teet sifuare, and male of an oblong piece of sealskin, part of an olıl kaiak eover, doubled at the bottom and setwed up each side, with a thomg to sling it wer the shomlders.

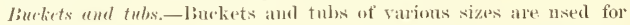
hohling water and otluer fluids, blublese, flesh, entrails, ofe., in the lonse,

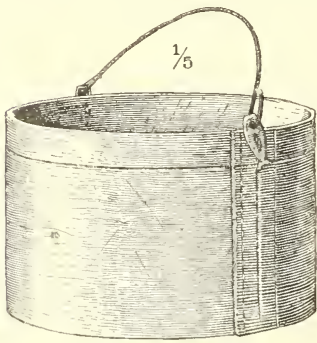

FIG. 16.-Woeten bucket. and are made by bending a thin plauk of wood (spruce or fir) romed a nearly eireular bottom and sew. ing tha ends together. These are probably all obtained from the Namatañminu, as it would be almost impossible to prosme snitable wood at Point Barrow. The andlection contains four s]ecimenstwo tubs and two butckits.

No. 56764 [370] (Fig. 16) will serve as a type of the water bueket (kintau's). A thin strip ot spruce simeles wide is bent romel a cirenlar bottom of the same woml 101 imeles in dianeter. The elge of the latter is slightly rommled and

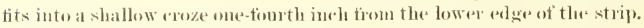
The encls of the strif overlaj, $3 \frac{1}{2}$ inches and are sewad together with narrow strips of whalebone in two rertieal seams of short stitelese, one

ISce. l'arry's 2nd Vosage, p, 271 aud plate oppesite. Compare also Chappell, "Hudson liay, " pp. 757.. tigrure on P. 75 .

2.Whou out traveling, ther mostly earry their water supply in a seal's stomach, prepared for the purpuse," Kumliew, op]. git.,p.41. Compare also Hall. Aretie Kesearcbes. p. 584. 


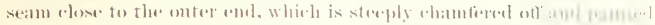

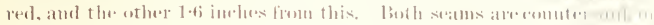

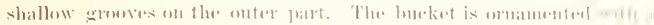

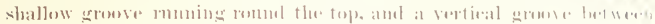

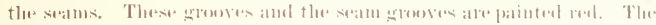

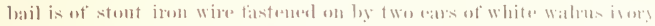

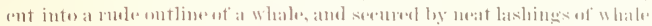

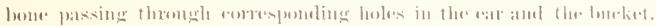

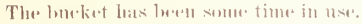

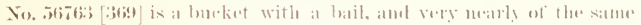

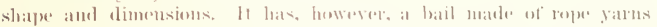

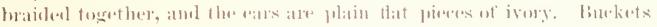
of this size, with bails, ame espereially nswet tor water, partientarly for

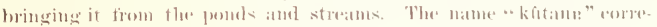

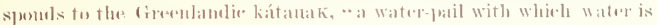
bromelit to the humse." t

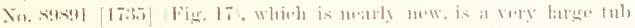

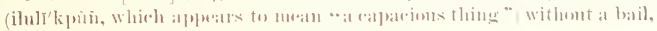
and is 11 inehes ligh and 20 in thameter. The sides a me malde of $f$ wo pieces of plank of expal lemerth, whose ands overlape altere

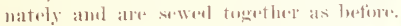
The buttum is in two pireres, onw lange and onw. small, matly tastened logether with

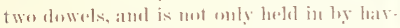

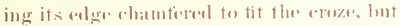

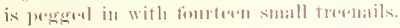

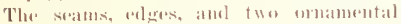
growres aromel the fop are painted recl as

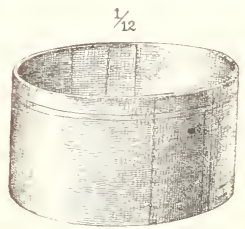

Fut, $7-\mathrm{L} a \mathrm{tt}=\mathrm{tul}$ hefore.

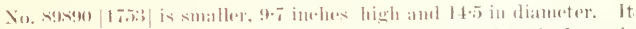

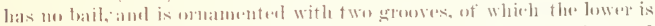

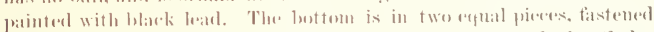
fogetluer with thenelowels. This is a new tub and has the kuotholes neatly phoggerl with wosel. There ane a mumber of these tuls in every

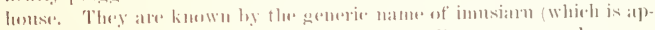

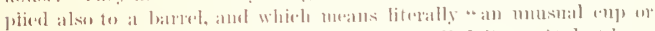

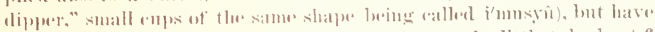

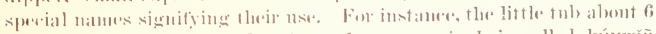

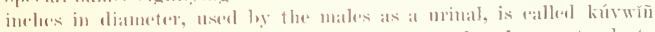

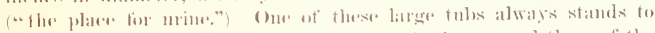
rateh the drip from the lump of smow in the homse, and these of the

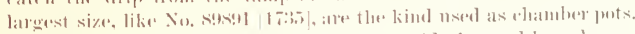

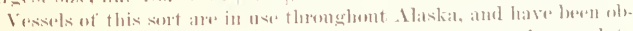

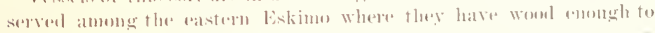


mak them. For instane, the Eskimo of the Coppermine River "torm very neat dishes of fir, the sides being male of thin deal, bent into an oval form, seremed at the ends by sewing, and fitted so nirely to the bottom as to be perfectly water-tighte" 1 There are sperimens in the. Musenu from the Mackenzie and Anderson Rivers, deseribed in the Mate Farane MS. as "pots for drinking with, pails for carrying and keeping water, and also as elamber pots. Oil is also sometimes earried in them in winter."

In some places where wool is searer vesseds of a similar pattern are matre of whalebone. Tessels "male of whalebone, in a rirevlas form, one piese being bent into the poper shate for the sides, ane mentioned by (ajet. Parry on the west shore of Baffins Bay, and "reireular and oval ressels of whalebene" were in use at Iglulik, This is the same as the Greenlandie: vessel called fortak (a mame which appears to have been transterred in the form prótino to the wooden meat bowl at Point Barrow), "al dish mate of a piece of whalebone bent into a hoop, which makes the sides, with a wouden bottom inserted." Nordenskiobld speraks of vessels of whalebone at Pitlekaj, lunt does not speeify the pattern. Whalelone dishes were nsed at Point Barrow, but at the present day only suall ones for drinking-eups are in general service. One large dish was eollected. (Fig. 1s. No. 89850 [1199]).

A strip of whalebone $4 \frac{1}{4}$ inches wide is bent rond a nearly eirenlar bottom of eottonword so as to form a small tub. The edges of the lot-

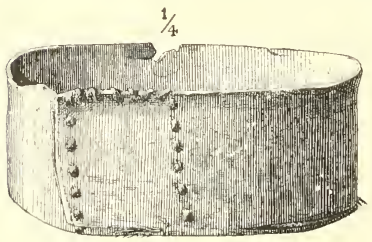

Fir. 18.- Whalehone dish. tom are chamfered to fit a shallow croze in the whale. bone. Theoverlapping ends of the whalebone are sewed together with a strip of whalebone in long stitcles. This dish is ruite old and impregnated with grease. Vessels of this kind are uncommon, and it is prolualle that nome lave been mads since whaledsone acruired its present eommereial value.

They were very likely in mon more general use formerly, as when there was no such marlet for whalelome as at prosent it would be eleaper to make tuls of this matrial than to buy wools ones. In corroboration of this view it may be noted that Tr. Simpsom deses not mention woodenware anong the articles Jought tor sale by the Numatañmim. ${ }^{6}$ The subll whalebone vessels will be described unler drinking eups, which sees.

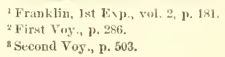

4Gronl. orelbog., p. 293.

h Vega, vol. 2, p. 224.

6 Op. cit., p. 266. 


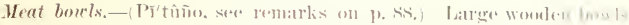

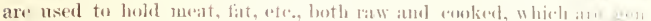
erally served on trays. These are of local manufartume and anverl

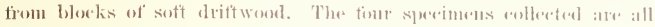

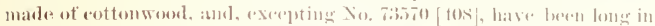
use and are thomenghy impresnated with grestse and blond.

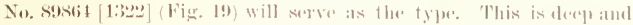

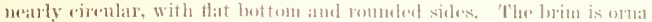

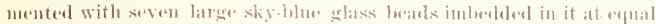
intervals, exerpt on one side, where the re is a broken notels in the place of a bead.

Another, No. s9863 [1:320], is langer and mot thattened on the bottom, and the brim is thimese It is also provided with a bail of seal thoug, very neatly made, as tollows: (Oile end of the thome is knotted with a single. knot intoone of the lobles so as to leave one long part and oure slowt piut (al)ent 3 inches). Thu lowg jout is the+11 arricel aeross and thromele tlat

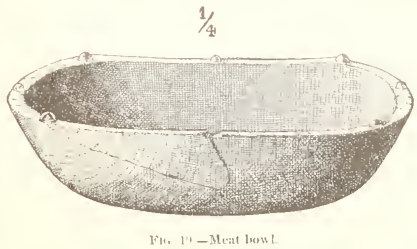
other hole from the ont side, lalek a gain thomgh the first hole and again areross, so that there are three parts of thomg stretelued ateross the bowl. The end is then tightly watpues in a close spiral round all the other parts, imelueling the short amb and the wrapping is finishes ote by turking the end nudere the last turn. The sperimens shows the method of meneling woeslen dislees, hoxes, pte., which have split. I lobe is

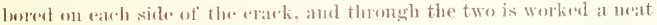
lashing of nalrow strips of whatelome, which draws the parts together.

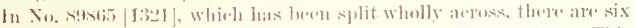

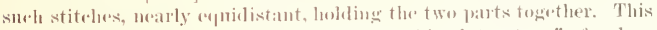
lowl is strengthemed lyy meatly rivoting a thin flat "strap" of wallow

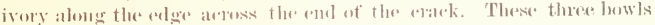
are of uealy the same shalje, which is the common one. The new bowl

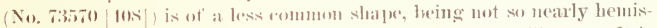
pherieal as the ot lecrs, but shapes more like a common milk pam. It is ollamented with stratight limes drawn in blatk leald, dividiug the sur

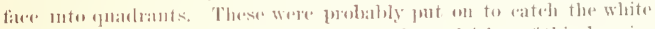

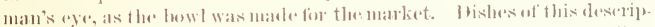

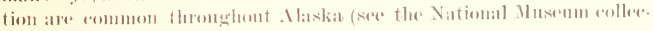
tions) and have beren noted at I'lover Bay.' 
Pots of stome and wher meterials (u'thuziñ).-In tormer times, pots of seatestome resembling those amployed by the eastern Eskime, and probably abtained trom the same region as the lamps, were used for

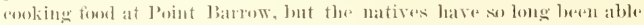
to prosure metal kettles directly or indirectly from the whites (Elsen

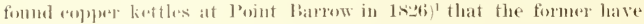
gene wholly ont of use, and at the present day fragments only are to l $x$. foumc. There are tome such fragments in the collection, of which thee are of the same model and one efuite difterent.

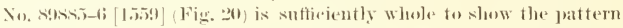
of the tirst tyee. It is of soft gray sometome. A large angular galp is brolien from the midlle of mese side, taking ont alsut half of this side,

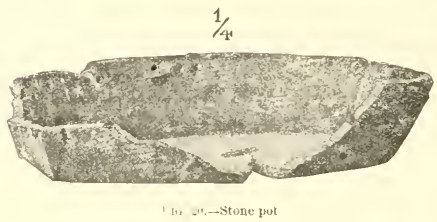
and a small angular piece from the bottom. From the eorwer of this gall the pot has been broken (1) linfuely aross the bottom, and mended in threa plawes with stitelees of whalebone malle as deseribed muler No.

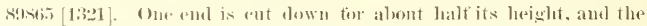
edge carried round in a straight line till it meets the gall in the broken side. This and appears to have heen piesed with a fresh piece of stone, as there are lades for stiteles in the edge of the whole side and in the

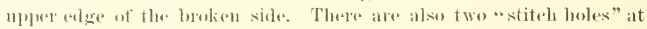
the other side of the galle showing how it was originally newhed. A low transverse ridge arose the mislelle of the whole end was probably an oruament. lloles for strings ly which the pot was luung up are bored one-fontle to one-halt ineh thom the linin. Two of these are bored obligmely through the esorers, whish are nuw broken off. The

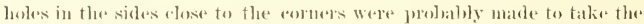
place of these. The pot is meatly and smootlely mate and the lorim is slightly romudod. It shows signs of great age, and is blackened with sout and "rusted with oil and dint?"

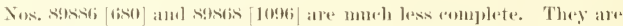
the lowken encls of pots slightly sualler than the above, but of jore

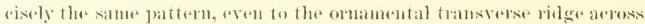
the end. The string lobles are bored thromgh the aromers as betione, and

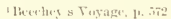

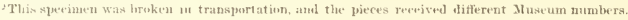
It is unw nemeded witli glue.

scomplare these pots with the two figureal in Parry is $3 d$ Jogage (plate opposite p. 160). The smaller

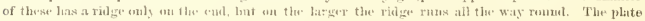
also shows how the puts were truug up. See aho Fig. 1, plate opposite p. its.
} 


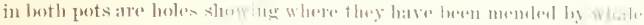

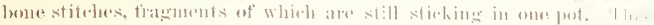

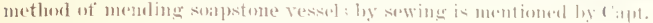
Parry ats plactionel at lublulik.

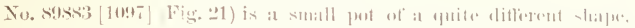

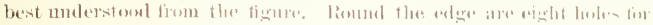

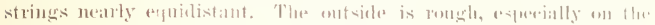

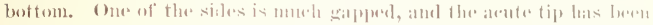

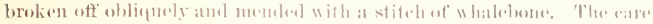

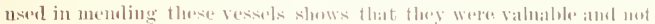
easily replitrel. 1 (:an find no previons mentions of the n-e of stume ves. sels for coroking on the. western const, and there are mo sperimens in the

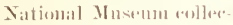
tions. The mily Exkimo steme verside arr a comple of smatl steme luwls firm Pristed Baly. The ate are

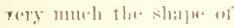

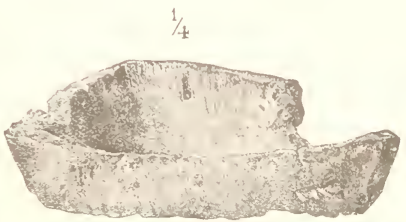

Fil, $21-$ sim.ll stone pol.

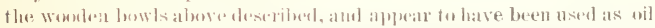

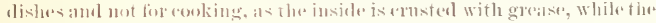

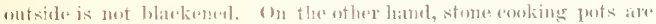

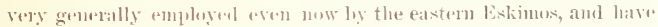

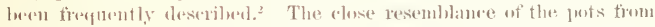

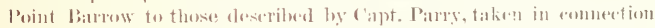

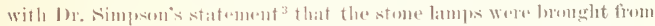

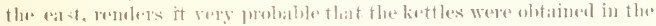

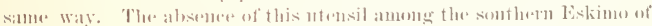

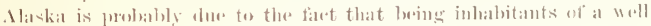

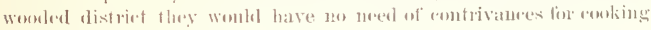
wrer a bampl.

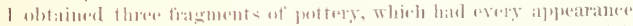

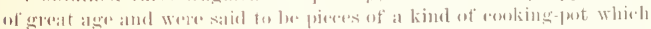

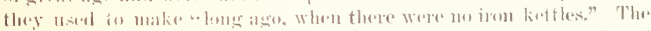

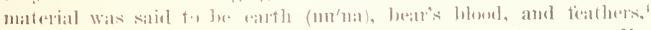

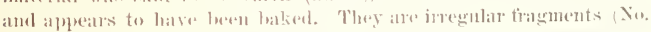

13a Voyagn, p. .018

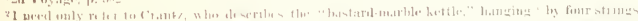

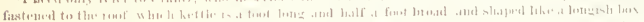

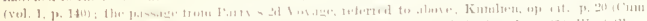

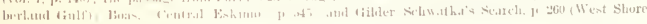
of Itulsm lingr.

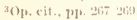

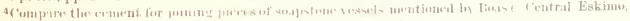

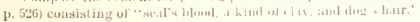




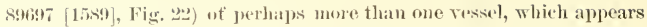
to have bexin tall and cylindrieal, puhaps shaped like a bran-pot, juetty sumeth inside, and roated with dried oil or bloul, blark from age. The ontside is rither Jough, and matked with fint romulal transerse rillgas, as if a large and had been womd round the vessel while still soft. The dargest shatrol has beren lorken oblinpely arross and mended with two stitches of sincw, and all are very old and black.

linchey (Voyagu, 1\% "295) speaks of "earthen jars for cooking" at Hotham Inlot in 1 s.26 and 1827 , and Mr. E. W. Nolsm has colleeted a
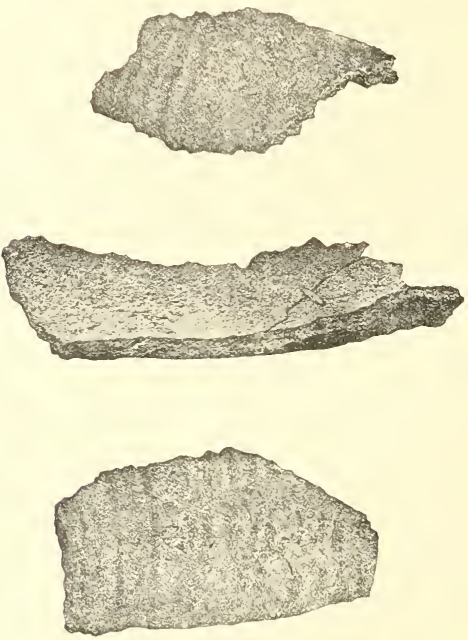

Fic, 22,--Fraguents of pottery.

few jarts from the Nortom sound region, very like what those nsed at Joint barrow must hate berm. ('Juris figmres a similar vessel in lis

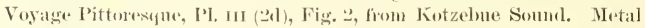
kettles of varions sorts are now exclusively used for conking, and are called by the same name as the old sontsitone vesisels, which it will be olserved correspmuls to that name nsed by the eastern Eskimo. Light sheet-ion eamp-liettles ane agerly purchated and they are very gland to get any kind of small tim eams, smeh as preserved meat tins, which 


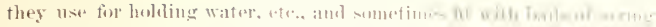

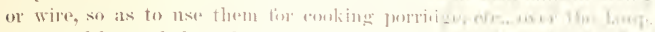

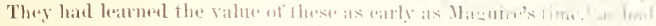
the people of Ploxer lial in 1st?

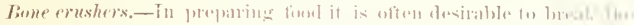

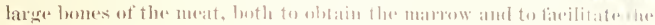

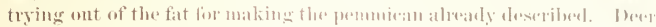

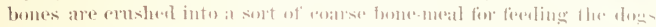

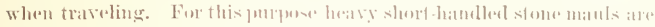

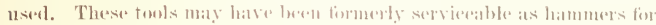

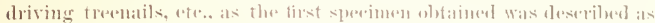

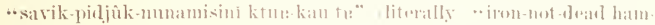

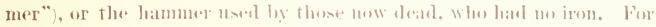
this purpose, howerar, they are wholly supersented by iron hammers,

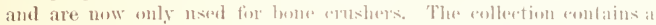
large series of these implements, namely. I: complete manls ame fis

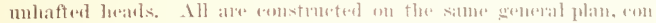

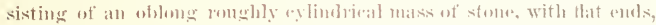
momnted on the expanderl end of a slont latit, which is alppliest to the middle of ame side of the eylimber and is slightly enrewd, like the hamdle

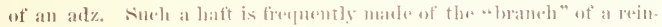
derer antlere and the expanded and is male by enlting off' a portion of the ..heam" where the haneh juins it. I hatt so made is natmally elliptial and slightly enreed af right angles to tlote lomger diamefor of

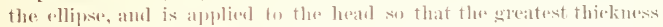
and therefore the greatrest strength comes in the line of the blow, as in

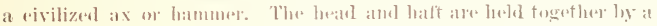

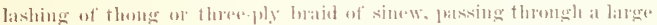

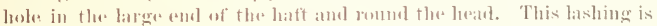

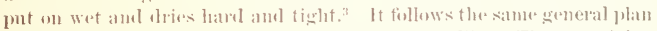
in all the sperimens, thomgh wo two atre caretly alike. The material of

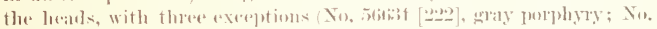

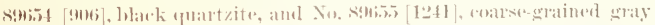

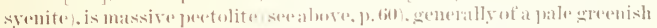

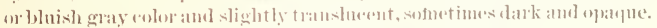
No. atios. $[2013]$ will serve as the type af these implements.

The heal is of light hluish glay peretulite, and is lashed with a there.

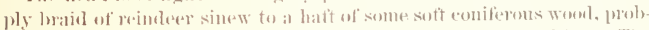
ably spruce, rather smosthly whittled ont and soled ly hambling. The

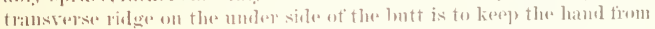
slipping off the grip. The whole is dirty and shows signs of ensider. able alge.

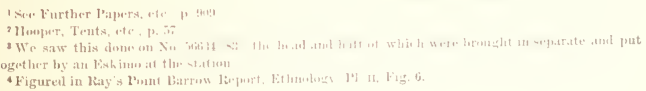


These manls vary considerable in size. The largest is $7 \cdot 1$ inedes long

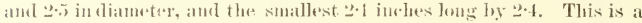

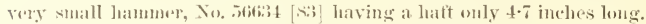
The hatt is nsually abont is iuches long. The longest (belonging to one of the smaller heats, 4 incleses by 2 ) is 7.2 ind los long, and the shortest (helonging to a slightly larger lead, $4 \cdot 7$ by $3 \cdot 1$ incluss) is $4 \cdot 5$ ineles. The

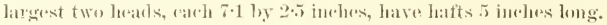

The daslung of all is put on in the same gemeral way, namely, ly se. cming one end roment the head and throngh the eye, then taking a varia-

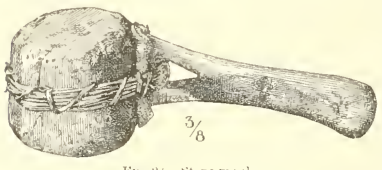

Fir, 2 i _. Stone matul

ble mumbry of tulus romud the head and thromgh the lole, and tightening these II) by wrapluing the end sporally round all the parts, where they struteh hom leeal to latet on ealele sir]e. seal thoug, narrow orluoad, is more generally user than

sinew hraid (moly thee specimens out of the thirteren have laslings of sinew). When broal tlomge is noed the leopl is mate by splieing, as follews: A slit is ent abont $1 \frac{1}{2}$ incluse from the end of the theng, and the end is donleder in a bight and passerl thromgh this slit. The end is then slit and the othere ent of the thomg passed through it and trawn tant, making a spliee which loolds all the tigliter for drawing on it. I simple loop is tied iu sinew braid.

The following figmes will illustrate tlue bust important valiations in the form of this imple. ment. Fig. 2:3, No. is663t [*:; firom Tthiaswĩn, has a hoarl of light smay pestolite, slightly translurent, and evidently groumel flat on tlee tares.

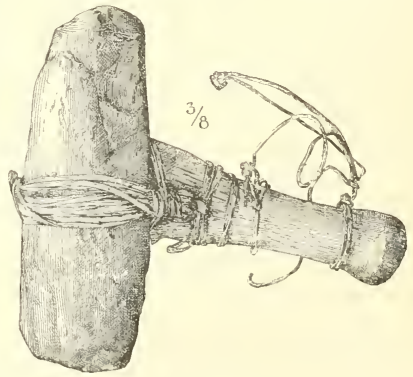

I. 2.,-Stone manl.

and the halt is of remelees anther, with a slight knob at the hutt. A sepuare piose of bueleskin is doubled and inserted between the lead and hatt. The bashing is of tine sealskin twine, and the spiral walpoing is rarried wholly rouml the head. This was the first stour maul collected, and was put together at the station, as mentioned above. It is rather smatler than usual. Fig. 24, No. inti37 [196], from It thiarwion, has the 


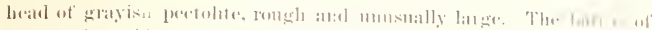

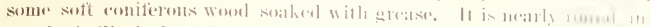

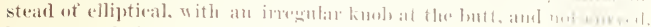

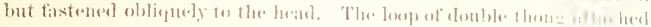
to the hatt is probahly to gen lomel the wrist.

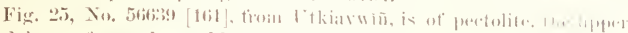

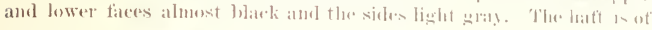

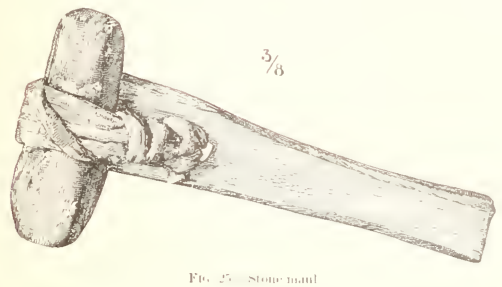

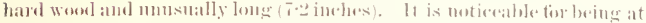
fareded at riglit angles to the head, Jy a very stont lashing of theng of the usual kind, atud further tightened by a short that stick wedgerl in

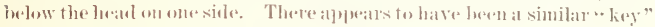

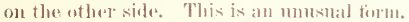

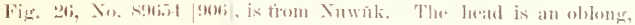
nearly reydindrieal, watre.

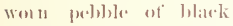

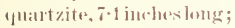
the halt isof reinhererantler, aud the latshingot'seal thouls.

Fig. 27, No. Xatio.s

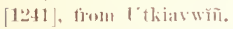
The heal of this mat is a loug peloble of rallow

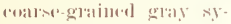
enite, and is juenlial in having a shallow groove ronghly workerl ont bomel the midelle to keces) the bashing firem slijepinge. It is 1.7 inclues

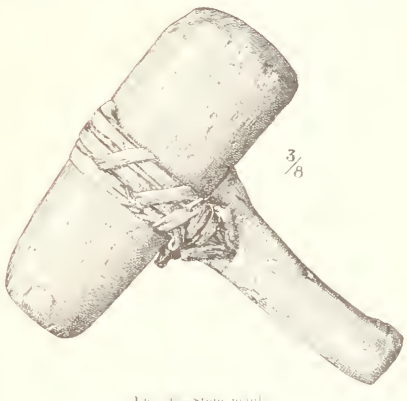

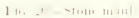
lone and $3 \cdot 1$ in tianeter. The hatt is of reindere ant ley 4.5 inches long, and the lashing of weal thong peculiar only in the latge number of tnlos iu the spiral wrappings. 
Fig. 28, No. s!) batt fitted into a deep angular growve on one side of the head, which is of peetolite and otherwive of the common pattern. The haft of reindeer antler and the lashing of hroal thong are evidently urwer than the head aud are clumsily malk and put on, the latter making several turns

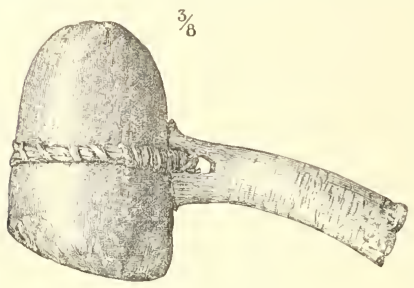

Fit, 27, Stone manl. about one sisle of the hatt as well as through it and romel the liead.

None of the unmennt(at hetuls, which are all of pectolite, are greored in this way to receive the laft, but No. 566:s [20.i] las two shallow, imemplete grooves romel the midille for laskings, and No. 56665s [21s], which is mearly square in sertion, lats shallew notolies on the edges for the same purjose. One sperimen of the series cones from Siclaru, lont differs in no way from specimens from the northern villages.

Sitonemanls of this type have previously beren seldom found among tha. Americus Eskinu, Thromly sperimens in the Jusem from Ameriat are two small mulatted mand beads of peretolite, one from Hothan Inlet and the other from calpe Nome, and a romghly mads: naml fiom Norton Souml, all collected by Mr. Nelsem. The last is an oblong piece of dark-

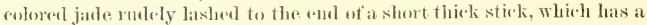
lateral projection roned whieh the lashing passes instral of through a

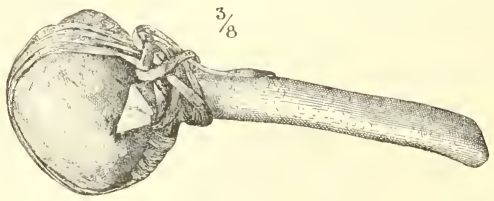

Fif. 28,-Stone manl.

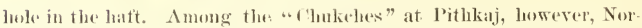
denskiëld fonmel stone manls of precisely the same model as oms amel also now as bone crushers. He observed that the matives themselves ate the crushed bone after boiling it with blend amb water. ${ }^{1}$ Lient. Ray saw only dogs ferl with it in the interior. Sordenskiöld does not men-

$$
1 \text { Vega, vol. 2, p. 113; figures on p. } 112 .
$$




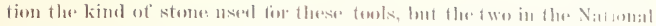

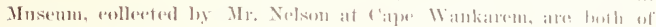

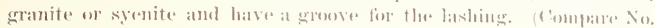
sตtion $[1241]$, fig. 27.

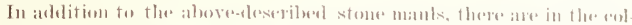

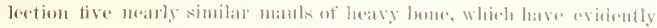

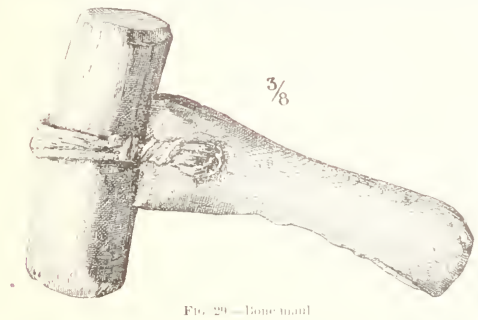

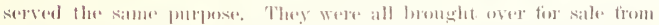

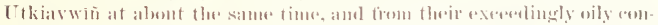
dition wore evidently benght to light in rommaging romed in the old

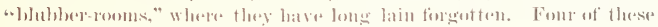

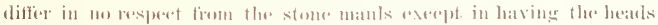
mate of whales rilh: the lifth is all in whe pioce.

The following tignes will illustrate the groural tom of the se imple.

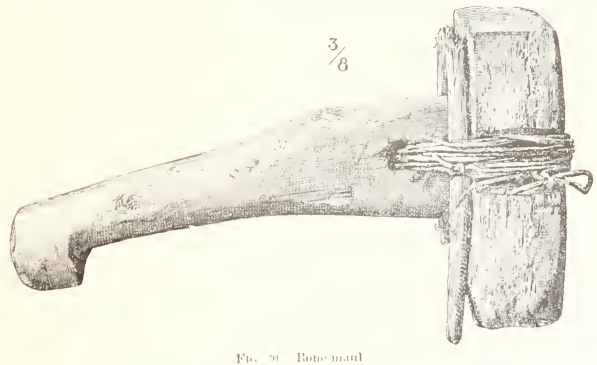

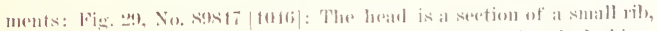

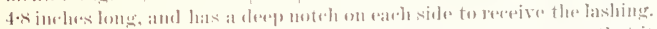

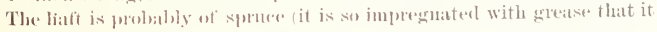
() ETHL-i 


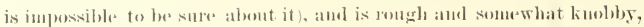
with at romendel lineb on the butt and two shatlow finger notelese on the muler sicle of the erip. It is attarelerl loy a lashing of stout thomg of the

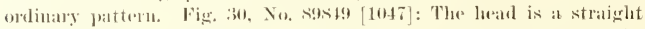

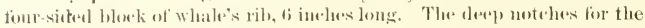

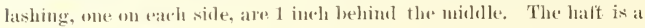

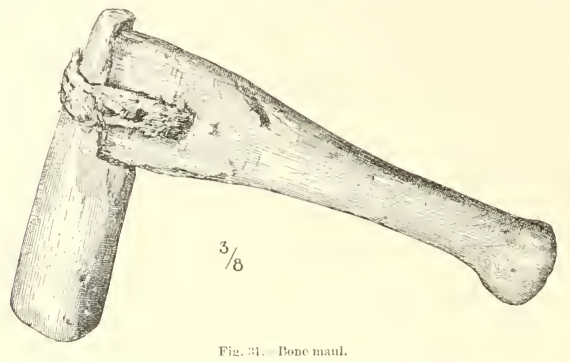

roughly whittled knotty piece of spruer, and insteal of a knob has a thirek tlange on the lower sile of the loutt. The lashing is of fourterem or

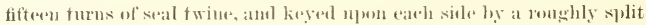

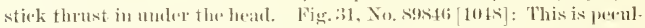

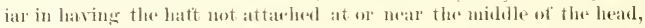
but at one end, whielt is shouldered to redetre it. The hatt is of the common paftern aul attathed as usual, the lashing leeiug made of very stont

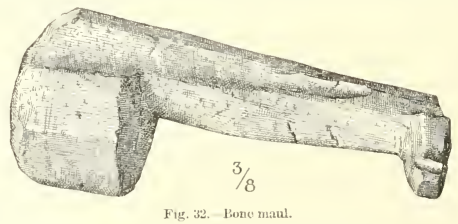

sinew braid. The head is a seetion of a small rib fi iueless long. Fig. 32,

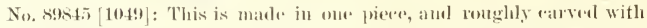

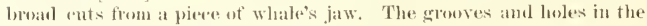
bone are the natnral canals of blow vessels. All these manls are battered on the striking fioc, slowing that they have been used.

At the first glane it serms as if we had here a series illustrating the development of the stone hammer. Fig. 32 would be the first form, while 


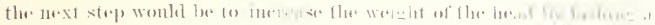

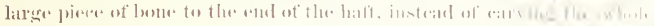

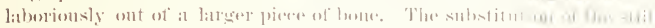

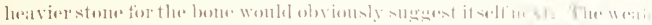

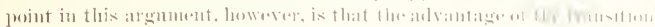

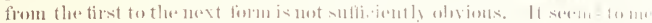

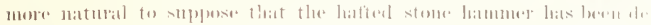

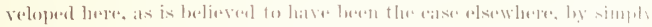

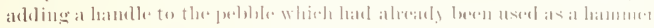

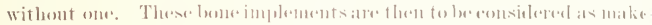
shifts or substitutes tor the stour hammer, when stones suitalue for

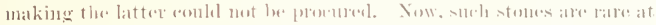

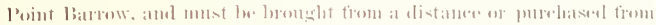

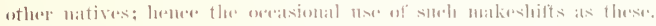

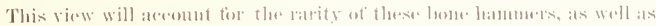

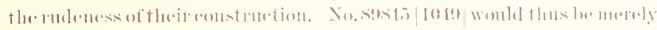
the result of imelivilual tanes and not a link in the chatin of derolopment.

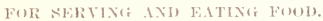

$11: 1 Y$ r.

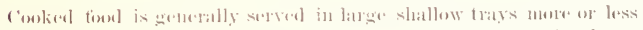

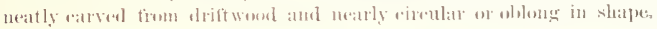

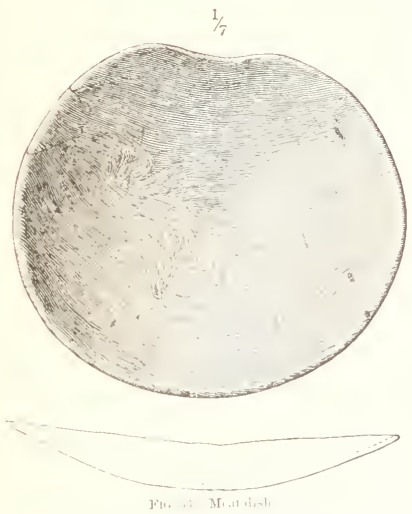

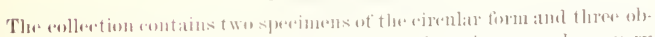

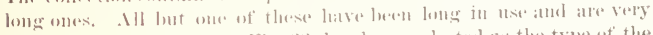

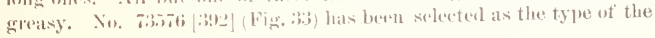




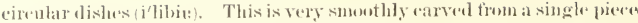

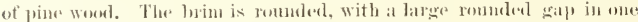
side. Where a pioce bas probably been broken out. The brim is slightly

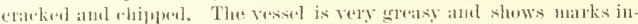

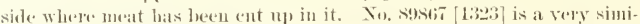

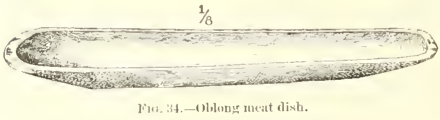
lar dish, and mate of the same mate. rial, but elliptical instead of cirmular, and linger, being 23.. inches loner, 1.5.5

broad, and $2-1$ deep. It has bean split in two, and monded with whale bour stitelaes in the manner previously described.

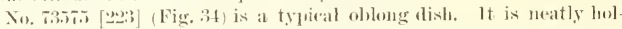
lowed out, laving a broal maregin painted with red owher. It measures

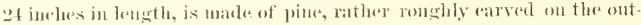
sidr, and is new and eleam. This is a common torm of dish. Fig. 3.5, No.

1 ,

$1 / 8$

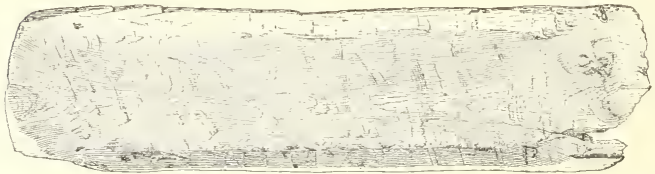

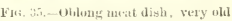

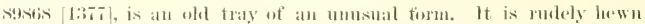

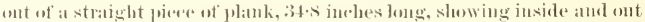

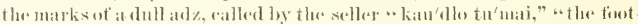
printsof the stone (seil, aldz)." The excavation is shallow and leares a maregin of 2 inehes at one end, and the ontside is renghly loeveled off at the sides and rods. The lobles near the ends were evidently tior hatudles of thong. The material is sproce, discolored and somewhat ureisy. Fig. 336, No. stostits [1:3iti], was salis loy tlec native who loromglit it ox w for sile to loe especially intemded tor fish. It is much the slatae of No. 73.7.5 [2:3], but boader, slightly deeper, and more

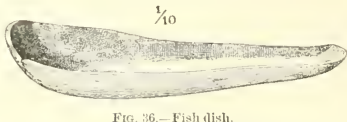
enved. The lorim is narrow and roumled and the bottom sumotluly roumled off. It measures $23 \%$ ineles in length, and is made of pine. It has been derply split in two places and stitehed together with whale- 


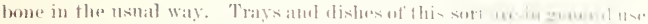

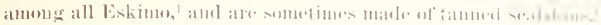

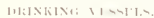

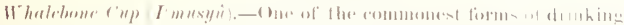

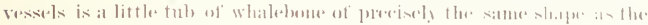

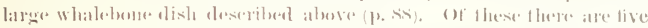

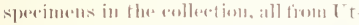

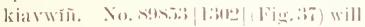

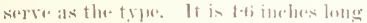
amel mate ly bioding at strip ot blatek

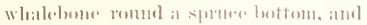

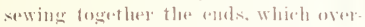

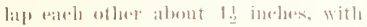
roalese strijes of whalelone.

There ate two sertieal seatus throe. fourths iurle ajout. The buttem is leclel

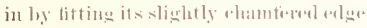

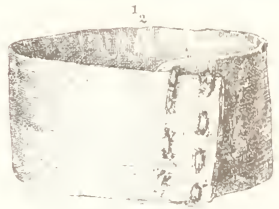

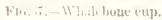

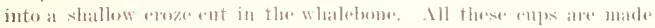

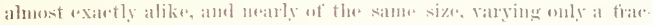

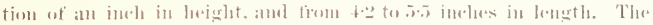

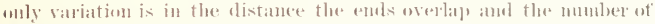

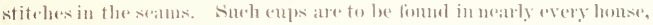

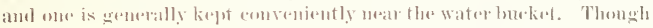

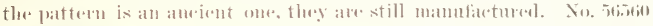

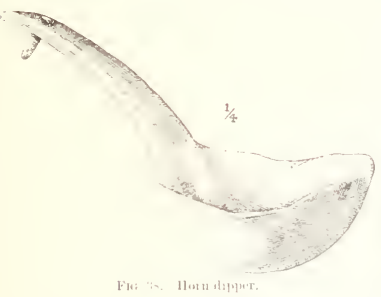

[ii.,t] was fomel anomeng the theris of one of the rained lusks's at letkiarwin, anul differs from the menleru rups omly in havinge the rimls sewed togetlere with one. seam insteat of two,

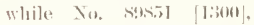
thougle it has berell in ate that use. Was male atter nur arival, as the bottom is matle of a piese al one of our vigar boxes.

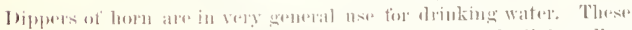

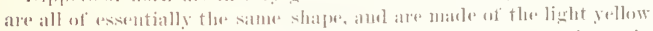

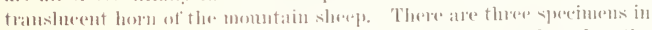

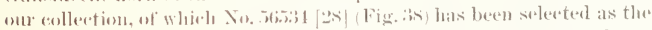
type. This is mate of a single piece of pale fellow tramsheent horm,

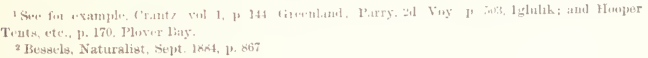


apparently softened and molded into shape, cut only on the edges and the hamble. A stent perg of antlere is driven themgh the bamble, 1 inch form the tip, and pojerets belind, serving as a hook by which to hang the dipyer on fle enlge of a lmeket. The othes two are similar in shape

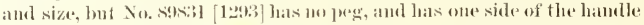
rut into a serifes of sliglit noteles to keep the hamd from slipping, while No. s!s:3: $[5 \pi \sigma]$ is rather straightor and has a smaller, shallower bowl, amel the grip of the lamble rouglemed with framsterse grooves. Fig. 39, No. s9739 [75t], is a horn dipleer, but one that is very old and of a

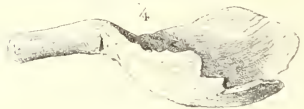

Fid. 39,-Hotu dipper. pattarn no longer in use. Tha bowl, which is mueh boken and gapjed, is oval and derep, with a thek landle at one end, rmoning ont in the line of the axisof the bowl. This handle, which is the thick part of the lemen, near the $t i_{p}$, is flat alsose, romuded below, and has its fip slightly romuled, apparontly ly a stome tool. dust where the lowl and hamble med there is a deep transverse sawent, mame to fareilitate hemeling the handle info its plate. The material is horu, apparently of the momtanin sheep, tumed brown by age and exposme. The speeimen had been lomg lying negherted romud the vil lage of Utkiavwrîn.

Ilorn dippers of the same general pattern as these are eommon flnemglout Alaska. The Musenm collection rontains a large series of snels uteusils, collerted by Mr. Nelsen and oflers. The eups and dippers of musk-ox lorn tomed by l'arry af Iglulik are somewhat diflerent in shape. These mate of the enlarged base of hementere a short hamele and a nearly sequare bowl, while the hollow top of the born is used for a eup without alteration heyond sometimes lending we the

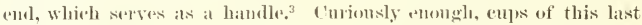
pattern appear not to lo fond anywhere alse except at Plover bay, eastern Siberia, where rery similar vessels (as shown by the Mnsem collections) are made fiom the horn of the siberian mountain sheep. An musmal form of dipper is beantifully made of fossil ivory. Sue cops ane rare and highly prized. Wo saw only thee, ome from ath village, Numǔk, Itliavwiñ, and Sistarn, and all were ol,tained for the collestion. They show signs of ane and houg nse. They differ somewhat in shape and siz" but each is earved fiom a single piece of ivery ambl laas a large lowl and a straight hatudle. No. 56535 [371] (Fig. 40),

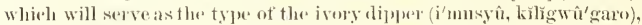
is neatly earved from a single prese of fine-grained fossil ivory, yelbow bed by age. The handle, polished by leng use, ferminatex in a blunt, recorved, tapering hook, which serves the pmpose of the jug in the

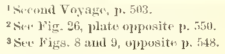




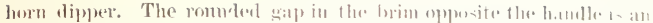

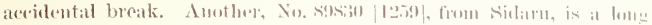

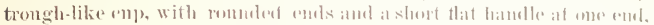

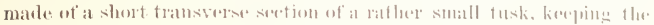

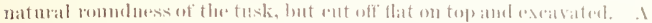

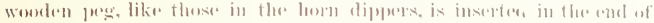

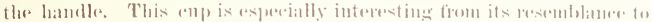

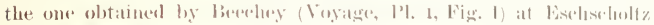

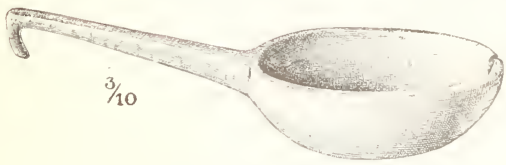

Fir. 40,-Dipler of limall ivars.

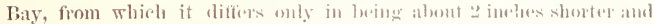
deeper in proportion. Thomas simpen spealks of olotanime an ivory

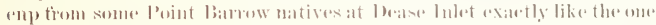

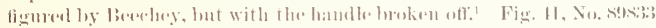

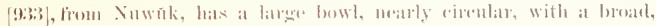
straight haulle and a broal howk. The patt of the lowel to which the

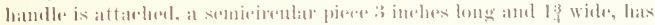

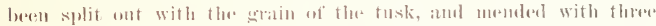
stilelese, in this rase of simew, in the nstal mamer. There was an whl

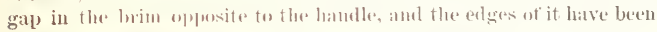

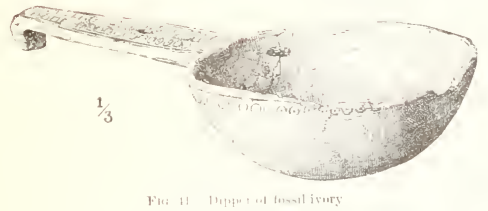

freshly and ronghly whitflod down. The on manentation of the ontside

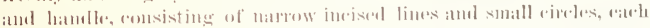

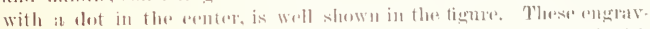

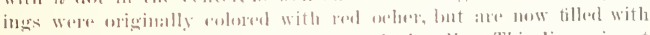

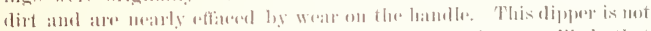
of sueh the anality of isory as the other two. It is mot molikely that

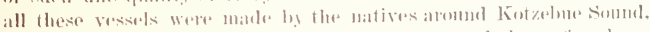

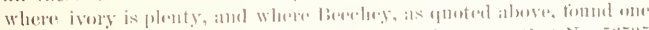

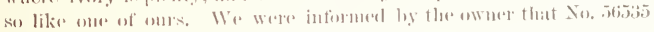

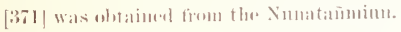

$$
\text { 'Xatritin, 1, } 148 .
$$


spoons and ladles.- Each family has several spoms of vartots sizes, and narrow shallow ladles of lown, lome, ete. The barese spoon is for stirring and ladling somp, ate. There is only one specimen in the aol-

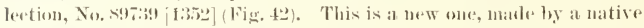
of Utkiarwiō, whom I asked to make himself a new spoon and bing

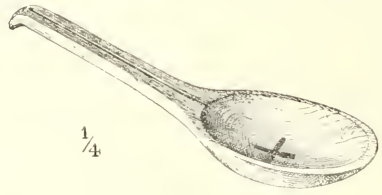

Fu, 4:-W Woulen spose me his ollt one. Ile, loww. aver, mismolerstood me and loromgt over the niw one, which Lient. Ray jmr(risised, not knowing that I bat esprecially asked for the old one. These spoons seren to be in surh constant use that the matives did not offer them fior sale. This sperimen is smoothly earvel from at single piece of pine, and painted all over, except the inside of the bowl, with med ocher. A eross of rest ox ber

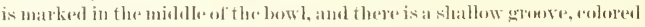
with blackleat, along the misldle of the handle om top. The length is $13 \cdot 2$

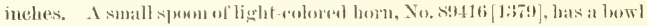
of the common spen shape with a short, llat hamelle. Spooms of this sort were not seen in use, and as this is new and evidently made tor sale it

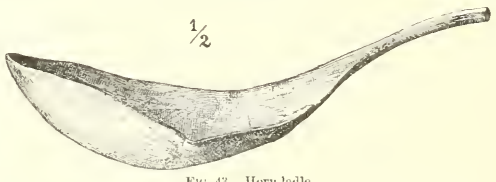

Fit, 43.- Horn latle.

may be meant for a copy of one of wur spons. The narrow latles of hom

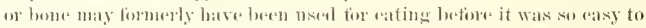
get tin jots, but at present are diefly used lor dipping oil, espeedally tor filling the lamp. The abllation contains one of horn and fom of lome.

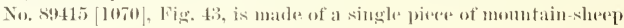
horm, dark lorown from age and use, soltenesl and molded into shape.

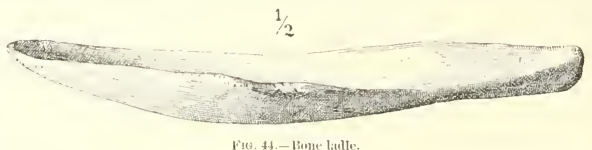

It is impregnated with oil, showing that it bas loren long in use. This otemsil closely resmbles a great momber of sperimens in the 11 usem from the more southern parts of Alaska. No. s9411 [1294] (Fig. 44) is 


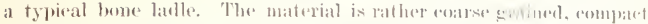

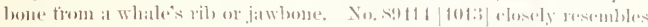

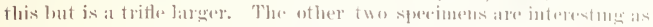

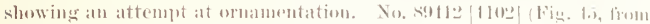

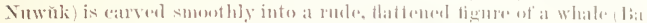
latena mysticetus). Ther thokes form the batmello and the lxelly is loblleweel out inte tlae bowl

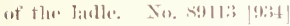

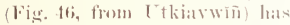
the hatulle earved inte a mole bear's heat, which has the eyes. mostrils, and ontlins of the moutlioncised and ti]led in with

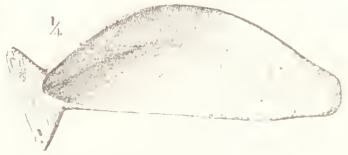

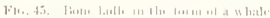

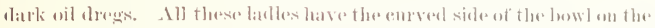
left, showing that they were meant to he ared with the right hame. The

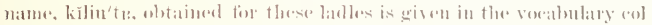

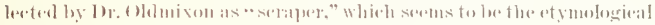

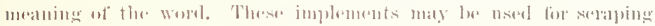

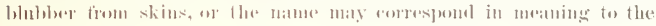

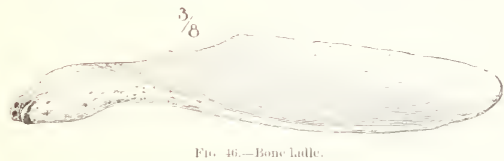

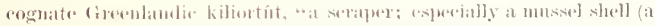

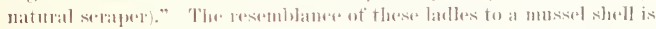

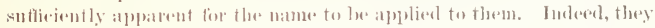
may have heen marlo in initation of mussel shel]s, which the Eskino,

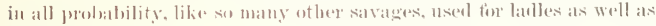
serajurs.

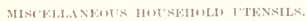

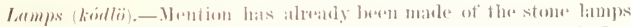
or oil burmers used len lighting and watring the lonses, which, in Dr.

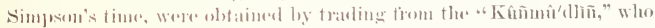

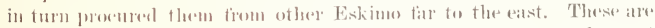

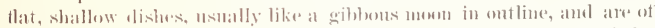

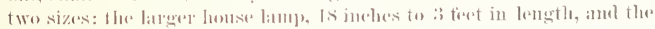

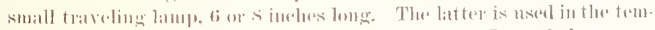

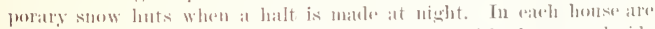

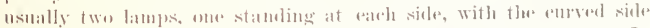

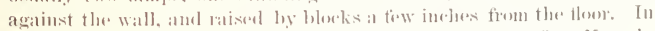

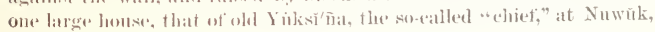




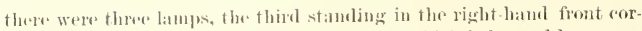
nel of the house. The dish is tilled with oil, which is burued by means

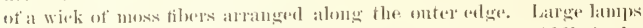
are usandly divided into three compartments, of which the midelle is the

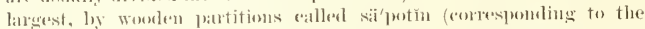

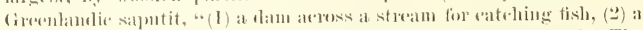

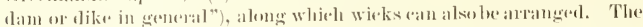
womenteme the lamps with great ware, trimming and arramging the wirk with little stieks. The lamp burus with seareely any smoke and a

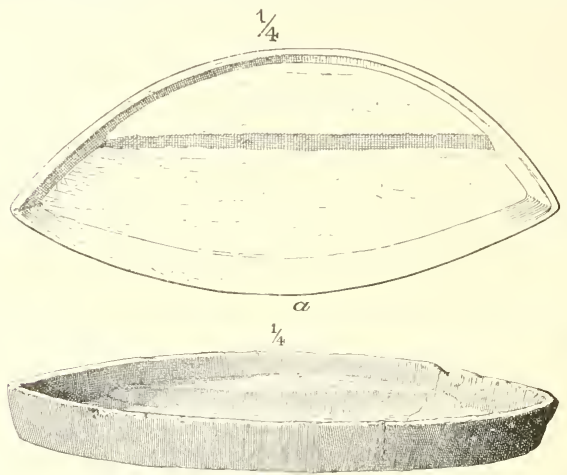

Fig, 47-Stune hotrac liump.

bright thame, the size of which is regnlated ly kindling more or less of the wirk, and is tosmally kept filled by the drip from a lump of blubler

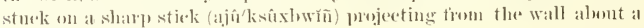
fout above the michlle of the lamp.'

In most lomoses there is a long slemler stirk (knkmu, "al lighter"), which the man of the hense nses to light his pije with when sitting on

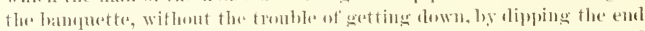
in the oil of the launp and lighting this at the thame. The stirks used tor trimming the wiek also serve as pipe-lighters and for carying fim

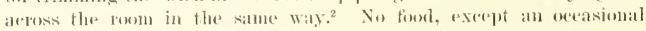

Wompare the custom matieca by Parry, at lylulik, of hamgine a Jony thin strij of blubber near the

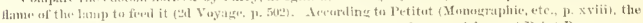

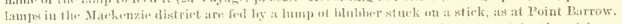

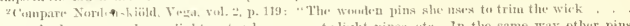

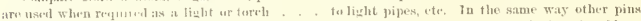

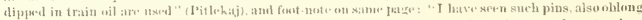

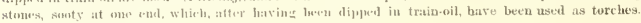
. . in old Eahino graves in northwestern Greculand." 


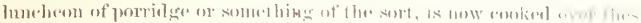

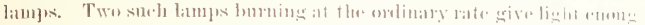

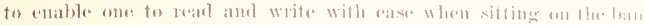

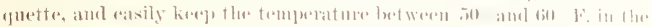

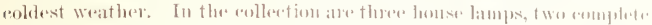

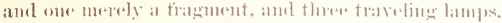

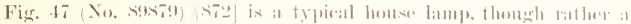

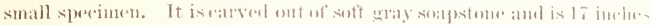

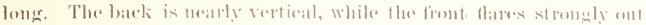

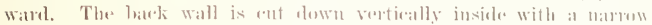

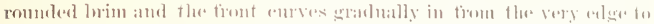

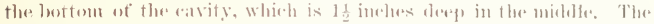

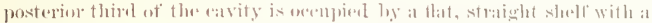

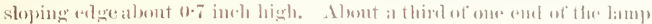

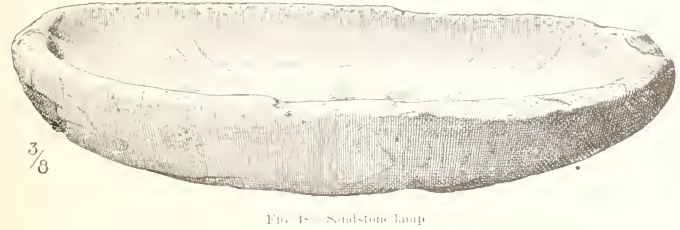

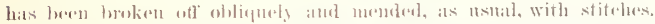

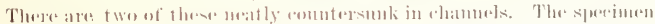

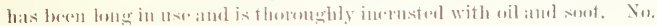

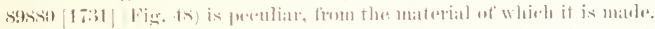

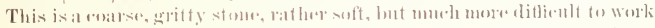

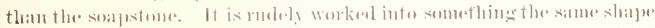

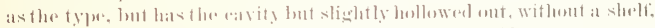

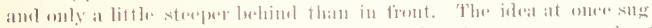

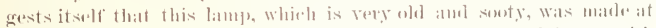
Point barrow anel was an attempt to imitate the imported lampe with

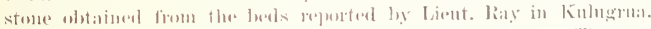

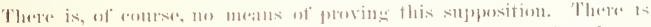

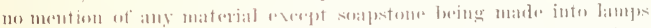

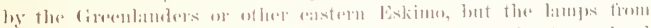

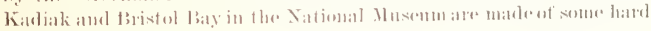
griay stome.

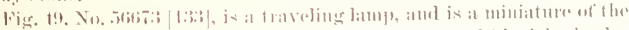

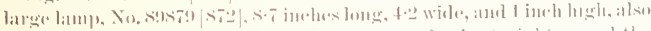

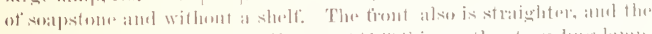

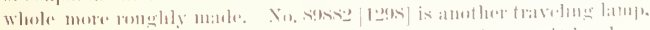

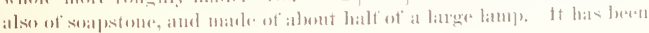


usel little if at all sinee it was male over, as the inside is almost new while the outsiclo is conted with soot and grease. It is $69.3 \mathrm{im} \cdot \mathrm{hes}$ long.

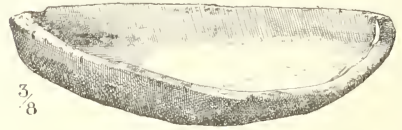

Fis, 19, Trituling laup.

No, s!osit [ [20?] is a mini ature of No. S!ssit, s.1 inclues lomg, and is made of the same gritty stome.

Sinitalofe material is net at hand fir the poreper rompririsom of the lampes nsed lo the different bameles of the Eskimo rate. All traveless who have writen alent the Eskime sperak of the use of sueh lanus, whieh

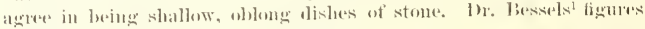
a kaum of solapstome from Ita, Suith Somul, ekosely resembling No. s!sso, amel a little lamp in the Musemu trom Greenland is of essemtially the sime shape, but dereler. The same formale pears at IJulsen strait in the latups collected by Mr. I. M. Turmer, whilw those nsed at tghlulik are nearly simi rirenlar. ${ }^{2}$ Somth of Kotzebue Soumel lamps of the shalpes se common in the east are lised, het thesese, Mr. Turmer informs me, are never mate of sorals stene, but always of saludstome, shale, ete. The people of Kalliak and the Alents anejently used lamps of hard stome, genetally wal in slatjw, and sometimes matl. by slightly hollowing ont whe sidle of a latge round pelshle. sueh a romgh lamp was homght ly Lient. stomey, U. s. Nols, fiom kotzelone sommel. Xo surh highly tiuished and elalorate fampos as the large homas lanpa at Point barmo are mentioned exerept by Sordenskizild, who tigmes one from siberia.t This lamp is interestimg as theonly ame deseribul with at lolese eomparable to the shelf of No.

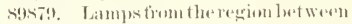

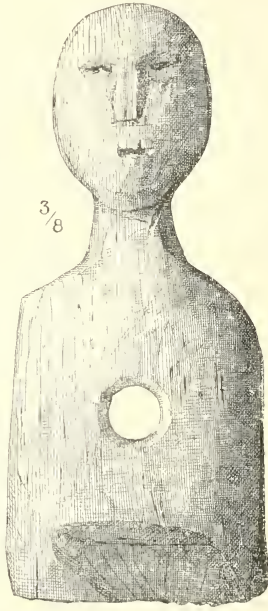

Fui, 50,- sorket for lobbler holder.

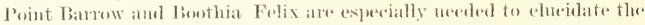

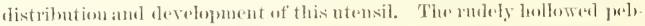

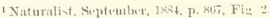

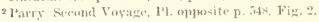

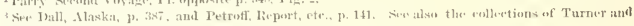
Fisclury from - Ittu amel Kialiak.

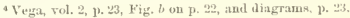




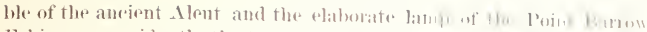

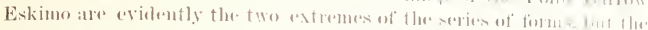
intermediate patterms ane still to lue d leseribed.

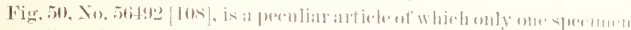

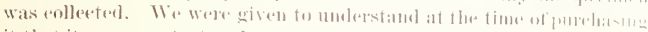

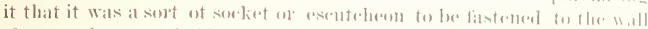

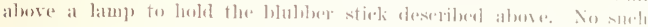

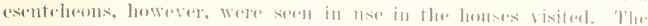
artiele is evidently old. It is a that piene of thick plank of some solt

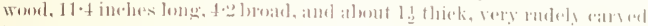

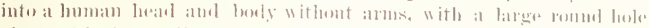

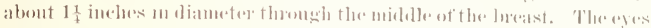

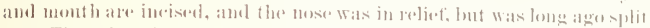

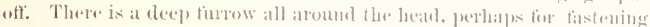
on a hood.

\section{('LOTIIIL,}

M.LTIIIII.

The elething of these people is as a rule made entienge of slius, themgh of late geatrs drilling and alion ate used for some parts of the dress

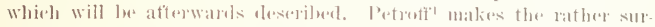

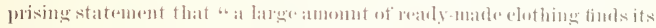

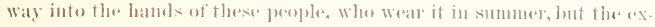

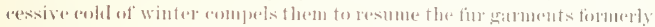

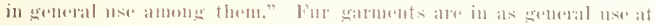

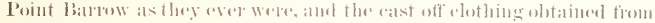

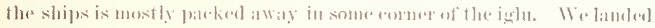

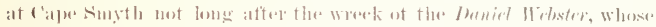

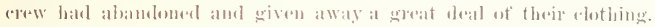

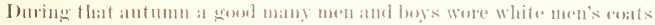

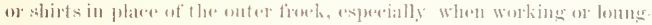

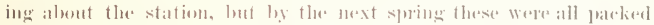
away and were not resumed again except in bare instances in the sum mere.

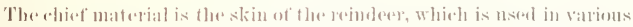

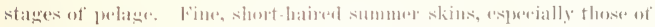

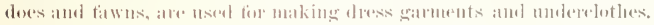

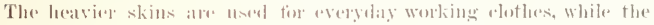

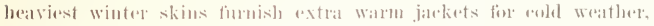
warm winter stoxkings and mittens. The white or spotted skins of the

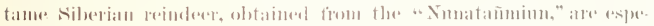

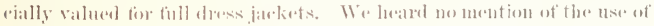
the skin of the nulurn reindere fitwn, but there is a kind of dark deepe

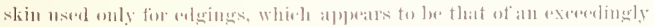
yommg deer. This slin is attemely thin, and the hate so slowt that it

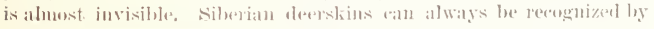




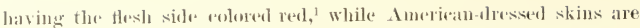
Workel soft amel rubberl with rlatk or gyjsum, giving a beatutiful white surfice like pipe-clayed leatlere.

The skins of the white mountain sherp, white and blue fox, wolf, dog, rrmine, and byax are sometimes used for elothing, and moler jackets made of eider duck slins are ranty used. Sialskin dressed with the

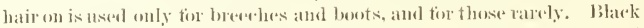
dressed sealskin-that is, with the epidermis lett on aud the hatir shaved ofi-is nosed for waterporoof boots, while the

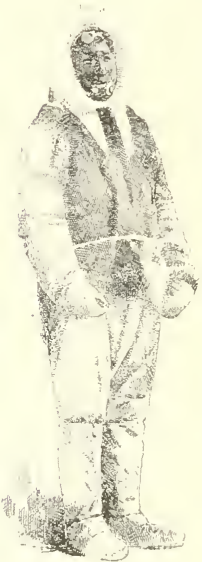

Fin 51,-Man in ordinary dect. skin clothes. white sealskin, tammel in mine, with the epidermis removerl, is used for the soles of winter bents. Waterporoof loot soles arr mate of oildressed skins of the white whale, hearded stal, wallus, or polar bear. The last material is not usually mentioned as serving fire sole leather among the Exkimo. Sordenskiöld, " lowever, foumd it in use anomg the (louke hes for this pmosese. It is ronsidereal an exrellent mal terial for soles at Point barrotr, and is sometimes nsed to make boat eovers, which are beantitully white. Heavy mittens tom the winter are mate of the fim of the polat bar or of dogskin. Waterproot onter frocks are of seal entrails, split and dried and setwed togertlers. For trimmings ar used derersin of difterent colors, mormtain-slewe skin, and blawk and white seakkis, wolt, wolverine, and matten firl, and whole ermine skins, as well as red worsterl, and oreasionally loads.

\section{STYLE OF DRESS.}

Dr. Simpson gave an excellent general deseription of the dress of these people, which is the same at the present day. While the same in [ereneral pattern as that worn by all other Eskimo, it differs in many details tiom that wou loy the easteru Eskinm, ${ }^{4}$ and most elesely resembles the style in vogue at and near Norton Semol. The man's ders (Fig. it. from a photograph of A paidyao (eonsists of the nsual lonse hooderl thork, without opening exerpt at the neek and wrists. This reacles just orer the hips, rawe ly about to mid-thigh, where it is ent

I Compar. Nordenakiöld, Vega, vol 2. P. 213.

${ }^{2}$ Verga, rol. 2, p. 98.

s()p. (it , DT, $241-245$

4he for exanple, Eqouls, p. 219; Crant7, vol, 1, p. 136: Lessels, Op. cit., pp. 805 and 866 (Smith

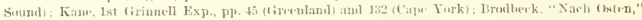

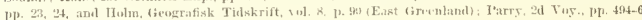

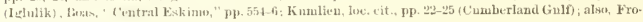
bisher, in IItakluyt's Vuyagrs, $15 \times 9$, ete., p. 62k.

'ball, Ilaska, pp. el aed 141 . 


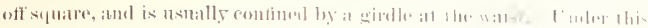

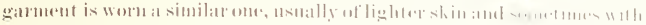

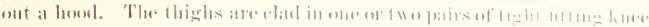

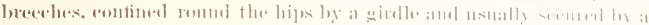

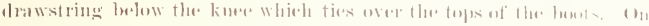

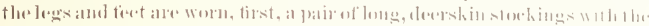

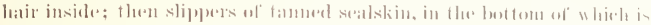

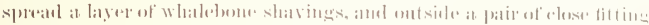

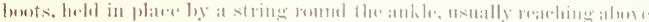

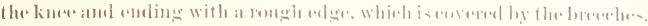

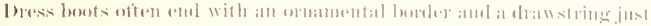

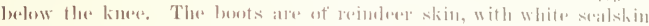

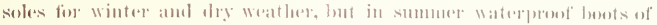
blatek sealskin with soles of white whale skin, ele, al1 worn. (1) wer-

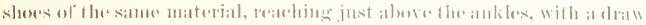

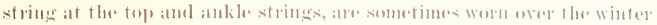

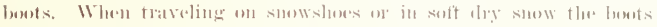

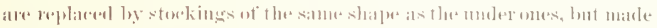

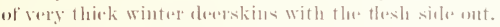

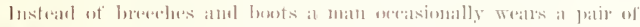

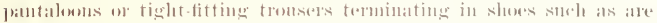

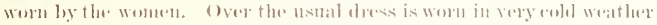

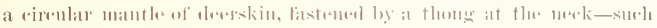

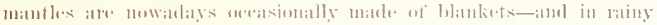

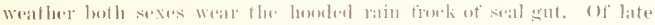

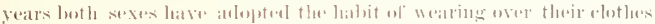

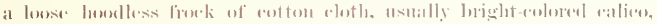
especially in blustering wather, when it is aseful in kerping the drifting sumw ont of their thrs.

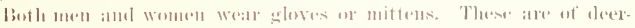

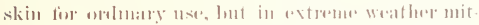

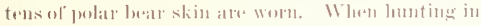

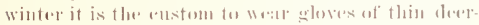

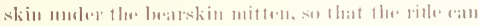
be hamellal witlent tomelinge the harre hatud to the

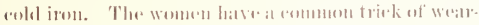

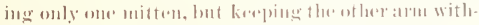

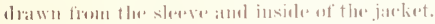

The derse of the wometl romsiste of two froeks.

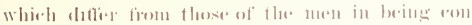
tinued from the waist in two rather thell romblet

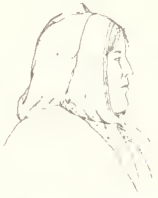

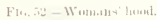

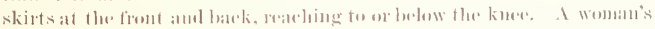

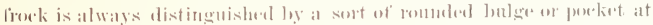

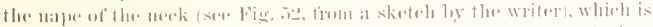

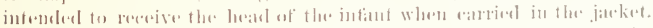
The little preak at the tope of the lomed is also charameteristie of the 
woman's freels. (1) her logs a woman wears a pair of tight-fitting deerskin pantaterons with the hatir next the skin, and outside of these a similar pair mate of the skins of deere legs, with the hatir ont, and having soles of sealskin, but uo ank lestrings. The outer pantaloons are nswally

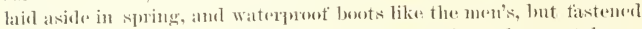
below the knee with drawstrings, are worn oter the nuter pantaleons. In the smomer pantalooms wholly of waterproof seakkin are otten put 611. The women's pantaleoms, like the men's heredoes, are fistened with at girelle just alueve the hips. It alpuears that they do not stay uy very werl, as the women are continually "hitehing" them up and tightening their girdles.

Intil they reach manlesed the lows wear pantalene like the women, but their jarkets are ent just like these of the mens. The dress of the girls is a complete miniatme of that of the women, wen the poeket

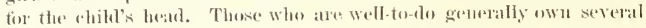

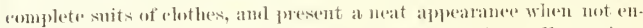
gatged in dirty work. The porer ones watr one sult on all oreasions till it heromes shably. New elothes are seldom put on till winter.

The outer frock is mot of ten worn in the ighn, leeing usually taken off before entering the rowm, and the muler one is gemerally dispensed with. Men habitnally leave wif their boots in the lomse, and rarely their

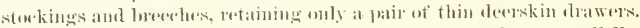
This enstom of stripping in the homse has heen notiond among all Es-

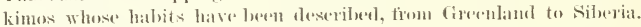
The natives are slow to adent any molitiontions in the style of dresise

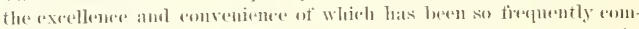
mented nfon that it is umeressary to retere to it. One or two youths learmed from association with us the convenience of porkets, and ancordingly hate "patrle porkets" of eloth sewed on the out side of the skirt of the inner frock, and one yommg man in 1 s.s.3 wore a frat of seatskin lip lowts, evidenty eopies firom our india-rubler wating boots. I now

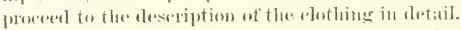

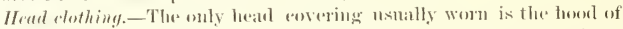
the frock, which reaches to about the midelle of the tarad, the front being avered Jy the hair. Woment who are earying ehilelen in the jateket semetimes walp the heat in at eloth. (I have an inclistiuet rese-

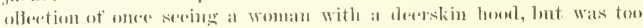
busy at the time to make a mote of sketele of it.) (One man at C'tki-

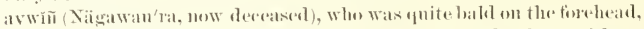
used to joroteret the fiont of lis head with a sort of talse frout of deerskin, tied romel like a tillet. No spereimens of any of these artioles were dotainet. Fancy enteal eaps ane worn in the danees and theat

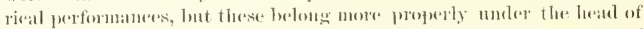
Ciames and Pastimes (where they will be teseribed) than moder that of Clothing. 


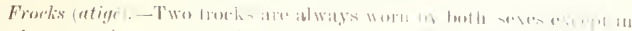

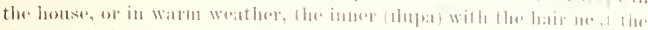
skill, :url the onter (kathin'res) with the haije out. The outer. frock is also sometimes worlu with the hatir in, esperefally when it is

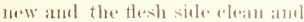
white. This side is wten ornatmented with little tuftes of maten fire and stripes of reel axhere. The difterenes in shatpe betweren the freckis of the two sexes hat heren allearly mentioned. The mall's tion.k is a lowse sliert, not fitterl to the berly, widening at the bottom, and warlhing, when muluelterl, just below the hips. The sliets are rut oft' stuare or slightly rommlerl, and ane a little longer behimel than in forent. The loser is

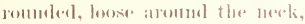
aluel fitterl in more on the sislos than on the nalpe. The frout enluge

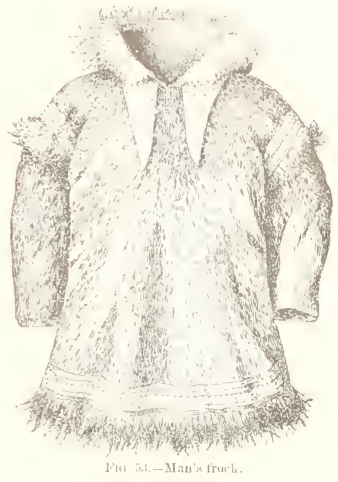

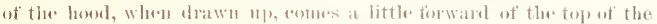

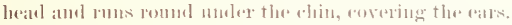

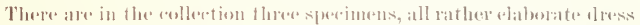

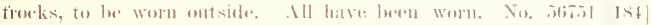
(Fig. 5i3), brown dereklin, will serve as the type. The pattern "atu hest
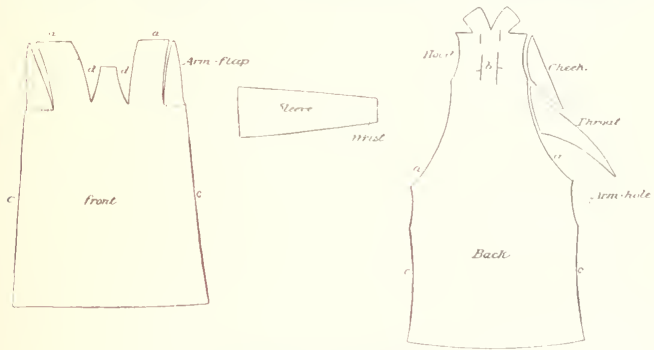

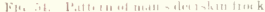

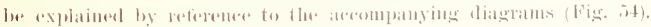

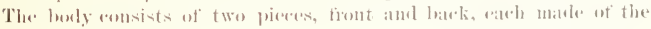
9 ETHI- 
greater part of the skin of a reinderer fiow, with the latek in the nidalle and the sides and belly eoming at the edges. The beal of the

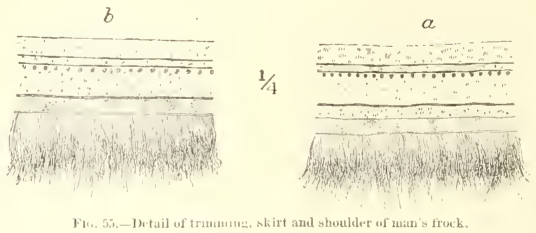

animal is manle into the lowod, whiels is contimons with the loak. bath sletre is in two pioces, frout and bark, of the same shape, which are sewed together along the upper edge, but soparated below by the

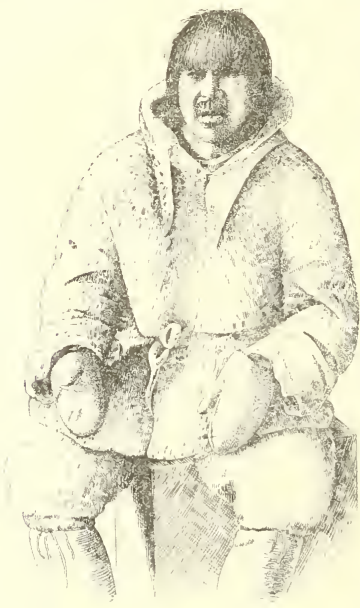

H16, 56,-Man wearing plain, heavy frock. arm flap of the fromt, whinh is bent down and inserted like a gusset frem the armpit notrly to tlee wrist. A hand of deerskin an inch broad is sewed romud the relge of the lowal, flesh sirle ont. The trimunge enusists, first, of a narow striput leng laired woltikin (taken from the midellent the latek) sewed to the anter side of the bind ing of the loood, it ends sep arated hy the chin pieece, so that the lomg hairs form a frimge aromud tle fisee, Sim. ilar strips are sewerl romol enth wrist witle the fiu inwart. The binding rousel the skirt (Fig. 5ina) is $2 \frac{1}{4}$ iuslese broat. Tlu light. colereel strips are clipped monutain sheep skin, the narrow pipings are of the lark brown skin of a very young fawn, the little tags on the second strip are of red worsted and the fringe is of wolverine fur, sewed on with the flesh side, whith is colored red, prob. ably with ocher, outward. I band of similar materials, arranged a 


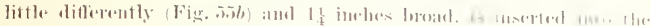

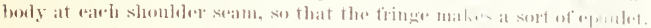

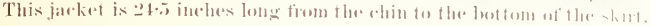

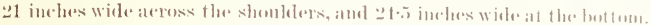

Apart from the trimming this is a very simple pattern. There are

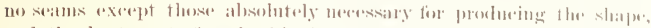

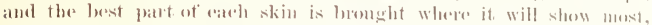

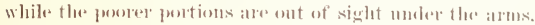

The ellief ratiation in dereskin fionek is in the trimming. Ilt hatse

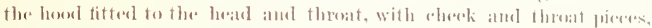
and the se are invariably white or light eolored, exen when the frenck is

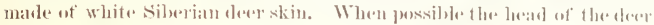
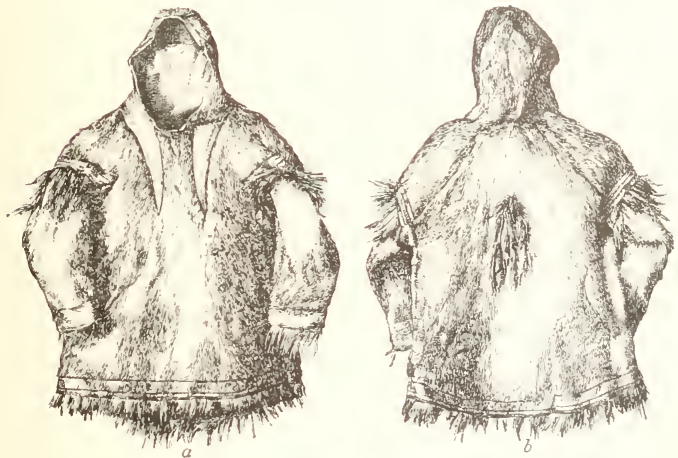

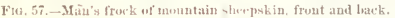

is always used for the bask of the lowed, as fapt. lamry observed to low the enstom at lghlik. A plain trock is sometimes used tor romgh work, hunting, ats. This bas un fringe or trimming romel the losed,

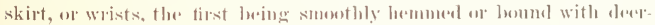

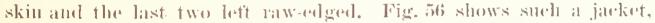

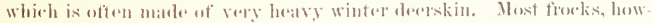
ever, hate the border to the hoos eithere of woll or wolverime skin, in the latter alse asperially having the and of the strips hanging down

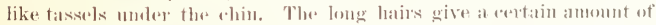
protertion to the fare when watking in the winel, ${ }^{2}$ Instead of a fringe the luod semetimes hats three tufts of fur, one on earle sisk and one above. 
Trimminges of edginge like that alowe deseribed of of platin woherine

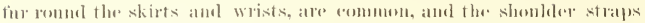
rather less sos. Frorks anr sometimes also hingerl on the skirts anel seans with little strips of dereskin, after what the leoint Barrew pesple

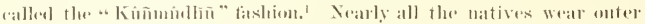
fouks of deerskis, lut on great oceasions raberately made garments

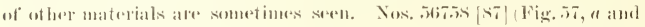

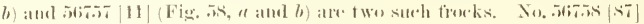
is of momatain sherep skin, nearly white. As shown in the diagrams

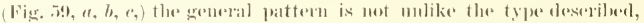
lout there are more pieces in the houl and several small gasserts are inserted to improve the set of the sarment. The trimminge are shombler
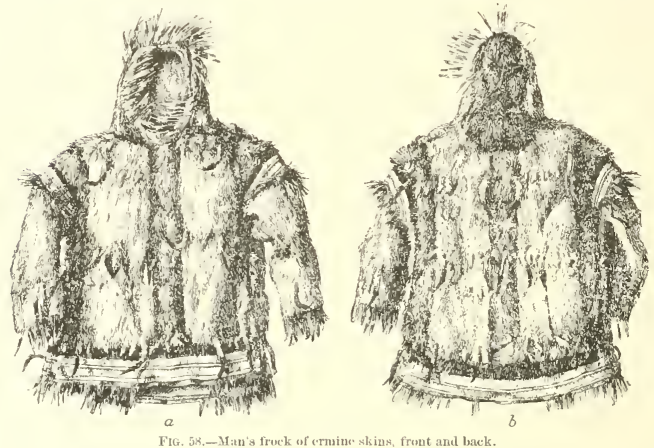

strajs, and a border remed the skirt of mbing like that deseribed above,

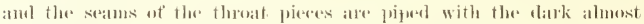
hairless deerskin, which sets them off tiom the lest of the coat. The

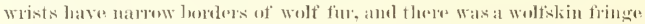
to the hood, which was denoved betowe the garment was ofleded for sale.

No. 5tiat $[11]$ is a very handsome gallment (Fig. is). The burly and slepese ate of white and loww (winter and summer) ermine skins arranged in an elengat pattern, and the lesed of reineleer and memntain shere skin. This is the only froek seent in which the hoos is not fitted to the sides of the throat hy eurved and pointed throat piecess atter the fakhion universal among the western kskimo, from Caje lathoust at least to Sortom somul. The pattern of the lowed is sloww by the diat-

\footnotetext{
'There are several frecks an trimmed in the National Museum, from the Hackevzie and Anderson region.
} 


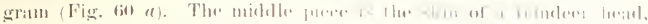

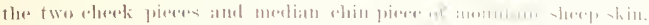

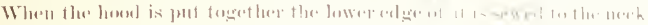

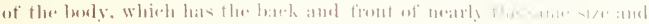

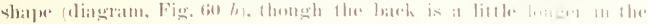

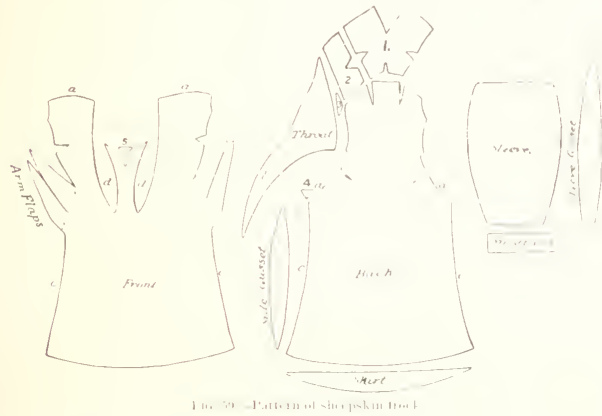

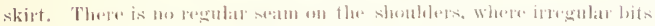

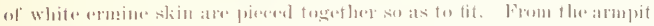

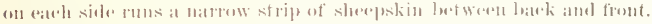

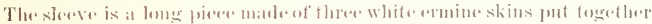

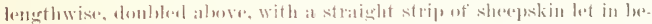

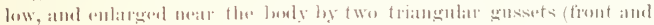

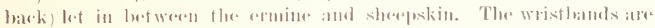

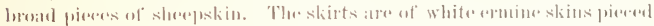
together irregulaty, but the skins emmposing the front, bate, and

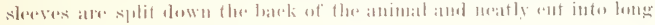
reetallugulatr pirees. witlo the fert and tatils sfill atlatuluth. They atre atrauged in al pat

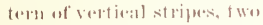
skins fitstened together and to end making a stripe. which is the satum on the fiont and the latek. There.

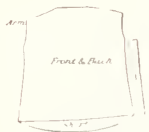

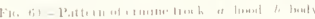

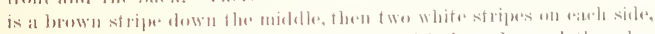

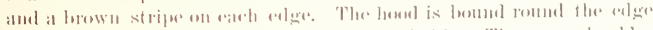

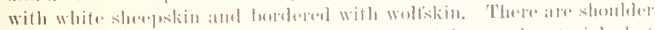

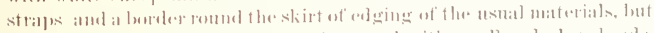

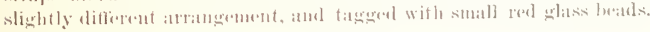


The former owner of this leantiful frock (since dead) was always very olegantly dressed. Hisderskin elothes were always mush trimmerl, and les owned an elegant frock of foxskins, alteruately bhe and white, with a hood of deerskin, whieh we did not sueceed in shtaining for the collection. The "jumper of mixed white and blue liox pelts," seen by Dr. Kane at Ita, must lave berall like this.)

The woman's frock differs fiom that worn by the men, in the shape of the hood and skirts, as mentioned above, and it is also slightly fitted
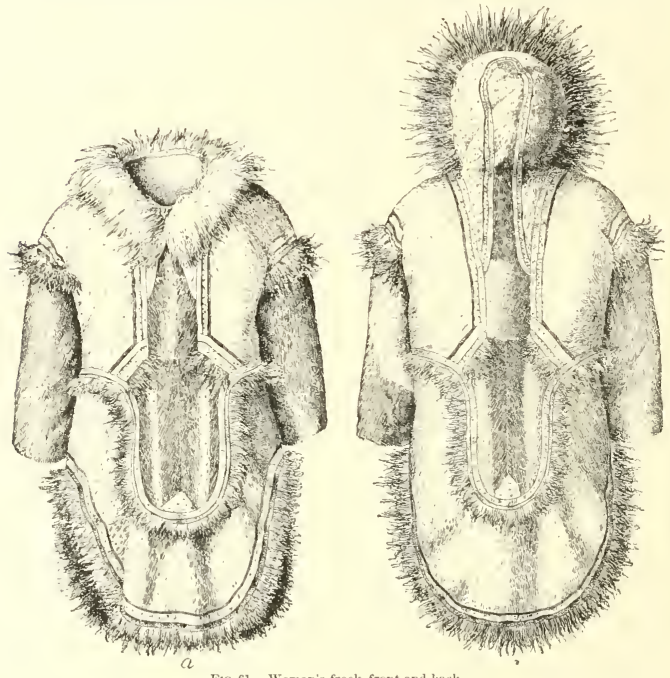

in to the waist and mack to "lage" somewlat in the back, in orter to give room for arlying the child. The pattern is eonsislerably different from that of the man's frock, as will be seen from the deseription of the type specimen (the only one in the eollection), No, 74041 [1791] (Fig. (it, a and b), whioh is of deerskin. The hoon is raised into a little point on top and bulges out into a sort of pomuled porket at the nape. This is a holiday garment, made of strips of skin fiom the shanks and belly of the reindeer, piesed together so as to make a pattern of adternating 


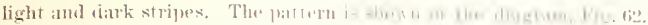

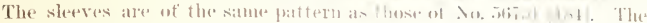
exlge of the horel is bonmel with deerskin, hair onfw:11, Trim ming: a strip ot aldeing Fig. tiii) in which the light stripses are elipered white momatain shere skin, the datk piphes lorown, almost hairless, fimblim, and the

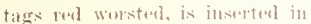
the seran betweten 7 (n) aml fi and 2, and a similal strip between the inner wage of $3, \ddot{-}, \bar{T}$, 9. and 1. I broater stripot similar insertion, fringed lewew with marten fur, with the the sh side ont

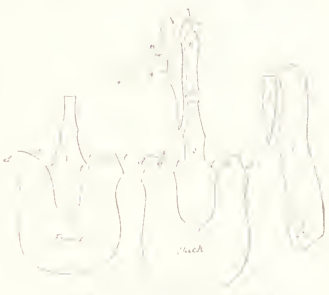

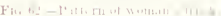

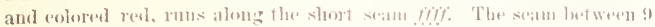
and 7 has a narrew piphing of thin bown deerskin, tagesed with red morsted. A strip of edging. Withent tags and tringed with marten fiur

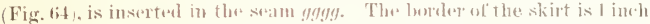

$1 / 2$

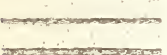

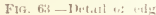
ing, woman's fres $h$ wide: (Fig. 1it. The dark stripe is hown derskin, the white, momntain shere, and the liur, marten, with the red thesh sideout. The fringes are deuble strips of white dererskin setwed to the insidenf the last seam, abent $;$ ineles aprat. The shoulder straps are of alging like that at $y$, but have the tiar sewed on so as to show the red thesh sirle. The hood has a tiringe of woltskin seswed to the ont side of the biuling. This

fresk measures 45 inches in the bat. 32 in the fromt, 19 andost the shoulders, and 17 at the waist. The slirts are 21 inches wide, the

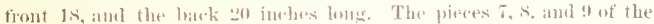
hood are white. This is an umsually handsome garment.
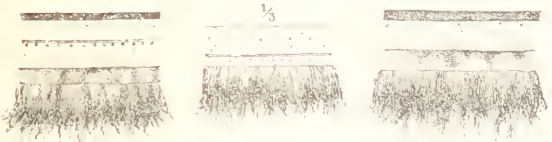

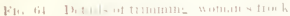

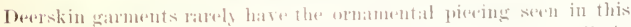

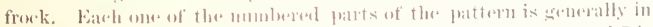

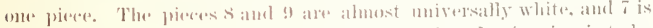
often so. Abont the sime varisty in matrial and trimming is to be

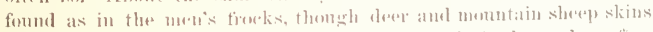

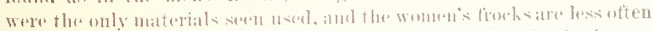

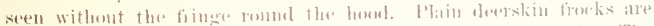
often bordered romed the skirts with a fringe ent tirom deerskin. The 
women nowalays often lime the onter frock with drilling, bright ealieo, or "yen hedtieking, amb then wear it with this side out.

The froeks for both sexes, while male on the same general pattern as those of the other Exkimw, differ in many detaik from these of east ern Ameriea. For instaner. the lowel is not fited in romel the throat with the pointed throat pieses or fringed with wolt or wolverine skin until we reale the Eskimo of the Andersen liver. Ilere, as shown by the specimens in the Satiomal If wide apart, and the ments hoods only are fringet with wolverine skin. The women's hoods are very lange everywhere in the past tor the better ateonmodation of the ehild, which is sometimes arried wholly in the hood. ${ }^{1}$

The hinel flap of the skirt of the woman's froek, exeept in firemland, has develoged into a long namow train leathing the gromed, white the

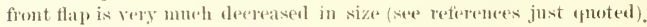
The modern frock in fresulamel is very short and has very small flaps (sece illustrations in link's Tales, ete., pu. A and 9), Int the ancient fashion, judging fiom the plate in franty's History of (ireenland, re. ferred to above, was much more like that worn by the western Eskimo. In the Anderson and Mankinzir regions the flaps are short and romoded

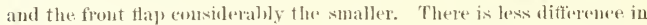
the general shape of the men's frockis. The heod is generally romder and close fitting, extept in Labralor and Baffin Land, where it is pointed on the erown. The skirt is sometimes prolonged into rounded flaps and a short seallop in fromt, as at Ighhlik and some parts of Bafliu Land. ${ }^{2}$ Petitot ${ }^{3}$ wives a full deseription of the dhess of a " chief" from

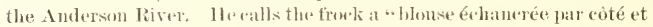
termince en powes arrondies par devant ot par derriere." Thestyle of frock wom at Joint liarrow is the prevalent one alomg the western coast of Amerion nearly to the Kuskoliwim. On this river long hoodless frowks reathing nearly or quite to the smound ane worm., The frock worn in Kadlak was hoodless and long, with slont sleeves and large armholes beneatlis these.

The men of the Siberian Eskimo and sedentary cloukelues, as at Plover Bay, wear in summer a loose straight-bottomed frow without a lookl, lut with a frill of lomg fur romel the nexk. The winter froek is

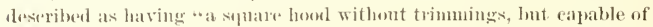
being trawn, like the month of a bag, aromel the fare by a string in.

\footnotetext{
1 Egede, P. 131: ('ranfz, i, D. 137 and P1. 11. (Greenland): Begsels, op. cit., P. 86r (Smith Sonnd-marricl women only); Parry, 2nd Toy., p, 44, and unme rons illustratious, passim (Tglulik); Packard, Naturalist

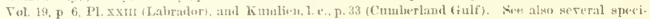
mens in the National Dhosum from lugava (collocted hy L. M. Turner) and the Mack+nzie and Ander

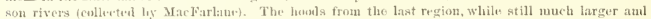
wider than these in fishiom at Puint Barros are ust so enormens as the murv wastorn ones. The little peik on the top of the Woman's hase af point Barrow mas be a romiaiscence of the poiuted bood worn

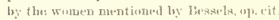

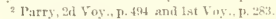

* Mutmeraphic, itc., p. xiv.

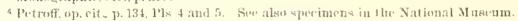

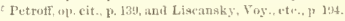




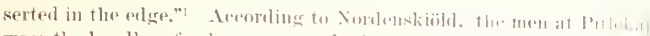

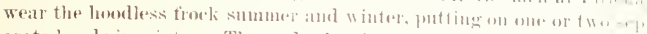

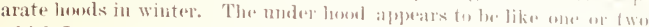

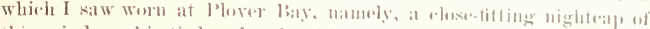
thin reinderer skin tienl muler the whin. The dress of the siberian women monists of for $\mathrm{k}$

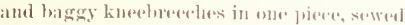
to tightetting lowets rear hing to tha linews.

Mantles.-" ('iremlar" mautles ut dorersin. fastemed at the mek ly a thomg, and put on wer the lesal like a pomelw, ase worn by the

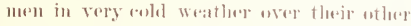

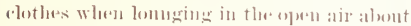

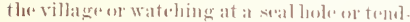
inge the seal mets at uights. The rlosiks alle

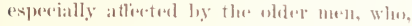

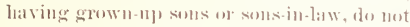

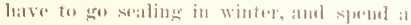

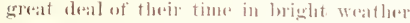
chatting togethere ont of doors. There is

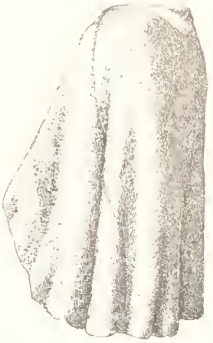

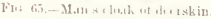

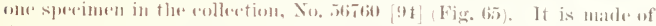

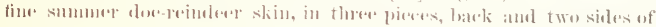
dark skin, sewerl to a rollat of white skin from the lully of the animal.

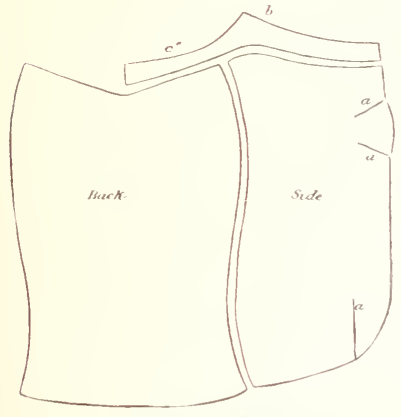

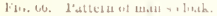
Fon patteril sere diagram (Fig. titi). The sceams at a are gererel tomalis the aloak latuge pounerly firm the slemblare. The collar is in two pineses, jeimerl in the midhlle, and the alger or is

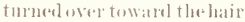
sidle and "rou" down in a natrow hem. The points $b$ ot the rollas ane liforeght togethere in the millalle and joined ly a little strap of lemplin alumt an iuch lomes, so that the edige o makes a romol hole tor the nerek. The width of the mantle is bol inshess amel its depth 39. It is wor't with

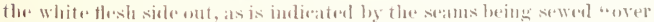

1 1)all. Mlaski, 1. 379

2 Verga, vol z $2, p: 8$

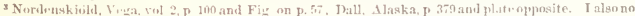

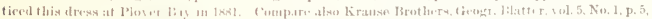

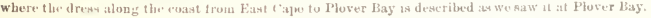


ald orep" on the hatr side. All the mantles seren were exsentially of the salme patterm. The adge is sometimes cot inte an omamental

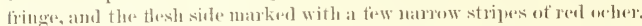

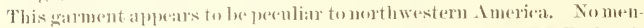
tion is to be fouml of any surch a thing exerpt in Mr. Mar. Farlane's IS. notes, where he speaks of a derersin blanket "attahed with a line acress the shomlders in eold weather," anonge the Anderson River Bskimo. Wo hase no means at peresnt of knowing whether such rloalks alle worn by the enast natives leswern l'oint barrow and lotzebue Somnd, lunt one was worn ly one of the Numata'numu who were at Nuwnk in the antmum of ISts.

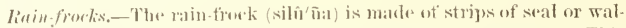

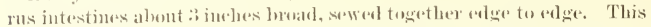
matrial is light yellowish brown, transluecent, very light, and quite

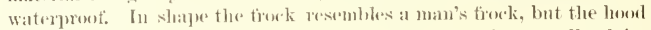

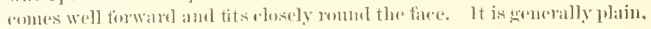

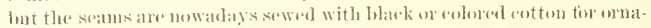
ment. Tles garment is of the same slatere fin both sexes, hut the women

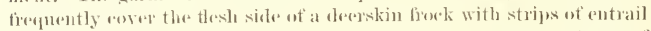
sewrol towather fertically, thus making a gamment at once waterproof and warm, which is worn alome in smmener with the hate side in. These gat shirts are worn over the clothes in summer when it rains or when the wearer is working in the boats. There are no speecimens in the collections.

The kaiak jacket of blark sealskin, so miversal in Gosuland, is moknown at Point Banrow. The waterporef gat tirocks ane peraliar to the western Eskimo, thongh shirts of seal gnt, wom butween the juner and unter forek, ale mentioned by Eugede (p. 130) and Crantz as ased in

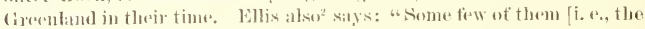
Eskimo of IJulsoms strate wear shifts of stals' batklers, sewed toaether in pretty near the same form with these in Emope." They have

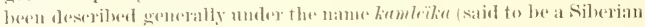
word ly all the all then's who have treated of the natives of this regiom, Eskimo, sibrams, of Alents. Wr. saw them wom by neally all the matives at Plowe lay. One handsome one was observed trimmed on

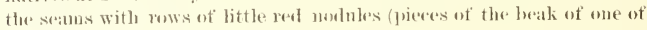
the pulfins) and tiuy tuits of llack finathers.

The rotton frock, alleady alluded to as wom to keep the driving snow ont of the fins, is a long, Joose slint reaching to abent midleg. with a

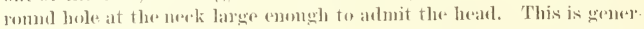
ally of bright colored alioo, but shirts of white aston are sometimes wom when hunting on the ice or snow. Similar frocks are worn by the natives at Pitlekij. ${ }^{3}$

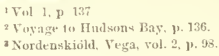




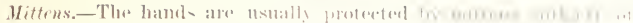

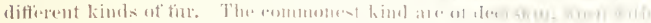

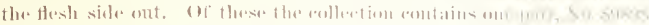

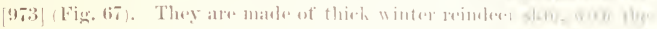

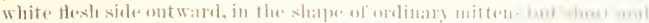

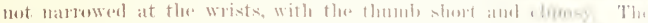

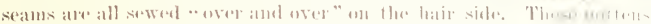

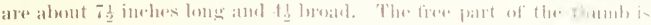

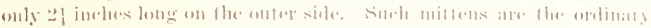

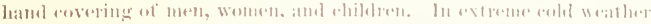

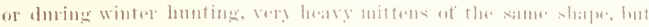

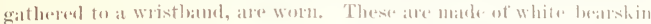
for men and women, tion rhihloren ot despskin, with the hair out. Whent the liatud rovered with smbli at mitten is lachl mon the windwand sidnot the fiter in walking, the long hair attionts a very etliejent prettertion andiust the wind. The long stift hatir of the hearskin alse make's the mitten at very an venient busth tor ro
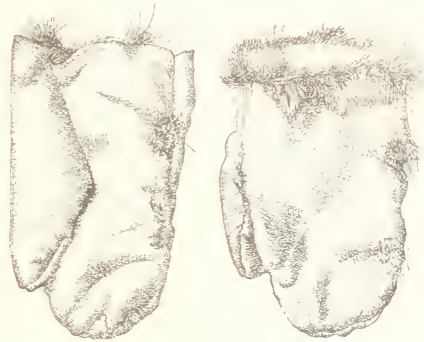

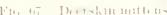

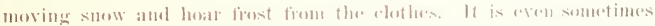
used ter boshing up the thoor.

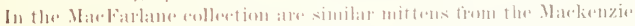

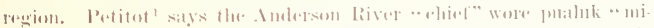

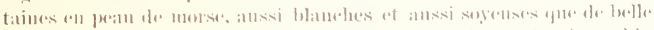

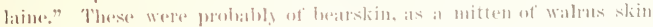

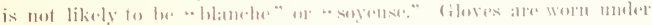

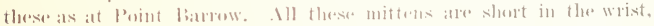

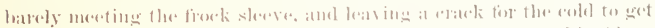

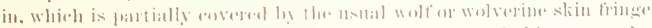

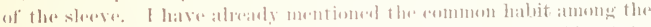

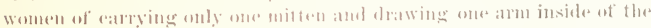

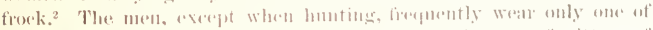

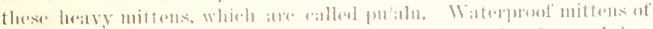

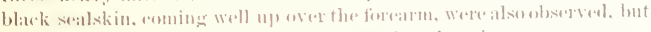

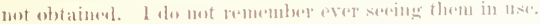

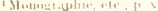

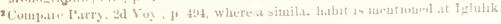


Gloves.-Ciloses of thin dereskin, worn with the hair in, and often

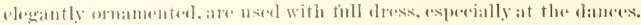

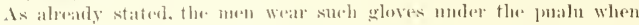
shooting in the winter. When realy to shoot, the lmoter slips off the mitten and holds it between his legs, while the glove anables him to rock the ritle and drat the triggen withent tomeding the eold metal with

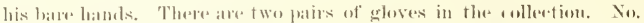
s: They are mate of thin reimleres skin, with the white flesh sicle ont, and

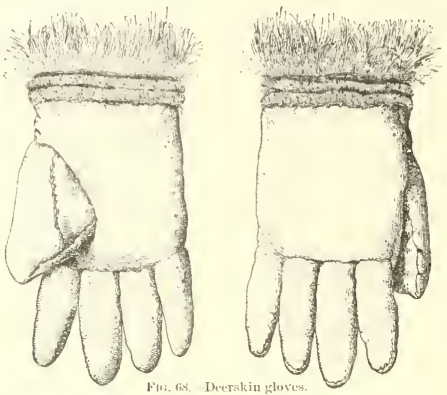

are rights and letts. The short and ratluer chomsy tingers and thumbs are sepalate pieses from the palm, which is one straight, brokl piece,

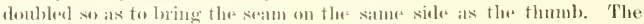

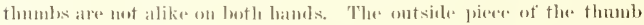
num down to the wrist on the left glose, but is shonter on the right,

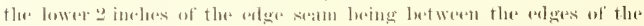

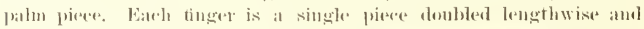
sewerl over the tip and down one side. The wrists are ormamented with

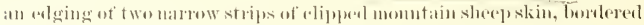

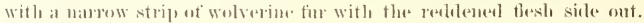

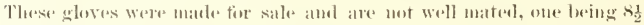
inches, with tingers (anl of the same length) $4 \frac{1}{2}$ inches long, while the

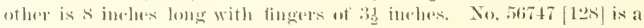
gatir of gloves mate in the same way hut more elaborately ormamented. There is a band of deerskin but no fringe romel the wrist. The baek of the bitud is covered with bown derersin, hat ont, into which is inserted the sipuare oruamental pattern in which the light stripes are white dearskin and the dark pipinge the nsial almost hairless fion-

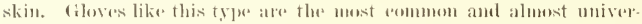
sally late a thinge romed the wrist. They are also usmally a little longer-wristew than the mittens. 


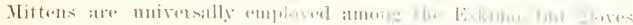

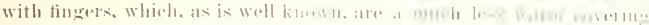

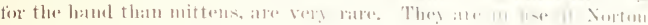

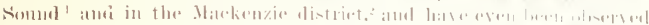

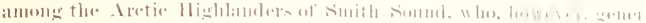

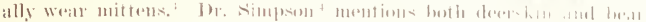

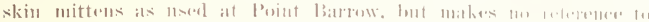

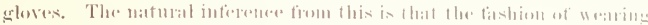

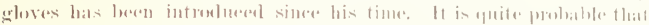

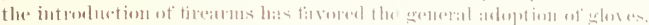

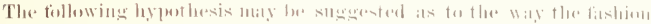

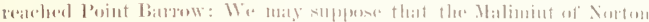

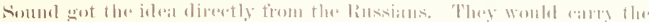

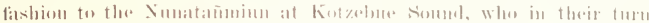

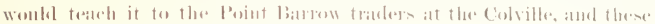
would earry it on to the materen natives.

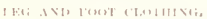

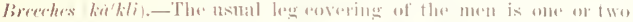

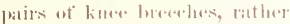
lowse, lut litted to the shalpe ot the leng. They atre very low in

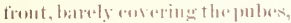

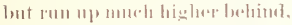
sometimes ats hish in the smitll of the batek. They ane laekl in plater by it giralle of thome romal Hhe waist, and atre Masually fis

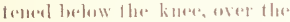
leots, loy a drat stling. There is one patir in the entlention, Xos.

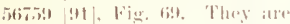

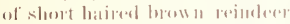
skin, tous the lenty af the and mal, worts with the latir ont. The watist is highere luebiust than in firmt, and ate h low is slightly watheroel to a lamel just be

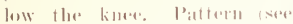

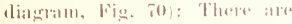
two pieces in eatell lang, the in sieke aterl the ontsiels. The

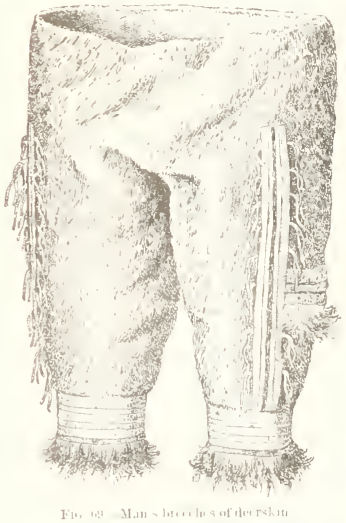

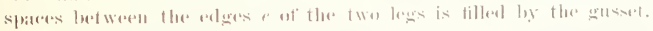

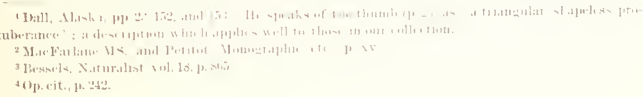


mate of five pienes. which anders the pubes. The arotele is reinfored by a square patelo of whito deerskin serwed on the inside. The trim. ming consists of strips of etging. The first strip (lig. 71) is $1 \frac{1}{2}$ inelies wide, and rnos alonge the thont seam, inserted in the antside piece, to

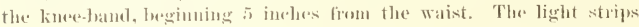

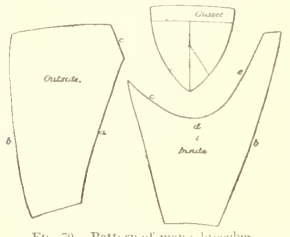
are of elipyed sumutain shrepskin; the dark one ot dark bown deerskin; the pipings of the thin fawnskin, and the talus at real worstent. The edges of the strij are fringed with narrow double. strips of monutain sleep pkin 2 ineles long, put on alwout $1 \frac{1}{2}$ imelaes apart. A stratight stripe, 2 ineleles wide, is inserted oblieporedyaross theoutside jiecer from rean to sam. It is of the samue materials, lout differs slightly in

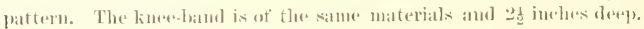
The length from waist to kure is 24 ineles bethind, 23 in tront; the grirth of the leg 24 inches romel the thigh and 14 romed the Enee. These fepresent a common style of foll-flress berehes, and are worn with a pair of trimmed boots ledel up by drawstrings They are alwats worn with the hatir ont and nomally over a jair of deerskin drawers. The ordinary breseches ane of Jeaviel deerskin, mate perfectly plain, being nsmally worn alone, with the hair tormed in. When a pair of umber loseches is worn, lowerers the bair of the onter ones is tmrned ont. Trimmed breecthes are less ammon than trimmed frockis, ati the plain breeches when new are often worn for finl dress. The clean, whito flesl! side presents a very neat alprearance. The skin of the rongh seal is sometimes, but rarely. 11sed tor summer bresehes.

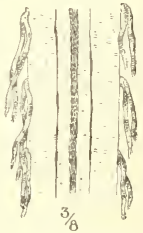

Fis, 71 . Trimming of man s biraches. which are worn with the hatir ont. With this exception. brewehes reem to be invariably male of dorskin. This garment is prationlly universal anong the biskino and vares very little in pattern.

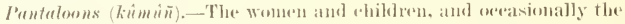

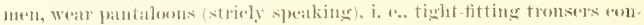
timous with the ferst eorering. Of the two pairs of pantaleons in the

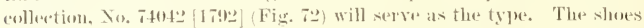
wifl stalskin moreasin soles and dererkin mplers are semed at the ankles to a pair of tight-fitting dereskin trousers, rearhing above the hips and higher behind than in font. Pattern (diagram, Fig. 73a):

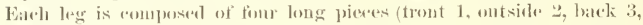

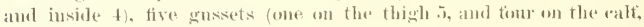
6, fi, 6, 6), whiels enlarges the garment to fit the swell of the ealt and thigh and the half-waistband $(\overline{6})$. The two legs are put together by 


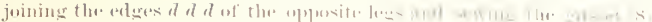

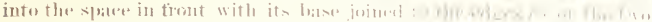

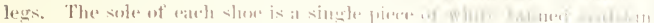

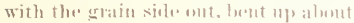
$1 \frac{1}{1}$ inehes all romed the fint, rommetert

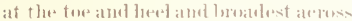
the ball of the tiont. The tore and heret

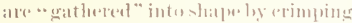

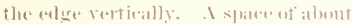

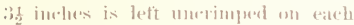

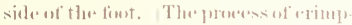

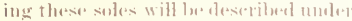
the lated of buots and showes. wheye it

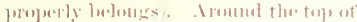

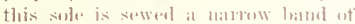
white sealskill, sewed "aver allu over"

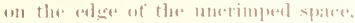
but *roun" thanteht the watthers at the ends. sis as to draw them 11 ). The upere is in two pioses heol, !) : and

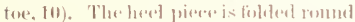
the lowed, and the tere pieces dembled alome the line $f$, and the anrtod adeas g g joined to the straight enlges h $h$.

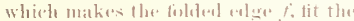
outline of the instell. The lestem is then cut ofl aremately to lis the sole alled sewoltedherdegent thebalul. The trouscts and sheses alle sowed torgether at the ankles. The whole ismateof the

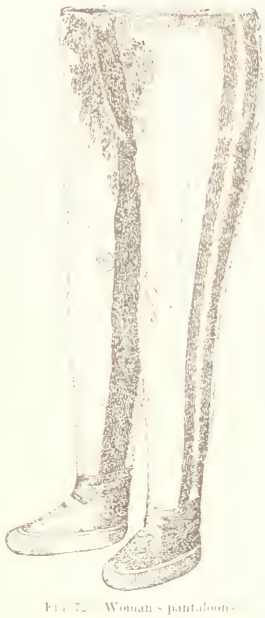

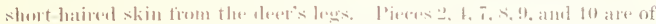

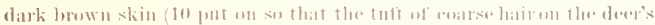

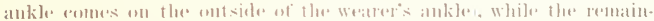

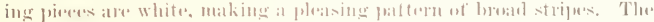

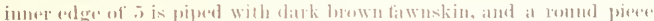

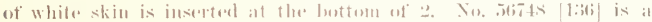

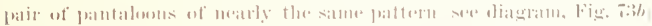

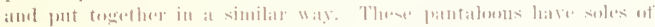

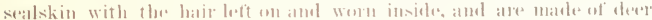

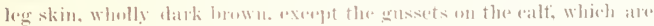
white. There is a piece of whife skin let ont. "2, as betore, and thes ankle tulft is in the same position.

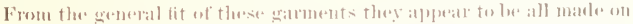

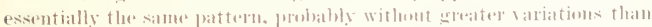
these atreaty deseriber. When worn by the woment the material is

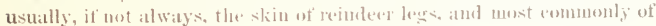


the pafterm of No. 567ts [136i], uamely, ]nown, with white leg gussets.

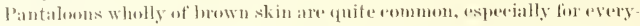
dity Wear, while striperl ones, like No. 74042 [1792]. are much less nsual and worn sperially for full drexs. C'hildren's pantaloons are always

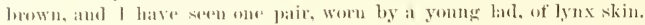
The two of there pairs which wo saw wom by men were wholly brown. These pantaloens of lege skin with sealskin soles are always worn with the hair ont ame nsually orer at gate of moler pantalooms of the same

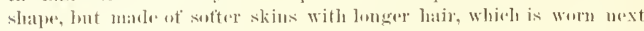
the skin, and with storlsing teet. The onter pantaloons are disearded

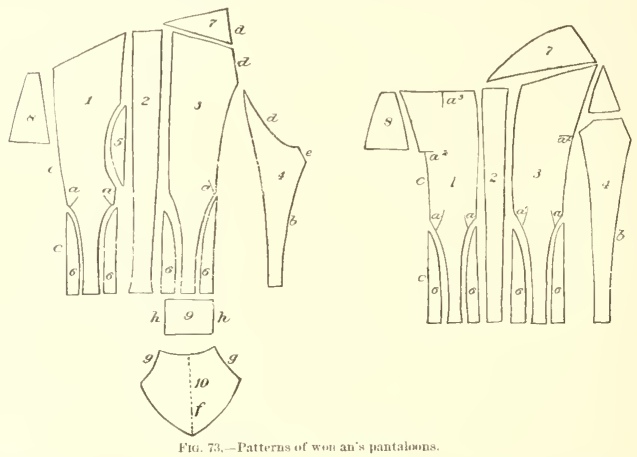

in summer and the inner ones only worle, the teet being potected by sealskin waterpeot beots, as alrealy stated. The waterpoot sealskin pantatooms mentioned in the same comnection alo not tit so neatly, as they are mate with as few seams as pessible (usmally only one, up the lege to aroid loakage. They are sewed with the waterperest seam, and held up rouml the ankle by strings, like the waterproof bonts to be described further out. This last-mentioned garment serems to lee peenliar to the Point barrow region (ineluding probably Wainwright Inlet and fremalys the rest of the coast down to Kotzelone somed). No mention of such a romplete protection against wet is to be found in auy of the publisher aceoments of the Eskimo clsewhere, uor are there any speeimens in the Muserum.

\footnotetext{
'Dr. Simpaou's language (op. cit., y, 243) is a little indefinite ("The foret and legs are incased in water-tight sealskin boots"), but probably refers to these as well as to the kner. bont . The "outside coat of the same material, "and tho hoots and outside coat "male all in one, with a trawing string round the face, " rumbtioned in the sume place, appesars to have gone wholly out at fashion siuce bis lime. At all srepta, wo saw neither, thongh we continnally saw the natives when working in the boats, and these garments, especially the latter, could hardly lave failed to attract our attention.
} 


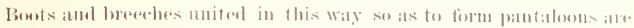
peculiar to the west of Amerieas. Where they are musersally worn from

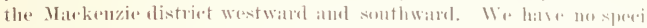

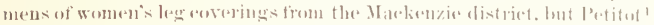

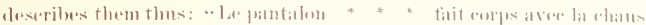

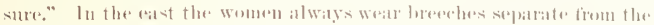

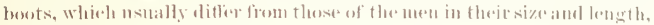
often reathing to the lipes."

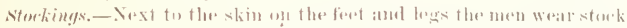

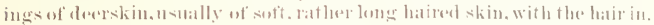
These are nsmally in thres piom, the leg. I,

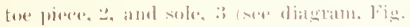

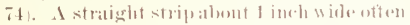
runs resund the foot lectwenthe sele and the

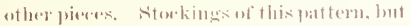
made of very thiek winted therskin. are sul, stitufed fir the onter bogts when doer-hunt ing in winter in the dry sum, espectially

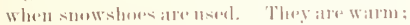
the flesh side sheres the smen well amel the thick hair awets as a sort of watkling which

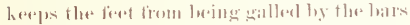

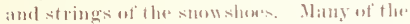

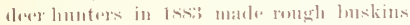
of this patteren ont of the skins of fireslils killed dese simply driml. withent finther prepanation.

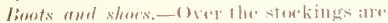

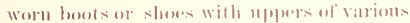
kimds of skin, with the hair on, or blatk tammed seaklsin, always fitterl to herellese

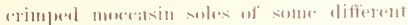
leatleres. of the patfer'n which, with some slight moditiontions of torm. is moversal among the liskimo. These soles ane mater at follows: I Nblank" tor the sole is rent

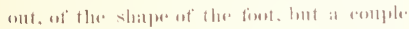

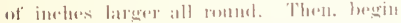
ning at one sicle of the ball at the forst. the

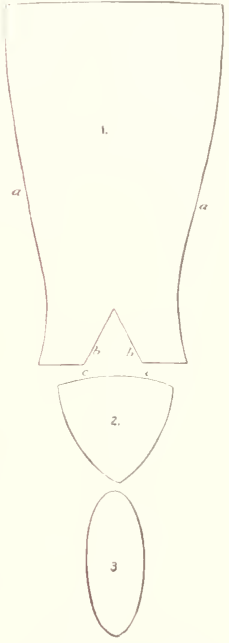

Yv, - it - vatten of stamking.

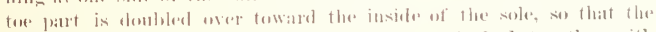
edges just mateh. Tlar two parts atre then pinelged together with

'Monographio, we, 11 W

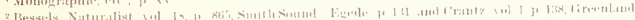

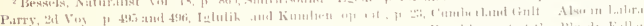

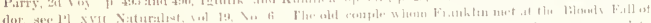

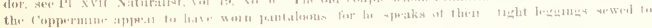

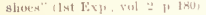

! $1: \mathrm{TH}-\mathrm{H}$ 
the teeth along a line parallel to the folded edge and at a distance from it equal to the elepth of the intemeled told. This bitten line rums from the edge of the leather as tar as it is intented to turn up the side of the sole. A series of similar tolds is carried romul the toe to a point on the other side of the sole opposite the starting point. In the same way a series of erimps is eamied rouml the heel, loaving an merimper spare of 2 or 3 inches on earh side ot the foot. The sole is then sewerl to a band or to threelge of the uppes, with the thread run thesgheach tiold of the erimps. This gatleers the solde in at the lieed and tore and brings the uncringen part stratght npon weh side of the shank. When the folds ane all of the sane length and bust slightly gathered the sole is tumed mp nearly straight, as at the lees usually, and at the toe also of waterprout lomots. When the folds are long and much gathered the sole slopeswell in orrig the foot. Some boots, especially those intenderl ior full dress, have the sole deeper on the sides thas at the toe, so that the top of the sole comes to a point at the toe. The ordinary pattern is about the same height all yomed and follows the shape of the foot, heing rather more gathered in ore." the toe than at the heot. The - blank" for the sole is ent ont by measuring the size of the fiot on the leather and allowing by eye the margin which is to be turned up. The erimping is also done by eye. Any incegularity in the length of the erimps an lo remeelied by pressing ont the enease. I hate never som at Point Barrow the ivory knices, such as are nasel at Norton somel for arranging the erimps.

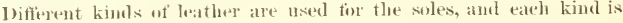

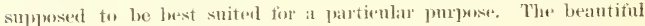
white nrint-tammed sealskin is ustel for winter wear when the suow is ary, but is not snited tor standing the longhness and dampness of the salt-water ise. For this pmpose sealskin dressed with the hair on and worn flesh side ont is said to be the very best, preferable eren to the varions waterprent skins used for smmum bost sules. Fur waterproof soles are used oil-llessed skins of the walrus, bearled seal, pelar bear, or, lest of all, the white whale. This last nakes a brantiful light yellow transluent leather abunt $(1 \cdot 1 \mathrm{inm}$ thick, which is quite durable and keepes ont water for a loug time. It is highly prized and equite an artiele of trade among the natives, a pair of soles namally eommameling a good price. These Eskime appear to be the enly ones who have discovered the exellenes of this materiat fin waterproof soles, as there is no mention to be fimul of its use elsewhere. The "narwhal skin" spoken of by lor. simpson is probably this material, as he ealls it "Kol-lel'-lu-a," which is the ordinary woml tor white whale at Point Barrow. The narwhal is very rare in these waters, while the white whale is eomparatively aloundant. 1) s. Simpsom appears not to have seren the animal trom which the skin wasobtainel. It is, however, by no means impossible that some skins af the natwhal, whinh when dresisel would be indistingnishable

\footnotetext{
I Proliblis prepared hkt the leat envers described by frantz, vol. 1. p. 167, by drying them without removing all of their own blublex.

(1), cit, pP+ $242-266$.
} 


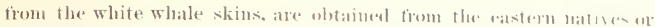

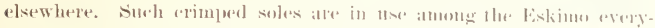
where, varying but litte in general pat

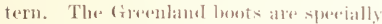
noticeable tion the neatmess of the tromp, ing, while speriutens in the Musemu timm

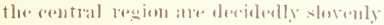
in their workmanship. The hents worte by the natives ot l'lover bay hate the sole narrowed at the shank and hatally eroming over the time eseref at the tore and leed, where they atre rimperl. lout less deeply than usmal. This style ot sole very much resembles thase of a pair of Kameloatrale lents in the Sational Mnsemm, which. hem out erimping, as is the atas with the loots used by the Alents on the ('ommander

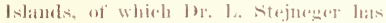
kindly slown me a sweinen. There is a folded "wolt" of sealskin in the seatu bu-

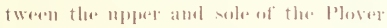

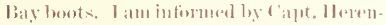

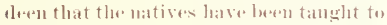
put thix in by the whalument whe erery

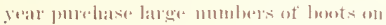

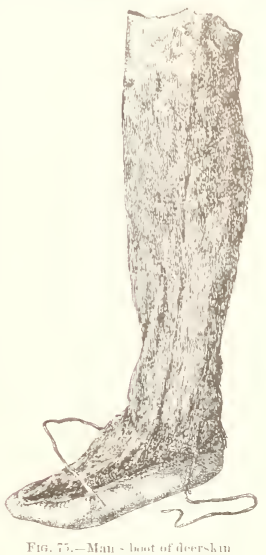

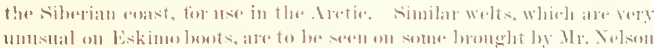

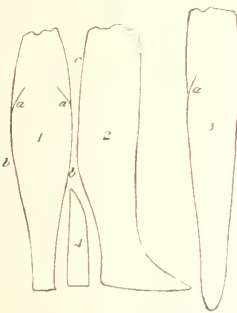

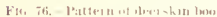

liom Kings Island and Norton somul. The

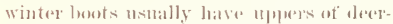
skin, generally the shent-Jaied skin firm Hhelegs. Mountain-shereskin is sometimes nscol for toll-dless lowts. andel sealskin with the latir ont tor working lowets. The lattere is not at gend material, as the suow stickis fo it badly. There are tom pairs of ments winter loosts in the adlection, from which

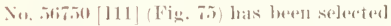
as the type of the everyday patteren. They

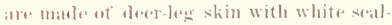
skin soles. laeg and npere are in tome

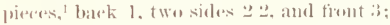
I and :3 are gored at a " " to fit the swell of the eall; 1 and 3 ane of datk skin, and 22 lighter colored, esperially along the midelle. Tla bottom is ant oft acemately to tit the sole lut the top is left incegular, as this is concealed by the breeches. The loots are 


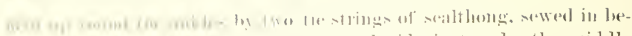

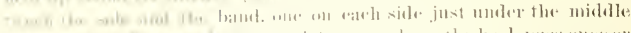

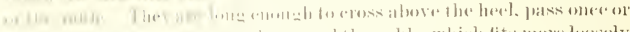

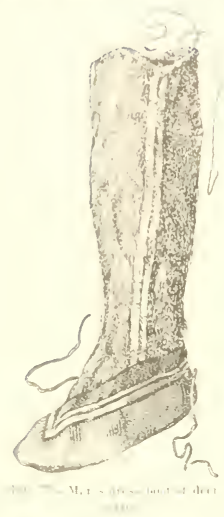

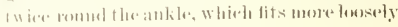

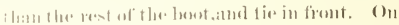

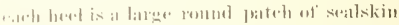

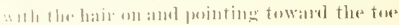

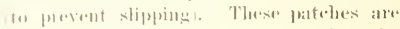

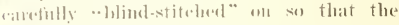

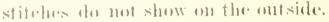

liosts of this style ate the common tyerydial wath of the man. sometimes male wholly of dark therskin and sommtimes variegated. Ther atreaften maslest a patteren like that of the lowere pan't of the woments pantaloons: that is, with flar nepers separate fiom the leg pienes, which are lom ne, with fom white gus

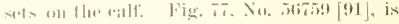

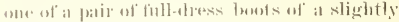
ditferent pitteres. The log piecess alle the

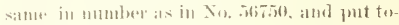
wether in the sallur way, lnt 2 and 8 are of a

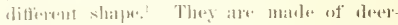

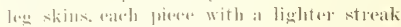

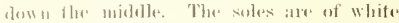

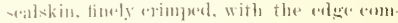

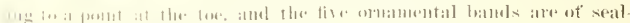

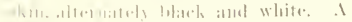

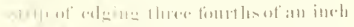

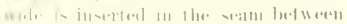

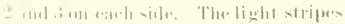

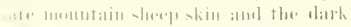

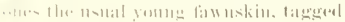

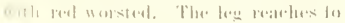

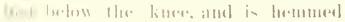

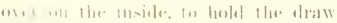

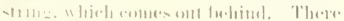

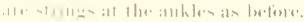

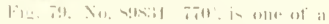

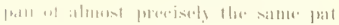

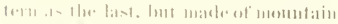

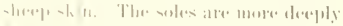

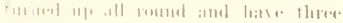
(1) -

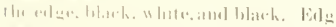

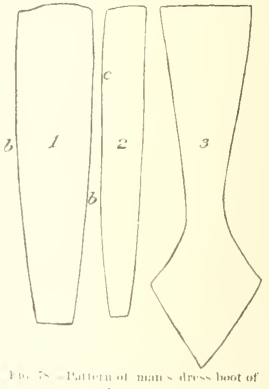
denthm

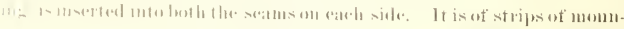




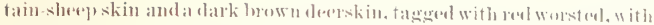

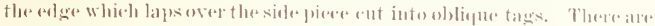

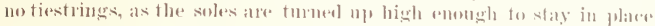

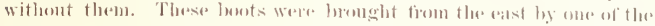

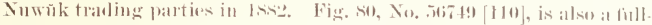

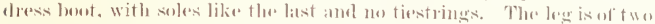

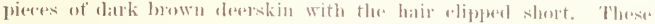

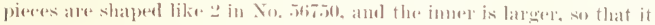

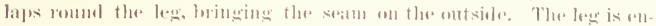

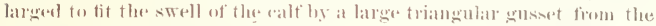
keresto the midleg, mesting the ill-

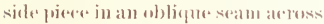
the ealt. lusteat of at twom, the top of the lowe has a haltine-h band sewerl remol it and at hombling for the drawstring above this. Bdying is inserterl in the firont seillu, and obliquely aleross the antsicle of the lege. That in tlee frout semom is there narlow strijk of dereskin, dark in tha. minhlle and light on ritel side. Tla other is of monatain-shentekin in tlares strips, pipest with fitwoskin and tageged with warstorl,

The loots lelonge with the

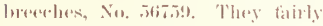

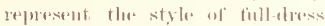
bouts worn with the foose bottemed hreerehes. Tlery all hate draw strings just below the kner, and offen have no tie-stringes at the

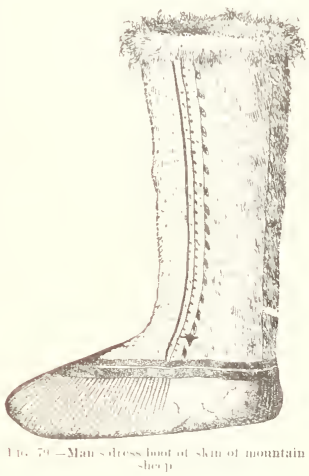

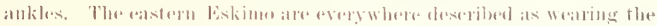

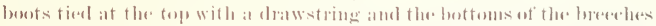

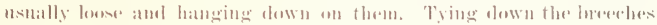

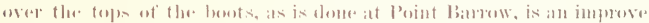

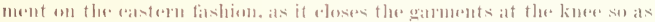

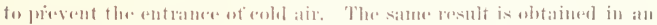

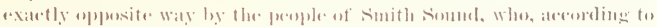

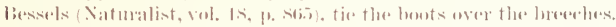

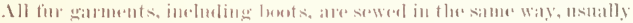

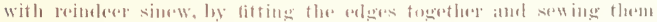

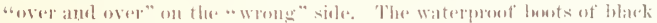

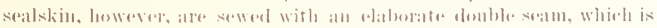

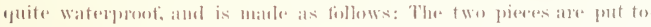

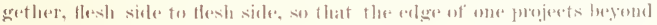




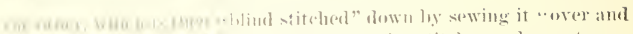

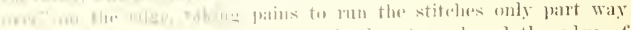

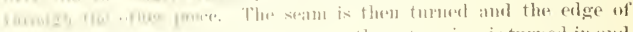

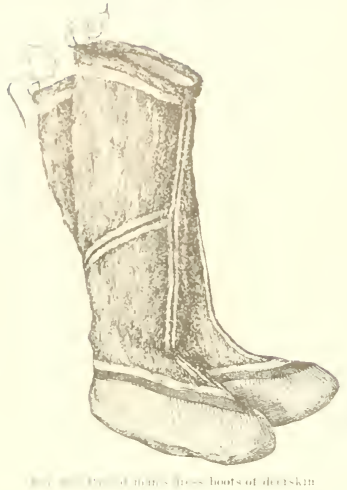
the onter piece is turned in and "roul" down to the grain sirle of the mulere with fime stitehes which do not rou thromgh to the desh side of it. Thus in meitlere seam are there boles thomeng looth pieres at mice. The sewing is done with fins sinew thesed and very fine mond medles (the women nast to ask fir "litthe meetles, lik" at hair"), and the edge of the leathere is sottened loy wetting it in the month. I similat watriplont stam is used in sewing fogetlere boat covers.

There is one pair of waterprost boots in the endlection Xo. 711 topk atre of blark dresised statsking leathing to the knes and esperiatly finll on the instep and

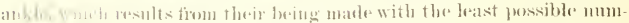

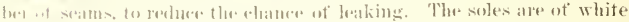

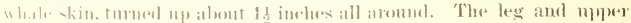

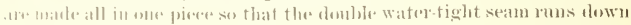

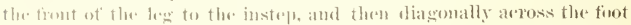

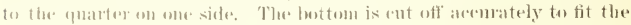

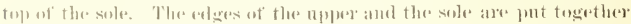
at that the inside at the lormere comes agatinst the inside of the latter,

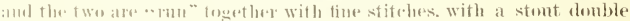

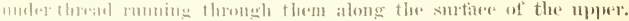

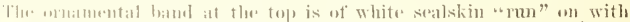

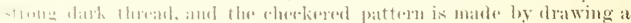

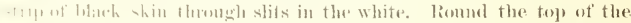

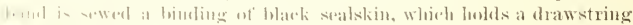

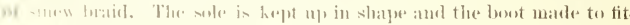

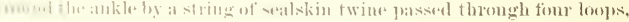

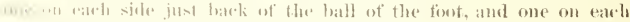

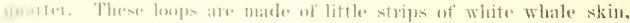

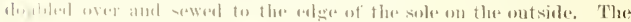

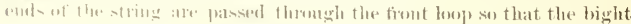




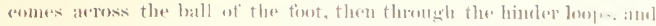

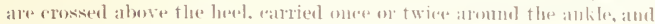
tied in firont.

Sull boots are miversilly worth in simmer. The me+11: luest- ille usually left with an irregular welge

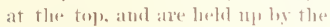
beerehes, while the wenuelis asmally have whifo bands aromel tloe tops with dowstrings. 1lalf-lnots of the salue matertal. reateling to midleg, withont drawstringe, al shoes reaching just alowe the ankle with a string rouml the top ane some times worn over the deenskin bouts. Similar shoes ot derersin alre sums. times worn in plase ot luots.

Waterpowe boots of blat k sa:al skin are muiversally rmployerl by

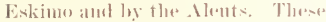
boots stand water for a longe times withent eqetting wot thromels, lnt when they beeneme wet they must be turened inside out and alried very sowly to putevent them fiom shrink ing, and worked solt with it stome

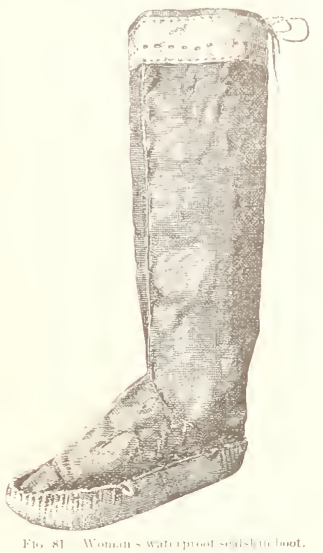

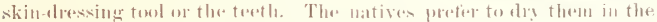

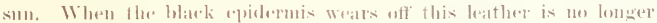
waterporef, so that the women ane atwats on the wateh tor white spots,

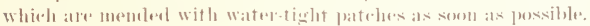

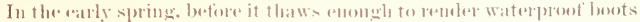

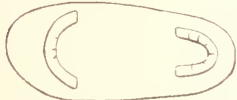

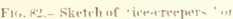
heot 40 l. meressary, the surtare of the smow lowemes

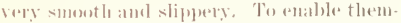
selves to walk on this smitale withont fall. ing, the natives malite a kind of ".repenter" out of strijes of sealskiu. These are donbled lemertlowise. and gentelally bent into a half-

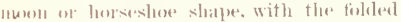

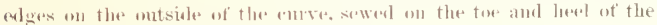
sealskin sole, as replesenterl in Fig. s...

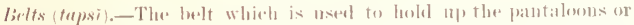
brecelues is simply a stout strip of skin tienl round the waist. The girdhe, which is always worn ontside of the forek, sacept when the weather

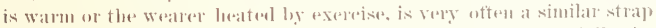
of deerskin, or perhaps wolfskin. (bten, howerer, and asperially for 


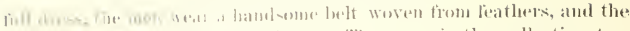

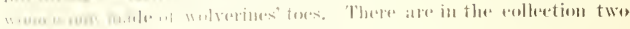

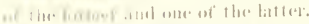

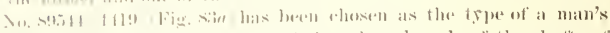

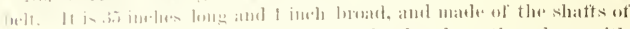

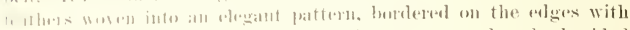

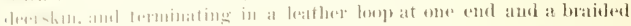

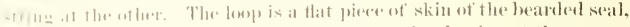

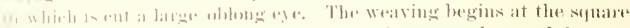

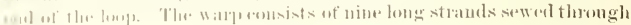

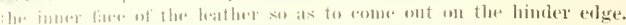

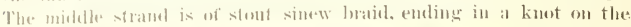

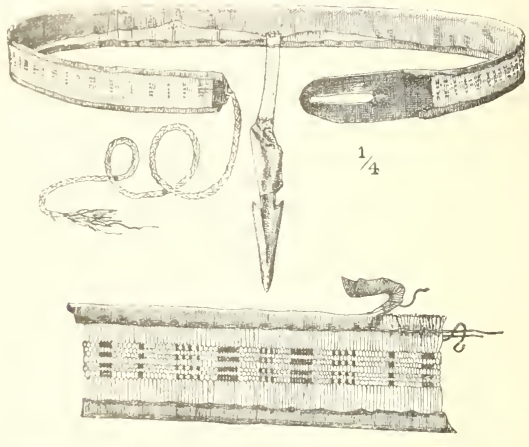

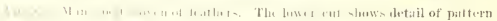

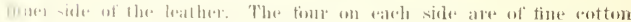

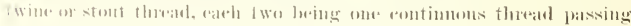
thomegh the leatlowe and wat again. The wow is the shatts of small

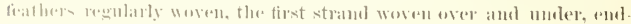

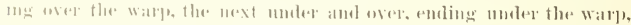

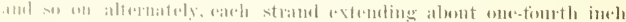

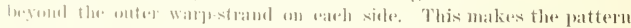

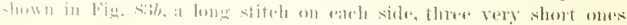

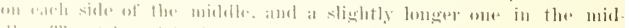

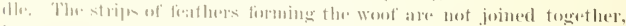

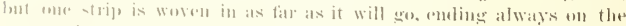

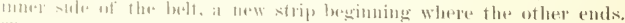

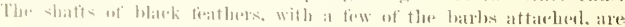




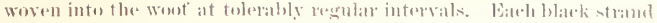
starts nuter the first strame of the walle, making the ontor and immer of the the shest stitehes on wach siste black. This produes a cherkered

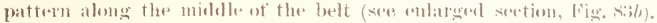
The woof strands are driven lone tightly and their ends ane socened

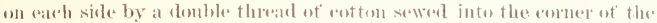

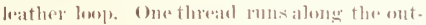
side of the bett and the other alenge the insicle, jasing betwerenthe endsot the feathersabent wery ten feathers and making a tmon romet the outer theade as in Fig. st. Theredgersent

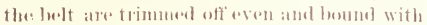

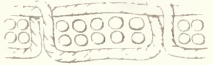

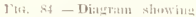
Intherel al' fitalenimes the

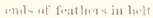
a narrow strip of desiskin with the thesh sien ant and painterl real.

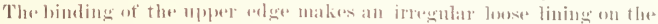

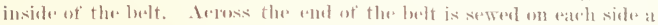
narrow strip of sealskin, and the ends of the warp are gathered into

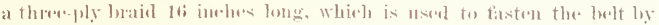
drawing it through the leop and kuotting it. An ancient bone spear head is attandued to the leslt as an amulet by a stout strap.

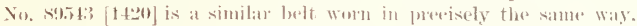

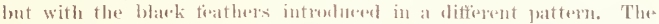

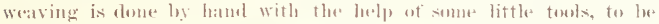

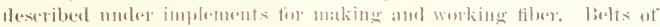

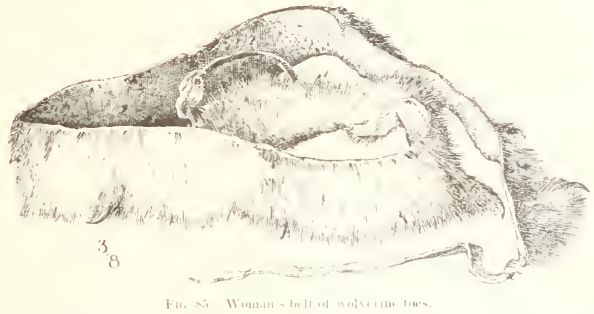

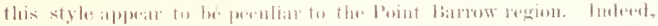
girlles of any kint are seletom wom were the jacket by the men in the anstern jegrions.

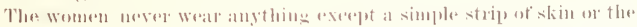

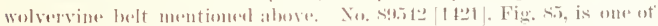
these. It is marle of nime strips of dark brown skin from roment the

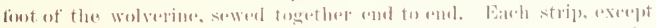

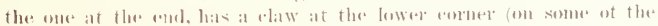

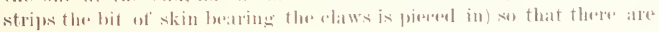




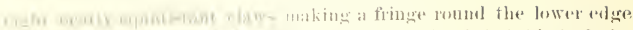

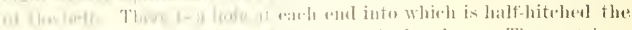

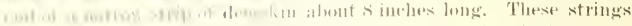

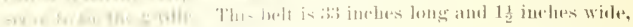

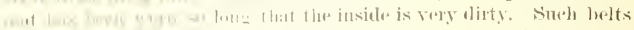

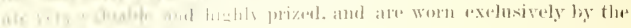

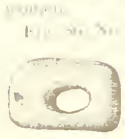

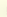

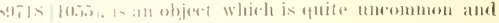

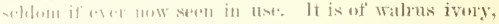

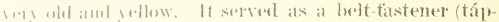

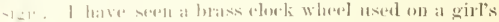

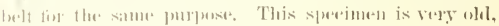

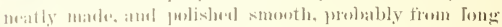
IIse.

1)

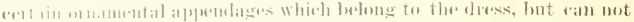

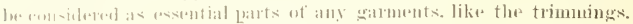

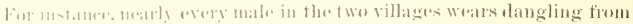

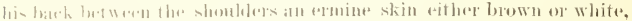

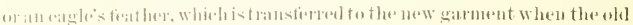

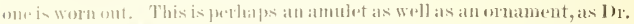

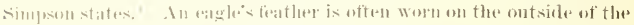

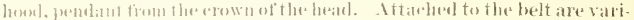

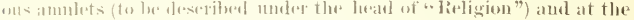
bate always the tail of an animal, manally at wolverine's. Very selelom

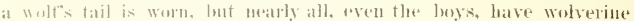

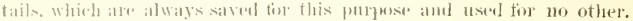
This lathit among the Eskimu ut westrotn Ameriea of wearing a tail at

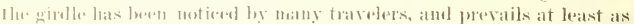

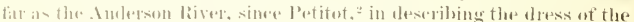

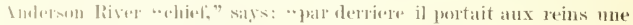

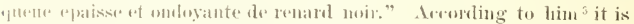
the women of that region, who watr, "it titre de talismans, des defroques

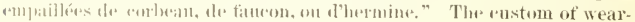

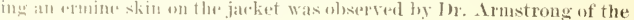
Inrestiguler at $\mathrm{C}_{\text {itpe }}$ biatlutrst.

PlikแNAL, ABuliNMENT.

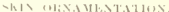

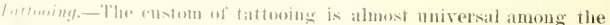

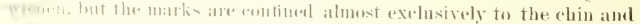
fir 11 at very simple pattert. Thisconsistsof one, three, five, or perhaps as

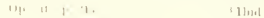

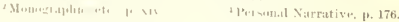


many as seven vertical lines from the mules lip to the tip of the than,

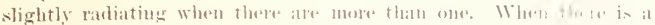

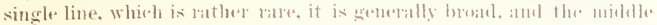

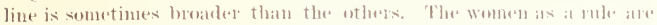

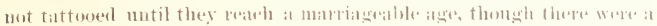
few little girls in the fwo villages who hat a single lime on the ethin. I remember seemg but one natriend woman in rither villatge who wats

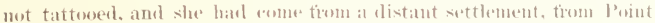
IIoje, as well as we rould mulerstaml.

Tattering on a man is a mank of dhatinetion. Those men who :He, a1 have heen. eaptains of whaling muiaks that have taken whalex hate marks to indieate this tattenel somewhere on their persoms, sometimes

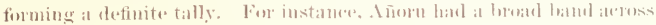

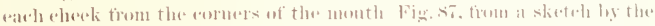
writer), mate me of many indistimet limes, which was silul to indurate

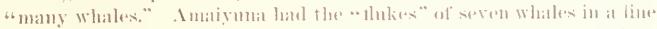

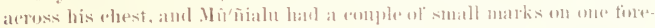

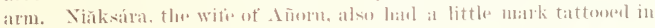

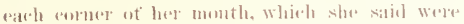
"whale marks," inclieating that she wat the wife of a suceessfil whalemin. Sueh malks ancont

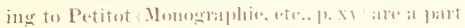
of the nsual patteru in the Halkenze distriet-

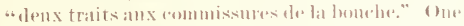

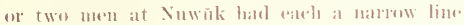
areses the tawe, asere the bridge of the mese, which

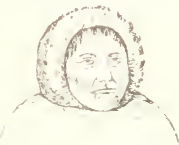
Fin, si-Mtin w1t $1111+\cdots+4$ (licilis:

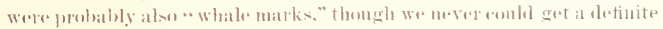
answer ecomerning them.'

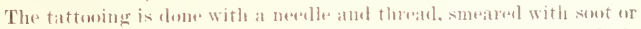

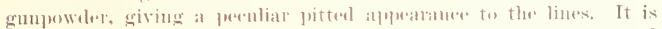
rather a painful operation, producing vousisletable. noflammation and swelling, which lasts several days. The pratice of tatteming the women is almost moiversal among the liskmo, from ciresulanel to

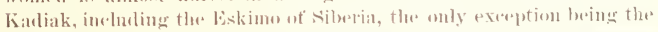

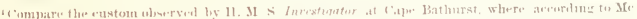

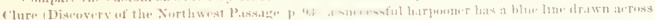

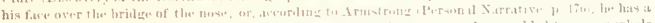

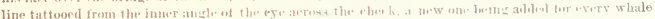

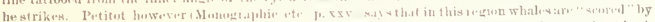

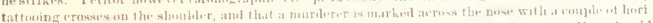

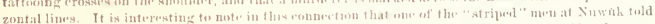

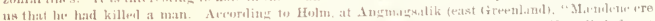

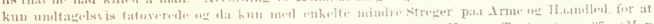

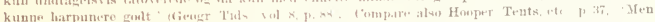

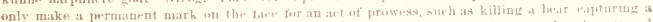

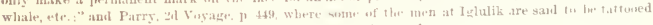
on the hack of the hand, as a sonvenir of sume distant or dectasind jeraon.
} 


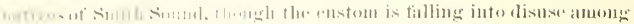

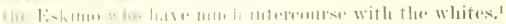

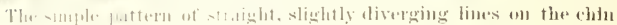

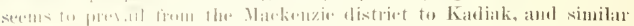

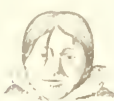

... $11+1+4$

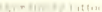

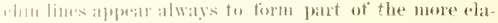

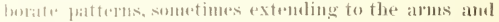

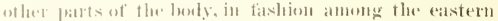

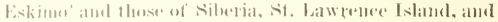
the lomedes.

ling, sis, from a sketch mathe ent the spes by the writer. slows the Point barrow pattorn.

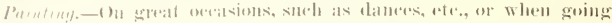

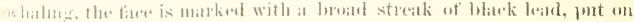

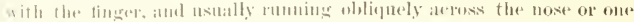

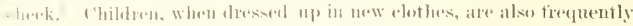

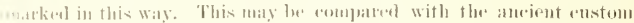

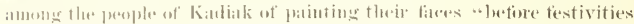

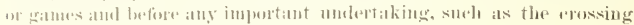

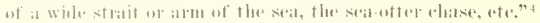

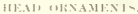

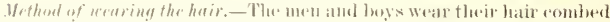

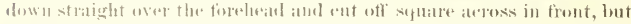

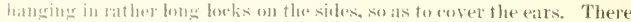

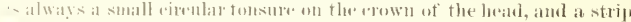

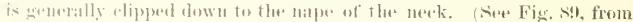
a sketeh tion life he the writere) The natives ledieve that this alip ping of the hatek of the hest prevents smow blinderess in the spring.

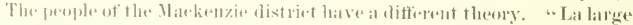

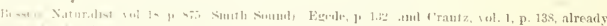

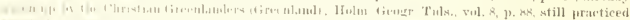

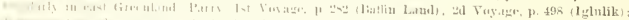

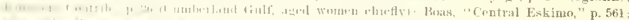

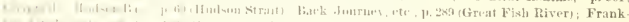

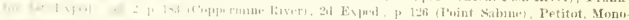

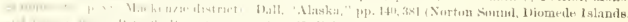

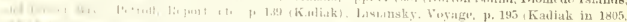

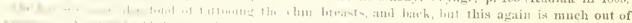

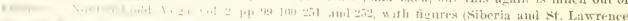

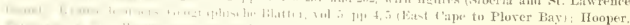

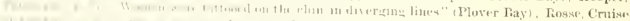

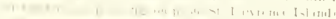

Whacto

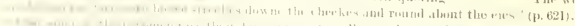

20w

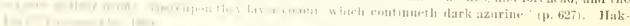

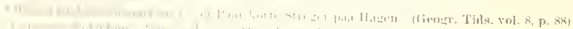

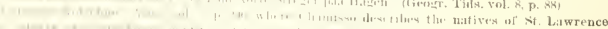

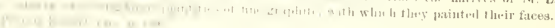




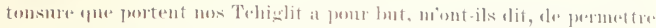

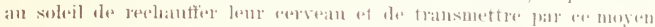

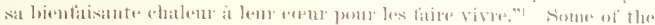

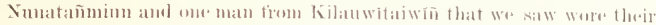

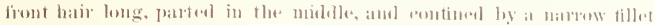
of leather romml the bow. The hair on the tomsure is not always

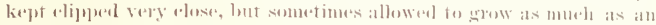

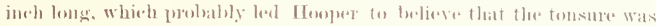
not rommon at l'oint linerow." It is miversal at the present dity, as

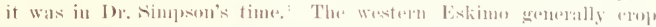

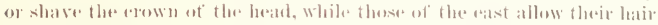

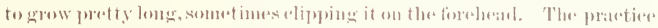

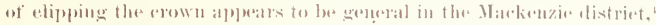

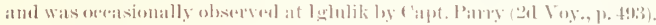

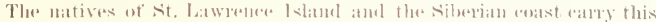

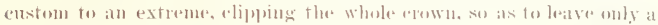
fringe round the leasl. The women dress their

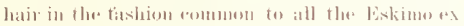

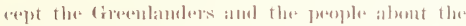

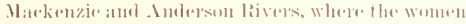
bring the hate up from helome inte al solt of high top knot, with the andlition in the latter alistriet ot

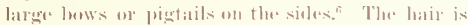

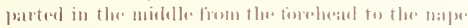

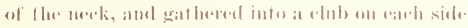

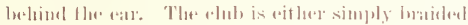

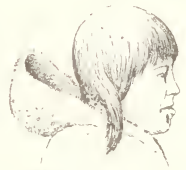

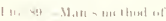
uraring ilu lout or withouf furthel dersing twistent and lemgthemed ont with strips of

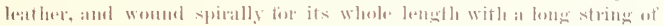
small beals of varions rolors at large that torass buttom heing stuek into

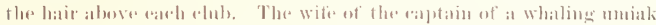
wears a strip of woltskin in plase of the string of beask when the loat

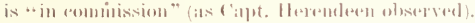

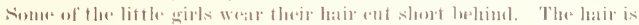

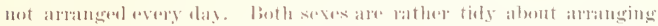

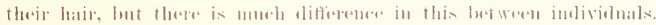

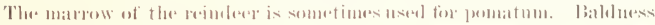




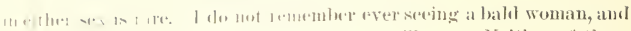

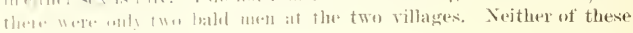

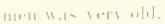

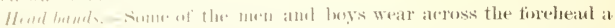

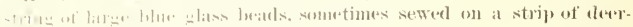

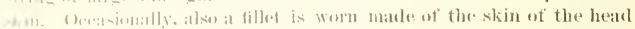

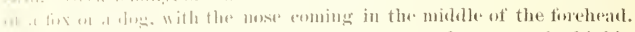

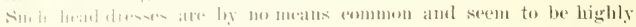

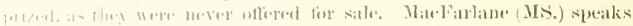

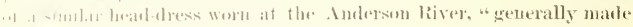

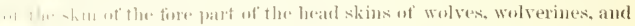

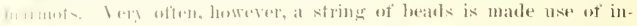

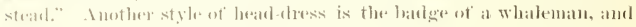

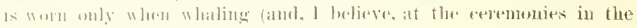
slown preparafory to the whalingl. This some to be very highly

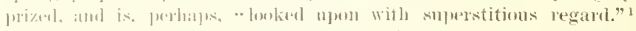

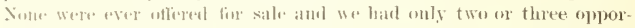

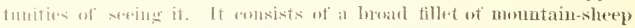

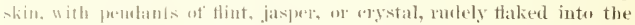

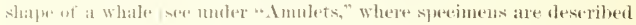

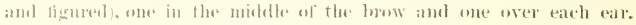

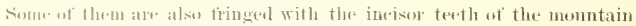
sherp attan-hed ly means of a smatl hole drilled through the end of the

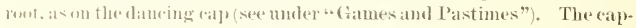
tain and harponer of a whaling rew which I saw starting ont in the sproing of late each wore oue of the se tillets. The harpooner's had only the whale pendants, hut tha captain's was alse fringed with teeth.

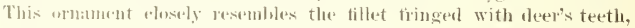

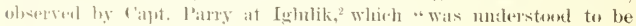
- worne on the heat hy me-1, thomgh we did not learn on what ereasions."

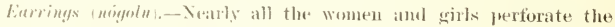
lober of the ans and wear parrings. The commomest pattern is a little

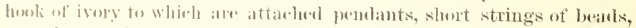

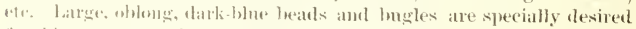

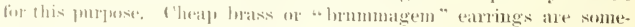

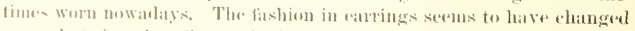
snm what since lor. Simpons time, as 1 do not remember ever having

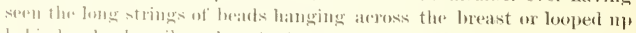

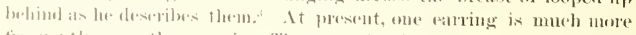
trecpuenty worn than a pais. There ane in the eollection two pairs of the irory herkes for arrings, which, thomgh made for sale, are of the

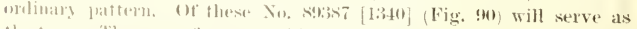
the type. They are of andse, whe walles ivory.

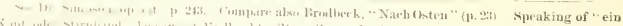

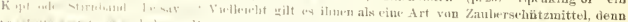

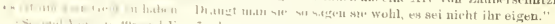

स

$(11)+1,111$
} 


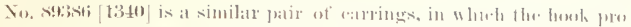

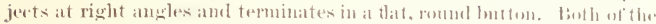

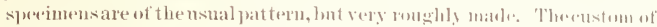

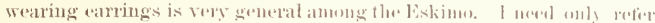

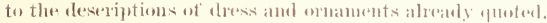

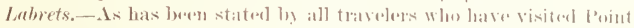
barrow sime the time of blam, all the alult males wate the laturets

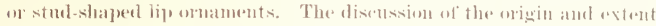

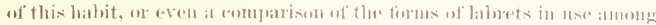

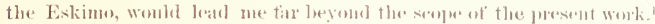

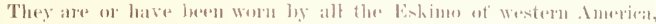

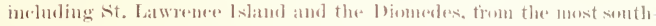
"ln point of their range to the Matekenzie and Amberson distriet and

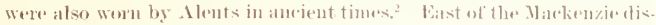

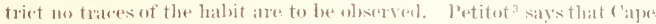
lathmst is the most "astern puint at

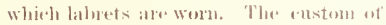
wearing them at this plates is perlater reent, as 1)r. Armstrong, w the Inesti gutor, expressly stafes that he sall nowe

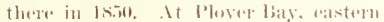
Silueria, however, I notiond one or two men with a little eross or eirele tatterel nutere anels cormer of the montl, just in the position of the labert. This may lu"a reminise ene of all ancient halbit of weat img labrets, or may havelesell dere in imi tation of the people of the loimedles and thr. Anetican anast.

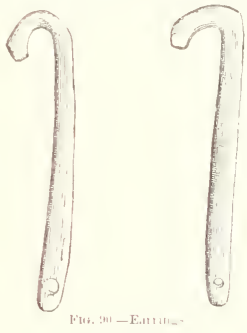

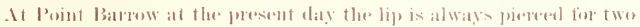

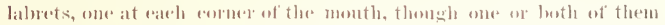

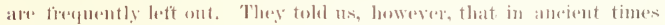
a simgle babet only was werm, for which the lipe was juereed direetly in

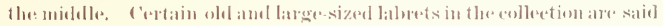

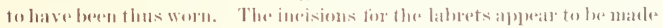

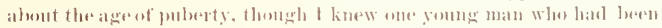

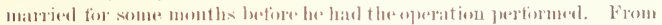

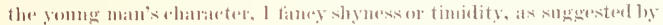
1). Nimpsen, hat something to do with the delay. Contraly to lly.

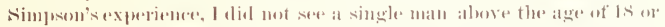

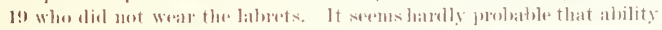

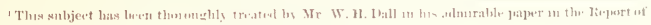

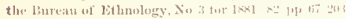

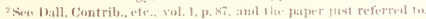

*Monographiu elc. p. xxvi.

(1) 1. eit , p... 241 . 


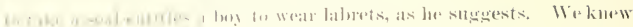

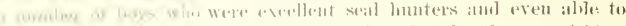

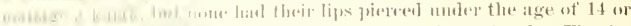

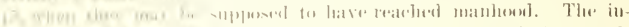

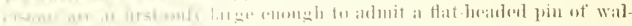

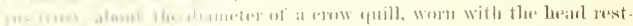

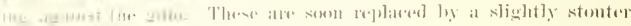

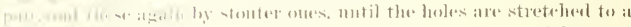

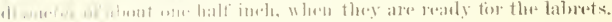

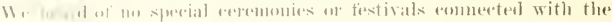

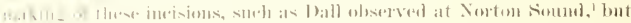

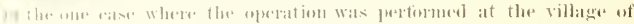

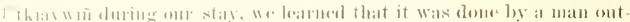

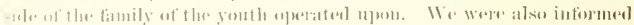

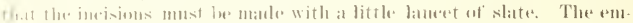
Fin mus af an implement af ane icut form and obsolete material for this

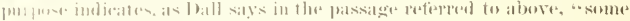

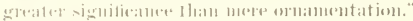

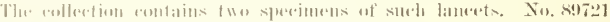

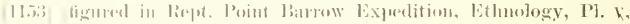

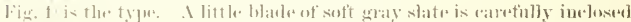

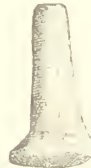

(1) it (1) $-1.1+\operatorname{tin}$

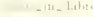

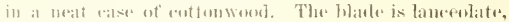

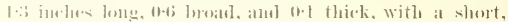

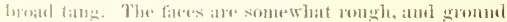

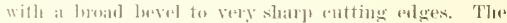

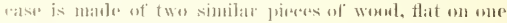

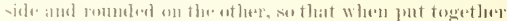

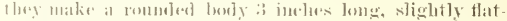

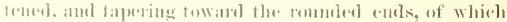

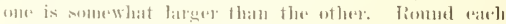

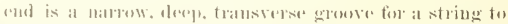

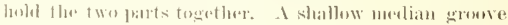

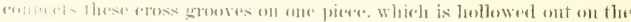

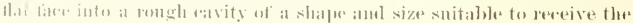

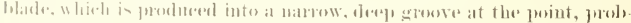

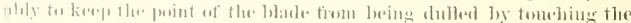

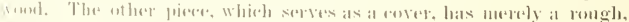

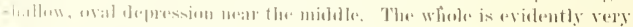

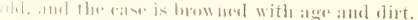

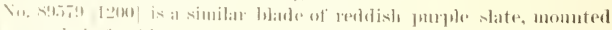

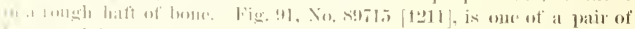

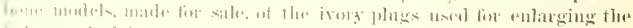

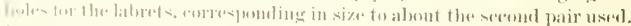

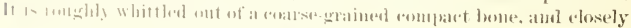




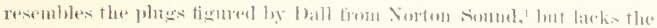

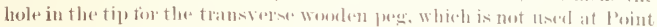

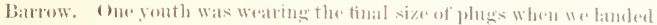
at the station. These were bumght to a point like the tip of a walles

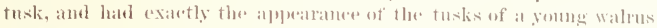

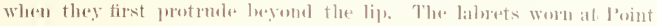
batrow at the present day are monally of two patterns. One is a latege. flat, rirenlar dlisk abent 1, incles in cliameter. with a flat sturl on the batek something like that of a slectebuttom, and the other a thick

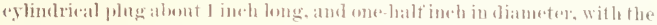

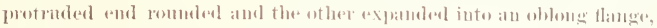

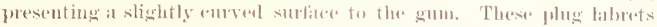
are the common fashom fir exeryday wear, and at the present day, as in 1r. Simpents time, alre almost withent rexeption made of stone. Granite or syenite, penphyry, white mathle, and sometines coal (rately jade are used tor this jurpose.

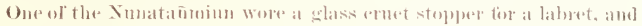

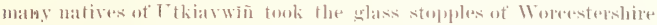
saue bottles, which were thrown away at tles station, and inserted them

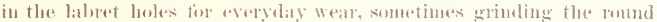
tope into an chloleg sturl. There is one spereimen of the plus baloret in the collection. Labrets ot all kinds an very highly prized, and it was almost impossible to olotain them.' Thongh we lepeatedly asked

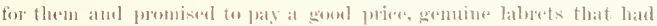

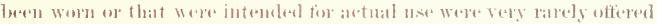

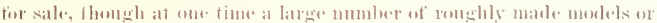
imitations were bromeht in. The single sperimen of the plug labret

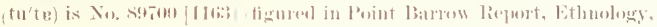

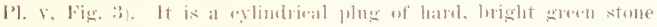

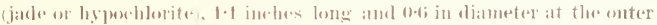
end, which is romeded ofl, tatpering slightly inwaral and expanded at the base into an elliptional disk le-

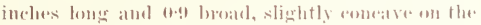
surfare which lests atwainst the twoth and genm. The sperimen is old and of a material vely musmal at

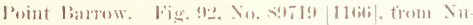
wotk, may also be atled a plug labret, but is of at very umsmal pattern, alus said to be rery ohl. It has an obloms stud ol walrus ivory surmontont by

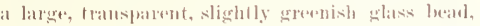
on top of which is a small, trausherent, sky-blut

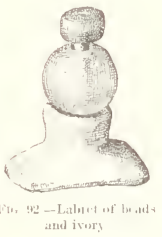

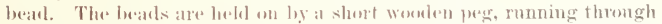
the pertionations of the bads and a hole drilled throngh the ivory.

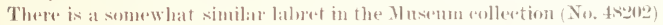

'Alakka, p. 140

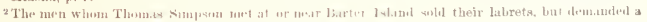

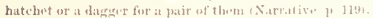

(1) ETII- 10 


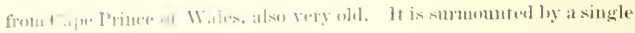

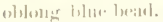

I sill but ane of lee labret makle of whole beads, and this had three

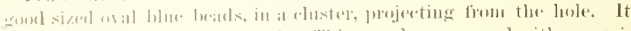

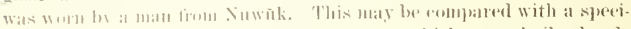

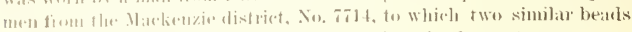

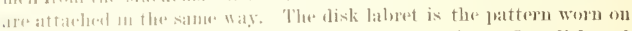

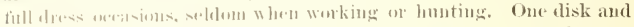

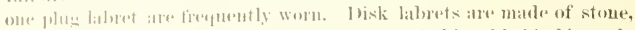

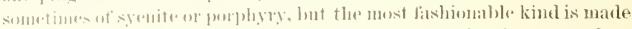

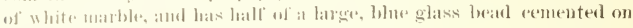
the enter of the disk. These are as lighly prized as they were in Dr.

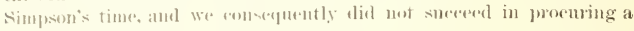
sperciuren.

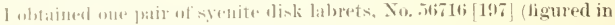

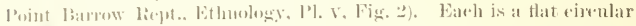

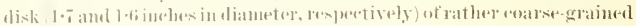

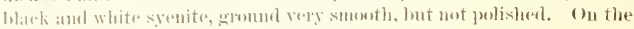

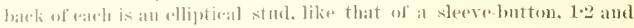

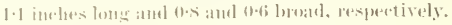

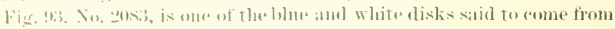
the Interson livers. This is introduest to represent those worn at

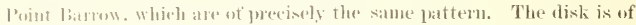
white mathle, $1 \frac{1}{2}$ ineles in dizmeter, and in the center of it is remented,

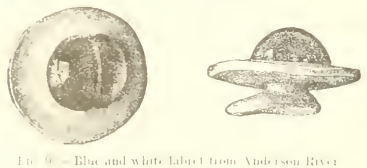
alpharently with oil dhegs, halt of a transiarent blue glass bear, three-juarters of atu inch in diameter, aromed the misldte of whieh is ceut a - latllow greove. Similar marlole diskis wilhont the beat are sometimes worn. These

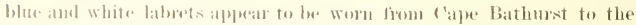
Kinnag peninsula, including the Diomerle Islands (sere figme on p.

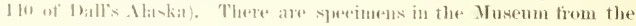
Indersen lifiel and from the north shone of Nortom somed and we Gall them worn by the Nunatañume, as well as the matives of Point batrow and Wainwight lulet. The lotals, which are larger than those sold ly the Ameriean traters, were mudenbtedly obtained trom siberia,

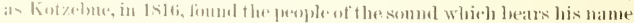

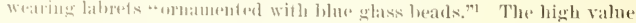

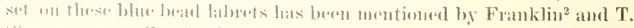

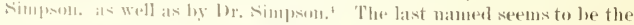

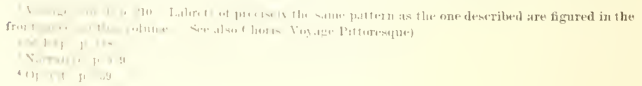




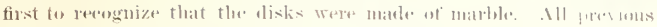
writers squeak of them as made ot wallus ivory.

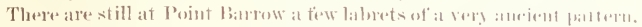

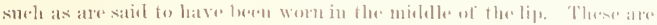

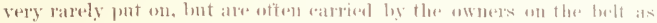

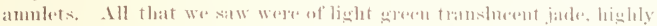

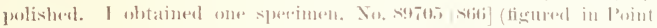

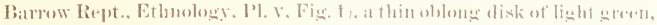

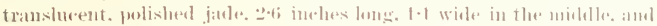

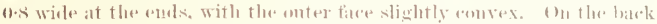
is an oblonge stud with romuled ends. slightly arved to fit the gims.

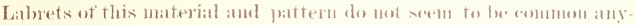

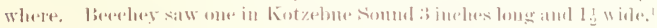

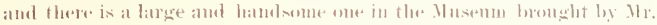

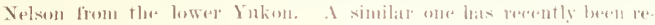

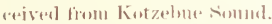

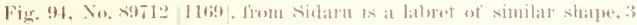

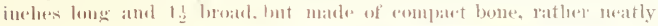
rarved and intemud smerth. It shows some signs of havine beren worm. There a1t+marks+ut the sturl where it apprats to

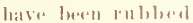

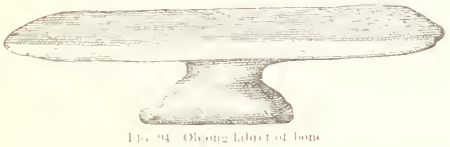

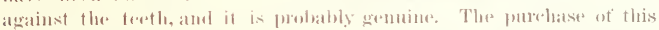
specimen apparently startal the mamutarefure of lose laberts at 1 thi-

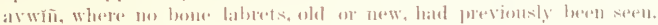
For several dats after we bonght the spereimen firen siolarn the natives contimuel to bring over bone laborts, but all so mewly and relumsily made that we declineal to purelative

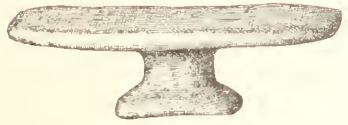

Fic. 45. Oblun: labut ul wetp-ture any more than four specimens. Alout the same time they betgan (1) make oblong laborets ont of strapstone (a) matrerial which we

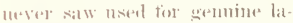

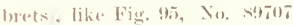

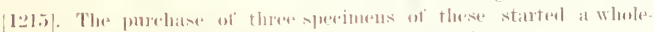
sale manulatere of them, and we stopherl pureloasing.

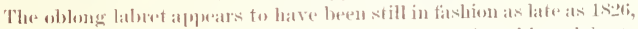
for Ekon salw many of the men at Point batrow wearing oblomg lathets

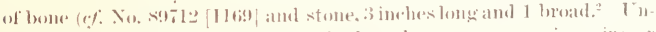
fortmately, he does not specify whether they were worn in pairs or 


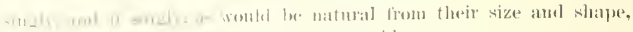

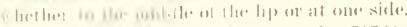

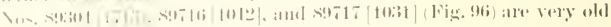

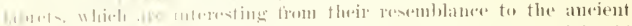

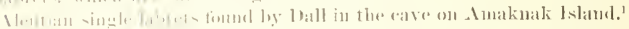

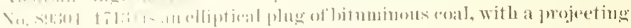

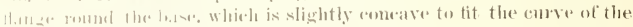

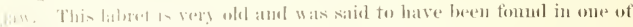

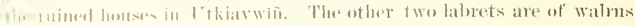

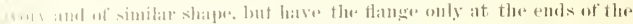

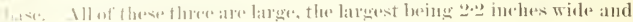
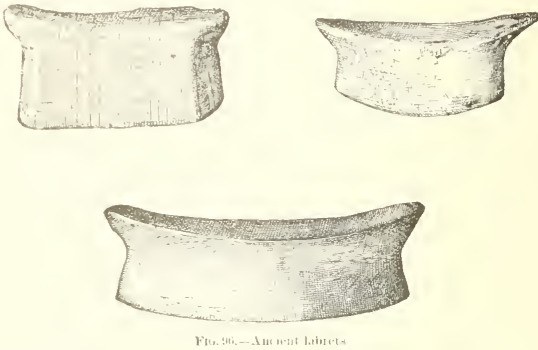

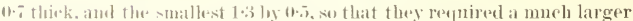
incison in the lipe than is at pursent made. In commeetion with what bats beren satid ol the aneient hathit of wearing labrets in the mishlle of the lip, it is interestimg to note that Nonclenskiöld saw ment at Pont Clarence

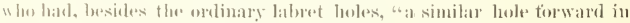
the lipe." The varions portraits of natives previomsly inserted slow the

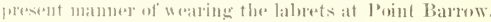

VYGh HI: NAMEST

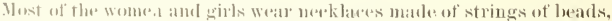

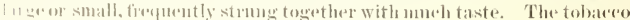
pureh is often allawhell to this neeklawe.

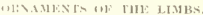

Liracelets.-The women all wear batedets, which are sometimes strings

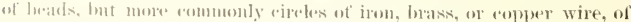

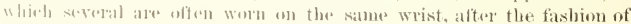
hatmiglos. Themen also sometimes weal hracelets. These comsist of rip-

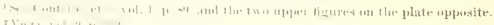

$$
\begin{aligned}
& \text { Vitat }+4 \geq 11+
\end{aligned}
$$




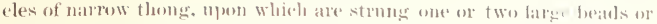
a comple of l tentalimm shells (pir'tii).

We bromght home one pair of men's loratelets (newly mates), one of

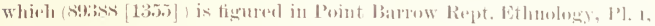

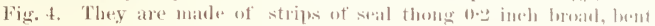

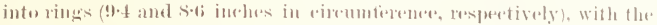

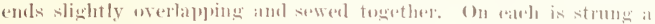

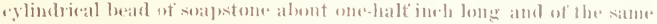
diameter. A single bratelet is genenally worn.

Finger-rings.-both sexes now treffuently watr brass tinger rings,

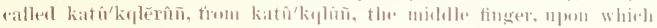
the ring is always worm.

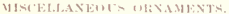

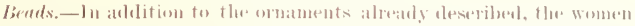

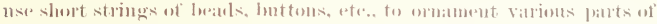

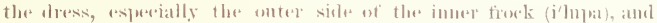

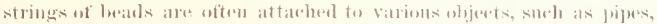

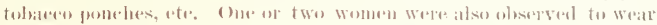

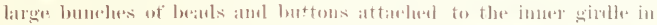

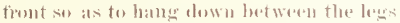
inside of the pantaloens. I similat stringe

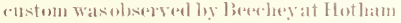
lulet, where a young womban wore it goosl sized metal bell in the same nuenufiotable

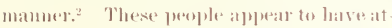
temptecl the mammentmet of lwats in former times, when they wore not sonasilyohtained as at poresent. There is in the eollewtion at

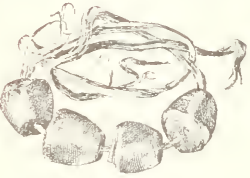

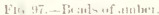

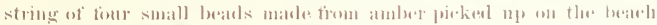

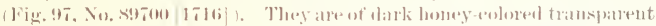

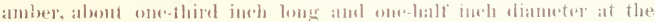

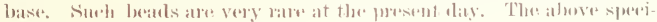
mens were the ouly ants setets.

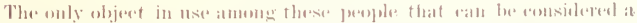

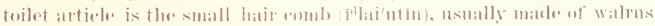
ivory.

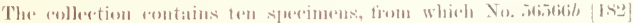

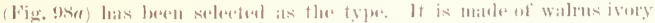

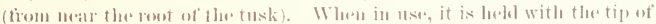
the foretinger in the ring, the thmmb amel midelle finger resting on atell

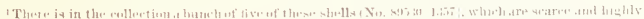

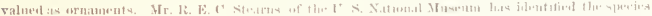

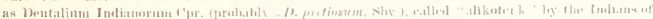

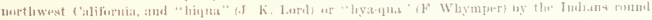
Queen Clatarlutt. Siomud.

2loyage, p. 293. 


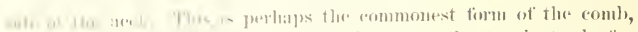

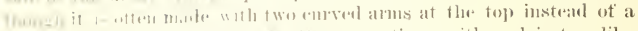

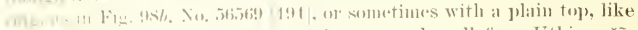
1. . a

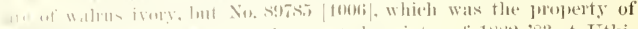

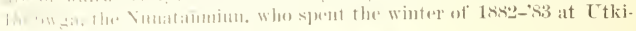
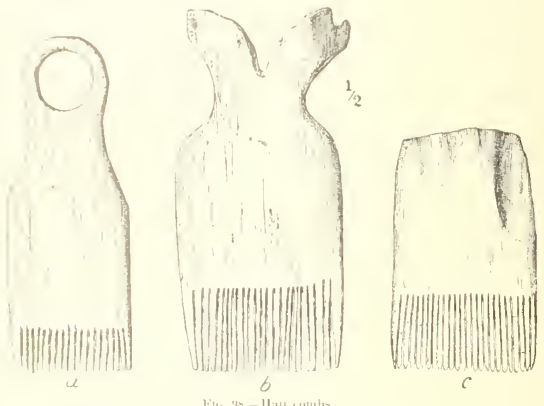

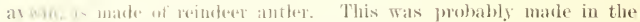

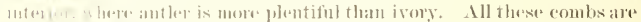

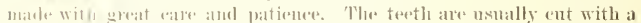

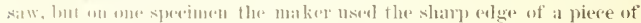

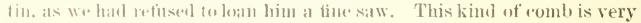

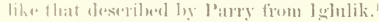

IUPLEMENTS FOR IUNERAL TSE.

ToแI.

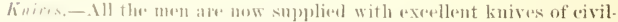

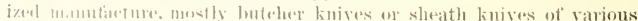

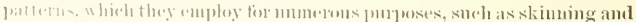

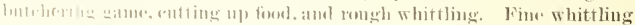

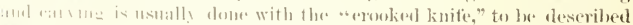

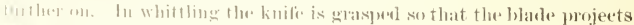

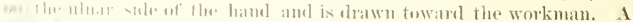

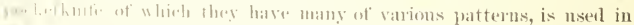

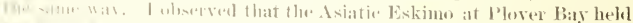

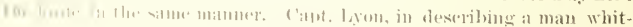




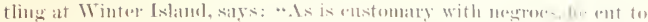

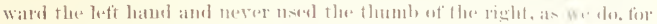

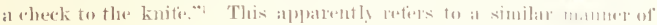

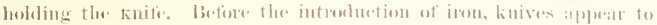

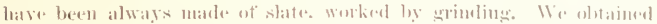

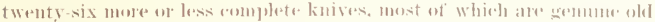

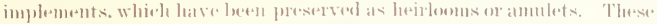

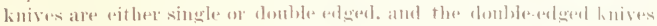

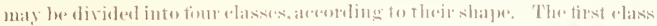
(onsistsof bather small knires ith the edeses stritght or only slightly emved, tapering fo al slatrpor tritu eated point, with the lutt terminat ting in at short lomal tallo slightly narrower than fle blade, which is inserted in the end of al straight wouden haft, at least as longe as the blade. The anumonest mate. rial is a hard, dark purples slate. themgh some are of thateli or dark gray slate. Of this elass we have three eompleter knives and five blakdes withent the haitt.

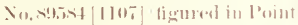
Batrow Rapt.. Ethonologer. I'l. II, rig. 3, will repolesent this class. It is a blade ol dark pmople slate,

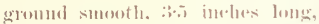

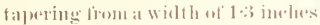
at the butt, with anded enderes to a slan' point, and beveled on both fares from tlar mislalle line to flus ederes, and the tlat tauge is insertert inter a elelt in the and of a sl ratight haft of sprues. The blate is se

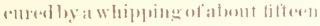

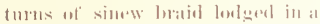

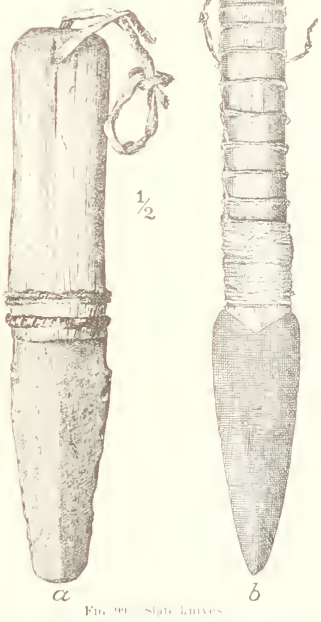

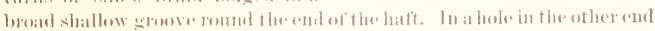

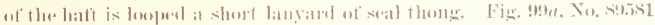

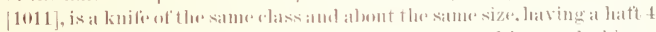

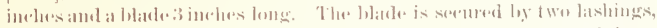

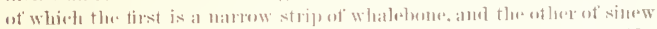

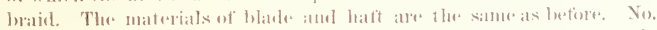

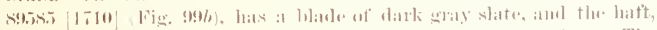
which appears to beot cottonworl. is in two longitulinal sections. The 


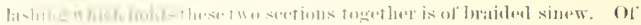

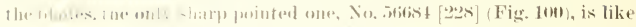

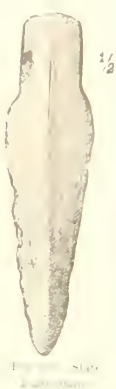

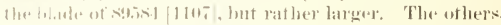

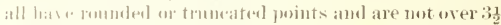

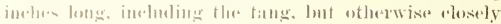

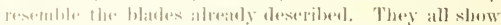

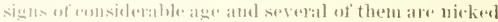

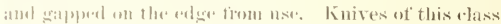
are wot like an! in use at the present day, and it was tof gussible to leart detinitely whether this shape served

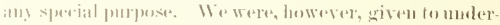
stamel that the slialy-jerinterl ones were sometimes, at

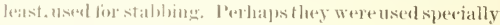
(in whthe up the smatler animals.

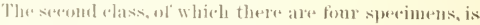
rent unlike the lirst, lnet the lolade is shent and lorearl, "w ith strongly anvel olges, and always sharp pointed, while the hatt is always merh bouger than fle blate. lusteat al beingerenly bevaled off on both taces firom the

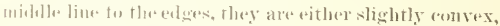

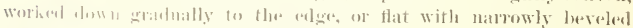

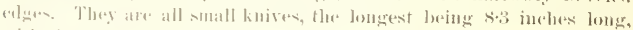
with the blake projocting 3.1 inclues trom the. Hatt.

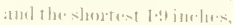
with the blate. projecting mils 1.1 inelaes.

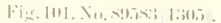
is a huiti- of this wlass, with

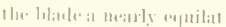

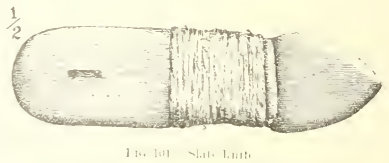

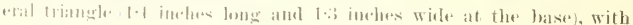

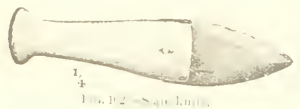
at flat Mornlen hatit as wide as the lilate and $3 \frac{1}{2}$ inelhes lomer, retet at the tipand lasked with thirteen or fourteren furus of sinew brail. The lables an:an the lontt of the halt were mobably to recerive a lanyard. Fig.

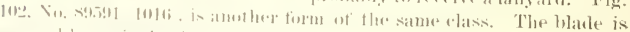

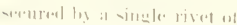
waxkl.

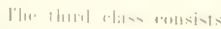

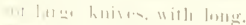

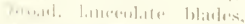

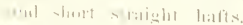

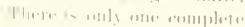

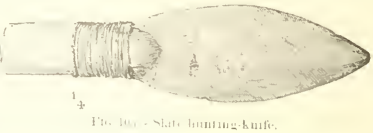

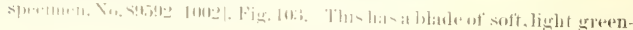




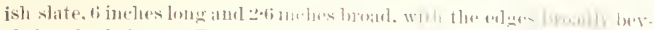

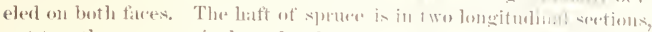

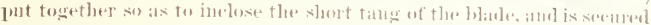

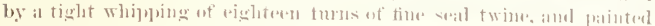
with resl orher. This knife is new and was mate for sillu. but is molomlotenlly at iorrest model of an aneinent pattern.

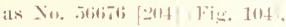
which is rentably ancient. at)peills to be the blakle of just

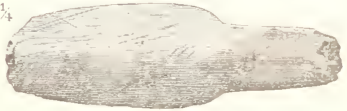

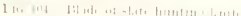

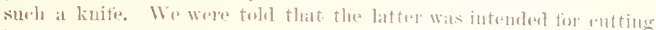
blnbluer. This perhapes uneans that it was at whaling knite. Mr. Nelson

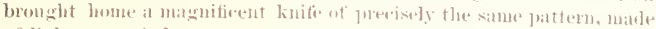
of light glesen jatu.

The two linives, repesesuting the fometh rass, are both netw and

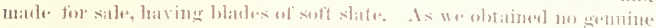
knives of this jatterm, it is presilhe that they are melely anmuereial

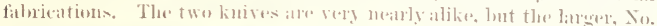

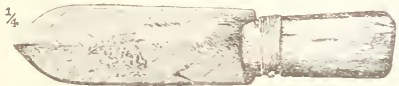

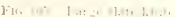

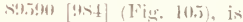
the more anofitly makle. The blante is ot' lieglet enteren-

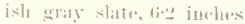

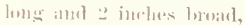
and is stritight Juatly to

the tipe where it atrves to a shatep periut, making a blate like that of

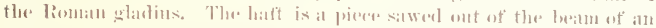

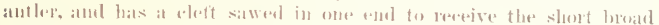
tang of the blathe. The whipplen is at sinew bratid.

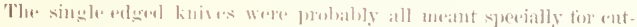

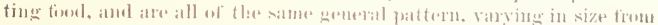

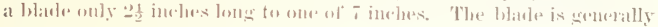

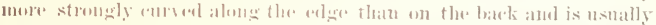

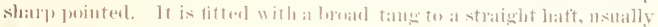
shortere thase the biale. There.

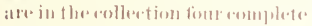
knives and five mahathed blades.

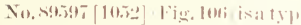
inal kinfeof thekind. The blate. is of blawk slate, lat herroughtoand

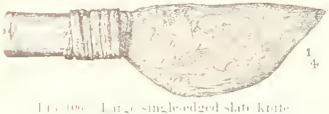

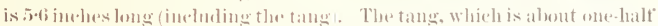

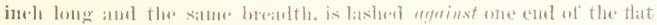

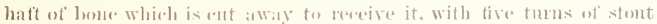

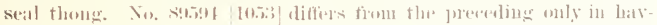

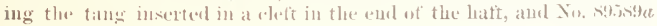




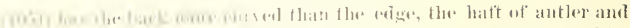

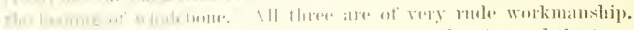

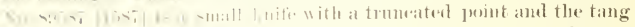

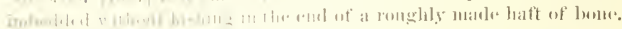

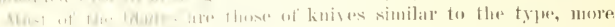

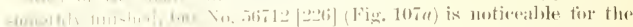
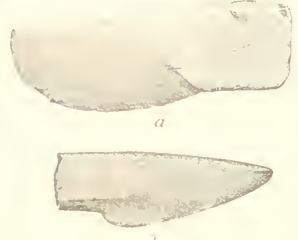
"xtreme "luelly" of the edge and the sucutheress with which the fieces ame beraled from batek to edge. Sirch

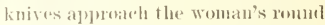

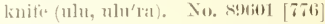

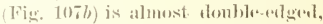
the hack lecing rommed off. Fig.

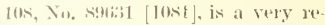
markalle forme of slate knite, of which this was the only sperimen secoly. In slaine it somewhat resem. blus at bateleet, having a bowal tri-

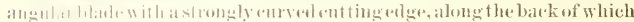

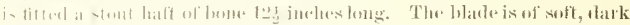

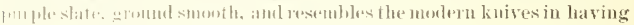

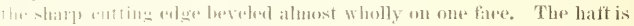

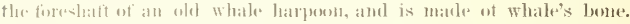

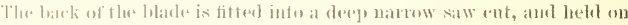

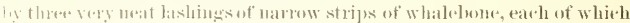
passes through a lowe drilled thromgly the blate clese to the haft and

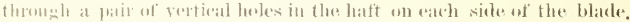

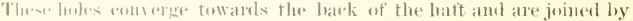

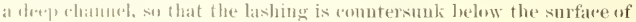

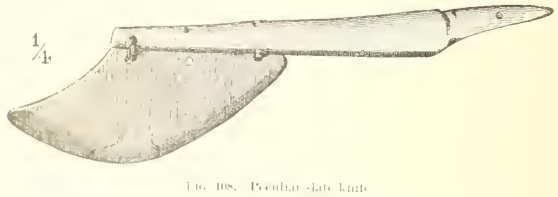

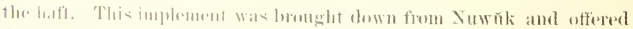

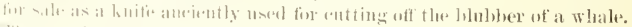

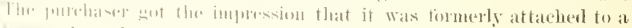

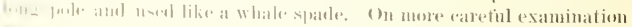

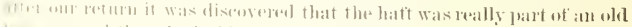
hitlpute and that the lashings atul boles to receive them were eridently newere thatia the hatit. 


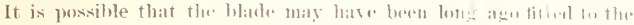

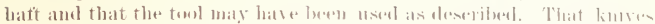

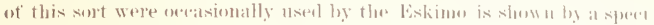

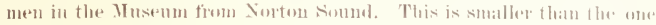

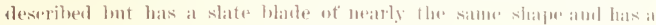
latt, for hand nat only, put on in the sane way.

With surh knives ats these the ent is malde by drencing the knife toward the nser instead of pushing it away, as in nsing the romul knite. W.

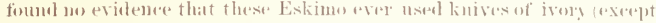
for entting smow) or ivory knires with trits of iron inlaht in the alger. smeh as have been oloserted among those of the bast.

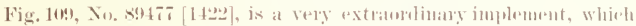

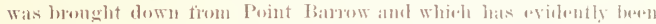

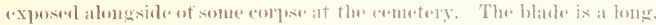
flat, thin piecese of whale. buse wedgerl between the. two parts of the hatt, which has been sawed lengthwise for

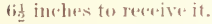

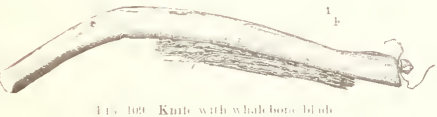

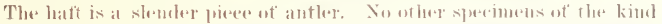

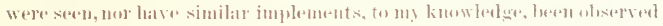
elsewhere. The natives insistenl that it was germine, and was formery used tor entting blubber.

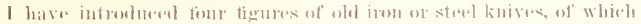
we hatre six spermens, in oreler to shew the way in wheh the natives

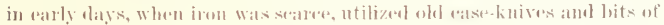
toels. titting them with hafts of their own make. Ill agres in having

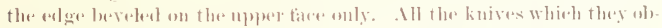

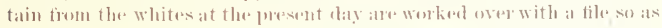

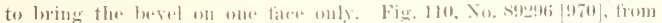

Nowñk, has a blate.

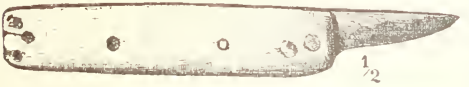

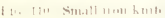
ot irom, amel the that hatt is malle of two

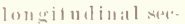
tions of reinter.r anther hedet togethere

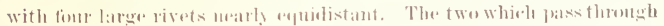

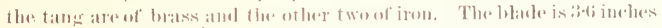

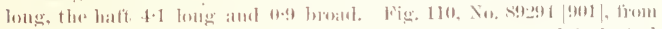

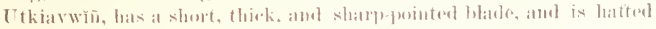
in the salue way with antler, one section ot the lat th beinge ent ont to

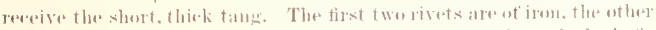
there of brass and not puite longe enowgh to gen wholly throtegh the hatt.

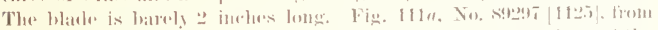

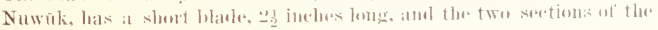




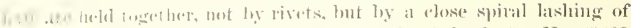

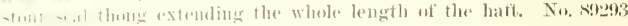

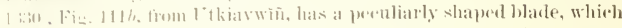

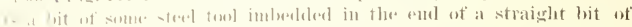

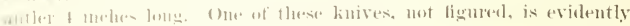

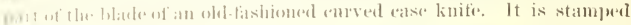
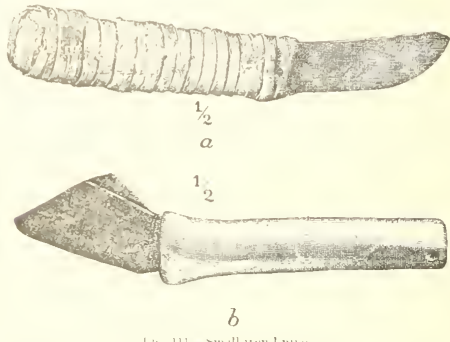

weth the rame -. W'ilson," and molerneath this are three figures, of

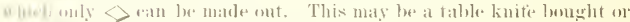

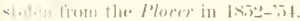

There is in the collection one la1ge dlomble edged knifo (Figr. 112, No.

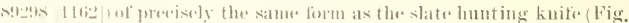

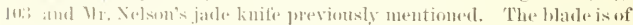
thich shere irom, which has in it a comple of rivet holes, and the hatt of revinderer antler in two seetions, held together hy a large enpler rivet

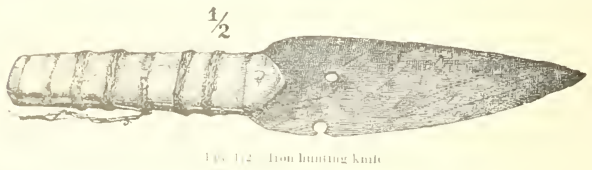

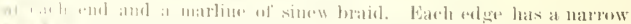

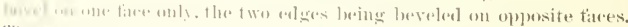

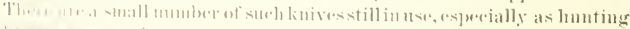

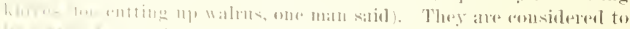

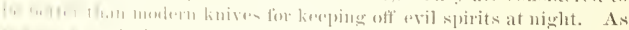

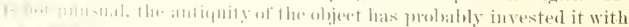

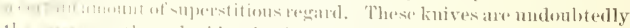

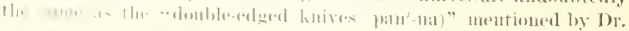




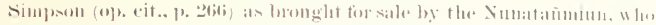

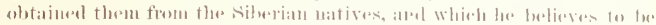

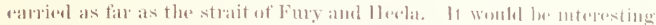

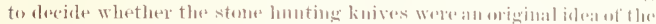

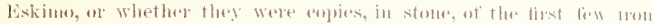

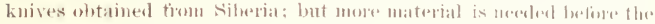

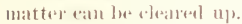

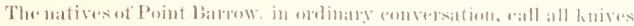
savik, which also means iron, and is identeally the same as the worel

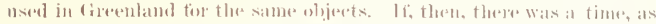

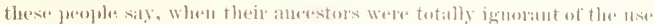
of iron-and the large number of stome implenents still fomml anmeng them is strongly aromberation of this-tles nse of this name indirates that the first irom was obtaimed fiom the ast, alonge with the soap-

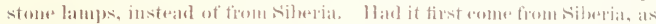

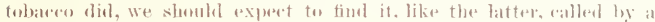
Rusian or silurian na!ne.

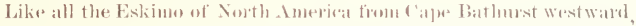

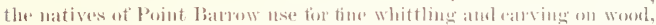

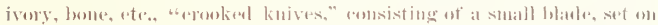

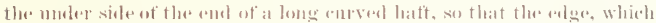

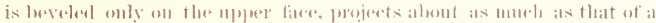

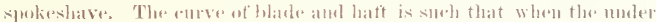

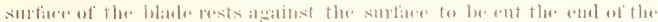

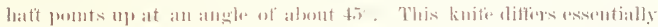

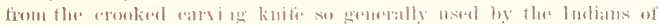

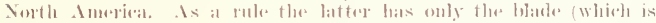

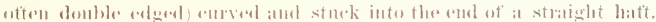

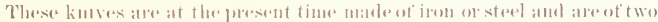

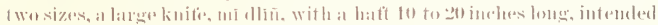

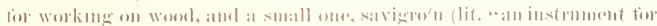

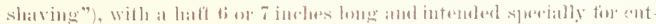
ting lone and ivery. beth sizes are bantled in the sime way. The

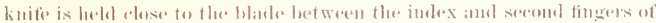

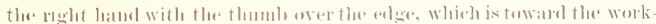

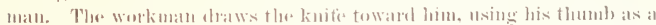

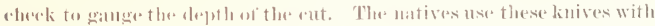

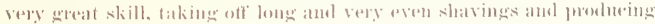
very meat workmamship.'

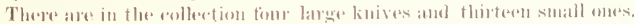

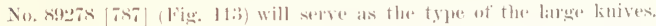

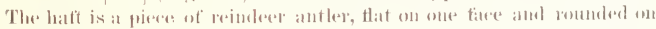

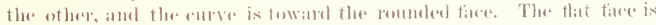
hollowed ont by anting away the ancellated tissue firm the bend to

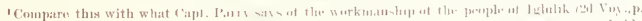

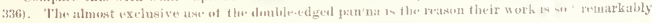
coarse and clunsw:"
} 


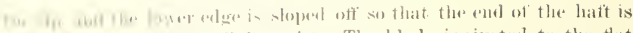

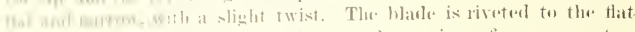

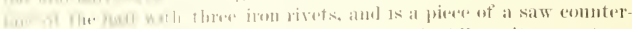

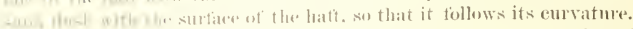

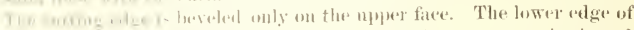

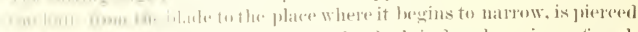

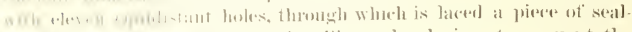

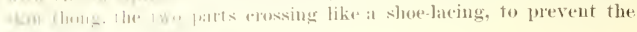
1

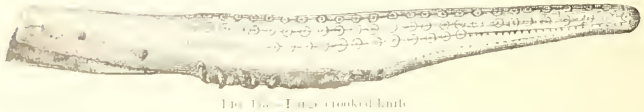

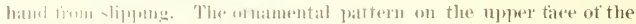

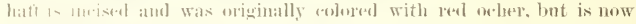
tillenil witl thirt.

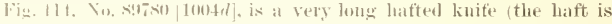

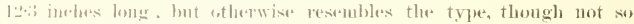

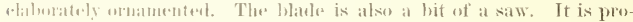
vithet with a slueath :3 inclus long, marle of liack sealskin with the black side wht, dombled over at one side, and sewed "orer and over"

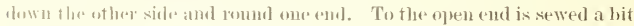
of thomg with a slit in the end of it, into which oue ent of a lanyard of satal twine 1.5 inches lome is tastened with a becket-litch. When the

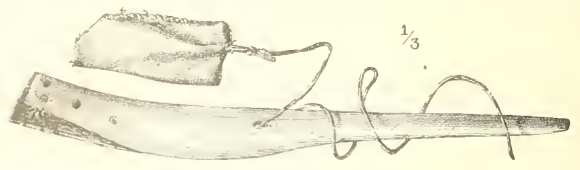

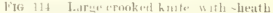

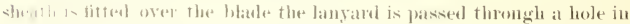
the hath and makle filst ly two or three turns aromed it. Sneh sheathe

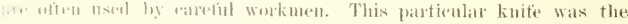

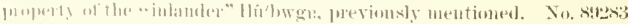

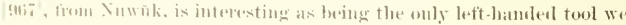

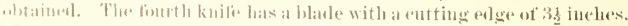

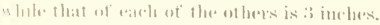

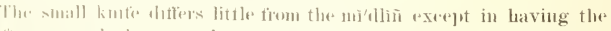

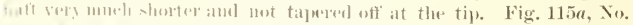

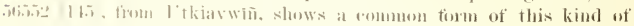
knte thengh the blate nsmatly has a sharp joint like those of the lauge 


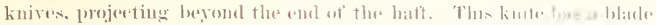

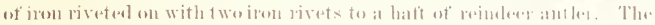

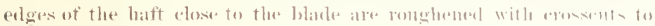
prevent slipping.

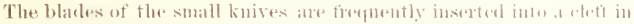

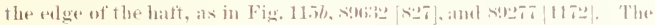

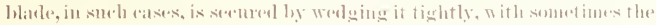

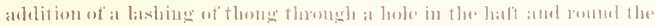

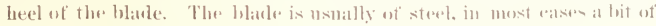
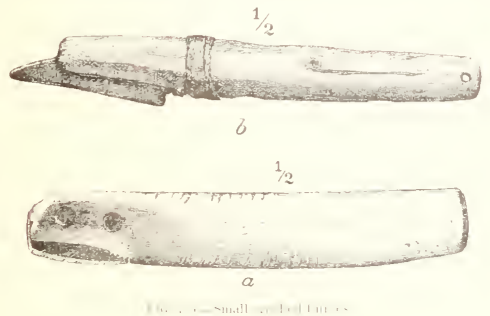

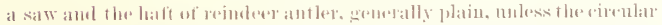

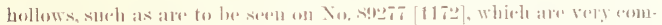

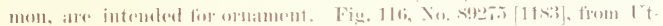

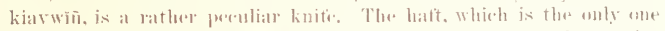
seen of wallus ivory, is mally straisht, and the mmsully lum point

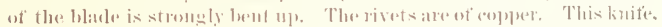
the history of which wo diel not obtain. Was very likely meant beth tor wood and ivory. It is old and lusty and has been loug in mat.

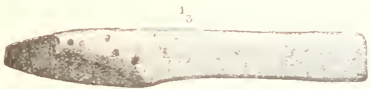

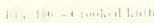

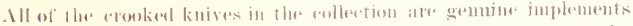
whirb have been actmally in lose and do sut chifter in type fiom the

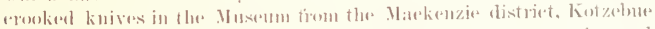

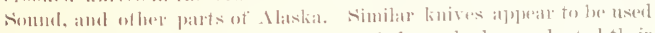

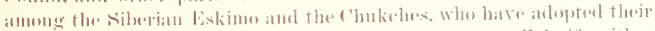

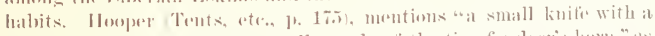

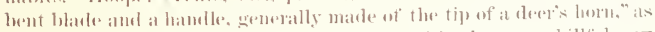

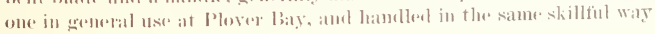




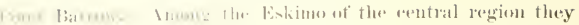

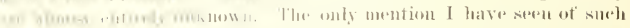

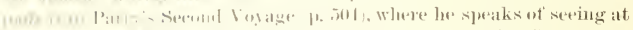

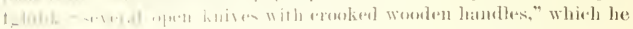

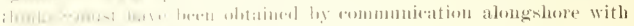

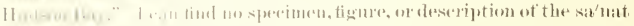

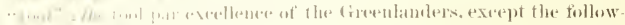

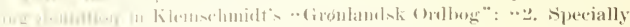

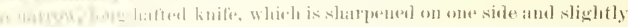

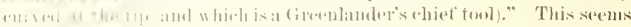

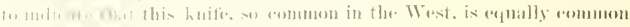

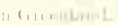

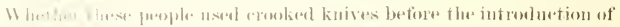

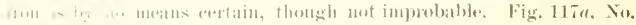

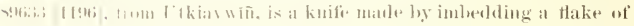

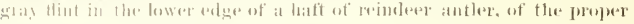

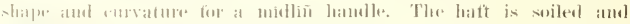

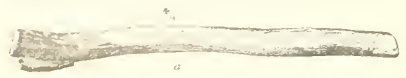
muloultedly old. while. tlat thakedsurtacesot the. flint lo bot seresu fresli, atiul the pelge shows

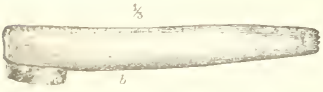

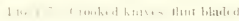
slight nieks, as it it latel been nsest. IIad this kuite leen fol fowerl by others apually gemuin. leoking, 1 shomld have no hes

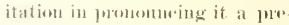

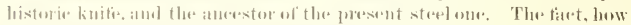

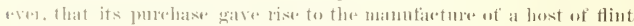

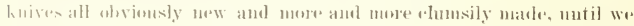

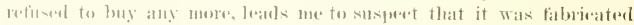

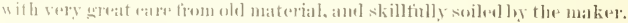

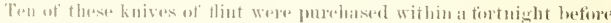

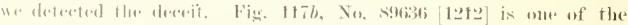

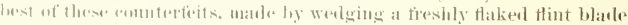
imto the latit of an ohl savighon, which has been somewhat trimmed to

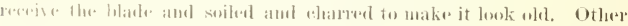

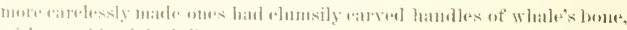

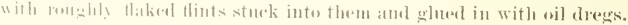

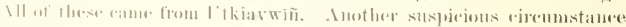

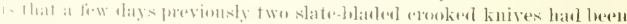

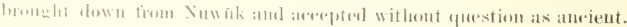

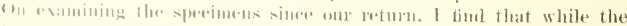

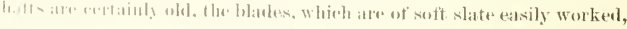




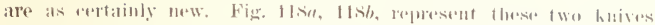

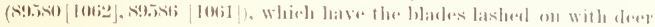

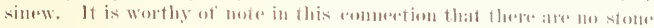

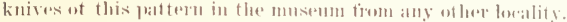

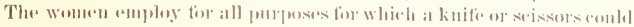

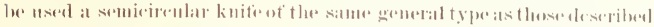
by every witer time the days of ligede, who has had to deal with the
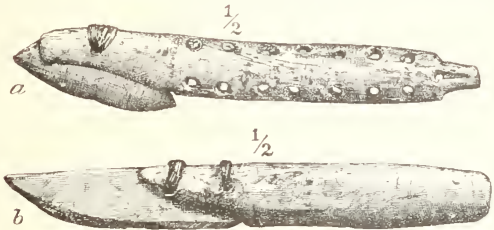

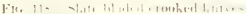

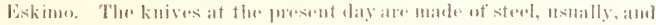

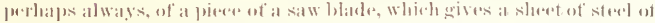

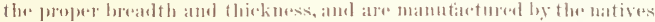

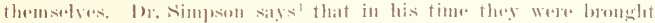

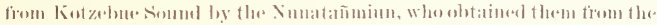

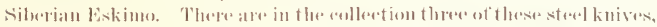

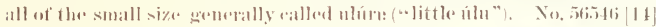
has lowen pieked ont for description (Fig. 1]!) ) The blate is werlegel into at hamelle of wallus ivory. The ormanentation on the hamble is of ine ised lines and dots blackened. Therelt

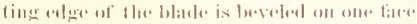
only. This linte represents the general

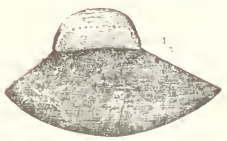

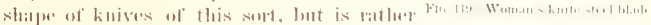

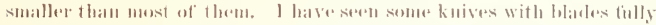

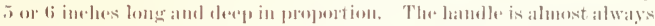
of wables ivory and of the slape tigned. I do not remember ared

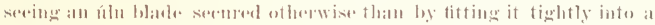
narrow slit in the hamblle, exerpt in one rase, when the hamelle was part of the original handle of the salw of whieh the knife was made. lelt still liveral ont.

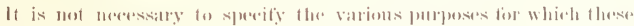
knives atre nserl. Whenerer a woman wishes to cut anything form her

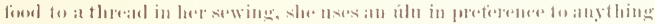

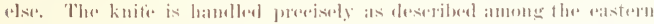

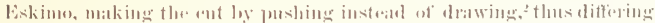

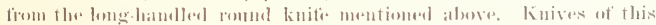




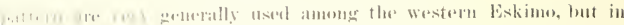

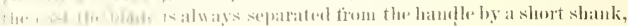

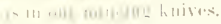

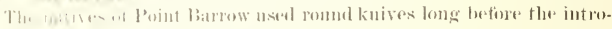

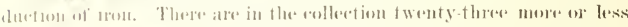

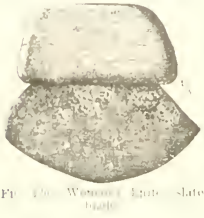
complete rouml knives of stome, most of whith are entume implements that have hem used. (of these at few, whieh are perhates the more

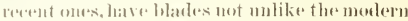

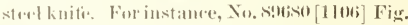
130, has a blarke of hard gray miea slate of al

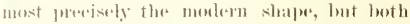
fires are grathally workent flown to the wat ting atge witlesut a bevel on either. The hatulle is very larede and stont and made of

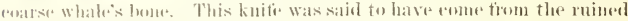

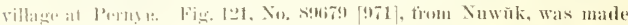
for sale. lout is perhaps a molel of a form sometimes teret. The shatpe of the blade is quite diflerent trom

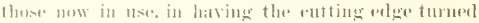
(1) strongly to the tront. The laturle is of oak ame the

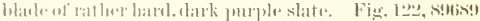

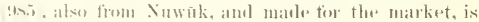
intorlused to show a methorl of hatting which may

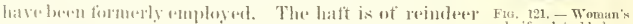
:utler in fwo homgitulinal sections, between which

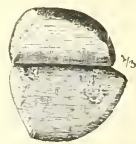

knife, slate blad

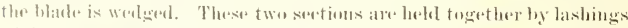

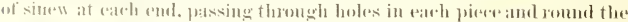

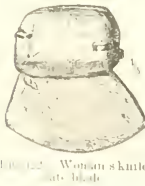
aruls. These lashings being jut on wet, latre shrmuk (a) that the blade is rery tightly rasped between the

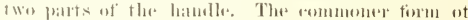
these stone knives, lawereer, has the bark of the

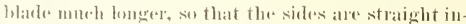

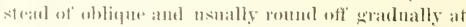

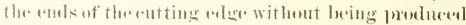

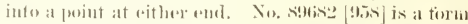
intrmesliate betwern this and the modern shape,

baving at batle witl a long bark, but pro-

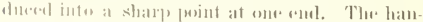

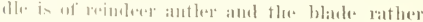

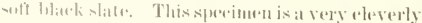

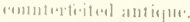

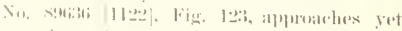

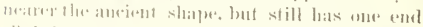

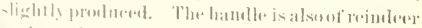

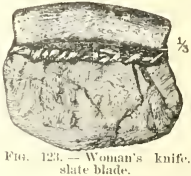

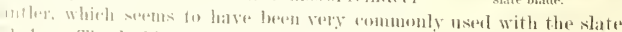

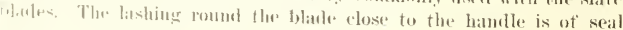




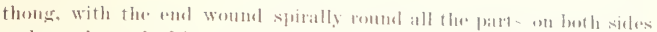

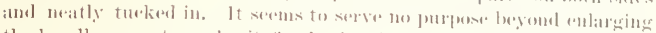
the hamble so as to make it lit the hamel better. (Jue heautionl blate

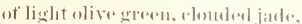
No. semitis $[1170 \mid$. helongerl to is knitie of this pattern. The ollew pattern is represented he No.

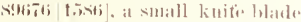
trom l kiavwiti. Whieh hats leeren kejet ats all amulet. No. intifiol [1:39], is at bladeol the salme ty]e,

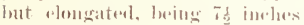

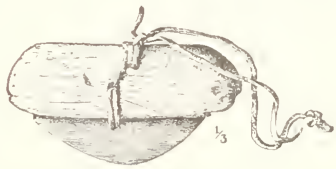

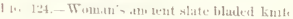
long and 2 lowad. This is a very leantitul implement of palde olive jarle.

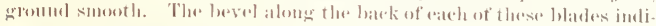
ates that they were to lo titted inte a natrow slit in a long hatt, like

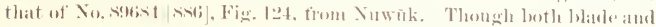
hamdle of this spereimen are very old, and hase lreen put togethey in their

pursent shaipe tor a long time, flec

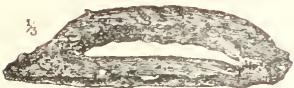

Fiv. Ias Anewent lumi that lomit
huits hatudle, which is ot whalle's lene, eri

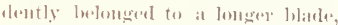
which tittenl in the ele it withour the uned of any lashing. Fig. 125, No.

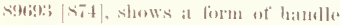
rvilsutly of very great antiquity,

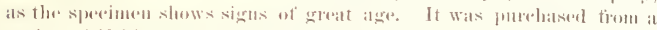

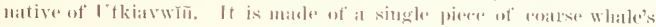

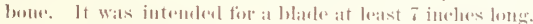

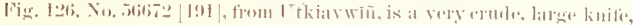
intemates for use witheut a hamble. It is of rengls. hard, datk purplish

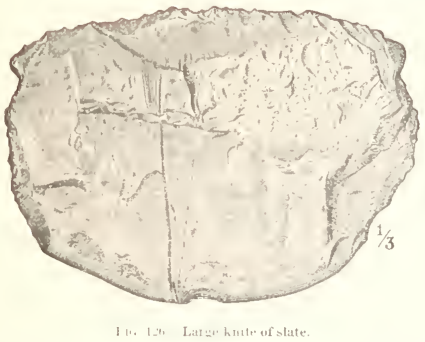

slate. The mpere there-quarters of buth tares are almost mutonehere

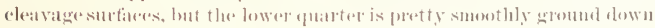
to a semieireulat eutting alge, which is somewhat nicked from nse. 


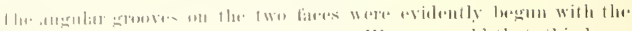

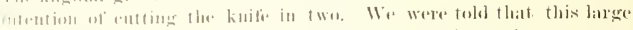

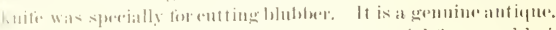

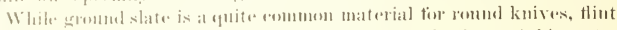

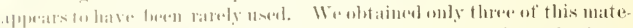

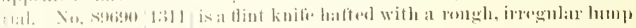

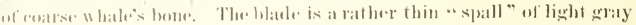

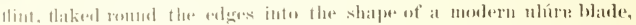

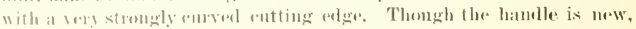

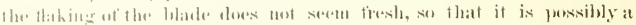
genuine old blade titted with a mew hath for the market. I similar

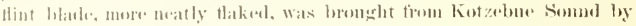

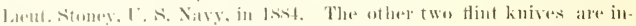

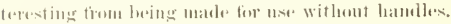

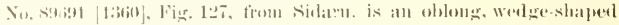

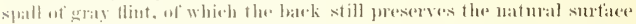

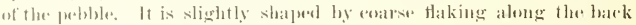

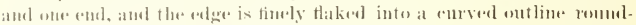
ing mp at the ands. The speceimen is old and dirty, and was pobably

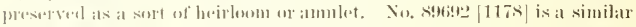

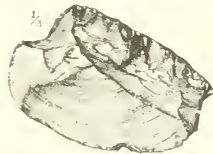

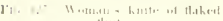
Aluit spall from a romel pelblele. Sule knives ats these are evidently the first steps in the development of the romol linite. The shatpe of the spalls, produced lis breaking a round

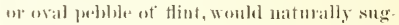
gest using the-11 as knives, and the bext step) would lo to impore the alge by thaking. The greater aldiptability of slate, from its suthess and easy cleavage, for making surh knives wonld seon lo reagunized, and we

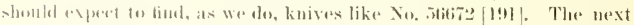

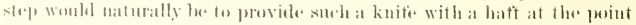

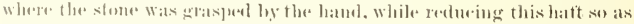

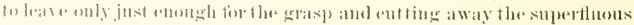

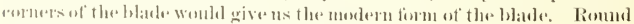

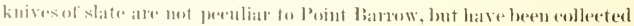

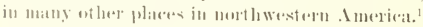

The lotationshijo between these knives and the semilumar slate blades

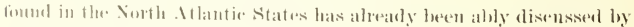

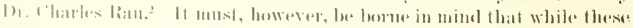

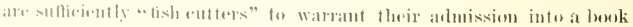
on lishing, the cutting of tish is hut a small part of the work they do.

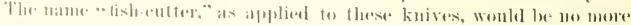

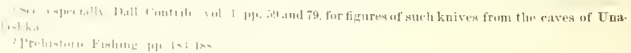




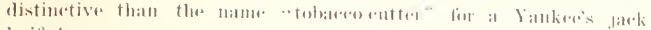
knite.'

Adzes (ullimeu). - Wven at the present day the Eskime of lonint liale.

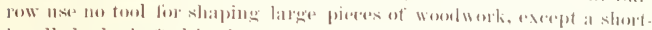

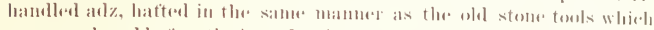

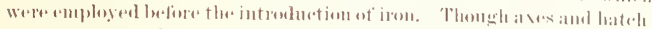

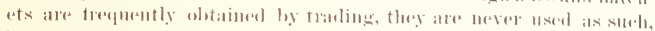

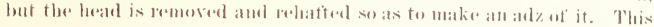

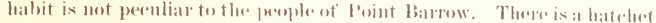

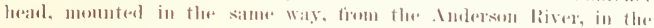

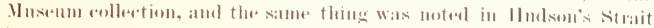

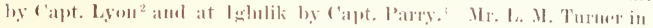

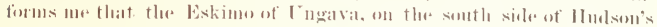

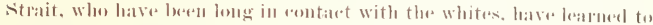

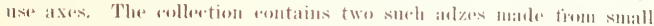

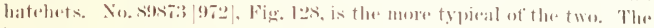
blacle is the head of a smatl lateluet of tomalnawk lashecl to the hatit of wak with a stout theng of salal hide. The lashing is ome piecen, and

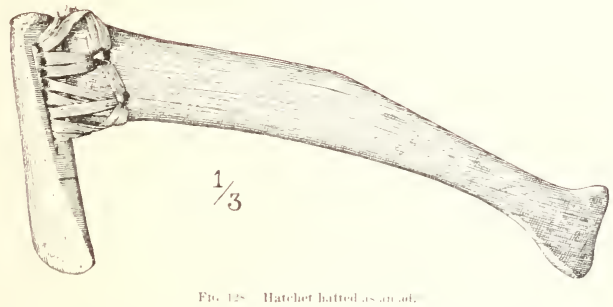

is put on wet and slumb tightly on. This tool is at littly lomger in the

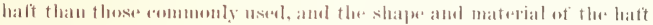

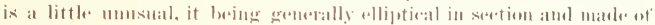
solt woesl.

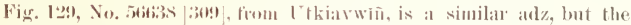
head las been narowed by contting ofì pioces tion the sides dome by tiling past way thomgh and hreaking the piece off'), and a deep trans. verse growve has lowen rat on the thont tace neal the butt. Part of the lashing is hele in this gromese as well as by the eye, the lower latt of

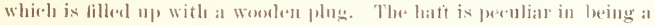

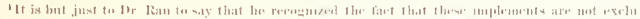

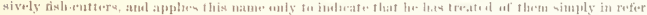

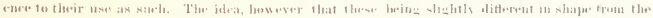

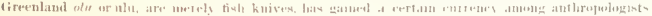
which it is desiralile to casmatelset

2.Jurnal, p, wh.

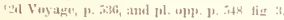




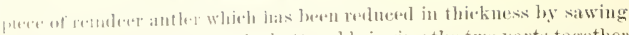
anl at sliere tins in lues from the Intt and loringing the two parts together

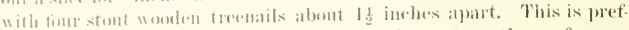

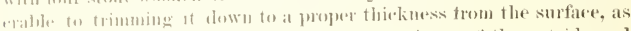

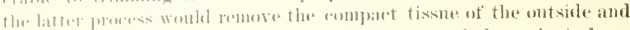

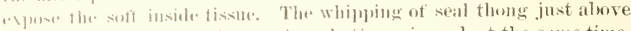

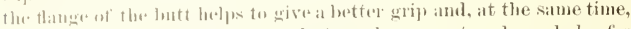
to lubl the prats tomether. Is lutire, there are two large holes for

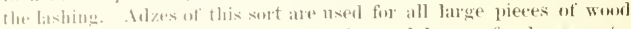

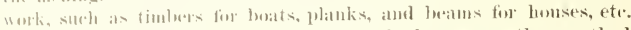

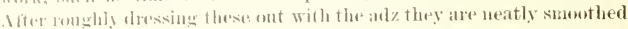
ofl witl the crenlinl knife, or sometimes, of late frars, with the plane,

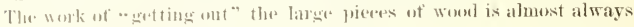
deme where the deift loge lies on the Joeach. When a man wants a new

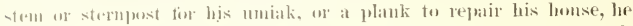

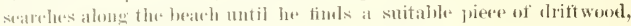

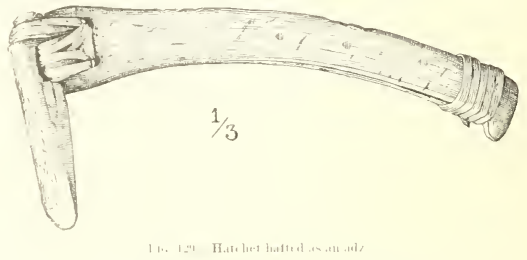

wheh le claims by putting a mark on it, and sometimes hauls up out wh the way of the waves. Therl, whem lee has lejsme to go at the work, let gurs ont with his ant and spernds the day getting it into shape and

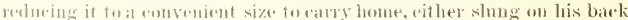

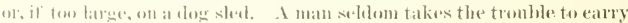

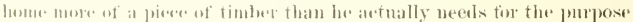
in h:1111.

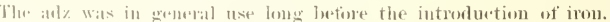

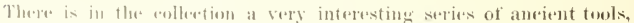

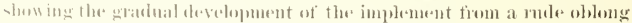

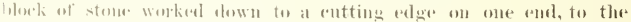

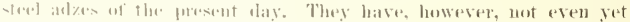

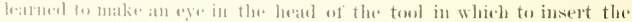

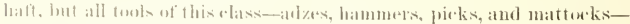

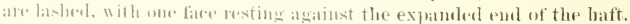

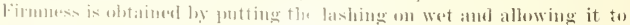

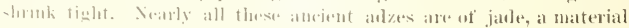

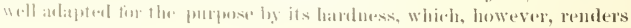




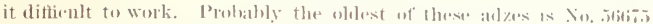

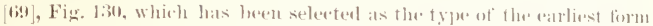
we have represented in the collowtions. This is of dark olive areen,

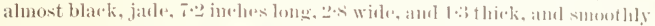

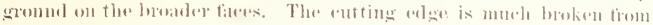

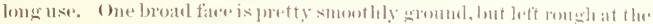
butt end. The other is rather thattere, lut more than hallof it is iresent

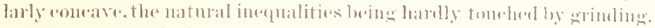

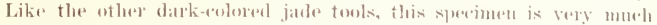

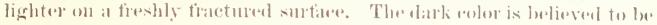

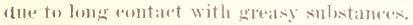

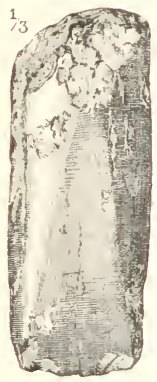

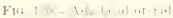

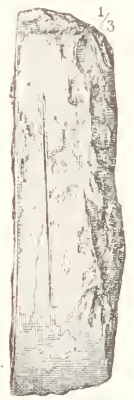

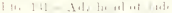

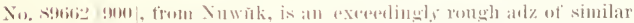

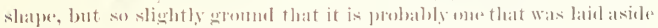

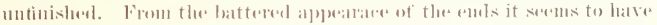

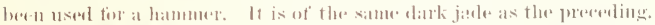

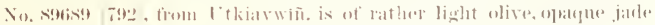

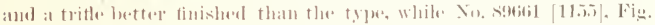

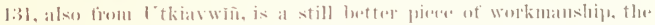

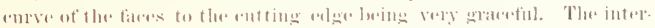
esting point albut this specimon is that a straight piese has been ent ofl trom one side by sawing down smonthly trom eath taes aluost to the

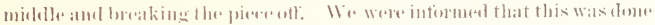

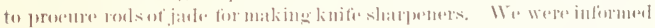
that these stomes ware ent in the same. Way ats mathe and firestome are ent with us, namely, ly sawing with a that lolale of inon and sand and water. I thin lamina of lated boure was joblably used hefore the intro-

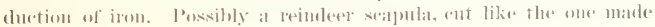




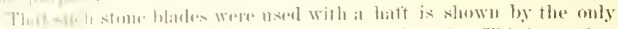

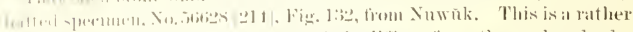

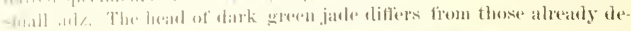

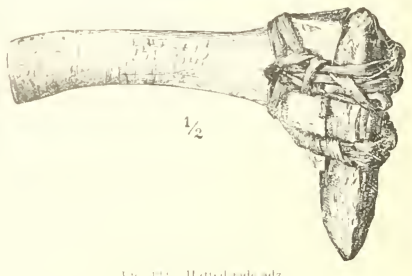

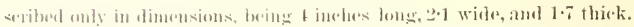

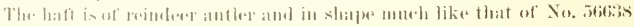

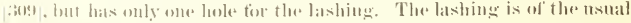

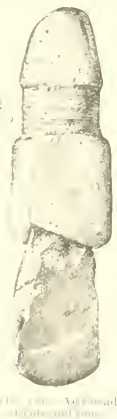

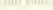

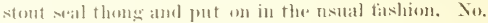

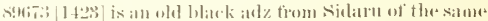
buttern as those deseribed, but very smootluly and meatly male. Ilent one-halt of this

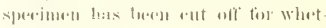
stomes, ate.

The mext stepe is to make the lashing more secolre by enting tralls.

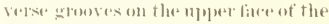
larial in lowld the thome in plates.

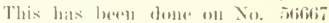

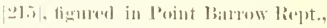

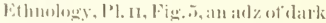
olive grente jiule, trom l'tkiarwion, whicls shuws two shel grooses, broal and shallow, rumbing areosis the Hejere liace. (1) these two elasises the collention contaims thirteen unlatitud

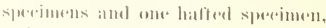

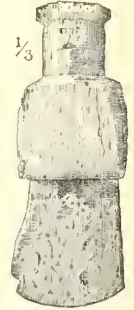

Fit, 2:4, - Allz-herul of bute and inm. with. ont eis.

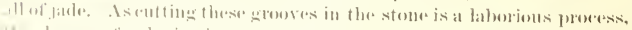

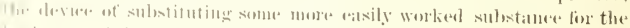

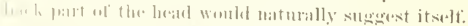

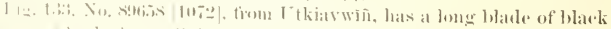

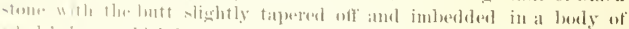

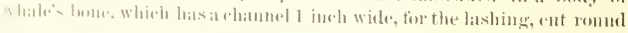




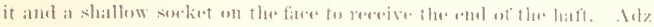

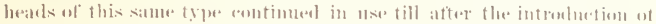

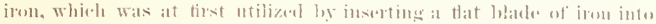

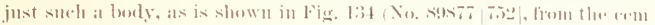
etery at L'thiarwiñ).

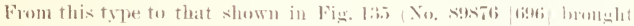

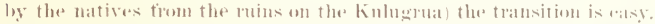

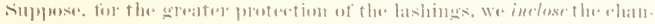

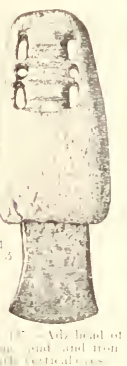
mels on the sicles of the heat - in

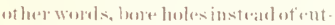
ting greoses- wat have axarty this

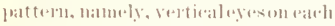
sideot the head joined hy tratusverse whanels all the mpere tites. The specimen tigmed has oneareh sidle two oblong slots with a romber eye bes tween theme. The blade is of irou,

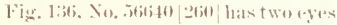
on carle side, and shows a ditterent netherl of attarehing I he hlasle, whieh

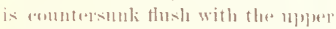

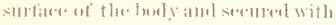
thasestent irm rivets. The nextstepe is lo sulestitute horizontal ayestenthe revtieal ones, so ats to have ouly one

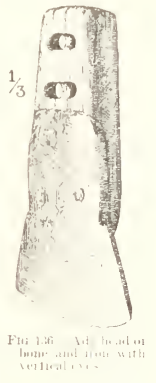

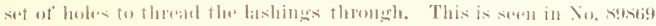

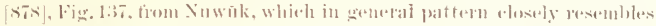

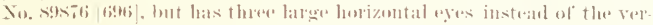
tioal ones. The barke is of irom and the hatt of whates lome. The

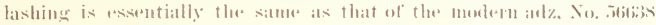
(:30:!),

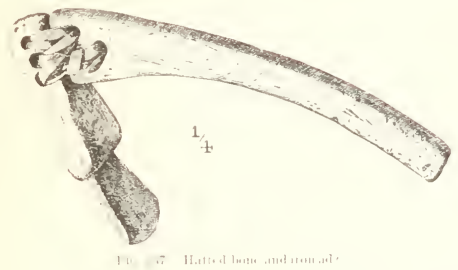

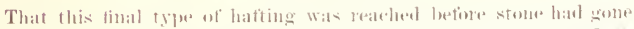

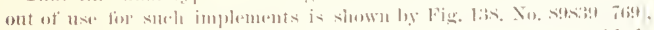

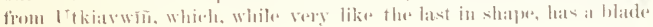




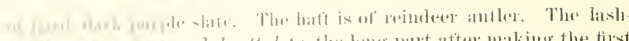

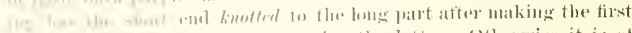

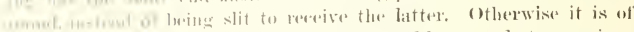

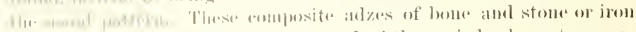

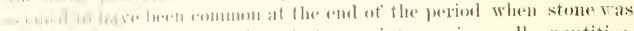

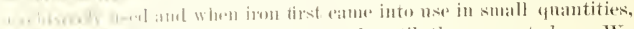

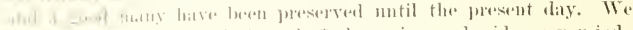

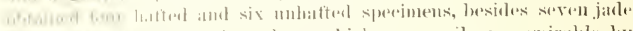

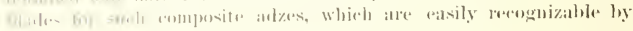

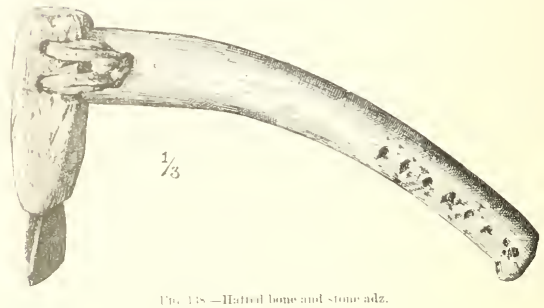

ihent shatl size and their shaje. They ane nsully boul and rather

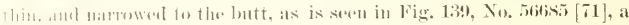

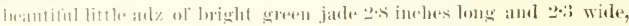

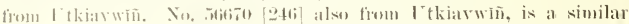

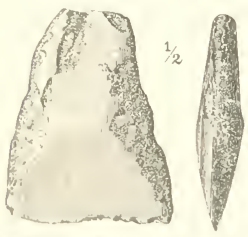
blate of ereenish jate slightly largere, being 34 inclues long and 2 inches wide.

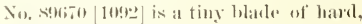

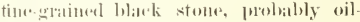
sematied jatele, only 1.7 ineles lomg and 1.5 wicle. It is velysmenthly giomul. Sueh

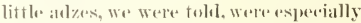
usecl tor entting bone. The imjulement, which Vimbenskjoild ealls a " st one nhisel," fomm in the ruins of an old Es kimulutse at a ape North, isevitently the

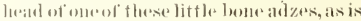

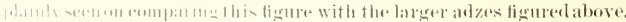

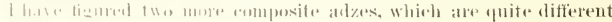

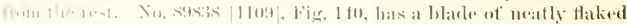

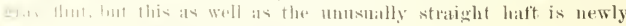


mate. These are fittal to a vary ohl lome bouly, which when whole

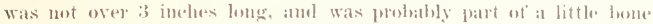

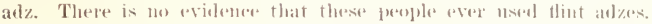

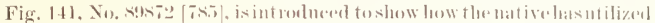

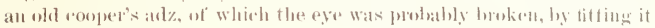
with a bone borly.

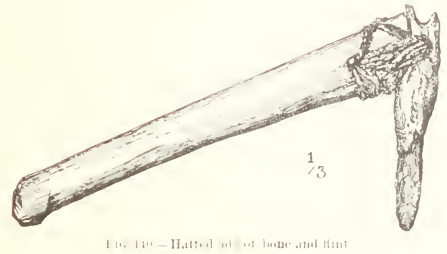

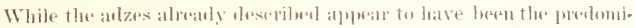

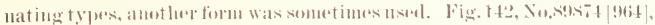

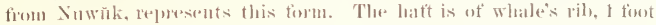

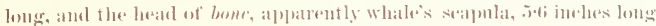

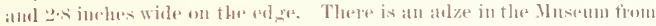

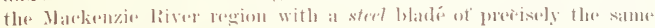
pattern. That al\%es of this patteril sometimes laat stome blates is

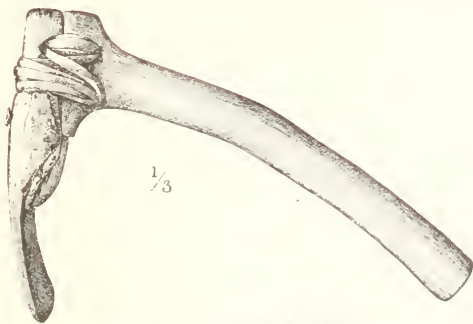

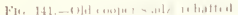

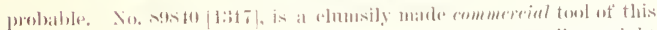
typer, with a small heal of greenisl slate. It has an unusually straight hatt, which is alisponertionately longe and thick.

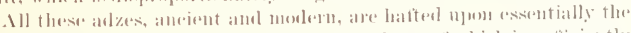

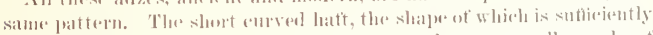

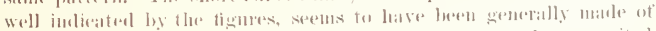

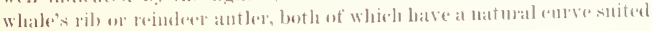




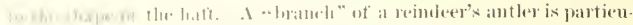

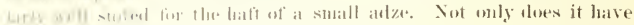

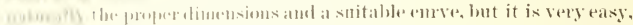

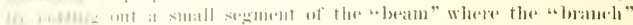

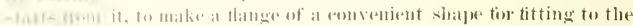

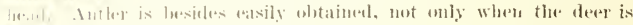

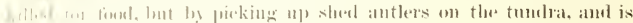

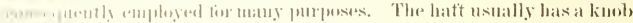

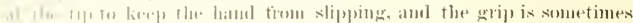

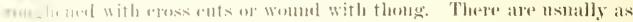

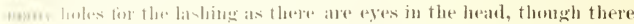

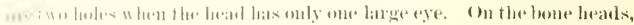

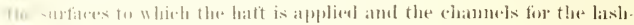

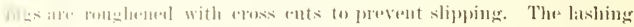

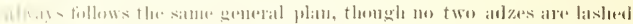

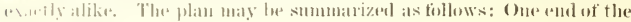

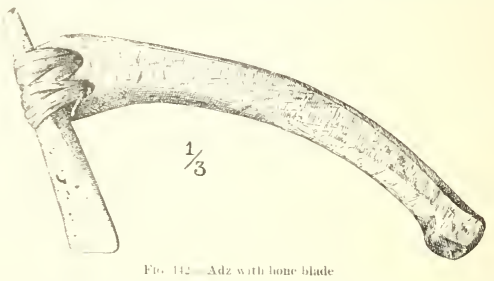

Honce anakes at turn thomgle one of the holes in the hatt, and aromel or foromgh the heal. This turn is them somed, usinally by passing the forge and througle a slit in the sluent and amel hanling this loop taut, sometimes by kuntling the shert ame to the lomg part, or by eatehing the slent and down moler the next tom. The long part then makes

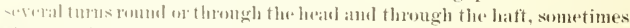

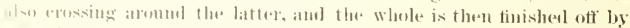

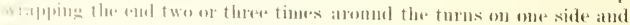

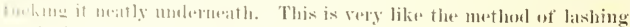

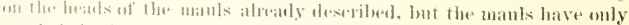

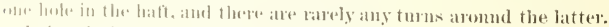

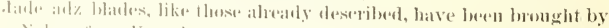

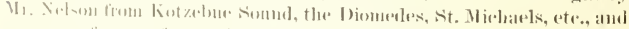

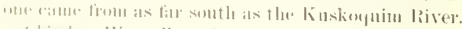

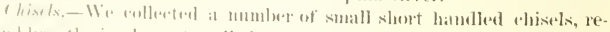

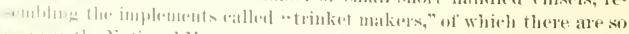

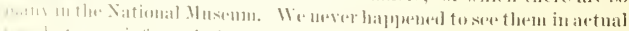
45.) hut were intenmed that they were especially designed tor working 


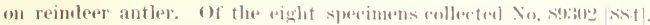

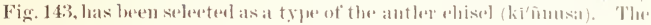

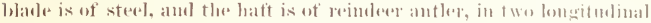
sections, put together at right angles to the plane of the blakle, lachl

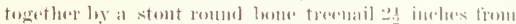

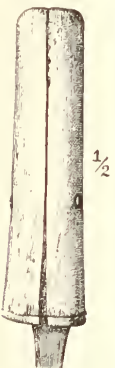

Fici 143. Antler i hise. I.

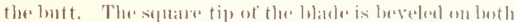

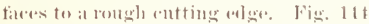
(No. s!)301) [ [0001 hats a small b]atle witl an obligue tip not beveled to all mlere. and a hatt of walrusivory yellowerl from age, and ormanemeted witl rows of lings, rach with a dot in the renter, all inciserl and rolored with red ocher. The two parts of the hatt ane thestemed togerther by a stemt waslent treenailand at stiteh of whalelume.

The rest of the sterel-hatiol rhisels, four in number, alle all of alumet the silme sime alud hatteit with antler. The b]:mles are somerolut irregular in shape, lut all have squate of oblique tips ante no shate relge. There of them have

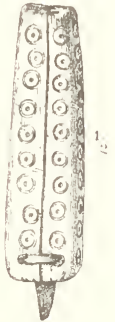

Fui $144-$ A witlor

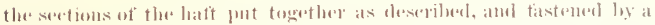
treenal atud a whippring of soal twine or sinew habl at the tip. One has the two seretions put together in the plane of the lalade and fastened

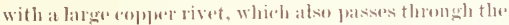
loutt of the blawle, ant there stont iron ours. The hatts of all these touls show signs of mueh hambling. Thr remaining two spereimms have blatesof blark tlint. Xo. s!n:37 $|1 \geq 07|$, has a hatt of walrus ivory, of the ustal fattern, fastemed togethere by a lome tremat and two

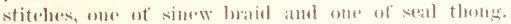
The lashing of seal twine neat the tip serves to ment a crack. The latit is old and losty about the slot into which the blate is fitterl, showing that it urigiually

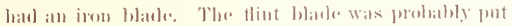
in to make it seem anciont, as there was a spereial

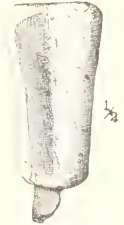

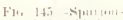
twel flont lifinl.

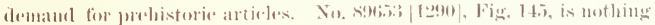
but a fanciful tool marle to meet this demand. The latt is of light-

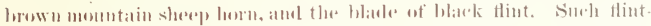

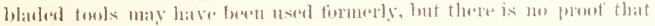
they were.

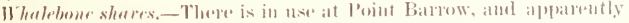

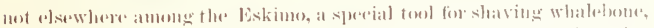
a sulstane which is rery umele used in the torm ot long, thin strips for fastering together boat timbers, whipping spear shatts, etes The 


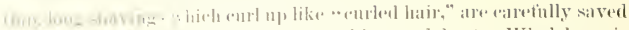

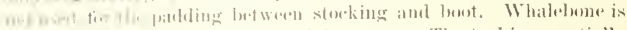

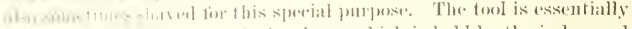

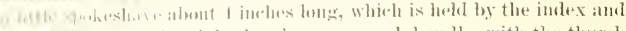

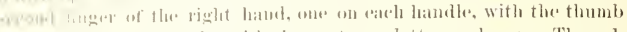

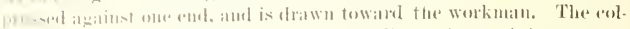

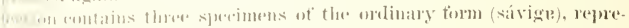
-

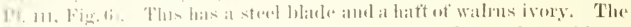

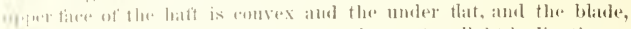

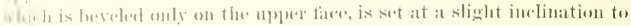

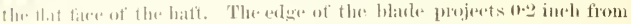

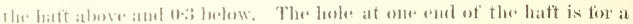

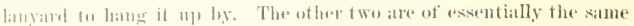

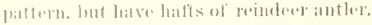

The (a)llection also contains six took of thix deseription, with stone

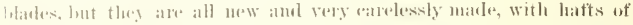

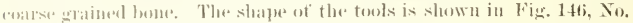

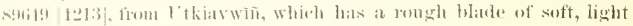

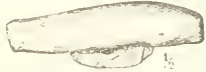

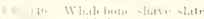
i.tide. greansh slate. The of her five bave blades of black or graty thint, roughly thaked. All these litades are glued in with oil dregs. No. s965" lo:-5 is like the oflers in slatum, but more neatly male, and is prosuliar in having a blate

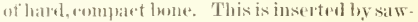

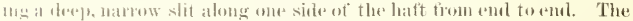

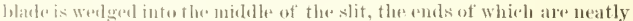
fillect in with slips of the silme material as the haft. This was the only

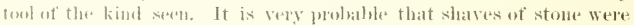

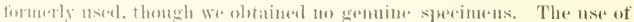

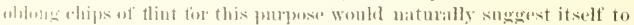
at savages, and the eomventenere of titting these Hakes inte a little hatt

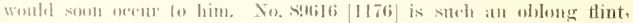

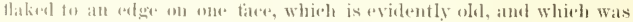

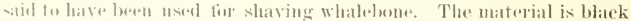
that. Whaldugne is often shaved nowalays with a common knite. The stal, of lone is baid upon the thigh and the erlge of the knifie pressed

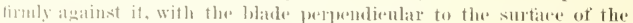
stald, which is drawn rapidly under it.

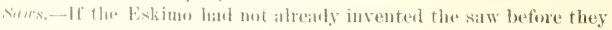

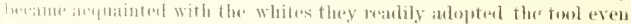

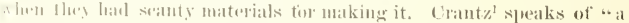
little lork sall" ats one of a Cireenhander's regular tools in his time, and

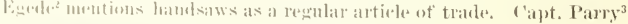

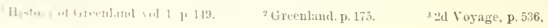




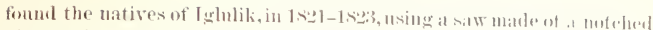

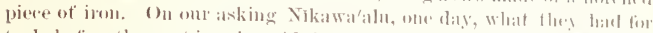

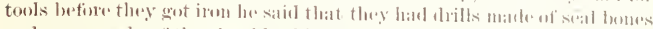

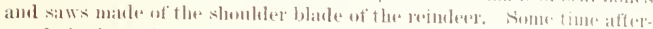
wath he bought over a morlel of sile b a saw, which lee saicl was ex. artly like those tion. merly userl. Fig. 147 ,

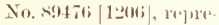
sentstlis specimen. It

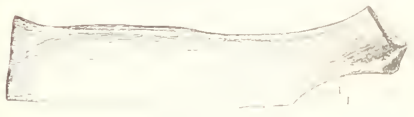

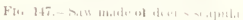

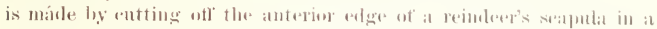
straight line parallel to the pusterior edge and entting fime silw tereth on this thin wege. The spine is also ent wef mealy Hat. This makes at tool rery mulh like a rarpenter's batksiw, the namow patrt of the

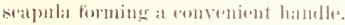

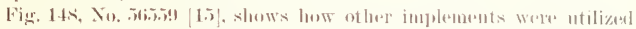

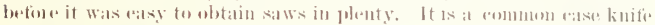

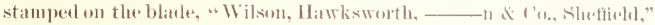

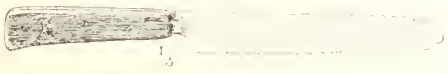

Fig. 148, Silw made of a casc-kunfe. whith jurluajes rame. from the Plorer, with salw treetlo tont an the [alge. It was piekied 11) at the 1'tkiarwĩn rometery, whem it

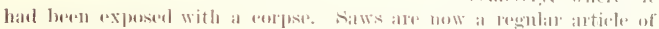

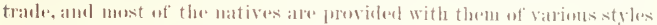
amel makes. T'le mame tor salw is mhat ktum.

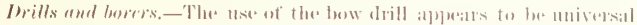
amonge the Eskinm. Those at present amploged at l'oint barrow do

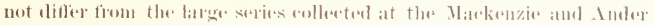

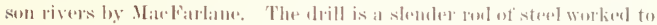
a drill point and imbelded in a stont worlen shatt, which is tapeered to

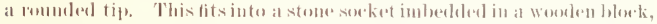

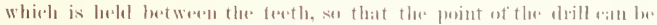

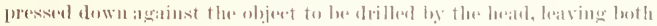

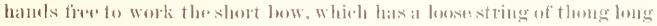

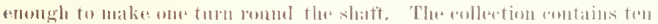

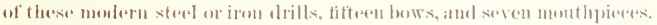

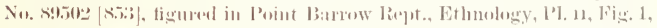

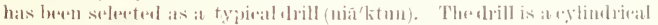
roul of steed beaten wat into at small latmetolate print, which is filed

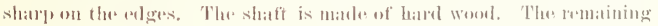
drills are of essentially the same pattern, varyime in total 'ength firm about 11 inches to itis.

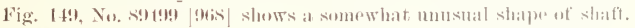
The lashings round the large end are to keep it from splittiug any more 


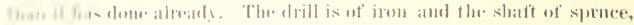

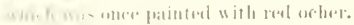

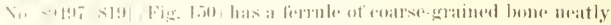

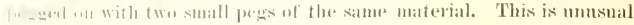
with stow diells. The shalt is af

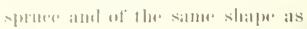
in the precelling squeimen. No. (4) slum the was in which the shatt

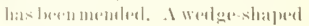

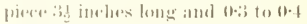

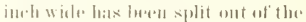
large roul and replacesl by a firsh

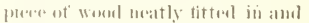
scrurel ly two tight whipjings at

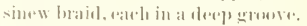

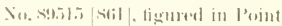
liartew lixport, Etlmology, I'l, II, Fige "2, is a typieal low (proiksua) for use wath these aldills. It is of wallews isory, lli inelues long and

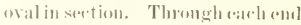
is alrilled a transirerse lowe. . I

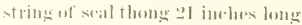
is lewperi into one of these holes ly passing one and of the thume thumgh the hole, coutting at slit in it. :und passing the other and through this. The uther end is

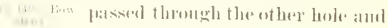
kilotted at the tij).

These bows vary slightly in dimensions, but

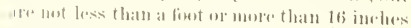

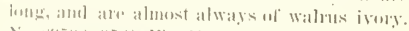

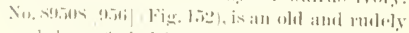
makle bue at whalebene, which is nowe strongly molech that ustat, and has the string attar.hed (1) metelues at the emols insteiul ot into looles.

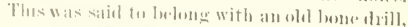

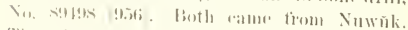

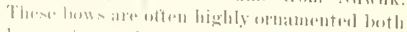

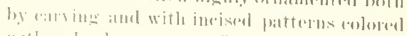

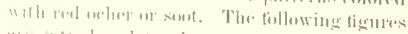
atre introlumed to shem some of the diffierent

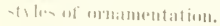
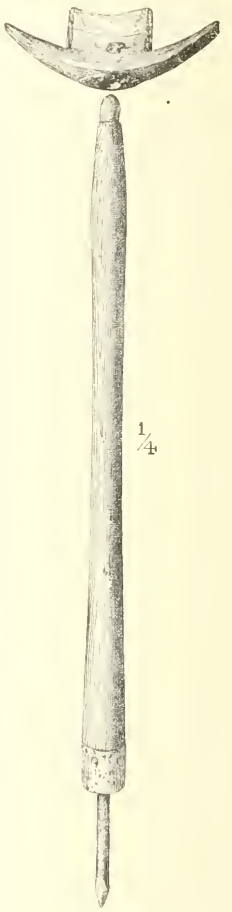

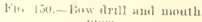
puses.

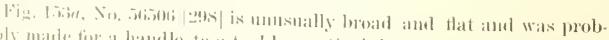

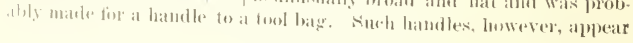




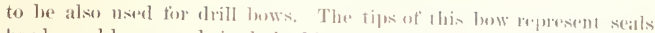

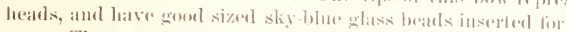

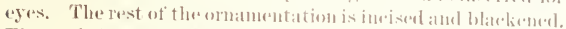

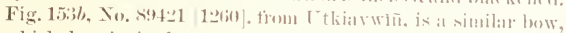
which has incised on the batele figmes of ment and animals,

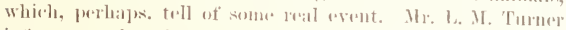

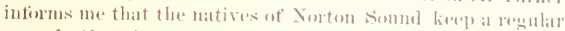

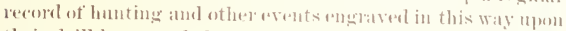
their drill bows, and that no one wrep ventures to talsity these

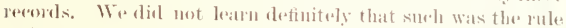

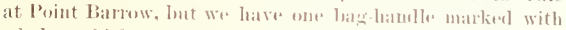
whales, which wo were tohl indieated the number killed ly

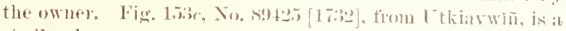
similar low, ormanented on the lowk with simply an incised bolder colored red. On the other side are the figures of ten

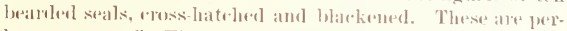

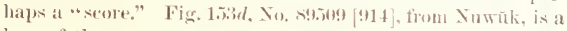
bow of the common pattern, but oruamented by carving the barek into a towthed keel.

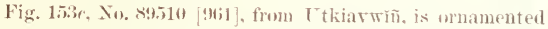
on one side only with an incisend pattern, whish is blatededed.

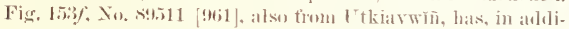
tion to the incised and blackened pattern, a suall transparent sky-blue glass beal inlaid in the midlle ot the lack. Fig.

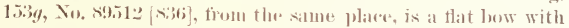

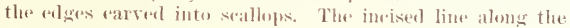
midelle of the batek is rolored with renl oreher. The string is made of simew braid.

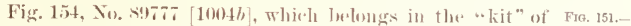

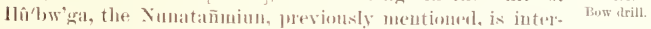
esting from having lexen lenethened 3 t inclese by riveting on a piece ot reinderer antler at one end. The two pieces ate neatly joined in a "lape spliece" alone 2 inclaes longe and tastened with there iron rivets. The owner appears to have conclumed that his drill bow was too short when

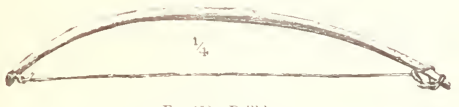

he was at home, in the intrior, where he eonld obtain no walms ivory.

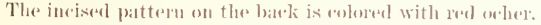

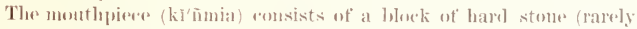

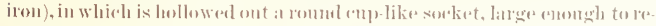

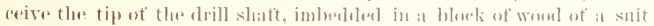
able size to hold between the teeth. This block often has curvect Hanges 9 ЕТН-12 


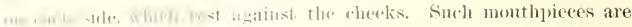

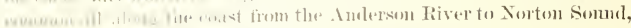

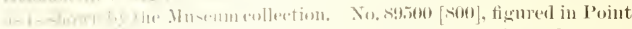

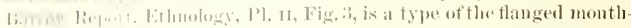

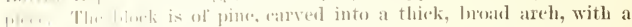

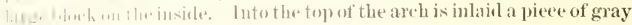

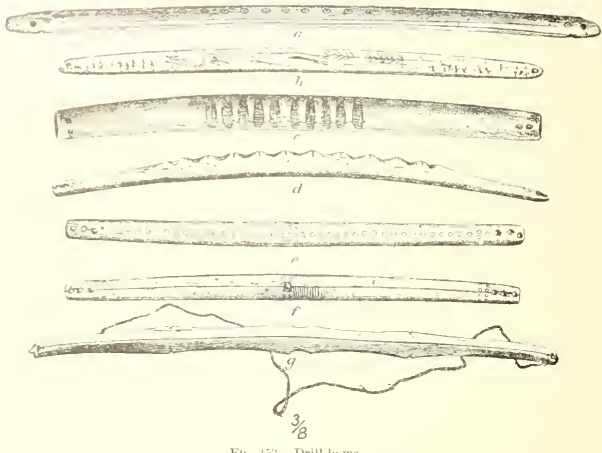

Fitr 1:i:-Drill lowa.

porphyry with black sjots, which is slightly eonvex on the surface, so as

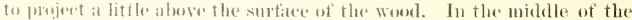

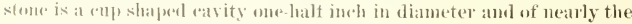
same dopth. This is at rather latge monthpiece, bejug 6 inches across from one end of the ale to the ofhes.

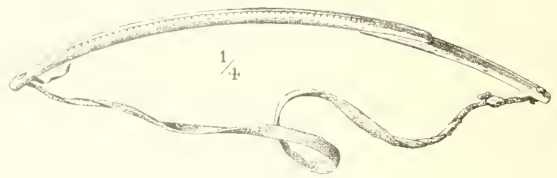

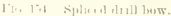

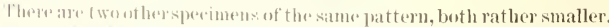

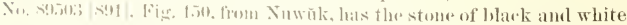

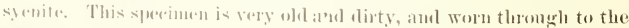

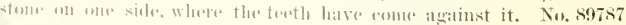
fould Fig, lin, is almost exatety the same shipe as the type, but has 
for a socket a piose of iron 1.1 ineles sipuare. hollewed out as msual.

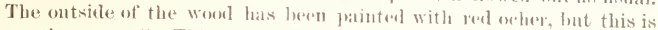
mostly worn off. This montlipiere helongerl to llit'bw'gal.

Fig. 156, No.8950.5 [ $(x)^{2}=$, from Ctkiawñ̄, represents the pattern which is perhaps rather conmoner than the preceling. The wood, which lobls the sereket of black and white. syenite, is simply an ellutical block of spmue. The remain-

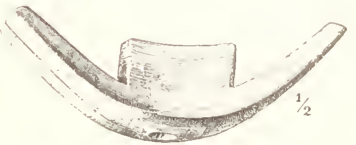

Fig, 155-Thill tumthpiese, with iron sochet.

ing three speeimens are of the same patteru and of the same material as

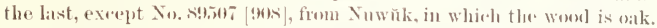
As it appeas very old, this worl may have come form the Plocer.

When mot in use, the pont of the chill is semetimes protesest with a sheath. One such sleath was obtainel, No. s9447 [1112], tigured in Point Barrow Report, Etbmology, l'l. If, Fig. 1. It is of wallus ivory, $3 \cdot 6$ inelue long. The end of a pioce of thomg is pasied through the eye and the other part fostened romed the open end with a marline hiteh, watehing down the ent. This leaves a lanyard ge inclees long, whinle is hiteled or knotted round the shatt of the drill when the sleath is fitted over the point.

The drills above dexweribed are ased for perforating all sorts of material, woxl, boue, ivory, metal, ets., atud ale almost the

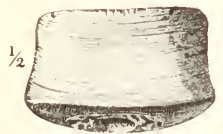

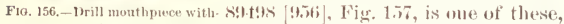
out wintry. awls being unmsual. betore the introduetion of irou, the point was made of one of the smatl boures from a satal's 1 ,

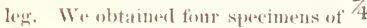
these lene drills, of whith two, at least, alpeatr to be gennine. No. only boring implements used, even from Nuwak. The shat is of the ordenary pattern and made of some hard wood, lust the point is a roughly eyliudrieal roul of bour, expanding at the point,

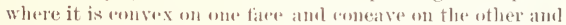
beveled on luth tians into two intting alders, which meet in an arete angle. The lareger end of the shaft has been split and mended by whipping it for alout there-quarters of an inclo with sinew luatel. No, s!lits $[1174]$, is aplanently also genuine, atud is like the preeceding, but bereled only on the

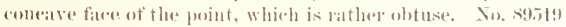

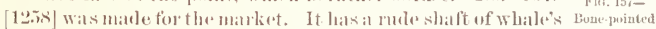

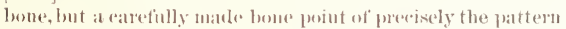

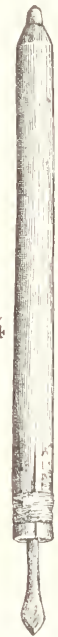

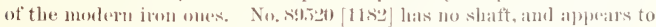
be all old untinished drill fitted into a earelexsly made bone ferrule. 


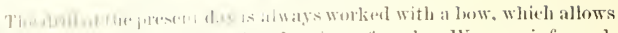

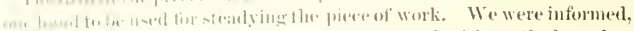

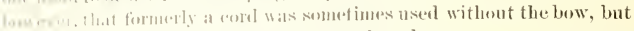

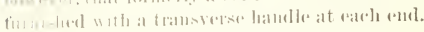

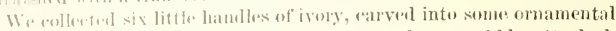

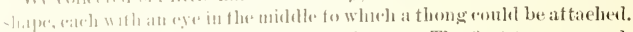

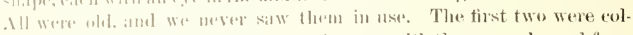

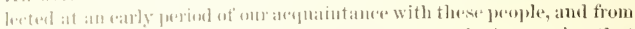

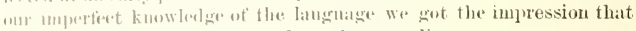

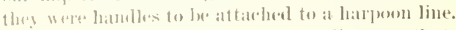

Wo were not long, lowwerer in finding out that fhe harpoon has no such apjemlage, and when the of here four eame in a year later, at a time

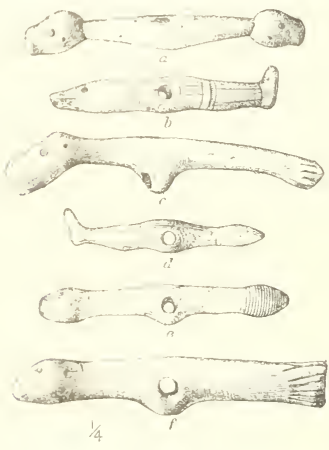

Fit, 158, Il:inullew for dill corals when the presis of other work prevented rareful infuiry into their use, we supposmd that they were neant for hambles to the linesused for dragging deat seals, as they somethat resemble sneh an imphoment. On our return home, wlen I had olportunities for making a carreful stuly of the colleetion, I foumd that none of the drag lines, rither in our own collection or in those of the Museum, hat hambles of this description. On the other hanel, I fommel many similar implements in Mr. Nelsou's collertion labeded "drill-cord hamdles," and finally one pair (No. 36319, from Kashunuk, near Cape limmanzoff), still attached to the drill word. Theses handles are almost identical in shaje with No.

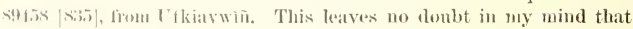
I he so callet "dlag linc hamdles" in our colleetion ane wothing more than

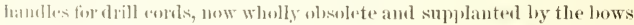
alrauly described. I have figmed all six of these hambles to show the

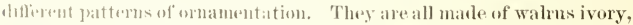

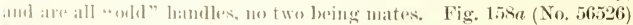

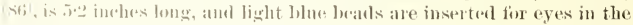

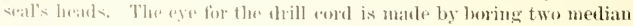
holes at the midhlle of whe side so that they meet under the surface and malke a lomgitudimal rhatum,

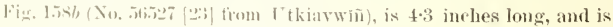

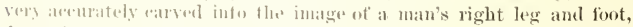

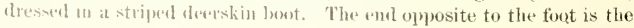


heal of some animal, perlaps a wolf, with lits of dark wool inlatid for eyes. The eye is a simple large transwerse hole thengh the thigh.

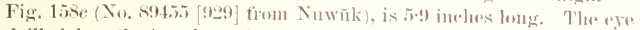
is drilled lengthwise throngh a large hump projereting firm tha middit. of one side. Small bhe beads ate inlaid for the eyos, and one fo imdi. cate the male ganital orening.

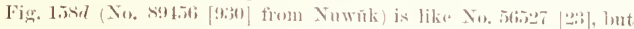
represents the left foot and is uot so artistically carved. It is :3. 6 ine hes long.

Fig. 15se (No. S9457 [925] from Nuwnk) is 4.7 inches long, and re.

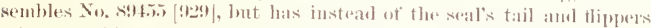
a large ovoid knol, ormamented with incised and blackened rings. The "eye" is bored tramstrersely.

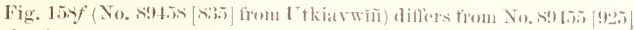
in having a transverse eye, and heing less artistically "arvod. litis of lead are inlaid for the eres. It is 4.4 inches long. The names of this implement is kin'ñ.j.

We ohtained six specimens of an old flint toml, consisting of at ratler long thick blade momed in a straight latt alwout 10 inches long,of which we had some difionlty in ascertaining the use. We were at last able to be quite sure that they were intended for drilling, or rather reaming out, the large cavity in the base of the ivory beat of a whald barpen, whieh fits upen the conieal tip of the fore-shatt. The shape of the blade is well titted tor this purqose. It is not mulikely that such tools, worked as these are, by hand, preseded the bone drills tor boring all sorts of objects, and that the hathit of msing them tor making the whale hatpon was kept up firm the same conservatism fommler on superstition which smrommls the whole whale tishery. (See muley "Whale tishing," where the sulgjaet will be more tiully discussed.) No.

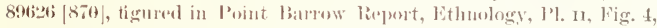
is a typical implement of this class (itam, i'tingetsan'). The blacte is

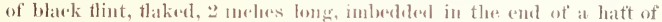

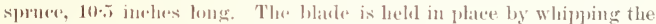
cheft end of the haft wath sinew lorad.

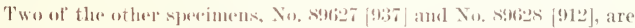
of exsentially the same patter'u and material, but have romeded hatits.

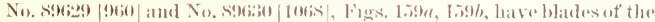

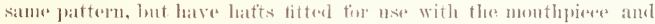
bow, showing that sometimes, at least in later times, these tools wore so

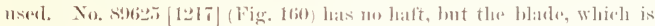

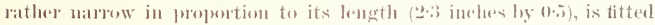
into a short ferruleof antler, with a little dovetail on the edge tor attaching it to the hatt.

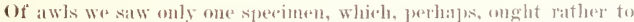

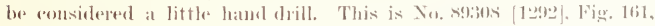
fon l'tkiavwin. The point is the tip of a common threeseruerest file, 


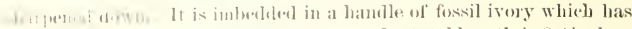

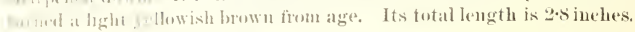

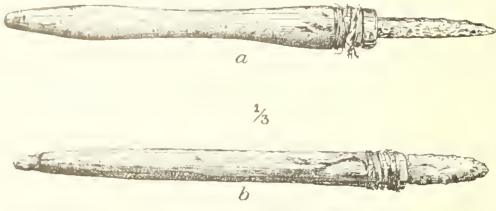

Fir, 139,-Flint-blade il reamet

It ummers.-. It the present day nearly every man has been able to procure an iron latmmere of some kind, which he nses with great handiness. lisefore the intrerluetion ol iron, in addition to the bone ant stone mank alowe described als bone comshers, mhafted gebbles of eonvenient shape were also employed. No. be66r1 [27t] is such a stone. It

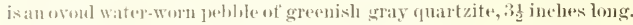
The onds are battreml, showing how it had been used. It was bromght from one of the rivers in the interior by one of the matives of Ctkiar. พักิก.

Files. Files of all kinds ar. cagerly somght after by the natives, who use them with very great skill and patienes, doing nealy all their

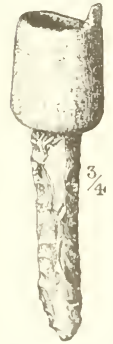

Fi. Itil Fhut

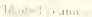

\section{the gun.} metal work with these tools. For instance, one partienlarly ingenions native eonverted his Winchester rifle liom a rim fire to al central fire with notling hut a file. To (1) this he had to make a new firing pin, as the tiring pin of the rim-tire gnn is too slort to reath the lead of the "antritge. He aceomplished this by ateduratelyentting off, (1) the propere length, an old worn-out theeromerest file. He then filed off enomegh of eatefordge so that the rod fitted "venly in the "glindrial hole where the tiring pin works. The work was done so carefilly that the new firing pin worlied perfectly, and lor hat only to romplete the job by rutting off' his central fire eartridge shells (1) at proper length to fit the chamber of

They have ahmost no know ledge of working metal with the aid of heat, as is matural from the seareity of fuel.

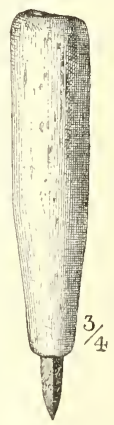
Fig, 161.-A wl. I have, howerer, secen them romglily temper small artieles, such as fire sterk, ete., by heating them in the fire and guenching them in cold 


$$
\text { thi }
$$




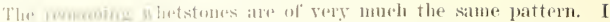

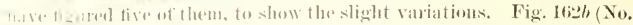

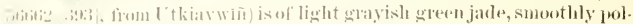
What and f.l inclese long. It is chambered only on the small end at

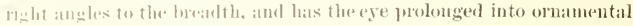

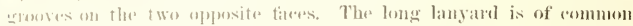

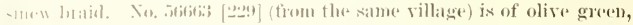

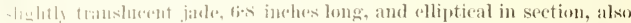
chamtereatonty at the suall mal. The lanyard, which is a strip of seal

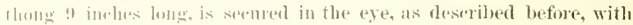
(wo slits, one in the standing part thongh which the end is passed and the other in the and with the standing jout passed floromgh it.

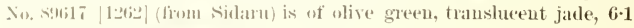
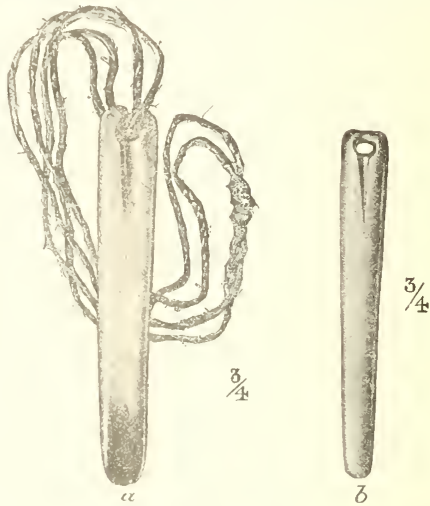

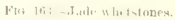

inches longe and shaped like the type, lut thamfered only at the small

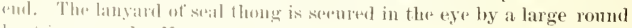

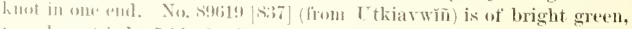

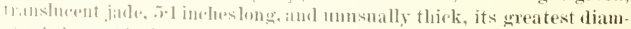

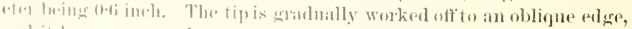

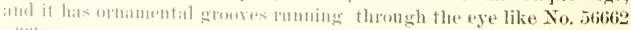
(1):3.

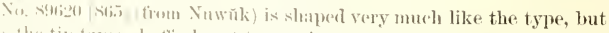

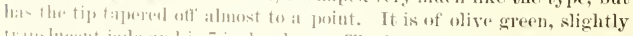

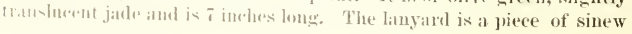


braid with the ends knottert together atud the hight looped molo the are. A large sky-blue glass beal is slipped on wor both partsof the lanyout

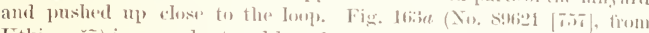

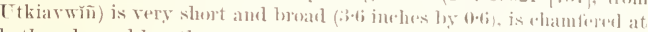
both ends, and has the ormamental gromese at the eye. The material is a hark, opatene, bluish graty stome, veimet with hlack.

A whetstone of similar material was bromght hy Lient. Sitoney from

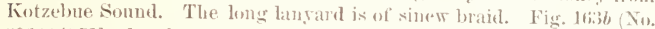
satiz [!51], also from Ttkiarwini) is a very small, slender whetstone, 3:3 ineles Jong, of dark olive green semitransluerent jade, prolished. The tip is not ehamtered, but tapers to a bhut point. It has the ormamental grooves at the exe. These are mithnhtrilly the "stontes for making . . whetstomes, or these ready-mate" reforred to by I)r. Simposon (Op. cit., 1. 266) as brought by the Nunatanumum from the people of

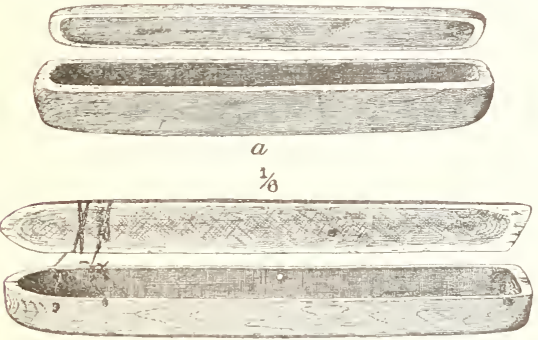

Fig. 164.-Worlen temil hoxes.

the "Ko-Wak liver." I few such whelstones have been eollerted on other parts of the northwest const as far sonth as the northern shore of Norton somul. The broken wlectstone: mentioned above is of a

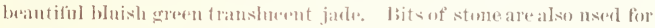

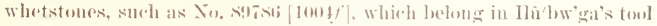
bag. They are two romgh, whomg bits of harel riark gray slate, apparently split ofl a that, wathered surfaure.

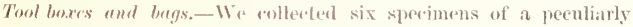
shajed long, narrow bex, wared from a single bleck of wood, wheh we were informed were formerly nsed for heloling tools. They have gone out of fishiom at the present lays, and there are lont tew of them left.

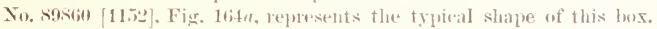
It is earved from a singhe block of pine. The onere is slightly hollowed on the muler side and is held on hy two donhle rings of twine cone of seal twine and the other of sinew braid), large enongh to slip orer the 


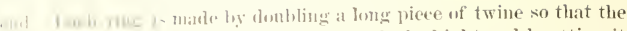

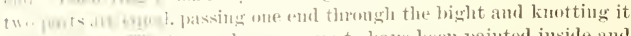
to th. whlo: The lus and eorer seem to have been painted inside and

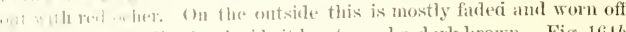

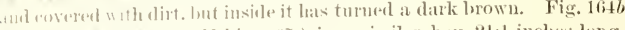

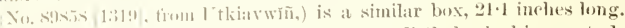

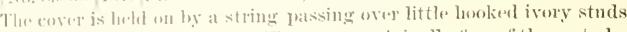

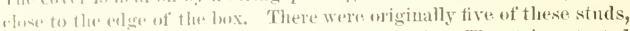
two at carch end and one in the midhle of one side. The string started from ome of these studs at the printed enul. This stud is broken and the string fastened into a bole rose to it. To fasten on the cover the string was atried orer and hooked under the opposite stud, then crosided orer the coscre to the middle stud, then across to the end stad on the other side, and the lingy on the end hoeked onto the last stud.

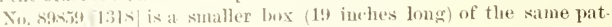
teru, with only fom stmds. The eover has thee large blue glass beads,
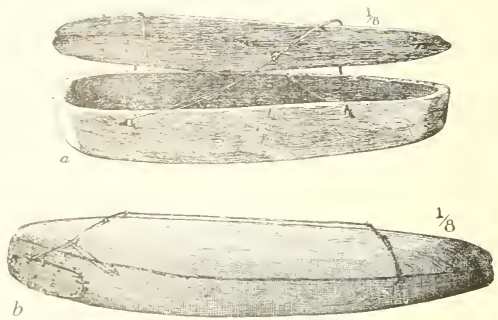

Fig. 165.-Litrge wouden toul boxes.

like those used for labrets, inlatid in a line along the midale. No. 89858 [1111], from l'tkiavwion, is the shate of the type, but has a thisker cover and six stmb lubles in the margin. No. s!s61 [1151], Fig. 165a, firm the same plare, is slaped something like a violin case, 22.2 inehes long. The cover has bern split and "stitehed" together with whale-

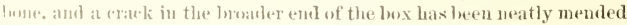
1.y proging on, with nine little worden treenails, a strap of reindeer malle of the same width as the edge and following the curve of its withese. There are four studs, two at each end. The string is made

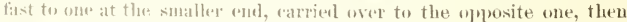

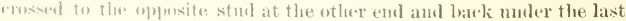
wie, at hight of the ond being tured under thes string between the two last mantionet stmk. The string is makle of sinew braid, rope-yarns, and at long piene of seal thoug. It was probably at first all of sinew 
braid, and, gradually growing too short by lwing hroken and linotted together again, was lengthenest ont with whatever eame to hanel.

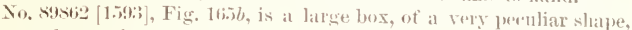
best understorel from the figure. The outsils is mur. we wathered, but appears to have been ronghly earved, and the excavation of the lox and cover is very rudely done, perhaps with a stone tool. I hole in the larger end is mended by a patch of worl chamfered off' to fit the hole and sewed on romind the elges with "over-aud-over" stitelles of whale. bone. The string is arranged in permanent loops, under which the cover can be slipped offi and on.

The arrangement, which is ratlere complicated, is as follows: On one side of the box, one-half inch from the eder and abont 7 inches from each ent, are two pairs of loles, one-half inch apart. Into each pair is fistrened, by means of knots on the inside, a looj of very stout sinew bratil, 3 inches long, and similar loops of seal thung, 5 inches long, are

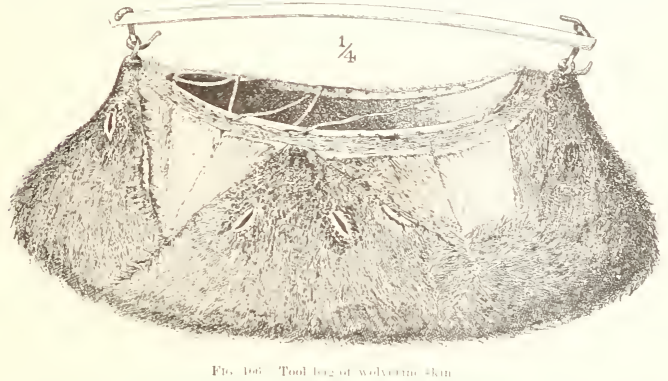

fastened into corresponding pains of hols's on the other side. A piece of seal thomg is fastemed with a leecket-hitell into the loop of seal thong at the small end of the lux, pasies thromgh both braid loops on the other side, and is ravied over throngh the loop of seal thong at the large (nol. The ent of the thomg is knotted into one of the patirs of holes left ly the loraking away of a stitele at the relge of the wooden patelo above ment ionesl.

All these lowes are very old and wore paintes inside with red oxher, which las turued dark brown from age. Tools are mowadiys liept in a large oblong, flat satehel, ikguxhwiñ, which lats an awehed handle of ivory or bone stretched lengthwise aross the open month. These hags are alwaty made of skin with the hate ont, and the skins of wolverines?

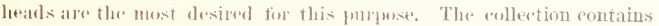

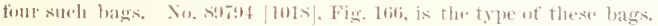
The bottom of the bag is a pree of short-haireel brown deerskin, with 


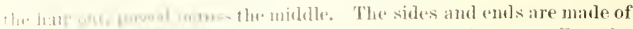

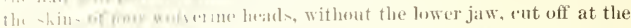

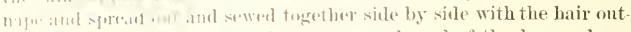

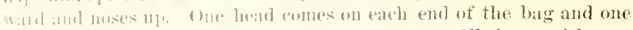

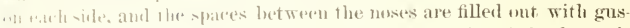
an wherstin and wotverine skin. A narrow strip of the latter is semel romud the month of the hag. The lande is of walros ivory, $14 \frac{1}{2}$

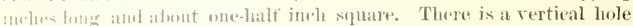

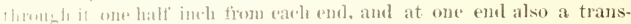

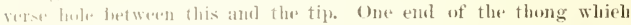
fisten- the hanulle to the hage is drawn throngh this loble and cut off rlose to the surfiate. The other and is brought over the handle aud down through the watical loole and made fast with two half-hitches into at hole through the soptum of the mose ol' the head at one end of the bag. The other ent of the hamble is fastemed to the opposite nose in the same Way, but the theng is seroured in the lote ly a simple kuot in the end

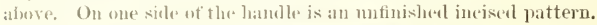

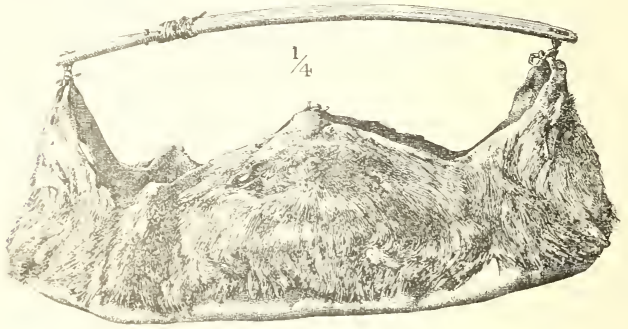

Fi. int-Toul tag ot wolverine akin.

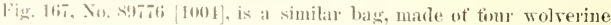

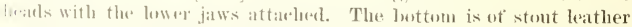

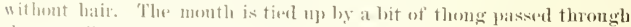

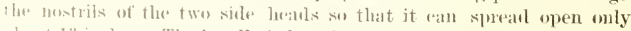

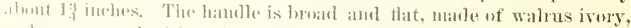

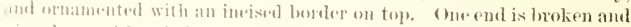

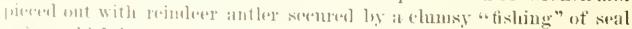

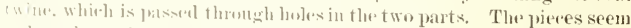

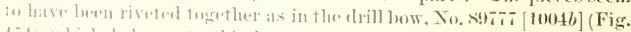
1.it. Wheth belonges to this bag. There is a rivot still sticking in the mather. It is jessibue that the ivery may lave broken in the proess of

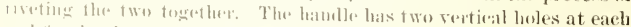
chat tor the thomg. by which it is tistenul to the and noses, both in the 
median line and joined by a short ahamel on top of the hamble. This

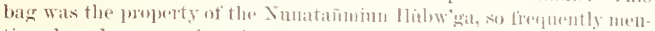
tioned, and was purehased with all its esntents.

These are two bow drills, me large and one small (Figs. llise and losis,

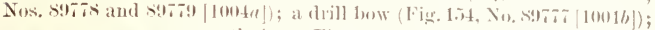

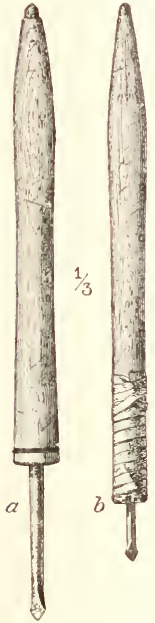

Fis, 16R,-Trills belong. ing to tbetoot bag.

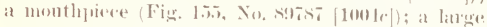

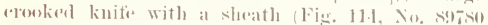

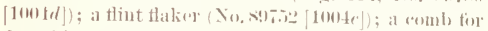

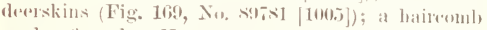
marle of antler (No. sto-sis $[1006]$ ); at fishluook (No.

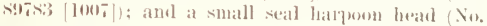

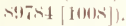

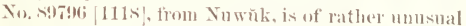
matrials. The bottem is of lowwn reindere skin and the sides and ends

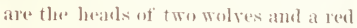
fox. The wolf beals meet on whe sible, and the for lested is put in between them on the ofleer. The tox head has no lower jaw, and one wolt loat bas only the left half of the lower jaw. The vateant spates aromed the momth ate fillot ly triangular gnssets of wolt and reindere skin. The ereboles ane

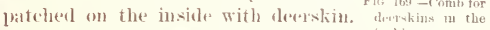

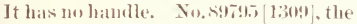

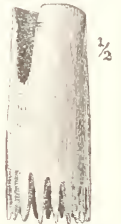
remainug bag, is of the msual jattern, but carelessly mad. of small pieses of deerskin, with a hamdle of coarse grained whale's boue. It was probably made for sale.

I have figured four hautles of such bags to show the style of ornamentation. Fig. 17the (No. 89420 [1111], from Nuwnk) has incised figmes of men ant reindere on the bark, onesendored with order, of which traees ean still be seen. This is per haps a lemuting seore. (Nee rematks

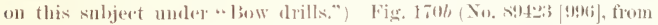

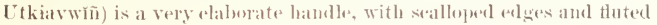
batek, whele is also orlatmented with an incised pattern colored with real wher. The other side is covered with series of the ineised eireles, eatele with at dot in the aentere, so trequently mentioned. Jig. 17oc (No.

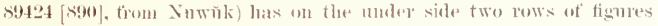
representing the flukes and "smalls" of" whales. This is the spereimen already mentioned, whish the natives called an aw tual seone. Theseriess of

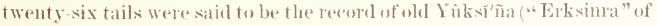

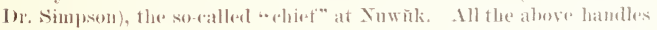
are of walcus ivory, and have been in actual use. Fig. 170e (No. 5tisl3 
4: froth T'tbiartin is a A.andle of ditherent material (reindeer antler)

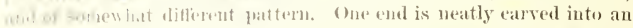

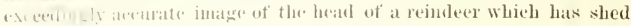

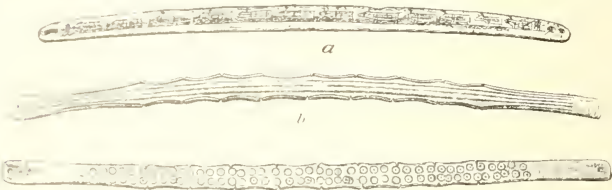

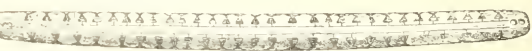

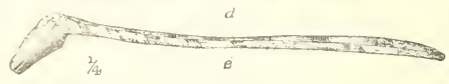

Fig. 170.-Bag handleg.

its antlers, with small bhe beadk inlatid for the eyes. The back of the hatulle is ornamented with an incised pattern colored with red ocher.

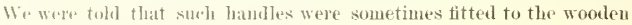
burkets, but 1 never salw one so used.

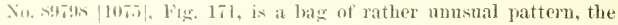
only one of the kims we salw. The bottom is a single round piece,!

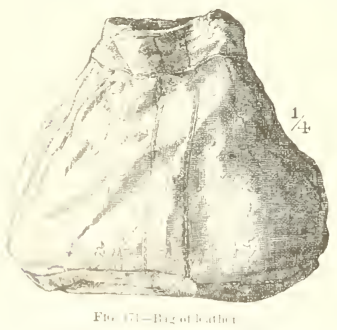
inches in diameter, of what seems to be split skin of the bearded seal, flesh side ont, and the rest of the bag is of white-tamed seal leather. The sides are of five broal pirees $\left(1,4 \frac{1}{2}, 4,5 \frac{1}{2}\right.$, and 5 inches bural at the bottom, re. spectively, narrowing to $2 \frac{1}{2}, 1 \frac{1}{2}$, $1 \frac{1}{4}, 2$, and $2 \frac{1}{3}$, respectively, at the top), alternating with five straight strijs, respectively $1 \frac{1}{2}$, $1,1 \frac{1}{3}, 1 \frac{1}{4}$, and $1 \frac{1}{2}$ inclues broad. The edyes of these strips overlap the edges of the broad pieces, and are matly stitched with two threall. ats on the soles of the waterpoot boots. The onter thread,

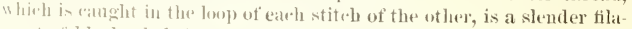
ment of black whale bone. This produres a sort of embroidery. The now is stitcherl to the bage with the same seam, but the hem at the month is merely "run" pouml with sinew. This bag was probably tor holhugr small tools and similar articles. 


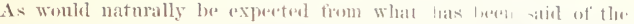

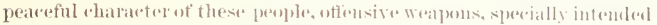
for use against men, are excodingly rane. In ratso of (puarels between individuals or parties the bows,

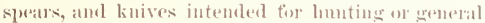
use would be tornesl against thrir phemies. Even their rifles, nowallays, are kept numblo more for honting than as weapons of offense, and the revolvers of various patterns which many of them late obtained from the ships are ehieflyearried when traveling latek and forth between the two villages ax a protertion against a possible lrar. We, lowever, obtationd a few weapons whish were experially desigued tor taking homatu life. Ons of these was a little cluh

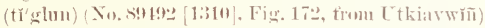
male of the lutt end of an old pirkax leead of whale's bour, with the point ant (lown to a blunt end. It is fo.t inehes long and meant to be alemelest in the hand like a daggere and used for striking blows, probably at the tomple. The transwerse groover for hafting give a gent hold tor the fingers. This was the only watpon of the kind seent.

We collerted a single sperimen ot a kind of slnng

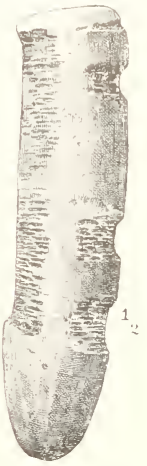

F10. 172,-Little hand.

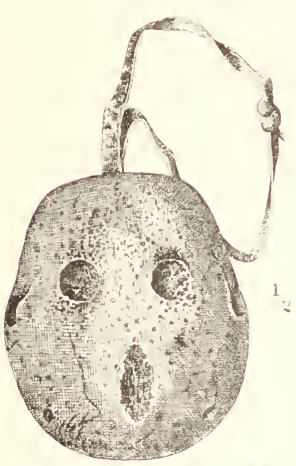

Fig. 173.-Slungahot male of walrua jow shot, No. s?t72 [90.) (Fig. 173), makle of a roughly ovoid hmo of heary lome, the symplysis of the lower jaw of a wahus, is inehes lomg. It the snatler alul two large boles are bored in obliguely so as to meet under the sur. tares and form a channel through which is passed a slipot white seal skin about 1.5 ineles long, the romls of which fiasten togrethere witlo two slits, so ats to make a loop. This may be rompared with the stone balls nsed ly the ameirent : Alents for striking a man on the temple.

The ammomest weapon of oflemse was a broald dagerer malde of a bone of the polar leater. This was satid to be experially meant for killing a "bat man," possibly tor certain spereitied oftenses or perlatps in cases of insanity. losane persons were sometimes killed in Greenland, and the ant was monsidered "meither deejdedly atmissi- 


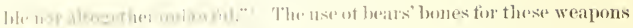

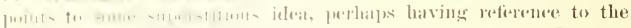

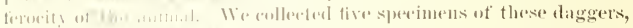

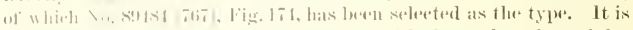

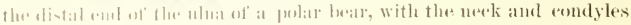

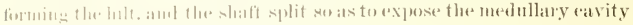

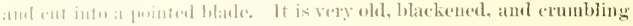

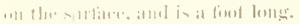

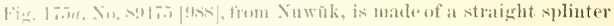

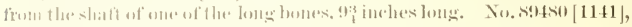
fion l'tkiamin, has a loughly whittled lailt and a somewhat twisted

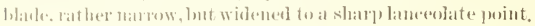
It is 12 inches long. Xo. sto s 117.5$]$, from the same place,

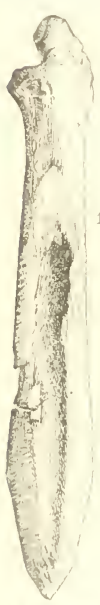
hats the ronghly shaped hilt whippiel with two turns of sinew. No. s!t ts $[1709]$, Fig. 17., also firem 1 t kiarwiñ, is dirk-slatped, laring lut one edge and a straight baek. The litt, as before, is romehly salwed tirom the solid liearl of the bone. No. s!thit [?6is], 1. Fig. 17t, fłom Nuwñk, was also satid to be a diggerer, but could not have boen a very eflective weapon. It is of whale's bone, 5 inches long. It is mather rulely arved, old, and dirty, hut the not hes on the hatt atre newly reut.

birks or dagegers of beats's bone, like tlose described, are really rather formidable weapous, as it is masy to give the spliuter of home a very keen proint. The Mnximu romtains a bene dagger enrionsly like these Eskimo weajons, but matele of the bone of the. Fow for the ane grim/ly bear, and used by the Indians of the Maclonel

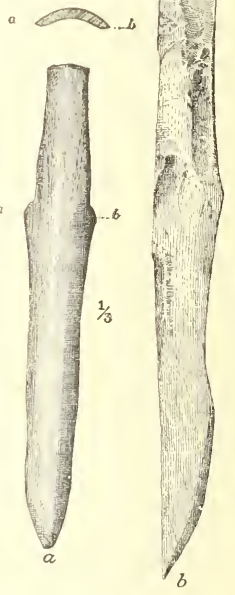

FIT. 175.-Bone daggers.

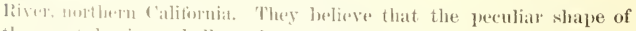

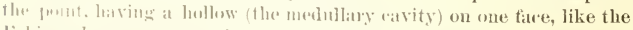

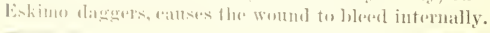


PROJECTHLF WEAPUYS,

Firearms. - When loase and simperm tirst met these perple, in 15:37. they hat no fireatem, lut the next party of whites wherame in sentaret

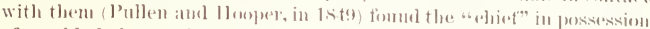
of an okl shaky musket of Enghish make, with the name " hitmett" on the loek. Howper beliesed this to be the gon lost by sir doln Frank lin's party in 1s2ti.2 This gan was, howerer, often seen by the people

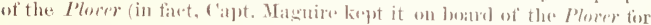

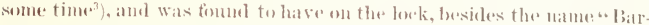
nett," also the date, "1st:"," so that of eourse it was met lost in 1 s.t. $^{2}$. Armstrong also mentions seriug this gum, which, the natives told him, they hat prosured "from the other tribes to the south wart." In the summer of 15.23 they bexan to purchase

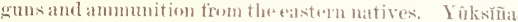
and two other men wath lomght a gum this year. ${ }^{3}$

As the whalers began to gor to Point latrow in 1sit, the opprortunity for obtaining tirearms las been afferted the natives every year sine then, sil that they are now

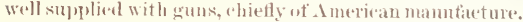
That all their tirearms hase net betell obtained foum this somece is probalule from the far they have still in their possession a number of smoothbort perension arums, double and single barreled, of Russian mannfacture. They are all stamper in linssian with the name of Tula, a town on the Gopa, lois mikes south of Moseow, whieh hat receiverl the mann of the "shetheld and Birmingham of Russia," from its vast mamutatery of arms, established lyy leeter the (ireat. These guns must have enue from Fio 176_-Soealled the "Sunatanmiun," whos olotained them either fiem daguer of twee. the siberian traters or from the liussians at Norton somul thromenh the Malemint. Buth smonthbore and rittert gums are in genteral nse. The smeethluores are of all sorts and deseriptions, from an old flintlowk musket to more or less valualble single and double perelssion fowling-

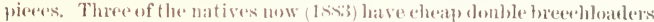

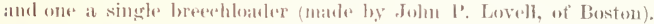

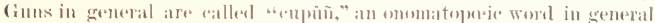
use in western Ineriea, lut many of the different kinds lase sperial

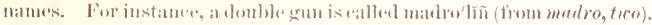
The rifles are also of many different patterns. The kinel prefereal by

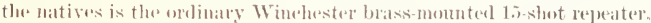
which the whalers and tralers purehase eheaply at wholesalle. This is

\footnotetext{
'Honqur. Tents, etc., p, 2ais.

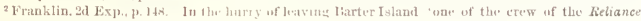
left his gon and amemeนtition."

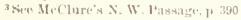

Nitration. p. 109.

${ }^{5}$ Maguirw, Further 1:ipurs, p, 907. () ЕTI- 13
} 


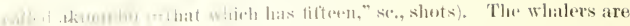

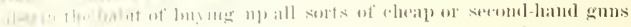

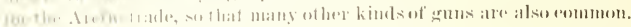

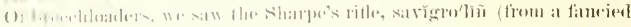

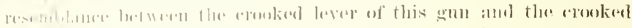

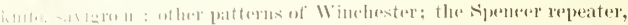

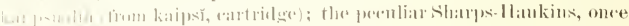

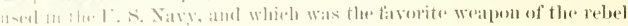

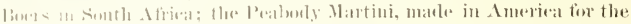

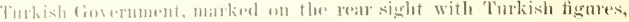

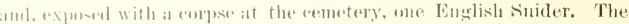
tombition surtugtiold rifles belonging to the post, which were often

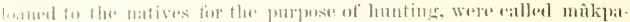

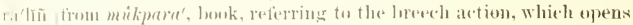
likitia bowk).

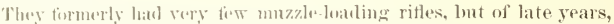

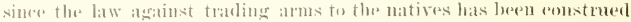

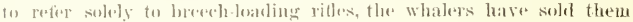
yigen rifles, of the old It. S. Army pattern, Bnfind rifles, ship's mus kiots with the Tomer mark on thrm, amel a sort of bogus ritle made esperelally for trade, in intation of the old-tishomed kenturky rifle,

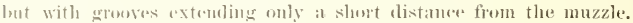
Ther of (")

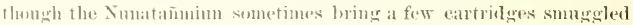
acrosis trom siberia. They naturally are most desirous to proseme (artridges for the rim tire Winchester gems, as these are not intemed

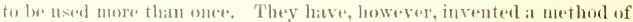
priming these rim-fire sledls so that they eam be reteated. I common

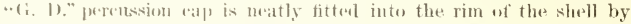
rutting the siles into strijes which ars tiolded inte slits in the shell,

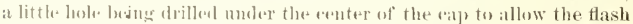

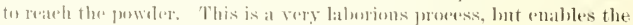
natives to nse a rille which would otherwise be nseless. Sneh ear-

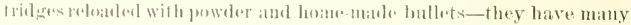

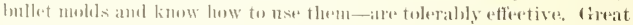

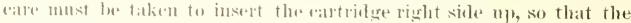
cap shatl be struck by the dimg pin, which interferes with using the

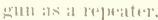

Thery ate very ato less with their ritles, allowing them to get rusty,

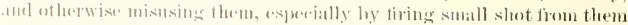

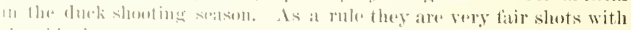
the ritle, hut axtremely lasish of ammonition when they have a sup.

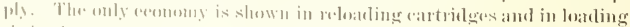

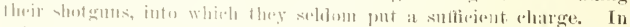
spite of this some of them shome very well with the shotenn, thomgh

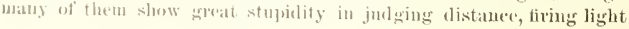




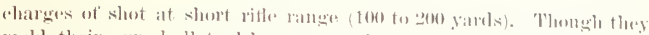
molel their own bullets, I have never known any of them to attempt

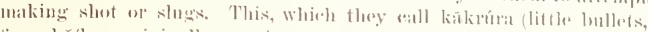

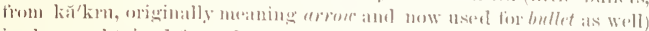
is always obtamed trom the whites. The gun is habitually tarred in al

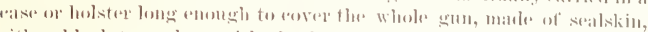
eithere black-tammed or with the latir on the antside. This, like the

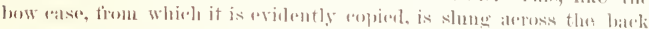

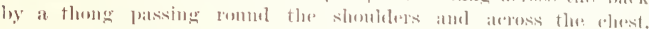
This is the mathol miversally patetioed for arrying lumbens af all sorts. The butt of the gnon is on the right sille, so that it ean leesasily

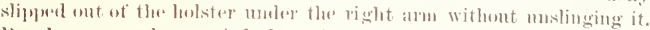
lievolvers are also carried slung in loblsters on the batek in the same way. Ammunition is atriesl in a ponch sluns over the shomber. They are careless in laanlling tirearms ame ammmition. We knew twa men whe slut off the tip of the forefinger while filing eartridges which lat fated to explester in the gents.

Whaling gnes.-In ablition to the kimbs of tiretrms for land lunting above deseribed a mumber of the natives bave procured from the wbalemen, either ly purhase or from wrecks, whaling gums, smeh as

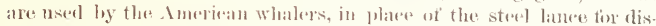
patching the whale after it is loaponeds. These are of various pat.

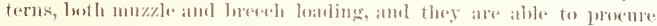
nearly every yeall a suall sulply of the explosive laures to be shot from them. They use them as the white men do tor killing barponed whales, amel also, when the leakls of open water are narrow, tor shooting them as they pass elese to the ellege of the ine.

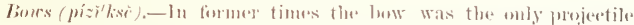

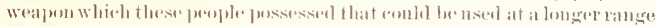

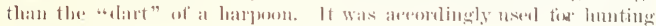
the bear, the wolt, and the beimleres, for sheoting birds, and in rase of necessity, tor wathere. It is worthy of mote, in this rommetion, ats showing that the use of the bow for tighting was only a seremelary eon-

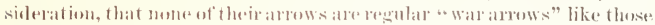

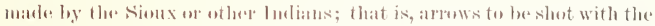

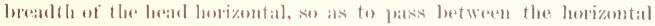

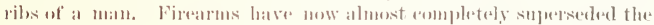

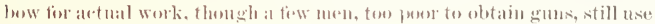
thint).

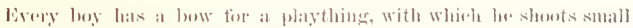
birls and practions at matks. Viag tow bogk, boweres, show any great

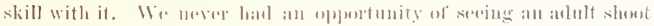

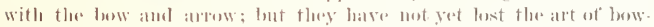
making. The newest loys' bows ane as skiltilly and ingenionsly an.

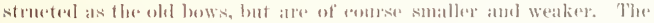
bow in use anomg these preple was (he universal sinew-backed bow of 


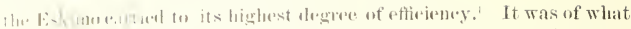

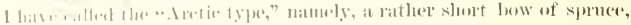

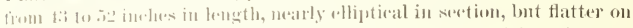
the latk that on the belly, and slightly narrowed and thickened at the

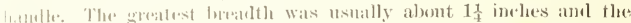

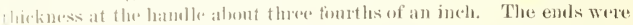

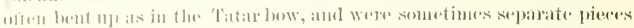

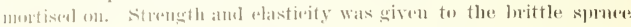
by alplyeing a mumber of strands of sinew to the barek of the low in sich at way thall drawing the lowstring stroteded all these elastic cords,

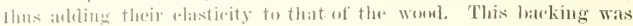

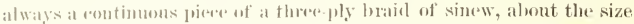
of stout pareli thread, and on a large low often fo or .50 yands loug. It

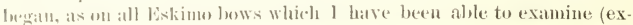

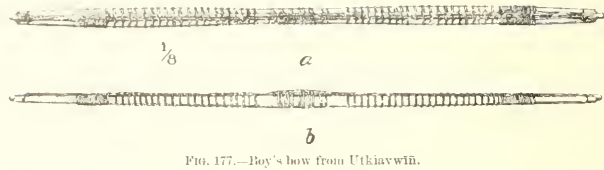

rept these from st. Lawrence lsland and the mainlamel of Sileria-

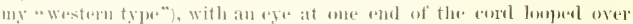

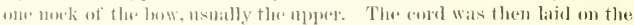
batek of the bow in long strands roming 1 p and down amd romel the unckis, as ustal on the other types of low, hut ather putting on a num-

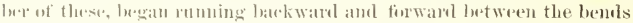

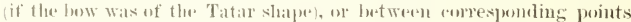
ou at straight bow, where they were fistemed with commlieated hitches aromul the how in sm-lo a way that the shortest strands ame to the (a) of the bareking, which was thus made to grow thicker gradually toward the midelle of the low, where the greatest strength and elas-

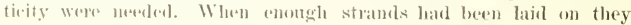

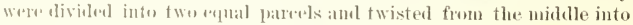
two tight a albles, thus gratly increasing the tension to be overcome in

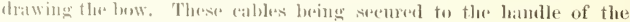
bow, the and of the rorkl was used to seize the whole serenely to the low.

This serang and the hiteles aldealy mentioned solved to incorporate the batking wry themghty with the bow, thus ergualizing the strain

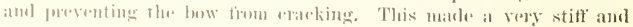

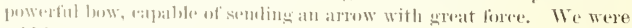
fold by a reliable native that at stome-hetaled arow was often driven by

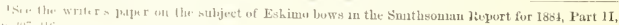
J. 31 307 316 


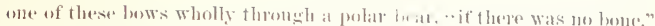

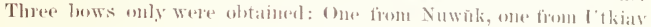
wนī (a lad's low), and onc from sidan.

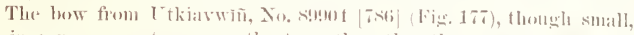

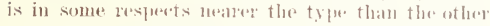

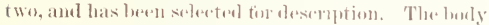
of the bow is a single piese of the healt of a logs of

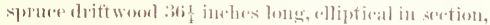
flattened mose on the latek than on the belly. It is

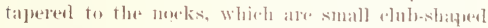
knobs, and natrowed and thiekened at the banmle. The barking is of romel threse phy brate of sinew in one contimens piere. Tlus string is a roment fomply loaid with a loes at each end, made by tying a single knet in flue stameling part, passing the end throngle this and talkinga half hitch with it romul the standing

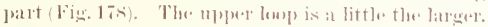

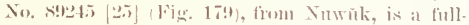
sized man's low, which is olel and loas beren lome in nse. It is of the same material, and is $47 \% 3$ ineles long. Its greatest brealth is $1 \frac{1}{3}$

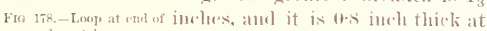
lowatring. the hamelle. It is slightly nampwerl

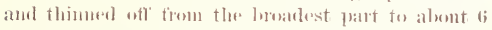

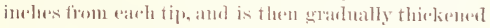
to the nocks and bent 11 po that the emols malie an angle of aloment tis with the low when mustrung. The rols atre separate pieces fitted on at the loends. The

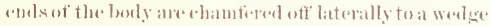

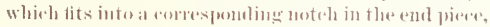

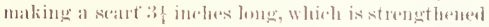

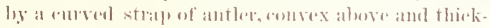
est in the michle, fitting inte the bend on the batek. The joint is held togetlee wholly ly the bateking.

We never sal bows of this pattern mate anul rou-

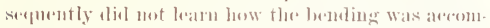
plished. The metloul is probably the silme as that

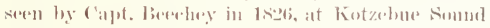

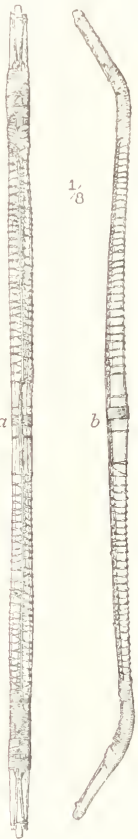

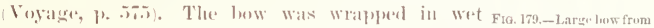

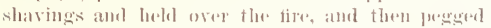
Nuwuh.

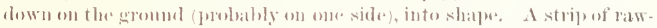

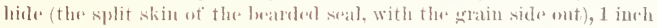

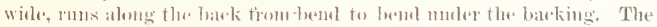

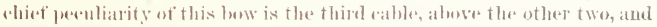
the gleat and apparently muneessary complication of the hitehes. 


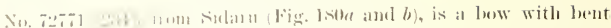

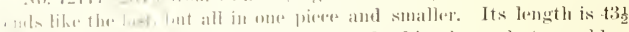

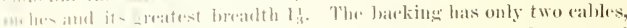
and it - chind pecoliarity is in having the loose enel of the last strand

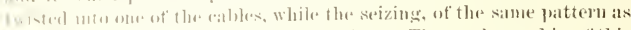

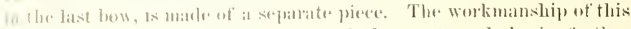

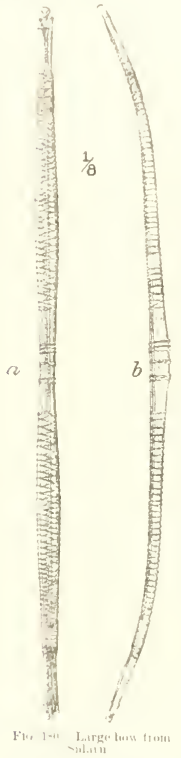
bow is partionlarly mat, and it is further streregthencol with strips of rawhiste (the skin of the beateded seal, split), muler the bateking. T'he mothou of making the string is very ingenions. It appease to hase henen made on the bow, ats follows: llaving the bow sproug lawk one end of a long piece of sinew twine was made fast temporarily to the mpere moek, laiving an end long anought to finish olit the lowstring. The ot here end was rarried ronul the lower nock and the returning stratud half hitehed rouml the tirst smogly up to the now, amd them earried round the mplet mek and batk again. This was repeated, each strand being balf-hitched mound all the preceding at the lower moek until there were vight parallel strands, and an eye fitted smugly to the lower noek. The hight was then slipped of the uppor nork, the end untied and the whole twisted tight. This twisted string is now about 2 inelhes too long, so the

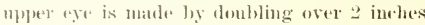
of the end and stepling it down with the free and mentioned above, thus making a long ege of serom strands. With the eml, six similar stramk are aldded to the eye, each being stopyes to the twist with a half hiteh. The end is notly tueked in and the strands of the rye twisted tightly together.

In my paper on kxkimo bows, already mentioned, I cane to the anclusion that the bows formerly usal lig the Eskimo of western North Ameriat and the oppusite roast of $\mathrm{Asia}$ ware eomstruatiol upon these well defined types of

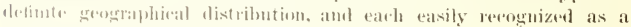
development of a simple ariginal type still to be found in Baffin Lamd

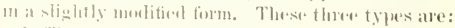

1. The sunthere types whieh was the only torm used from the island

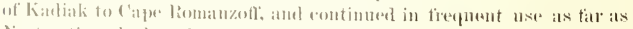

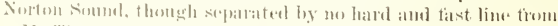

11. The Aretic type to which the bows just deserilued beteng, in nse 


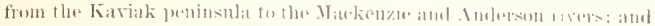

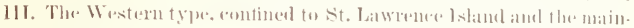
land uf silurial.

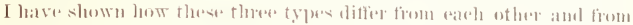

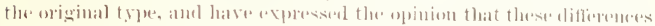

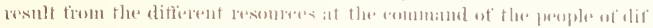

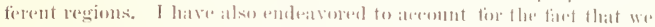

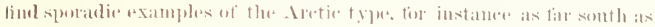
the Yukon, by the well kinwn habits of the Eskimo in regind ro trat inge expeditions.

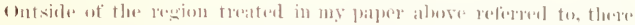
is very litfle material tor a compantive study of liskimo bows, wher

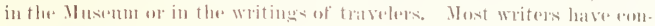

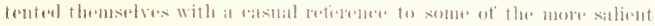

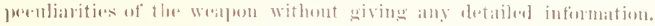

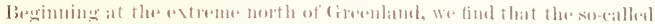

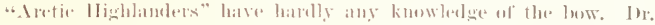

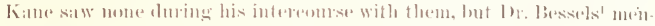

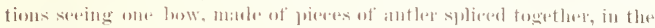

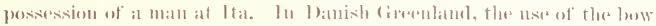

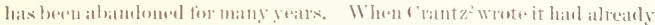

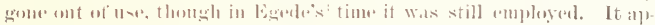

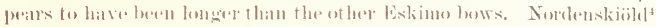

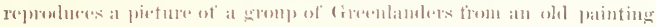

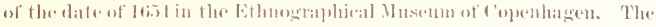

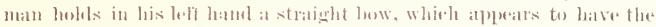

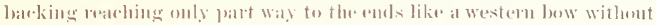
the end rables, and yet twisted into two calbles. If this repasentation be a eorrect one, this antingerment of the bateking, taken in connection

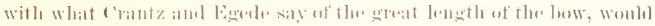
be an argument in fivor of my theory that the St. Lawrenee Islanel

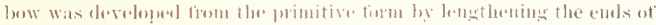

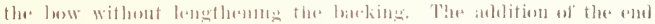

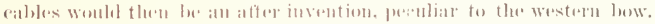

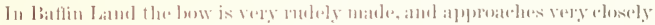

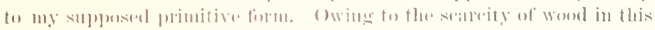

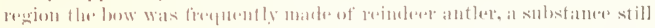

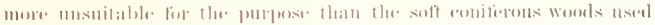

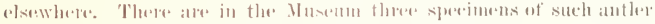

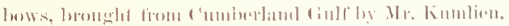

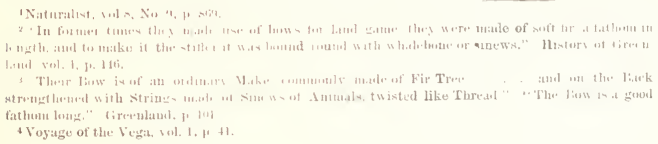




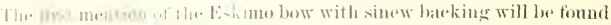

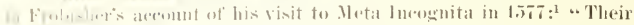

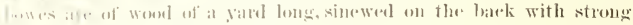

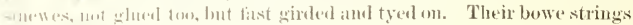
ate likewian simewes."

1) the how used at the stratits of Fury and Ifeela we have a most

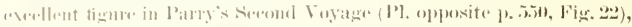

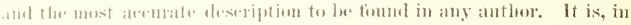

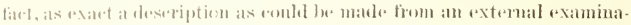

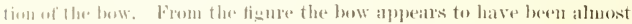
of the arefie type having an mumsual mumber of strands (sometimes

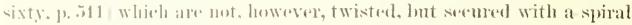

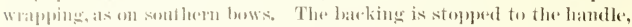

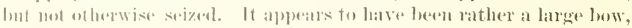
as l'ary gives the length of one of the be best bows, made of a single

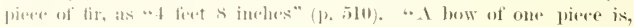

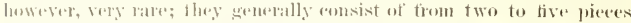
of home of morepual lengths, fastemed together by rivets and treenails" (p. sil). P'arry alko spealis of the nse of wedges for tighteming the

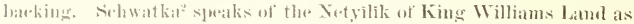
using lows of spliced pirees of musk-ox horm or driftwood, Int gives no fim her texcription of them. EHis deseribes the bow in use at Hudson's strat in 17 ta as tollows:

Thest freatest lugenuty is shown in the structure of their lows, male commonly of thu+ l'itces of Went, calh making a paxt of the same. Arele, very nicely and exactly joined tougther. They are numbuly of Fir or Jareh, which the English there call Junipere and an this wath strength and Elasticity, they supply both by bracing the

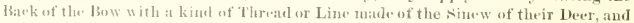
the baw sting of the same material. To make them draw more stifly, they dip them

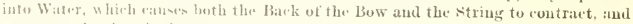
cubsequenty gives it the greater fores."

Bllis's figure (plate oplusite p. 132) shows a low of the Tatar shape, bul gives an details of the hatking, exeept that the latter apuears to be lwislal.

W. have no publisherl deseriptions of the bows nsed in other regions.

Is fiar as I hawe heral ablo to aserertain, the practice of backing the how with romls of sinew is peruliar to the Eskime, though some American Indians stiflen the how by ghing flat pieces of sinew upou the tratk.

(1m. trilw of tmians, the " Jomehenx" of the Mackenzie district, howerer, used lows like those of the Eskinos, but sir Nlexander Mae-

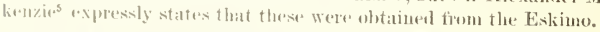

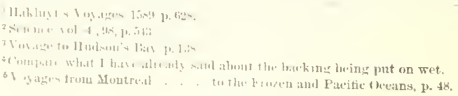




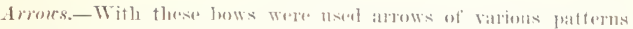

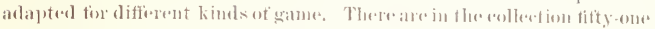

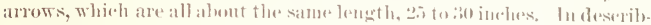

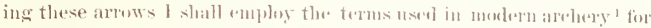
the parts of the arow. The greatest ramition is in the sfalpe and size of the pile. The steld is aluest always a stratight aylindrieal rocl,

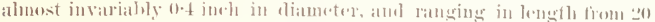
to 2 inches. Twenty-tive inches is the commonest length, and the

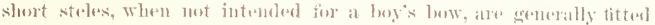
with an mumsually longe pile. From the lesinning of the teathering the stele is gradnally flattened atrove and below to the nork, which is a

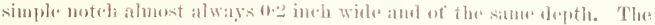
stele is sometimes sloglitly wirlened just an tiont of the nock to give a

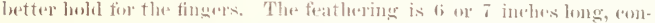
sisting of two, or less often, there featluers. (The set of sixterell arrows from sidarn, two from Siunk, and one from Ltkiavwin, have three forthers. The rest at the fifty-ome have two.) The shatt of the feather is split and the woll is ant 11 ar row, and tapereal olit to a joint at rachered (Fig. 1si). Therendis of the feathers are filstered to thestele. with whippingsot tine.

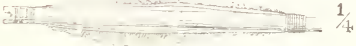

Fin: 1.1.-Feathering of the Eshime arrow. sinew, the small end of the feather which, of amrse, eomes at the nock, being often wedgerl into a slit in the wood (with a speredal tool to be deseribed below), or whe doubled baxk over a few turus of the whipping and lashed down with the rest. The smath end of the feather is almost always twisted almot one turn, evidently to make the arow revolve in flight, like at rifle ball. (ienerally, if not mixersally, the

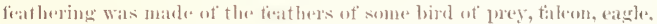
or ravelu, probably with some notion of eqiving to the arrow the deathdealing quality of the hird. Out of the fifty-ome arrows in the colleetion, only nine are featherest with gnll's teatlurs, and of these all but

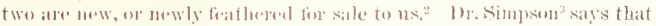

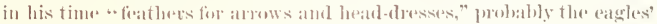

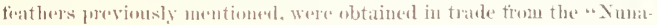
tainminn."

Font kinds of arrows were usod: the bear arrom, of which there were

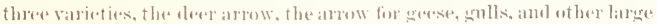
fowl, and the blunt headed atrow for killing small hirds withont manfrling threm.

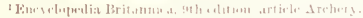

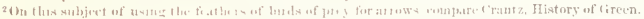

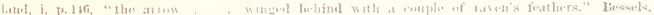

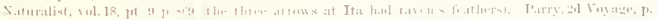

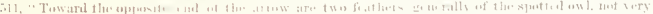

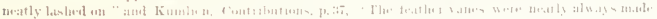

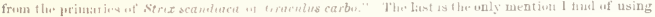
any fouthere exerpt these of birits of phey.

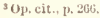




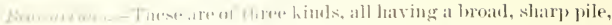

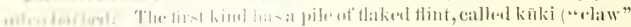

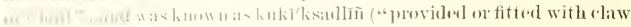

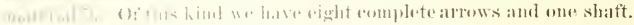

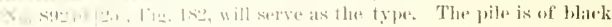

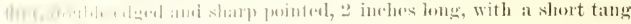

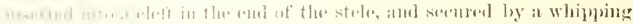

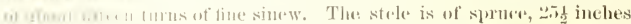

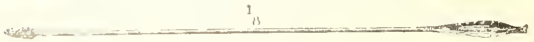

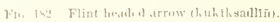

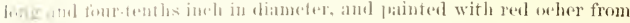

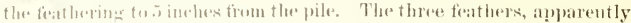

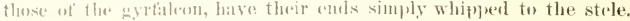

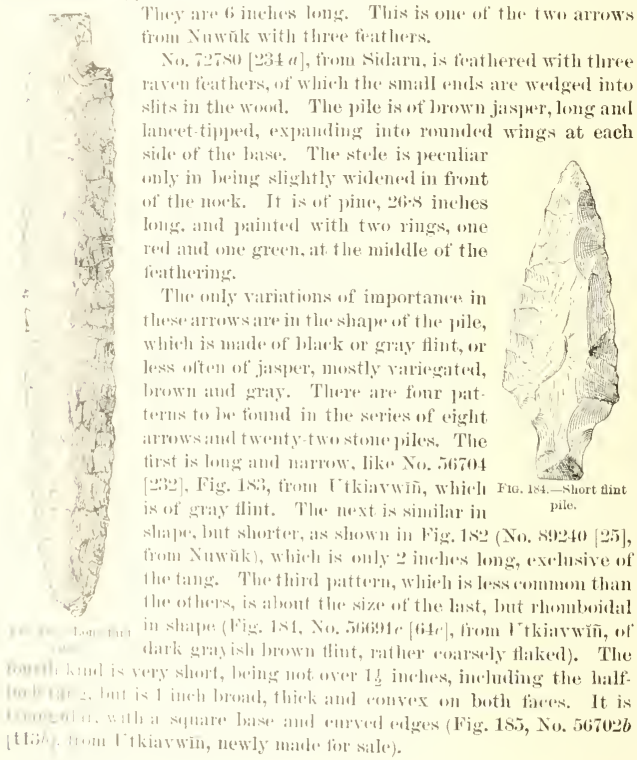


No stome arrow or dart heats mathe hy these preople latwe anstloing

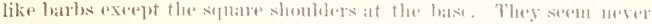
to have attained to the skill in flint-worling which enabled many ofluer salvages to make the beantiful barbed heads sooftent seren. Tor lieep the flint-hearled arrow from droppling ont of the womm they hit ajou

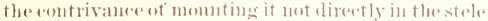

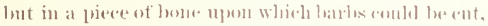
or, as is not molikely. Javing aldeatly the deer arrow with the barleed heakl of antler, they adelest the thent head to this, thus amblininge the penetration of the flint arrow with the holding jomer of the otlase. I was at first inelimed to think that this piece of louse

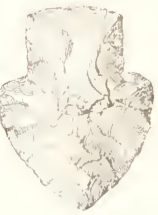
Fin 18: Heart-ulaipm that julw. bere the same relation to the rest of the armo as the fore shath of many Indian arrows, and was to be ansidered ats part of the stele. Consislering. however. that its sole finetion is to fumish the pile witl,

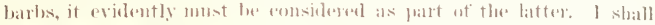
dexignate it as " after-pile." Arrows with this barthed "after-pile" form
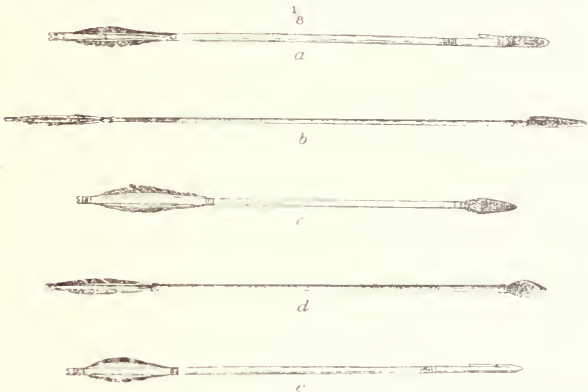

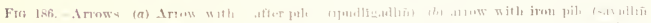

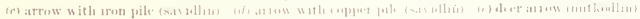

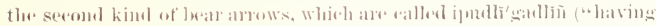

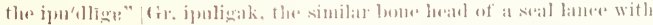
iron tipl). After tlee intruluetion of isom, metal piles sometimes be-

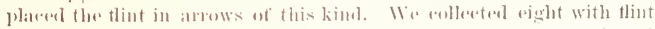

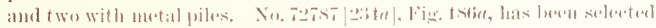
to illustrate this form of arrow. This pile is of grat flint with the tams walked by a slip of sealskin into tlet tip of the after-pile, which in

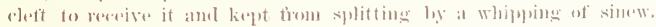

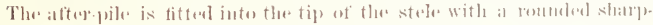
pointed tang, slightly anlaresed just above the tro. It is of reinderer 


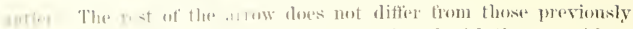

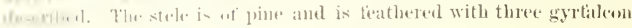
andine?

Two otler's tion sidatu have only a single barb on the after-pile, but

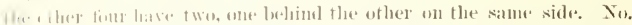

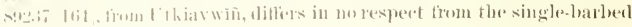

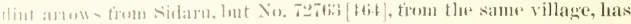
hat suatl barts on the after pile, which is musually (nearly 7 inches) 1.1. and a pile of shert brass. This has the bisal angles on earth side

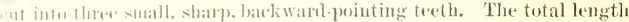
ot this :trow in -3 inches.

The aftor piles of all arrows rexpet one were of reindeer antler, which

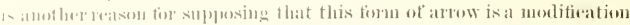

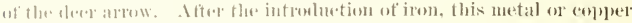

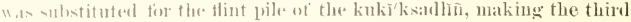

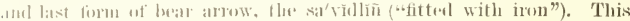
arow dithers from the of leers only in the tom of the pile, wheh is gen-

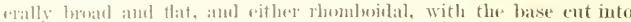
mumatos small tooth, or else triangular, with a slank. The barbs are II:nally bilattral.

Xis, Tzis

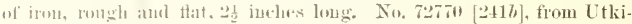

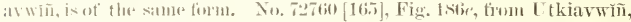

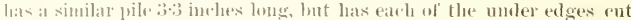

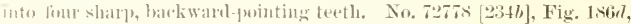

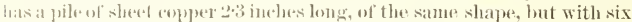

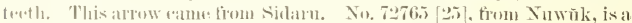
long, namew imon pile. with there bilateral barbs, all simple.

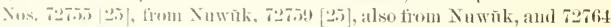

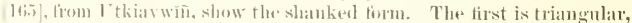
"ith at that slank anul a simjele barls at each angle of the base. It is of

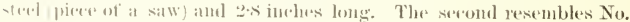

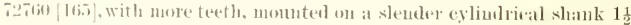
inclus long. It is of iron and :3e! inches long. The thimd is a long pile with a simate ontline and one pair of simple bilateral barbs, aud a tlat

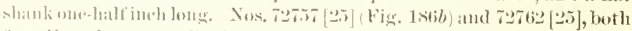
from Xuwnk, anc pertuliat in being the only iron pointed arrows with un-

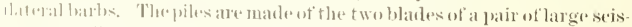
sat - ent oft at the poinl, with emongly of the-haudle lett to make a tang.

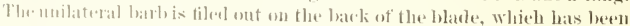

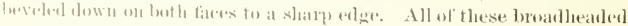
.roms hatre the lowalth of the pile at right angles to the plane of the mo-k. showing that they are not meant to dy like the Sioux war arrows. Nhlowgh irom makes a lecter material for arTow piles and is more atsil? workinl than thint, the quivers which some menstill carry at Point barmw ontain flint as well as irou headed arrows. They are probably 
kept in use from the superstitions conserwatism alrealy menumel. It is certain that the man whoratised al emple of wolt anlos fin the salke of their fur was obliged by trahtion to latre a dint-hadeled aldow to kill

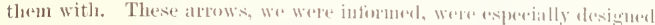

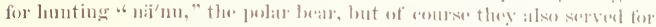
use against other damgerons game, hile the wolf and lowwn bate, and

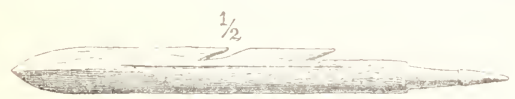

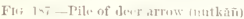

there is no reason to believe that they were not also shot at reindreer,

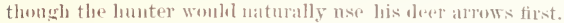

Deer arroms have a long trihedral pilu of antler forn 4 to s incleses

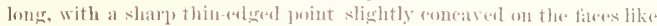
the point of a bignomet. Two of the edges are roumded. but the thim is shap and ent into one or more simple barks. Fehind the hath the pile takes the torm of a romberl shamk, ending in a slowklese and a sharpe roumblol tange a little enlarged alwove the point.

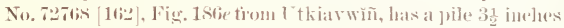
long with two barbs. The pile of Xo. sigess [160] fiom the same village is : $3 \frac{1}{2}$ inches longe and has but one louth, while that of

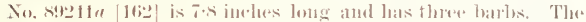

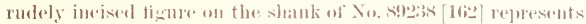
a wolf, pobably a talisman to make the arrow as fatal to the

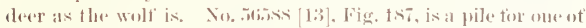

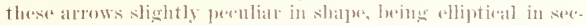

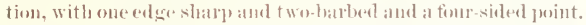
The figure slows well the shatpe of the tang. The jeeruliarity of these alowow is that the pile is not fastemed to the slatit, lunt

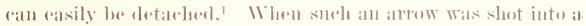
deer the shat woukl (asily le shaken out, leaving the shan' batreal pile in the woumel.

The liskino fold us that a deer momuded in this way would

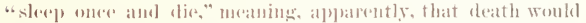

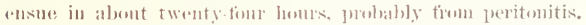
The bone pile is alled not than, whence eomes the name of the

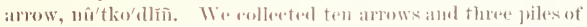

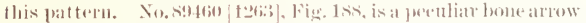

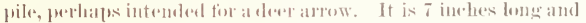
mate of one of the long bones of some large hird, split length wise so that it is lonmeled on one side and deeply comeate on

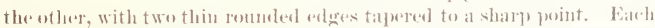

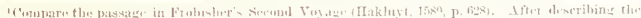

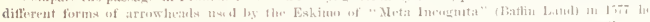

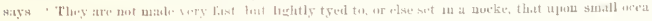
sion the arrowe loaveth these luesle lontand them.
} 


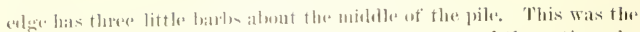

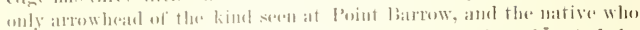

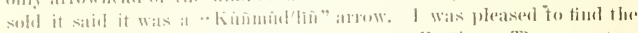

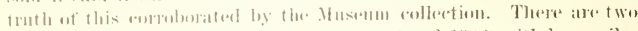

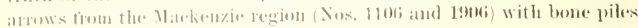
of alumest the satum timm.

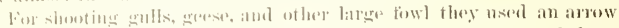

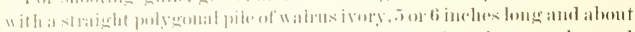

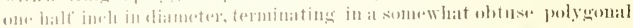

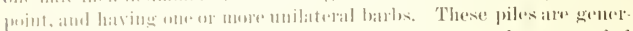

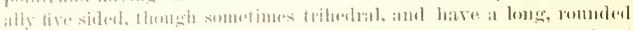

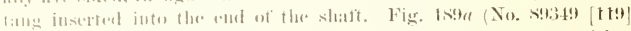

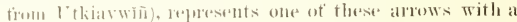

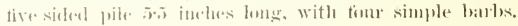
The rest of the allow aloes not differe firom the ofleres de-

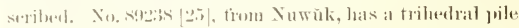

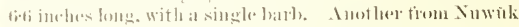

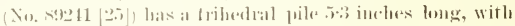

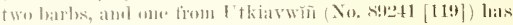

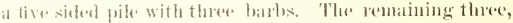
trom Sidath, all hate fire-sided piles with one barls.

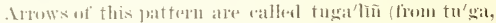
walles ivory). There alle also in the (rollection two small allows of this pattrin suitad for a boy's bow. They ate

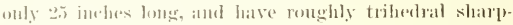
pointed ivory piles about 4 inclese longe, withont barbs.

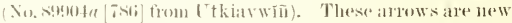
and matlue carrtessly malde, and war intended tor the

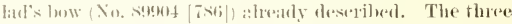

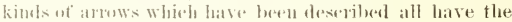
pile sererreel to the stele loy a tamg tittiug into a eleft or hole in the ent of the lattere, which is kept timm splitting ly whipponge it with sine tor abent one halt inch.

The temeth kind, the libut bind arrow (kĩ'xodwain), an

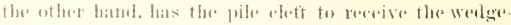

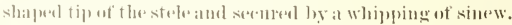
The then arrows of this kind in the enflection are alumest "xaletly alike, exerept that there of them, J whonging to the

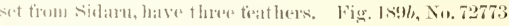

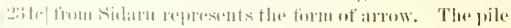

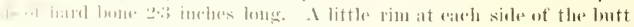

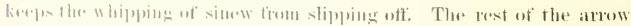

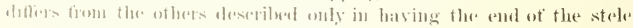

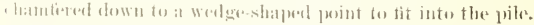

'This is the kiml ot' anow mestly uxed hy the boys, whose game is altumat exchusively small hirds or lemmings. Nowadays the bene pila. 


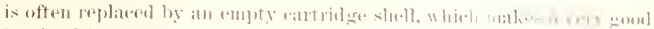

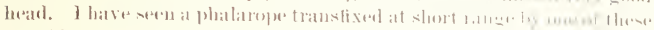

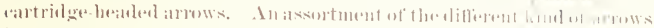

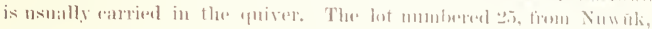

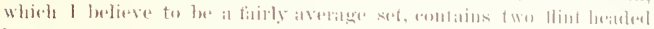

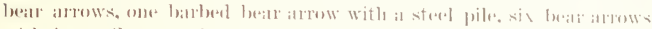

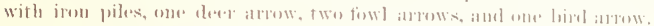

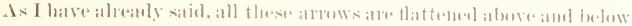

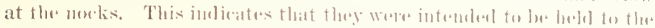

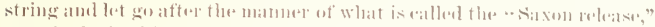

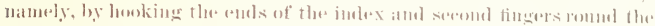

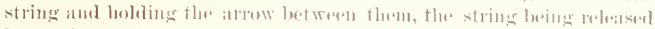

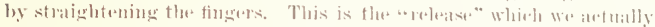

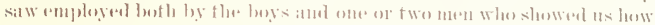

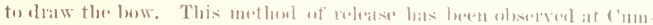

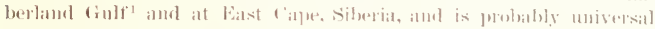
ameng the Eskimo, as all the Eskinu aryows in the National Mnstum are fitted for this release. There is ample material in the M[usenum eo].

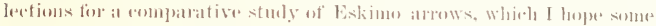

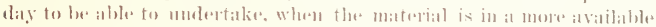

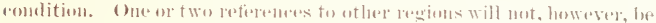

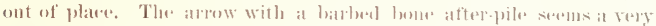

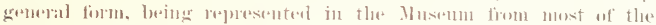

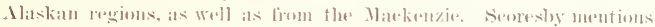

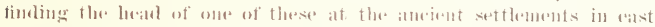

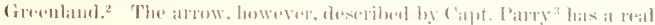

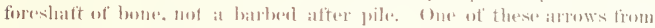

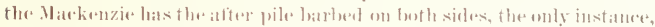

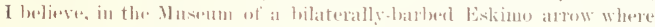
the pile is not whelly at metal.

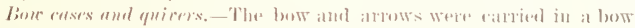

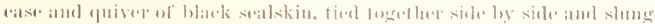

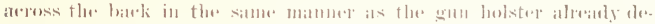

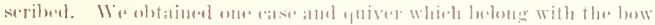

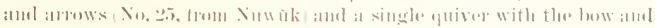

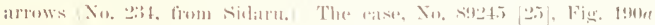

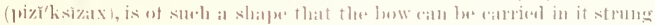

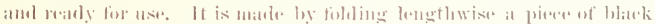

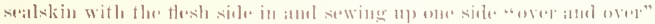

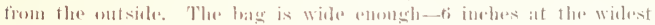

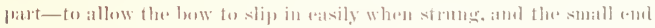

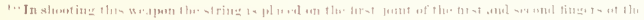

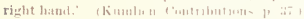

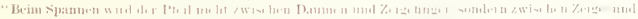

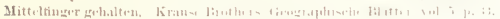

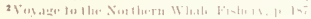

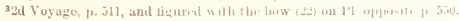




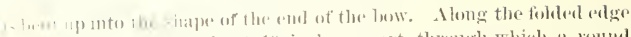

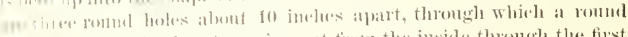

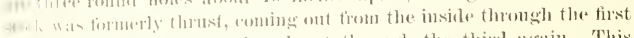

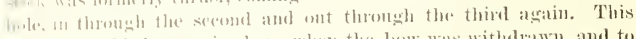

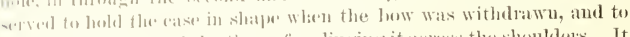

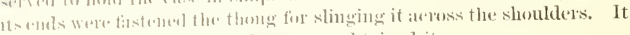
was gane trom the sperimen laclioge we obtained it.

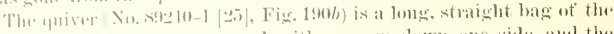
sime material, open at one ond, with a seam down whe side, and the
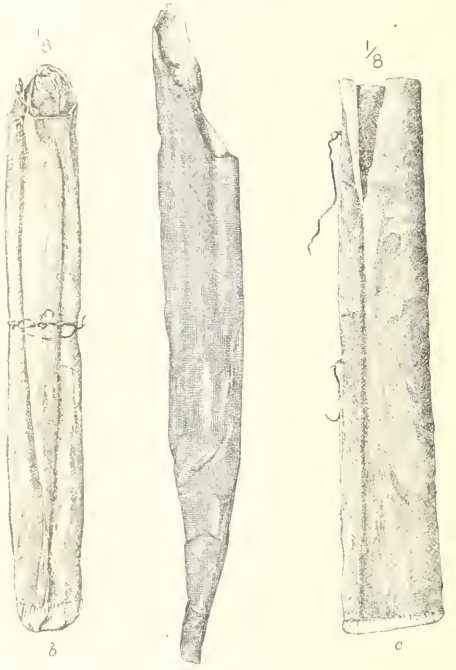

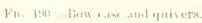

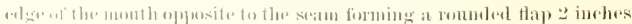

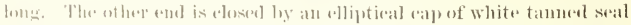

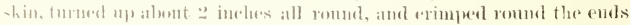

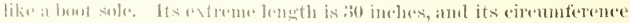

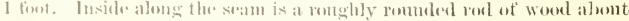

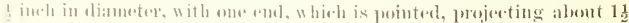

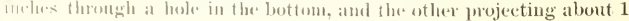


ineh beyond the month, where it is semped by a bit of thong linuttent

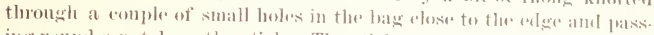

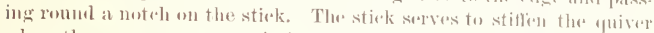
when there are no arows in it. A bit of thong is linoted remul the

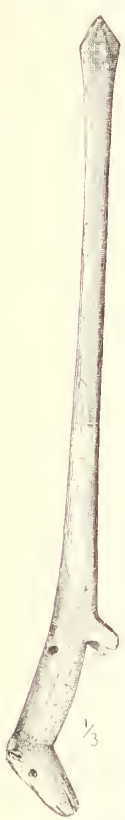

F16. 191, Quiva resi. midelle, one end lusing hiteled into a lowe on the ot leser, for tiglitening 11 the "1uiver anel anfining the arows.

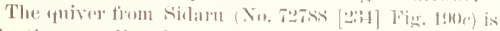

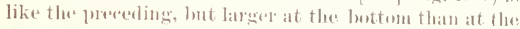

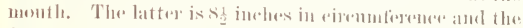

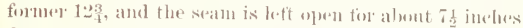
from the menth to facilitate gotting at the arows. The

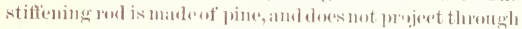
the bottom or reach the adge of the month. It is held in by two piedes of thomg about 10 inches lomg. whith also serve to fasten it to the bow case. This quiver is nearly new.

It is probable that the form of the how ease and triver varied lout little, amomg the Ineriean Eskimo at least. Those figured by ('apt. Lyon' are almost exaletly like the ouss we rellected at Point Barrow, (x)ell to the aimped "alp on the bottom of the yuiver. I similar set belong with a latls bow in the Muxemu

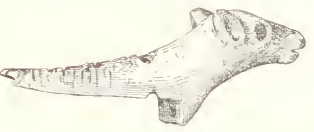

Fit. $192-1$ ap for ynives rod.

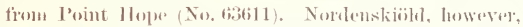
figures a very ralomate tlat quiver, ${ }^{2}$ in 11 se at l'itlekaj, which is avidently of gemuine Asiatid origin.

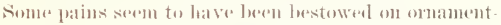
ing the quiver in former times, whels the low was in mose

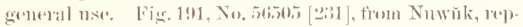
resents what we understers had lesen a stiflening rod for a 'puiver or bow dase. It is of remelerer antler', 17 incles

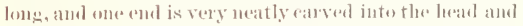
shemlelers of a leinteer, with small, bhe glass luads in. serted for the eyes. The lanerolate point at the tip was pobably made with an ites of imporing it tion sale. The lowe at the back of the neek is for a thomg to tasten it on with. I sintalu reindere lotal of antler, Fig. 192, No.

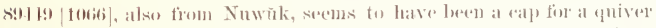

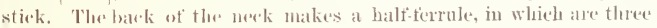
lowes for rivets or treentails.

Bracers.- In shooting the low, the wrist of the bow hamed was pres. 


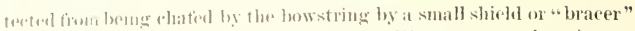

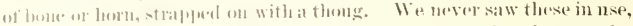

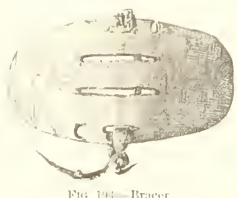

Fir il: Britas as the bow is so soldom romboyed except by the ehilderis. Two of these, newly mate, ware ofteres tor sale. I will describe one of

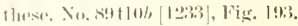

It is of pals yollow momation shep horn, (onvere on the outer fare and and ane on the inner and rousiderably areded lougthwise. In the midhle are $t$ wo straight longitudinal mancow shots, whind serve no apparent pur-

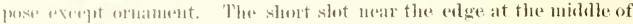

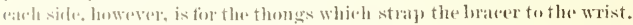

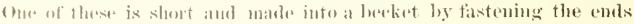

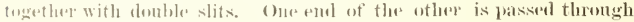
ther slet, slit, atmel the oflece ond passed through this and drawn tant.

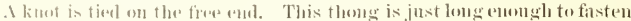
on the bracer by pasing round the wrist and eatedeing the kuot in the

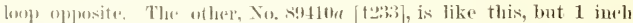
shorter and nearly llat. The areh of the specimen figured is probably unintentional and due to the natural shape of the material, as it does met tit well to the wrist. It is pobloblut that these

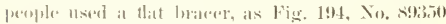

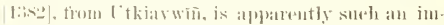
plement. It is a thin wliptical plate of hard bone,

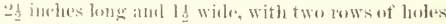
crossing at right angles in the midele. The holes at the side were probably for the thenes and the ot hers fin orlament, ats some of them go ouly part way thongli. Font surall pebbles are loulgerl in the

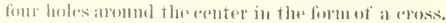

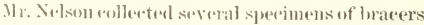
from Kotzobue somend and st. Lawremes Island. 'Phese are all slighty larger than our specimens, atul bent rouml to tit the wrist. They are of bone

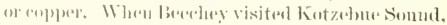
in 152ti, ho found tha brarer in general use. I timl

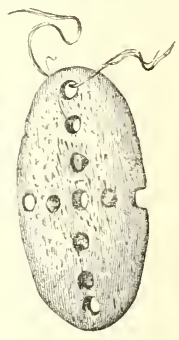

Fit. 194.-Bracer of bone.

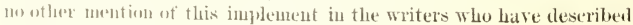
the Eskimo.

lird durts, - for capturing largw birds like ducks or geese, sitting on the water, wejerially when they hatre molted their wing feathers so

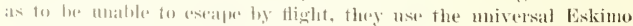

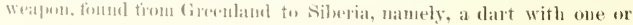

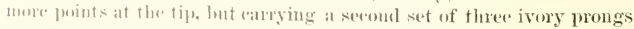

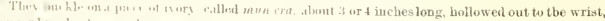

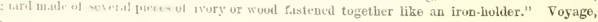


in a cirele romel the milde of the shatt. The objeret of these ponges is to increatse the whanee of hitfing the birel if he is misserl by the leat of the dart. They always anve forwarl, so that the points stanel out a fere inclues firom the

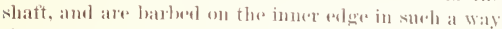
that, themgh the neek of a towl will tasily pass in lee. tween the promg and the shatit, it is imposible to dlaw it back again. The weapon is in very gemeral nes at Point Barrow, and is always thrown from the loat with

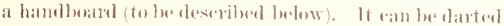

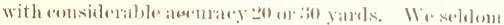

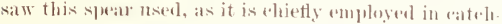
ing molting fowl, in the smmmes seasoll, a way from the immerliate mighborhood of the station. It is allowl miátipai, which is a phual reforring to the numlese

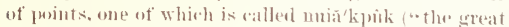
minik" ).

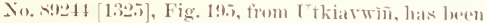
selecterel as the type of this watpen. The shatt is af

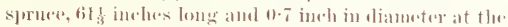
heacl. The eme of the butt is holloweel out to fit the rateh of the theswing beard. The heal, of white wal. mes ivory, is titterl inte the eleft remel of the shatt with a wolge-shaperl tamge as loroad as the shatt. The head and shaft are leelel togerther by a spareal lashing of braieled sinew. To the enlarement of the shatt, aze inelas from the loutt, are fastened thres enrved pougs of walrus ivery at efual distanees from each othere remel the shatt. The inmere sile of eate prong is ent away obliefuely for abont 22 inelues, so that when this elge is applied to the shatt, with the proint of the promen

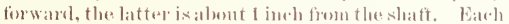
prong has two little ridges on the out sisle, one at the lower end and the other alout 1 inellabose this. Ther are seemeel to the shaft by thees separate lashings of sinew brail, two nartow ones alvore the ridges just mentioned and one broal ome just helow the barts. los making this the line is knotted romel ous promeg, then darverel one-thind of the distane somel the shat to the

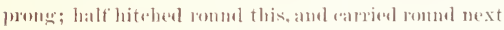

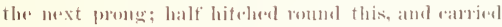
rounel to the starting peint, and half hitelowl romel

This wat :

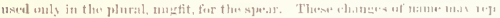

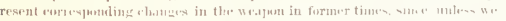

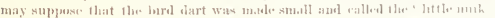

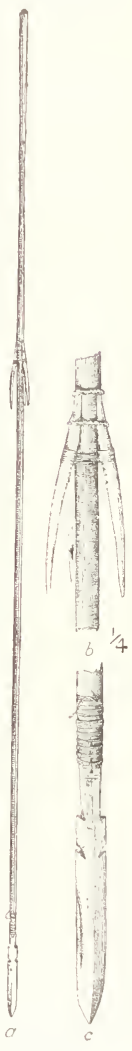

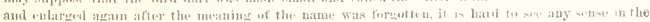
present nause, "big little nuik." 
this. It gross around in this way sarent times, and then is earried one

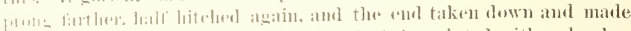

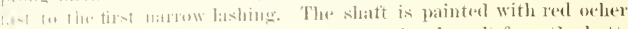

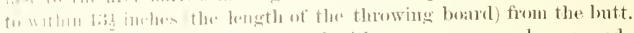

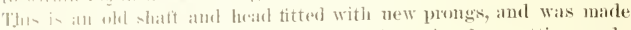
ly Xiknuat alu, who was ansious to borrow it again when getting ready 1. - - tall on his summer trip to the cast, where he would find yomug dueks wat metting towl.

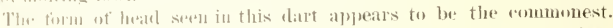
It is callod by the same natme, nintking, as the bone head of the deer arrow. Thure is considerathe variation in the number of harlos, which are always bilateral, wxeept in one

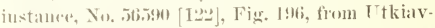
win, which has tom barlos on one side only. It is

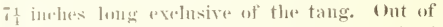
vight sperimens of suel heaklsone has one pair of

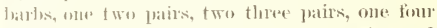
unilateral harbs, one tive pairs, one six pairs, anci one seven pairs. The total length of these hears is from ! inelies to I foot, of which the tang makes ahout 2 inclues, and they ane generally made of wallus ivory, wherein they difter from the mugfit of the (rrentanters, whicli, since crantz's time has always latd a head of irom. Jron is also nxed at cumberland finlt, as shown log the sperimens iu the National Musmem. Fig. Ist represents a very aneinent spearhead from Ltkiarwiñ, No.

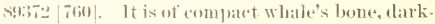
enesl with aget ame impregnated with oil. It is s. 7 indies long aud the other end is beveled off into a wedge-shajed tang roughened with crossculs on lootlo faress, with at small hole for the end of a lashing as on tha leat of No. 8924t [1325]. This was ealled by the native whe sold it the heral of a seal spear, a'liplignili, and it does bear some slight resemblaure to the leat of weajom

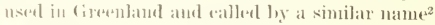
aglligak). The ronghenul tang, however, indicates that it was intended to be fixul permanently in the shati, and this, takes in enmection with

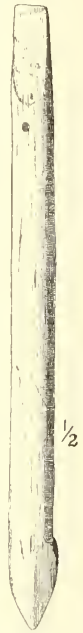
jts strongerescmblane to the one-barlyed bead of

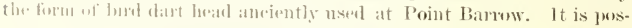

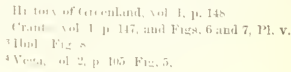




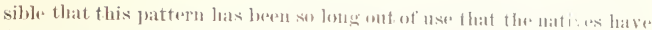

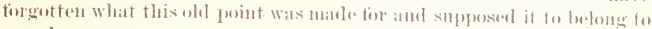
a seil spear.

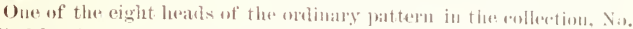

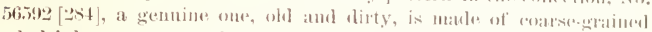

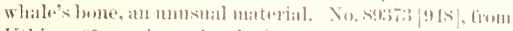
Lthiarwin, an ivory head of a gord typical slatpe, liak been figured (Fig. 19s) to shor is cosmmons style of orna-

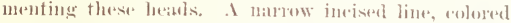

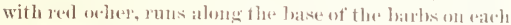

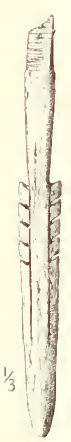

FiG. $19 x$. Point for. biril dart.

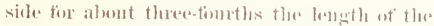
blable. Tluse heads are sometimes seromed by treenath as woll as by at simple latshing, as is slown ly the holes throngle the tang of this sperimell.

An imporement on this style ot dast, which

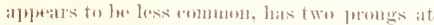
the tip insteal of at shatp leeal, so that the hire may be "aught if struck on the new with the point of the spreas. Yo. S(9) from T thiarwin, is one of this pattern. The two prongs are fastened on with a lashing of fine sinew braid. The rest of the dart does not liffer from the one deseribed exrept in the methos of attaching the these promgs at the mislle (Fig. 19:bb). These are tifted into slight groures in the wood and seromed by two neat

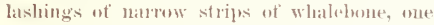
just abore a little ridge at the lower emel of

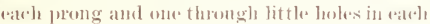
prong at the top of the oblique adge. Eateh lashiug emeists of several tums with the eurl elosely wrapped atremal them. There is one sperimen, Yo. 59243

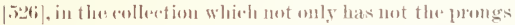

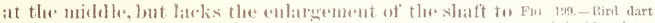

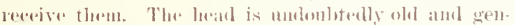

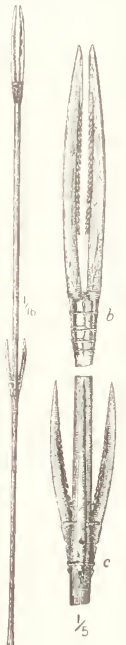
nine, but the shatf and tiffings, thongh dirty, look snspieiomsly fiesh. I an inelinerl to beliere that this bead was nomenterl for sile by a man who hath no pongs realy mate. and was in tou muth of a lemry to get his price to stoy to make them. Imprerlect or mutinshed objerts mere frecturently whereal firr silte.

The birl darts used at Point Barrow, and by the westem liskimo

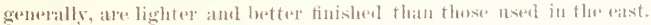
The latter lave al heary shatt, which is fomp-sided in biatin lamd, and the prougs are areolitil and wumsy. ${ }^{1}$

theo Crantz's figure referred to above; also one ia Parry's second voyage, Pl. opposito p, 55h, Fig. 19, and Rink, Tales, ete., Pl. opposite p, 12 


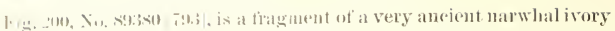

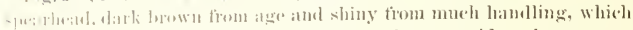

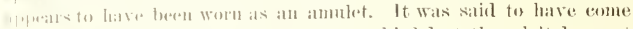

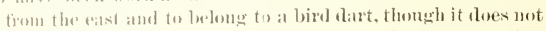

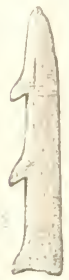
resembly any in nse at the present day in this region. It is a

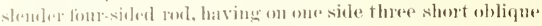
actulistant simple barts. The resemblanee of this speeimen to the trome lart heads from seanta figured by Dr. Rate is very striking.

Seal darts. - The Eskimo ot mearly all localities nse a dart

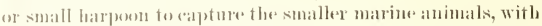

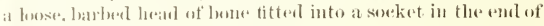
the shaft, to which it is attaleled by an line of greater or less

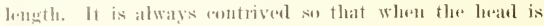
struek inte the quarry, the shaft is detareded from the head and ants as at drage upon the animal. This is effrected by

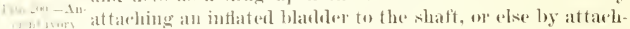
Thentral ing the line with at martingald so that the shaft is clragged sideways llorongle the water. Nearly all Eskimo exeept these of Point latrow, as shown in the National Mnsemm rolleretions and the figures

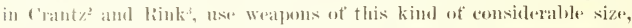
alipted mot only to the eapture of the small seals (Phoce ritulina and I'. fertille), but alse to the pursut of the larger seals, the narwhal and helugat. It leoint banrow, bowerer, at the present day, they employ only a suall form of this dart, not over 5 taret longe, with a litte heal, arkapted only tor holding the smallest seals. That they formerly used the lareger watpon is shown

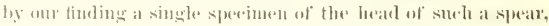

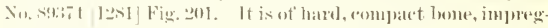
nated with oil. set inelow long. The that shank is evidently intented to tit into it soreliet. The two holes through the widest fart of the shank are tor attareloing the line.

This is very like the heat of the weapon ealled agligek

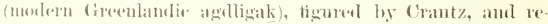

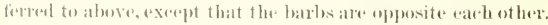
Mr. lueven .I. Turner tells me that it is presisely like the lead

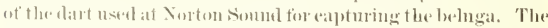
native who sold this speceimen called it "main'kpai nô'tkoa," "H the point of a birl diort," to wheh it does bear some resem.

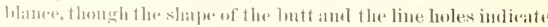
plainly that it was at detechable tart heatd. Probably, as in the

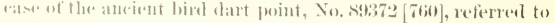

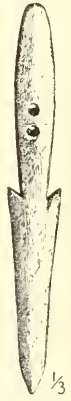

Fig. 201 lome dart lieitd. alueve. this watgon has lorese so long disnsed that the natives have

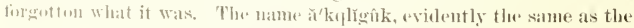

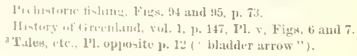




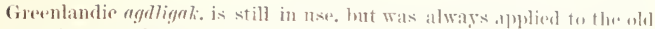

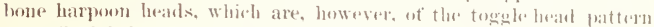

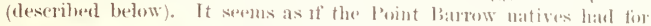

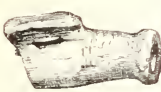

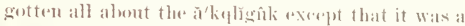

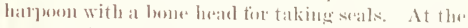

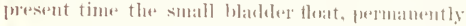

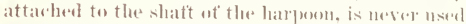

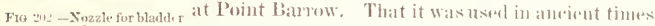

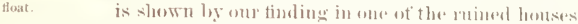

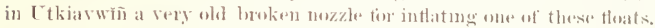

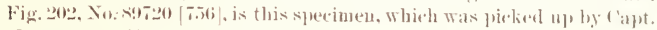
Herenderen. This is at momded tulue of fossil ivory, $1 \cdot 3$ inche hes fone and alwont one-halt juch in cliameter, shightly enutrant. al towarl one end and then (xpandeel into a stout mollas: At the other is a stont lomer. tuclinal tlange, thres-fourtlex ineh longe, pertorated with an oblowg slot. betweren the flange and the collar the sure face is rengherenel with cross. ents, and the othere enel is still choked with the jemains of a werlen pluge. This nozkle was inserted inter heole in the blad de' ats fall at the thange aud stemed by tying the blarlelere above the asllar. The whole. was then sereured to the shatt lya bashing thromen the slot, aud romld be inflated at pleats

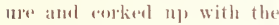
wootlen pling.

As I have alreadly satit. the only harporm of this kiml now noed at lowint bamow is a small oue intemeled only tior the capture of small seats. It has no bladiler, hut the rather long line is attached to the shaft hy a martingald. whirh makes the shatt doag sideways

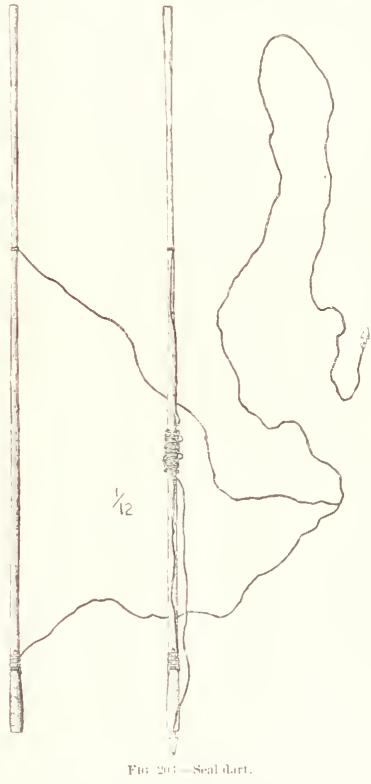
through the water. There of these little lates, which ane thrown with a haudbeard like the hird dart, make a set. The resistanerot the shatts 


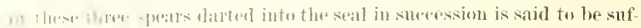

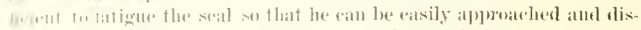

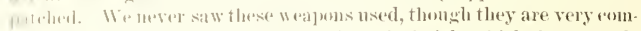

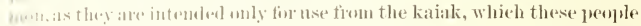

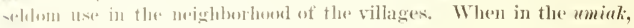

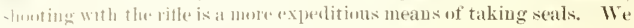
..ollected three sets of these darts (kúkigii).

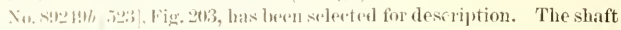

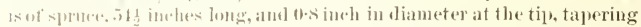
- lightls almest to the hutt, which is loblewed an the end to fit the eateh of the throwing loard. The fireshatt is of white walrus ivory 5 inehes lomg, and is fitten into the tiprof the shatt with a werlge-shaped tang. This formblatt. Whith lats a derp oblong slot torecoive the head in the misflle of its that tip, serves the demble purpese of making a strong

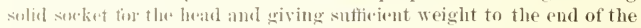
dant to make it tly straight. The hearl is a simple that barbed arrow-head

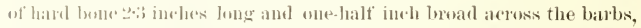
with a tlat tang. hovalest in the miclle, where there is a loole for attaching the hine. This leatel simply serves to attach the drag of the shaft to the sat ats it is too small to infliet a serioms womme. It is fastened to the shatt log a martingale made as follows: (1) end of a stont line of

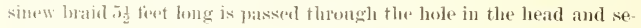
amol ly tying a kuot in the and. The other end of this line divides Into twi prants not yuite so stont, one 3 feest long, the other 2 feet 8 imelus. The latter is fastemed to the shatt 1 sid inches from the butt by a single malling hituh with the end wedged into a slit in the wood and seizad lown with fine sinew. Tha lomger part serves to fasten the foreshatt to the shaft, and was probably put on seprarately and worked into the brathes of the rest of the line at the jumetion. The foreshaft is licpt fiom slipling ont ly a little transverse ridge on eate side of the tang. Whan the Wapou is momuted for use the two parts of the brielle are brought togerther at the midelle of the shatt aud wrapled spirally alomul it till moly enowgh line is le ft to permit the lowal to be inserted in the socket, and the hight of the line is secened by tueking it under the latst turn. Where a seal is struek with this dart his sulden plunge

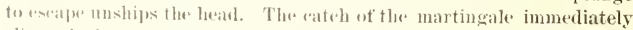
slips: the latter unolls and drags the shatt thromgle the water at right andes to the line. The slatft, losicles acting as a drag on the seal's motions, atso serves as a float to indieate his prosition to the lunter, as

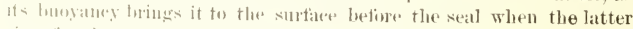
rises fin atis.

The shatt is tsmally painted red except so much of the end as bes in the gronse of the thowing board, in the aret of darting. These darts vary lont little in siza and ntaterial, ant ane all of essentially the same pattern. They are always almont is feet in length when mounted for use. (The lougest is $64 \frac{1}{3}$ inches, and the shortest 57 .) The head, as 
well as the foreshatt. is sometimes mallo of wallus non and the latter sometimes of whale's bome. The ohief variation is in the lomgth of the

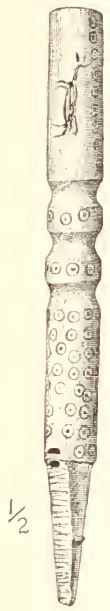

Fig, 201, Fort: ghaft of menal dart. matingale. and the destails oft the methenl of attarthing it.

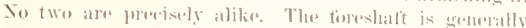
plain. but is oreasionally highly ormanenterl, ats is shown in Fig. 204. No, jti.s16 [10.i]. The figures are all incised] and colored, some with orlere and somes with soot.

Botle of the kinds of darts alwese describul are thrown by means of a hand hoard or throwing losint. This is a

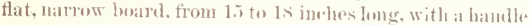
at onernd and a groove along the mper surtios in whicls the spear lies with the loutt resting anilinst al ratril at the other end. The dart is propelled by a quick motion of the wrist, as in casting with a fly-rol, which swings up the tip of the board and lamuches the dart firward. This and. trivanere. Which pratically makes of the latnd a lever 1s inclies longr. enables the thrower by a slight motion of the wrist to impart great ves. leseity to the dart. The use of this implement is universal amongthe Eskimo, thomghnot jusculiar to them. The (ivesul. landers. Low rever, not only ns. it fior the two kinds of darts alrealy mentionel, but have andeterel it to the Jarge hampen. This is moloubtedy to adapt the large lanperen tion use from the kaiak, whichthe (iresthanders use more lab hitually than most of her Eskinos.

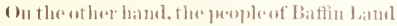
and the aljoining rewions, as well as the inhabitants of northeasteru silueria, nse it only with the biml dart. Thomehont west. mon North Anerien the throwing-board is nsel essentially as at Point lialrow. Prot. 1). T. Misonl hits given an intelesting ale-

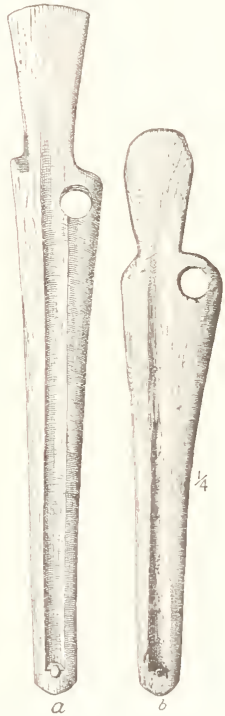

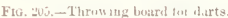
eount of the ditlorent ferms of throwime-board used hy the Estinn and Alents of North Americis.

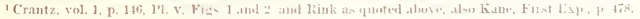

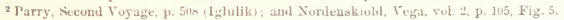

Smitheonian Keport for 1884, part I1, pp 279-289. 


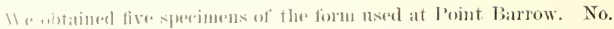

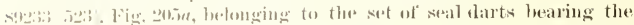

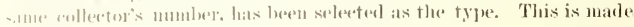

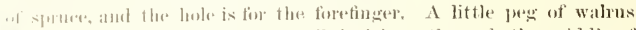

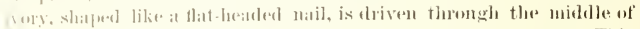

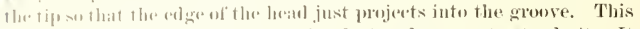
lit into the loullow in the lutt of the dart and serves to steady it. It

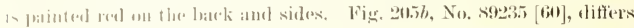
from this in having at double anrve instead of heing flat. A slight ad-

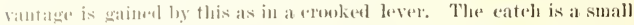
irom natil. The otherise are exsentially the same as the ty]e. No. s!2 234

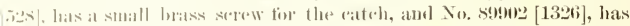
an isory perg of a slightly ditherent shape, the hear baving only a pro. forting point on one side. They are generally painted with

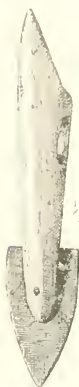
Fit: Zuti H:Ir

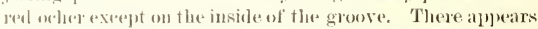

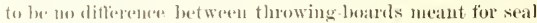
dants and those ased with the bird tant.

Infirtmately I had no opjertunity of observing aeeurately low the lamolle was grasped, but it is probably lede as

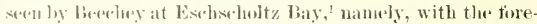

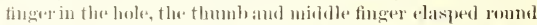
the spear, and the thind and little fingers elasping the hamdle moler the spear. This seems a very natmal way of holding it. oft course, the fingers reketase the shear at the moment ot casting. Alt the throwing-boatds from Point Barrow are right latudiel.

Horpons, _ 1ll kints of marine animals, inelnding the smaller stals, which ale also eaptured with the darts just descriloed and with uets, are porsued with harpoons of the simm gemeral tych, but of difrierent patterns for the different amimals. They may be thivided inte two classes-those in-

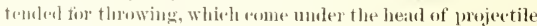
watpous, and these whiclo do not leave the hamd, but are thrust into the

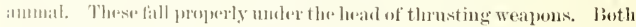

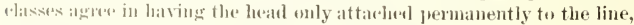
fifted louscly to the end of the shatt, and alranged so that when struck into the animal it is detarhed fiom the slatt, and turns molex the skin at right angl ('s to the line, like at togghe, so that it is almost impossible tion if fo draw 1011 .

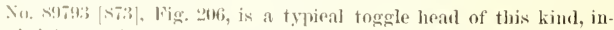

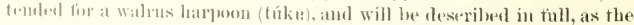

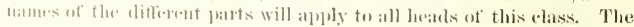

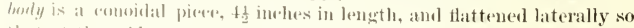
thist at the widest part it is 1 incele wide anel 0.7 thiek. On one side, Which laty be cathed the fooer, it is cut off straight for about half the 


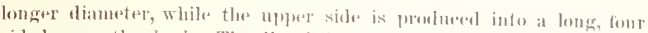

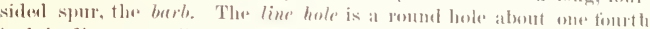
ineh in diameter, a little bark of the midelle of the lody, at right angles

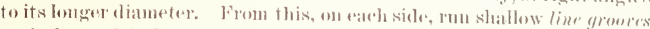
to the base of the body, gradually despening as they run into the line holde.

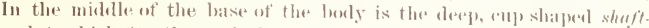
socket, which fits the emiseal tip of the shatt or tore shatt. In the tip of the body is ent, at right angles to the lomger dianeter of the boly, and therefore at riglit angles to the plane of

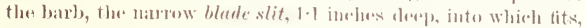
secured by a single molian rivet of whalelenes, the flat, thin blade of metal (torass in this atase). This is triangular, witle nurved edges, narrowly bereled on both taces, and is 1.3 inches long and 1 lroad.

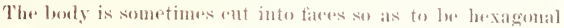

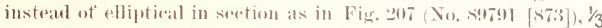

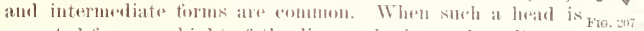

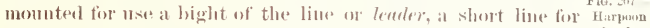
connesting the heat with the main line, lons though the line lead. loole so that the head is slong in a loop in the rod of the line. The tip of the shatt is then titfed inter the shatt sockot and the line brought

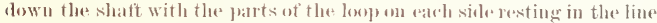
grooves and is made tast, nsually so that a slight pull will detareh it firom the shaft. When the animal is strock the blade cuts a woumd barese emongh to allow the hetal to pass in beyour the bath. The struggles of
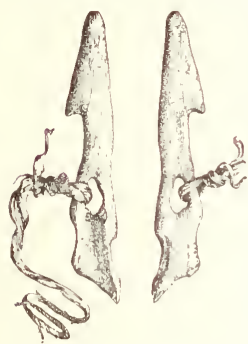

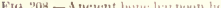
the amimal make the leat slip off' the tip of the shat and the strain on the line immediately fogegles it ancoss the womed. The togerle heat of the whale harpeom is ealled kiateron, of the walous latjoon, tuke, anel of the seal hatrooon, natule. They are all of assent ially the same pattern, thiftering chiefly in sizn.

There is in the wollection an interesting series of ohl harpoon heads, showing a momleer of steps in the derelopment of the modern pat ero of hanpon heal froman aneient form. These larals seem to have been preserved as amulets; in taet one of them is still attacherl to: a belt. They are not all of the same kimel, but since the different kinds as mentioned above pratidally difter only in size, their development was probably

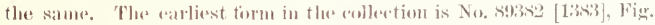
208, form Nuwnk, which is evidently very old, as it is moneh wom and weathered. It is a single flat pien of tine-grained lone 3 inches long, pointed at the end and povided with a single unilateral barb. Be. 


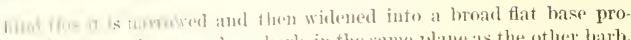

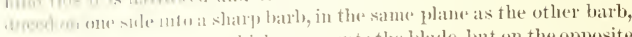

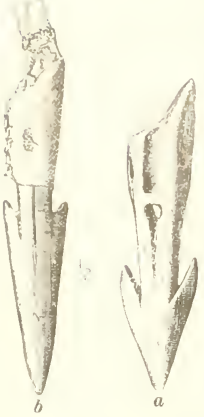

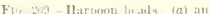

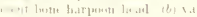
1. weth wit the 1 is which represents the blale, but on the opposite side. The line hole is harge and irregularly triangular, and there an mo line grooves. Instead (1) a slatit sondiet bored in the solid loody, one side of the bouly is axeavated into a deep longitudinal grouse, which was evidently converted into a socket by a tramsverse band, probably of sealskin, rmuning romul the lody, and kept in flate ly a shallow fransterse groove on the convex sile of it. I harpoom head with the sorkict mak by inclosing a groove with thongs was seenll by J1. Kane at smith sommt.'

The uext form, No, s9331 [9:2], Fig. 209k, has two bilateral barlos to the blade part, thes inereasing its lowhling power. listrat of an open transierse groove to hohl the thoug, it has two slots parallel to the sordict growe ruming ols.

liguely to the other side, where they open into a shallow depression. Figs. 2096 and 210. Nos. S!).34t

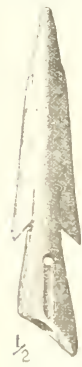

|1.419| and s9:37- [76ti], are variants of this form, probably intended for the bargar satal, as the blade part is very long in propertion. No. Sestst [141!) is interesting trom its elose resemblance

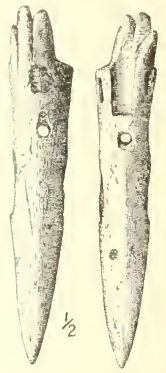

Fic. 210.-Bove harpoon leasl.

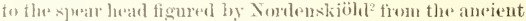
"()ukilon" house at North (apes. No. s9:377 [7660] is a pe('nliar form, which was jerlatps not geremal, as it has loft

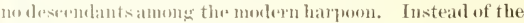
bilateral blade barlos it has an irregular slot on each side, which pridently sorvend fo bold a blade of stone, and the single latrb of the boly is replaced loy a eluster of four, which are neitler in the plane of the blade nor at right angles fo it, but lutworn the two. No modern harpoon leads from l'oint barrow have more than two banbs on the body. The mext imporement was to bore the slatt soeket

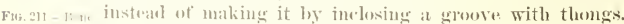

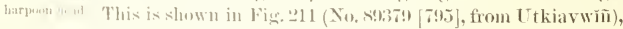

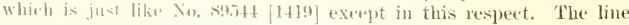
grooses first alperar at this stage of the development. 
The next step was to obtain greater penetration by substituting : triangnlar blade of stone for the binluel bone point, with its bratelt still in the plane of the body bath. This lolul, was eitlut of slate (Xo. $897+4[964]$ from Xnwriti) or ot Hint, as in Fig.

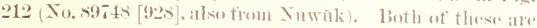
whale harpeous, such as are sometimes nset areat at the present day.

Betore the introduction of iron it was discoverent that it the blate were inserted at right angles to the platus of the

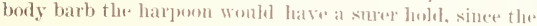
strain on the line would always llaw it at right amgles to the length of the womme ant ly the blauls. This is slowem

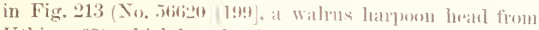
[thiarwiñ), whieh has the slate blate inserted in this position. Substituting a matal blate fin the stone one gives us the modern togeghe lowd, ats alrualy describerl. That the insertion of the stone black proseres the rotation of the plane of the latter is, I think, eonelnsively shown loy the whale harpoons' alleaty mentioned, in suite of the faret that

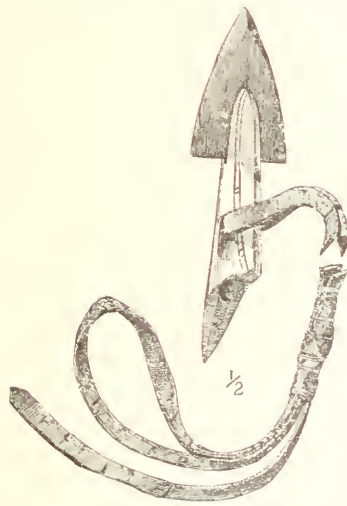

Fio. 2t3.- Harpoon head. bour atmi - twa we have a boue har. poom he:al in the eollection, No. s!mis [1ㅎt], tignrest in Point barrow report, which is exat ty like

which is exatetylike FH. 19 - Har. (*)

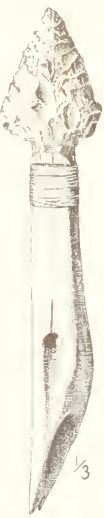
blate ot right angles to the plane of the borly latrl,. This is, how ever, a nowly mate molel in rein.

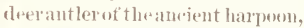
and was evilently masle bs a man sis nsed to the modern pat tern that he forgot this inpertant distine. tion. The development of this spear head has been carried no tiurther at J'oint Barrow. At one. or two places, howerer, namely, at ('mmberland cinlt in tlee east' and at sledege Island in the wost (as shomา in Mr. Xelson's collece tion), they go at step furtlere in making the hear of the seal harpoom, borly and blade, of one pioce of irem. The slatpe, botrever, is the satme as those with the ivory or lome louly.

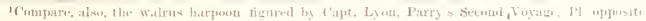
p. $550, \mathrm{~F} \div \mathrm{L}, \mathrm{I}:$.

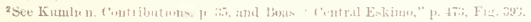


Ill of the Eskime riter, ats fur as $I$ lave any definite information, use

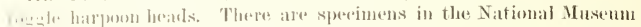
fimm fireenland, cumbertand (inlf, the Andersen and Matekenzie region,

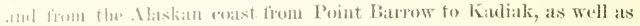

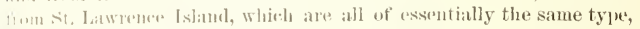

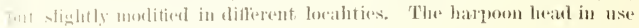
1 Suith somml is of the satme form as the walles harpoon heads used at Point bartow, but appuas always to have the shat sorket mate by

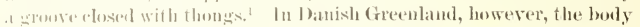
lis an extra pair of frilateral larbs below the biale. The Greenlanders halle, as it Were, suhstituterl a mexal blate for the point only of the

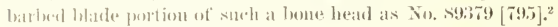

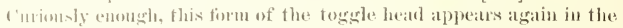
Iatelinzie and Anderson legion, as shown by the extensive collections

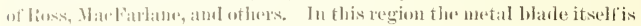
witer ent into one or mere patis of bilateral barls. At the straits of Fury

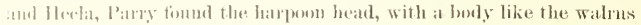

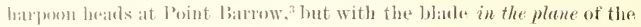
houly barb. Most of the pirtures stattered through the work represent the blade in this position, lont Fig. 19 on the same plate has the blarles at right angles te the barb, so that the older form nay not be nuiversal. Af cumbertand finlt the form of the body is considerably moditiol, though the blate is of the usat shape and in the ordinaty postion. The fex] is thattened at right anghes to the usual direetion, so that the thichnesis is mong greater than the width. It always has two body

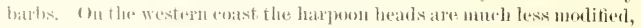
thongh there is a tembency to inerease the mumber of lowly barbs, at the same fime ornamenting the body more aborately as we ge south fom bering strat. Walms harpoon beals with a single barl, hardly alislintwishatble from those nsed at l'oint Banrow, ane in the collectien from the I bomedes and all along the enertiern shore of Norton Soumd, and one alse trom the month of the Kiskorpin. They are probably also

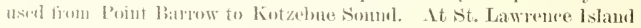

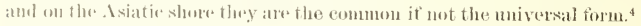

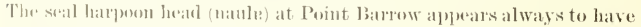
the body barls split at the fip inte two, and this is the ease ratrely with the tukte. This torm, which alphears oeerasionally morth of Norten

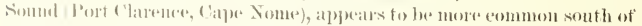
this lecality, where, howerer, at patteren with the ballo divided into there

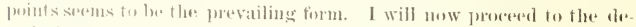
scription of the dibterent forms of harpoun with which these togrgle he:als : atre usal.

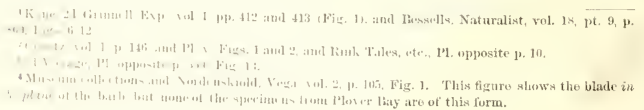


Throwing-harpoons are always thrown from the hand without at

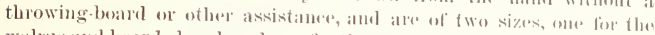

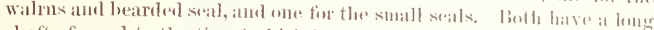

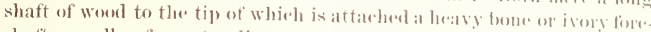

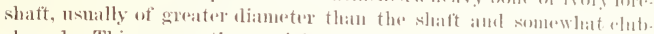
shajed. This sorves the special furpose of giving woight fo fle hesid of the harjoom, so it wan be darted with as sure ane. The native name of this part of the sjeatr, nkmualuta (freenlamlis, okimatilutak, weight), indieates its designe. This contrivanee of weighting the heald of the harpoon wite: a heary foreslatt is peenliar to the western liskimo. (1)

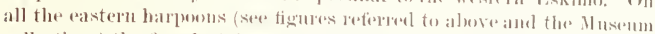
collertions) the foreshaft is a simple eapof bone mo larger than fles shat

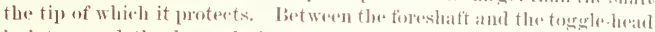
is interposed the loose shatit (i'simii), a slomeles rod of lone whose lip)

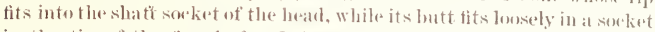
in the tipe of the fireshaft. It is seroment to the shaft by a thong just long enongh to allow it to be mohipued foum the foreshati. This mot only prevents the loose shatt from lowesling unter a lateral strain, but by its play facilitates moshipping the hatad. On these harpous intended for throwing, this loose shaft is always shout. This loringe the weight of the foreshaft close to the head, while it leares suace enough for the head to peretrate beyomel the barls.

The wallus harpoun varies in size, being ablated to the strength and stature of the owner. (of the six in onr collection, the longest, when

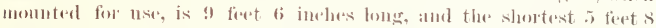

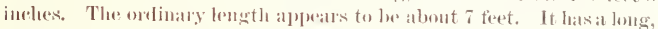

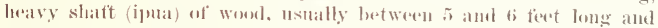

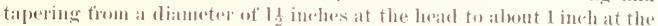
butt. The lewal is wot usually fastened divestly to the line, lut has a

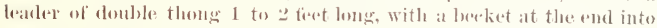
which the main line is loopert or hitehed. It the other end of the line, which is about 30 teret lons, is another bereliet to which is tistented at that consisting of a whole sealskin inflatecl. Whe+1 the head is titted on the tip of the loose shat the line is brenght down to the mishle of the shate and leokerl by means of a little beeket to an ivory pese (ki'lerlywhii) projecting fom the sisle of the slatit. The easteln Exkime have, iu plate of the simple becket, a unat little contrivance consisting of at plate of ivory lashert to the line with a large slot in it which hooks over the rateli, but nothing of the solt was observed at Point Barrew.

The hampon thus monuted is poised in the riglit hamd with the fore. finger restiug against a curved ivory juojertion (ti/ka) and darted fike : white mats harpoon, the that and line being thown overluant at the sature time. Whena wallus is struek the head slips off and togegles as al

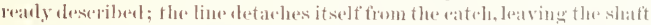
free to float and be pirked up). The float is now fastemed to the wall rus, and, like the shatt of the seall dart, both shows his whereabonts 
und atets as a drag ou his movements until he is "played" enough for

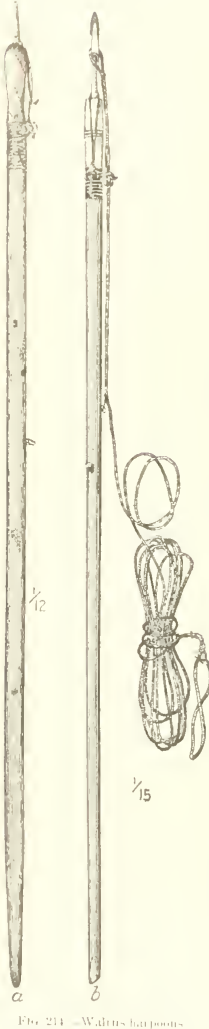
tha hunters to come up and dispateh him. This watpon is called n'nakjuk, "the great n'na or spear." U'na (unik, n'nañ) appears to be a generie trun in Eskimo for harpoon, lut at Point Barrow is now restricted to the latrpon used for stabbing seals as they come (u) to their breathing holes.

Wre collected six of these walrus harpons eomplete amel torty-two separate lieads. Of these, No. 56750 [534], Fig. 21 to, has the most typural shalt and loose shatit. The shaft is of sprume if inclues long, romghly romuded, and tapering from al dianeter of $1 \frac{1}{2}$ inches at the tip to (1). at the lutt. The foreshaft is of whit wallus ivory, 6*7 inches long, exthsive of the wedere-shajer tang which fits into a retet in the tip of the sbatt. It is somewhat clnh-slatued, being 1. in inebes in dianeter at the fip and taly ring to $1: 3$ just alowe the butt, which expands to the diameter of the shatt, and is separated from the tang by a scuare transverse shonder. The shat and fineshaft are fastemed together by a whipping of broal seal thong, put on wet, one end frasing thromgh a liole in the foreshaft onequarter inch from the shalt, and kept from slipuing ly a low transverse ridge on each side of the tang. In the tip of the foreshaft is a deesp, romul sosket to receive the loose shatt. which is a tapering rod of wahns ivory 4.4 inches long, shouldered off at the butt, which is 0.7 inch in sianeter, to a blunt, rommled tang 0.9 inclu long. It fits loosely into the timeshatt 11 , to the shoulder, and is senres by a piece of narrow seal thong which passes through a transwerse loole onehalt inch above the shomlder. The end is spliced to the standing part with double slits about dinches from the loose slatit, and the other end makes a comple of tums ont siele of the lashing on the shaft mentioned above and is secomed with two half-hitehes.

The line catch (ki/lerbwiñ) is a lit tle, blunt, larkwarl-pointing look of ivory inserted in the slaft 17 inches from the tip amel projecting

abont one-thind incl. Ten and one-fourth inches fartler back and 90 


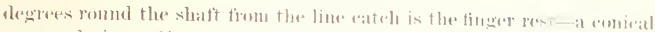

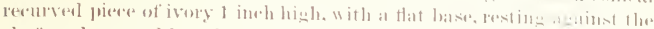

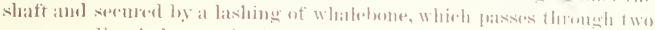

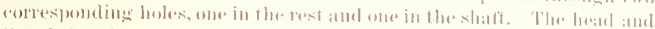

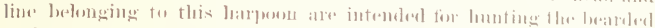

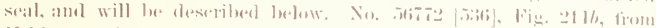

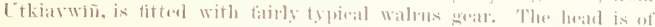

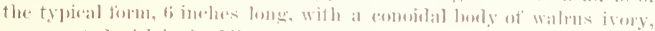

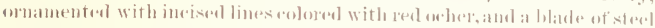

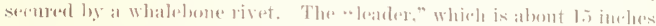

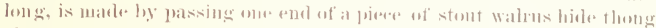

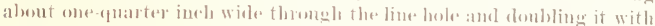

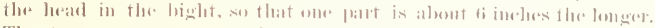

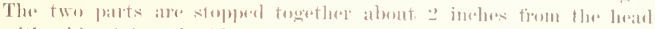

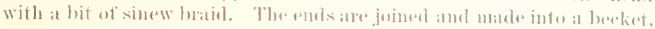

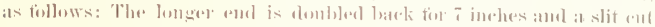

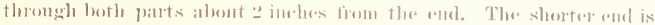

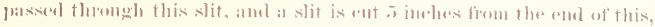

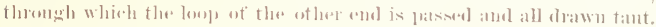
The whole joint is then tightly seized with sinew lomed so as fo leatre a

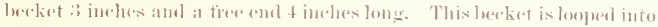
an rye $1 \frac{1}{2}$ inelyes long at the end of the main liwe, made ly doulding

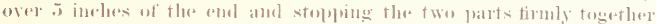

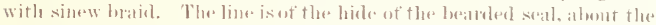

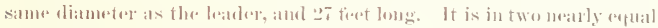
farts, splieced together with domble slits, timly seized with sinew

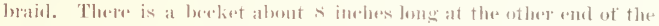

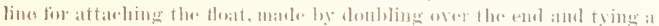

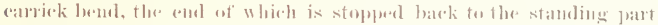

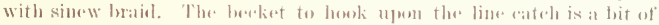

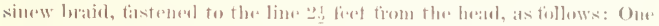

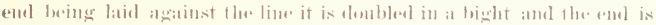

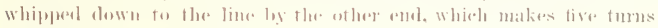
romul them.

I will now romsisles the variations of the different parts of these har.

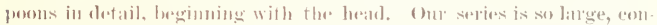

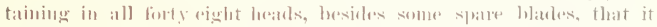
pobsably gives a tair representation of the rommon variations. The

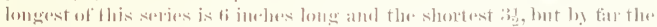

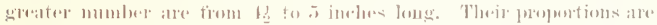

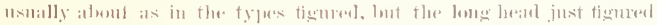

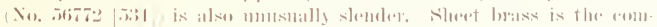

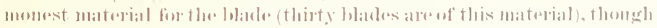
iron or steel is somerimes 11 sed, and rarely, at poresent, slate. There is

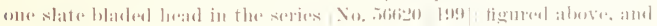

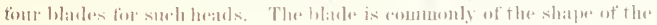

a $\mathrm{x}$ Tu-15 


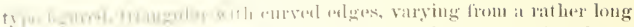

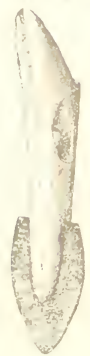

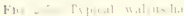

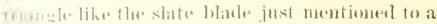

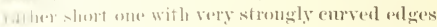

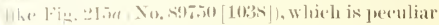

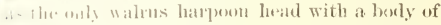

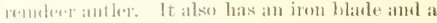
rivet of irom, not seldom with romeled hasal an-

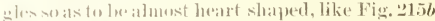

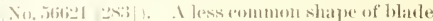

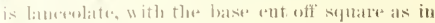

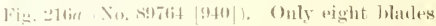
ont of the serties ate of this shatpe. I still more

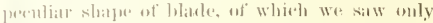

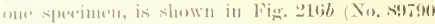
194:3. This is malle of loriss. It was perhaps merilut for an infation of the batred blates used at the Nackenzir, of which 1 hase already spoken.

The hlarle. when of netal, is genterally fastened in withat single rivet. One maly ont of the whole mumber has $t$ wo rivots, and thres anr simply wedged into the blade slit. The - late hlides apluear neter foltavelenen rivetol: Nordens.

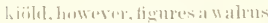

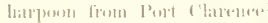
with a jarle blakte rivered in. The riset is semerally mate of whaldebone, lout of here materials are sometimes misel. For in stialere. in the serites rollected two has r. rivets of ilon, two of workl, and five of raw hicle. The. buls is generally marle of white wallos ivery, five of these aol. lected are of hand bone, and one aldeaty ment ioned and tigured,

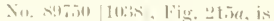
ut remeloer antlere, and the hevagural shille, ofton with

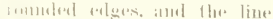

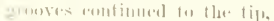

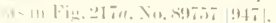

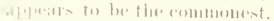

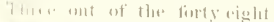
fingere lime sicled borlies. It is

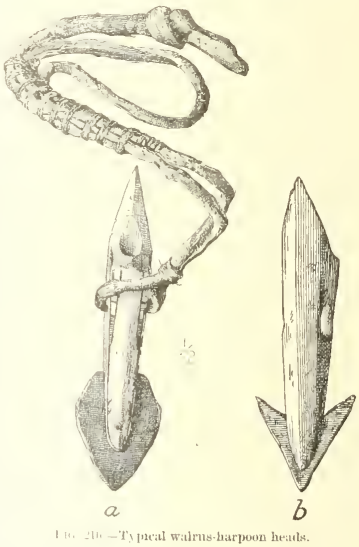

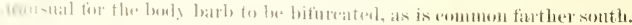




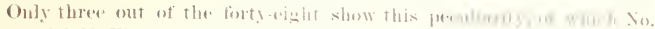

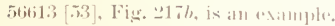

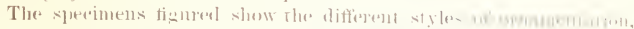

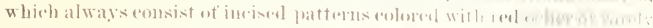
with seot. Thene+mevis me resent natmial oljerts. but arealwatysonventional pat terus, generally at single on

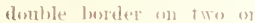
more farces with short ob liqquereoss-binessand branch es. 11:arpom leamlsat loint barow ane pobals! lespl oruamented with the -. c.ireles and dots." sa conmmon on other implements and on the harpoens of the sonth. thu liskime.

Twenty-eight of the hearle still have the leallers at tar-hed tothem. Theolyeet of this short lime is to nat ble the laweter to rearlils de. tach a booken leasl and put

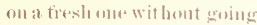
to the tronble of undoing at spliee, whith mast be mate. strong to kereptle lead from

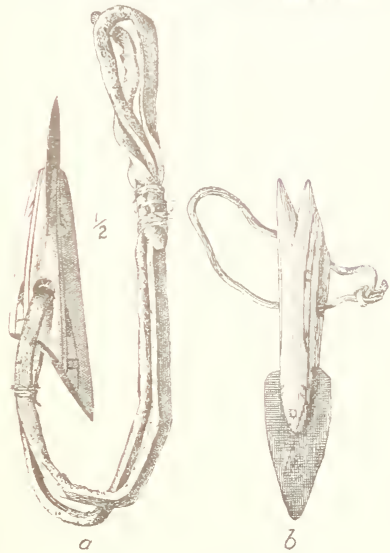

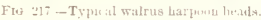
separating trom the line. It is maule of a stont piece of rawhise thong, the skin of the watrus or bearled seal, about ene.third inch in dianeter,

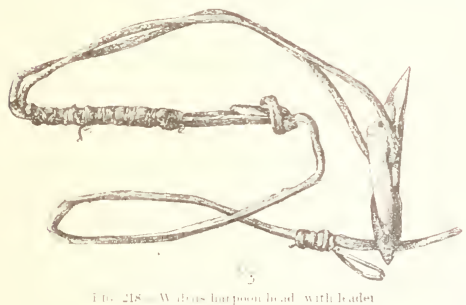
and nsually fiwn 2 to is feet long. It is al. wajs passed through the line hole, ats in the specimen describesl. and the ands alre made into a beeket tor'ittachiug the biure, with in enel lett to serve as a haturlle tor pulling the twa herels tots a but whent the matin line ('muls in at

bereket. Gorasionally two ane made this way) the lomger eme is simply doubled in a bight, and the these pates ale then selged togethere with sinew bratel, lont it is genemally mate with a splice, the details of which dither slightly on the diffirent baders. 


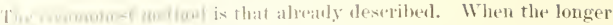

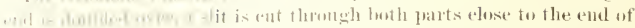

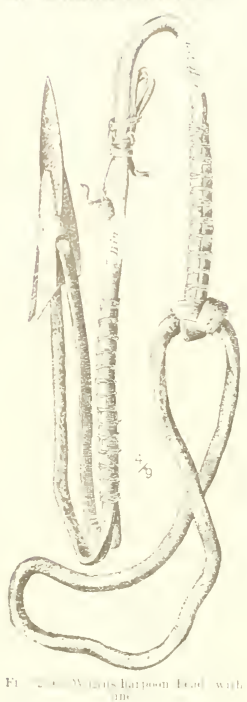
this through whielithe slorter eut is pasised. I slit is thell ent a fow incless fiom the tip of this part, the bight of ale beeket passial throngh this slit and all drawn tant. This malios a very strong splice. Fomten lowe. ets ale splioed in this way. A variation of this splice has a slit only thromgh the enel part of the longer end, the shorter end being bassal through and slit as before. In bus bered the standing pant of the longer enul is paskeel thowngh the slit of the end part lactore some thromgh the line lowe, while the lest of the lyerket is mate as before. Ireververl splice is tomel an three of the leaters, whind is mate as follows: Whon the long end is dombled over, the slont and is slit as usial and the longre end passed thromgh this and slit close to the tije. Thomegh this slit is passed the hearl and all drawn tant. The spliee is always firmly seized with sinew loaid. The main line. which serves to attach the bracl to the flost, is al ways makle of stout thomg, prefereably the skin of the bermbed seal (very fine

limm are somotimus mate. ot belugal skin. 4hent une thinel inel

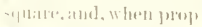
wh mate, trimmed of and the e.tgen st at an to 10. Ilumet romul. It is

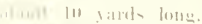

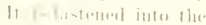

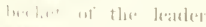

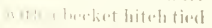

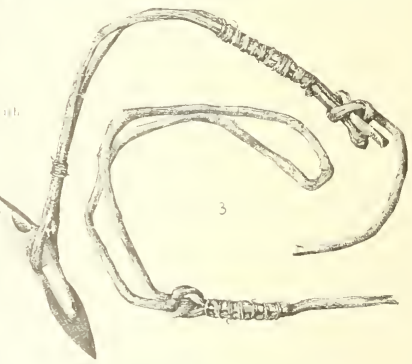

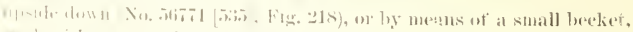

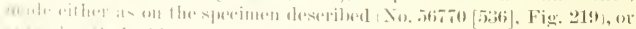

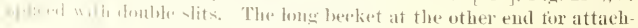




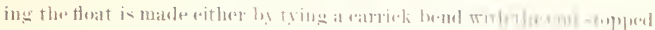

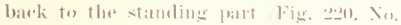

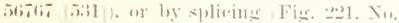
5tititi?

The lowse shatt varies rery littlu in shates. thomgh it is sometimes lomblal ont at the.

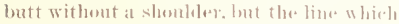

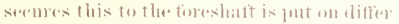
ently on eath of the six spears. Fire of

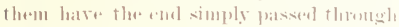
the lowe in the leose sloaft and splieted to

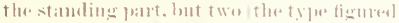

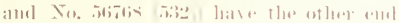

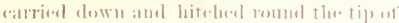
the shaft: ancither has it pasued throngh at

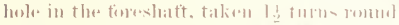

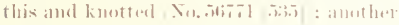
has a loop as lome as the formshaft with the

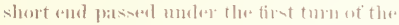

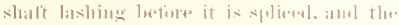

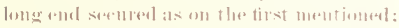

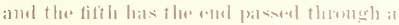

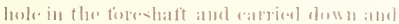
waplenel romed the shaft lasking. The

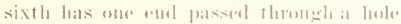
in the smallest part of the forreshalt amel knotted at the and. the otlew. end edrred

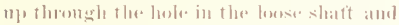

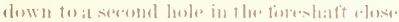

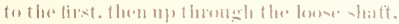

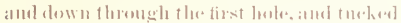
undere the two pate som the ot lawe side.

The foreshalt is mate at watrus ivory of

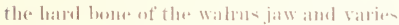
litule in linen and almensoms. It is vome times oruamented hy arvilug ats in No.

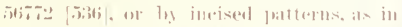

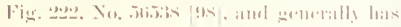

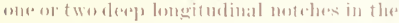
thirkest part. in whirh the limes rall be drawn smugly down. It watlally is joimed

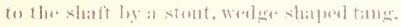

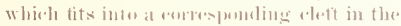
slatt, amel is seremed by woslen tromenatio

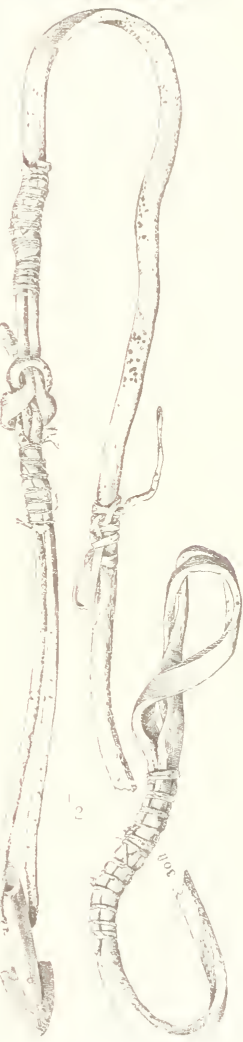

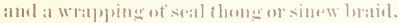

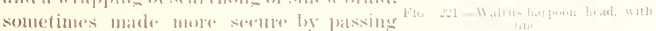




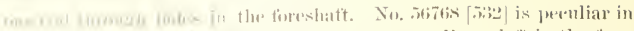

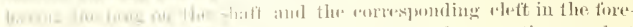

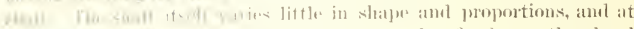

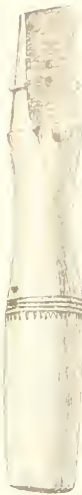

1.... Ins Gisti it $\rightarrow$ Hit

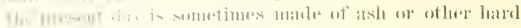

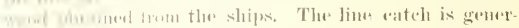

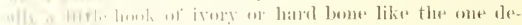

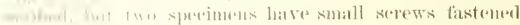

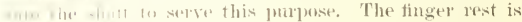

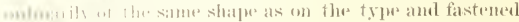

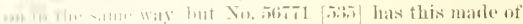

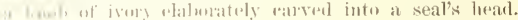

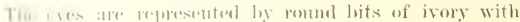

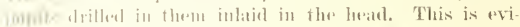

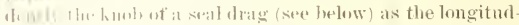
in.il furtiation trom thin to naje now serves no purpose.

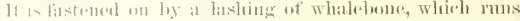
ramol the shatt and thomgl at transterse lowle in the knob.

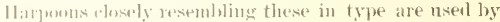

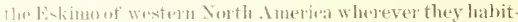

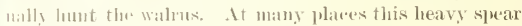

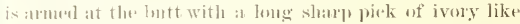
the smaller seal spear. Two of these large harpooms ap.

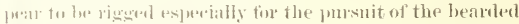
stall, as they latve hearls whinh are of preasely the same shape ind matrial as the small seal haproms in the ool

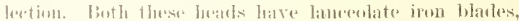

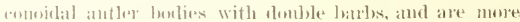

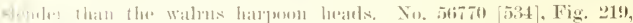

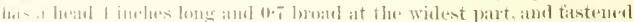

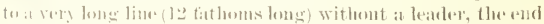
heine simply passed thromeh the fine lobe and seized down fo the stameling part with sinew braid. This is the mether

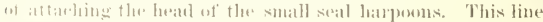

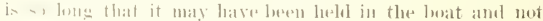

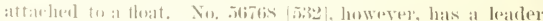

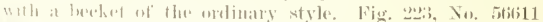

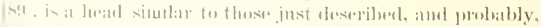

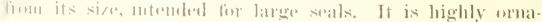

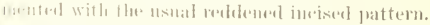

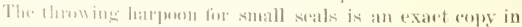
miniature of the wallons hanjem, witl the allition of a long

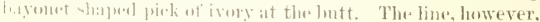

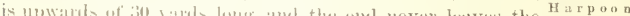

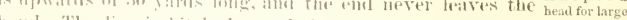

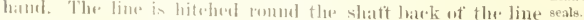

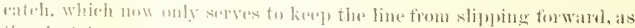

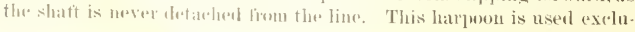




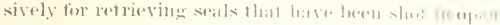

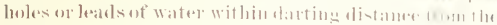

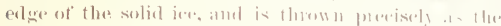

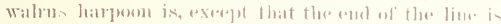

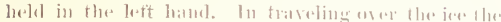

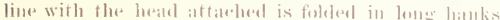

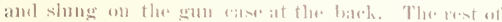

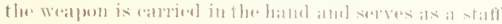

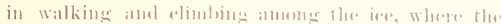

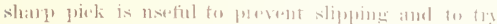

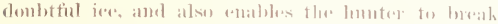

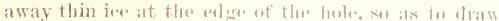
his wame up to the solid flere. It tall also sefve as a

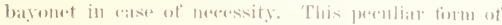

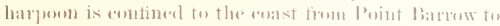

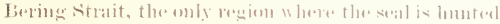
with the rifle in the surall open heles of water

Sime my note in the Nithralist wats written, I halve

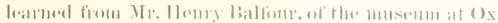

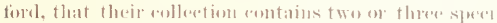

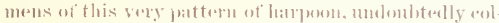

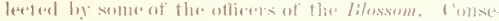
quently, my theory that the retrieving hatrent was at

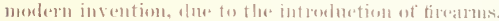

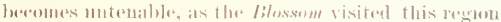
befine tireams were knuwn to the liskime. It was

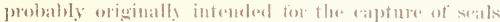
"hambed wett" on the iere in the early smmmer. There is an dombl, howeser, that it is at the present dar usecl for mothing but retrievine.

Thomgh this wapen was universally nsast at leoint

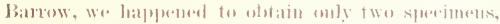

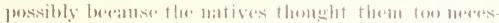
siry : an implement to part with lightly. No. s!!!ot

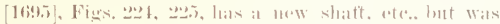

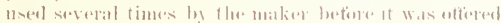

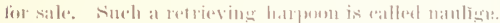

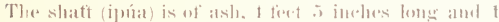

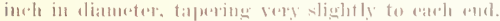

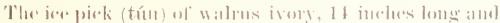

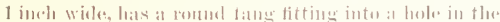

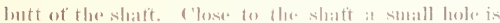
drilled in one alye o" the picke and thement this is

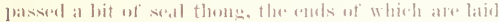
along the shatt and neatly whipged down with simew brait, with tlas and werlesed into a slit in the worel.

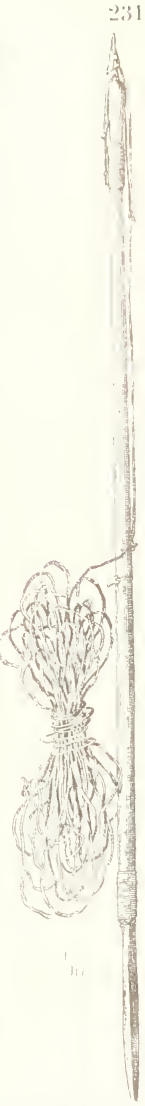




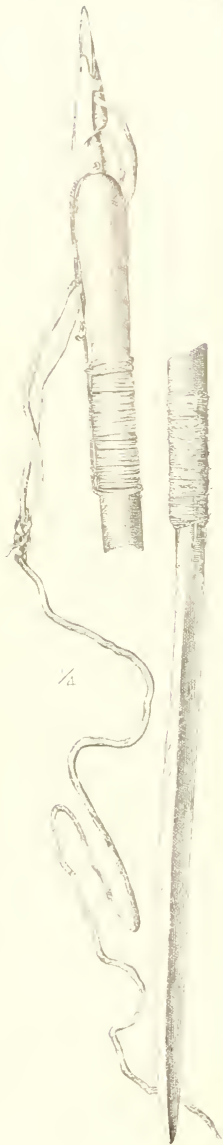

The forceslate (ukumailnta) is of walrus ivory, th ind Jes long and $1 \frac{1}{2}$ inehes in diameter at the thickest part, and serenred to the

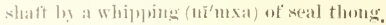
The louse shatt (igrimin) is also of ivory anc 2 inelues loug and secoured by a thoug (younta) splical into a leope thromgh the hole at the loutt, ats provimsty deseribed. The enel is hitched romal the tip of the shatt with a mating lite-lo. tollowed by a clowe hiteh below the whipping. The ivory finger rest ti'kal) is fastmurel on with a lashing of whip coryl (white matr's) passing romud the shatt. The Iine ratele $(\mathrm{ki} / \mathrm{l}+\mathrm{b}$ wiñ $)$, whieh was of ivory and shaperl like these on the wallus harpogns, has been lost in transportation. Ther leat difters mly in size from those just

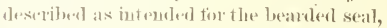
exerent in having a luxagenal body. It is :3*3 im lues lowg aud las a hade of irom lastened into a ledy of wallons ivory with a single: Worken rivet. While there is no

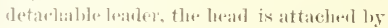
al sirparate piene of the same material to the Jim (tikinkisia), which is sib feet 10 inchess lomgr and urarle of a simgle piece of fiue seal thong abont onterighth inch thirk. This

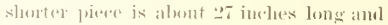
is pasiofl thromgh the line loble and dombled sothat on part is a little the longer. It is fastemed strongly to the end of the line by a somplinates splice made as follows: A slit is ent in the and of the main line thronghe which are passed both ends of the slont line. The longer part is then slit alunt 2 inderes tiom the eurl and the shorter pant passier through the slit, and a slit ent elese to the "mel of it, through which the lougere end is pasised. The whole is thest drawn tount and the longer

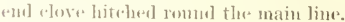

No. simens [10.s. is one of these speats rigeral realy for darting. The line is se. cored at alont the mildle of the shatt with a comple of malling hitehes. This sperimen, except the head, is new and was rather carelesty makld for the market. It has neitler line "ateh nor finger rest. The 


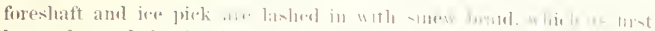

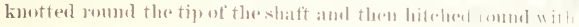

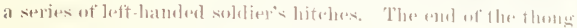

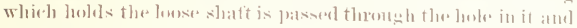

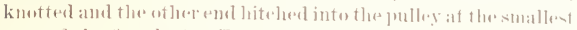
part of the foreshaft. The lowad is like that of the pureseding.

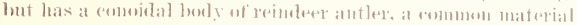
for seal-harpen luakls.and the line, which isof stout sinew luat

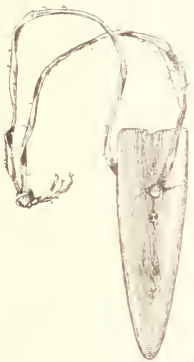

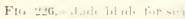
It if fis fint lome, is attarehed to it simply by paxsinge the end threngh the lank hole. and tying it with as elese hitelh for the standing part !) inches tronn the luakd. This sleat is allout the salme size as the powedimg. These watpems are all of the same gemeal patterm, but vary in longth aceousling to the lowight of the owarte. The latals lore these harjousts.

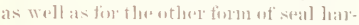

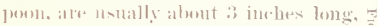
audl. as a rale. have lameenlate blades. Tlu bouly is wanerally comoldal, often made of reinderer antlere and always, atprarently, with at double batro. It is

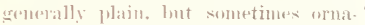
muntol like the watrus-harpoum lieads.

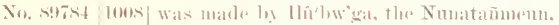
when thinking of coming to winter at Ttkiarwiñ. Ile has

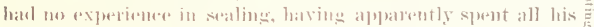
winters on the rivers inlaul, and this harporm head seemens to

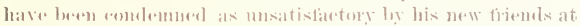

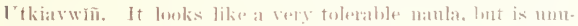
sually small, being only 20 in inclu- long.

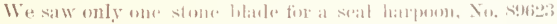

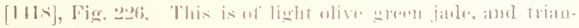

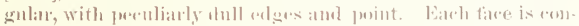

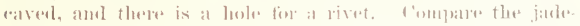

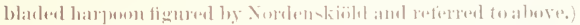

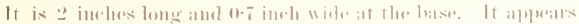

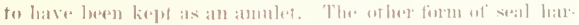

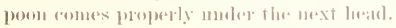

\section{H1:1-HIN, WI UWD-}

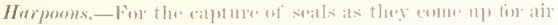

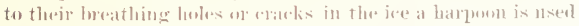

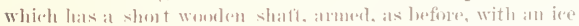

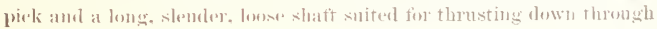




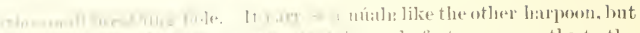

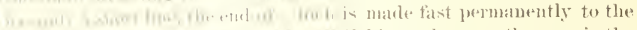

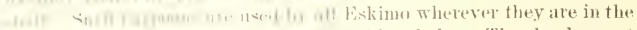

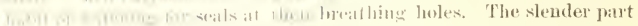

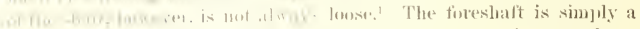

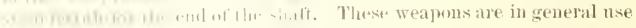

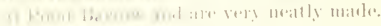

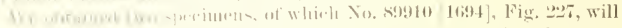

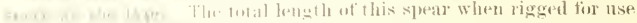

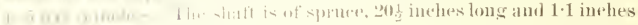

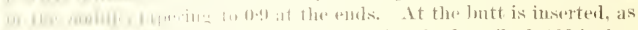

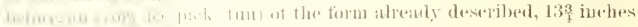

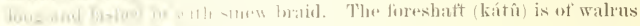

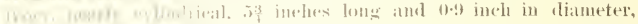

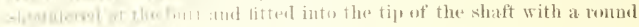

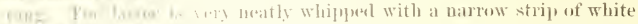

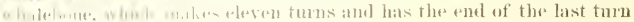

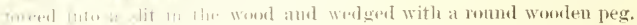

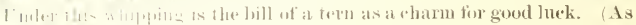

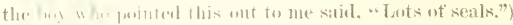

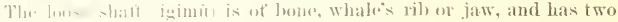

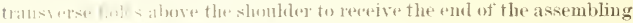

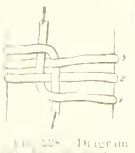

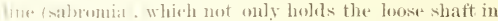

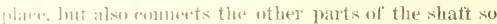
that in case the woos lorraks the pieces will not be

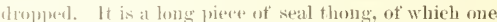
cond nalies a turn lonum the leose slatit between the

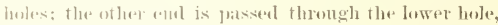

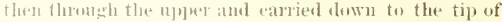

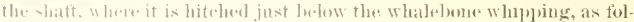

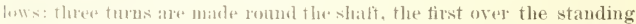

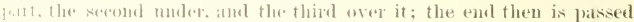

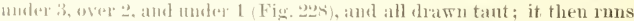
down the shatt alumst to the lontt-lashing and is secrured with the same hitels, and the ond is whippes around the lutt of the ice piek with five

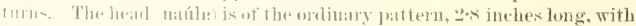

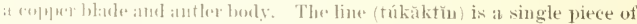

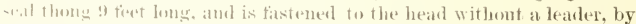
simply patsing the and thomgle the line-loble, denbling it over and stopplite it to the standing part so ats to make a her ket 21 inches loug.

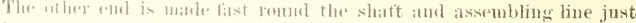
hatel of the midhles as lollows: An eye is matle at the end ot the line,

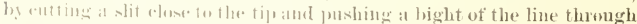
this. Therent then thathes a turn round the shatt, and the other end,

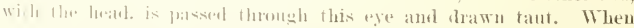

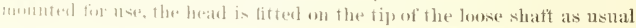




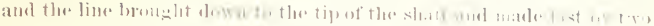

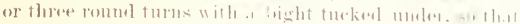

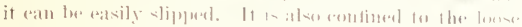

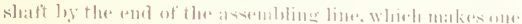

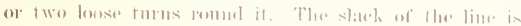

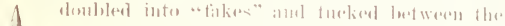
shatft and atsarmblime linte.

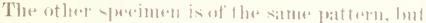

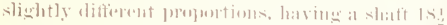

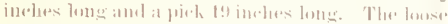

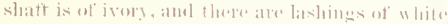

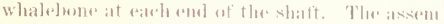

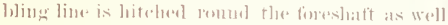
as romel the two ands at the shatt. and simply

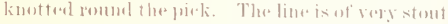
sinew balid, and has an eye meatly spliced in the

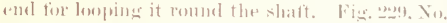

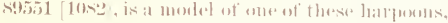

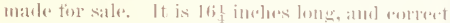
in all its parts. exrejt that the whole heat is of isoly, "ven to having the ends of the slatit whipperl with light eolomel whalelone. The shatt is of pine and the rest of wallus ivory, with line

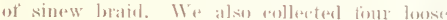

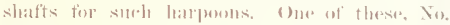

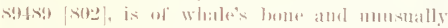
shert. only 11 inches long. It perhatps betongerl

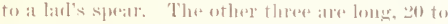

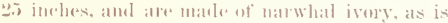
slown ly the spiral twist in the grain.

The harpens nased for the wlate fishery is a heavy, lolky watpwn, which is never thrown, lout thmost with looth hatmis as the whald rises ander

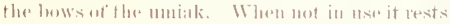
in a large ivory crotels, slatjes like at rowleck, in the low. The shaft is of woes and s or ! feet long, and tlaere is no louse shatt, the lome or

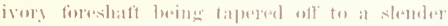
peint of smeh a shaje that the leval easily un Fos esa-ships. This foreshatt is mot weighted, as in the

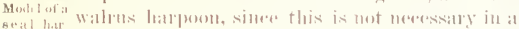

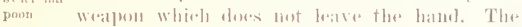
harpenen lime is titted with twe inflated seatskin Hoats.

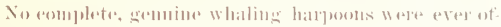

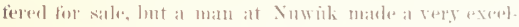

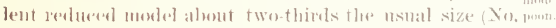

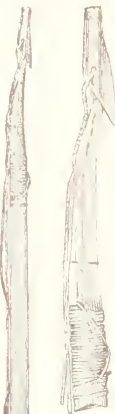
6.

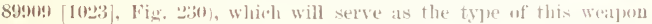




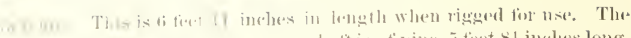

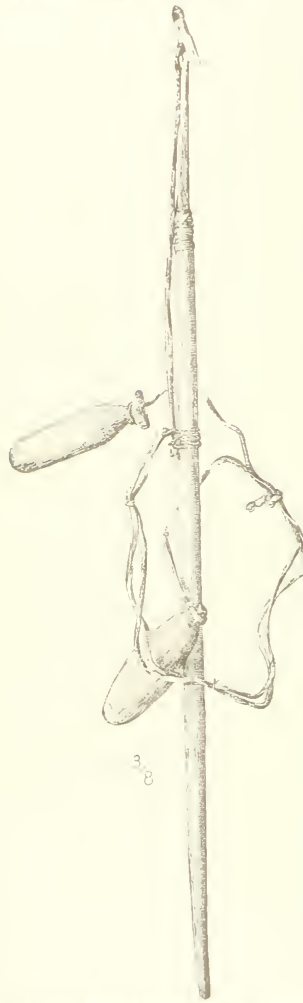

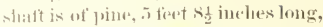

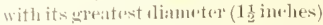
well forwatid of the midlle and taproded more towari the butt thas toward the tip, which is chanfered a17 (1) onle side to fit the butt of the foreshatt (igintio), and slomblered to kerepthe lashing in plare. The fore shati is of whale's inome, $11 \frac{1}{2}$ imelores long. threesesiled with wore adge romeled off, and tapers from a diam. refe of 1 inch to a tapering roundert point 11 inehes long, and slightly areved a waty from the flat tare of the foreshatft. It will a asily loseren that the shape of this tip fiecilitates the unshipunget the lasar. The lontt is r. liamberes off on the flat face to fit the "lomenter of the shatt, and the whole toreshatt is slightly enreed in thes same direetion as the tip. It is sectured to the slatit by a stomt whipping of seal thome. The learl is 7 inches longe, and has a bedy of walmis ivory, which isornamented with incisal pattems abored red with weler. and a blade of dart reddish frown jispere neatly flakme. This blard" is mot unlik" at large arrow lutal, heing trimgular, with rused rolgess, and a short, loroad tang imberdad in the tipe of the berdy, which

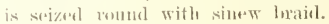
The burly is musmally lomeg and slenlet and is fomr siclesl, with a single long. sharp harb, kesded on the onter fare. The line hole and line grooves atre in the nsual position, lust the ferentiarity of the heal is that the hlade is inserted with its breadth in the plane ot the body barb. In otluer words, this ladad has not reached the last stage in the development of the tergele-head. The line is of stont

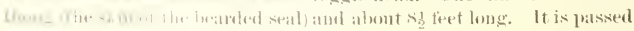




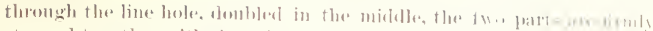

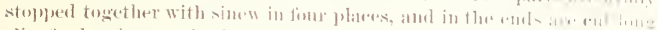

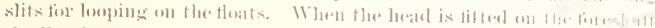

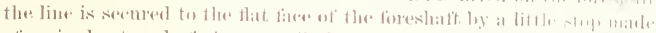

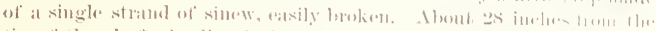

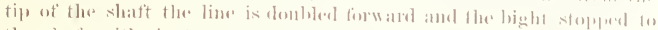
the shaft with six lowes of seal thohge, so thatt the line is held in plate and yot an ber easily de. tached by a straght pull. The ends are then donbled track over the lashing and stoplyed to the shaft with a single thrad of sinew.

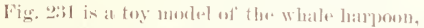

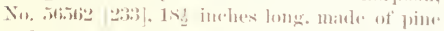
and ivory, and shows the matmere of at atelling

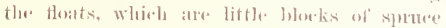
romghly whittled into the shape of intlaterl seal. skins. I piow of seal thome $1: 3$ inclus long

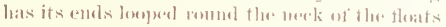
and the harpun-lime is leoperl inter at slit in the. mialdle of this line.

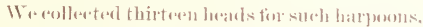

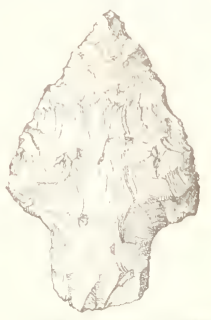

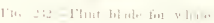
1) 11 1

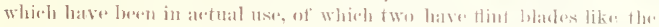

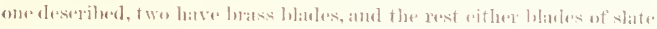

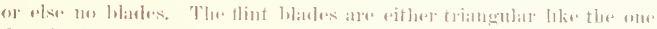

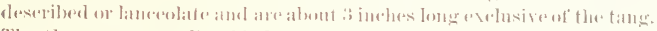

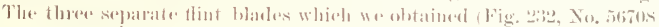

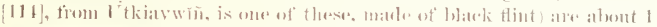

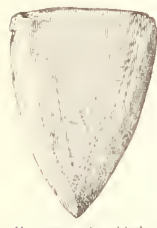

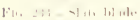
tor is fit. Hertunit

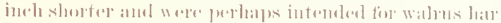

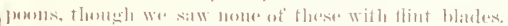
They atre all new ly mate for the natret.

The slate blades of which we abllecterd eleven, semer

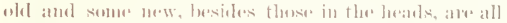

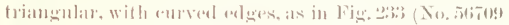

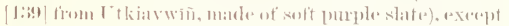

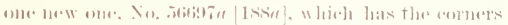

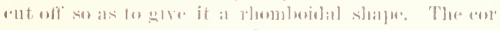

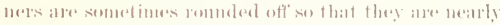

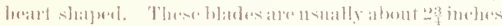

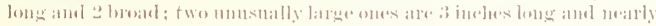

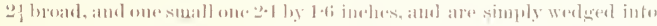

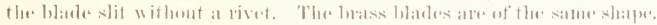

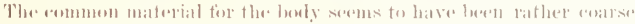

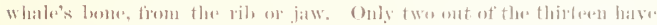

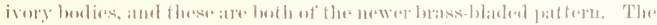

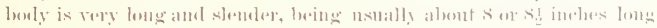

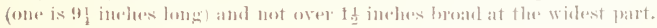




\section{Z2.}

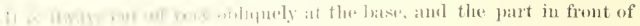

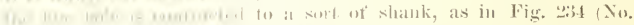
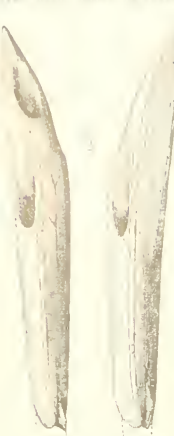

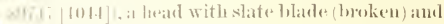

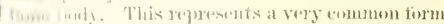

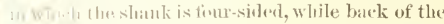

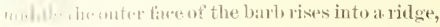

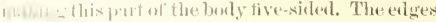

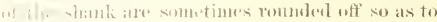

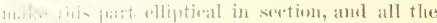

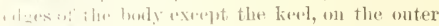

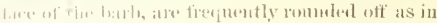

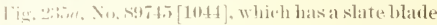

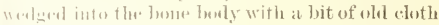

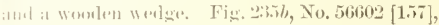
fon r thiswiñ, is a heall of the same shape, but

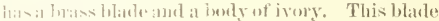
in wolsut in with dete hair, lont the of her brass. biated haspone, No. j6601 [137], has a single rivet of whisletrous.

The blate slit, and cousequently the blate, is always in the plane of I lae barls, which poxition,

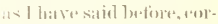
respomals to tha latst stope lint ane in the derelope-

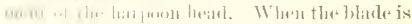

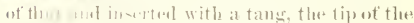

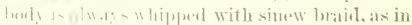

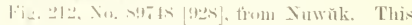
yneimed is ramarkalble as treing the only one

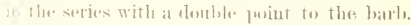
These lomlies atre sometimes ornamented with incised limes, incomventional pattroms, as shown

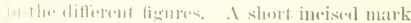

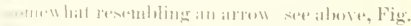

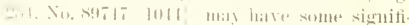

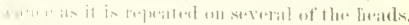

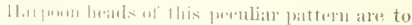

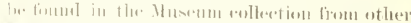

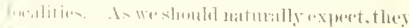

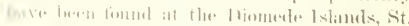

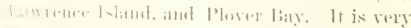

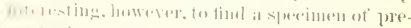

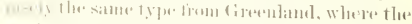

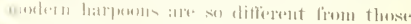

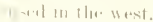

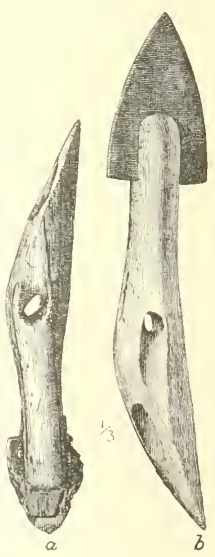

Fu, 2h, - Whale harpoon lw:tul.

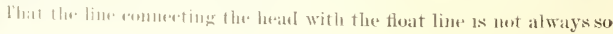




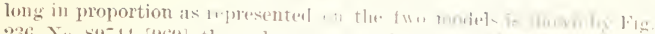

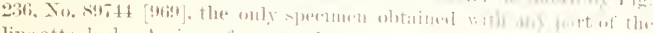

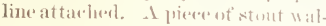

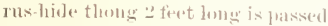
through the line-hole and douldore in two enutal parts, whitels are timmly stopreel together with simew aluent 2 inelaes firm the latal. Imother piece of similar thome t fiect 2 inelyes long is also dombled into two mateal parts amel the emels dimuly spliecel to those of the short piese thas: The

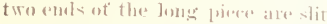
and onereme of the short piece prasided

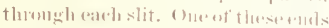

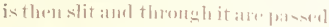

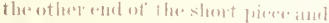

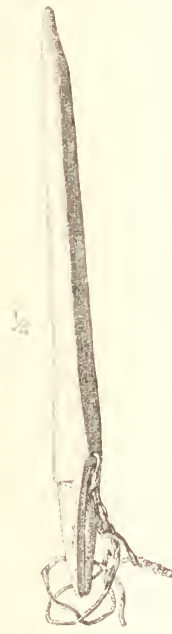

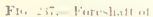
whato liarpoon

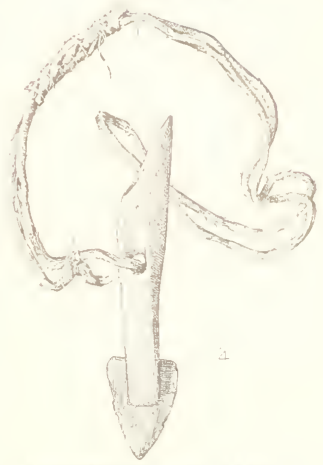

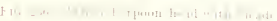
the lisint of the lengerienes andall isthatwh tallt and sereutely st izul with simew. The bereket thus

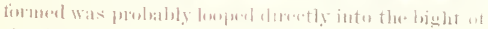
the that lias.

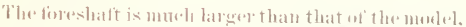

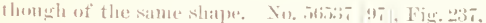

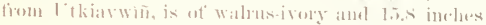

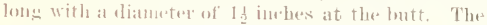

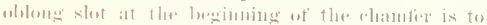

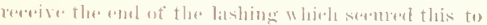
the shatt. This form of foreshatt is very well adapted

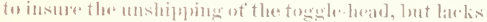
the sperial all vantage of the loose slatt, namely, that

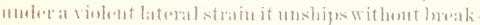
ing. The question at onee smgensts itselt, why was

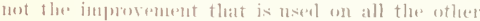

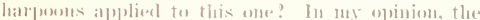

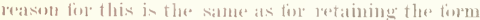

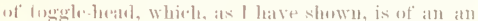
(-ind pattorit.

That is to say, the murlem whale harpoon is the

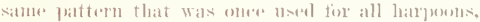
peserved tor smperstitints reasuls. It is a well kuown tiat. that amomg many peoples implements,

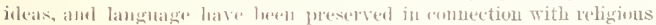




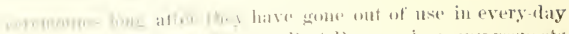

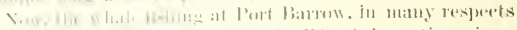

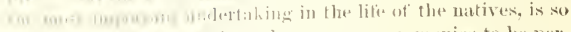

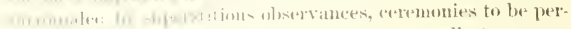

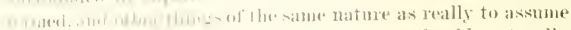

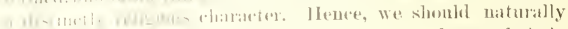

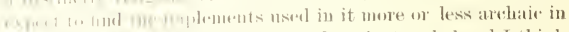

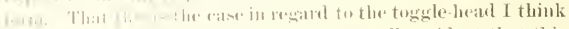

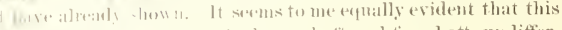

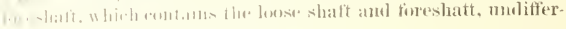

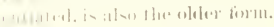

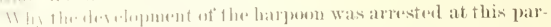

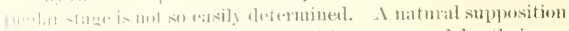

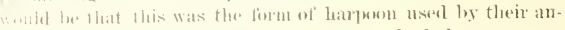

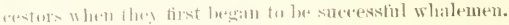

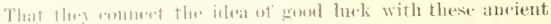

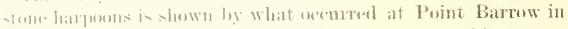
ins. (of late vatres they have obtained from the ships many

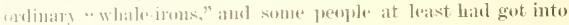
Ite lathil of $11<\mathrm{ing}$ them.

Nom, the lo:kl luak of the seasem of $188^{2}$, when the boats of _loth villages together manght only whe small whale, was attrib

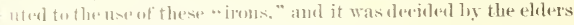
Hhat the first harguon strmek inte the whale most be a stone-

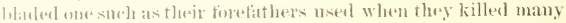
"Itales.

In flis connection, it is interesting to note a parallel custom

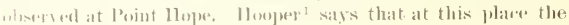
hedher must always he struek with a flint spean, ween it it has

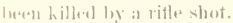

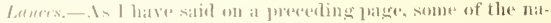
fises now use bomb. guns tor dispatching the harpooned whale, and all the whaldedrats are povided with steel whale lances

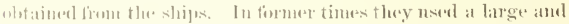

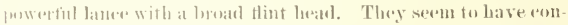
asmes the ase of this wetpon, probably for the same reasens that lat them to retain the ane ient hampon for whaling until

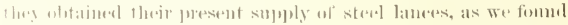

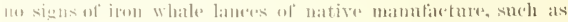

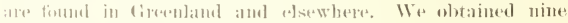

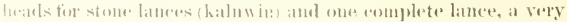

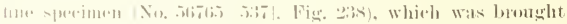

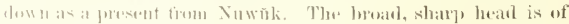

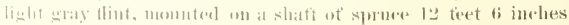
loms. It has a borad, stont fons inserted in the cleft end of the 
shaft. The slaft is rhomboilal in section with resmeled ederes, and

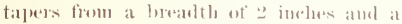
thickness of 1 at the tipe to a hutt of $0 .-$ inch $^{\circ}$ broat and 1 thick. The tipof the shate has

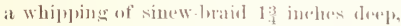

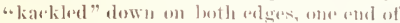
the twine on sach alderes so that the hiteh mate by one end aresses the romut turn of the other, making in all fwentr-six tmms.

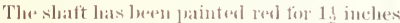
belew the whipping.

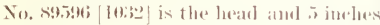
of the slatit of a similar lance. The lueal is of blark flint, and the sinew Jnatid forms a simple whipplug. The remaining hearls ale

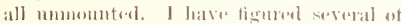
them to slow the valiations of this mow

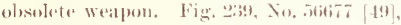
fiom l thiavwin, is of graty tint elsipwad in lange Hakes. The total length is (ion) ineless. The small hage on the exleges of the tamg atre to keep it fiom slipping ont of the whipprime. No, 566069 [23:3], also from l'tkiaswin, is of

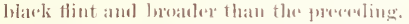

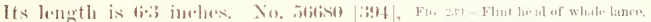
from the same villager, is of light bluish gray thint amel very borotel. It
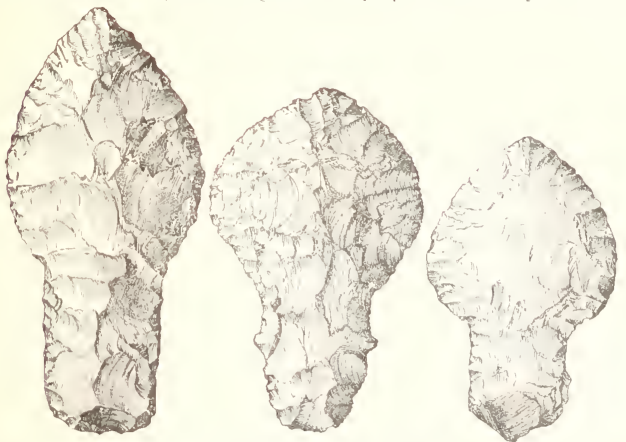

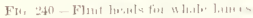
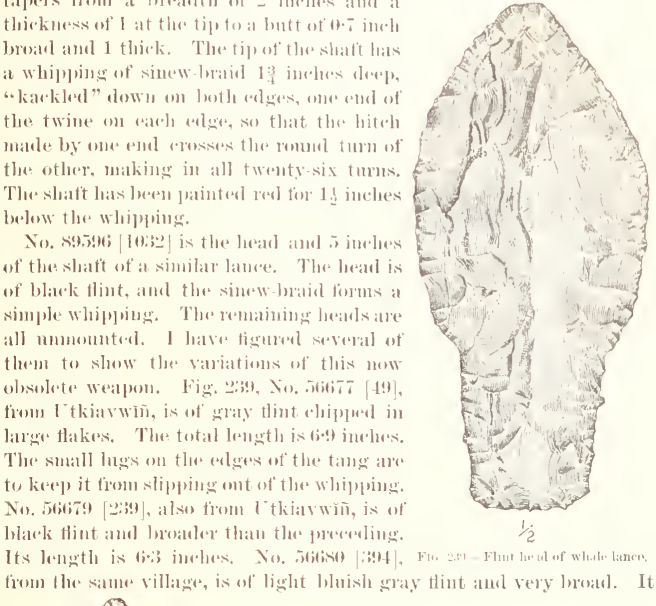


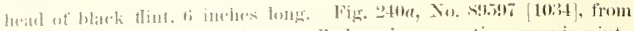
Suwhe, is of hlatk thint, and musually long in proportion, running into

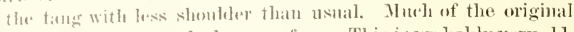

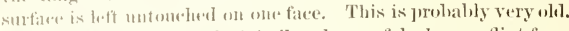

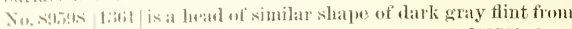

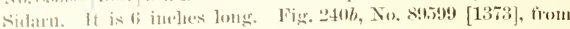
How same fliwe and of similas material, is shated very like the

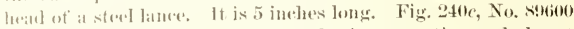

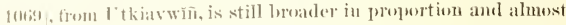
heart shajuel. It is of bluish graly flint and 4.8 imeses lomg. These hats probahly represent most of the different forms in ne. (Only twotypes are to be pongnizal among them, the long. fointed oval with as short tame, and the lorwad leaf-shaped head with a rather longe tang, which alyears to be the eommoner form.

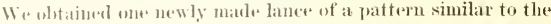
above, but smaller, which was said to be a model of the weapm used in attacking the pwlar bear hefere the introduetion of firearus. The mame, pit'min, is entomsly likt the name pamat given by 1). Simpiom atul (aipt. Parry to the large

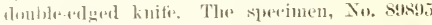

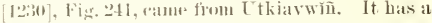
Jueal of gray thint $3 \frac{1}{2}$ inches long, exclusive of the tame, romblily tonvex an one face, but flat and merely bevaleal at the alges on the other. The mlares ale finely serrate. The slate is of spruce, di fiect s inclues long, renumlerd and somewhat flattemed at the tip, which is 1 inelo wide and taper.

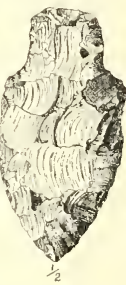

Fig. 242.-Flint ing to a diatmetor of 0.7 at the loutt, and is painted head for lear lance. real with oreher. The tip has a slight slondeler to keep the whipping in plate. The tame is wellyesl in with bits of leathere and

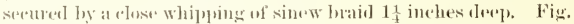

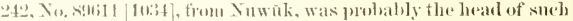
a lanee, althongh it is somewhat narrower and slightly slowter. Its total length is 34 indeses. The other two large lanep-beals,

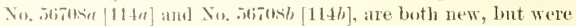
probably mant tor the luar lance. They are of gray flint, $3 \frac{1}{2}$ ineles long, and hate the edges regularly serate.

One torm of latues is still in general use. It has a sharp metal

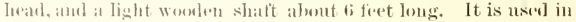
the katak for stabbing ther swimming in the water, after the

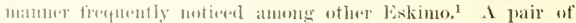

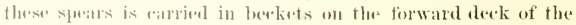

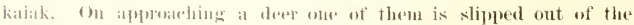
luakhet and lainl on the derk, with the butt lesting an the combing of 


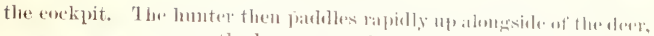

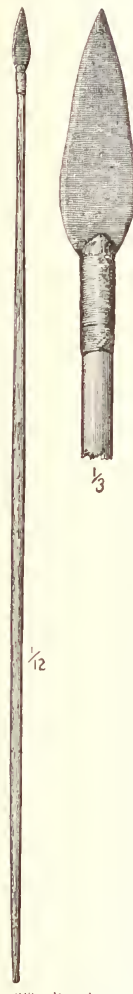

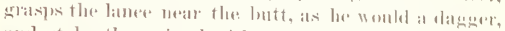
and stalss the animal with a cuick downwald thrust. This speatr is alled ka'pun, which in the Point barrow

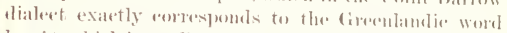

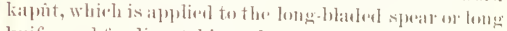
knife nsed tor dispatehing a harpooned seal. The worel

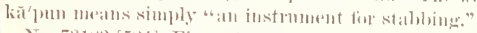

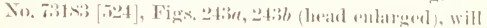
serve as a type of this wealpen, of which we have two sperimens. All that we saw wee essentially like this.

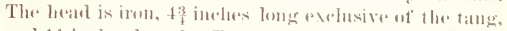

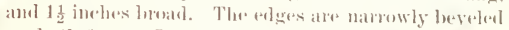
on both facess. The slate is fo feet "z inehes long, and tapers from at diameter of of ine he

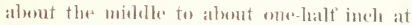
earhend. The tip is eleft to recoive the tang

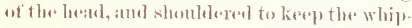
ping from slippring off." The latter was of sines batid aud 2 inebes deepr. The shat is painterl with red oxluer.

The other has a slate fient 4 ineles boug, but ofluerwise membles the pueseding. The leats for these lanees are not always made of

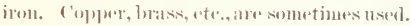
So. 566t:99 [166i] is one of a patir of neatly made

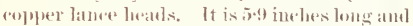

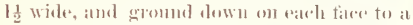
shate alge without a bevel, exerent just at the peint. liefore the intresluetion of iron these lances latel stone heads, but were of herwise of the sime shapke. Fig. 241 repexentis the

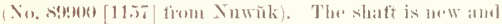
rather ancelessly made of a romgh, kuotty pione of sprotere, and is of teet is inches lome. The leatel is of black flint and 2 ineles lomg, rxelusive of the tang, and the tip of the shat is whipped with a marrow strip of light colored whalebone, the end of which is secmed by passing it thomeh a slit in the siche of the shaft and werlginge it into a relaek on the opposite side. This is an old head newly momnted tor the maket, and

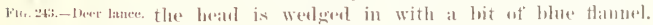

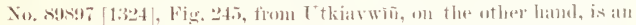

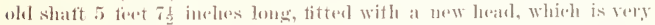

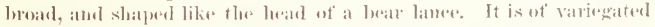




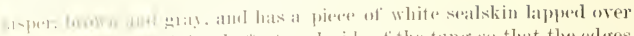

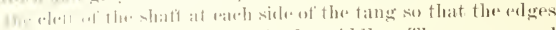

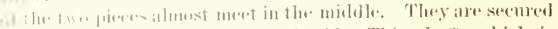

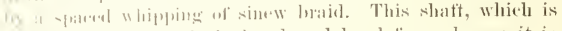

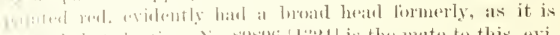

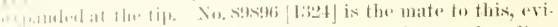
Henth mate for matede it. Wre also obtatined one other flint-

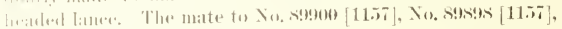

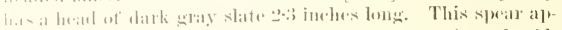

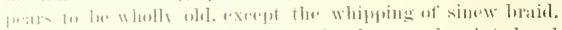

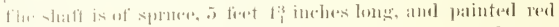

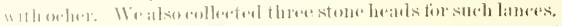

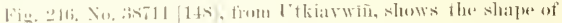

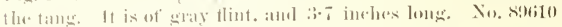

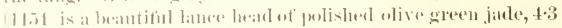

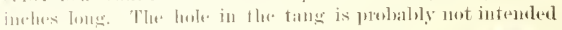
for at risut, an mome of the lathere lemals which we salw were fastemed in this way. It is more likely that it was porforated for attalehing it to the belt

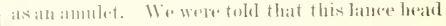

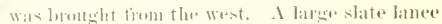

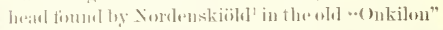

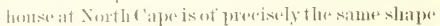
as these dest lance lowals, lut from its size was

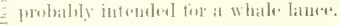

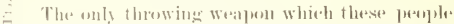
use is a small bulas, designed tim atching birds 6) the wins. This amsists of six er seven small

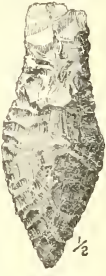
FiG. $246 .-$ Flint heat for deer lanee.

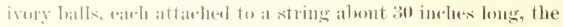

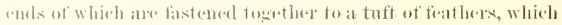

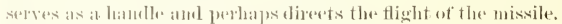

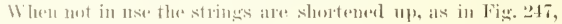

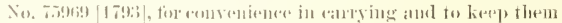
from tangling, Ly tying tlam into slip kuots, as follows: All

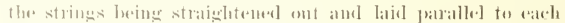
ofluer, flas an donbles in al bight, with the end under the

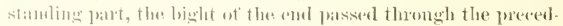

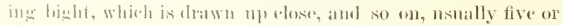
six times, till the strimgs are suliiemently shortemed. A pull an the 1 tro ends slips all these linots and the stringse come ont -traight and untangled.

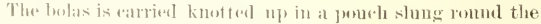

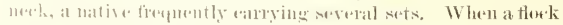

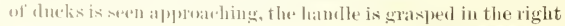

$$
\text { Wing. Fol 1. 1, 144, Fig. } 7 .
$$


hamel, the balls in the left, and the strings alde straticilemel ant with :

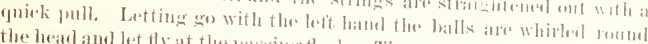
the head and let ty at the passilge flock. The. balls spread apart in flying themght the and.

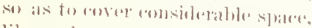
like a rloarge of shot, mol it they

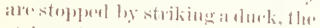
strings immoliately wrap armuml lim amol hamper his flight so that lee coures to the grommi. Tlar nit tives said that the lasls flew with

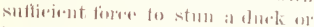
break his wing. lont wo metor hal peneel to sees any taken axerest in the way just deserilent. I lawk is ereasionally lett with subtient fresdom of motions to asiaje witl the bolas hamginge to him. The weajom is efferetive ny to :30 or 40 yamls, lut the natives olten throw

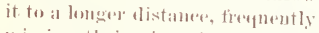
missing their nim. It is moirme

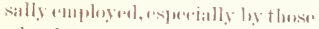
who halie no genus, amel at gromel

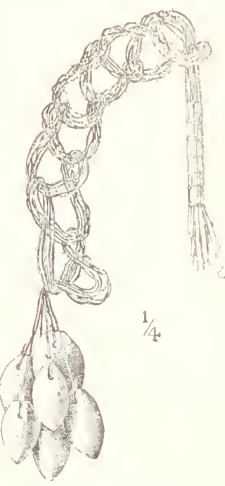

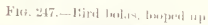
tor' many derelis are captumed with it. In the spring, when the

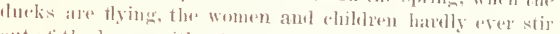
out of the hons. Without one or more of these,

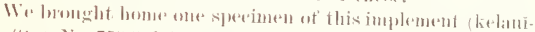

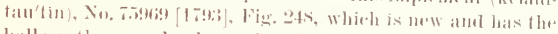
balls rather radrelessly uale. The balls, which are six in

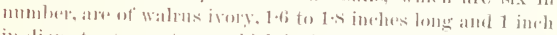

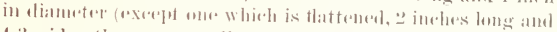
$1: 3$ whle; thay ane usually all of the same shape). 'Thromgh

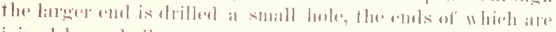

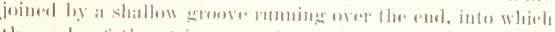
the ends of the strings are tastened by thee halt hitehes

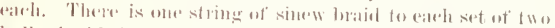
balls, dombled in the miehlle so that all six parts are equal and

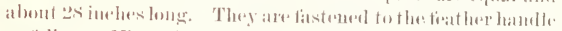

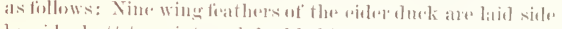

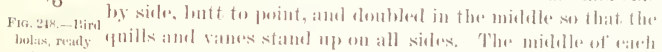

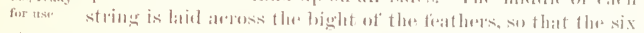

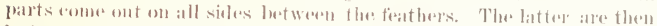

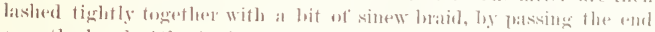
over the bend of the featler's and tying with the rest of the string roumb the feathers. 


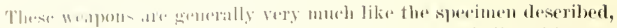

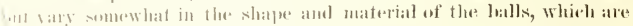

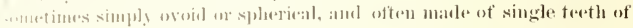

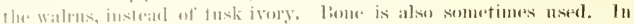

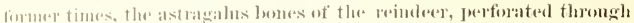

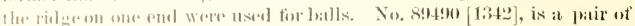

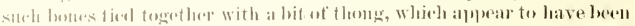

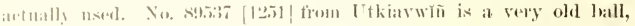

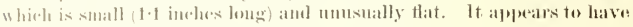
lonete kejet as a relis.

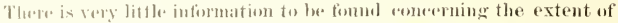
the region in which fluis implement is used, eitlore in the Musemm rol foclions or in flac writings of anflows. I liow points, howerer, have

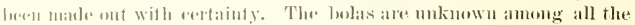
lakime ant of the Inderson liver, and the andy avidenes that we have of their nas at this point is an entry in the Musemu ratalogue, to

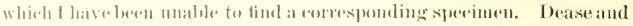

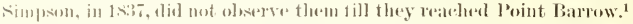

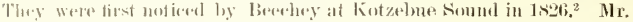

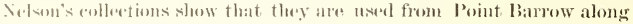

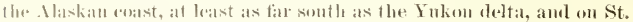

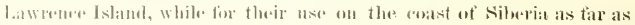

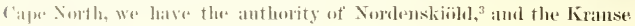
Iimothers.'s

\section{HINTING IMPLEMENTS UTIER THAN WEAPONS.}

Flouts, - l have alrearly spoken of the floats (apotî́kjoiñ) of inflated sealskin used in eapturing the whale and walrus. We olstained one

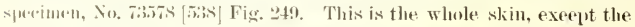

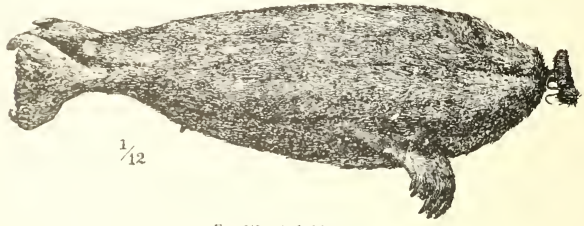

FIf. $249-\sin$ l skin float

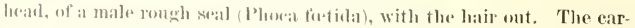

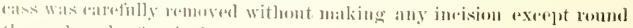
the meck and a tiew inches down the throat, and skimed to the very

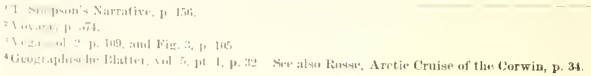


toes, leaving the elaws on. All natural or areidental apertures are are

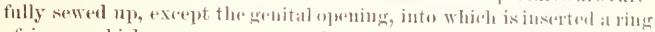
of ivory, which serves as a monthundere tor inflating flue skin and is

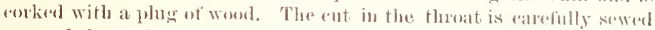

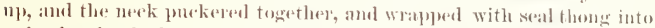
a slebeles shank abont 1 inch long, leaving a thapot skin which is wraplent

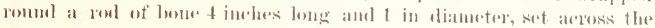
shank, and womel with thonge. This makes a handle tor loopingen thes luarpoom line.

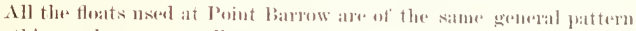
as this, and are gemerally mate of the skin of the remeh semal,

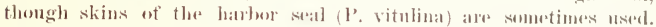

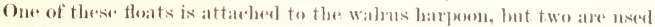
in whaling. Five or six floats ane earried in each beat, and are intlated before starting out. I have sen them nsenl tol seats during a lalt on the ire, when the boat was being taken out to the " leadl." The nse of these larege floats is not jesuliar to loint barlow. They are amployed

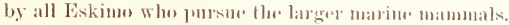

Flipper toggles. - Wo collected two pairs of pouliar implements, in the shape of ivory whales al wout in inclues long, with a pertioration in the belly through which a latge thong eonld be attateded. We understood that fleeg were to be tastrened to the ends ot a stont thomg and used when a whale was killod to tougre his flippers together so as to liepep

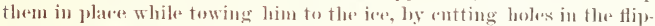
pers and passing the ivory thromgh. Wo motiontmately never hat an opportunity of veritying this story. Noither pair is new. Fig. 250

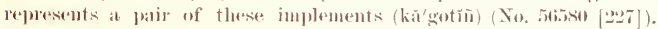

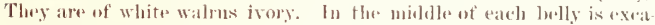

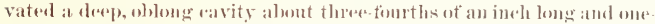
half wide, atrose the middle of which is a stomt transwerse lat for the attachenent of the line. One is a "bow-head " whale (lialarna mys.

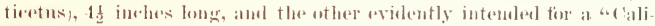
fornia gray" (Rhathimetes glameus). It has light bhe glass beads inserend for eyes and is the same langrth as the other.

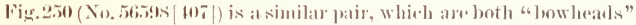
nearly 5 indhes longe. lioth have egliodrieal phese of ivory inserted tor "yes, and ate made of a piese of ivory so old that the surtaes is a light

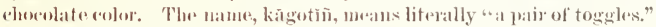

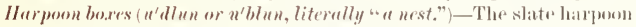
blades alreaty desegibed were very apt to be lost or broken, se they always arried in the bat a supply of spatre hlades. These were kept in a small box eareed out of a blerek of soft wool, in the shape of the animal to be pmisued.

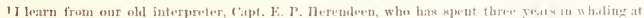
Point Parrow since the return of the expelition, that a thirl flat is aled used. It is attached by at longer line than the others, and serves as at sort of "telltale," coming to the surface some time alueind of the whale.
} 


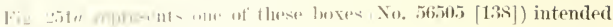

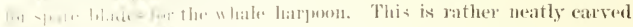

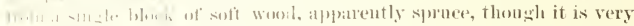

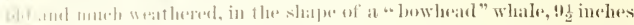

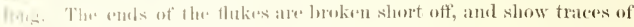

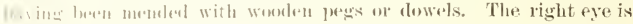

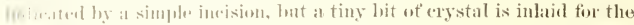

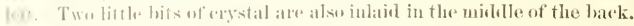
The indls is that and exmivated inte a deepe triangular mavity, with its balse just finwarel of the angle of the month amd the apex at the

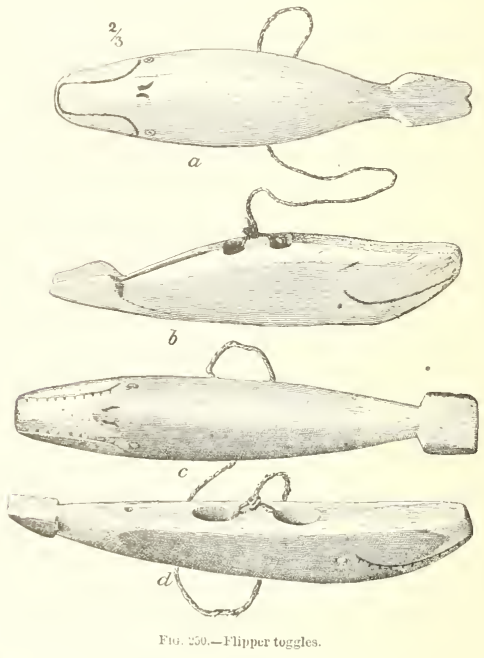

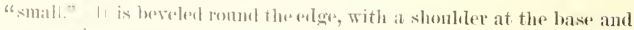

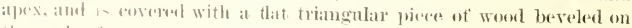

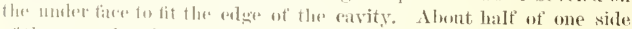
of the coser lats bean sulit off amb memded on with two "stitches" of whalebune tiber. The worer is helle on by thee strings of seal thong patsing throtgh lowes in eich cormer of the cover and secured by a 


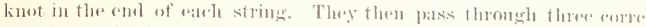
sjomding holes in the bottom of the cavity, leaving ond side of the hatek

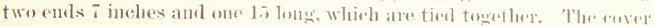

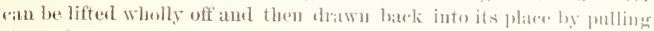
the string.

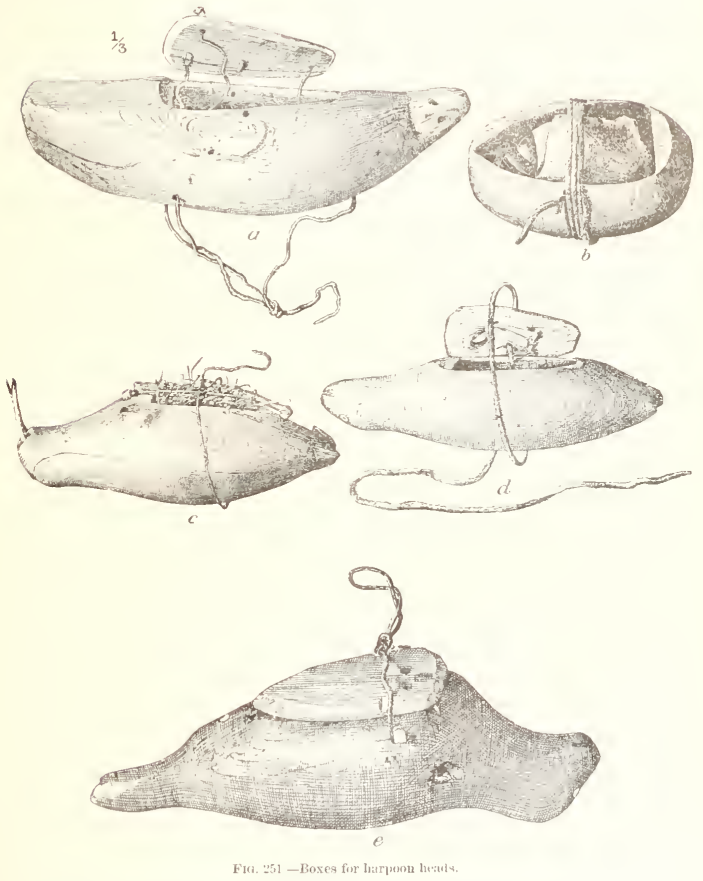

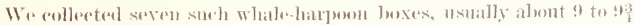
inches longe. Xearly all have bits of erystal, amber, on pyrite, inlaisl

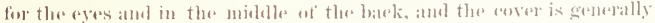

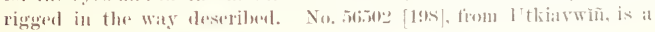


large whale, a fort long, and has the tail bent up, while the animal is tostally represented as if lying still. It has gorl-sized sky-blue beats intaint tienthe ryes.

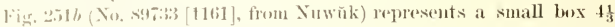

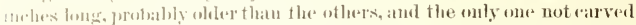
Into the shate of at whate. It is ronghly eggestalped and has no worlen

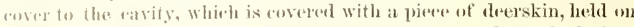

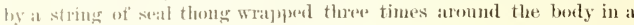

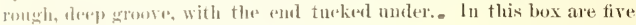
slate biates for the whale harpoon.

We also colleeted two loxes for wallus harporms mate in the shape

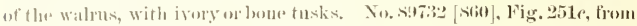
Nuwhk, is old, and 7 inches longs, and lass two oval bits of ivory, with lobes bornd to represent the pmpils, inlatid tor the eyes. There is no mover, but the ravity is tilled with a number of slate blades, carefully patked in whalelone shatings. There is a litfle eyelolt of ivory at

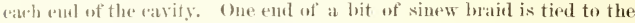
anterion of these, and the other earried down thromgh the hinder one, and flem bromght up and fastened ronnd the body with a manting hiteth. The other (No, 5its? [127], is new and rather roughly made, 5 inches fong and painted all wer with red oether. It has a cover, but no strings.

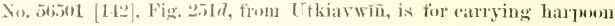
lobules tom the ehatse of the bearded seal (Erignathes batbatns), and is neatly earverl inte the shape of that animal. It is $7 \cdot 4$ mehes long and has ivory eyes like tha walms box, No. s9732 [s60]. The cover is fitted (a) the anvity like those of the whale boxes, but is ledel on by one string only, a piece of seal thong abont 3 teet long passing through the mid dle of the toxer and wat at at hole on the left side, alont one-fomth ineh from the atvity. The box is tilled with raveled rope-yatus. Fig. 25le

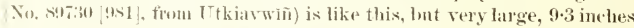
long. The cover is thick and a little larger than the eavity, beveled on the uprea fare and notrled on eath side to receive the string, which is a bit of siuew bratil tistened to two little ivory hosks, one on earh sideof the besly. It is tistemed to the right hook, earried across and

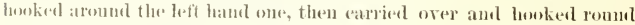
the other, and secmmal by turking a hight of the end nuder the last part. The hox contains sevaral slate blades. We also collected one

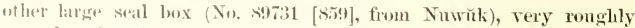
marved, and as inehes long. The cover is fitted into the avity and hefel on by it narow strij of whalebone ruming aross in a transverse groove in the cover and thromgh a loole in each sile of the box.

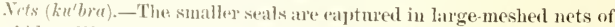
rawhicle. Wr bronght bome one of these, No. 56756 [109], Figs 252a-

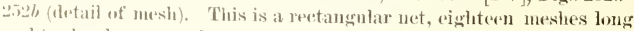
:and fwelvederep, netter of tine seal theng with the ordinary netting knot. The leugth of the mesh is 14 inelues. 


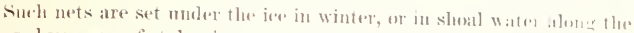
slate by means of stakes in summer. In the ordinary medlum of settime

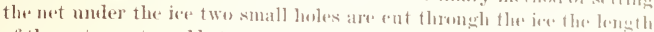
of the net apart, and lestwen them in the same straight line is ant at thind
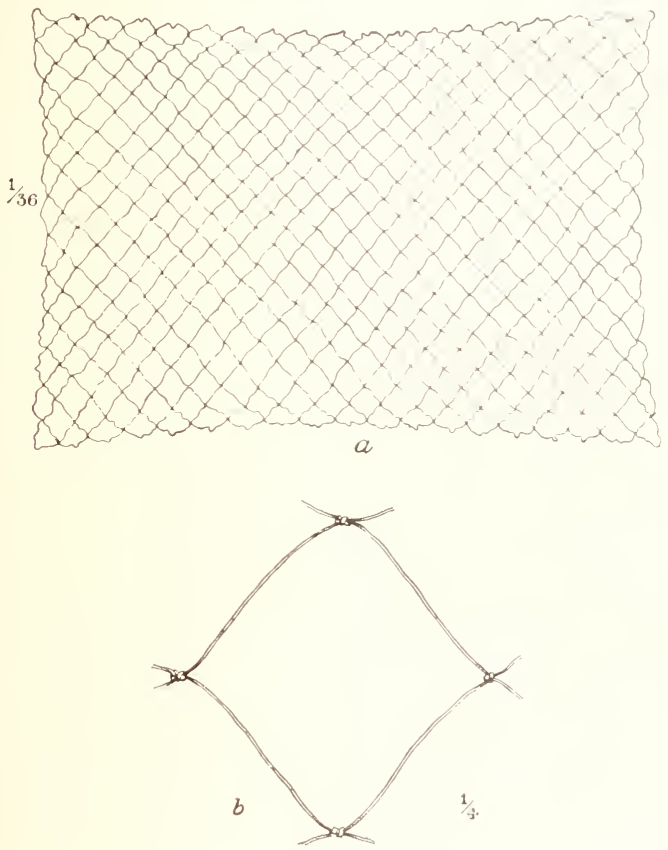

Fit, 25:-Seal net.

large enongh to permit at seal to he drame un throrgh it. A line wath a plummet on the end is let down thangh oue of the small heles, aud is

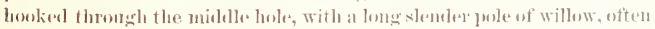
made of several pioses splieed together, with a suall werden hook on the 


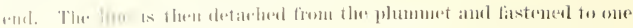

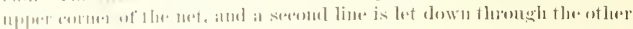

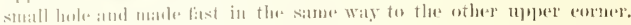

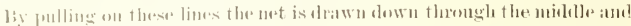

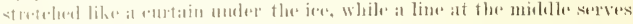

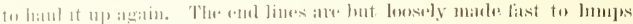

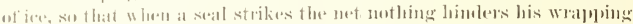

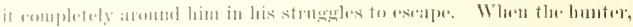

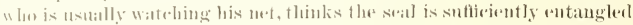

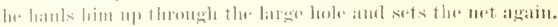

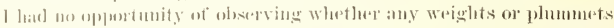

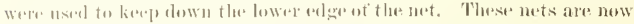

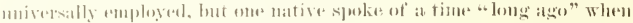

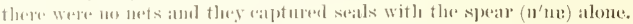

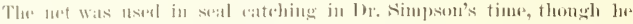

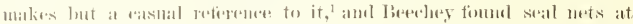

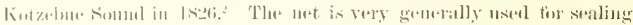

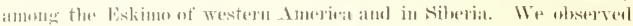
seatl mets set with stakes alome the shore of the sambits at I'lover Bay,

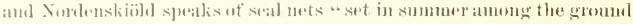
ines along the slone," and at opren beruls in the winter, but gives mo

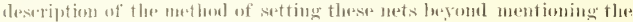
"leng pole which was used in setting the net," as mome of his party

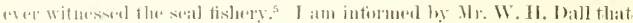

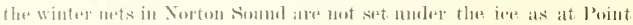
liarrow, but with stakes in slobld water wherever tlete are open lowes

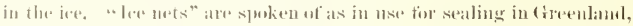

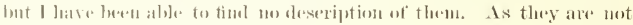

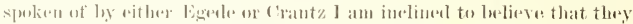

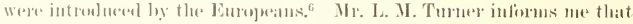

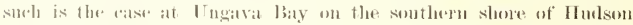

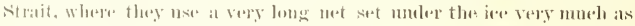
at l'oint barrow. I fan timl no mention of the use of salal nets among any other of the astern Bskimo.

It is well kmown that keals lauve at great floal of euriosity, and are

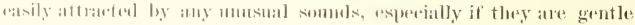

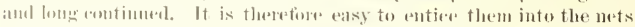

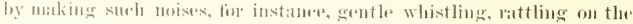
ire with the piok, and so torth. Two spercial implements are also nsed for this purpese. The tirst kind l have andlecl:

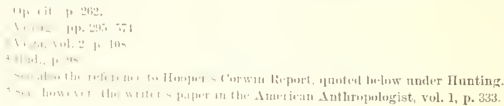




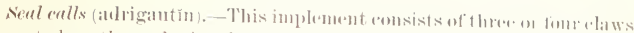

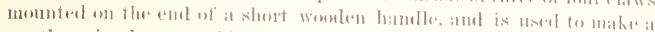

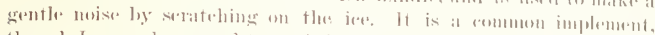

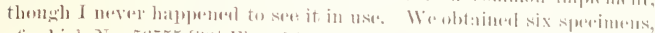

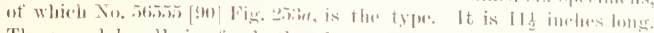

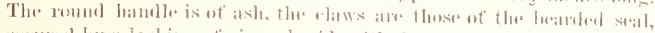

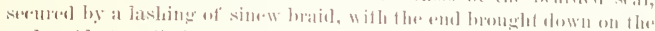

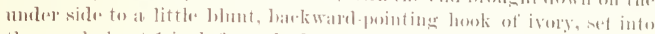
the waxl alwote 1 ineh fiem the base of the alms.

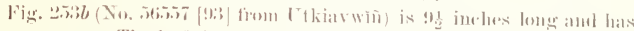

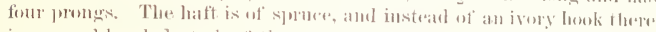
is a remel-headed stut of the same material, which is driven wholly through the workl, haviug the point ant off thes with the npere sur

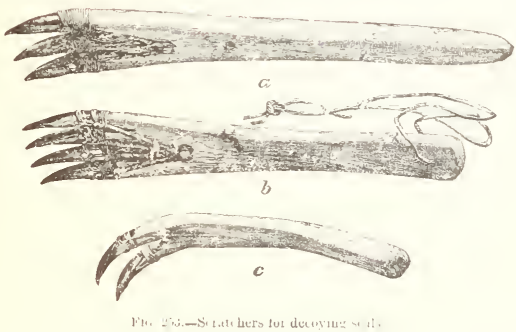

fare. It has a langard of seal twine knotten inte the hole in the hatt.

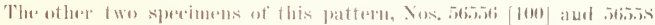

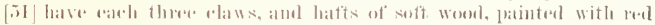

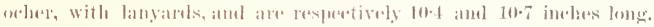
Oore has an ivory hook, hut the ot here in plater of this las a small ibon

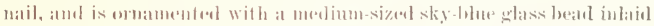
in the larek. The of hele two alo losth new and small, being resperticely

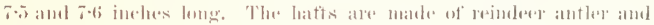

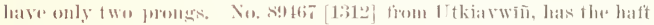

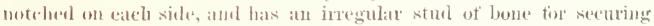
thit lishing.

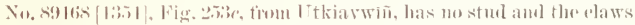
are simply held on by a slight lashing of twisted sinew: lat to of these

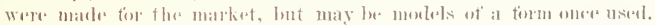

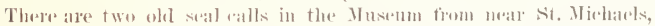

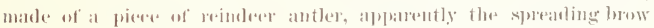
antler, in which the sharp points of the antler take the place of chas. 
The 11 se of this implement, as shown ly Mr. Nelson's eollection, extends

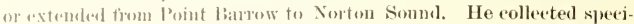
mens firm st. latwrenc. Islame and ('ape Wankarem in Siberia. Nordenskicild speaks of the use of this implement at Pitlekaj and figures i) sperinen. The of her instrument alperars to be less common. I have callect it a seal rattle.

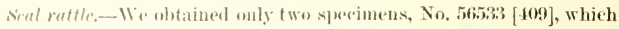
serem to be at pair. Fige. 2it is one of these. It is of cotlonwood and 4 inelues long, roughly wared into the shape of a sealls lead and painted rel, with two small tramsparent blue glass beads inlad for the eyes.

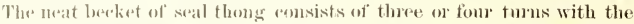

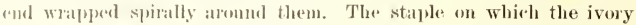

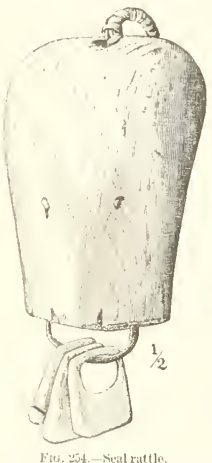

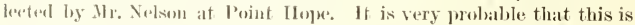
the "or rect explanation of the use of these ulyjects, as il assigns a fimetion to the ivory pendants which would of herwise betseless. They have lowen callecl "doge bells," but the Ekkimo, at Point Barrow, at least, are not in the haloit of marking their doge in any way.

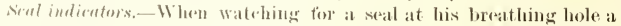
native inserts in the loble a slender lool of ivery, which is beld loosely in

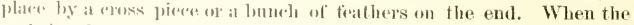

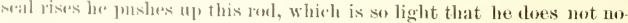
tice it, and thus warns the lometer when to shoot or strike with his spear. Ilost of the seal hunting was done at such a distane from the station that I rememlun only one oreasion when this implement was 


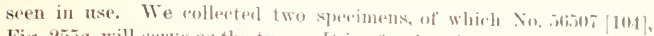
Fig. 25isa, will serve as the type. It is of wallos ivory, 11 ineles long and $0 \cdot 3$ in diameter, with a small lanyard of sinew. The amverl cross phese of ivory, $1 \frac{1}{3}$ inclues leng, is inserted into a slot ons-lourth of an inele from the end and sermed ly a liftle treenat of wousl.

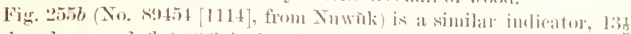
inches long and flat (0.3 inch wide and $10 \cdot 1$ thick). The njeper and is carved into seallops for ormament and has a small ayo into which

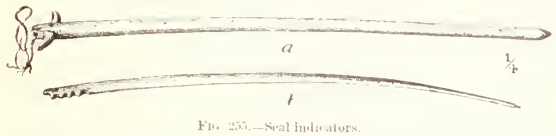

was knoted a bit of whalelone fiber. The tip is beveled off with a concave bevel on both fiaces to a sharp edge, so that it ean lo IIsel for a "tiatluer setter" (ignewail) in teatlering arrows. sueh implements ate mentioned in most pepular aceonuts of the Eskimo of the east, and Capt. Parry deseriles it tom persomal observation at lglulik. I lave been unable to find any mention of its use in western Ameriea, and have seen no spereimens in the Satimal Museum.

screling stools.-When a native is watelung a seal-hole lo frequently has to stamd tor lowis mo.

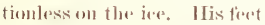
would bereme: axeredingly rolel, in spite of the excer. lene of his fout envering, were it not for a little theree. lesgred stool about 10 inclues high بpon which he stamls. This stool is masle of woed, with a triamgular top ,just

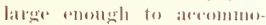
date a man's feet, with the

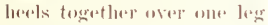
of the stoml, and the other two leges supperting tlat toes of eacle foot, respertively.

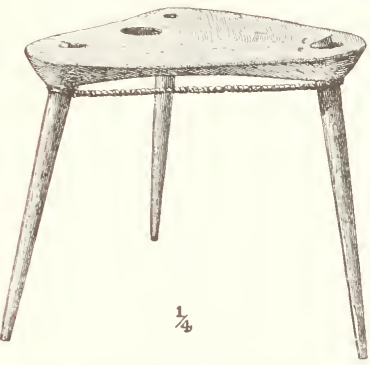

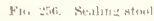

Tha stool is neatly male, and is as light as is consistent with strength.

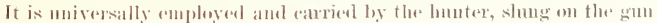
cover with the leges projerting lehind.

When the lunter lak a long time to wat be generally squats down so as almost to sit on his heels, holdling lis grun and spear in readiness, and wholly aroved with one of the deerskin doalis aldeady deseribed. Thry sometimes nse this stool to sit on when wating for duckis to thy over the ier in the spring. 


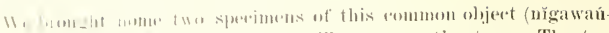

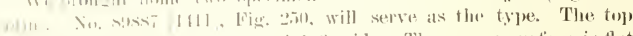

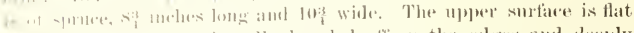

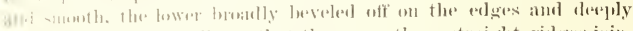

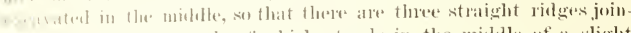

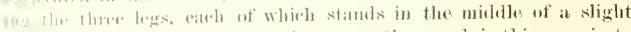

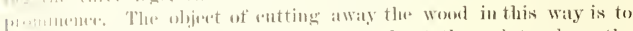
mathe the slool lightol, leaving it thiek only at the points where the

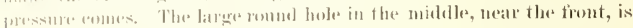

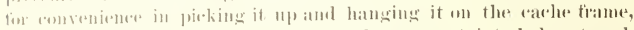

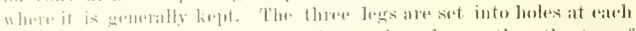

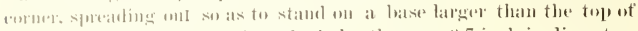
the stome. Where they tif into the hohes they ale 0.7 inelo in diameter, tajerent slighty to tit the hole, and then tajering alown to a diameter

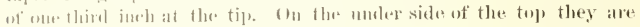

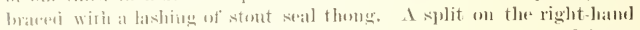

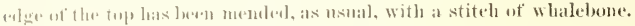

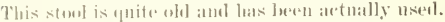

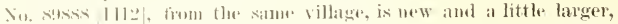

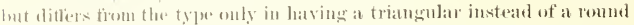

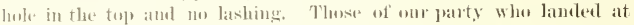

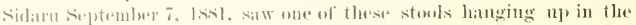
then valuat village, and there is a preisely similar stool in the Mosemen fion the. Indusen region.

Matelarlane, in his mamuseript notes, destribes the nset of these stools as follows: "bofle tribes kill seals muler iere; that is, they wateh for them at their holes (loreathing) or wherever opers water ajpears. At

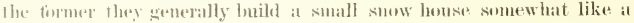

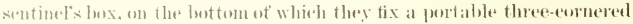
stond, mate of woml. They stand on this and theroloy estape getting

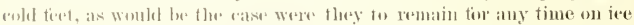

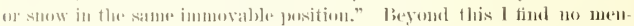

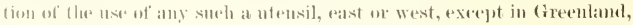

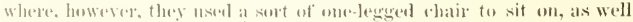

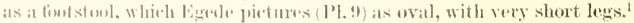

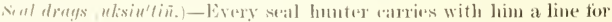

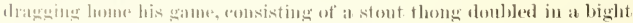

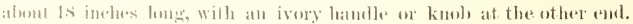
The bight is looper into an incision in tlat seal's lower jaw, while the kmole serves for attaching a lomere line or the end at a doges harness. The soul is dragenol on his hate and roms as smoothly as a sled. We

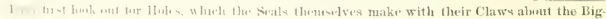

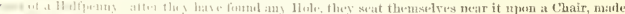

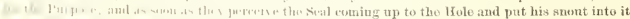

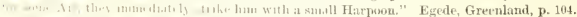

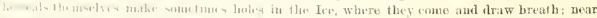

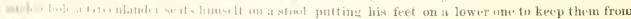

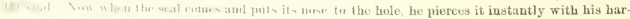

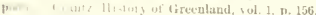


collected eight of these drag lines, from whim I have selereted No, siffiel [4], Fig. 25ia, as the types.

This eonsists of a stout thonger of rawhide (the skin of the huarded
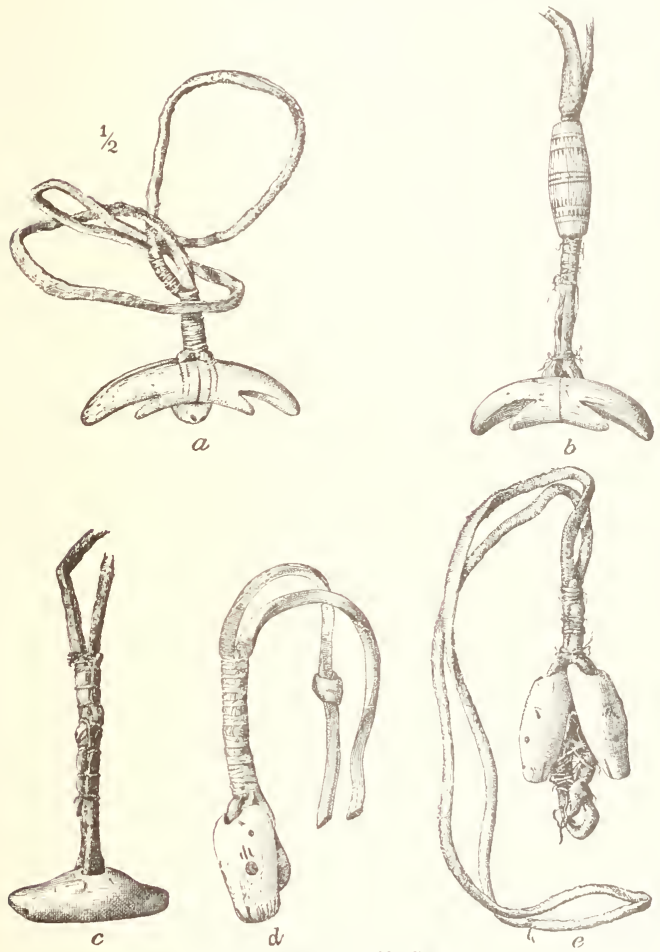

seal) 0.3 inele wide and 37 inches long, and doubled in a light so that one end is alout $2 \frac{1}{2}$ inehes the longer. These ends are fastened into a haudle of walmos ivory, consisting of three pieces, namely: a pair of 9 ETH- 17 


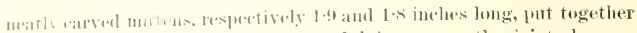
whic to wrist will the palms up: and lying across the joint abewe, at

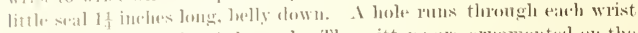

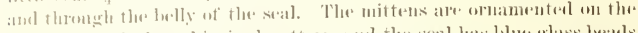

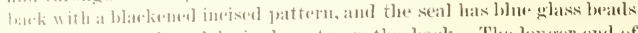

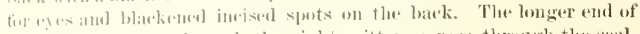
the thomg rums up throngh the right mitten, aross through the seal,

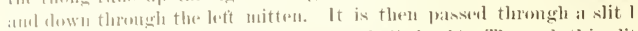

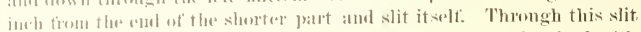

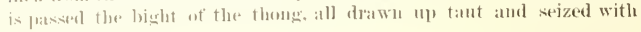
simell brais.

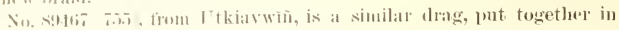
unch the same way, but it has the mittens dowelesl together with two

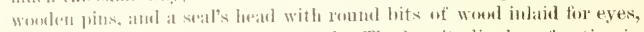
ars, and nustrils, in plawe of the seal. The longitudinal perforation in this head slows that it was originally strumg lengthwise on one of these

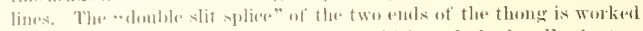
inte a complieaterl monul knot, lest weren whieh and the handle the two

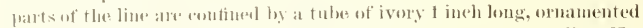

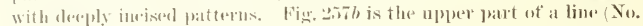

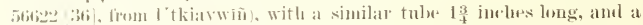

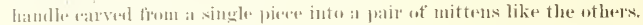

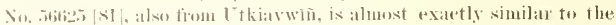

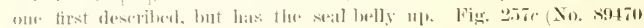

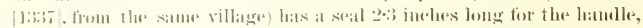

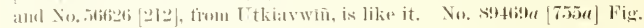

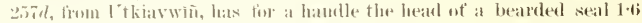

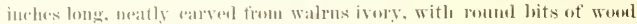
inlaid for the eyes and ears. It is proforated longitudiually from the

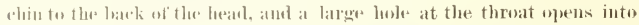
this. The lengere end of the thomg is passed in at the eluin and ont at

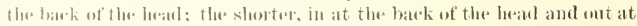
the throat; the two conls brought together between the standing parts

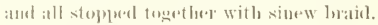

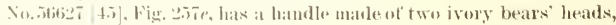
very luatly sarved, with rirmlar bits of wool inlaid tor eyes, and per-

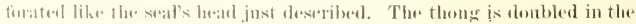

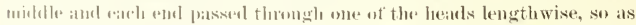
to potrule abmit 7 inches. About 4 inehes of end is then doubled were throst through the throat hole of the opposite head, and brought fown aloug the stamling parts. All the parts are steplped together with simew hainl. This makes a small becket alowe the handle.

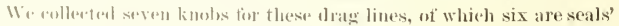
heads and onte a leatr's. They ate all mate of wallos ivory, apparently

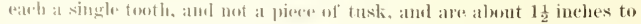
2 methes long. The atre generally "atred with ronsiderable skill, and 
often have the ears, ruts of the whiskers, mostris, and outliue of the. mouth incised and blackenei, while small blu- beals, bits of ivoly. or

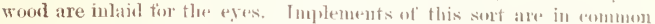
nse among Exkimo generally wherever they are so situated as to be ahle to engage in seal-hmoting. Mr. Nelson's collection eontains sperti mens from as far sumtl as ('aje- J )arthy.

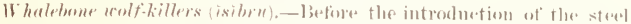

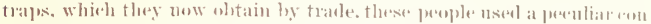
trivane tor cateling the wolt. This consists of a stont rex] of whale. lone about 1 toot long and wose-half ineh broal, with a shale point at eareh end. One of these was folded lemgthwise in the form of a $\%$, wrapped in bhober (whale"s blubber was used, atesordiug to our inform

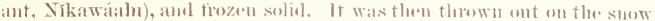
where the woll aomld find and swallow it. The lowat of the animal's bouly would thaw ont the blubluel, relatasing the whalelsone. which wonld straighten out atud pierere the walls of the stomath, thus atusing the

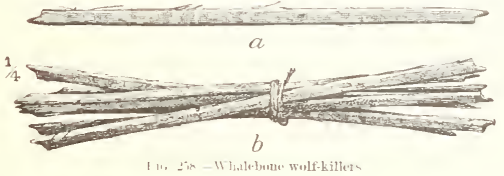

animal's death. Nikawalu salys that a wolt womlel not gon far after swallowing one of these blubluer balls.

We collexted form sets of these eontrivanees, one set containing seven

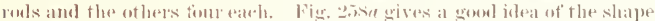

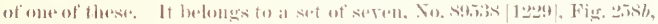
from Ithiavwin. which ale old atud slow the matks of having leen

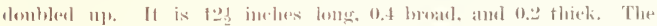
little noteles on the oppesite alges of ateh end were probally to lould a lashing ol sinew which kept the folded roul in shape while the

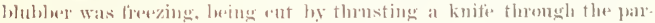
tially trozen blubber, as is stated by soluwatka? Two of the sets are new, but made like the ot hers.

This antrivane is also used by the Eskimo of IJulson Bay and at

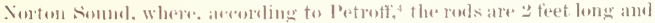

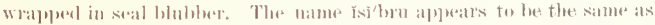

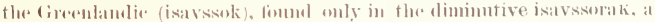
provinual name for the somewhat similar shan'p-pointed stiek baited witl blubher and nsesl for catehing gulls. The diminntive tom of this

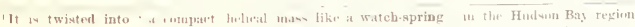

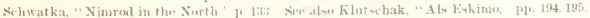

".. Nimroul in the North. 1. 1:3

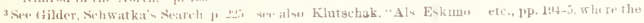

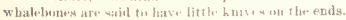

+1keport, etei, 1, 127. 


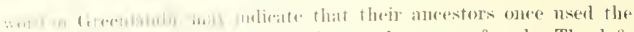

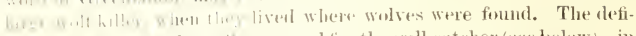

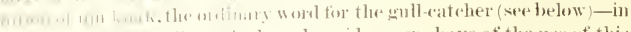

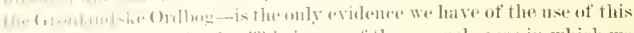

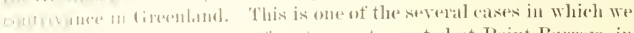

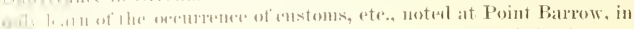

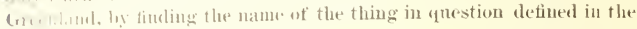
dietinituts.

Trup,-Foxes ane anght in the winter by deadtalls or steel traps Haim a sot gencally along the beath, where the foxes are wamler-

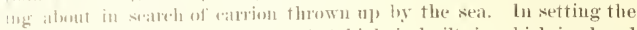
thattalls it little homses about 2 thet high is built, in which is placed

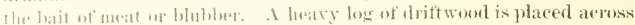
the entrane, with one and ratisut high emough to allow a fox to pass

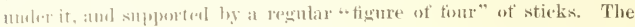
for and unt ent at the hait withent passing nuter the log, and in doing

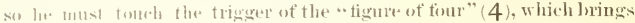
dons the low ancoss his lack. When a steed trap is used it is mot

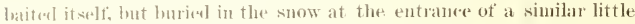
house, so that the fiox ran mot reach the bait without steppiug on the plate of the tratp and thus springing it. Many toxes are taken with such traps in the comese of the winter.

The beys 11 se a sort of smare tor eatching setting birds. This is simply a strip of whaledone make inter a slip-nowse, which is set over

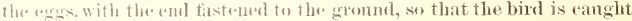
ly the low. (1) one on twiee, when there was a light snow on the beach, we saw a mative eatelung the large gulls as follows: He had a stiek of hard woorl, pointid at talch end, to the middle of which was fastened one end of a stont string alkont 6 feet long. The other enel was secured (o) at stake triven into the firozen gravel, aud the stick wrapped with Lhobles and laid on the beareh, with the string carefully hidden in the

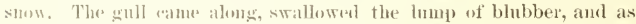
soon ats be tried to fly alway the string made the sharp stick turn like a togele arross his gullet, the juints forring their way through, so that

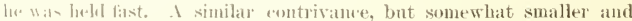
manlw of bome, is msal at Norton somel for catching gulls and mores, a number of them leing attaclest to a trawl line and baited with fish.

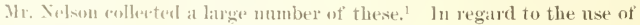
this sontrivame in (ivenland, ses above moler "wolf-killers."

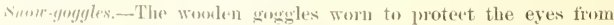
smo blinduess may lon considered as aressories to hunting, as they are worn chictly ly these engatges in hunting or fisling, especially when deat hunting in the spring on the snow-rovered tundrat or when in the whateluats anomg the ice. They are simply a wooden cover for the

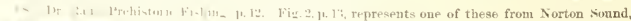

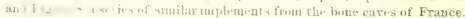




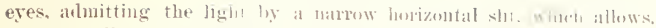

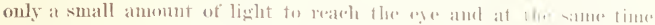

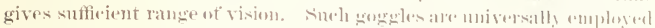

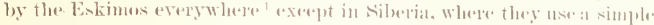
sharle tion the eyes. ${ }^{2}$

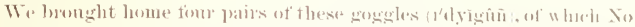

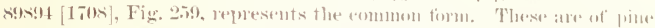

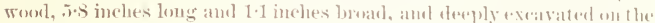
insjele, with a nawow horizontal slit with thin edges on wath siele of the midelle. In the uiddle are two motelese to tit the mose, the one in the

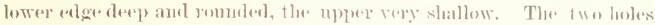

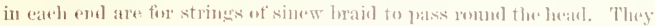
are ueatly mate and the ont sinle is seraped smooth and shows tranes of a ereat of red oedier.

The history of this partieular pair of gogeles is perdiarly interesting.

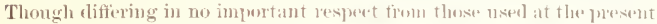
day, they were found on the site of the ans.jent villageof' $\left[\times \hat{\imath}^{\prime} t \mathrm{k} w a\right.$, where ontr station storl, lumied at a deptlo of '27 finet in undistorbes frozen yolond, and were merevere in elieging the shatt sunk by Lient, lasy for obtaining earth temperatmes, Tha layer. in which they were fombl was

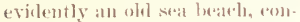
sisting of saml and gravol mixed
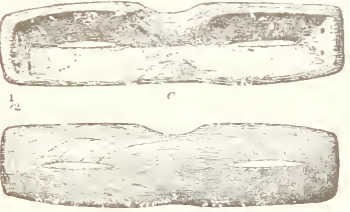

3 with broken shells, amome which Mya tmumata was reconnized. The

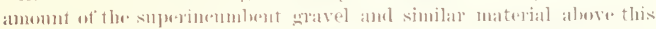

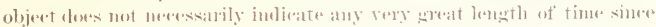

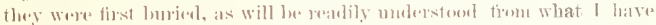

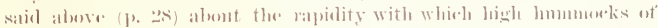

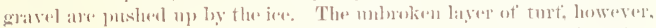

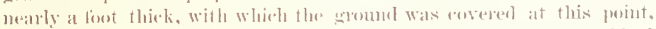

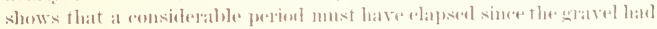
re+alelued nealy to its present lavel.

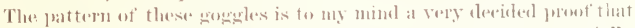

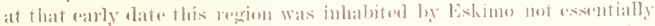

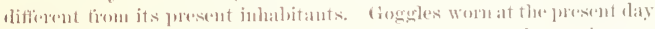
are almost always of the shape of these, thumgla 1 remember secinge one

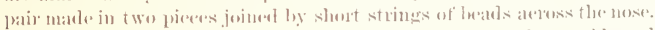

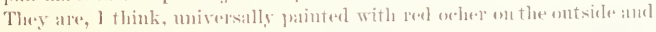

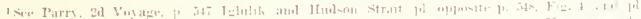

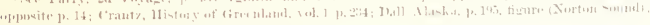

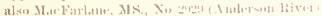

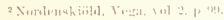

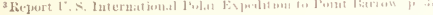




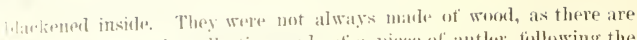

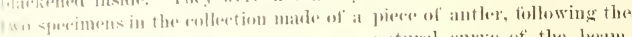

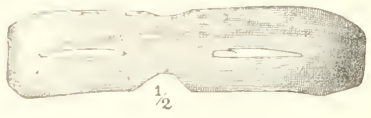

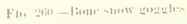
uatural curve of the heam, dividesl longitndinally, with the solter inside tissue loollowed ont.

Fig. 260 ( No. S!9701 [763), from Itkiawwîi) represents one of these sperimens. I

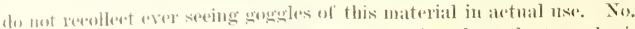

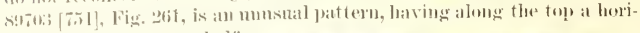
zontal him alont one half inch high, which serves for an alditional shaule to the peres. Alowe this are two whlique holes opening into the arvity inside, whith are prohably tor the purpose of ventilation, to jorevent the motistme from the skin from being depositud as fiost on the inside of the goggeles or and the eyelashes. I do not remember lat hing seen sme. gogules wrim. I)all tigures
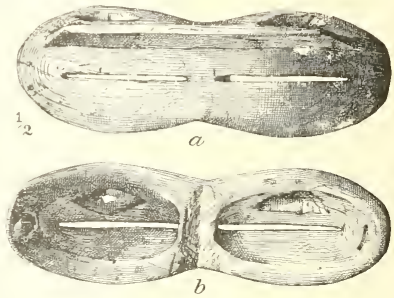

F1G. 261.- Wooden anow rgoggles, numsual form. a similar pair fiom Norton Somed, and thuse brought by Mr. Turner from [rogavia have a similar Irim and vertilating holes. The snow goggles

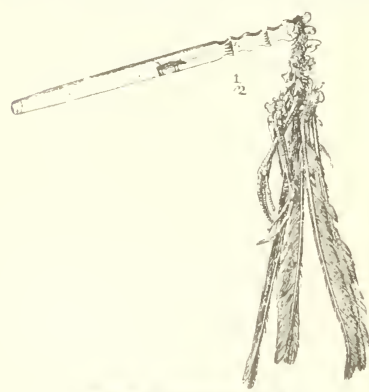
mentioned in Parry's Second Voyage (p. 5.to as aceasionally seen at Tylulik, but more commum in Hudsou's Strait, apprear to have resembled thesse, luet hart a brim 3 or 4 inchess deens.

Weat-carhe markers.-We piurhased a comple of little ivory rods, ealde with a little bumely of feathess tied to one and, which wa were told were hased by the deer lounters to matrk the place where they hatil buried the flestlo of a deer in thesnow. This implement is ealled tirlinsial.

Fig. :4i: represents one of

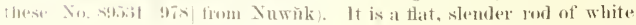

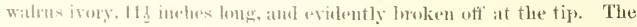


other end is ent intornamental notehes, and ormanented w it h an ime ised

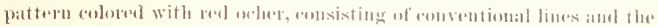

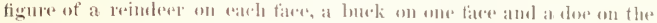

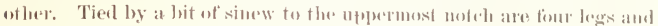
there wing tips (three or tour prinaries, with the skin at the base) of the buff-breasterl samdpiper (Tryngites sulbuticellis). This was evidently:

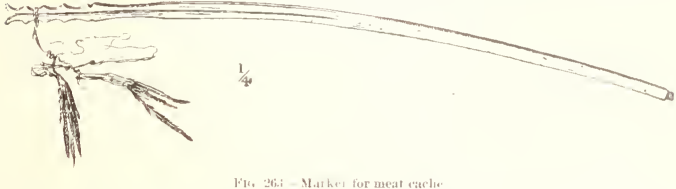

longer when new and perhaps was originally nsed for a seal indicator

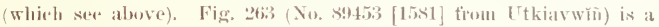
similar rosl, the tip ot which has been bronght to an edge se that it eam be usesl as a "feather-setter" in thathering arrows. The remains of two wing tips of seme small bird are tied to one of the notehes at the npper ent.

\section{METHOIS UF IITNTING.}

Having now dexpribed in detail all the weapons and other implements

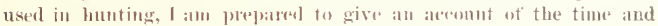
methods of pursuing the ditlierent kinds of gante.

The polar bert:- Bears are aceasionally met with in the winter by the seal lumters, reaming about the ioe fields at some distane from the shore. They usmally rom fiom a mam amb oftell do mot make a stand evell whell wambled. Oreasionally, lowever, a bear remdered bold by

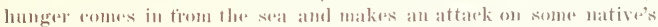

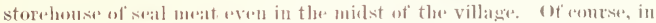

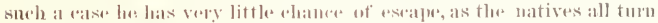
ont with their rifles and ent off his retreat. Two beas were killow in

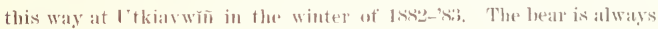
attackesl with the ritte, often with the help of dogs to bring him to baty. The muiaks when wallos lumting sometimes ment with hears amoug the loose ine. It the latar is atught in the watere, there is very little

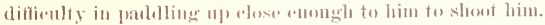

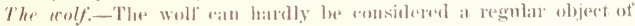

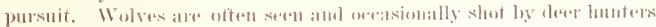

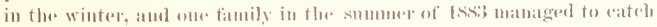

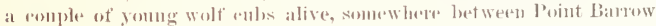
and the colville. These they bromght lowe with them and kept them pisketral on the fumbla just ontside of the village, with a little kemol

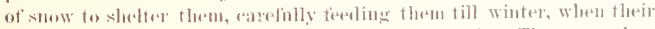
fur had grown long enongh for use in trimming hoods. They were then 


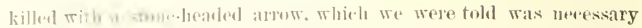

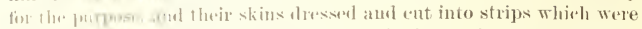

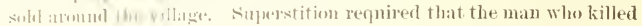

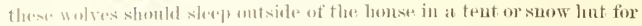
". nur mon" anter killing them. Whe did not leam the reason for this pration beyoul that it would be "bad" to do otherwise.

The fir.-Foxe ane sometimes shot, but are gemerally taken in the

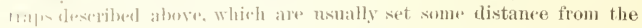

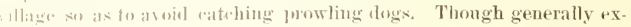
enetingly shy, the for is sumetimes remdered areless by hunger. One

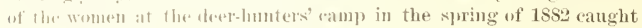
on+ in the little suow house built to store the meat and killed him with a stirkl.

The reinder:-Reindeer are eomparatively searee within the radius of in daty's mareh firen Point Barmow, though solitary animals and suall partick an to be seen almost any day in the winter a few miles inland from the seacoast. In the antumn, which is the rutting season, they ocmisionally wateler dewer to the lagems back of the beach. Nearly (xery day in the antumu and winter, when the wratber is not stomy, on of more natives are ont lowking for reinleres, ustally traveling on

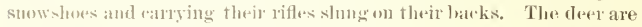
genetally very wikl and olten peeredve a man and begin to run at a clistance of a mile of fwo, though a rutting buck will sometimes fancy that

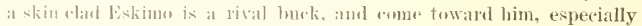
if the huntere eroulas down and keepes pertectly still.

The usual mothes of lumting is to walk off inland until a deer is sighterl. when the hunter moves direstly toward him at a rapid pace,

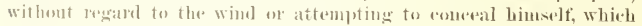
Wonld be almost hopeless in smeh open country. As soon as the deer starts to run, the lnenter quickens his pare-to at run, if he has "wind"

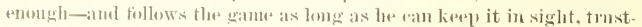

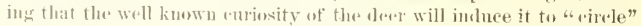
round, in order to sere what it is that is tollowing hine with such pertinacity. Shomld the deer torm, as often lasplems, especially if there is more than one of them, the lounter alters his course so as to head him oft, and as soon as lu gets within long ritle range opens fire, aud keeps it 11 , till the animal is lit or ustapes ont of range. Strange as it may secon. a number of deres are killeal arery winter in this way.

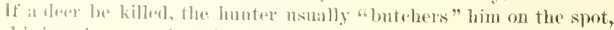
and brings in as muelt of the meat as les "an earry on his back, leaving the rest, and fully coswenl with slabs of snow to ploweret it from the foxes, to be bromglat in as som as convenient by a dog sled, which follows the hunter's trackis to the plawe.

I) noing the spring the derer retire some distane from the Point, and the does then drop their finws. At this season nearly all the natives are busily engaged in the whale tishery, and pay little attention to the 
reinder, so that we dicl sot learn where they went 1o. Whom the lan as

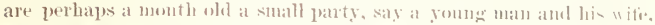

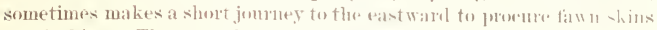
for elothing. They say that the tawns at lhis aye ("all be anght by

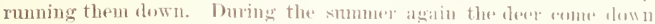
to the coast in small mubers, taking to the water in fle latwoms. or even in the sea, when the flies become tromblesome.

simetimes in warm, wilm weather the flics ale so mumeroms that the deer is driven perfertly trantir. and rus along withont lowling where he is going, sil that, as the natives saly, a hunter who places himself in the deer's jath has mo diffinlty in shooting hin. Fliss were umusmally sare both summers that we were at the stationt. so that we never had an opportmity of seeing this donc. When a derer is seen swimming he is punsued with the kaliak and lamed in the math

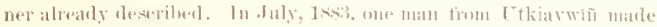
a short joumey inlimul, ".angyiug " his katiak fom lake to lake, and killed two deer in this way without firing a shot. I believe this method of hunting is frespently practined by the partios who go east for tamling in the summer, and those who visit the rivers tor the purpesion lounting.

The natives seemed to expect deer in summer at the lagensm as

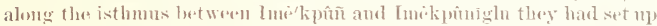
a range of stakes, evidently infemded to tum the deet me the beath

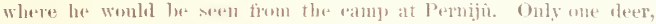
bowerer, "ame down either summer, and he escaped withont being seren. This eontrivance of setting uj) stakes to guille the ders in a cortain direction is very eommonly used by the Eskimo. Egrole gives a curions deseription of the pratice in Greenlamd in lis day: They

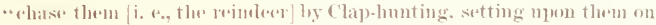
all siles and survoumling them with all therir. Women and Childeren to fore them into I befiles and Xarrow Passages, where the Men armet lay in wat fio them and kill them. Am when they latre not People enough to suromul them, then they put mo white Poles (to mak up the Number that is wantel with Pieses of Turt to heald them. which

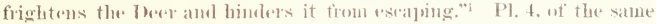
work, is a very emrioms illustration of this style of huntinge.

I similar method is pationd at the Conpermine River. where the deer are led loy ranges of turf toward the spot where the areher is hiblen. ${ }^{2}$ Famklin also noticed hetween the Markenzie and the Colville sinilar langes of driftwool stumps leading aeross the plain to two eairus on a hill, and Thomas simpson mentions a similas range near Hersehel 1sland, and domble nows of turf to reperesit men leading down to a suall lake near l'oint l'itt. for the pminese ot

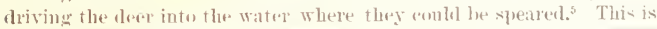

\footnotetext{
(iruenlant, p, fiz

${ }^{2}$ Fr.inklin, Jat Expul, vel. : 1, 1-1.

3.21 Expu+l. 2. 137

4 Xarrativ. 1" 114

Ibidl, 1), 1., it
} 


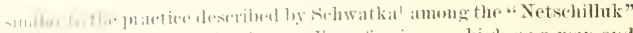

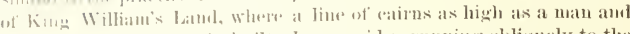

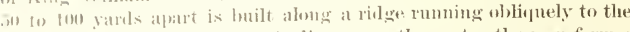

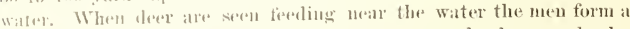
stimish line trom the hast atim to the water and advane slowly. The dere mistatie the arims lor men and take to the water, where they

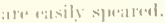

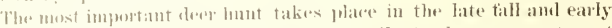
spring, when the natives go inland io or 6 is miles to the nperer waters of

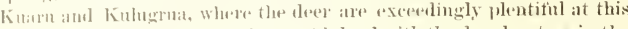

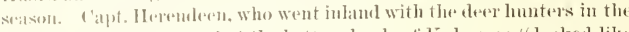

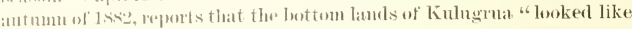

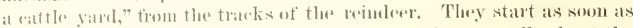
it is gustille to travel atross the comntry with sledgas, usually about the first of (O)tolur, taking gums, ammunition, fishing tarkfe, and the neeasing houserold ntensils for themselves and their lamilies, and stay till

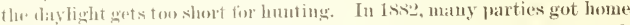

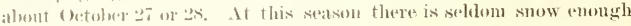

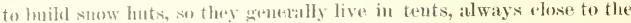
rivers from which they procure water tor bouschold use. The men spent their time louting the dere, while the women bring in the game, atteml to drying the skins and the honseloshl work, and eateh whitefish

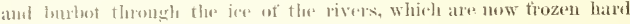

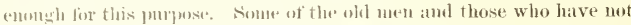
al supply of amumition engage in the same pursuit.

I comparatiwh small number of tha people go out to this fall deer

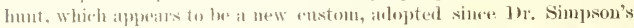
time. It wats probulnfy not worth while to go ont alter deer at seasons when there was not onomgh sum tor digging pitlalls, sine they depended

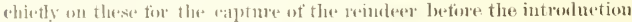

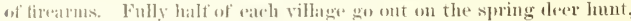
ats ther flid in Inagures time, the first parties starting ont with the

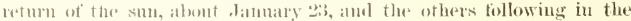
comrst of two or there wates, and remain out till abont the midlle of

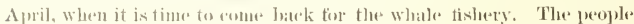

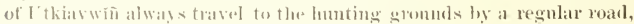
which is the sine as that followed hy lient. laty in his exploring trips.

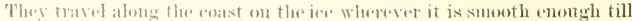

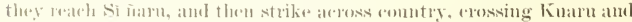

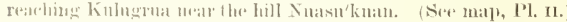

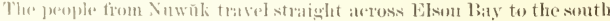

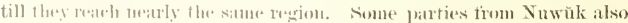

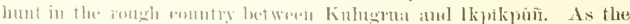

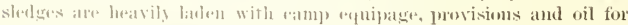
the lamps, they travel slow ly, taking tome or five days tor the journey, 


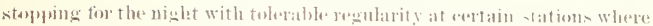
the first party that travels over the trail lonilit snow huts, which alew userl by those whe follow them. It the risers they alle seattered in small eampes of tour or tive tamilies, about a day's journey alpan. As

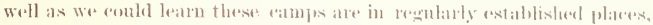

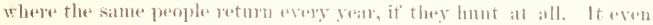
seemed ats it these localities were comsidared the property of motain influential families, who eonlel allow any others they pleased to join their parties. It is atertain, at all "rents, that the peoplen of (thiarwin

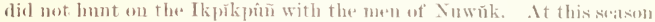

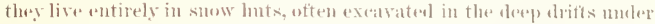
the river blutis, and the men humt deer while the women, as betione, eateh fish in Kuaru and Kulngrua. Nome are taken in Ikpinkpin. See above, p.in.

Derer are generally very plentiful at this season, thomgh sometimes, as

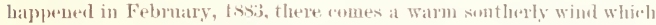
makes them all retreat tarther inlauel tor a tew days. They are gemer. ally lunted by thasing them on snowshes, in the mamer alleaty te. scribed, lout with much better ehances of suress, sime when a mumber

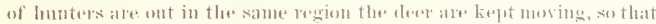
a herd started by ane hunter is very alyt to rom within gmonet of an-

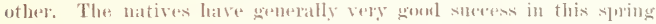
lome. Two men who were huntiug an shame for the station killed up-

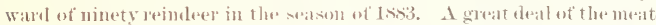

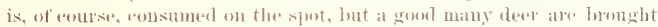
home trozen. They are skinned and bromelet lome whole, only the

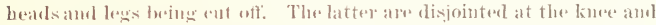

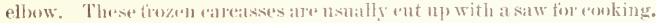

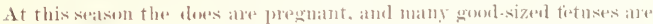

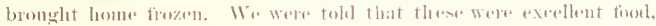
themen we mever salw them ratm. For the first two an thredaysater the return of the deer hunters to the village all the little boys are play ing with these tituses, which they set np an targets for their blunt arrows.

Befine starting tor the doer hunt the hunters generally take the move

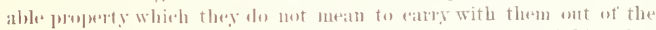

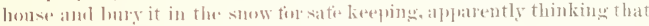

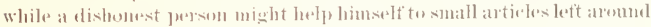

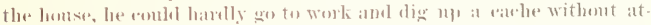
tracting the attention of the neighlors. If both timilies fiom a house

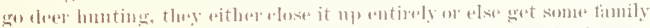

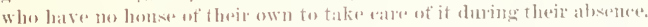
During the seatson, small parties, tratreling light, with very little bas.

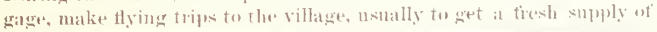

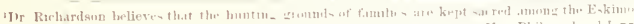

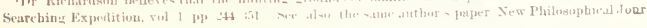
nat, vol. 52, p 72 . 
mentanimen or oil. atul at the end of the season a lueky lunter almost

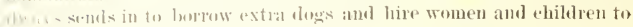
fels. thimg in his game. The skins, which at this seasen are very thiek

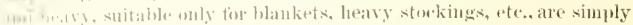

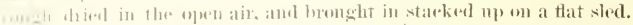

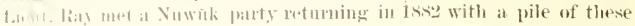

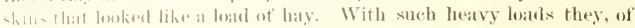

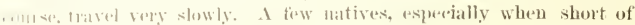
enmmitions still use at this seison the suow pittills mentioned by 1.1.1. M:1, Muire.'

The following is the description of those seen by Lient. Ray in 1ssis: I ronul hole is dhe in the drifted snow, along the hank of a stream or

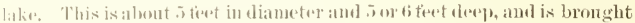

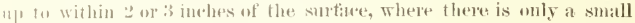
hole, thromgle whild the snow was removed. This is earefmlly elosed with it thin slath of slow and batitet by strewing reindeer moss and

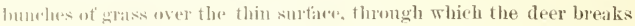
as soon as he stepson it. The natives say that they sometimes get two deen at onee.

This method of hunting the reinleer inpears unommon among the kiskino. I tind no mention of it "xerpt at Repulse Bay. and anomg He Xetsillingmint, where logs" mine is said to be sprinkled on the

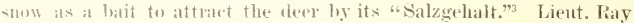
was informed hy the natives that the "Nomatañum" also captures doer loy means of a bawhisle noose set across a regular deer path, when they discovereal sueh. The noose is lectd up and spreal by a comple of stivkis, and the emd staked to the gromml witha piece of antler. A similar methoul was practiced by the natives of Norton Sound. A few parties visit the rivers in summer for the purpose of hnuting reindeer, lont most of the natives ale either off on the trading expeditions previously mentioned or else settled in the small camps along the coast, : 11$)^{4}$ miles apart, whenes they oceasionally go a short distance inland iti seatrele of reinderer.

The seul.-The thesh of the smaller seals forms such a staple of food, and their bhuber and skin serve so many important purposes, that their capmore is one of the most neessiary pursuits at Point Barrow, and is carfind on at all stasensol' the year and in many different methods. Dnring the statson of open wilter many seats ane shot from the nmiaks engager (a) whaling and wahrus hunting or mongt in nets set along the shore at

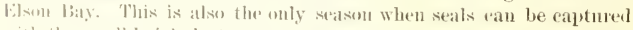
"itls the smill kajak darts.

The primijal sall tishery, howerer, hegins with the elosing of the sea,

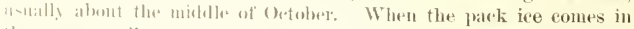

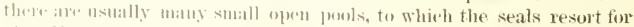
ati. Wost of the able hodied men in the village are out every day armed

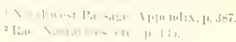

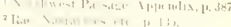

"Lihtr hat, "Als Eskino," etc., p. 131.

+1)all. Alaska. p. 147, 


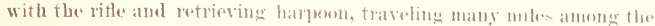

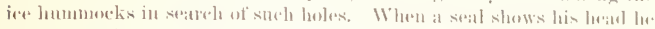
is shet at with the rifle, and the lometere, if suresestul, seroures his game with the hatroon. This mother of hunting is prat iued thromghout the winter wherever open labes lom in the ier. A native going to visit his

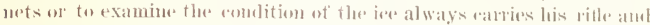

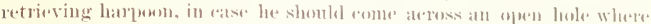
seals might be tomml. The hont at this seasom is aceompaniol witle

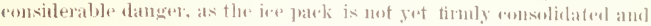
portionsot it frestuently more offishere with a shift of the wiul, wo that the houter rums the risk of leing rarried ont to sea. The mativas exereise consislerable eare, and generally aroid rewsing a drask it the wiud, bowever light, is blowing offishme: but in spite of their presantions

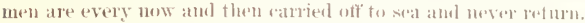

The hunters meet with many exeiting atrentmes. (1) the morning

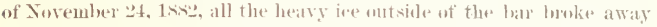

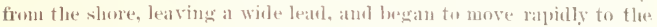
northeast, carrying witle it these seal hunters. They were tortumafely near enough to the village to be seen by the lomeers on the village hill, who gave the alarm. An umiak was immediately momted on al tlat sled and earried ont over the slore ion with great rapidity, so that

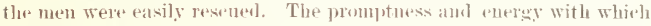
the pople at the villag acterl showed how well the danger was appre ciaterl.

It this seasou of the rear a single calum night is suffieient to cover all the holes amo learls with yomme ine stromg emough to smplont a man, and oreasionally botion the park anmes in the open sea freszes over. In this young ine the seals make their loneathere holes (arlun), "alout the Bigness of a llalfjemy," as Egetle says, amb the natives employ the

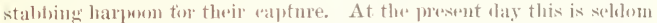
used alone, but the seal is shot throngh the lead as he comes to the surfiee, and the spear only usad to seeme him. Seals which have been shot in this waý are sometimes carried off by the enrent hetore they

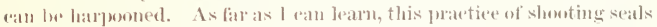
at the aclu is peenlias to Point barrow (induding probalbly the rest of flue Aretie eoast as far as kot $\%$ lne somm ), thomgh the use of the una, as alreatly stated, is very gemeral.

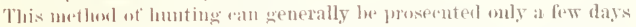
at a time, as the movements of the pack simm break up the fields of

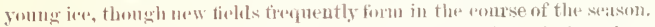
After the January arales the paek is so tirmly amsolidated that there are no longer any open boles or leads, and when the spring leats open yommg iee seldom forms, so that this method of lunting is as a mele cous. finet to the periogl betwern the midelle of ( )etober and the early part of Jammary.

With the departme th the smo, about the millle of November, begins 


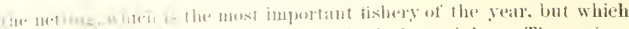

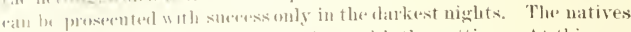

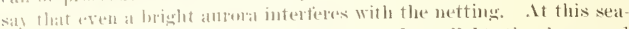

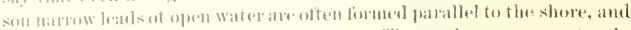

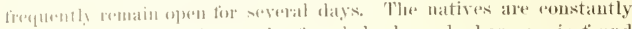

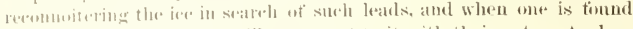
matrly all the men in the village gen ont to it with their nets. I place

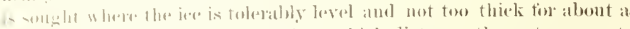

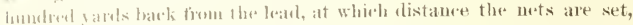
often a number uf them chas tosether, in the manner already dexeribed,

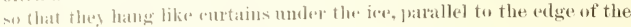
ofen water: When darkmesiones on the hunters begin to rattle on

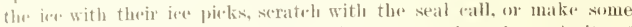

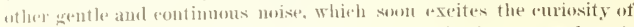
the sals that are swimming about in the open lead. (Om. at length dives unter the iee and swims in the direstion of the somel, which of

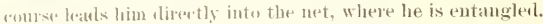

() flarobubl. mights a great many seals are eaptured in this way.

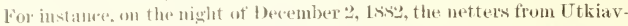
wiñ alonu fook at least one humbed seals. Sineh lueky hauls are not nommon, howeyer. Is the weather at this season is often exeesively

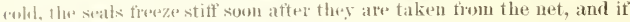
sullownt suow has tallan they are stacked up by sticking their hind hiphers in the snow. This keeps then fiom leing covered up and lost if ho smow leseins to dritt. I have comutes thirty seals, the property of on native, pilem up in this waty iuto a single stack. The women and

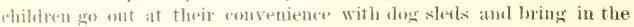
seals. I woman. however. who is at work on deerskin alothing must mot fomeh a hand to the stals or the sled on whiel they are loabled, but mas lend a hand at handing on the drace line. When the seals are bromslit to the elege of the beach they must not he taken on land till ateh has bera grivell a mouthtul of tiesh water. We did not learn the

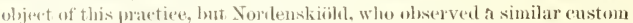
at t'ithekaj, was informed that it. Was to keep the leads thom resing.

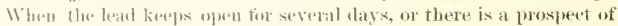

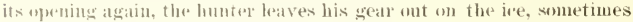

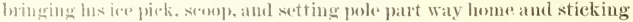

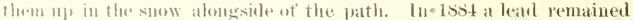
of ren tor sevoral days ahont 3 or 4 miles from the village, and the mative mate a regutar beaten trail ont to it. When we visited the net-

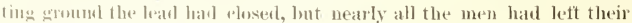

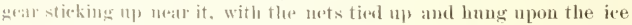
picks. They laal built tittle walls of snow slabs as a protertion against the wiml. The seasen fir this netting ends with the banuary gales, which gelose the leats permanently.

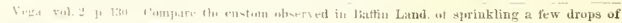

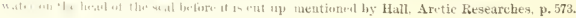




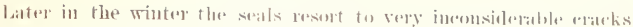
among the lummorks hor air, and nets alo set hanging alomul these

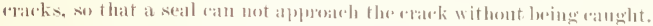

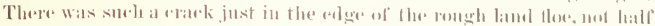

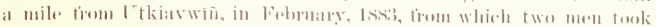
several seals, visiting the nets every dity or two. Those men whe des

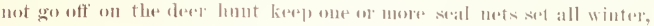

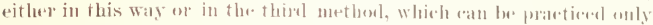

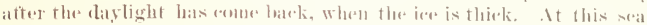
som there are tiecpuently to be tomme among the hummorelis what the

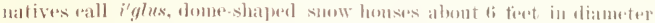
and 2 of 3 feet high, with a smooth romud hole in the top, and eommunnicating with the water. These are molonbtally the sallm as the suow burrows deseribed by kinulien, ${ }^{1}$ whioh the lemale sat builds to bring forth her yomeg in." They are enrions anstrontions, lonking astonishingly like a man's work. The natives told me that nets set at theses

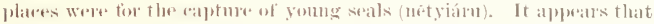

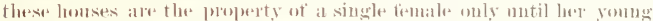
one is able to take to the watere, as a net is kept set at one ot theses holes, as well as I rould umderstamd, sometimes dapturing savelal seals.

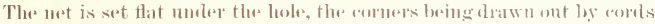
let down through small loles in a cirele pomel the nain opening. thromgh which the net is down. A seal rising to the surface rous his leatel thromele the meshes of the net. 'Tlue small boles anel sometimes the

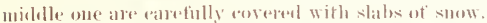

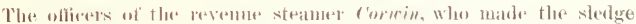
jomrney along the nentheast coast of siberia in the early summer of 1sit, saw stal nets set in this way, flat, moler air holes in the iere, with

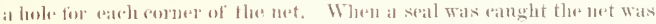

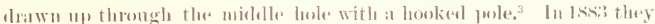

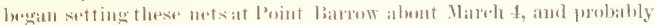
abent the same date the year hetore, thomglo we dis not happen to ab-

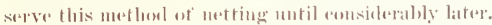

In Jume and fuly, when the ier lesemes rotten and wom into holes, the seals " " hanl ont" to hask in the sum, and are then stallied and shot. They are exteedingly wary at this season. The seal usmally talien in

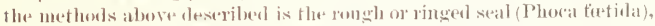

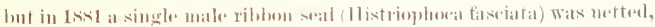

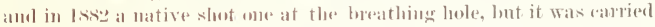
away by the enerent before lae eould sereare it. Tla matives salis that ther somerimes raught the hatrore seal (l', vitulina) in the shore mets in

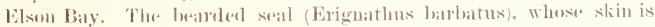

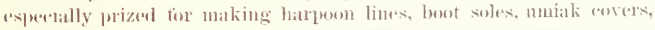

1 tomtribitions, p. 37.

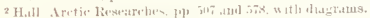

Hooper. Corwin Report. p. 25. 


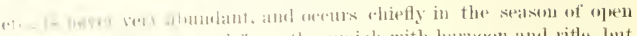

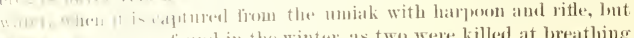
16. ate -mmetames limml in the winter, as two were killed at breathing

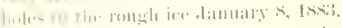

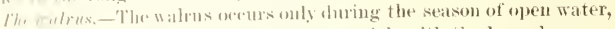

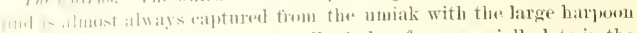
wat futh. The whalimg loats usably find a few, especially late in the axane and after the trating parties have gone in the summer the

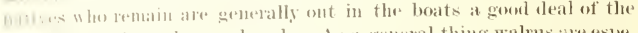

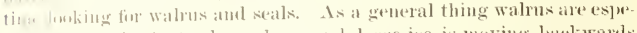

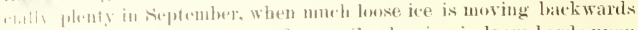

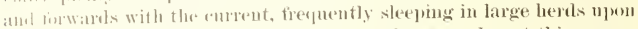

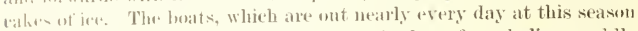
with voluntere crews, unt regularly organized as for whaling, paddle

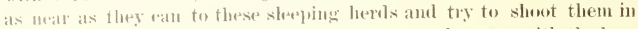

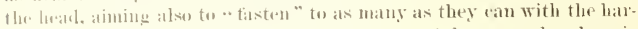
poron and that as they loury into the water. A harponed walros is followerl up with the bat and shot with the rifle when a chance is olterml. Swinning walruses are chased with the boat and "tastened fo " by darting How larpoun. When a wallus is killed it is towed up to the mearest cake of ier and ant up on the suot. We nexer knew of the katiak lowing usal in wallus hunting, als is the enstom amoug the eastern lEhimin.

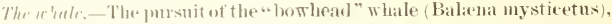
so viluablo not only for the food furnished by its flesh and "blackskin" and the oil from its bhobse, but for the whalelene, which serves so many usetnl purposes in the arts of the Eskimo and is besides the chiet antiele of trade with the shijs, is arried on with great regularity and formalits. In the first place all the muialiks (boat-owners) or those

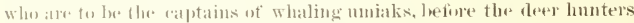
start ont in bannary. bring all the gatar to bo used in the whale fishers to the kindyigi, where it is rouseraterl by a reremony consisting of

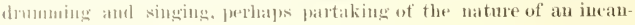
tatium.

('alt. Herenderen was the only ome of om party who witnessed this

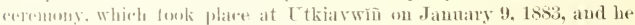
dial not bring hatek at detailed atcount of the proceedings. During pate of the ceremeny all the muialiks were seated in a row ujom the flens, and a woman passech down the line marking each arross the face with an whlique streak of blacklead. As soon as the deetr hunters re turn in the spring they begin getting ready for the whales, covering the hobits, fitting lines to harpoons, and futting gear of all sorts in per-

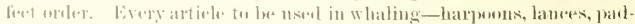

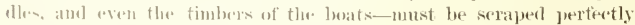
chealt. This work is gemerally done ly the umialik himself and his 


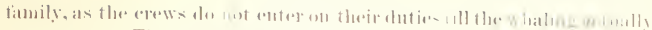

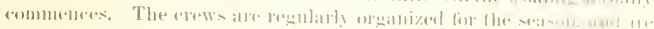

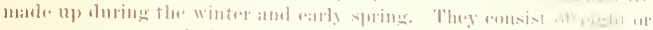

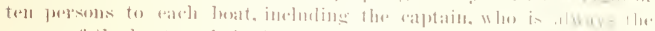

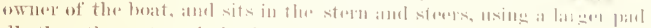

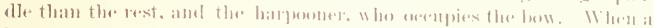

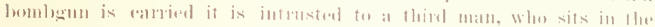
waist of the boat. and whose they it is to show the whale whenever low

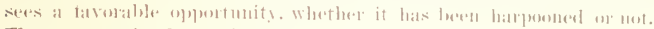
The rest al se simply pallallers.

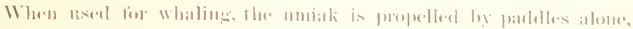

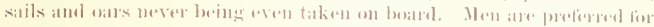

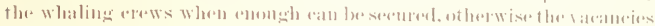

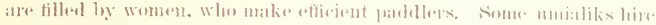

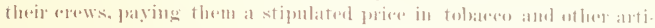

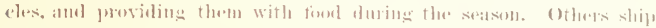

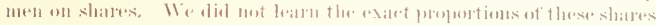

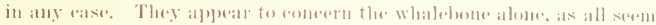

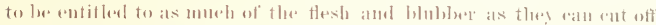

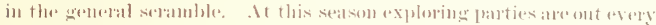
day ramining the state of the ien to astertain when the park is likely

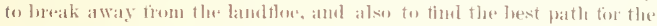

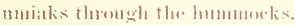

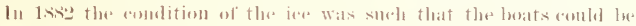

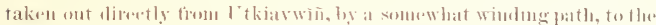

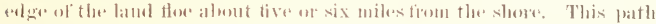
was markel out by the seal-hunters during the winter, and some of the

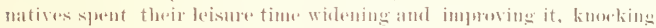

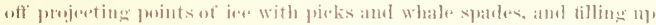

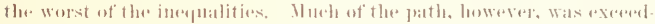

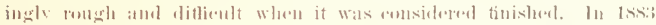

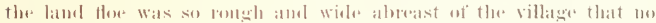

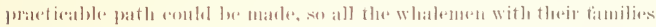

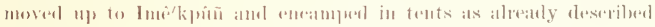

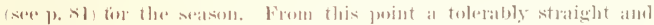

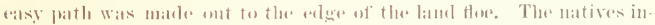

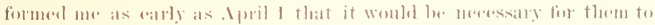

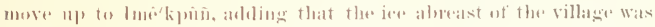
very heasy and wombl move only whell warm watherame. This pme

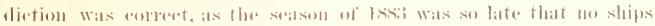
reaclerel the station until . Ingust 1.

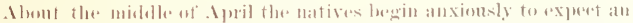

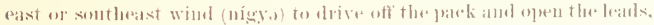

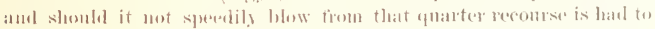

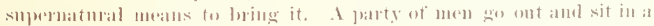

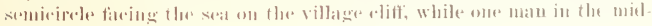

9) FIII-18 


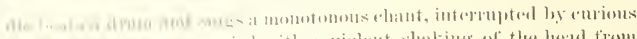

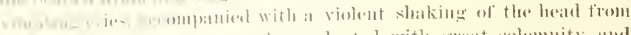

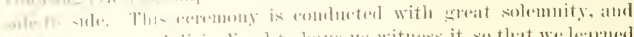

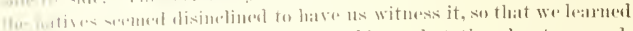

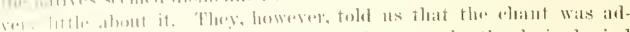

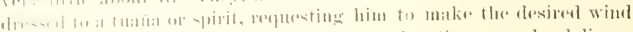

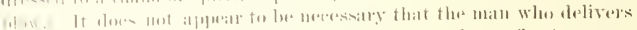

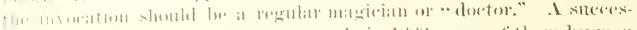

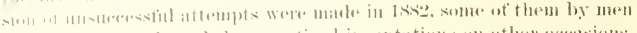

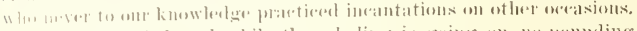

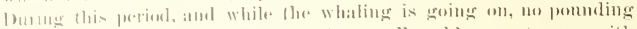
man be lone in the village, and it is mot allowalue asen to rap with Hor hutekles on woud for thar of trighteming away the whales. It is

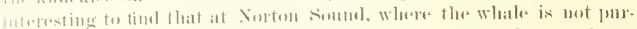

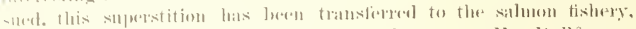
whe of the mest impmetant imblustries of the frear. Mr. Mall silys: -While the fislery lasts no worel must he ent with an axe, or the salmon will dis:aplear:"

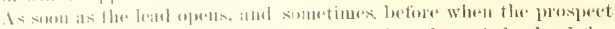

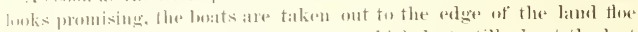

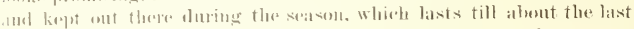

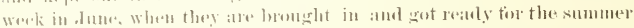

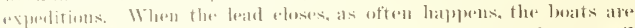

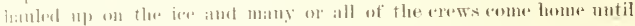

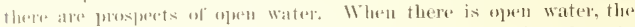

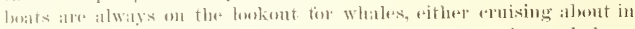

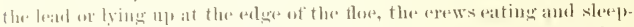

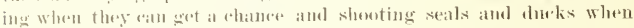

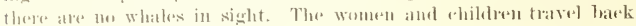

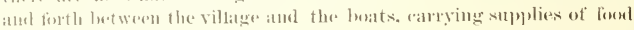
for the whalement

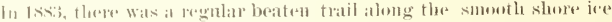

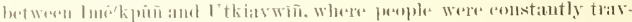
eling latek and forth. When the lwats ale out mo woman is allowed to

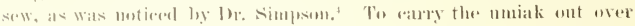

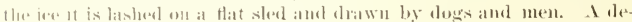

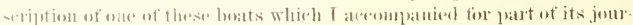
ner ont on the open watel. will show low a whalelonat is fitted ont. The

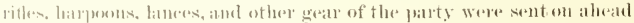

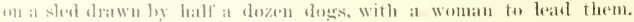

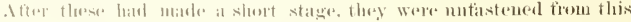

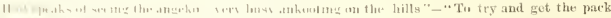

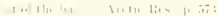

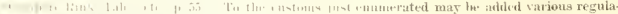

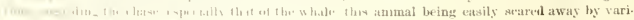

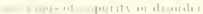

$4.1 \%$.1. 117

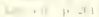




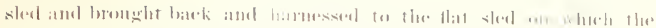

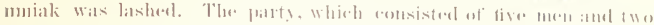

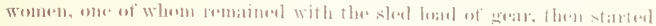

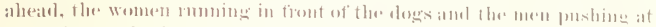

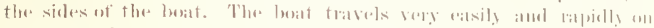

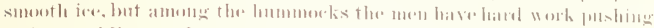

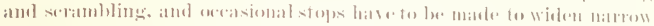

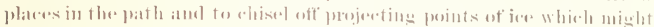

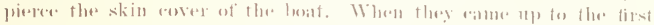
sled the women were angin sent on with llis while the ment lesterl.

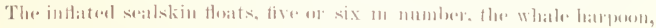

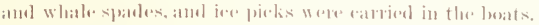

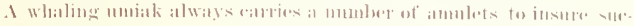

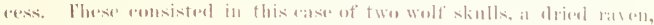

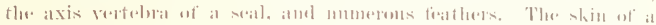

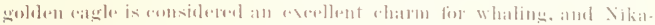

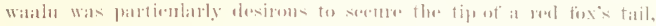

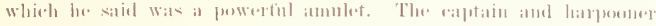

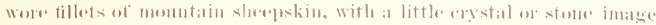

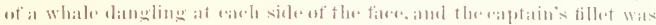
also tringer with the ineisor tereth of the monntain shere). linth ware

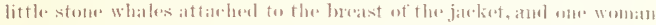

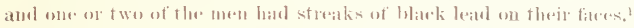

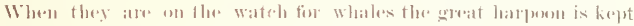

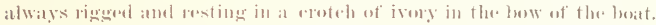

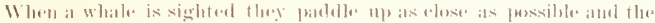

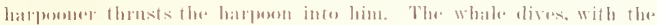

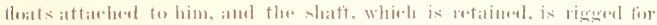

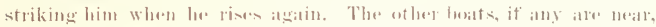

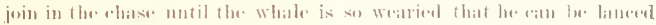

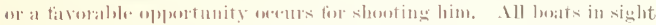
at the time the whale is struck, as l molerstomel, are antifled to an efunt share of the whalelwome.

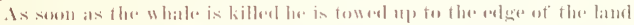

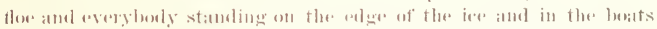

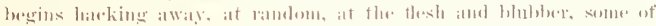

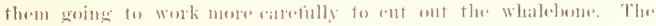

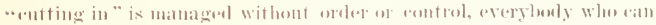

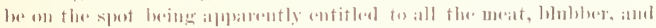

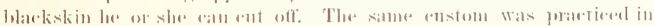
treenland, and is fo this day in eastern siberia.

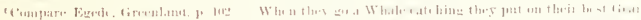

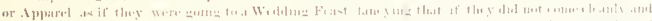

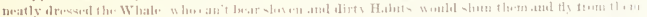

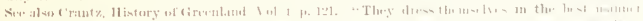

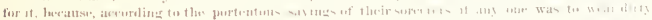

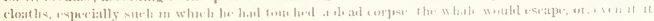
was alrataly dear. wathl at hests siak.
} 


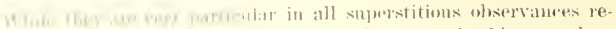

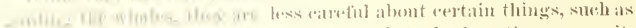

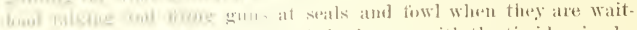

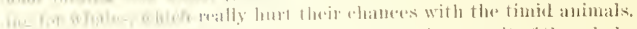

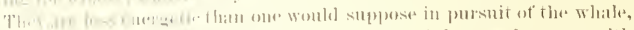

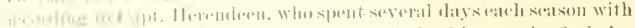

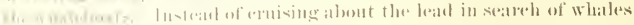

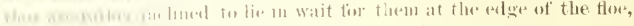

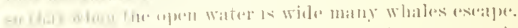

Bh

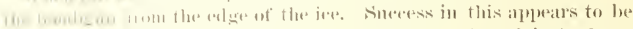

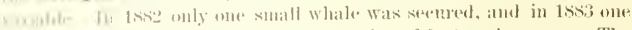

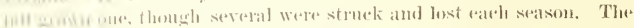

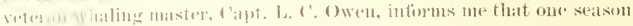

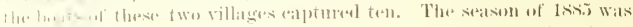

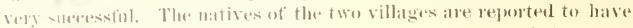
tation twenty eight whales. ('alpt. E. E. Suith. howerer, intorus me that only seren of these were finll-grown.

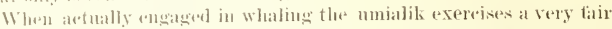

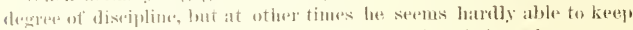
his men from stragegling off to ga home or to visit their seal mets, ete.e

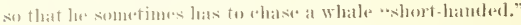

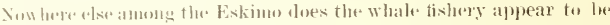
(e) mpon this morthwest aost. From all arooments the animal is moly eas. mally pursued alsewhere with thets of katiaks of umiaks manned hy

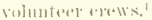

The beluga or white whale is only ensually pursmed, and as far as I andel tearn is always shot with the rithe. It is not abmulant.

Fonel-buring the winter months a tow fotamigan are oceasionally slut, but the natives paty 10 spectal attention to biols mutil the spring migrations. The tirst dorelis alpear a little later than the whales, alont the end of I luil or the first week of May, and thom that time till the

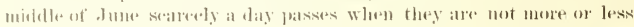
plonty. The king duelis somateria speretabilis alre the first to appear,

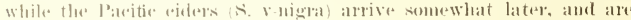
more atmontiant towards the end of the migrations. At this seasum all

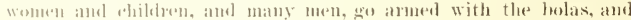

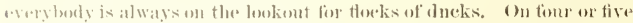
tammble days atels sasken, at intervals of at week or ten days, there

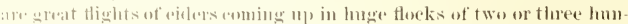
dred, stretelud ont in long diagonal lines. These flowk follow one

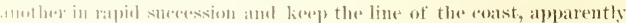
wriking straight atross l'atrel bay form the seahorse Islands to a point

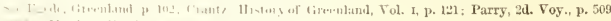

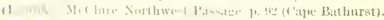




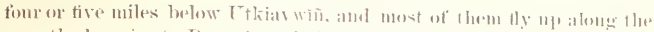

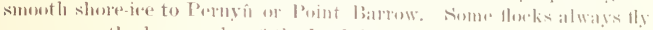

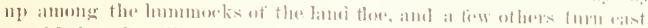

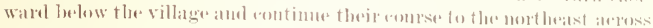
the land.

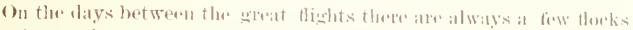

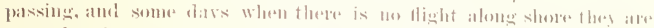

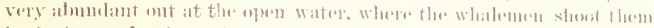
in the intervals of whalling. When at great Hight lexpins the people at

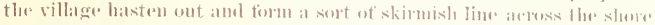

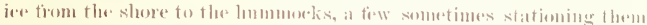

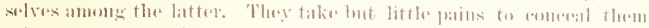

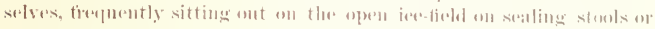

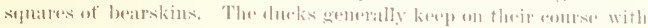

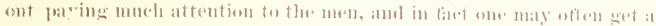

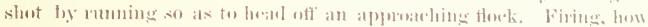
ever, frightens them and makes them rise to a comsiclerable height. often ont of stumshot. Many duckis atre takin witlo gums amel bolas in thesese flightsts.

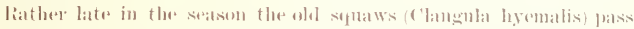

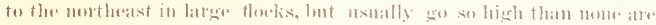

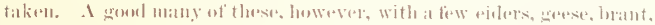

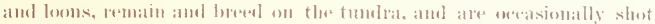
by the natives, thongh most of them are tow busy with whalime and sabl

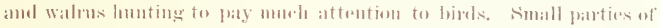
two or thar buk or young men. sometimes with their wires, make short 1.xemrsions inland to the smatl streams and sand islamels rast of l'oint

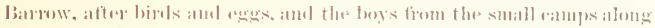

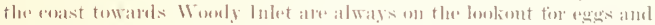
suall hirks, surh as they ran kill with their lows and arrows on ateh in shates. They say that the patties which go mast, and these which visit the rivors in summer, get many eggs and tind plenty of durks,

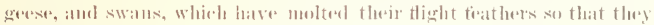
are unable tly.

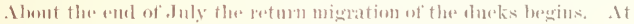

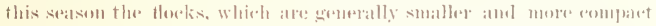

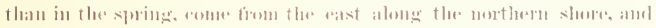

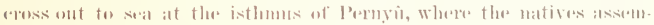
ble in lange mumbers to sleost them as wall as to meet with the Numat-

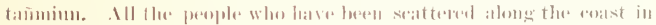

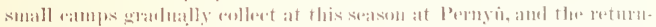
ing eastern parties genelally stop there two or these days; while, atter

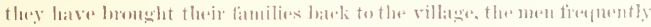

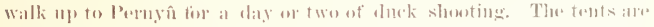
piteherl fust in the lweml of Elsom liay, and north of them is a narrow place in the saludspit over which the dueks often pass. Hewe the lat 


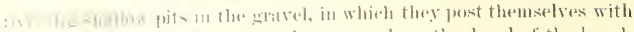

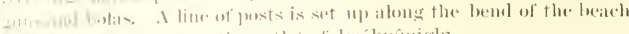

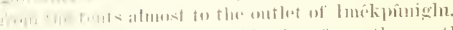

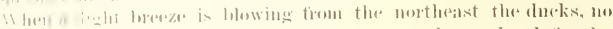

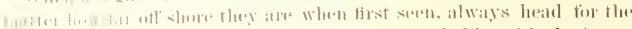

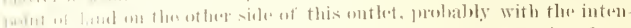

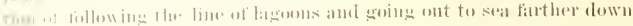

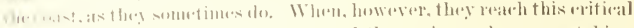
fortht they rateh sight of the pusts, and the natives who are watehing

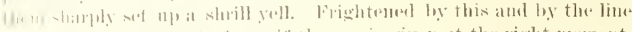

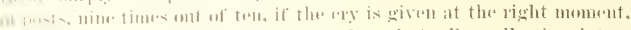

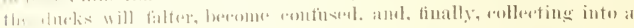

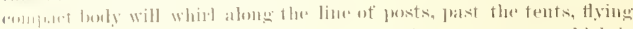

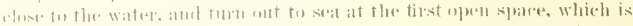

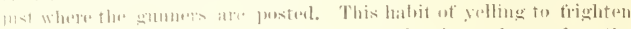

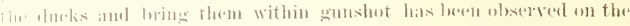

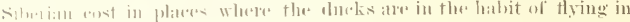
and and fiom lageons over low hatrs. Shombl the wind blow hatrd from

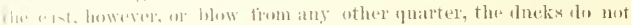

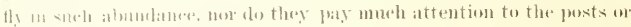

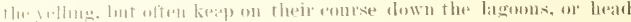

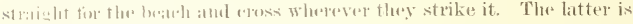

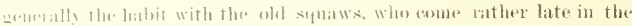

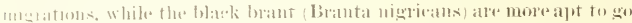

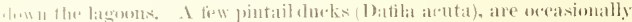
then at this stasent, and ale sometimes fomml in the two little village

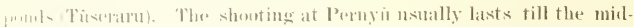
Ale of enet of september, , luring which month the natives also shoot a

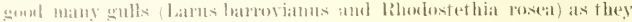
th stheng the shore.

\section{IMLEUENTS FUI HISHNG.}

Houhs and lims. The strams and lakes in the immediate neighber

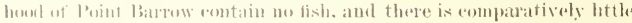

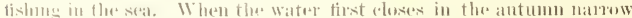

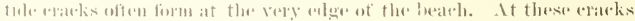

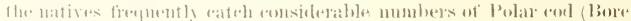

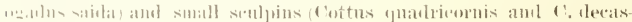

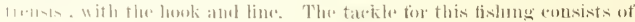

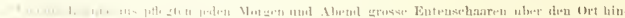

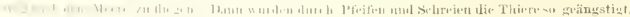

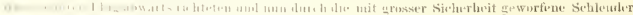

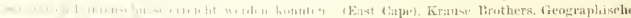

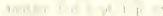

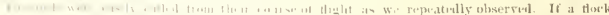

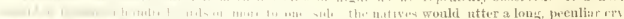

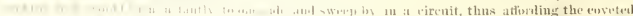

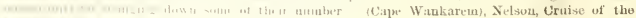

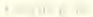




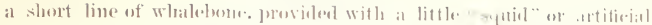

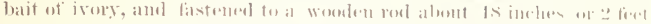

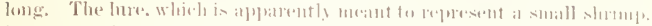
is kept moxing. and the fish bite at it. Wo lyought home fon com

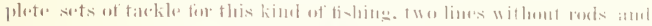

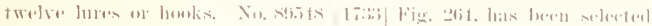
for stexipiption.

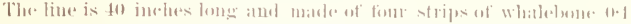

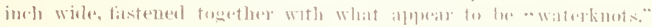

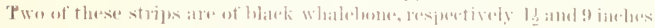

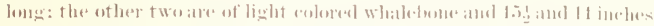

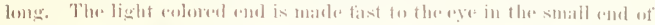

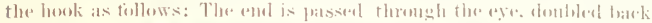

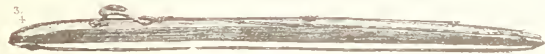

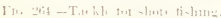

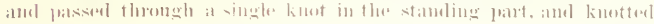

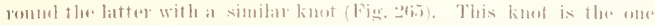

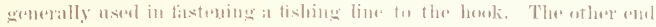

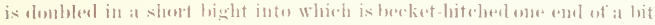

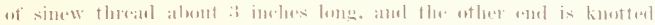

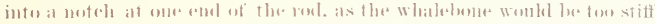
to tie serenrely to the stick. The roul is a roughly whittleal splinter of

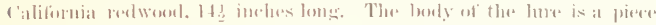

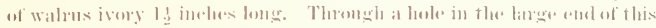

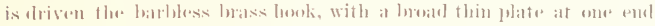

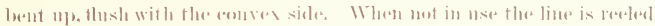

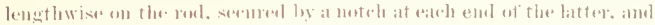

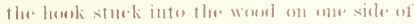

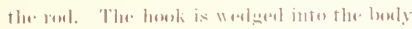
of the luw with a bit of whalelone. The

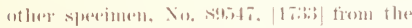
same village, is almost exatly like this, hut

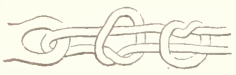

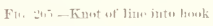

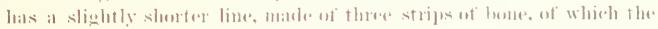

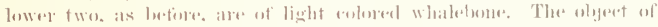
using this matterial is molbally to remeler the part of the line when is

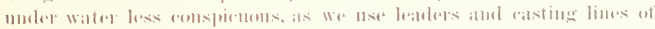

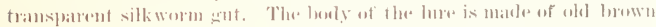

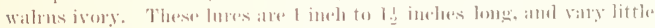

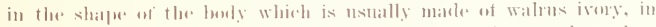

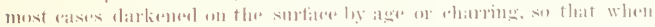

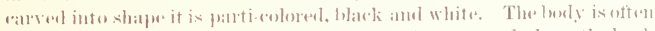

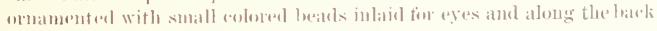

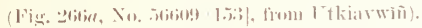

The hook is nsmally of the shalpe deseribul hut is sometimes simply at

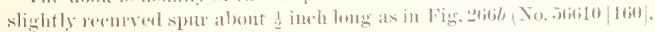




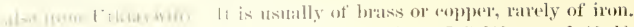

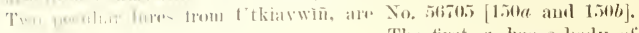

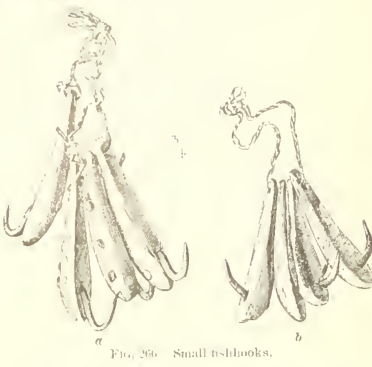
The first, ", has a body of masis of the nowal shape, and a copplete hook, and the other, b, has the body made of a strip of thin brass to the bark of whish is fastemed a lompot learl or pewter. The hook alphears to be madre of a rommon copprer tack. We were intomed that these lames were also ased fir (attelhing small tish, tront, smelts, and perhajs glayling in the rivers in stommer: No. s!s.5. [9.50], Fig. zoīa, from l thiavwin, is pere

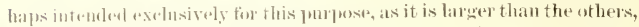

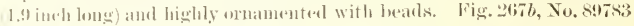

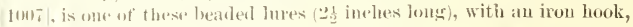

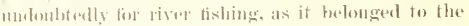

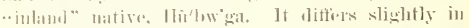
shape tion the oflers, hatring two eyes at the small enel inter which is fastemed a leader of sinew braid 3 ind he - long. On this are strung fout blue ghass heats and ole red one.

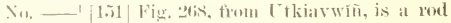
ngend for tishing in the rirers. The rod is at romghly

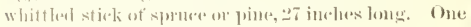
lint is $1: 3$ and the other 30 inelues lome and each is mamb of two strips of whalebour of which the lower

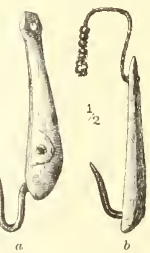

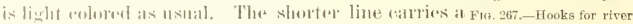
suall plain ivery loure of the common pattern, and the tishing.

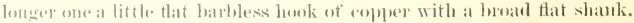
This wis probably seraperd bright and used wiflout bait. The lines are

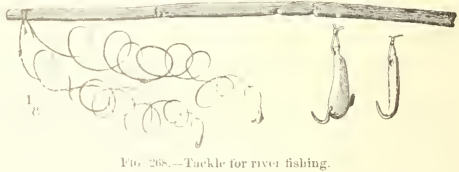

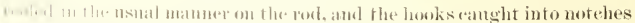

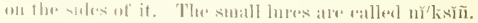




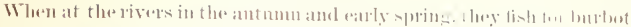

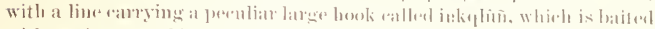
with a prese of whitetish. There are two forms of this hook,

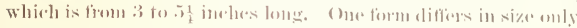

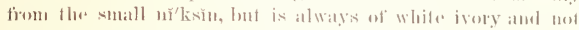

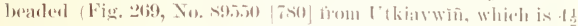

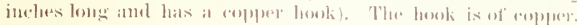

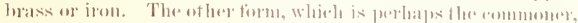

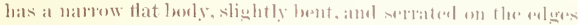

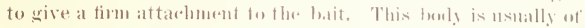

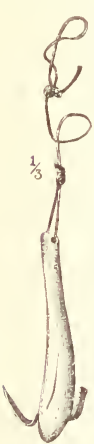

Fir. 2059 - lins inct laskl $|x|$ fatterth. antler, and has at eoppere or irou howk aither spur

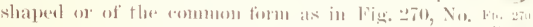

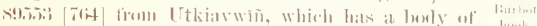

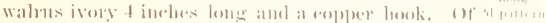

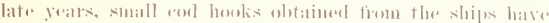

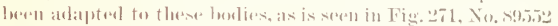
[st1] from I tkiaswion. The shank of the lowk las been half imberlded in al lomeitudinal somose on the thatfer sila of the burly, with the bend of

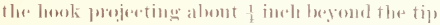
of the latter. The ring of the loosk hats been lent ope+l and the end siuk into the borly. The

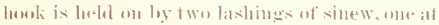
("ach r.ucl of the shank.

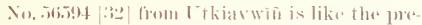
coling, but las a laregel looke, whish trom the

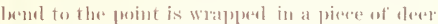
skin with llae Hesh sisle ont, and womel with

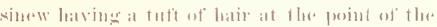
lusok. This is molnably to hick the point when

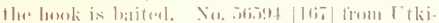

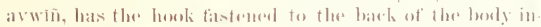

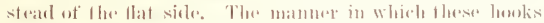

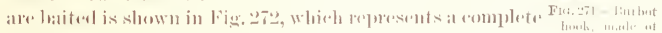

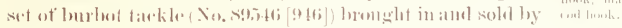

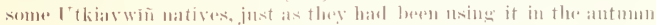

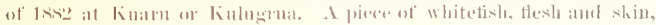

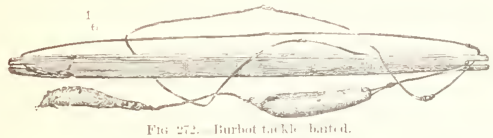

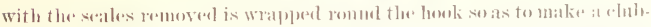

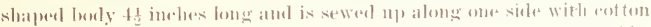

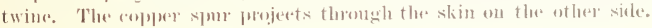




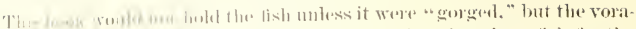

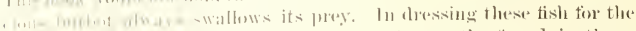

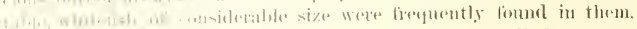

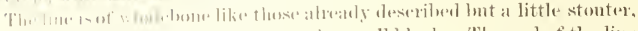

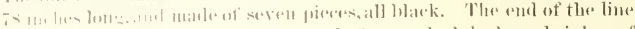

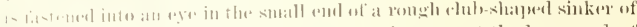

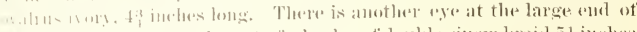

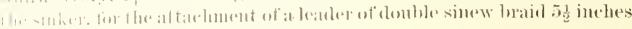

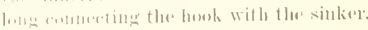

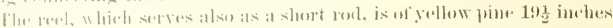

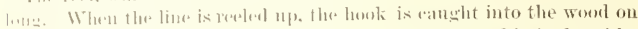

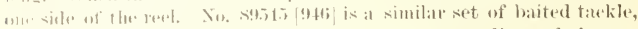

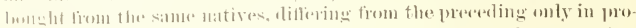

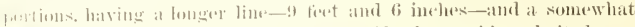

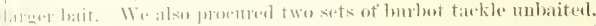

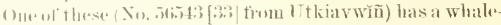

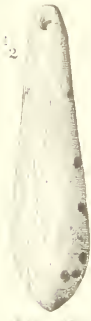

H...

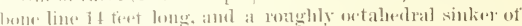

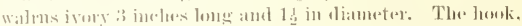
which is joined to the sinker as betore ly a leader of stout sinen blaisl, is of the second pattern, with serrated edges.

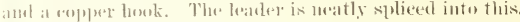

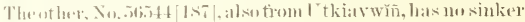

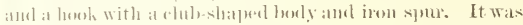
pobably put tougetlere for sale, as it is mow. The sinkers, of

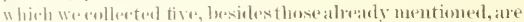
allwas alout the same weight and eithel club-shaped or roughly owtaledral. They are alwalys ot wallus ivory and

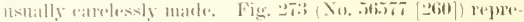
sents one of these sinkers (kilviea), on which there is some aftempen at ormamentation. ()n the larger are two "yes and the ontline of a menth like a slatrk's, ineised and tillod III with libati retiuse wil.

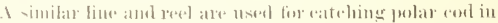
the spring and late wiste themgla the ies at some distance

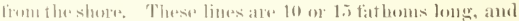

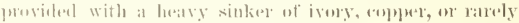

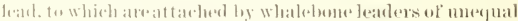

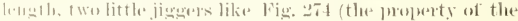

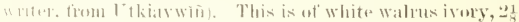

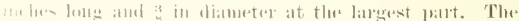

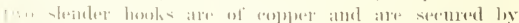

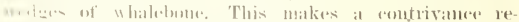

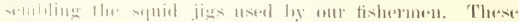

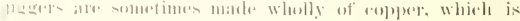

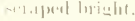

This tishery lescius with the return of the sum, about the

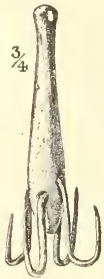

FIc: $\quad 27 t$. rvory jigger for polar sod. 


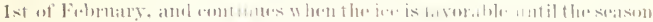

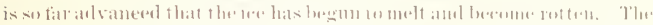

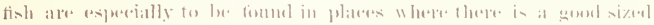

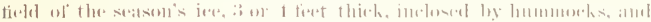

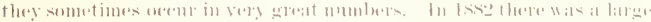

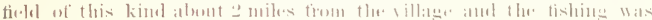

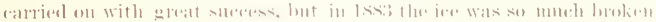

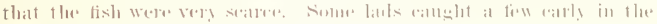

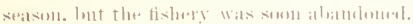

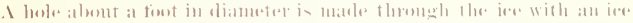

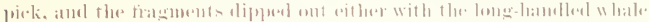

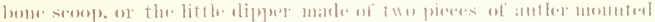

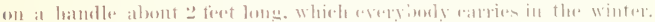

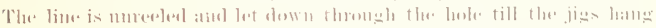

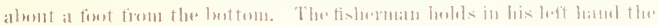

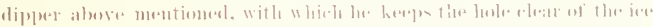

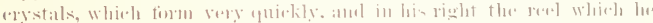

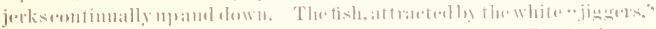

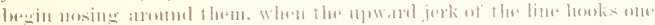

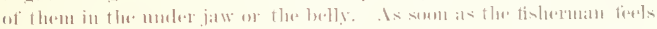

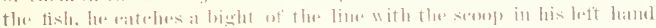

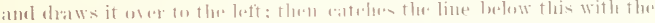

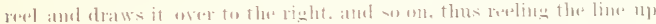

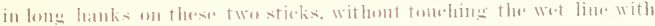
lis fingers.

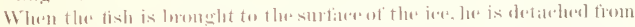

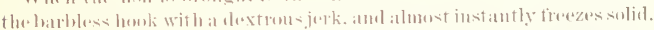
The chastid whalelwene line is thawn ofl the stick withent kinking and

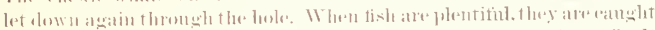

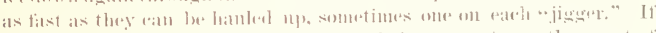

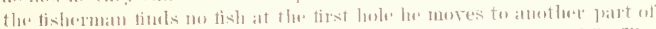

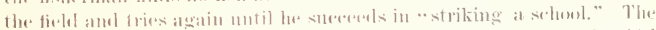

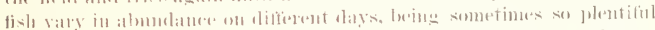

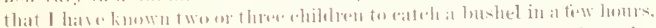

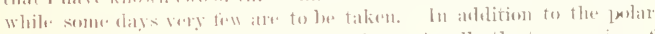

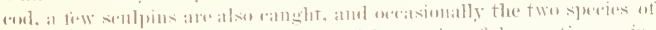

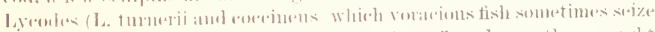

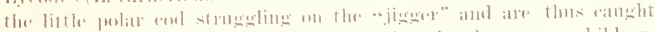

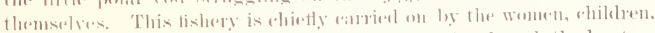

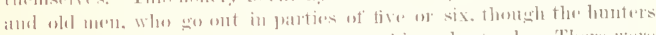

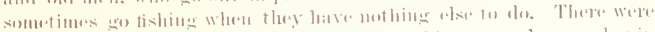

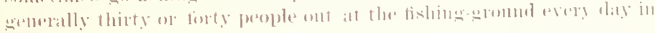
ふふ2。.

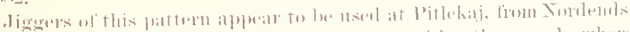

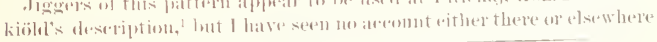

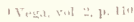




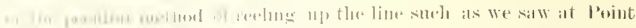

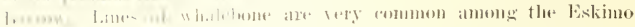

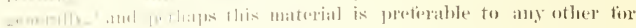

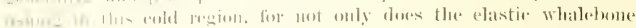

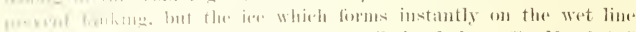

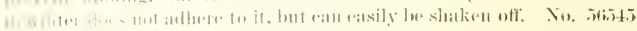

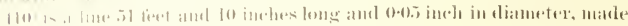

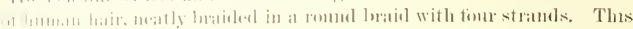

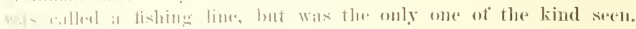

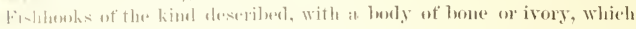

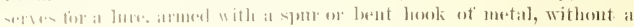

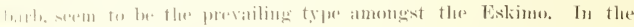

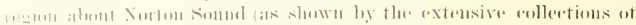

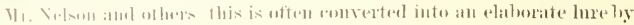

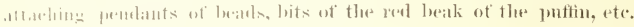

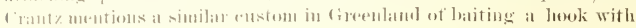
lisaris.

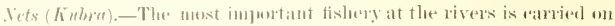
ly means of gill-mets. sect molde. the ies, and visited every tew days. In

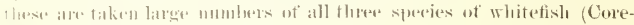

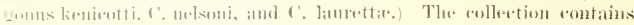

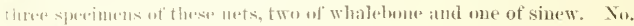

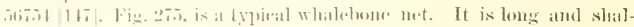

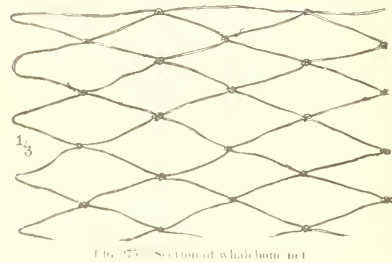
low, 79 meslies lomg and 21 deepe matcle uf tine strips of whaleboure fast. enesl together as in the whateleme fishing lines. Most of the whalebone is black, but a fin light aolored strips are intermixed at random. The length of the mesh is $3 \frac{1}{4}$ inches, and the knot mserd in making them is the ordinary wetting-kmot. Wlyen not

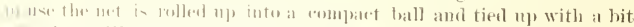

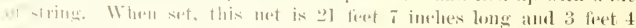

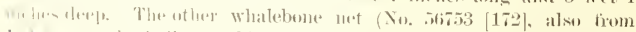

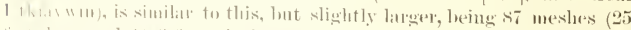

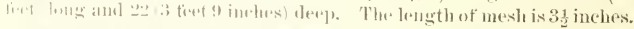




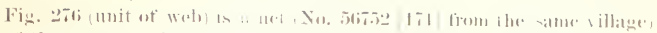

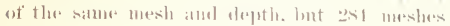

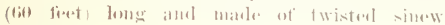
twine.

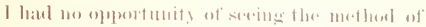

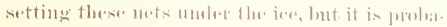

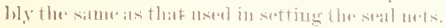

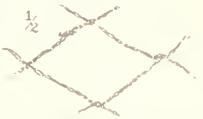

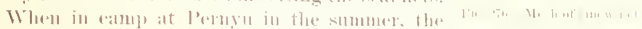
matives set these nets in the shoal water of Elson liage at right angle-

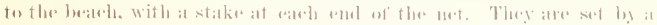
mau in a kayak. and in them ane gilled ronsideralle munters of white

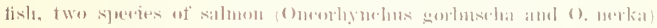

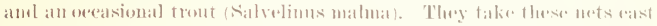

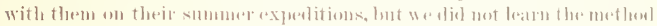

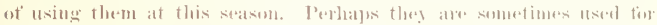

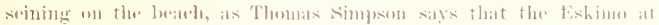

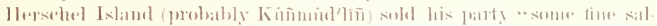

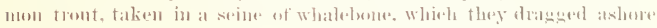

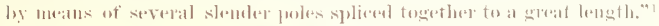

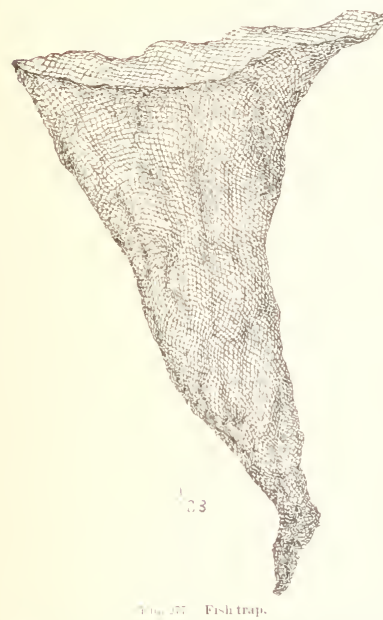

An Vtkiarwin native told 11. that lie formel trent (sial. velinus maluas) se plemtiful at or mear the month of the (inlville, in 1.x's, that he feet his doges with than.

Fig. 277 is a pential net

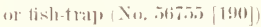
fiom lokiarwin, the omly sperinem of the lind seest. It is a conical, wide-montlues] bage st fiet + imelese long amel is teret wide at the montle, netterl all in one piones of fwisted sinew, with: : 21 -inelh mesh. This was bremglit owar for salle al an a arly date. latore wre were wall ats. qnatinted with the natives, and we moly deamed that it wats set permanesutly tor atching tish. Infintunately, we never saw another sineimen, and flomeng the press of oflate llaties mever happeresed to make finther 


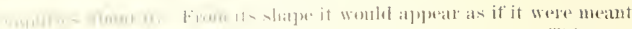

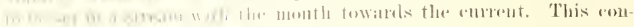

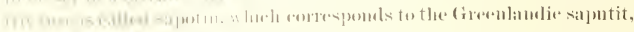
il ing int chilutary tish.

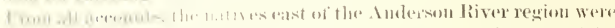

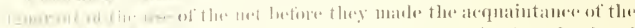

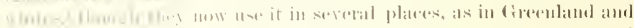

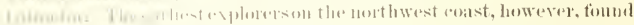

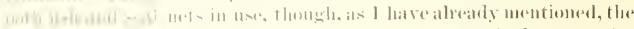

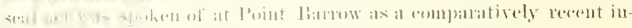

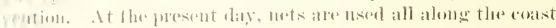

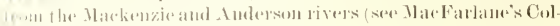

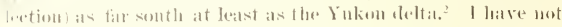

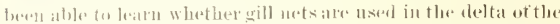

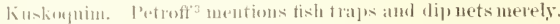

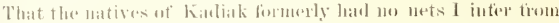

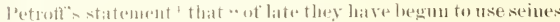

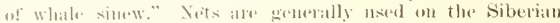

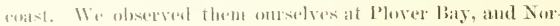

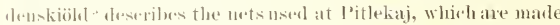

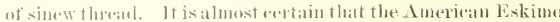
learmat the nas of the net firm the siberians, as they did the

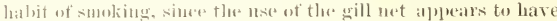

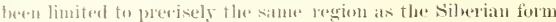
of totaiaso pije:

sperts.-The muly evidence which we have of the ne of spears for catching tish in this region is a single specimen, Xo. S9:001

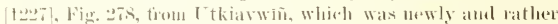

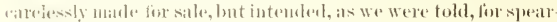

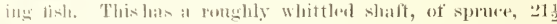
inelles long. armed at one and with there prongs. The middle

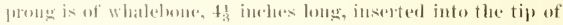
the shatt, which is rent into a shert merk and whippes with sinew. The side prongs ane alsontthene, !) inches leng. Throngh the tip

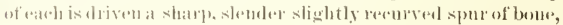

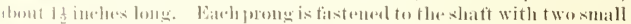

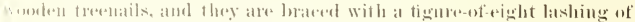

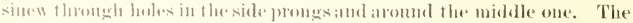

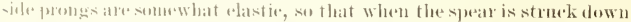

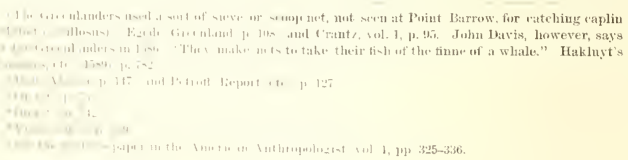




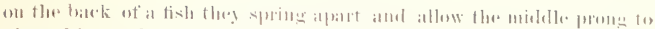

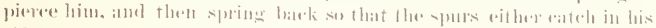

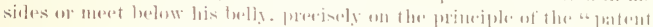

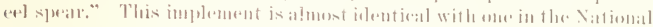

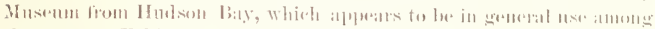

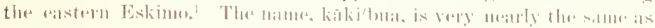

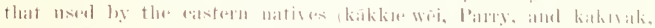

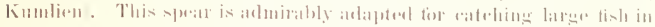

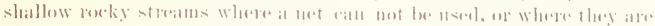

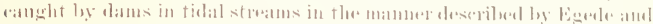

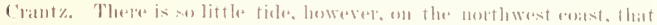

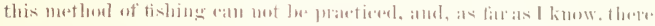

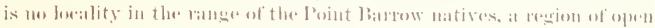

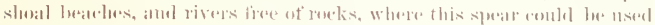

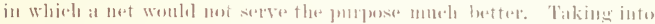

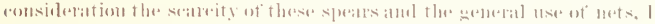

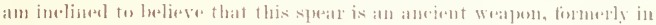

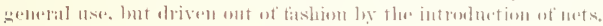

\section{PLINT WHRliva,}

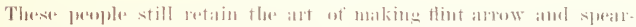

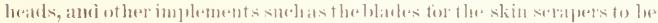

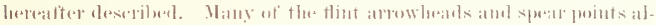

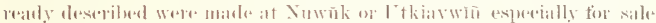

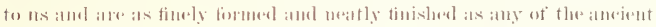

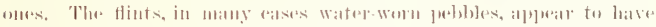

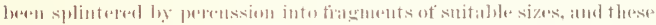

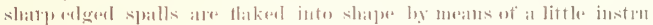

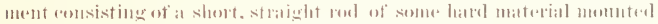

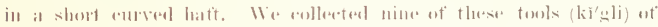

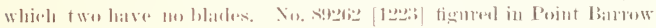

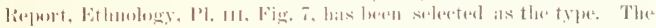

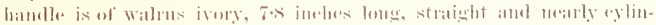

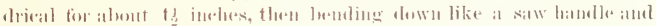

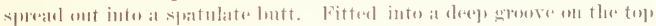

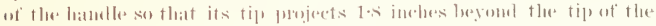

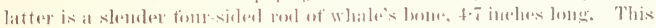

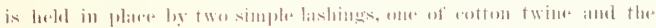

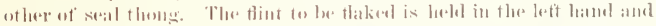

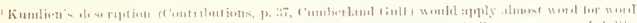

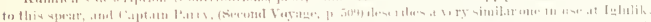

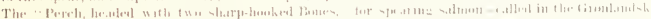

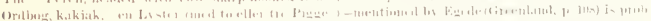

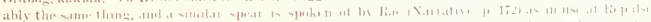

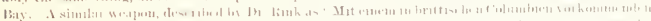

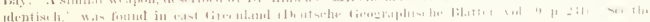

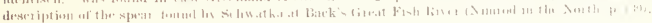

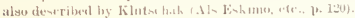




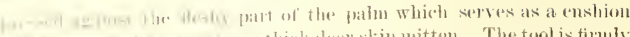

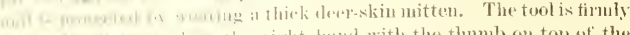

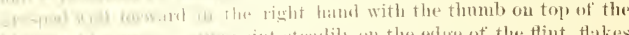

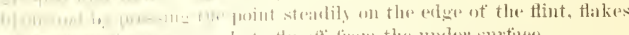

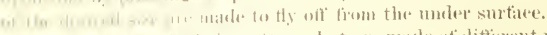

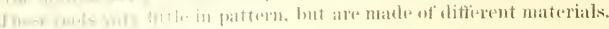

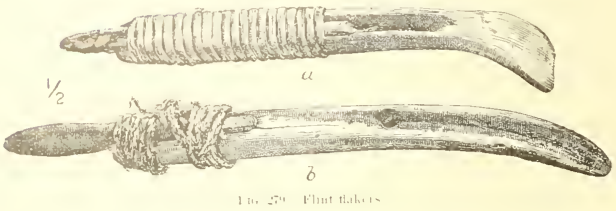

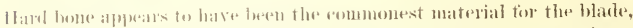

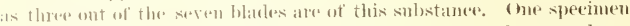
(1) s!e?

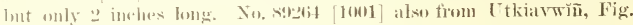

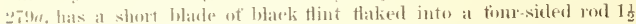
inclese fong. This is hell in plawe by a whipping ot stout seal thomg fightemes] the thrusting a splinter of woos in at the back of the groove.

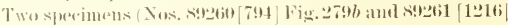

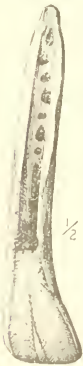

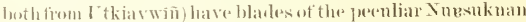

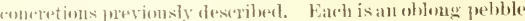
wedged into the croove ant serened by at bashing as nomal.

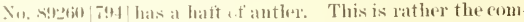
mones material for the haft. Two spe ejmens have hatts of uallus ivory and thee of fossil ivory. The length of the hatt

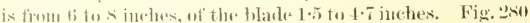

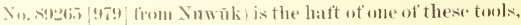
mathe of fossil ivory, follow from age and staned brown in blotelues. whicll shows the way in which the groove for the

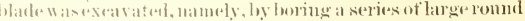
heles and entting away the material between them. Theres. mains of fle holes ane still to le seren in the loottom of the

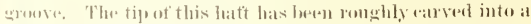

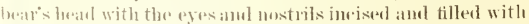
black dirt, and the ayres, mestrils, and mouth of a buman

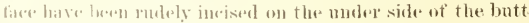
lachemed. Ill this arring is new and was dome with the

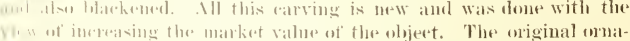
mentation emsists of an ineised pattern on the npper surface of the

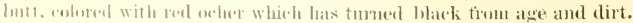




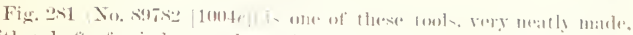
with a hatt of reimbere antler and a bour blakle, se enred by a whipping of seal theme which belongs witl the " kit" of tools owned ly the " inland" "na

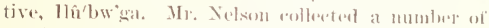
specimens of this tool at various points on the north. west coast from Point IIope als far soutla as Vintom

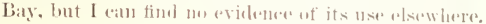

\section{FIRE MLIXi.}

Mrills.-In former times fire was obtaimel in the method (ommen to so many salvages, from the luat dereleperl hy the trietion of the enel of a stiek workenl

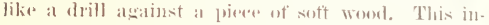
strument was still in use at lealst as late as 1 6:30. but alpears to have besen wholly albandoned at Point barrow at the time of the llerer's risit, themele still in use at liotzebue sommi."

A native of Nowne one diry lomenglit down for sale

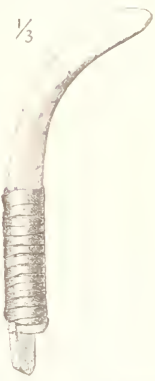

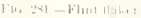

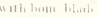

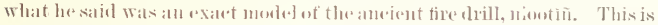

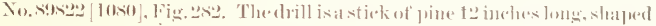

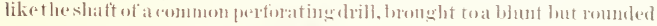

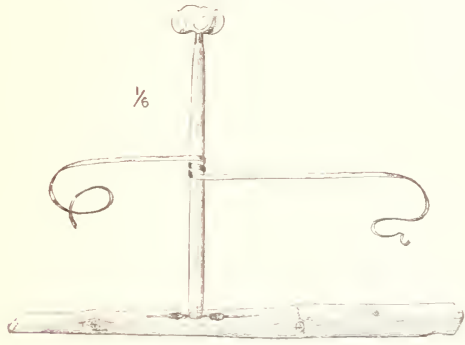

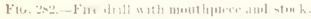

point. This is worked lya a string, withont low on hamdles, eonsisting of a strip of the skin of the beateded seal, fo incles bone. and has for a

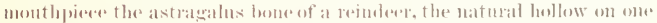
sile servine as a sorket for the butt of the drill. The point of the drill

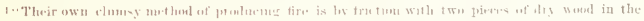

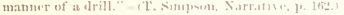

2 1)r. Simpsum, oje, cit., p. 212.

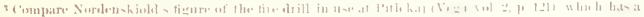

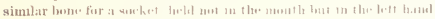

!) ETII-1!! 
is male to work against the split surtare of a stick of sprure 1 s inches

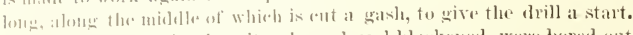

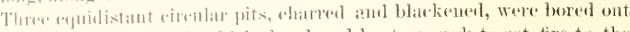

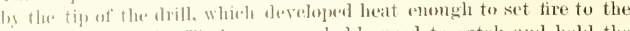

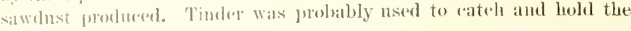
tim.

Inst antlous who have treated of the Eskimo have deseribul an un-trument of this sort in use eitlere in tinmer times or at the present dia: ${ }^{2}$

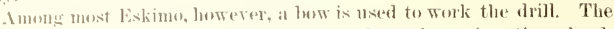

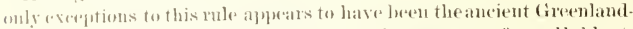
ars and the people of Iludsoll bay (sece the prassiges from llakluyt,

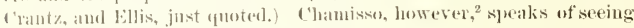
the Aleutians at I malaska produce fire by means of a stick worked by a string malking two tums about the stick and held and drawn with looth hands, with the nypere and of the stick tmening in a piece of wood lede in the month. When a piese of fir was tumed against another piece of the same word tire wats often produced in a tew seeomds. This passage

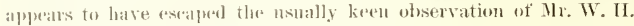

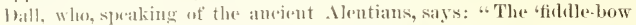
drill" was an instrument largely usial in their atrving and working bone and ivory; but fol obtaining fire but two jieces of quarz were struck tougether," ete.

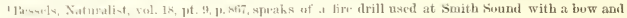

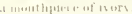

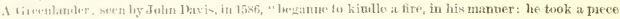

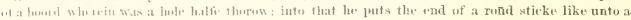

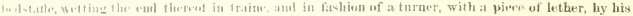

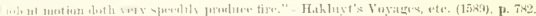

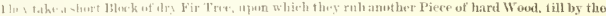
contumed \$ot

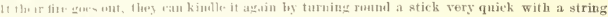

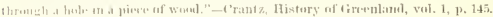

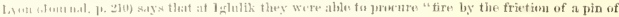

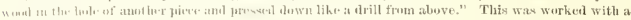

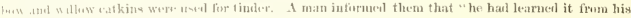

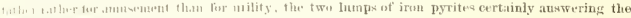

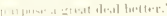

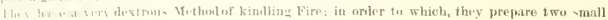

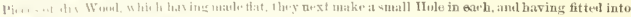

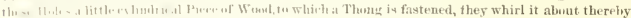

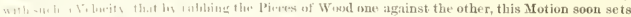

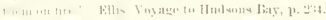

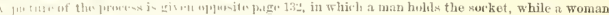

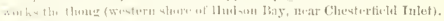

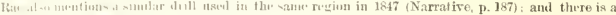

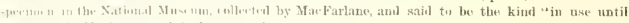

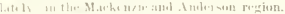

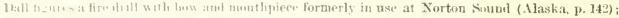

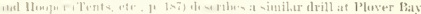

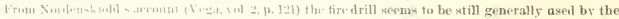

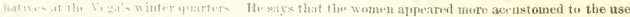

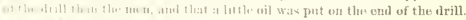

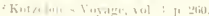

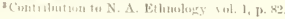


I hat 10 opportmity of soeing this drill manipmlated, but I hate and

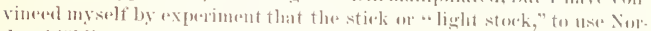

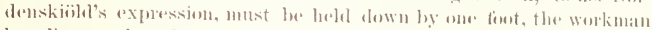
knerling on the other kane.

Flint and sterl. Fire is nsually obtanded mowaldys ly striking a

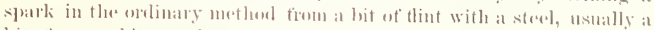

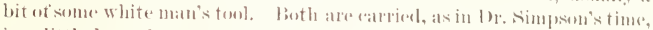
in a littlo bag slowg anomul the beek, along with some tinder masle ot

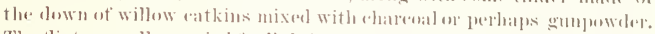
The tlints nsually earrial for lighting the jije, the only ones l have seren,

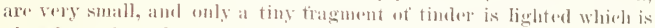

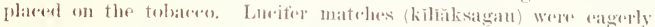

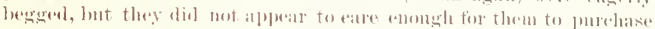

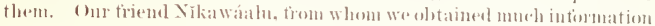
about the anejent enstoms of these [eesple, told us that long ago, "when

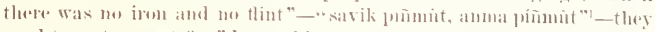

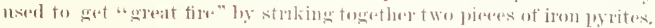

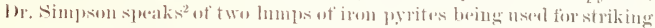
fire, but he does not matie it eleatr whether he salw this at lonint barrow or only at Kotzebue somml. Iron pyritos appears to have leeen used

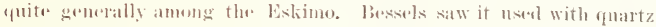
at smith sombl, with willow satkins for tinder and byon mentions the use of two pioces of the same material, with the samme kiml of tinder, at lghlik.' Willow ratkins are also nsed for timeler at the ('op)

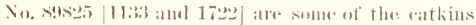
used tor making the tinder, which were gatheresl in comsialerable quantitiesat the risers. They andalled kimmimm, wheh perhajes mams " litthe chogs," as we

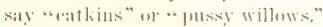

kimbllings.-From the same plase they also lowemght home willow t wigs, ! imeles long, and tiol with sinews

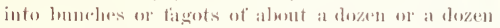

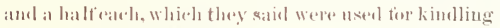
fires. (Xo. Nis:-1 17:-3.)

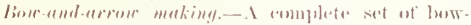
and arrow touls ensists of l pioces, viz: a matline sprike, fwo twisters, and a thatlere settere, ats shown in

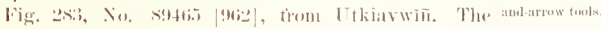

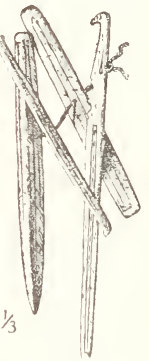

Fur. 2xy. sit of bow. pieces of this set are pertionated and strung on a piose of simew batid, 1 inclues longe, with a knet at ablele end.

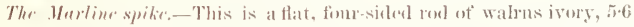

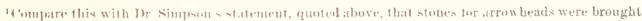
l.j th. Nunatamunu frou the Ku whk liver.

z) (1). cit., ). 243 .

3 Naturalist, val. 1x, pt. 9, p, nti7.

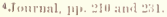

- Franklin, First Exped., vol. 2, 1. 18x. 


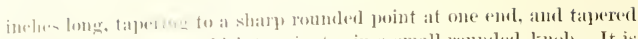
Thehts to the other, which terminates in a small romuled knols. It is vere watly made flom, rather old follow ivory, and ornamented on all tom lites with conventional incisal gat ferms colored with red ochre.

This inflement is nsend in putting on the backing of a bow to raise pats of the end when an end is to be passed under and in theking in the

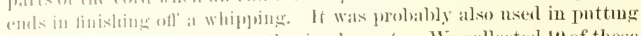
whippings or seizings onany ot her implements. Wo collecterl 10 of these

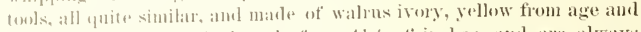
latmeling. They vary in length fiom $4 \frac{1}{2}$ to di inclies, and are always

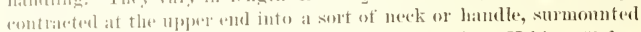

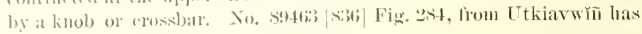

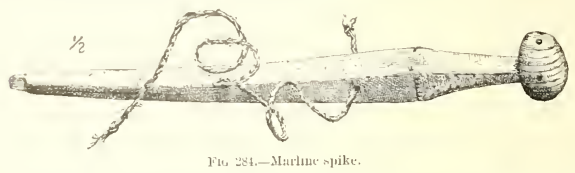

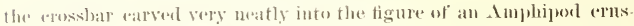
tacean withent the lears. The ryes, nonth, and vent are indieated

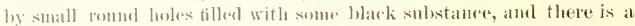
row of eight similat loles dewn the midele of the bark. The tip of this

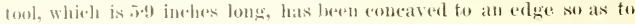
make at father-setter of it. Throngh the knob at the butt there is some-

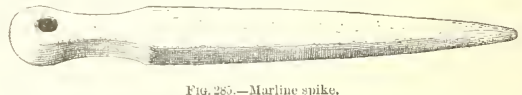

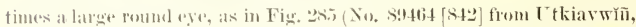

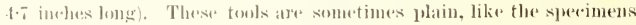
last figured, and sommetimes mamenterl with comventional patterns of ineised lines, colored with red ox here, like the of heers.

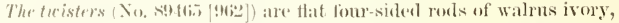
respertively 1.4 and 1.7 inelos lomg. At each end one broad face is ratisel into a low transverse risluge abont 0.1 inch high and the other

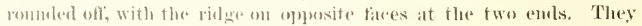
ate ormatmented on al] lour fares with longitudinal incised lines, colored with red orlerer.

The nse of these tools, which was disenvered by actual experiment alter our return to this combtry' is tor twisting the strands of the sinew backing after it has been put on the bow into the ables already de-

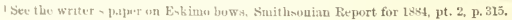




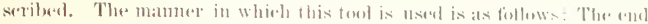

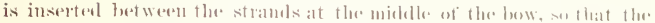

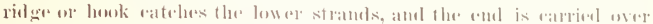
thromgh an alre of the , which gives the cable a lall furll of twist. This brings the twister anamst the hew, so that the twisting ant

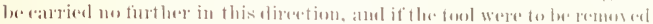

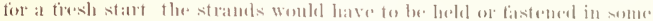

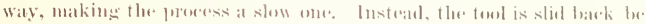
tween the strame till the other and andes where the first was, se that

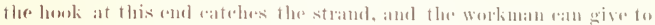

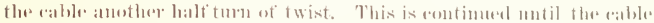

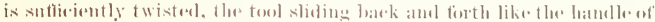

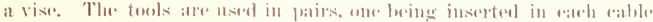

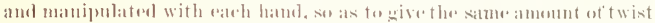

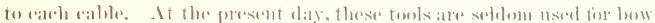

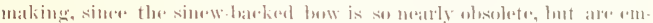

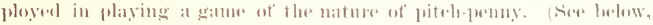
moler games and past imes.)

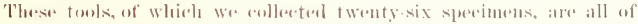
Walles ivory, and of almest exatety the same shater, varying a little in

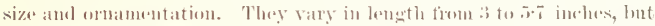
are usually about to inehes loug. The ammonest width is 10.4 inches,

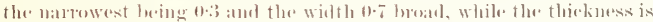
aluest always $0 \cdot 3$, varying handly $\theta \cdot 1$ inch. Yost of them are plain, but

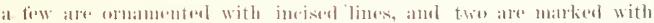

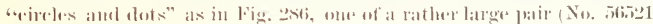

$3 / 4$

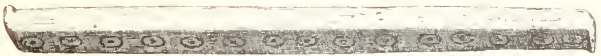

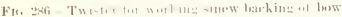

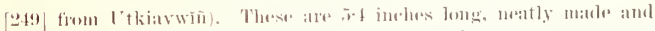
eprite eleatl. All the others shew signs of age and nse.

There are latere numbers of these touls in the National Wusenm trom

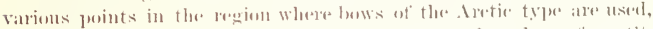

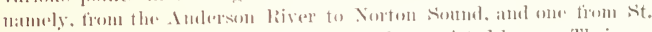

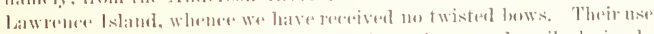
Was, lowerer, not definitely molestoml, as they are describul simply

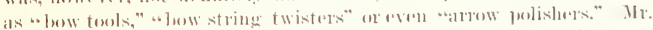

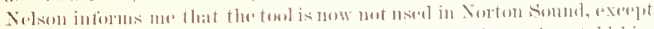
for playing a game, as at Point barcow, but that the natives told him that they were tormerly used for tighteming the backing on a low and

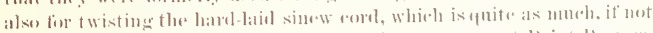

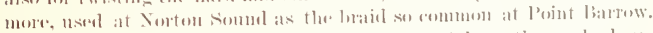
I tiul no mention of the use of this tool in any of the anthers who have 


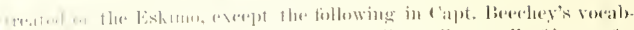

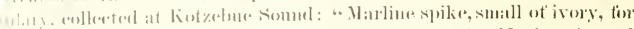

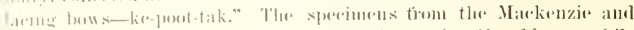

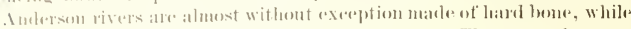
watrus ivory is flae comment material elsewhere. The name (kajmtos)

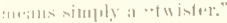

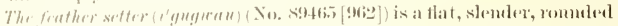

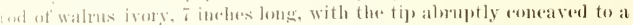

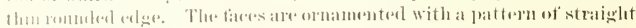

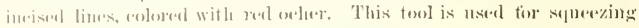

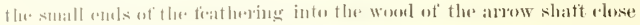

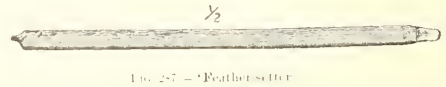

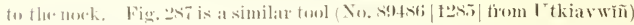

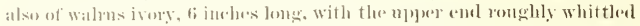

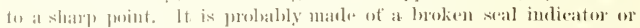

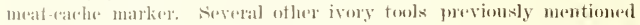

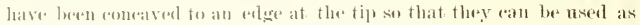
feat her seiters. I do not find this tool mentioned by previonsobservers,

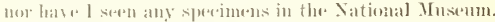

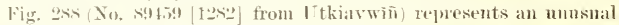
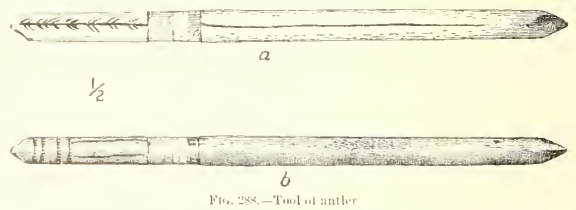

torl, the use of which was not ascertained in the hurry of tracle. It las a point like that of a wraver, and is made of reindere antler, ormamenterd with a pattorn of incised liness and lands, colored with red orher, and was perlapss a marline spike for working with sinew cord.

\section{SKIN-WOHKLI:}

Serapers biun.- For removing bits of thesh, fat, ete., from a "green" skin, and for "loreaking the grain" and removing the subrutaneous tis. sure from a dried skin, the women, who appear to do most if not all of this work, nse a tool ronsisting of a blunt stome blade, mounted in at short, thick hatt of word or ivory, fitting axaetly to the inside of the hambl and having holes or hollows to receive the tips of the fingers and thumb. The skin is laid upon the thigh and thomoughly seraped with 
this fool, whieh is arasperl tiouly in the right hamel and pushesl from

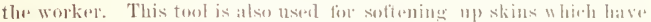

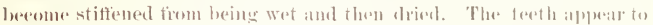
be less otten nsed for surle purposes than among the eastorm lishimm.

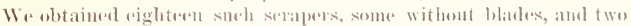
numomited blates. Every woman owns one of these tools. While

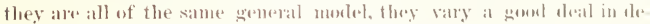

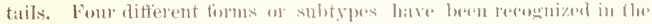

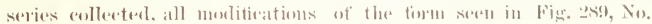

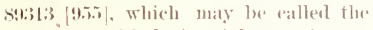
type. The blate is of low jows jor, ratlere eoarsely tlakiel, 1.1 inelues lome. It is wollewel with pireess of skin, into a derep slot in the tipe of the laandle, which isol tossil ivory, slightly yellowed from handling. The lett sile against

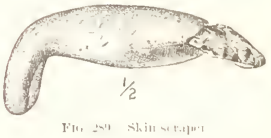
which the thmub rests is slightly thattemel, and the right slightly ex-

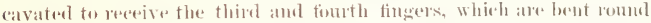
muler the lobe, their tijes pressing against the contave under surtiee

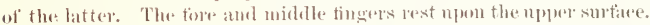

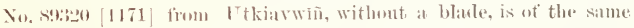
general pattorn. but is slightly exwatud on the lett as well as the right side so as to make a sort of shank. It is ot fossil ivory, stamed a dingy orange form age and grease. The two ineised rimble and dots on the mpere surfare close to the slot make the end of the lamble lesek like the heanl of a lophius, which it is perhatps meant to represent.

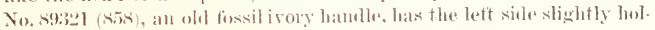
lowed to resere the tip of the thmmb, and it median keel on the mper surface with a bam ly parestible hollow on each sisle of it for the tips of the tingers. This is a stop toward the seromel subtyge as shown in

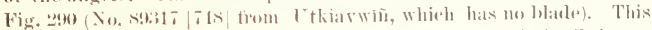

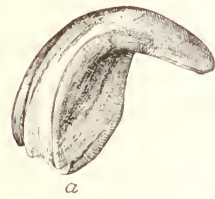

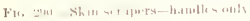

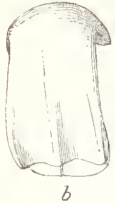

$b$ is of tessil ivory, thicker and more strongly arrelied than the type describul, derply axravited below sa als to forma biroat lobe at the butt, with the mples surface derply growed to recuive the tips of

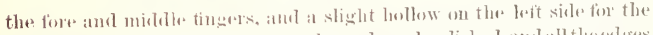

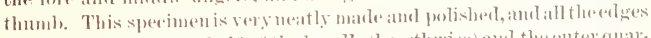

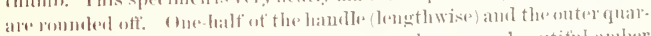
ter of the other hatf are stamerl with age and grease a heautiful amber 


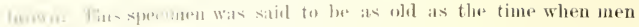

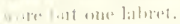

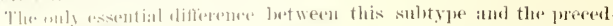

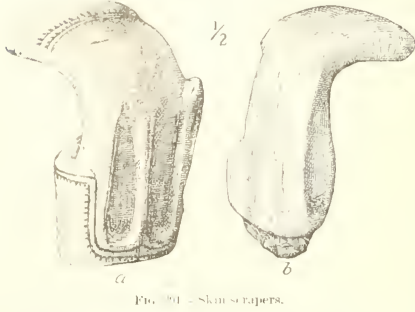

ing is that the former

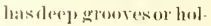
lows for the thomb and two firtars. We entlesterl tivespeeimens of this pattern, all but one with lamulles of tossil ivery. The single ex(e) from Sidlate hats a hate1]1 of walrms ivory, fellowerl with age and (artatse. This speciments (lig. 29)

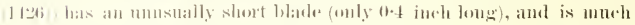

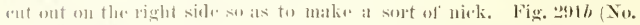

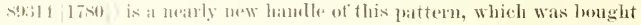

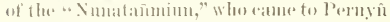

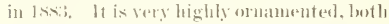
with incised pattems, colemes blark, and by arving the spate between the musmally derep thumb loullow and those fin the fingers into whal saems to be meant for an ear, in high relict, colored red insisle.

The thinel sulutype laas the lobe sejparated

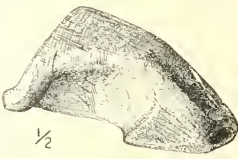

Frt. 292, - ikin seritper.

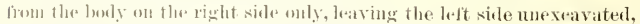

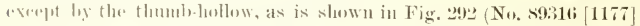
fom l tlitawiin) which has a hamtle of yellowed fossil ivory and a black

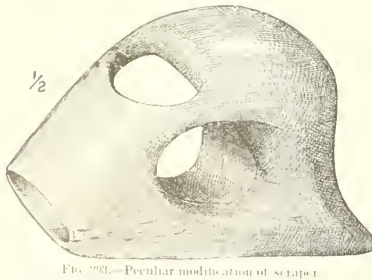
Hint blade. No.s!310 [1071]

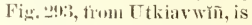
a rather musual morlifination of this pattern, with a woolen hathdle, in which the lostom is mot ent out. The thumb groove is deepenest into a large hole which opens into the exaration on the right side, while a large oblong slot on top, 1) rening into these cavities, talias the place of the two finger bollows. The blate was ef gray thint and ratlere longer than nasual.

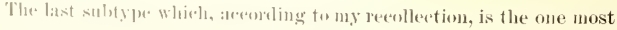




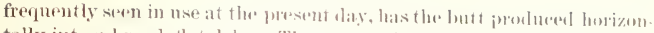
tally inte a broald, that lobe. The exeavalion of the right siele maly he

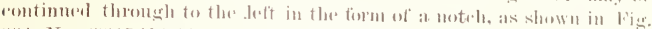

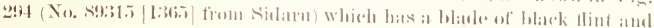
a hambllo of fossil ivory, with hollows for the thoml, and fingers; or the lett sicle may be muxavitiol except tion the thuml, growe as in lig.

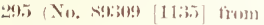
Utkiavwiit). This spmimen lais a rather large woulden

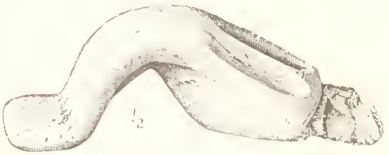

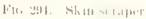
hamble, with the geroves at before. It appeats, lonwerer, to have been remosleled to tit a smaller hamel that that of the original owner, as the

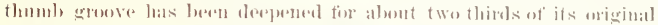

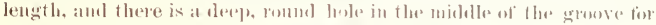

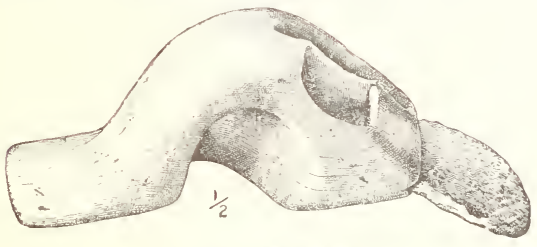

Fit: : $95,-$ Shan arrujer.

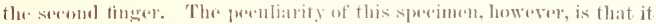
has a blate of sandstome, that and ratlow thin, with a smostlo, romoleal edge. The natives tolal us that serajue blatles of samelstone were the prevating form in old times.

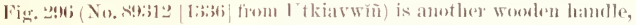

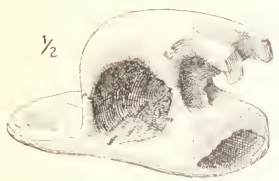

F'IG, 294 i. $\rightarrow$ Shin serat? in which the excavation tor the thiml atuel fomtlo fingers is merely a larwe romml lowe on thar light side, while in fromt the hall lle is ant into two slort lobes, between which in a dere greose the foretinger lifs. There is a lollow tor tlue tlommb moler the lett lobe and one on the right

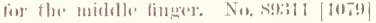
form the same village is almost exaly tly similar. These ale the anly twa speremens of the kind whith I resol-

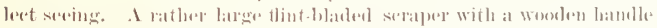

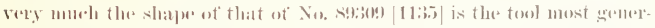

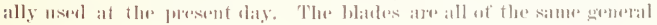
shape and vary in size fiom the little ome alowe mentioned (No. siligy 


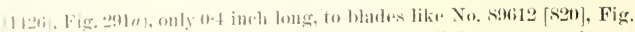

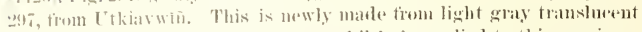

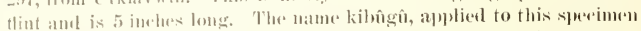
ly the mative fon whom it was furehaxed, appears to refer either to the material or the untenal sige. The lolude is ordinarily ealled kuki, "a claw:" With the ivory hambes at bate alwout 1 or $1 \frac{1}{2}$ inehes is emo

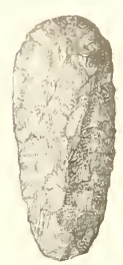

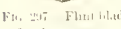
fiorohin ser.yen

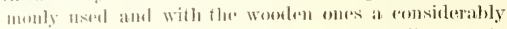

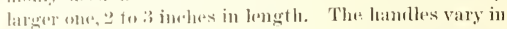
sime to tit the hamels ol the owners, lont ane all toe small for an average white man's hand. Alt that we colloweted arw tore the right hand.

This pattern of skin seraper which ap. jears liom the Museum ablections to be tha. provaling one fiom lowint birrow to Norton somed, is evisently the direst dessermatat of the torm uxed still farther senth, which eomsists of a stome or bone blanle of the sames shatee, momited on a woenlen handle often a thest or lis ine-hes long. which has the othere end hent down into a hamdle

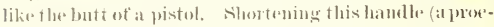
ass shown by spereimens in the Moseram) would bring the worker"s hamb nearer fo the blate, thes enahling him

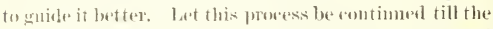
whole hamele is short enomgh to be graspest in the hame and we have the tirst subtype described, of which the

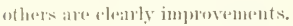

I still more primitise type of seraper is shown by Fig.

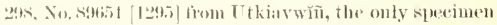
of the kint sem. This has a thint bland, like those of the mertern seralpers, inserted in the larger end of a

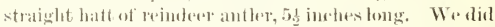
not learn the history of this terol in the horry of trade, but from the shatpe of the blate it is a vilently a serapere Its use as a skin seraper is remelered still more probatse

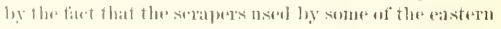

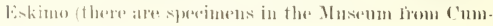

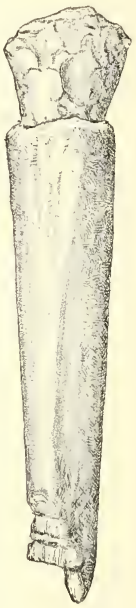

FIG. 298, - Straighthafter seralper. lertaml (inlf' and l'elly laay) lave straight handles, though shorter that this.

The silerian nafives use an whirely different fin'm of seraper which has a long hamblo like that ol a spoke-shave with a small blade of stone or iron in the milkthe and is worked with both hamels. ${ }^{1}$ Fig. 2a9 (No.

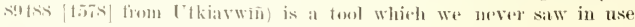
lut which we were told was intended for seraping skins. It is probably all obsolete fool, as a knile woutel better serse the purpose of re. 


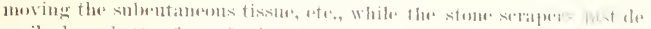
serilwel are lestere for suftening thes skin.

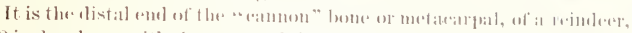

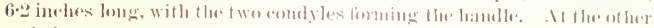

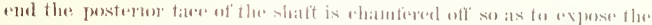

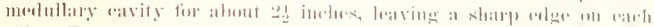

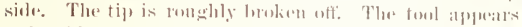

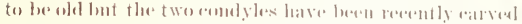

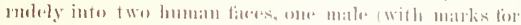
balrots and the ofluer lemate. There is a somewhat

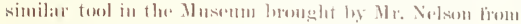
Nortom somud.

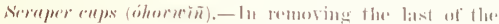
blublore from the skins of setals of walluses when 1 lacy

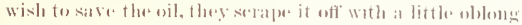

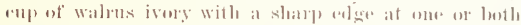

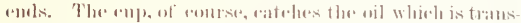
termed to a dish. These rops are semetimes, I believe,

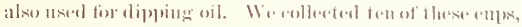

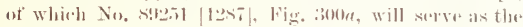

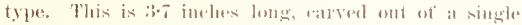
piece of walles ivory, and worked down firom the iuside.

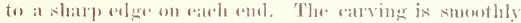
done on the ontside, lont more roushly within, where it is semewhat hatelect. If is stainet a dark yedlow with oil

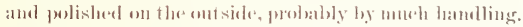

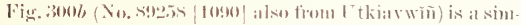

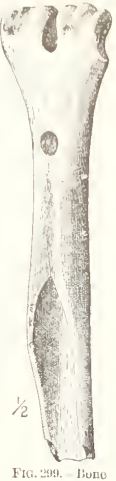

$$
\text { achenc. }
$$
ilar ،up, but las a share relge anly at one (and which is ant ont in a eomeave rurve.

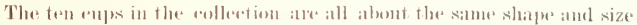
and all of wallus ivory, slabed yollow with ail. The lareest is t inches

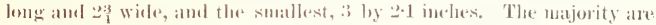

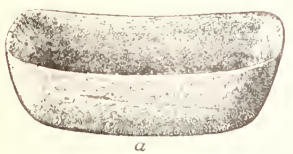

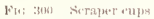

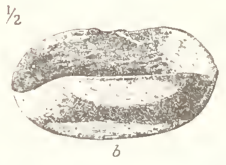

$1 / 2$

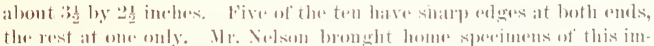

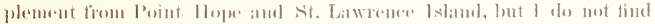
it mentionerl (alsinderer.

With these fords and their knives, they do all the work of proprang

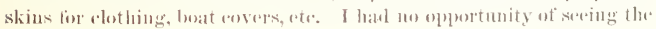




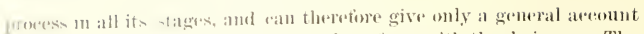

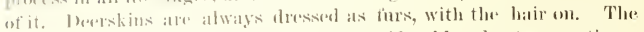

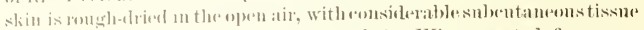

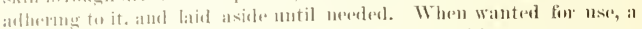
womitu takes the skin and works it overe carefinly with a stome seralere

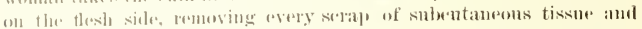
"Inraling the gratu" of the skin, which leaves a surfue resembling white chamois leather and very solt. This is them rublesd down with a

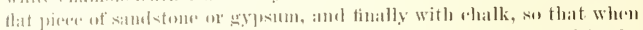

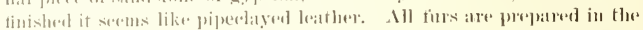

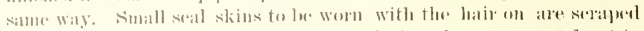

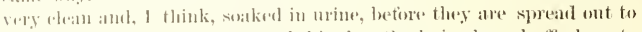

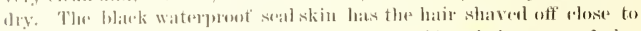

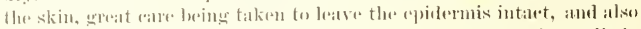

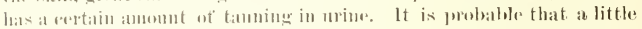
of the blubber is ledt an these skins, to make them oily and waterpoof.

When, lowerer they wish to propare the white-tamed seal skin, the skins alre lorought into the wam house, thawed ont or dampened anel

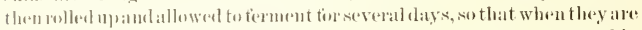

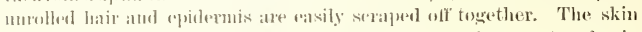

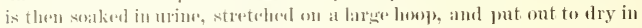
the smo and ail. Many of these skins ane prepared thring the first smmy wather in the early spring. The skins of the large seal, watrus or hear when userl for loat covers or lowt soles appear to be sweated

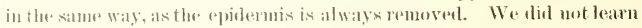
whether arine was emploged on these skins, but I think from their

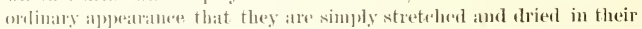

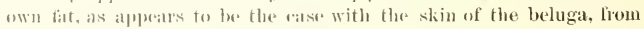

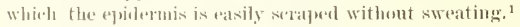

Combs for derestins. The lonsend hatrs on a deprskin garment are

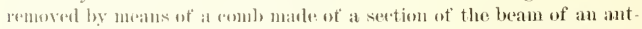
lore hollowed ont and ant into teetlo an the and. This instrument probally servos also to remos" vermin, as its name "kímotho" looks very

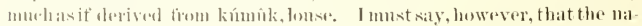
tives whom 1 askenl it kumotin hat anything te do with kumink said it hat mot. When roming get tromblesome in a garment, it is taken

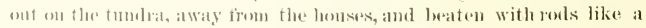

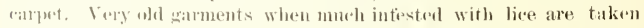

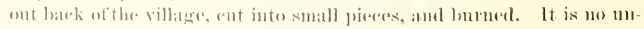
rommon sight in the spring to see : 111 old womans sitting ont on the tmo-

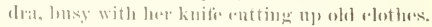

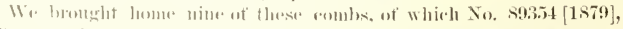

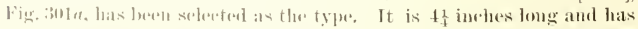

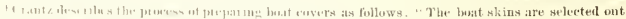

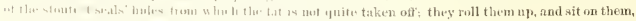

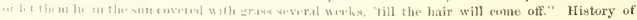

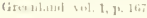




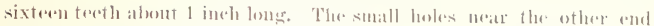
are tor a lanyard to heme it up liy.

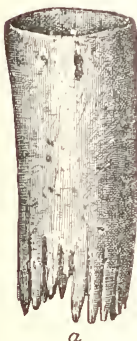

a
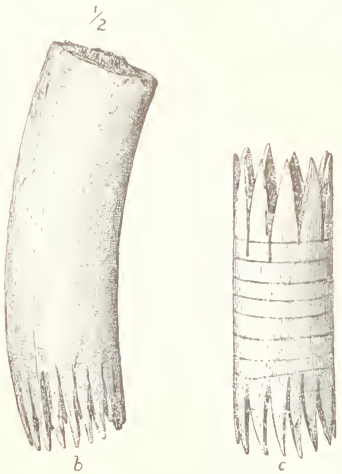

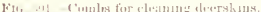

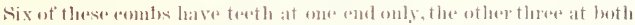

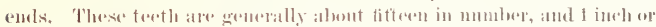

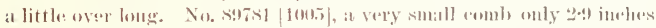

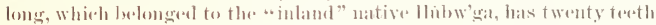

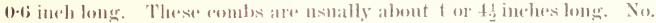

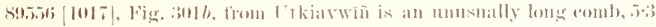

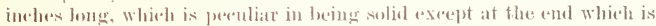
cut into tereth.

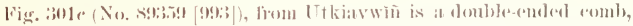
having ten terth on one and and thinteren on the othere. It is t.l inelhes

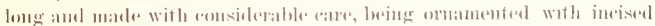
rings rolored with real ondere. This is a rommon implement at Point barow, hut sorms musmal alsewhere. There is a single specimen from the Dionedes in Mr. Nelson's aollection.

\section{MANUFA "TURE ()F LINES OF THON(x.}

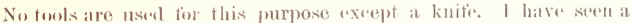
small jacklinife nsed tor entting the fine seal skin lines. The Horkman takes a wed skin from whieh the hair and epdermis have been removed and sits down cross-logerad on the gromend with someloody alse to hold the skin strefehed for him. Thes holding the knite vertieally up with the edge away trom hion, he stants at one cornere of the slin and cuts a uarow strip in one rontimums pieces, going round and round the 


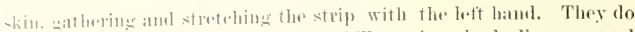

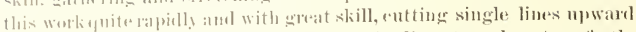

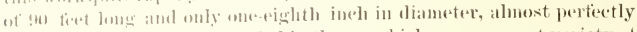

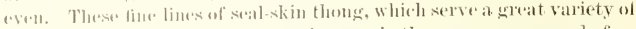
jurposes, and asually male when they are in the summer amps, before the Heaking up ot the ies. They are dried bystreteling them between

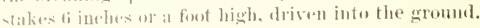

Tlue stout thougs of the hide of the berated seat, wathus, or beluga arm matly llade in the winter and stretehed to dry between posts of

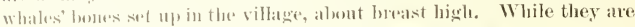

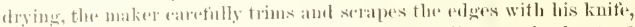
seras to make an almost remend line.' The usnal thameter is about 0.3 inelh. These lines are not ahwas male with such catre, being often

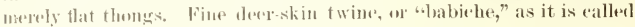
by the voyagents, for making the nettings of snow shoes, is matle in the sime way. I deres skin is dimpencel, rolled np, and put np over the lamp for a day or two to promove the hatr by swating, and then ent into a

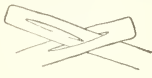
singlo longy piece of tine thong.

All the ment do not apprate able to do this fine

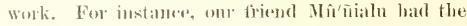

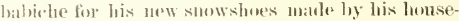
mate, the yomuger Tunazn. When it is desired

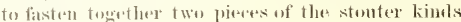

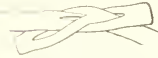
of thomg, what I hare so otton refereed to as the "double-slit spline" is gemerally employed. This

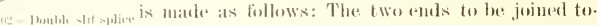

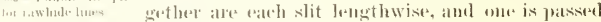
throngh the slit in the other. The of here ond of this piece is then passed thongh the slit in the first pieses, ant drawn thengh so that the sides

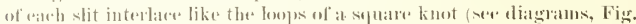

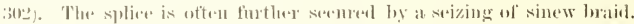
Most writersun the kskimo have mot gone sufticiently into the details of their arts to deseribe: their metherls of splicing. (Ote writer, ${ }^{2}$ howerer,

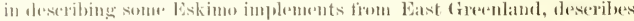
and ligures seyaral splices somewhat of this matmre, and one in partien.

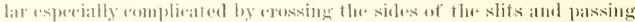
the end through several tines. This method of uniting thomes is probably wary gameral anomg the Eskimo ant is also eommon enemgh anong rivilized jeople.

\section{BUILDERS" TUULS.}

For faremeting.- It the present day they are very glad to use white ments pieds and sleovels when they want to dig in the gravel or elean ont the iere from their houses. They, howerer, lave mattoreks and piek

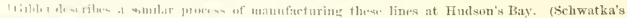

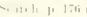

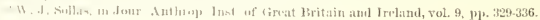


axes (sikla) of their own mannficture, which are still in use. These are always single pointed and have a bone or isory head, momeded like : an adz heat on a rather short hatt. The hatt, like these of the matuls and

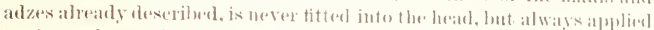
to the meler surface of the latter and held ou ly a lashing of thong.

The only eomplexte implimsut of the kimi which we ohtained is No. 735itt [397], Fig. 3033. The head is of whitle's rib, 173 inches long. The butt is shoml. derest on the umber smiface to recoive the liatt and roughened with erossents to prevent slipjoing, with two shallow

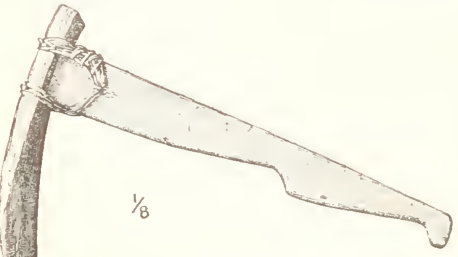

Fif 303 - Mattuck of whall's rib.

rough transverse notehes on the mper surfius for the lashings. The

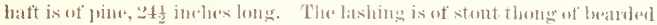

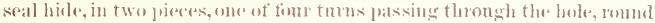
the front edge ot the hatt, oser the lower noteh in the head, and lanek across the hatt to the hole again. The ends ane knotted tomether on top
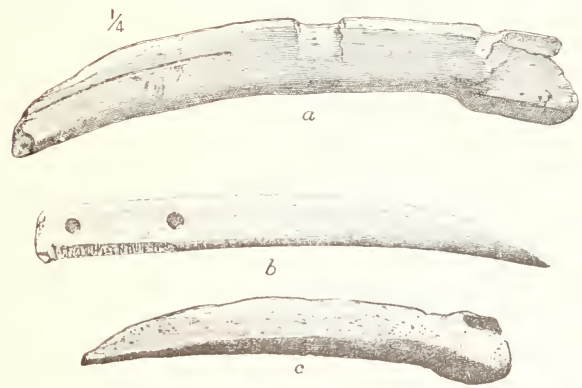

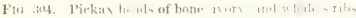

of the beat loy beket-litehing one end inte an eye in the other, made by slitting it rlese to the tip and patsing a bight of the statuding part through this slit. The other glat is of serentwes, jut on in the simm way, but

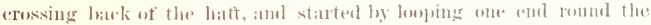
head and through the eye by means of atu eye at the end mate as before. 


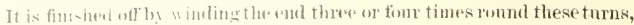
so as fo tightent them 11$]$, and hiteling it romed two of them on one side. This method of latting diffirs in no essential respect from that used on

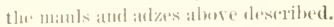

W. hatve also f wo heals tor smele mattoeks, which hardly differ from

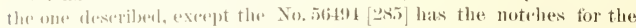
lasleines un the side of the head instead of on the mplere surfare. It is

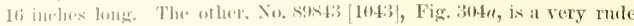

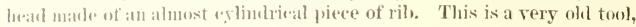
which fom ifsoily comblition lows evidently been long laid away in

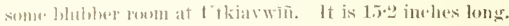

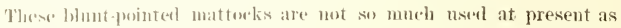
furcks with a sharp point momnted in the same way, and specially arlapted

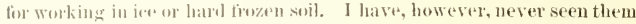
nsed the cutting holes in the ien tor fishing, which sone anthors have smp. posed to be what they were meant for. Their shape makes them very

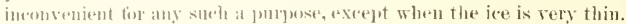

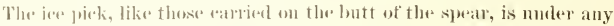

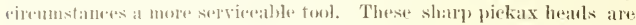
gemolally mate of a wallus tusk, the natural shape of which requires very little alteration to fit it tor the purpose. We rollected these of these irory locals, all very neally alike, of which No.56539b [96], Fig.

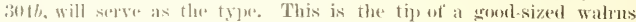

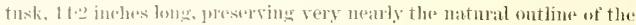

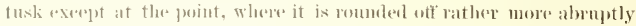

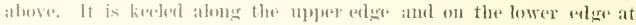

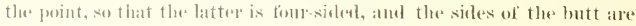

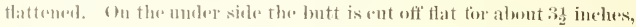

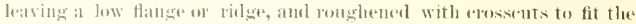
whd of the hatt, and the butt is perforated with two large tranverse eves for the lashing. The other two heads are almost exactly like this and vary nearly the same siza.

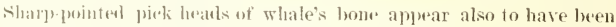

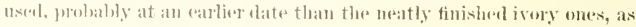

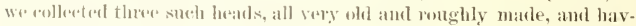
ing moteles or groures tor the las lings insteat of eyes. Fig. 304e is

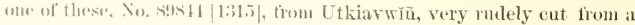
piene of whale's rilh, 12 inelares long.

I do not rewollect sering any of these bone-headed pieks in use, while Hoe ivory heated one was one of the commonest towls. This Eskime tomel is in use at Plolekili, a village smpposet to be wholly inhabited by sethlentary ('huliehes.'

TUILS FUR SNOT AND IOE WORKING.

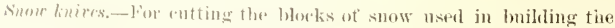




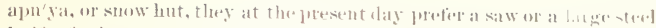

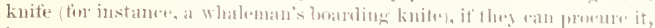
but they still have many of the large saber-shaped ivory knives se com monly used by the Exkimo everywhere tor this purpose. Thase alle. howerer, more generally used tor selat bing snow off their elothing. oth... alt

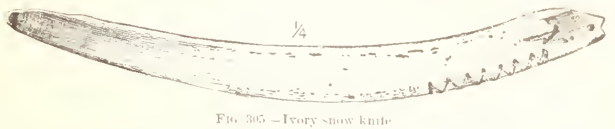

present. Wo bromeht home two of these knives, which do not ditlere in

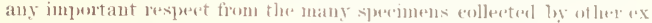
plorers in Mlaskit.

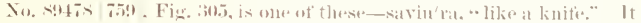

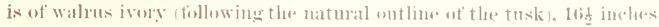

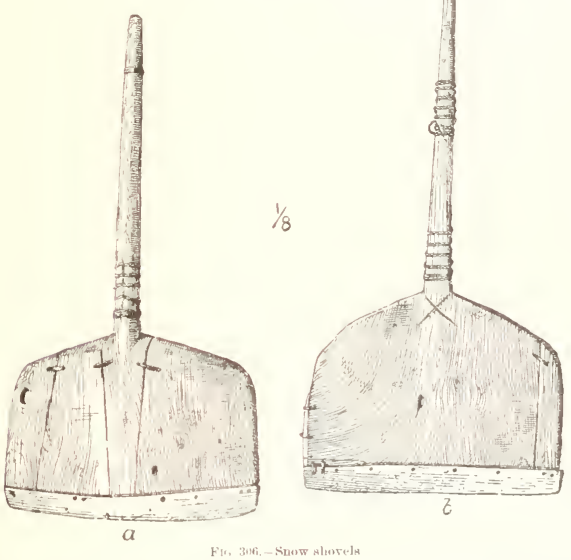

long. The blate is double-taliged, the hatt roumded on the redges and

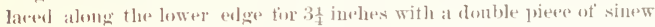
braid. The object of this is to give the hatel a firmer grip on the haft.

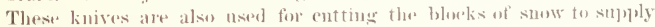
the lestase with water.

Snow shorels. - The hroatl. shont-hamuled snow shovel of workl with a ! ETIL_- : 


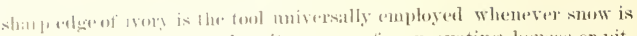

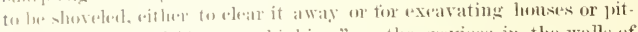

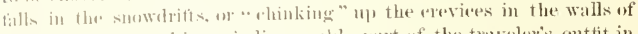
the smom hense, and is an imlispensalule part of the traveler's outtit in winter. The shotels (pi'kstur) are all makr on essentially the same pat-

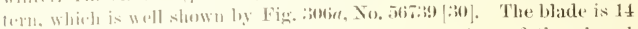

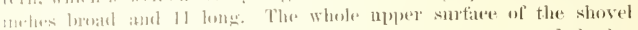

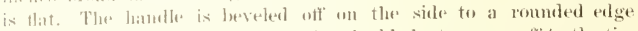
lwhol, and is quite thick where it joins the blade, tapermg off to the tip.

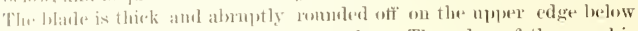
and gratually thimmed down to the edge. The alge of the woot is

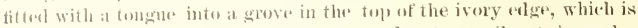
$1 \frac{1}{2}$ inclese deop. It is tistemed on ly wooden treenats at irregnlar intorvals, and at onemal, where the colge of the grose has been broken, lo at stited at black whaldene. The wooken part of the shovel is made

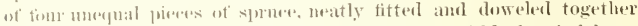
and latel by the irory alge and there stitrhes of blark whalebone

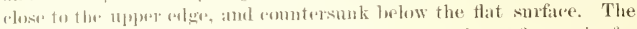
whippings of sinew bratil on the handle are to give a firm grip for the hatuds.

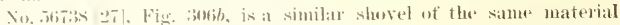
and almost reactly the samo dimensions, figmed to show the way it

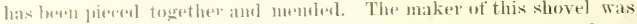
alshe to proeme a broal piese of woul which only had to be pieced ont with it namow strip on the hett side, which is tastemed on as before. It

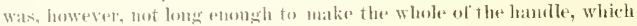

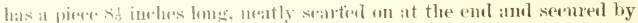
six stont treenatils of wool: thres at eatele end of the joint, passing throngh the thin pint of the searf inte the thisk, but not themgli the latter. Xualy the whole handle was seizerl with sinew braid put on as betore, lout minch of this soizing is boken otf. It the right side of the blate the glanin takes a twist, bringing it parallel to the ivory edge, and ren-

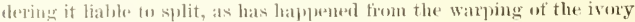
sine the sherel has berti in the Mnserm. The owner somght to pre-

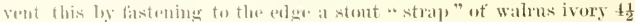

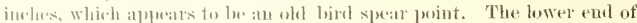

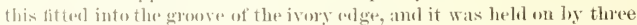

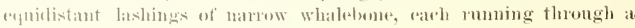
low in the rige of the woul and romel the ivory in a deep transverse ginew.

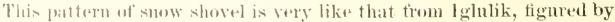

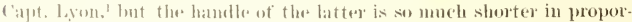
tion to the black that these is an achlitional hamble like that of a pot

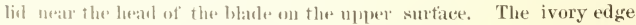

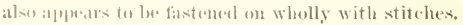




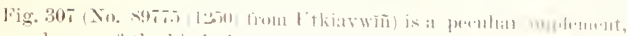

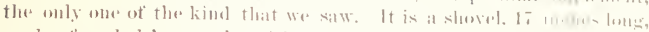
marle of a whales scapula, with the anteriog and postetiog bordersont

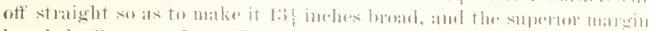

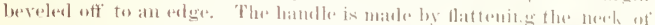
tha sapula and entting thromeh it at large horizontal elliptial shot, betew which the ame of the seajula is workesl into a romulesl hal a inch in diametes". The "utting aroumb this slot appeas new, and red oeluer has leeen robbed

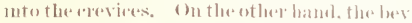
eling of the digging thlye alpleated to be olut.

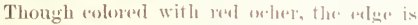

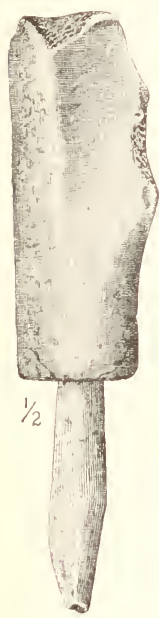

Fit, 308. - Snow pick walperd as if from IIste, atud thele are fraguentsot tum. flua moxs aticking to it. It is probably an old injele. ment "tourlier] nu" for siale. Wi. dis not learn whethat such took were mow semer

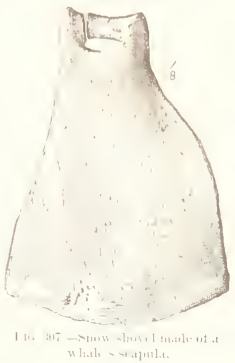
ally meet. This may hatw lwen a makeshift at :n indiviclual timey.

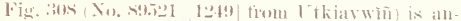

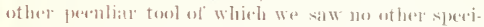
men. It alplears to lo mally an old implement and was silel to have leeen used tor digging or pieking in the snew. It is a stomt sharpepointerl piece of bone, 3 jurhes long, inserterl in the end of a piece of a long lone of some animal, $4 \cdot 7$ inehes long and about $1 \frac{1}{2}$ wille, which seceves als il hatt.

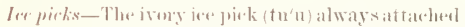

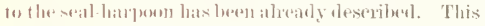
ditter: fiom the tok of the cireenlanters and other

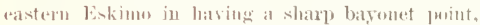
while the latter is atten ehinel-pointed. All the men now have irom ine pioks whieh they nise for cotting the hules tor fishing, sefting seal nets, ant such jur. juses. These are macle of some white malls tool which has a soeket, like a harpoon irou, a whale lanee, a boarding knite on bayomet, and usually latre a rather

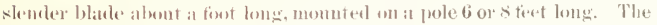

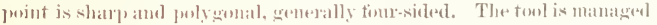

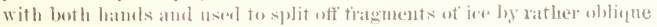
blows. In other words, it is used in precisely the satue way as the little

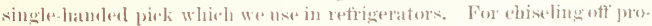
jeeting cornets of ice when making a path out thromgh the ine park, they 
when on whale - patules, of whirle they have ohtanined a great many from inlish.

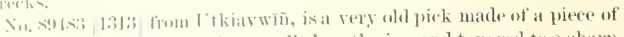
reinderer antler. $11 \frac{1}{1}$ incles long, split lomgthwise, and tapered to a sharp anderel point. The lout is cut into a sort of tang with a low

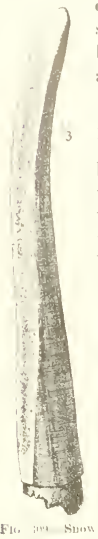
shomblar. The split fane is comeave, the sott interior tissme

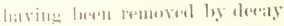
and ferhaps also intentionally. Imother forenlial tom is shown

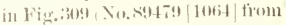
[tkiarwiô). This was ratled kitkatyaxion, and is a jommled pires of antler $10 \cdot 4$ imelest lomg, talueling from the butt where there is a low shemleler amel the broken remains of a roumber tame to be fitted to a shatt. Ome side is rent ofte that firom the shoulder to the tipe gradually lucoming eoreatre. The romeavity is derepest near the misldle. The tip is slightlyexpanded.roumded, atul sonewhat bent towaml the ronvex sille. The spereineell is suentlily and neatly marle and datk lorown from age. Noother specemens werescen. Wo were told that this tool was momnted on a loug pole and nated for drilling holes in the ice by making the polde revolve with the latuls.

Icr scoops.- When picking a hole through the ine they nse a long-handled seoop, made of at pirese of antler bent romel into at hoops, ami netted across tha buttom with strips of Whaleboue, so that the water may drain off in dipping piaces of iee ont of the water. Wr. bromelit home one sperimen of this miretsal implement ( No. . $9990: 3$ [1696], Fig.310). The handele is of walk, st teet $1 \frac{3}{4}$ inelues long and ellipitionl in sortim. The rim of the bowl is a long thin strip of antler, alpparently fiom the "palm," lwat rouml inte a

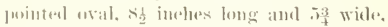

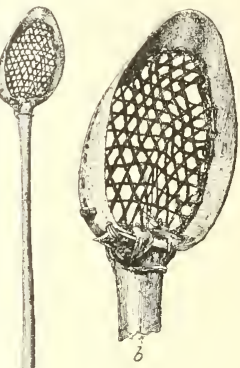

$1 / 12$

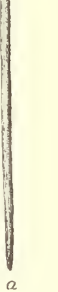

F1G. 310,-Ice scoop. with the ends of the strip ofelalphing abont 3 inches at the broader end. The ands are sewerl together with two vertical stitehes of whale- 


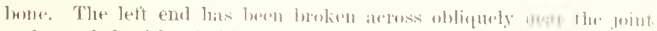

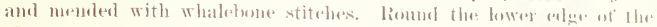

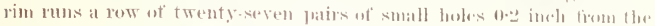

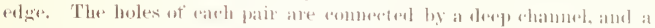
narrow shallow groove, forolably tor ornament, joins the pairs. On the

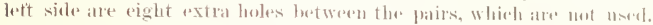
Through these holfs, omitting the first two pairs in the right hathe and, is laned at piese of setal thong, thes: Stanting at the point of llye oval, the

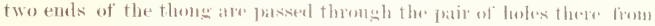

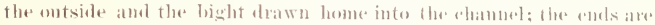

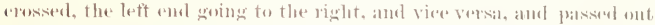
through the farther hele of the next pair and in through the meares, and so on till the ends meet at the broad and of the oxal where they are fied together, thus making twenty-tive loops an the inside of the rim into whish the netting is fostemesl. This is male ot strips of thin whate. bome, interwoven, over and under earhother, passing up throngh one

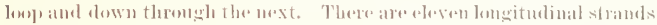
passing obliguely from right to lett, the same number tiom lett to right, and eleven transverse strands, making a netwolk with elongated hex.

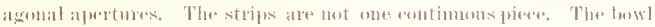
thus mate is tistened to the hamble by there pieses of stont seal thoug. The whole lashing was put ou wet, amel allowed to shrink.

Nordenskiobld mentions and figmres a seoop of almost identically the same pattern, but smaller, in gereeral use tor the same proposes at

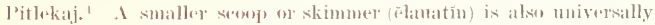

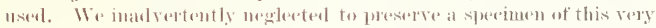
rommon implement, themgh we hal two or there alome the station tor our own use. I shatl theretore have to deseribe it fiom menory. The hatulle is a Hat, straight stick with rommlect alges, abont 18 ind hes or 2

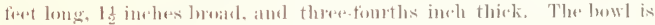

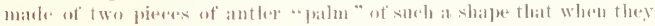
are tastemed togethere on the ene of the stick they make a shallow anp

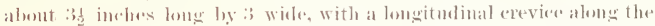
midelle whirh allows the water to dratio otil. The tip of the hamble is

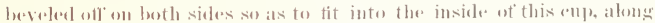
the jumetion of the two pieses, each of which is tastemet to it by ane of two neat stiteles of whalelonse. The two pieres are fistened together in front of the handle with at stiteh.

lo addition to the use of these seonges firs skimming the fishing holes,

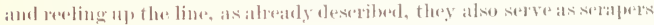

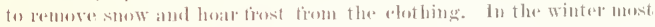

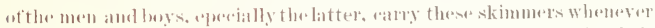

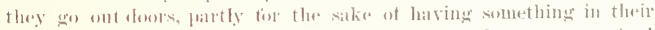

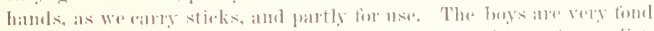

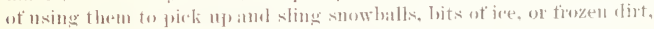
which they do with onnsidelable forese and acenracy. 


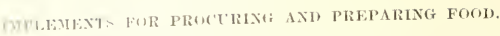

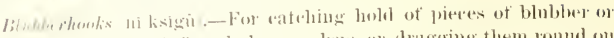

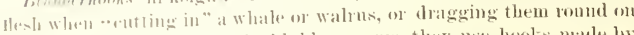

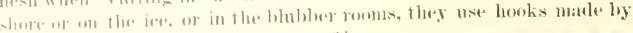

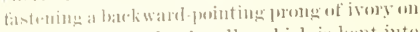

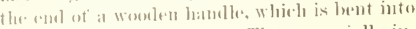

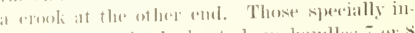
teluted for use in the leats have hambles 7 or 8

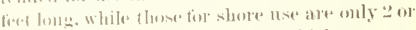
3 teat long. These implements, which are commen all alonge the dlaskan coast, may sometimes lo. used as loathooks, as ap. patss tobethe ease fitrthersouth, thomgh I never sal them so employed. Wi bought home two shont loweks and one long one. No. Diz6ti $[124 ;$. Wig.311. This has a promg of wabus ixory lastemed to at sproce poles, 7 teet is inches boug, to the othere and of which is tastemed a slerit "rook of antler. The pole is allip tionl in sertion. The rrook is a nealy

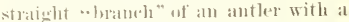
transierse an at the loise mate ly ant-

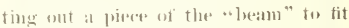
against the pwles and is leeto on by three mat lashings of whatebume of the nsmal patterus. The 110 per two of these are 1 lansterse lashings passing througheorresponeling holes in the pole and crook. The lowest, which is at the tije of the armo, is at right angles to theser, passing thromglo wood and antlor. The lashing ut whaleboure close to the tipot the erook. passing thromele a hole and romed the momler sicle of the lattere is to keepe the

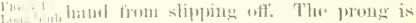

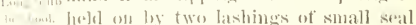

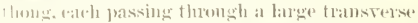
luste in the pronge atucl a corresponting ome in

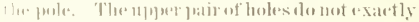

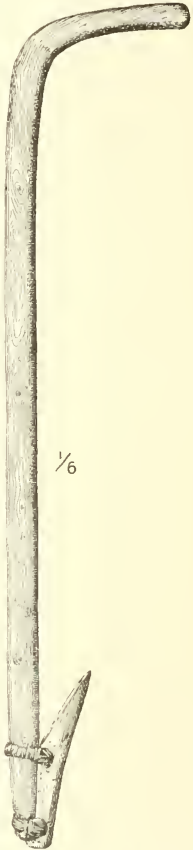

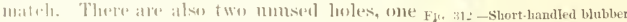

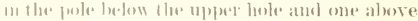
look.

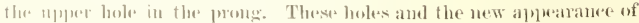

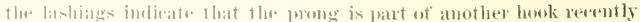
fitterl to this pols. The two lashingsare made by a single piece of thoug. 


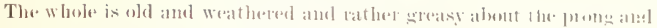
the tip of the pole.

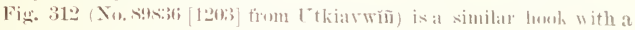

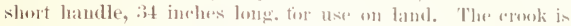

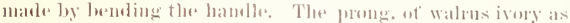
hefore, is 7 ineles lomg, and helel on hy two stout lashings of

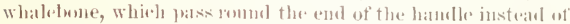
through it. The porng and tifl of the latulle are very greasy.

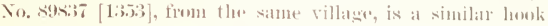

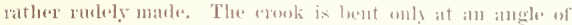
atout 4.5. and there is smmenthat of a twist to the wholo loan dhe. The ponge, whele is of antler, is 73 inches long and shoul dered at the butt like that we the longe book deserjoed. It is

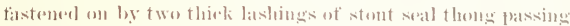

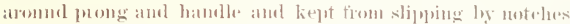

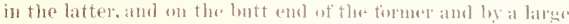

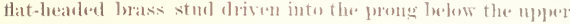
lashing.

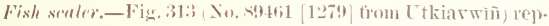

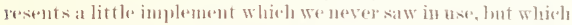
we were told was intendod for seraping the serales off a tish.

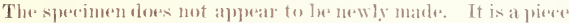
of hollow "long" bom "s ine hes long, cut into the shape of the blarle of a case knife, Hat on ouse tare with a broal. shatlow, lougitudinal gerove on the ot lee's.

MAKING AN1, WURKING FIBER.

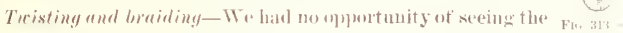

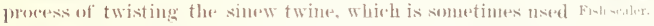

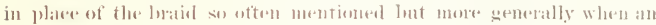
extra strong threal is desimel. as in sewing on best soles. Fig. 314 (No.

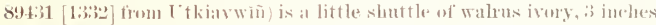

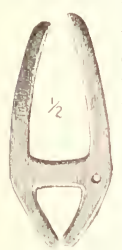

Fic. 314.-1uㅏ shuttli:. long and 1 s lowal, which we wrere tolel was nsed in this process. The luely of this sluttle is redlue to a narrow

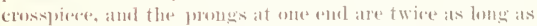
those at the othere. The tipent the lome pongs are alout t ineharart, while these of the short ones nearly meet. There is a small ponnd hole in one sisle ot the lomly. This sperei men was mathle for sale. As well as l romlel mulerstand the sellere, the ruds of soveral stramels of the simew were fias temel into the lole in the shnttle and twisted by twisting it with one hand, while the ot lese emal was hele prerhajes ley the other hamel. The part twistorl was then wound on the shuttla and a tiesh lemeth twisted. Thes would in at rely simple form of spinning with a spinelle.

No sperial implements tor twisting have been described ameng ot her 


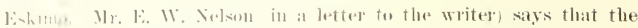

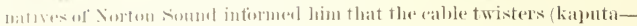

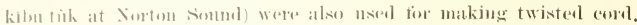

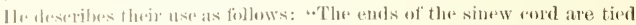
to the conter holes in the two ivory pieces, one of the latter at each end of the rorl, and then they are twisted in apensite directions, thes gettine the harel-latid sinew and nated on the bows."

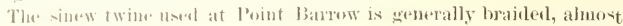

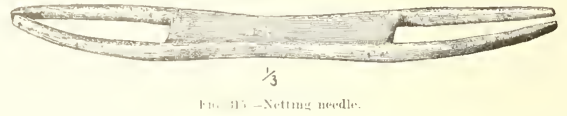

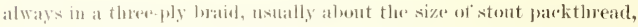
suets as is found on many liskino implements fiom all localitios repre-

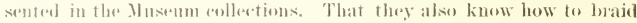

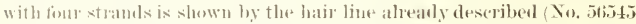

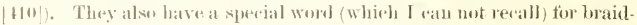
ing with four strands in distinetion fom batding with thee (jiclias).

Vetting.-Two implements are nsed as nsual in uetting, a

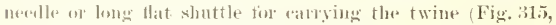
Xu, ation [101\}), and a mesh stick for ganging the lemgth of the mesli. The knot is the miversal "tislerman's knot" of beeket. litels mate in the monal manner. The methou of using the mesh stick, hewerer, is dather preculiar, and somewhat plumsy

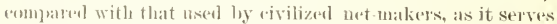
only to matame the mesh and not also to bold the snceesive meshes as they are malle. It is a lowg tlat piece of bone or antler, slatped like a mase knife, with a blade signare at leeel and point. There is often also a little blunt lowk (as in Fig.

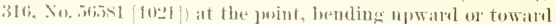
the barek of the blacle. The hlade is the prat of the stick which measures the meshe and its length from heel to point is always preceisely hall the length of the mesh to be mate. It is nsed as follows: The workman, holding the mesh stick by the han1le. in his lett hamd, with the blade downward, atehes the mesh into which the knot is to be male with the hook, and holls it while the twine is arried down the left sisle of the Fo. 316.

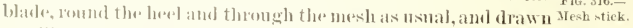

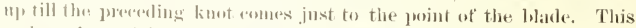
makits a loop of the proper length tor a mesh round the stick. The point where the wext knot is to be made is now caught between the thumb and finger wi the right hatud and the mesh atiok taken out of the loop. The lelt thmond and lingers, while the of here fingers of this hand still hold the 


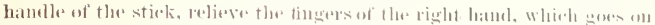
to make the kuot in the ws mal mammer:

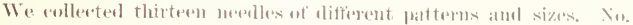

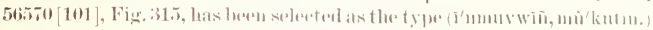
It is of watrus ivary, 11.9 inehes long. The small hole near the tip of one prone is tor a langard to hange it nu by when mot in use. This

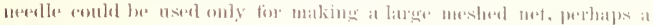
seatl uet.

We collected seven modles of almost the same patteruas this. varying

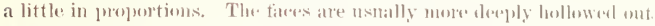
aut the ends usatly simuate insteal of lowing straight. Thare of these

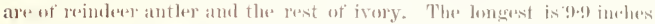

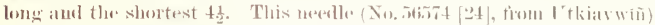

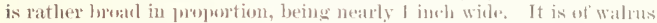
ivory. No. s!1433 [!4:] is better suited fin metting a small mesh, being ouly 0.7 inch broat at the widest part. It is male of reinderer antler amel

4

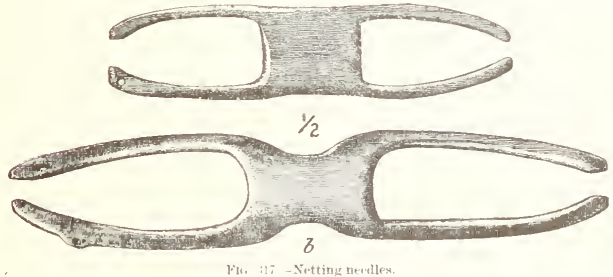

is $7: 3$ ineles long. These mealles sometimes have a small hole though

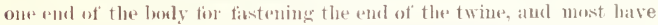

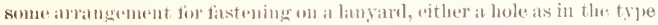
or a growe romel the tip of one ponge as in No, 5ti.5t [24].

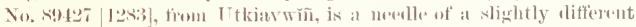

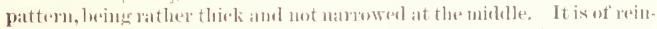

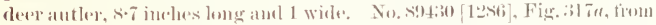

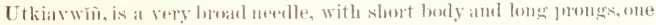
of which is expander at the tip and perforated for at lanyand. It is a piece of the ontside havel tissne of a rejuleer antler, s.t ineles lome and 1.2 broal. It is but slightly natrowed at the midale, while No, s!d 28

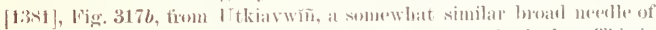
the same material is dereply notehed om each sisle of the berly. This is made from antley of smallere diametel than the preverting, and comser

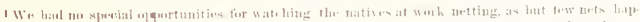

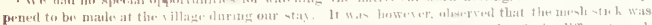

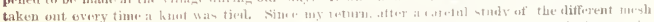

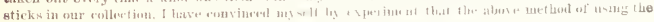

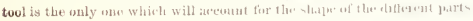




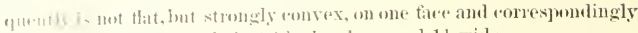

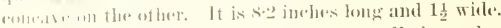

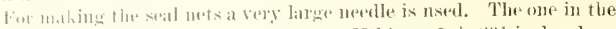

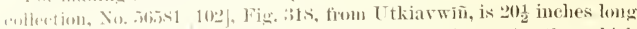

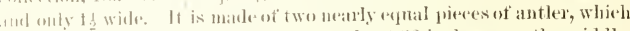

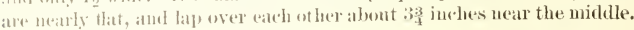

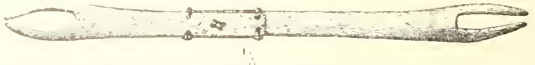

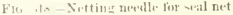

They ale strongly lastened together by tive whalebone stitches, one at eatch colmen of the splies and wue in the midelle. The eorner stitches rm romet the exlge of the two jarts, amb thremgh a hole thomgh both parts.

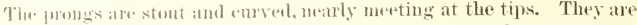
alout 3 inches fong. The latelad distortion applyears to be due to warping.

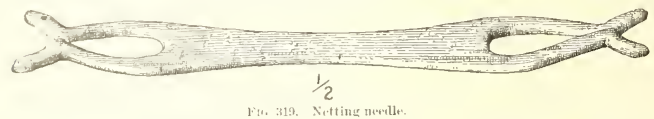

A puruliar uetting newle is slow in Fig. 319 (No. .69429 [1333], from ["thiarwiii), which is new and rather carelessly made from very coarse wathus ivory. The tips of the prongs, atter nearly meeting, diverge

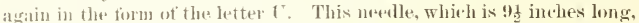
wits sail by the malker to be of the pattern need by the "Kinumâ'd'lin."
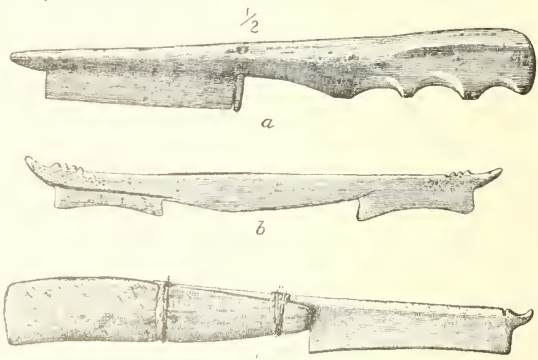

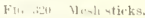

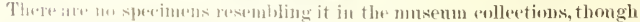

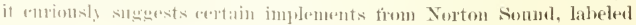

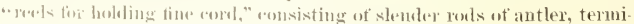
batiog at mols end in similar slablow I" shaped forks. 


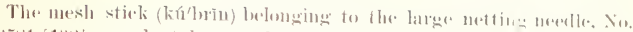
56ist $\{102\}$, may be taken as the tyje of this implement. It is a pioces.

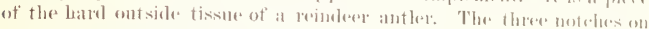

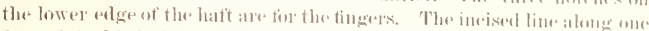

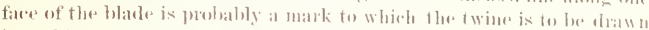

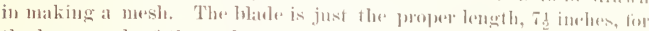

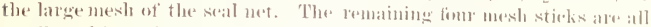

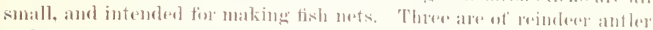
and the finuth of laud boure, with a woolem hatt.

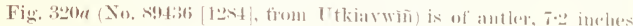

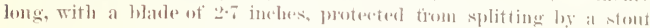
romel pege of havel bone, driven themgh the hamdle so as to lie against the heed of the blade. If terminates in a blunt point insteat of a look,

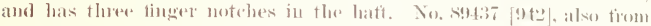
Etkiavwih, is of the same material, s.t. inches long, withemt a hook and with a blade only 1 inch long. There ale two finger notelos in the hatt.

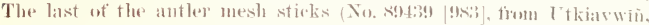

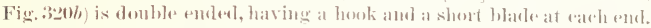

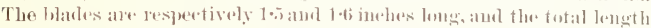

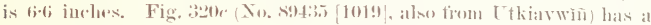
blate, with a small hook, of white romplat bone, amd what would he

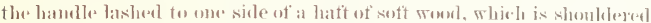

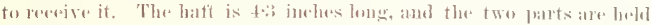
together by two lashings of tine simes, kept from slipping by noteles.

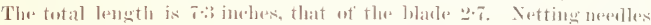

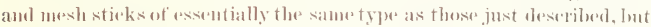
varying in matrial and dinemsions, ane in general use from the Ander. sou livere to Bristol bay, as is shown by the Mnsemm collections.

Setting urights.- We collected lo little ivory implements, each. when

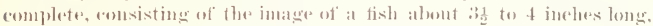
suspended by a string about t inclues long to a little ivory spring hook. Wa neser happened to see these implements in ust, but we were told that they mere used in netting to keep the meshes in proper shape. They anemerally were made in pairs. The only way of nsing them that I an think of is tirst to loesk one into the light of the tirst we sh marle in starting the net. This wonld make the sueessive meshes, as they were netted, hang down ont of the way. (Oll starting the next row in the opposite direstion, the serond weight lowked into the first mesh of this low wombl dlat the sucesesive moshes down on the lefthand side of the stiek, while the other weight would keep the meshes of the tirst row stretehed so that one conld be masily raught at a time. (On herginning the thim row the tirst weight would he transterred to the tirst

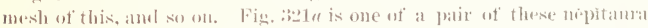

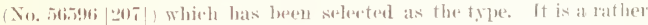

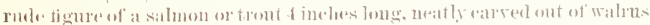
ivory. Tha string is of hrabled sinew and the look of walrus ivery. 


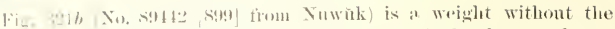

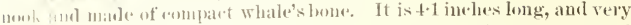
unth carrel. having all the fins in reliet, the gill openings, mouth, and

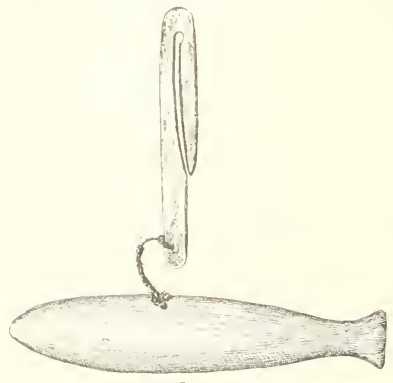

a

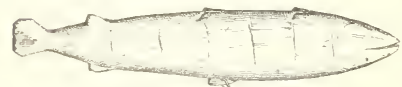

b

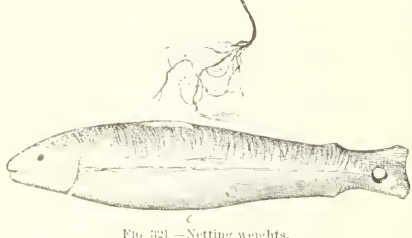

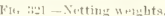
eres incised. No, 56503 17:3 from Utkiavwrin is one of a pair very rudely "arves ont of a piece of snow-shovel edge. The month and gill spenings are indieated by imeised and blackened lines, the latter fringed with short lines, ear h ending in a dot, perlatps to represent the gill filaments. It is 4.2 inehes long, and hastily mate for sale, Fig. 3ะ1c (No, .6558 [301 from Tt kiavwīi) seems to $x^{x}$ in. tended for a polar cod, and has the hole drilled through the root of the tail. The lateral line is marked by a serateh, col ored with black lead, ancl the dark rolor of the back is represented bycurred, tramsierse seratehes also, colored with black lead. When the rarving is snttiviently good to show what sort of a fish is meant, it is generally is salmon or tront. Ouly :3 out of the 16 are of any-

thing hut wallus ivory. These is als ot compart whale's bone, and one hat smath blue glass beads imlaid for eres, of which one still remains.

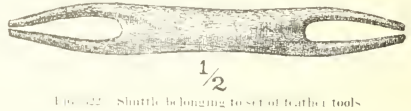

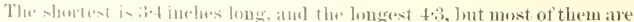
theost e varetly I inelies loug.

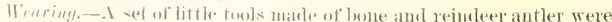

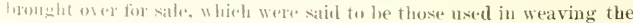


feather belts. I had ne opportunity of sering a beft marle, ime the work evidently does not recture all three of these tools. The little nettume

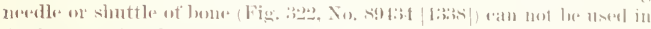

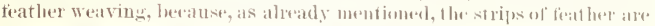

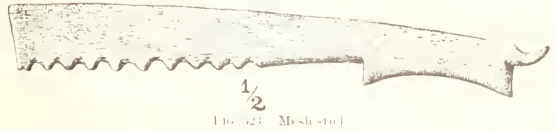

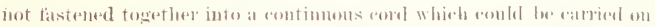
a shuttle. It is .59 inches long and 6.7 wide. Them is alse a littlomesh

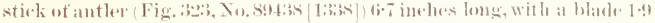
incles in length, and a little hook, which appears to le titted for nothing exept netting a small net. The

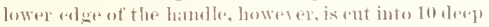
rommlal moteles, which perhajs serve the pmose of a Jure "frame" tor kesploing alpart the strands of the warly, while the woot of teather is passerd through with the fingers. It wonld be held with this enge 11p. and the loeginning of the belt being tastened to the wall, the warp stramds would loe stretehed over

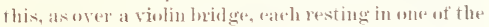

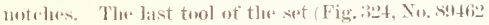
[1:33s] is madombtedly a "sword" for pushing home the woot, and pobalily also serves to sepmate the strands of the warp into a "sleed." It is a Hat, thin piece of antler, 9 inelese long and threestomenthe wifle,

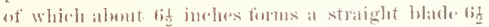

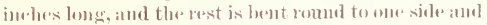
slightly down, torming a hamdle. When the strands of the warp are stretehed ower the bridge as above de. s.rilwed, pushing this herizoutally thromgh them altere. nately over and muder the suenesice stratuds, would maks a "shed" through which the ent of the woot embl be thrust with our motion, and pushed up atainst the preseding strand of the woot by sliding the sword tow ward. It wombl then be withdrawn amd passed though agais, going over the strands it went mules before and viee versa, sh as to opeen al "shed" tiar the larest strand of the woot:

Sturing-For sewing hom and leather they always

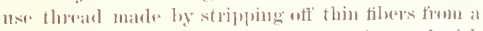
piece of dried sinew of the meinderer, as is usnal with

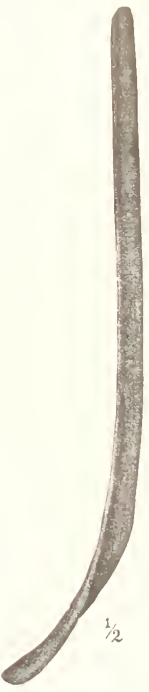

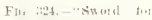

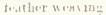

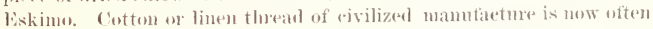
nsad for sewing the cotton trocks, ete., and sometimes for making an or- 


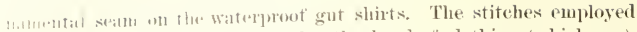

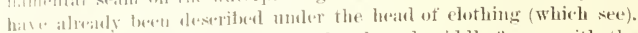

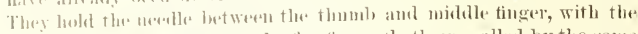

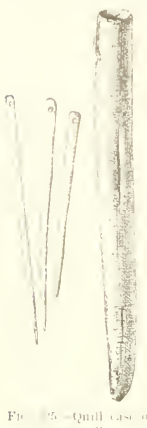
thimble on the forefinger (losth arr alled by the same Hilme, t $\left.\mathrm{l}^{\prime} \mathrm{kJ}, \mathrm{l}\right)$ and sew towat them. This appears to he the regular Exkimo method of sewing.

It the present day they are well smplied with steel menlle's (miksun) of all sizes aud patterns, but formerly

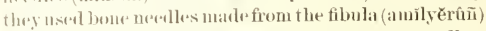
of the remdere. Wir collereterl sixty of these needles,

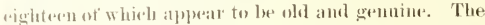
rest ware more or hess carefully made for sale. Nika wáalu told us that one. when lat and a young man were ont derer lom ting a long distane firom tamp their boots satre ont. Having killed a deer le made thread from the sinew, a needlo firom the bone, amb with pieces of the skin repaired their boots, so that they got home in (a)minitit.

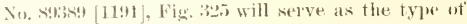
these newllets. This is a case $3 \frac{1}{2}$ ineless long, made of the butt of a large puill, whosesl with a phog of walrus hiule, and contains ti noedlex. One is 185 inehes loug, stont, and ronut pwinterl, with a lange eye. It is much discolored from age. The second is also romol-pointed but more slender, 1.9 inches fous and thattened atul expanderl at the butt. The third is $2 \cdot 4$ inehes long. and has a tome sided point like a glow "T's neerlle. All three of these ane very neatly manly and a alpear ald. The other three atre stout, roughty mate, and flat, respertively $2 \cdot 1,2 \cdot 2$, alml $25 \%$ inches kne. Twout then look suspiriomsly mes. This set was said to lat veluen the pouperty of the wite of Puka, Nikawalalu's tather.

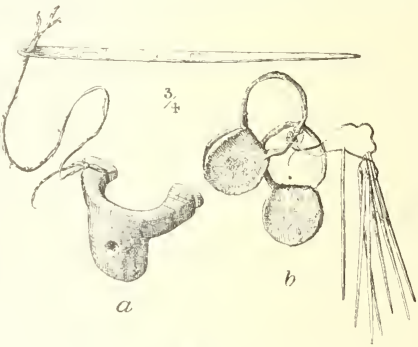

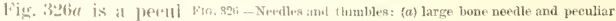
iarly large and that nee.

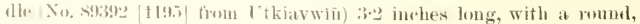

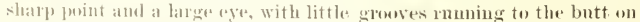
tath siele tor the threat to lie in. This needer was perhaps specially

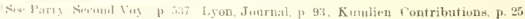




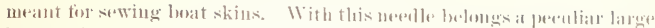
bone or ivory thimble. The remaining neolles are all very mow alike,

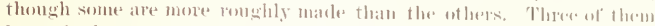

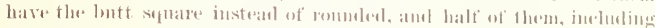

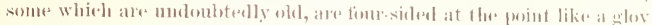

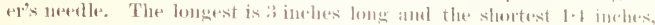

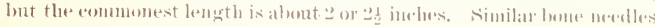
are mentioned by varions anthrs.

Searly all the women now 1 se ordinary metal thimbles, abtained in

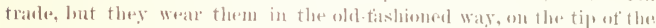

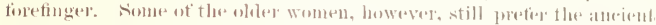
leather thimble. There are two patterns of these: ane motented tor the fore-tinger only, and the of her of sueh a slaje that it may also he worm on the ofleer fingers as a guard agaiust rhating in pullinge stont thesad

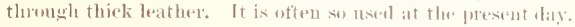

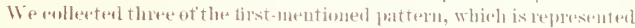

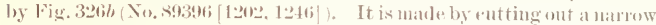
ring of lat sealskin 0.7 inch in dianeter, with a (ireular flap $19 \cdot 5$ inch in diameter on the ont side of the ring and a eorrespondiug one on the inside of the same size, rut ont of the midele of the ring. The Hays are doubles orer so as to make a pad on the inside of the foretinger when the tip of the latter is inserted inte the riug. The butt of the needle presses against this par.

The thind thimble, whirls belongs with the needleease (No. s937) [1276]), is of precisely the same form and limensions.

There appeared to be little if any variation among those which we saw. ('apt. Lyon ${ }^{2}$ tigures two similar thimbles from lglulik, whish are deserilued on page $53 \%$ of the same work as being mate of leatleet. The flaps, horever, seem to be only semicirenlar and not folded oser, so that the shield eonsists of only one thickness of leatleer.

A similar thimble with the flap also not folderl is nsed at (jumbeland Gult:

The wher patteru, wh wheh we bought lome nine specimens, is representerd by No. 89389 [1191], which belonges with the set of bone merelles of the same number. It is a tulbe, opeen at both ends, one of which is larger than the ofler, mate by bending romed at strip of split walrus hile and sewing the ends together. It is $0 \cdot 4$ ineh loug and $2 \cdot 1$ in sircumference at the larger end. It is worn smooth with handling, and imprognated with grease and hirt and marked with small pits where it lats beas pressed agaiust the butt of the reetle in use.

Four other old thimbles (No. s9:393 [1194], from Utkiavwiñ, are mate

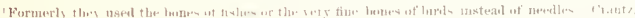
val $1, j^{1,}, 136 ;$

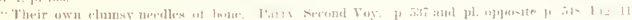

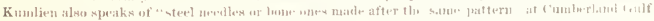
(Contributious, p. 25).

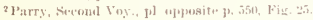

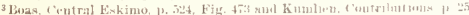


In the same way. hut are a tritle targer. As they show no veedle-marks, they were probalbly ust only as tinger gnards. The remaining four are simila to the aluse. bint newly made, for sale.

I most puruliat thimble, the only one of the kiud seen, is shown in

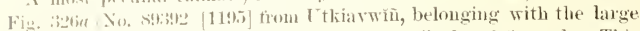
bene nombe of the same number aldeady deseribed and figned). This 1s male of a simgle piese of wallus ivery, browned with age, and the lanme shatlon socket is for the butt of the needle. The ends of the half

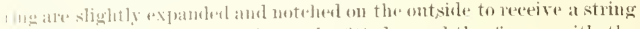
on anmplete the ring so that it wan be titted round the finger, with the Hange in the sante position as the part of a leather thimble.

Vectles alde kept in a case (njyami), eonsisting of a tulse of bome or ivory alsout if or fi inches long, through which is drawn a broal strap of

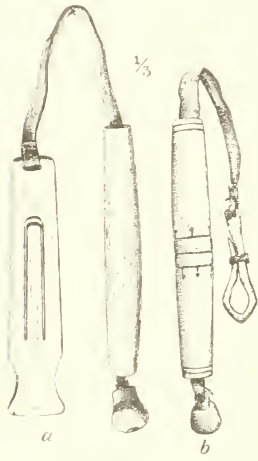

Fu, 327,-Nicde cases with lnat lowk o leather fumished with a knot at oue end to keres if from sliphing wholly thromgh. Into one sule of this straj the meedles are thrnst obliquely, so that when the strap is pulled in they are covered by the tulue. To the other end of the strap is usmally attached an irory suap hook for fastening the nededle case to the girdle of the pantaloons. These ned dle cases are made of two sligbtly difterent patterus, of which the first is rejeresented by No. s!36.5 [127\%], Fig. :32ite. It is of white walrus ivory, $4 \frac{1}{2}$ inches loug, and the strap is of seal thong about 11 imehes bong awd 0.3 incli widt. At one thul of this is a pearshaped knol, of walrus ivory, which is shoukdered off at the small end and worked into a short flattened shank perferated with a larges eye, through which the end of the strap, which is ent narrow, is thrust. It is fistened loy doubling it lack and sewing it to the standing part. A sky-blne transpatent glass bear is inlaid in the latge end of the knob. The other ('mol of the strap is fastemed in the same way inte a tranverse slot in the

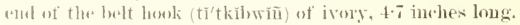

This frattern appears to be msnally made of walrus ivory. Only one of the six bromght lome is of bone, and this is au muswally small one,

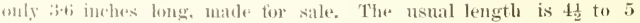

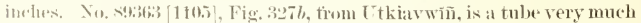

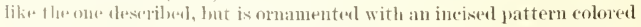

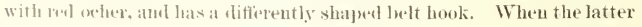
is lumkers over the girdle the ring is pusherl up the shank over the point of the hook till it tits tight, and thus keers the hook fiom slipping off the butt. 
Fig.

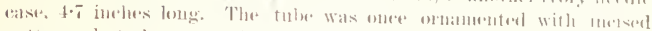
patterus, but these are almost wholly worn off hy eonstaut hatulling.

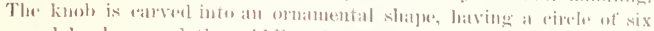

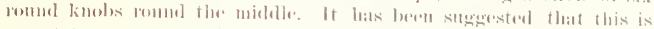

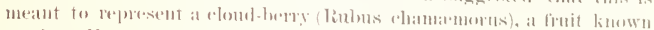

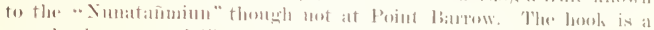

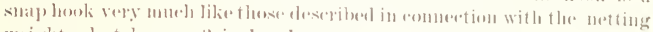
wojghts, lout langer (:3 inclues bong) and very lonomel at the mpere emel. which is mate into a boatl ring. The point of al stewl ueedlestill stirik. ing in tloe fleste siche of the stralj shows how the needles alle rarient with the points terwalel the knols.

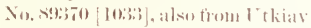
wiil, has we kubb, lut the end of the strap is kept from slippoing through by rolling it up transversedy and eateling it with a stiter of sine $\pi$. It has a lonoal that suap hork similar to the last, but ant on the esleges into ornatuental scallops. There tulye is ormamented with an ineised pattern coloreel reel with ander, and is .r. lomg. No. lorown wallus isory, anlaresel into it knols at ond entel. It hats an knob or lowel. lut a new strap of white stal slin, in tlee lewrer and of which is tiect a large linot. Theother jat tern lats

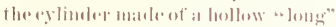
bone, in its natural slatje. This lome

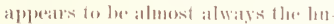
merns of seme lange bircl, probalbly

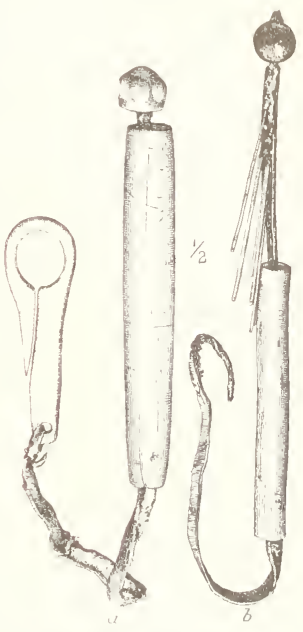

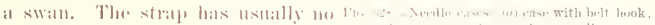
knob, lut is kept trom slipiping

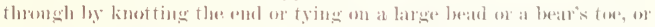

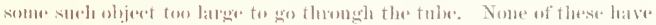

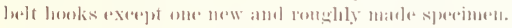

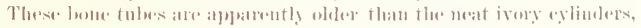
amel it is mot unlikely that the luelt lewk was mot invented till the former

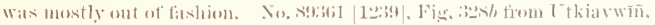
is one of these which las for knole one of the large dark bhe gratsis

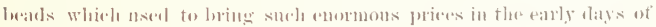
Aretie trading, and which ate still the kind most highly prized. The !1 $1711-21$ 


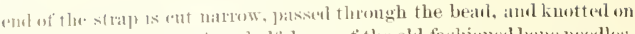
the+ent. This case callies at half-4lozen of the old fashomed bome needles,

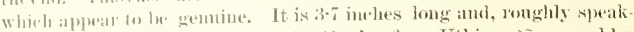

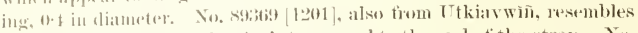

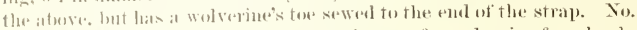

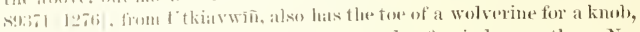

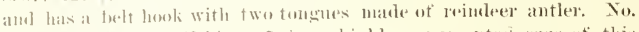

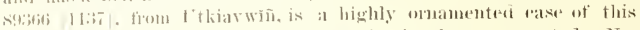
pattern, which hats a short rylimbiral knob, also ornamented. Xo.

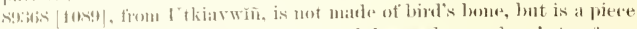
of a long loum fiom some mammal, and has a brown lean's toe tom a

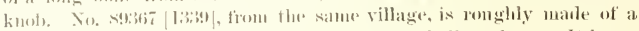

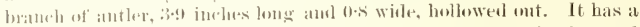

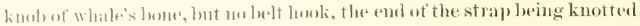
into a leatlue thimble of the first patterm. Of the six specimens ot this

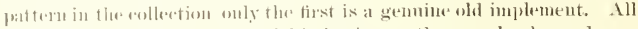

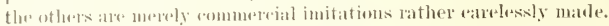

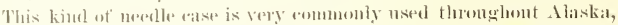
as is shown by the mommous oollections in the Sational Musam brought

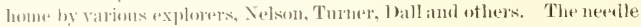

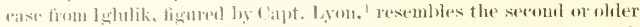

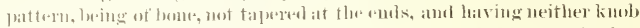

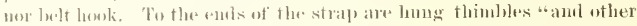

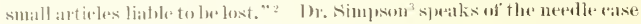

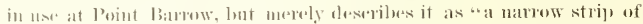

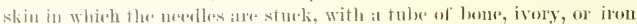

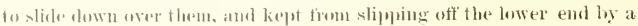

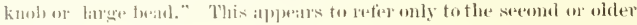
pattern.

The old-fishioned ring thimbles were nsually rarred on the belt look

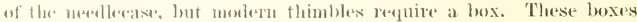
(kigiun?), which ase usnally small and eylindrical, also serve for holding

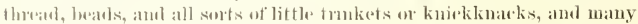
of them are so wht that they ware "vidently nsed for this purpose long beline the introfluetion of metal thimbles. Little tin ranisters, spice

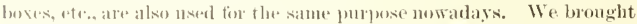

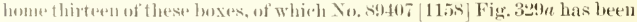

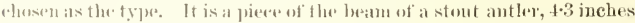
long, ant ofl' sifniste on the ends and loollowed ont. Into the large enel is titferl at flat botfom of thin pine, fistenesl in by four little treenails of woul. The cover is of the sime matrerial. It is helel on by a string of

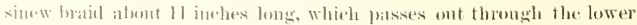
of the two liftle lobes on one sifle of the low, being held lyy a knot at

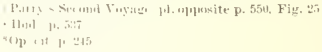




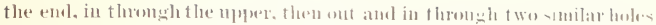

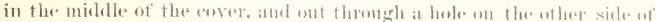

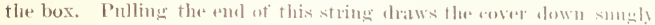
into its plate.

Some of the mematining boxes ane made of anther, and rary in latugth fiom 4.7 to s inclues. The last is, howerer, mustally lange, mosl of

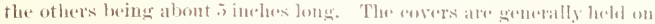

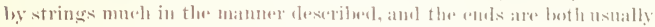
of worl, thomgh two old boxes hate both ends mate of ant ler, and one

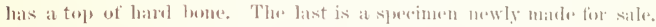
These boxes ane sometimesonenented on the ontside with ineised lines,

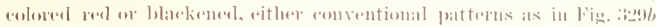

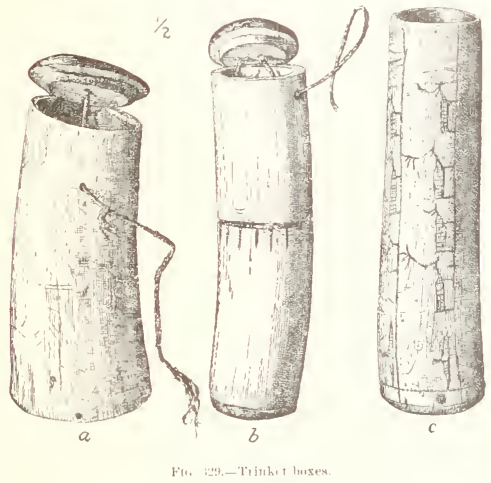

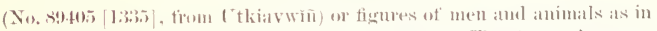

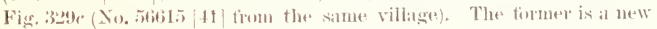
box, f.7 inches long, and hats the wooden ends both shouldered to fit tightly. The cover is workenl with a string.

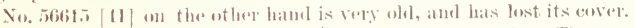
The womblo botom is shonlitered and held in with treenals. The surfare is elalonately ornamentad with imeised and blackened tigmes. It is divided by longitmlinal lines into fom nemly equal pands, an

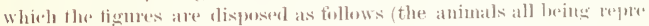
sented as staneling on the longitudinal limes, and fareing fowad the riglit, that is, towarl the eneen end of the box): (1) the first panel ane

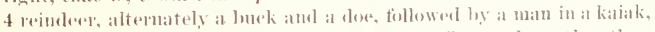
and over his heal two smatl "eireles and dots," one above the other. 


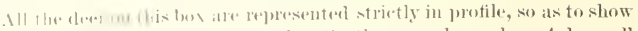

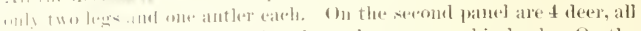

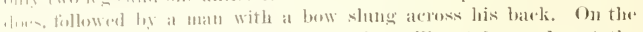

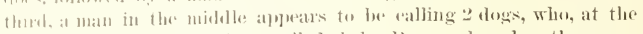

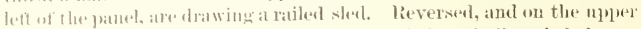
border ot the panel. is a man pushing behind a similar sled drawn

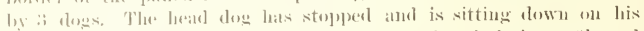

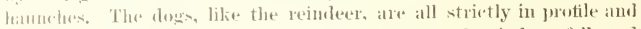
ratlun consentinnalized. In the fourth panel arw 3 reindere followed by it man in his katiak, aml upside down, above, a derer without legs,

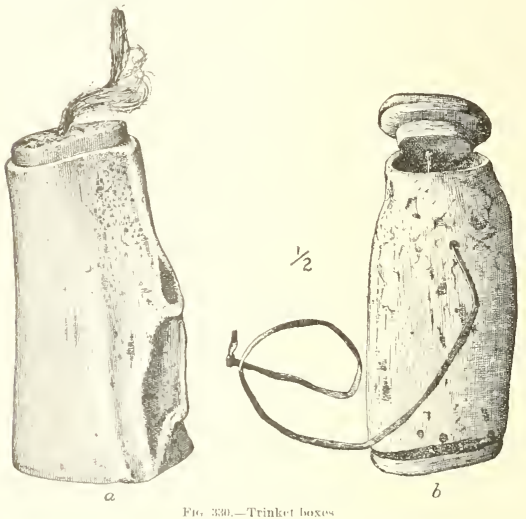

stup in his katiak. These tignes probably represent artual oecurrences, torming a sort of recort.

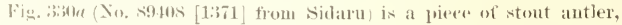

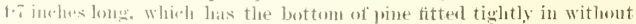
fartenings. The asowe is ot wood, novered, to make it fit tight, with

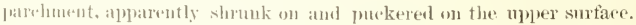
I thisk latuk of untwisted sinew is tastened as a landle though the midelle ot the covere. This box is olel and dirty, and contains an unfin-

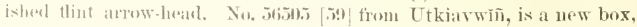
r.tosed at the culds with thick shouldered plugs of pine wood. The tube is s inclues long and ornamented withat ronsentional jattem of incised lines alored with real ocher. 


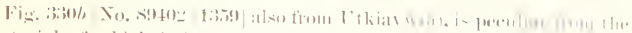
material of which it is made. It is of atrom the silme pallow the the ermmon autler loxes, but is marle ot the butt end ot the os promis of at latere

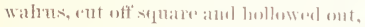
and hatsends of had whate's lomes. Its

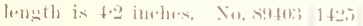

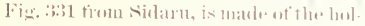
low butt of at guenl-sized wallus tnsk, 322 indeles lemg. It hats at lueatly fitted wooden lottom, land in with is treese nails. trow of ivory and fome of moser. The box has been eratied and split and

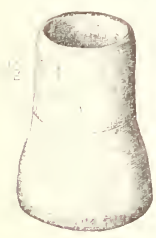

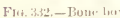
mencled with stitelus of sinew and whale. bone. I'eoruliat eonventional patterns are incised on the for and

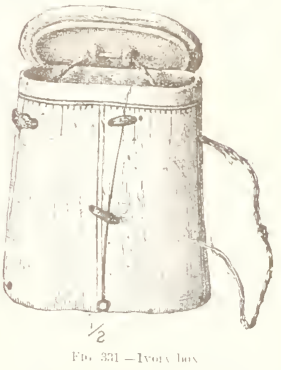

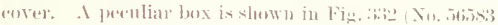

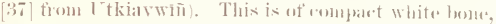

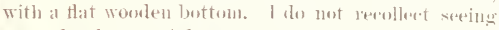
any other buxes of the simme sol't.

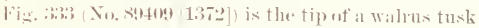

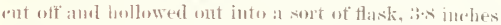

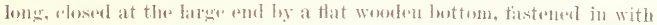

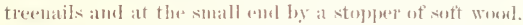

The mest perenliar box of all, how-

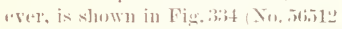
(2) trom Itkiavini), the mly sper.

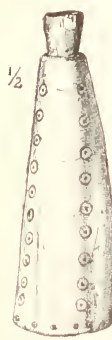

Fir, $\because: 4-$ Lit1ls thos of wars men of the kinel seen. It is 5 .

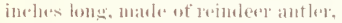
and very luatly rarvel inte a most exeflent inase of a reinterer lying on its lett side, with the hesul, whith has no antlors, tormed fown and to the lett. The legs ane tohled up against the belly, the tomelens with

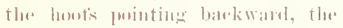
hinet lowts pointing timwarl. The eycs are reporesenterl by small skyblut wlass beark, and the month, mostrils, and navel neatly incivenl, the last luting partionliuly wedlmarkint. The tips of the lowis are romulal oft; whicls, taken in womm.

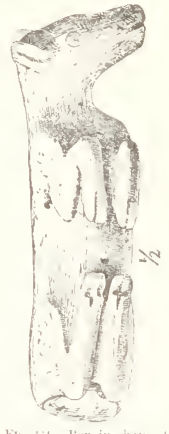

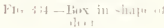

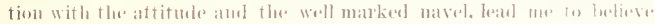


Fituf the phage meant to represent an mborn fetus. The whole if the benly is lowlowed, the ajerture taking up the whole of the but

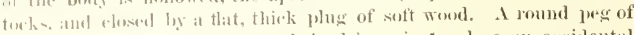

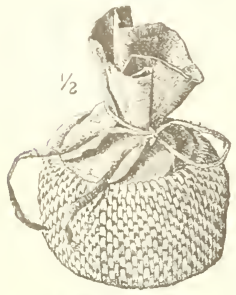

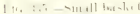
worl is driven in to rose an arridental hole just above the left shoulder. The box is old and diseolored, and worn smooth with murli landling.

Rarely these little workboxes are made of laskitwork. We obtained fom sperimens of these small biakets, of which

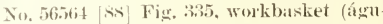
ma, ama, ipiám, will serve as the type. The nerk is of llawk tamned sealskin, $2 \frac{1}{2}$ inches loms, aud has 1 vertioal seam, to the midclle of which is sewed the mid. dle of a piece of tine seal thong, a foot long, whieh serves to tie up the month. The basket alpears to be made of the twigs n rows of the willow, with the bark removed, and is made by winding an osier spirally into the shape of the basket, and wrapping a nanrow splint spirally aronul the two adjacent parts of this, eam turn of the splint lwing separated trom the next by a tum of the sme.

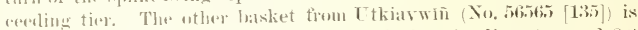
alnost "xactly like this, but langer (3.5 imbes in diameter and $2 \cdot 2$ high , and lats holes romul the top of the neck for the drawstring.

Two bakliets fiom siolaru are of the same material and wolkman. ship. But seme what barger and of a ditherent slatpw, as show

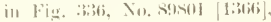

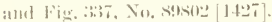
This was the ouly species of basketwols serell anome these perple and is probally not of bativa manntactume.

Prof', (1. T. Masom. of the $\mathrm{N}_{\text {i1 }}$. tional Mustume, has callew my attention to the faet that the

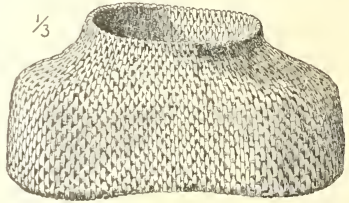

FIo. 336.-Small basket. methut of weaving employed in making these baskets is the same as

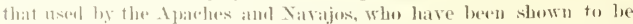

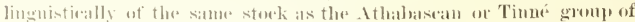

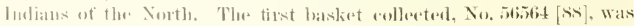

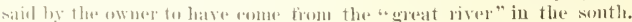
Xow, the namo. Kuwnk or Kowak, applied to the western stream thow. ing into Ilotham lulet, means simply "great jiver," and this is the Jegion where the liskimo enue into very intimate commereial relations with lmbians of Timne sterels.' Theretore, in consideration of the ludian 
werkmanship of these baskets, and the statement that ome of firem

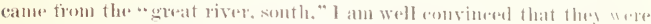

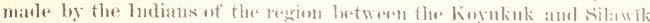

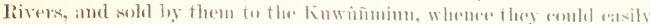
find their way to leoint Barmow thromgh the hands of the . Numatali minn" traters.

The Eskimo of Alaska sontle of Bering Stratit make and use bats

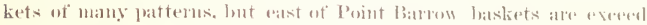

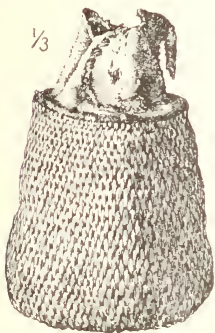

Fin, : :- Simall lustat ingly lane. The only mention of anything of the kind will be fomm in Lyom's fommal.' Il. mentioms sering at lglulik al "small romum lats-

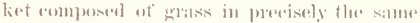
manner as those eonstruetod loy the Tibboo, in thes somthern patt of Frzatu, ancl agresing with the+u also in its shape." Now, these Ifrieans

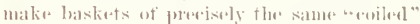
work (as Prot. Masul (alls it) als tlae Timue, so that in all probability what Lyou saw was one of these same baskets, aroued eist in trakle,

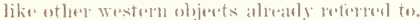
The name ámal alpolied to these baskets at Point barrow (the other two bames appear to fus simply the (iocentandie amat. the lome thin rumers trom ther root of a tree, "at present usest in the phural alos for a basket of kinopean basketwork," (beranse they late no irlea that fwigs rould be so small)—(rombandske (Holbog.

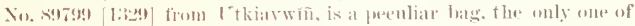

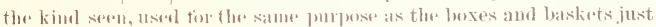
deseribed. It is the stematele of a phlat hear, with the muscular and glandular bayers removerl, driecl and ratetully worked down with a skin

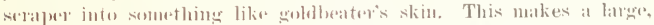

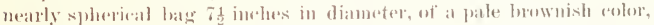

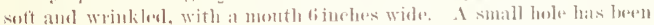
mended by drawing the skin together and winding it roumel tightly on the insitl. with sinew.

$$
\text { 1. 17: }
$$


WFAX: OF LOETIOTON AXU TRAXSPORTATION.

TRIVELING: BY WITEI:

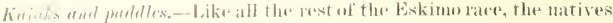
of Peint liarnow use the lsaiak, or narrow, light, skincovered eamoe,

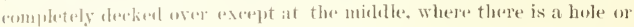
roukpit in which the man sits. Althongh nearly every male abose the

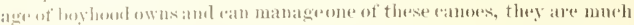
lass gemerally employed than by any other Eskimo whose habits have betell deseribed, exept the ". Aretic highlanders," whe have mo boats,

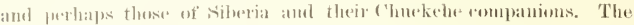

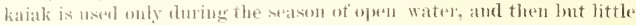

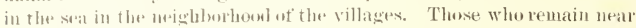
the villages in the stumer use the katiak ehiefly for making the short

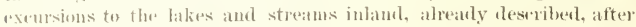

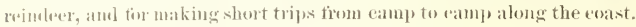
At Peruyn they are nasd in setting the stake-nets and also for retriev. ing towl which have fallen in the water when shot.

Areording to 1)1. Simpson ${ }^{1}$ the men of the partios whieb go east in the summer travel in their katalis after rathing the open water "to make roem in the large lont for the oil-skins." We obtained no information regarling this. It is at this time, probably, that the katiak comes sperially in play tor spearing molting fow land "flappers", and for catch. ing seals with the kikiga. They mamage the kaiak with great skill and contichere lont we never kuew them to go out in rough weather, nor

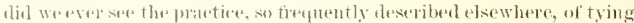
the skirts of the waterproot jacket romel the coaming of the eorkpit so as to coxlute the water.

It should, however, be borne in mind that from the reasons above stated om nprortmities for wherving the use of the kaliak were rery linitent. It all erents it is restain that the people depend mainly on the uniak, not only lon trateling, but for huting and fishing as well, which plates them in stroug rontrast with the Cireenlanters, who are

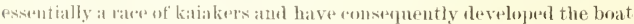

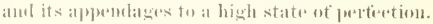

We lorought home one complete full- wizend katak, with its paldle, No.

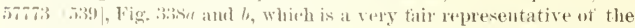

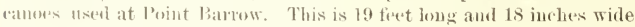
anichlops. The gumales are straight, exerpt for a very slight sheer at the bow, and therekpit is 21 ine hes long and $18 \%$ inehes wide. It has a fiame of wookl, which alperats to be all of sprue, held together by trenatsand whatebone lashimgs, and is coverol with white-tamed sealskins with the grain kide ont. The stoutest pant of the frame is the two

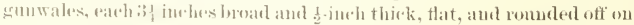

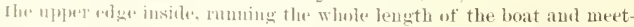

$$
\text { top. it p. 204. }
$$




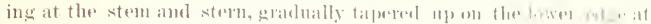

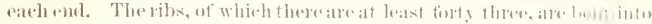
mearly a halt-rirele, thes making a U.shaped mishlip soetion, amd are

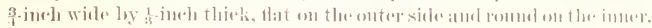

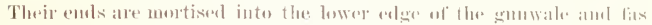

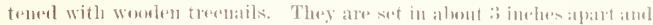

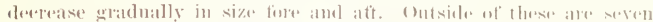

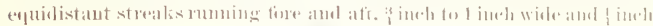
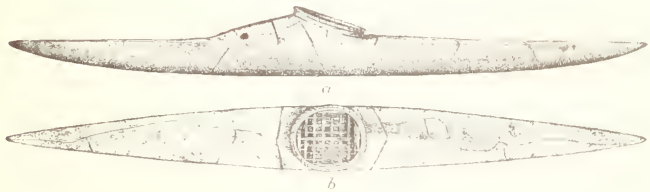

Fit. 3is - Kitul,

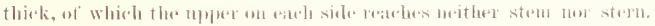
These ale lasherl to the ribs with a strip of whalelome, which makes at

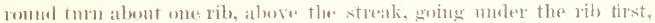

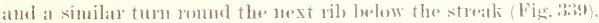

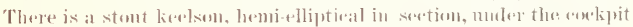

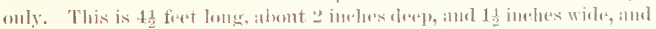

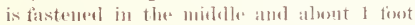

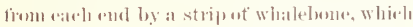

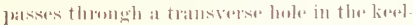
sell, round the rih on one side, hatek thromgh

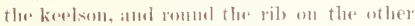

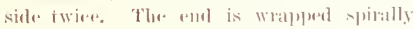
romel the tmrus on we sirle and toreked inte

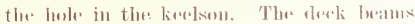

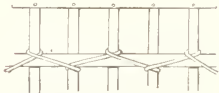

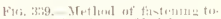

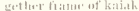

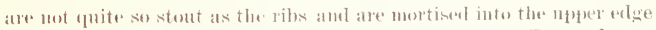

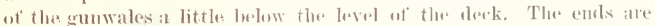

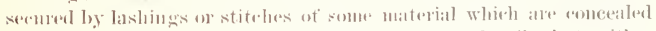
by the skin cover. They are abont as far alyont as the ribs, but neither exatly correspend nor lireak jounts with the latter.

It the alfer ond of the aselpit is an extras stout beam ar thwat to

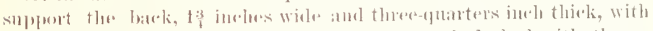

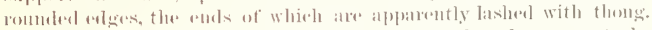

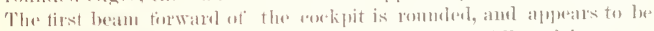

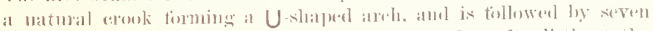

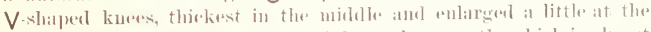

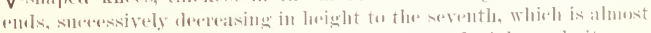

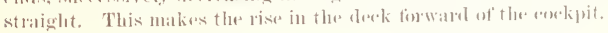




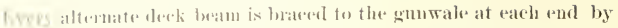

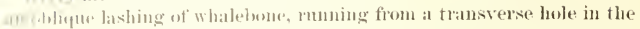
heam alout 1 incle tirom the ganwale to a corresponding hole in the gunwale, three-puaters inch from the lower "rlage. The bashing makes these or fom turns though thase holes and aromel the lower odge of the gamwale, and the and is wapled spinally rouml these tmms tor their whol. length. Abow these beams a narrow batten rums

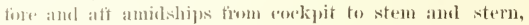
mortisenl into the two beams at the aockpit, and bashed to the other's with whalelone. The coaming of the rockpit is mate of a single flat piene of wood, I $\frac{33}{4}$ inehes broad and one inater imeh thick, bent into a hoop with the enels lappling alout 6 inehes and "seweel" fogether with stitches of whalelume. liound the mplex edge of this, on the ontside, is fitfed a "half-romel "hoog, which appeas's to be makfe of willow, three-pnarters by one-third inch, with its ambls lapped alout $t$ inches, this latp coming wer the joint of the larger hoop). It is fastened on hy slort stitches of

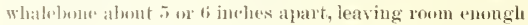
betwen the two boops to allow a lacing of fine whalebone to jasis thromgh. The maming is gut on orer the edge of the skin cover, whith is drawn up tight insite of the coaming and over its mpere mlge and fastemed by a lacing of whalphene, which runs spirally rome the onter howp and thromglt holes abont one-half ineh ajpart in the edge of the virer.

The coaming fits orer the crown of the areh of the forwark decek beam and rests on the middle of the thwart aft, atud is sement hy lashings of whalebone, which pass though lowes in the coaming and ore it s nper edge. The forward lashing makds three turus, whieh pass romul the beam with the and wapped spinally roum the parts betwern beam and coaming: the atter lashing, four similar turus, which pass through a bole in the thwart and around its forward

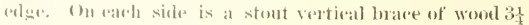
inches long, 1 inch wide, and ome-half imeh theck, with rommled exlges and cormers. The ends ane ent ont paralles to the brablth, so that one and fits on to the upenes elge of the genuale, while the other reares the bower solge of the coiming, potructing on the ontside throngh a lowh in the rover.

The cover is of six sealskins, put together heads to tails, (s) that there is only one lomgitudinal seam, which rons irresulary along the dexk. The transverse seams, wheh rom obfiquely aterosis the bottom are denble and sewed 


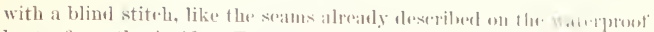

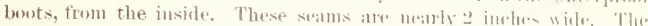
lomgitudinal seam is selwed in the same way from the ontride, fult not so broadly lapped, with the elge turned over into a rotl. There

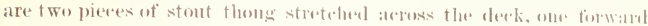
of the coekpit and the ofher aft, which serve to fasten altidese to

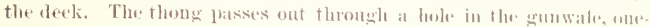

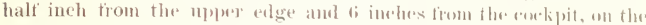
starboart side forward and on the pont side att, ans is sement by

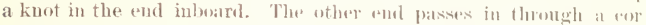
responding bole in the othere gunwale and is loosely knotterl to the derek beams, so that the line "am be slarkenesl off or tautenes up at pheasure.

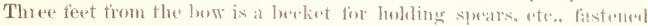

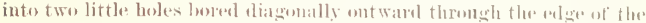
gunwales. It is of two jartis of seal thome, ome part twisterl round the

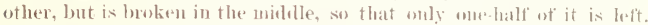
The weight of this katiak in its present dry andition as : 32 pumbls.

This is about the ordinary lattern of kaliak used at Point liaren, and is a metlium-sized one. These boats are mate to tit the size of the bwnere, a youth or small man using a muh smatler and lightor katak

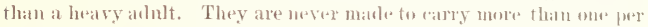
son, and I have never heard of their being nesil by the women. In rarrying the katak across the lamel from lake to lake, it is he ha hori zontally agatinst the sisle with the bow pointing forwam by thrustius the foream into the rockpit. Wr never sil them rarried on the head.

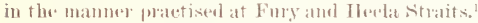

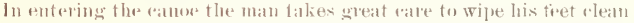

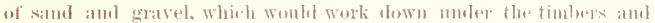
ehate the skin. The ranor is lanmeleel in shosl water, prefterably alongside of a little bank, and the mant stealies it by stirking town his

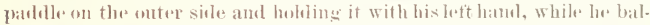
ances himself on his right foot. and with bis free band callefully wipes his left toot. Ile then stepes with his lett foot into the kalak, and still balaneing himself with the help of the pathlle, lifts and wipes his right foot betion he steps in with that. Ife then pushes his tiet and legs tor ward mule the raised leek, settes himself in a poler position for

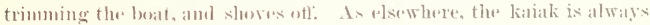
popelled with a parllle.

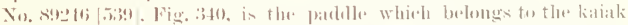
just deseribed. It is 7 teret long. The shatt joming the lobules is elliptieal in seretien, with its gereatest widtlo at right angles to the phawe of the blates so to preserent the greatest resistatere to flue strain of pard

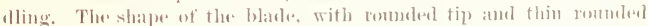
rolges is admimally anlaptert to give the blade a chean entry into the

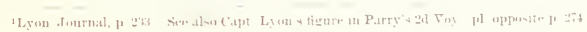


a nes The whole is very ueatly and smoothly made, and the blates

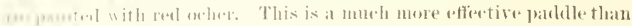

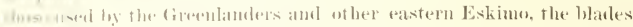

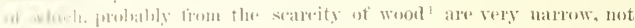

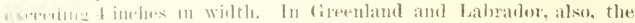

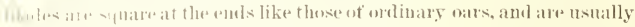

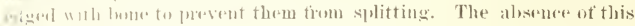

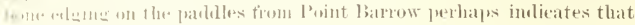

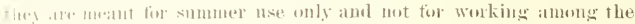

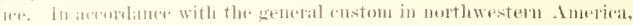

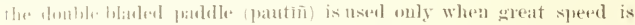

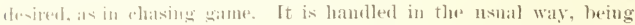

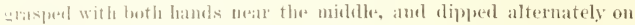

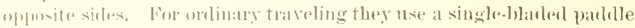

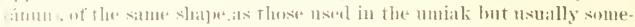
what smaller, of which we beglected to presure a sperimen. With this they maka a tex strokes on one side, till the boat begins to shees, then - hilt it wor and nuake an fiew strokes on the other side. They do this

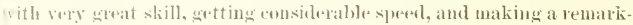
ubly straight wakd. The use of this single paddle appears to be unilersal along the colst of . laska, from Point Ibarrow sonthward, and it is also nsed at tho. Markmzie and Auderson rivers, ax shown by the andels rollected by Mar.Falane in that region. It is, however, mblinwn amonge the eastern Eskino about whom we have any definite intomation on the sulyjert, namely, the (ireenlanders, the people of laftin Land, Iludson Strait, and laalnaulor:"

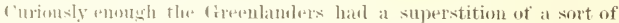

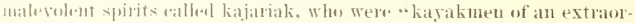
dinaty size, whe alwalys sex+ut to be met with at a distaue from land

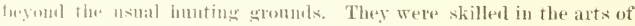
sorecry, partionlarly in rla. Way ot rasing storms and bringing bat

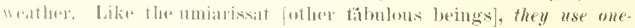
bladed puddles, likit thuse of the ludians." ${ }^{3}$ This tratition either reters birek to a time when the andestors of the Gitemulameles used the single padullo or to orasional and perhajs lostils meetings between eastern and western kskimo.

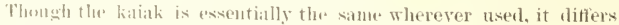

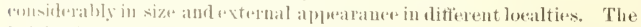

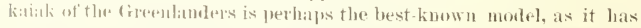

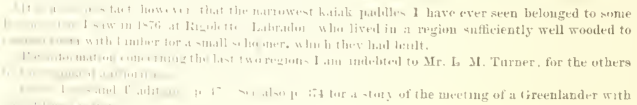




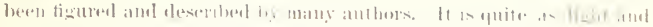

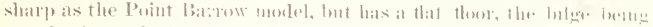

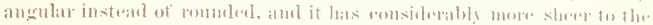

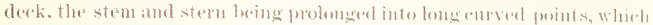
projert above the watere and alle often shoul with home or ivory. Tla.

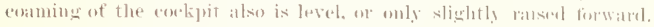

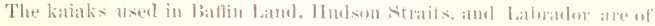

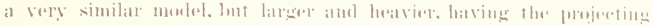

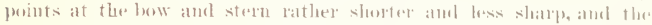

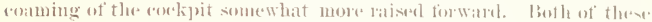

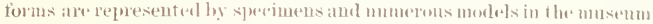

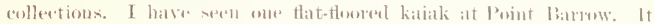
belomgerl to a youth and was verg namow and light.

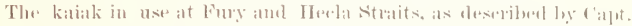

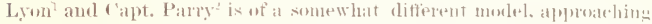

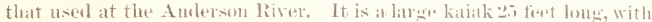
the bow and stern sharp and comsiderably mor bent uj, thin in the

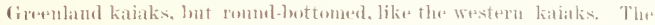
deck is flat, with the corekpit coaming somewhat raised forwarl.

lu the kataks nsed at the Anderson and Iackenzie rivers, as shem by the models in the Nationil Mnsenm, the bending mu of the stem and stem posts is carried to an extreme, so that they make an angle of

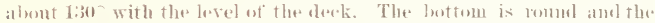

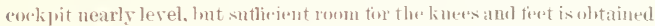

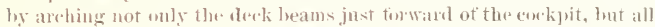
of them from stem to stern, so that the derek shopes away to wath side.

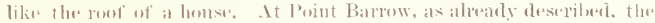

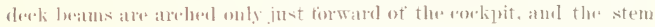
and strom an not prolenged. This appears to be the prevaling form

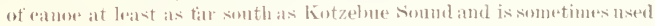

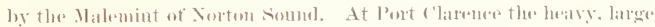

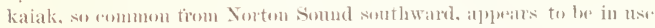

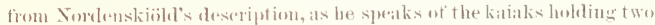

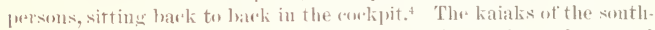
wotern Eskimo alre, as fir as I have besu able to learu, large and laras, with level coamings, with the deek conite streply arehed fore and aft, and with bow and stern nsmally of some perbliar shape, as show

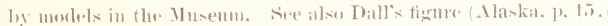

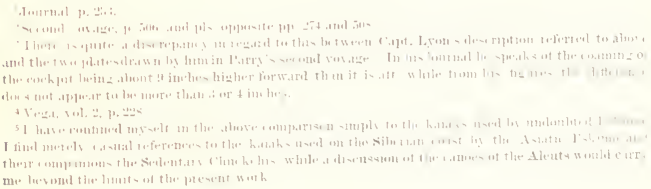


While the hatik, howerer, difters so much in external appearance in ditherent localities, it is probulus that in strncture it is everywhere "sichtially the same. (Only. two writers lave given a detailed descrip. fien of the trane of a katialk, and these ane form widely distant loealities, tyluliti and western cireenland, both still nore willely distant tron l'oint barmow, and yet both gire essentially the same component parts as are to he tomul at l'oint Barrow, namely, two (omparatively stout

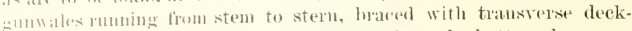
bomms, seren streaks ruming form and aft along the lottom, knees, or libs in the torm of leopse, and a hoop tior the eoaming, lommel together with whitebone or sinew. ${ }^{2}$

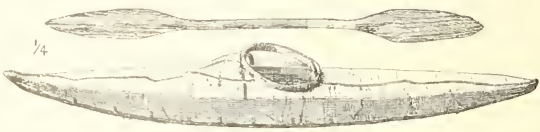

Fis.311,-Mndel kaiak and jattidle.

The donble bladed padtle is almost exelusively an Eskimo contri vance. The only other hyperbortan race, besides the Alents, who mse it, a1" the lnkagirs, who employ it in their narrow dngont canoes on the River Kolyma in siberia." [romble-bladed paddles have also been ob. serverl in the Malay Arehipelago.

Fig. :311, (No. 5tîtil [224] from I'tkiavwiñ) is a very neatly made mexlu of a kaiak, 13.3 in.lies long. It is quite aceurate in all its details, but has only five streaks on the bottom, and its width and depth are about twice what they slomld be in proportion to the length. The flame is lashed together with fine sinew and covered with seal eu. trail. The paddle is also ont of proportion. Many similar neatly fin-

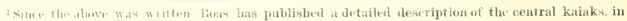

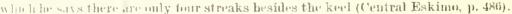

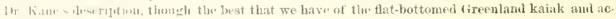

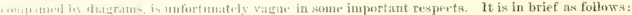

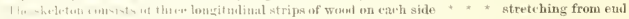

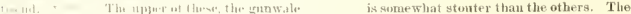

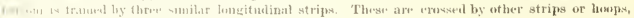

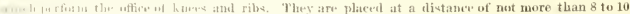

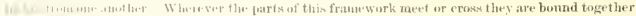

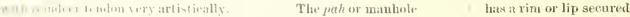

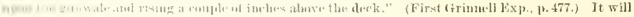

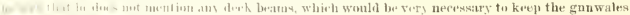

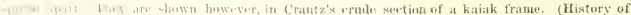

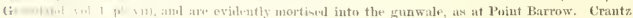

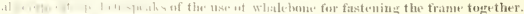

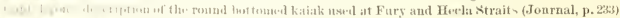

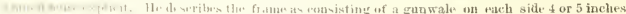

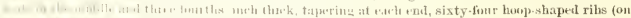

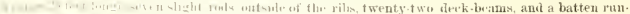

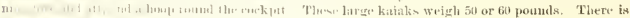

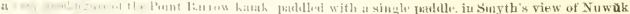

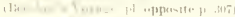

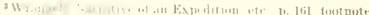


ished molels were mals tor sale. The native ane so skilltul in making them that it is possible that they are in the habit of malsing them tor

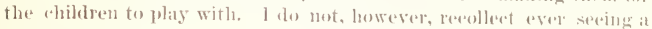
child with one.

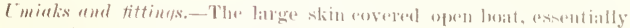
the sime in molel as that employed ly almost all Eskimo, as 11 ell as

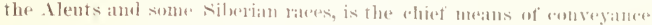
ly water, for travelins, honting, and tisling. Thongh the women do it great slawe of the work of navigating the boat when a single fintils ar

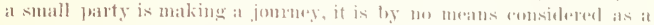

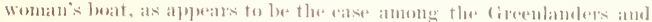

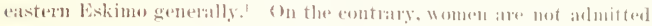
into the regularly organized whaling rems, muless the mulalik am uot

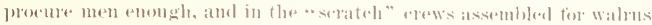
hunting or sealing there are nasually at least as maty men as women,

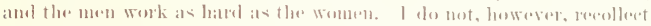

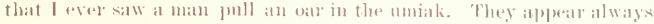

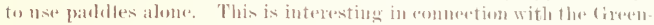
land enstom mentioned by Eerede in the continuation of the passatge just quoted: . And when they linst set ont tor the whale fishing, the men

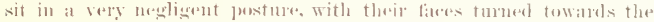

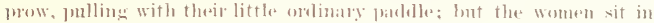
the ondinary way, with their faces towards the stern, rowiog with longe (lits."

We were unable to brimg lome any sperimen of these boats on ate

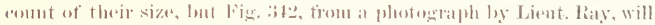

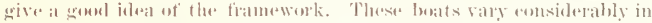
size, lut are usually very nearly the dimensions ot an orelinary whale.

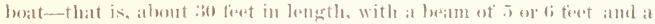

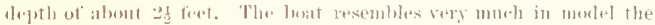

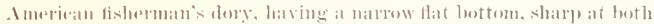

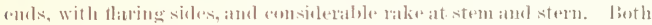

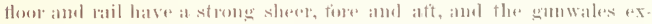

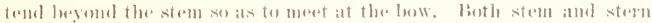

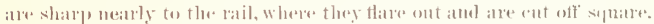

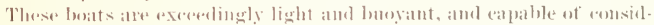

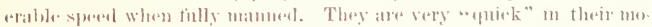
tion and putite crank till they get down to their bearings, but lowamel that alueats to be sery stitl.

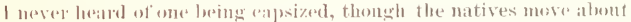
aboald of them witl pertient freedom. The fiame is ueatly made of pieces of driltwool, which it nsually takes a comsidnalsle time to aceumulate?

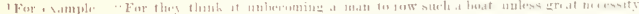

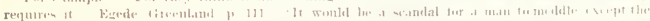

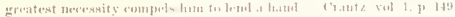

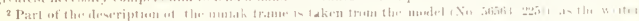

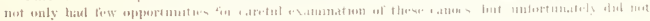

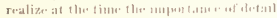




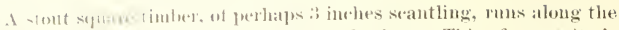
malllte of the fonton forming a keel or keelson. This of necessity i.

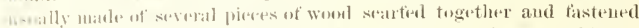

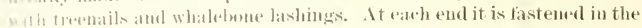
sme way to the strom and stermost, whiml are both of the same shape,

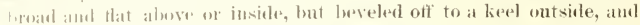
curs ing up in at kus. at the same time tapering off to the point where

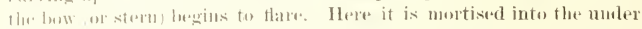

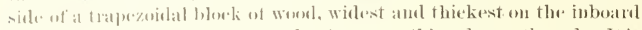

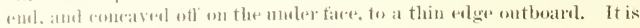
lowl on ly a transiorse lashing bassing though lobles in the end of the

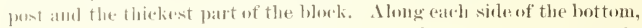
at what would lo the hilge of a remul bottom boat, roms a stont streak,
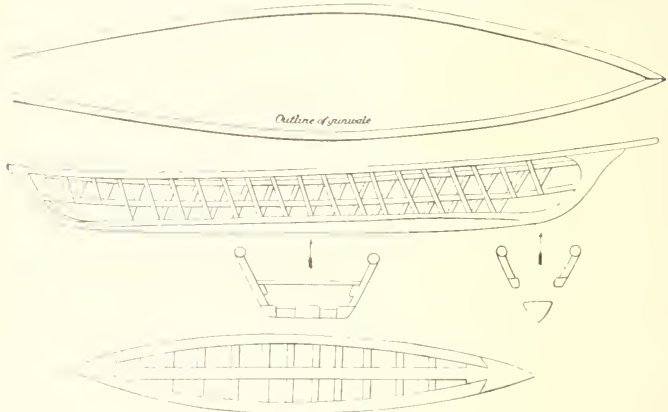

Fut 342-Frame of umiak

thimen and wider than llar keelson and set np adgewise. These are spreal aprat amidships, but bent together fore and aft so as to be scatfed inte the stem and stermpost (see diagram, Fig. $343 a$ ).

() 11 the model they are fastened here with toeenails, and this is prob. ably also the ase on the large raneres. They are spreal apart by

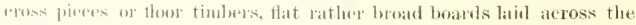

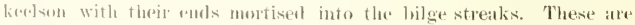

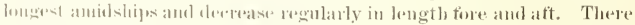

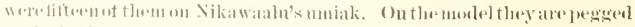

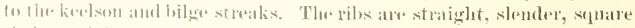

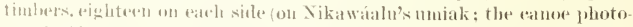

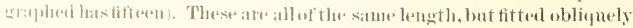

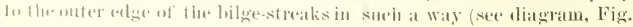


34:3i) that those amidships slant considerably ont ward while the wher

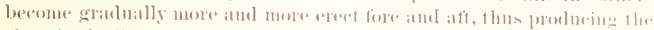

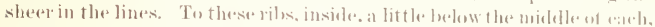

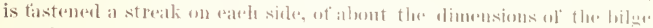

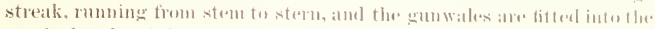

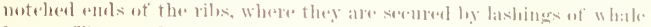

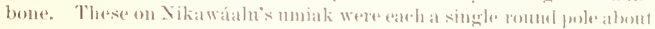

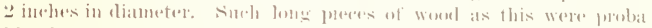

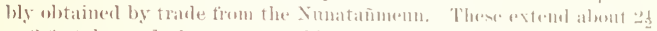

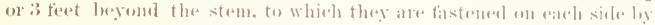

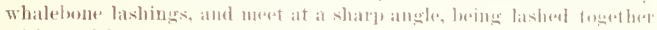

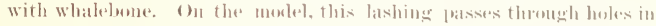
beth gemwales and romel umlermeatle. The gumwales atre fastemel to the sterngest in the same way as to the stme, in Juth cases resting on

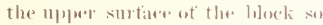
as to tim a low rail. but project only 5 or ti ineles.

Between the poot amel the last pair of long ribs at atel end are two pairs of short rils running only from the gunwale to the in side streak. The frame is still further strengthemed by an ontsicie struak leetweren the bilge streak ambl the insido streak, and Nikawatulu's ranoe hat an extrat streak of "halt roume" willow ont-

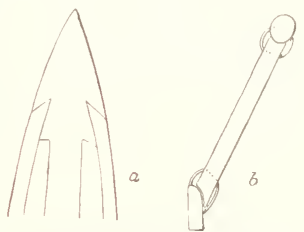

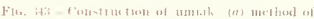

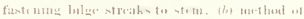
tramume tile to gunw.te, ets sishe of the lat ter. The thwarts lest on the inside streak and alle sermesl

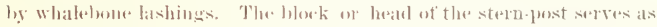
a high seat for the steresman. I'ranty's deseription and diagram show that the fiame of the Greenland uniak eonsists of essentially the same timlere, lacking wily the two ont side streaks.

The eover is made of the skins of the lareser mane animals. Wallus hide is often llsed and sometimes the skin of the folar bear, which

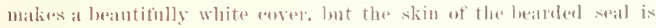

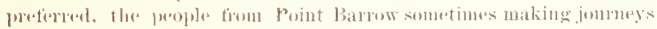
to Wainwright Inlet in seareh of such skins, which are dresied with their oil in them in the matmer already reterred to. We wore intomed that six of these skins were lespluired to mover one umiak. They an put together in the same way as the skins for the katak amd sewerl with the

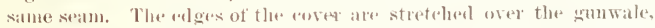
and lared to theiusidestreak with a stont thong. which passes through

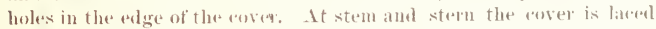
with a sejpatrate thong to a stout transwerse lashing of thong running from gunwale to sunwale close to the edge of the posthead. 
The omare is remosed in the winter and stented away on the carde frame of some of hor satfe phase (Yhiniahu, when preparing to start for the spring teer humt in lisi?, earefully buried his boat cover in a snowbank ont of rould of the llogs, and the trame is placed lrottom np-

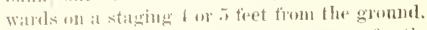

When they are reacly to refit the amo for the spring whaling, a hole is rut in the sea ice alose to the shore, and the cover immersed in the seal water for several days to solten it, the hole being eovered with skals of snow to kapp it from freezing up. ('rantz ${ }^{1}$ mentions a similar renstom in (irenland. After removing the hair from the boat-skins "they lay them in salt water for some days to solten them again, and so coner the womm's boats and kajaks with them." When not in use, the miniak is drawn up on the beach and nsually laid bottom npward with the gear, spens, ete., muderneath it, but sometimes propped up ou one grumwate to make a shelter against the wiud. This is a eommon practice in the cantp at Pernyin, where there is usually at least one boat set up elgewise, sheltered by which the men sit to whittle and gessip.

In the whaling campl at hovpunin in 1 sis 3 , the boats whieh were not ready to go out to the open water were laid np bottom up with one end resting on at shed set 11 , on its side and the other supported by a block of smow. They do not appear to be in the habit of using the canoe for at tant, as is salu to be the anstom among the more sonthern natives, as they always arry a trut with them on their jomrneys. The umiak is propelled by padillos, oars, and a sail, and in sunoth weather when the shore is chear of ice by "tratking" along the beach with wen and dogs, one person at least always remaining on board to steer with a pandlle at the stern.

The sail, which they are only ahle to nse with a fire wind, is square, nawow, and lat her high, and is nowadays always made of drilling. Watk blue frilling appeared to be the most popular sort at the time of om visit. The heal of the sail is lard to a light yard, and hoisten to the masthear by a halyard through a hole in the hatter. The mast is a stout square pole 10 or 12 feet long and is set up well forward of amidships, withont a step, the square butt resting against a bottom board, and lude up by two forrstays aut two barkstays, rmming from the masthesal to the insicte streak. Alt the rigging, stays, halyards, towing line, ote., are mate of stont thoug. The (ireenlambles set mp the mast in the how of the umiak-as a sailor wonld say, "in the very eyes of her," fut as far as I fan lean the Wrateru Eskimo all set it up as at Point liarrow.

Thu was are very chmsily made with very narow blades not over 3 inehes broad. They ale about 7 leet long and somewhat enlarged at thr loom. Instein of resting in rowlorks, they are seemed by two long

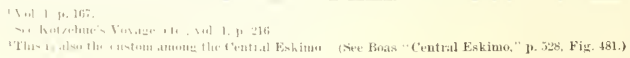


loops of thong as in the diatam Fig. 3H. To kecp the oal from chat ing the skin on the ganmale, they lash to the latter a long plate of

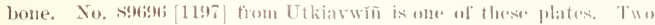
of these bass ane commonly 11 sed in an molat, one forward and one alt, amal the women row with great vigor, swingring woll from the hips, lut do not keele stroke. The use ot oars is so musual among savigum that it would be natural to suppose that these people had adopted the cous tom from the whites. It this les the tase, the enstom rearled them long ago, and through very indiret thanmels.

When Thonas simpson, in 18:37, bonght an moniak from some Point

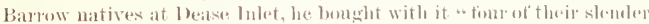
oars, which they nsol as tent poles, besides a comple of pruldles: litted the oars with lashings, and arranged our strangw vessel so woll that the ladies were in raptmes, leclaring us to be gennine lisquimans, and not. poor white men." Tha custom, moreovers atylears to be widle. spreat since Lyom speakis of sest ing in 1s:el, "two very rlumsy was with tat blades, pulled by wommell." in the miniaks at Ilut soll Nitrait." It was praticend at a still carlier date in firenemband.

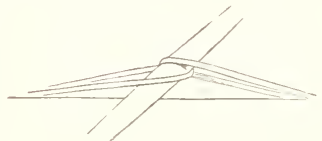

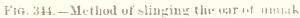

While at Point barrow the wars have very narow blades and the donble paddles very lowal ones, the reverse seemed to be the wase in

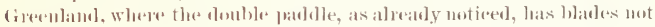
wrer 3 or 4 inclese bual. Crantz desoribes the oars as " short and broal luetore, pretty mor.h like a shovel, but only longer, and * *

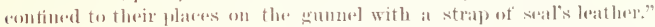

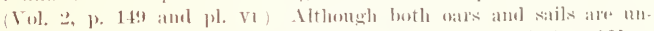

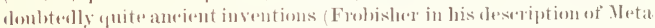

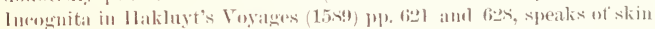
luats with sals of entrail).' I am st lengly inclined to believe that they

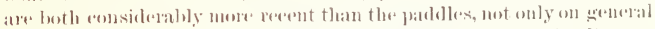

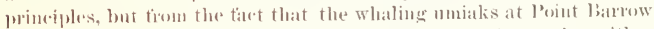

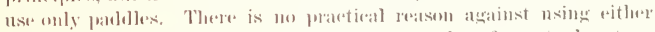
wars or satils, aml in faret the latter would often be of preat alvantage in silently approaching a whale, as the Americau whalemen have lome

Natrative, p. 14x

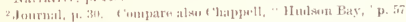

tsae Firale, Girentatul, p, 111.

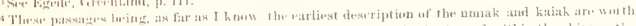

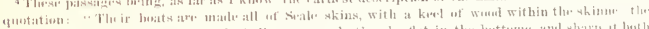

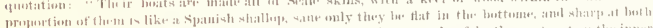

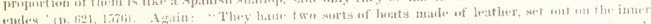
ereses to.

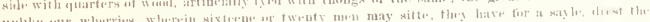

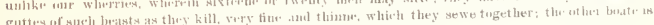
but for one matl to sitte and rowe in, with une aste (12, 62\%, 1577). 
necul anderel. It seems to me that this is melely another case of ad.

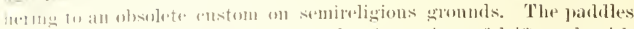

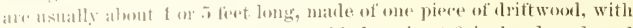

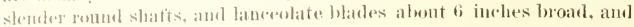

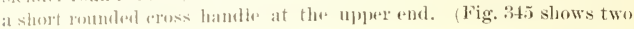

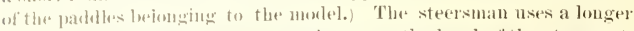
paldille. atml stamls in the starn or sits 11 , on the heat of the sternpost.

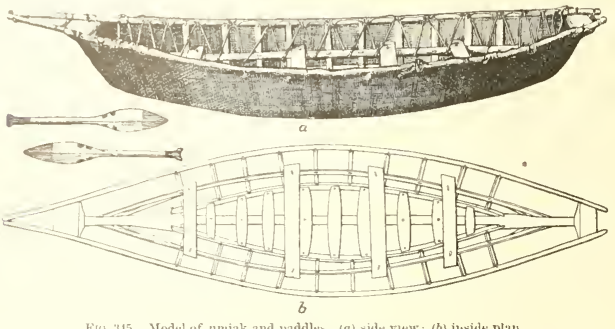

F[s, 345,-Yodel of umiak and paddle's, $(a)$ side v1ew: $(b)$ iuside plan.

Fig. 34.je represents the model (No, ifisti: [3:5] from Ctkiarwiñ), which gives a very gool hlea of the shape of one of these boats. It is puite correct in all its parts, thongh the timbers are rather too heary, and there ar not so many rils and floor timbers as in a full-sized canoe. The breat th of beam, (i." inches, is at least 1 im.h ton great in proportion to the length, 2.: inelies. The "orer is one piece of seal skin which has loeen partially tamed by the "white-tanning" process, and put on wet. In drying it has turned almost exactly the color of a gemine

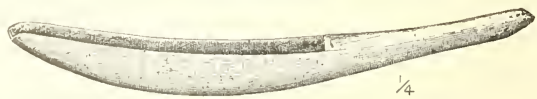

Fis, 346,-lvory baiter for umiak.

bat rover. The frame, as is often the ease with a finll sized boat, is painterl all oxm with ret oeher. (See Fig. 34.5b, inside plan.)

For batilig these boats a long naryow dipper of ivory or bone is used,

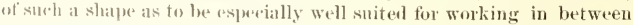
the thor timbers. Fig. 34f represents one of these (No. 5irisi [40] from l'tkiaywiì), It is a piece of walms tusk $16 \cdot 3$ inches long. The cavity

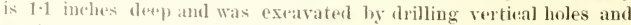
cutting away the substance hetween them. Some of the boles have not bestr eompletely worked ont. I similar bailer (No. 89835 [1010] also 


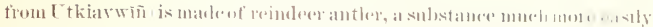
worked than the ivory, its the sott interion tissue axposed by enting the

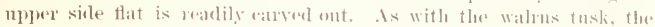
natmal eurve of the material gives the proper inclination to the bamalle. It is 1 s:? ineles long.

When the mmiak is fitted ont for whaling a stomt $U$ shaped aroted of

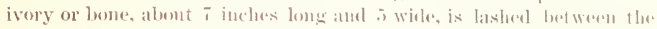
gumales where they meet at the how. In this the heary harposn rests when they are apponaling a whale. It is only now when whaling. The Insemm rollection eontains sperimens of this sont from as fir south as the biomede [s]ands,

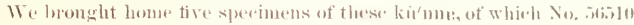
[117 Fig. 347 hats beell selereted as the type. This is marle of two bilat(a) ally symetrical piecesot white walrus ivory, each piece ensisting of one arm of the erotele and halt the shank. Its total length is $7 \times$ inches. The two pieces are liekl togetleer by a stont wooden tree-nail, and above this a lashing of sinew-baral, lod geed in two decp vertionl chamels one on earle sicle of the shank just below the arms, and sedged abore and below on both sirles with slips of woerl. A hole is drilled themeh each sicle of the butt elose to the emal, amol thromglo these a lashing is streteled aross the renenterine angle of the butt ansisting of fom turns of sinew inatal with the rud

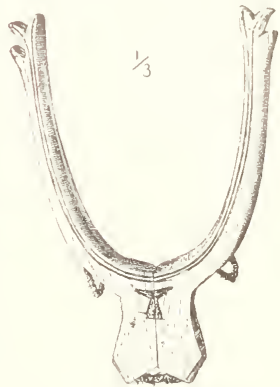

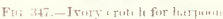

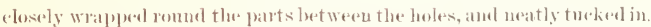

Just at the bent of earle arm is a small round besket loble, muning oblignely trom the baek to the onter side. In eareh of these is a mat

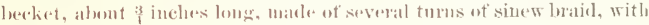

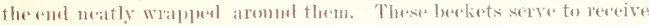

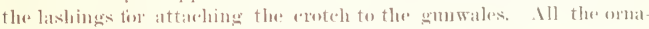
mental tignes ane imeised and blatkenesl.

There of the remaining tome spereimens are of wallus-ivory, and ot escontially the samm pattern, differing only in ormamentation and ot here

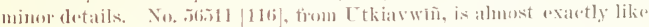
the tyge and of rely nearly the same size. It is fastened togetleer witl

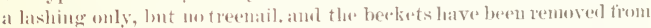

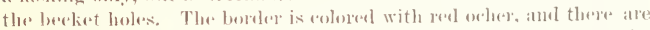
two whales taik instead of we on the shank. The other two hat we the

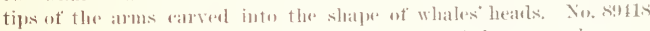

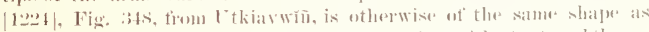
those aldealy deseribed, lont is lasherl togethere with stont seal thomg, 


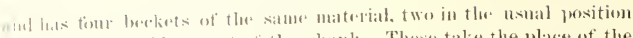
and two at the widest part of the shank. These take the place of the

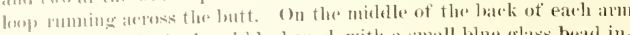
is a small aross inciscul and lolarement with a small blue glass bead in

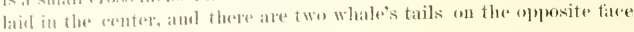
of tha shank. It is s imelues long.

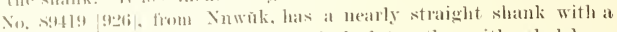
Hange on and side at the lutt. It is lasked together with whalelume and lats also a tremail. like the type. The mpere loekets are of sinewbratil. I lareg beeket at the butt is mate ly looping and knotting the ands ot a lit of thomg into a loole in each Hange. There is ane whates tatil engraved on the front of the shank. Whan lashed in posi.
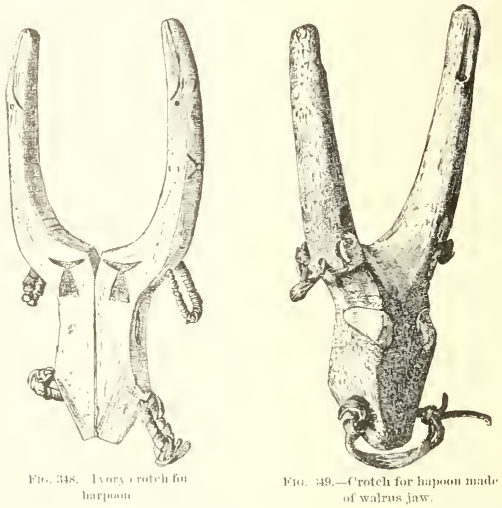

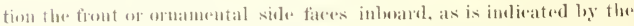
shape of the shank, which is slightly namewer hethind than in front.

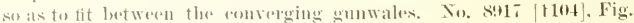
:34! from Nownk, the only one of the kind seen. is a very interesting lome. It is male ley entting a horjontal sliwe ont of the lower jaw of a Wallus, se that it form the arms of the eloteh, while the thiek symphysis is ant intora shauk of the usual shape, with the two upper heckets in the nsual place and at laree one at the butt, passing through a trans-

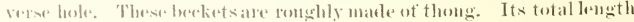
is tivti inclues.

This sperimen firom its sobles nondition is molombterly quite ancient, and probably of an older type than the highly ormamented ivory crotehes 


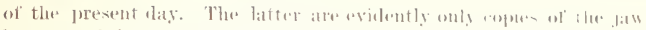

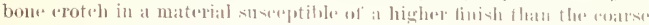
bone. The only reason for making them in two proces is that it is im possible to get a single phere of walme ivory large anomgh fior at whole one. It seems to me highly probable that the conteh was suggested lis the natural shaje of the walrus jatw, sine these ane liwenently usenl ton

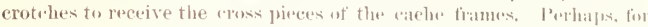

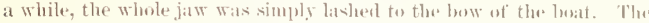

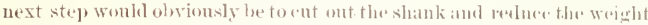
of the eroteh ly trimming off the superfluens material. The reason fir

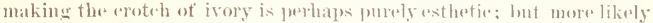

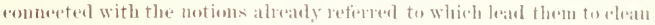

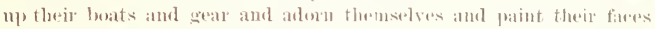
when they go to the whate fishers.

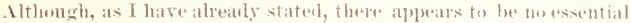
difference in the general plan of the frame of the firendant umiaks

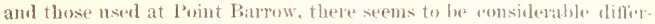
enee in the size and ontward appraraues. As well as ean be judged from the brief deseriptions and mule fignres of varions anthors and varions models in the Xational Mnsem the correstuess of which, hww. ever, I ean not be sure ot, withont having seen the originals) the muiati not ouly in Greenland, but among the Eskimo temerally as far west as the Naekenzie, is a much mowe wall sided sifnare ended lwat than at Point Barrow, having less shene to the gumwales with the stem and steru-post uearly vertical:- Mr. L. M. Tumer informs me that this is the

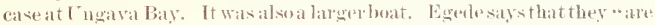
large and open * * * some of them "2) yatrds lomg;" Crant\% gives their length as "eommonly d, nay sor "t fathoms long:" Kimmlien says that it reyuires ".about fiftern skins of Plocal barlata" to eover an muiak at Cumberlaud (inlf, and $\mathrm{Mr}$. Turner intorms ne that eight are nsed

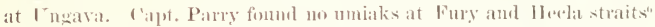

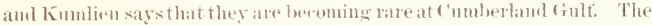

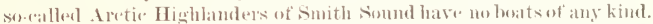
The motel used at Point Barrow polnbly prevails as tar sonth ats Kotmebue somel. The boats that buarderl us off Wainwright Inlet in

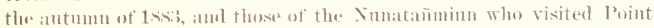
barrow, secumed not to differ timm those with which we were familiar, exerpt that the latter were rather light and low sided, nor do I remember

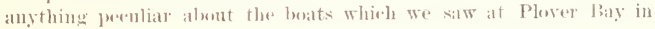
inst.

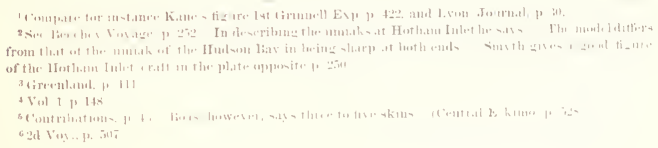




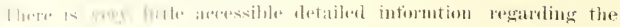

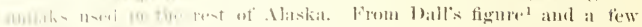

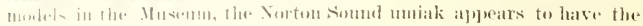
-Honwales muiteal at both stem and stern. These that we saw at st.

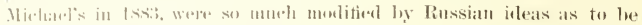

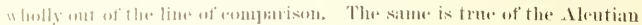

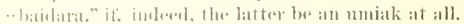

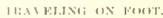

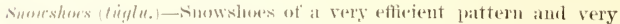

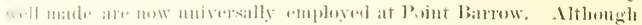

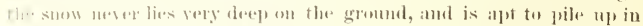

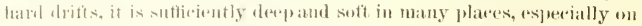
the elas farts of the tumban, to make walking withont snowshoes very

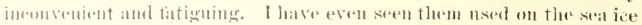

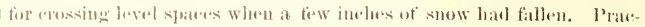
tieally, werly man in the two villages, and many of the woment and

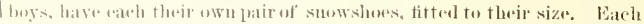
shoe consists ot a rim of light weorl, bent into the shaje of a pointed

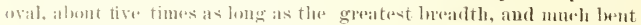
up at the remeded end, which is the toes. The sides are braces apart be two stont eress-bars (toe and heel bur) a little finther apart than the length of the wearer"s thet. The spates between these two bars is net.

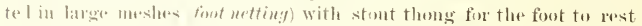

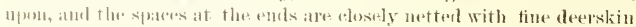

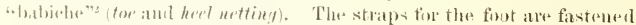
10 the timet wetting in suld at way that while thast salp is firmly tistened remul the ankle the sumshoe is shong to the toe. The watrer walks with longe swinging striche, lifting the toes of the shoe at earh step, while the tail of hese drags in the snow. The straps ale so sontrived

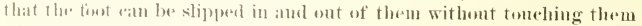
with the fingers, a great alvantage in exhl weather. When deser hunting. aceording to Lient. Raty, they take at long piese of thomg and knot ratele ent of it to the tore of one suowshes. The light is then looped into the he. the hind so that the suowshoes drag out of the way of the herels. When they wish to put on the sheses they draw them up, insert

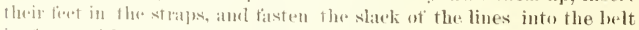

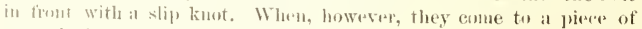

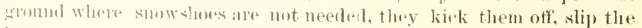

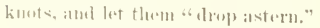

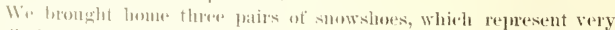

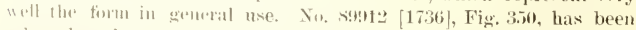

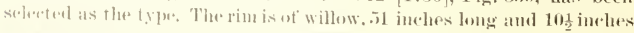

$1,1,1,1,-$

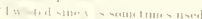

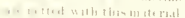

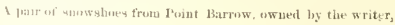




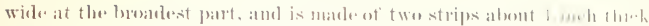

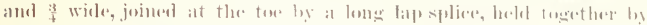

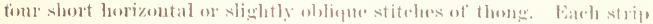
is alliptiont in seetion, with the long a

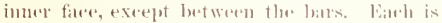

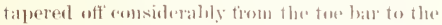
tor, and slightly tapered towathal the here]. The

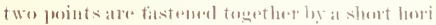

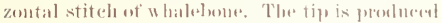

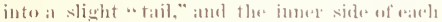
shor is slightly stribighter than the onter-that is to say, tlery are erights amel lofts."

The bars alle elliptical in seetion, flattrued, and have their endsumtised inte the rim. They are alout a finot apart, and of bak, the tow bat 9.2 interes lomg and the herel latr s.o. lioth are of the same brablth and thickmess, t hy $\frac{1}{2}$ inele. There is alse an extra last for stementh. ening the back part of the show 10 inches fiom

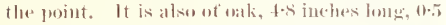
witle, and 0 :3 thick. The toe and lowel nettings are put on tirst. Small erfudistant vertical

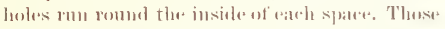

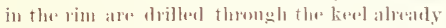
matiomed, amd joimed ly a shallow groove above and below; those in the bass ane about

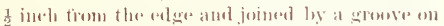
the molere side at the toe batr only. Inte these

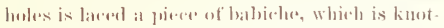

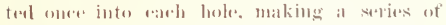
bereliets about 3 inele wide round the insiele of the sparee. There ane no lateinge heles in the parts spliedel at the tore, fout the laceing passes through a light of warh stiteh. At the tor batr the lating is a arried straight areoss fiom tim to rim illont there times. the last pant heing womed rotume the ot her's.

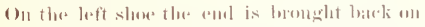
the lett-hatud side, passent thromgh the tirst hole

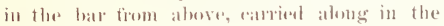

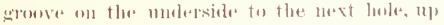

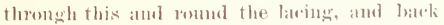

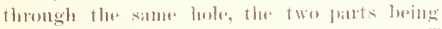

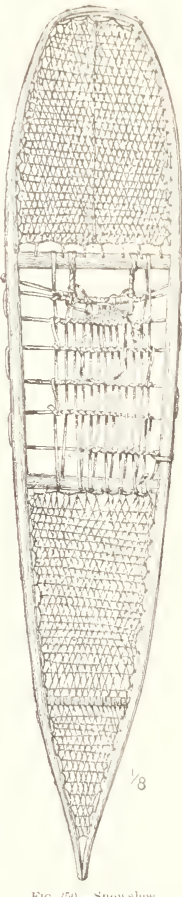

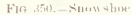

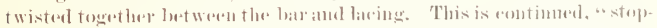
ping" the lawing in tiestoons to the bart, to the last hole wh the right, 


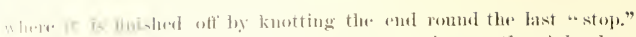

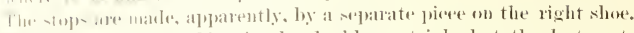

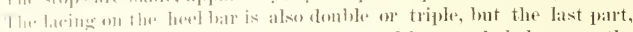
which is womel ronul the ofluers, is knotted into wath hole as on the rim. The lacings on the lim of the heel spare are knoted with a single

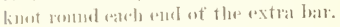

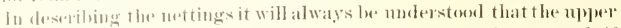

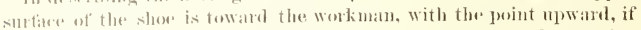

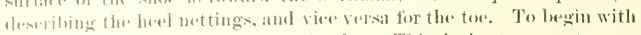
the hent metting. which is the simples: This is in two parts, ane from the hor late to the extral hat (heel nettimg proper) and one from the lattes (1) the proint (pwint netting). The netting is invariably fastemed to the laring he passing the end through the becket trom alowe and bringing it bate over itselt. 111 making the point uetting the and of the babiche is knotted round the bar at the right-hand bower tomel with a single knot. The ot her and goes 11 , to the lacing at the porint and andes down to the lett hambl lower comer, where it is

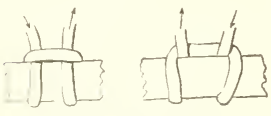

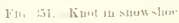
hitrhet romel the bar, as in Fig. 3.1, then goes up to the lowest berket on the latt sitle, crosses to the corresponding one on the right, and comes down anel is bitcheyl as before round the latr inside of the starting point. This makes a sertes of strants romud the ontside of the spate, two ruming oblinmly fom right to left, at bong one on the right kide and a shont one on the latt side; two similar strands frem lett to right, the long one on the lett and the short one on the right, and one transierse strand at the base of the triangle

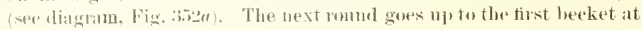

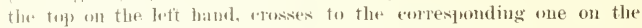
right, and then makes thas sane strambs as the first romed, rumbing

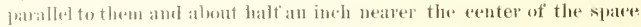

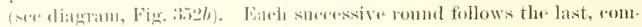
ing wah time about $\frac{1}{2}$ inely neares the center, till the spare is all tilled in. which lorings the end of the last romel to the middle of the bar, romml which it is kuntted with a singlu knot. This makes three sets

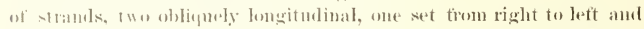
onc from lett to right, and one tramsierse, all of eareh set parallel and

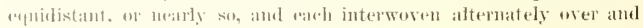

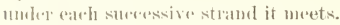

Theright shere has tourteren fomgitudinal strands in wath sot and

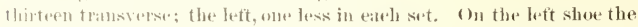
(mol is andied np, from the last knot to the lacing at the point, and then comes batk to the barr, fistening the other part to the netting with six

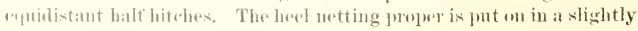




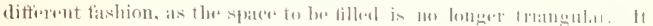
starts as betore in the right hand lower cormer, where it is kjottont into

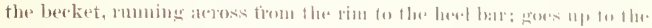

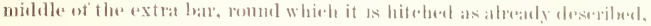

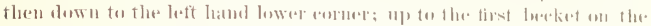

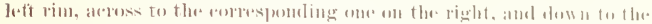

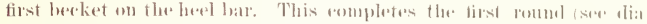

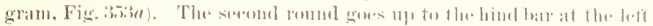

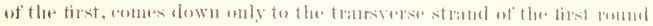

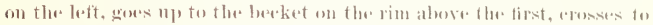

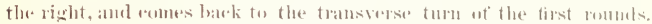

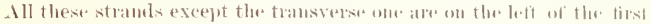
romol. The thind roment tollows the tirst, which brimgs all its strambs

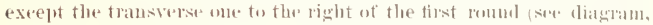
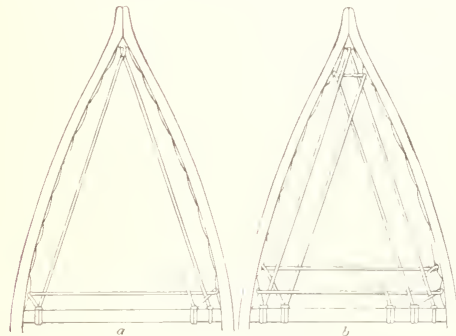

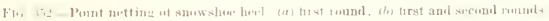

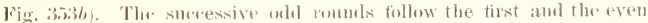
romuls the seend, bringing the longitmelinal strands alternately to the right and left of the first romml. until the end of the low har are realebel-that is to say, till the spare ontside of the first romul is filled-

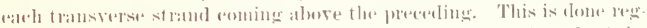

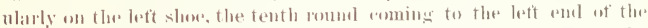

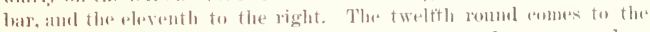

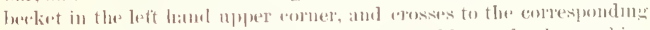
lweliet on the ot lere siele. It then tollows the erlel romols, thus making six stramels, four longitulinal and two transwerse, as in the point met-

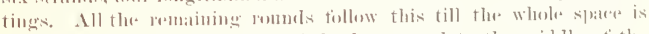
filled in, which briegs the enel of the last roumel to the midelde of the level bat, where it is knotted do the bereliet.

(B) the riglat slose the makel seems to have made a mistalke at the eiglth rouml, whieh obliged him to alter the order of the other stramb 


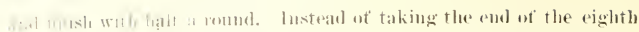

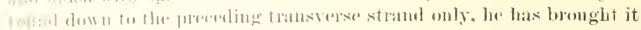

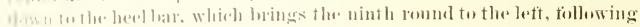

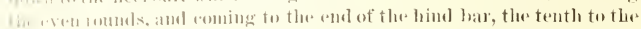

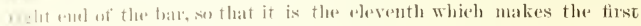

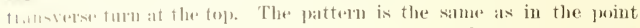
forthmis. The right sloce has 25,24 , and 19 strands in the these sets

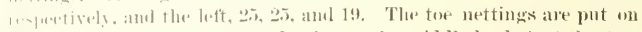

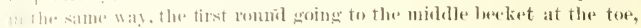
wat cressing to the tirst hes ket on the right hand, the second going to Ho tirst becket on the lett hand and rossing on the right to the first lomme, and the thind going to the first round at the toe and crossing on the right to the berliet.
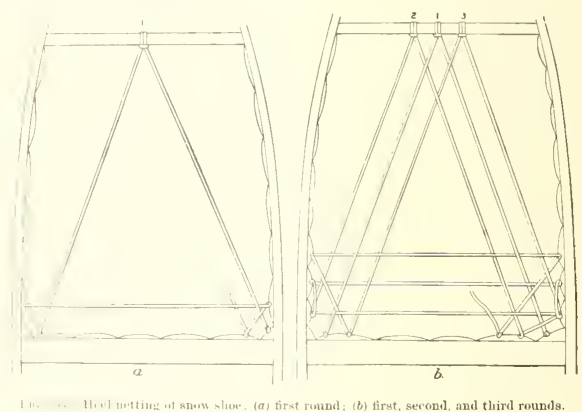

1 16. … He t firttiog of snow slue, (a) tirst round; (b) first, second, and third rounds.

Mll the even rounds go to the berket at the toe and eross to the prewhing wron roumd, and all the odd rounds go to the preceding odal romul at the tore and crosis to the becket, until the space ontside of the first romul is tilled with longitndinal strands, when they login to make dresenting transverse turns across the tore, going from the beeket on the leit to the corresponding one on the right and thus tollowing the misl munds. The fomterenth round on the right shoe legins this, the twelfth on the left. This bungs the end of the last romul to the middle of the tor bar. It is then "arried up to the berket at the toe, brought down and up again, and the end is nsed to fasten these three parts to the metting with equidistan half hitches-fourteen on the right shoe amul thirteen on the lett. The pattern, of comse, is the same as before,

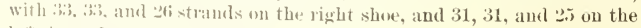
latt. in each set resperatively. 


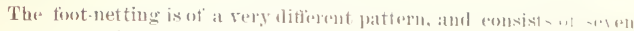
transierse and thirteen lomgitudinal strands, of which six, in the mid dle, do wot reath the tox bar, leaving an oblong transverse hole. thromgh which the tore presses andinst the snow at the locginnimg of the step. The rross stranks are a piere of stont thenge the skin of the

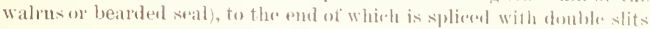
a long piere of thinner seal flumg, which makes the longitmolinal ones. The seren transrare strands pats in and ont throum lowh in therim. while the longitudinal strands pass orer the bars, warept the midello. three pairs, which pass romul the horizontal strand behime the tow hole, drawing it down to the next strand. The end of the thinterentl strand wattles these two firmly togethere as it does also the two paris

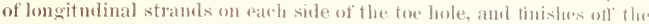
netting by whipping the two sets of strands together with a $\cdot$ bird (eage stiteh."

The objert of the complicated wattling romul the tor hole is, fist. to strengthen the hind borker against which the toe presses in walking.

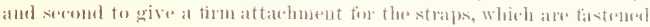

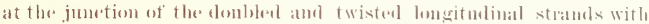

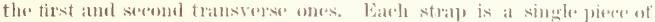
stont seal thong fastened to the shoe with two loops as follows: It the imere sisle of the shoe the enel is pasised into the tow lobe and makes a

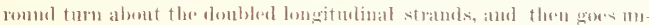
dere the two ross strands, coming ont behind them and betweren the twelth and thirteenth lomgitulinal strames. It is thenspliond into the stancling part with two slits, making a beeket about :; inches in

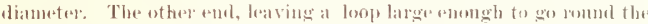

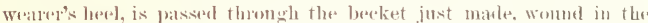

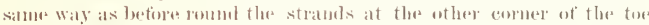
loke, and made into a similar berket loy knotting the end to the stand. ing part with a marlinghitals with the bight lett in. On the right show this hited is male in a slit in tle standing pant. The end is probaloly lett long tor the propese of adjusting the length of the strap to the we:trer's foot.

In putting on the shere, the tor la thrust sideraty through the hop till the bight ames well up over the beel, and the+1 turmed romal and stmek under the two berkets. which together form a strap to tasten the tow down to the shose leaving the latter fore to swing when the herel is raised. By reversing the provess the shoe is rasily kicked oft: These

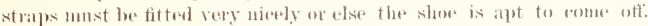
This is a very neatly male pair of slenes, aul the worlwork is all painted red aluse.

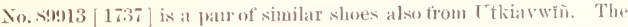
forme is matle in the same way and is wholly of willow exrept the extra hind bar, which is of wallos ivory. These slowes are shorter and some what broader than the preseding and not so well male. They and this 


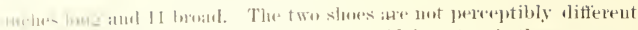
in shate. The lateing. Which is of sinew bratid, is gut on in the same way

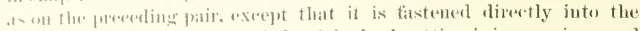
hules on the fore bats. The whole of the here net ting is in one piece, and maste precisely in the same way as the proint nettings of the first pair,

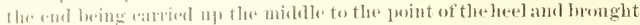

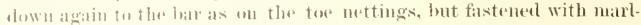
ing hitelhes. The number of strands is the same in each shoe, twenty these in each set. The toe uettings tollow quite regularly the pattern whthe presceling patis.

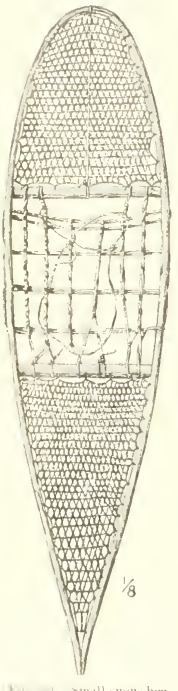

The shenes are not quite the same size, as the right las 3i, 3i, and 2 s strauds, and the left 33 ,

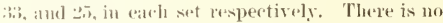
rexular rule alont the mumber of strands in any jart of the notting, the olject luing simply to make the meshes always about the same size. The tiont netting is male of stont and very white theng from the lowaterl stal. These showes have nos striugs.

No, s9914 [173s, is a pait of rather small shoes tom Ltkiavwiñ, one of which is show in Fig. 35. They are rights and lefts, and are t2 inches long by 10 broasl. The trame is wholly of ank, amel differs from the tywe only in having no extra hind has, and laving the heel and toe lans abont entual in length. The points are fastened together with a treenail, as well as with a whaleboue stiteh. The heel-nettings are put on with perfect regnlatrity, as on the pair last described, Int the toemettings, thongle they start in the nsual way, do not tollow any regular rnle of smeession, the lomuds being jut on sometimes inside and sometimes ontsinle of the preesling, till the whole suace is filled. The fout nettings are somewhat (-)umsily malle, esjuecially on the right shoe, which

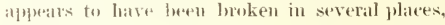
and "cobbled" lyy an mokillfisl workman. There are only five trausversestrands which are donble (1) the left show, and the longitndinal strands are not whipped to these, lont interwoven, and and pair twisted together between the trams.

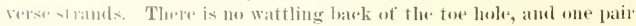
of lomgiturinal strancls at the side of the latter is not doubled on the lefi shee. The strings ane put on ats on the type exeept that the

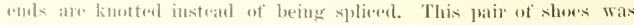




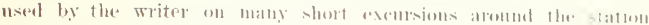

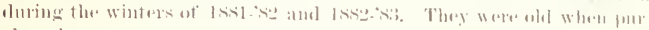
alatsed.

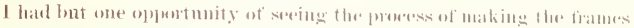

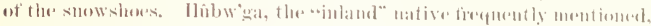

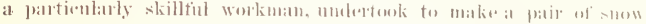

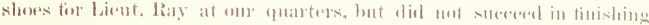

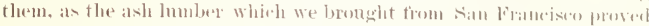

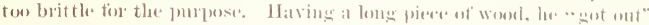
the whole rim in one piece. Orelinarily the splier at the tee must be made, at loast temporarily, letore the thame ain be bent into shape.

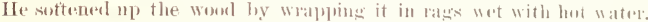
some of the other natives, however, recommented that the woul shomld be immerseal in the salt water tor a day or two, limm which a infere that this is a common patetice. After slowly bending the tore,

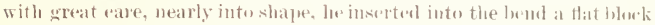
of wool of the proper shape for the toe and lashed the trame to this. A pointed block was alsi nised to give the moper slatpe to the lesed; the bars being inserted in the mortises betione the ends were bromght together. The temporary lashiugs are kejt on till the wod dries into shape. The toes are turned up by tying the shoes together, sole to sole, and inserting a transverse stirk betwern the tips of the tow.

The use of finty tinisled snowslues of this pattern is of comparat.

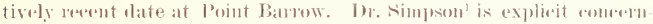

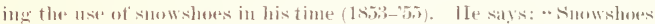

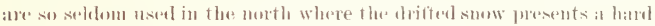

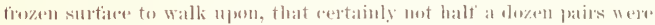

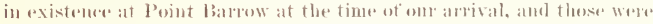

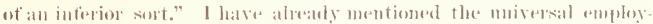
ment of these snowshoes at the present day, se that fle (anstom most have arisen in the last thirty years. The patteren of shoe now used is identioal with those of the Time or Athabasean Indians (as is mainly slown by the National llusem eollections), and 1 :m inclimed to beslieve that the loout barrow hatives have learmed to use them from the

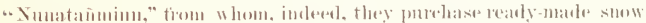
sloes at the present day, as we omeselves observed. The - Xumatainmiun," or the elosely related people ot the Kuwbik River, are kuwn to have intimate trading relations with the Indians, and aven in simp.

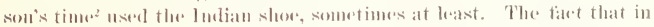

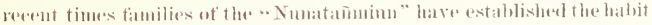
of spereling the winter with the peeple of Point Barrow and assoriat. ing with them in the wintor doer-hunt, would explain how the hatter

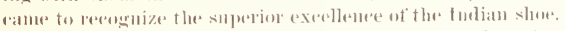

This is mone likely than that they leamed to nese them from the cast-

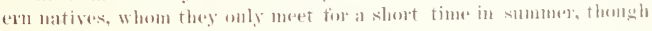

$$
\text { (1) }
$$




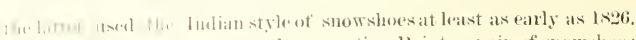

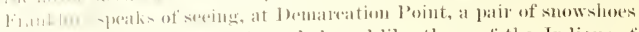

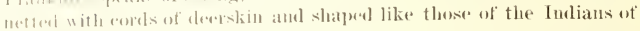

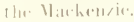

Yast of the ather liskinw of Alaskat, who need to nse snowshose at

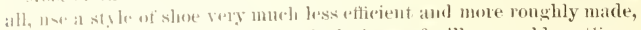

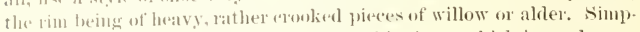

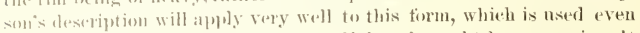
an far torth as ley lapes, whenes. Mr. Nelson bromght lome a pair. It

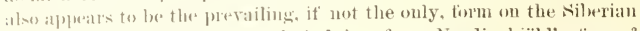
colst and t. Latwruke lslank, judging from Xordinskiöld's tignre and Mr. Xelsents ablentious.

Simpon says: ". The most rommon one is two pieces of alder, abont fwo fect and a halt long, curved towards each other at the ends, where they are boumd together, and kept apant in the midelle by two arosspiaces, ateh end of which is held in at mortise. Between the crosspieces is strefelied a stont thong, lengthwise and aeross, for the foot to rest mpon, with another which first forms a loop to allow the toes to pass bencitla: this is carried round the tack of the ankle to the opposite side of the toot, so als to sling thes snowshoe moler the joint of the great tore."

When there are tore and leel nettings, they are of seal thong with a

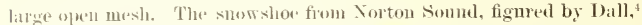
is at rather neatly made variety of this form. Sonth of the Yukon, the Ine of the snowshe apprears to lo confined to the lndians. As slown loy the Mnsem collections, the strings are always of the pattern desiribul throughont the whole not hwestern region. ${ }^{5}$

simmshoes apparal ti be rarely used aumg the eastern Eskimo. The only writer who mentions them is Kumlien. He says: " When tranching arer the thozen wastes in winter, they fi. e., the natives of ['mulwrlatul (inlt] use smowshoes. These are half-moon shatperl, of whalobeme, with sealskin thongs tiglitly trawn areoss. They are alont lit inclese long. Another pattern is merely a frame of wool, al hout the same length and sor 10 inches wiele, with sealskin thongs for the fiost to rest on."

The latter is apparently quite like the western snowshoes deseribed 1) ximpsom.

Staff.-The omly statt used hy the youmg and vigorous is the shaft of the syeat, when ond is anted. The aged and tieble, however, sul, port their steps with one or two stafts about is fiect long, often shod " ith hume on ivoly. (The old man whom Franklin met on the ('olper. mine kiver walked with the lewp of twosticks.7 ${ }^{7}$ Fig. 35.5 from a phote-

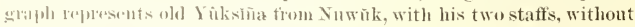
whiels lue wats haratly able to walk.

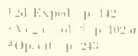

Cintrilntion w. p. 4.

7lst Exy., rol. 2, p. 180.

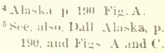




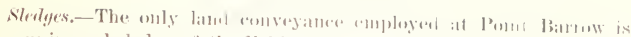

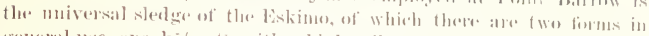

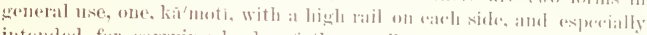

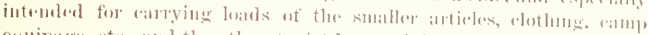

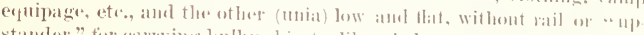

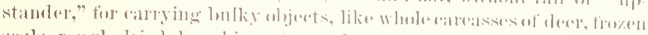

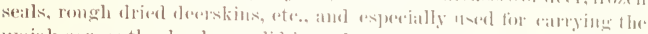
muiak arerose the lanel or solid ier. both kinds are made withont nails, lont are tist ened together by montises and haslings and stitehes of thoug and whatelyoure. I have, lowerer, seen one unial, which was marle in 18x:3, tastened togetleer with nails, a tat her interior sulestitute for the laskiugs, as they not only wonld not liold so timly, lont would alko be liable to brodk in colsl weatlerer.

Botle kinds of sledge are mate of drift. worel and shod with strijs of whale's jaw; about three-fonrtho of an inch thiek, fits. tened on with bone trenails. These lone rumers, which are abont"' inclus wide, run snfficiently well over ire, hard snow, the frozen gratvel of the heach or exen on the

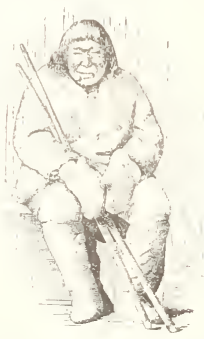

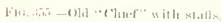
bare fundra, but for carying a heavy load wer the softer smow of the interior they are shod with iee in a manner peenlias to this regrion.

It is well known that mot only the Eskimo generally, lut other hyperborman people coat the rumners of their sleds with ice to make them run more smootluly, but this is usmally moly a compratively thin amst, podneed by penring water on the runbers or applying a mixtme of snow or mul and water. Mr. Turner informs me that at Ingava they are partioular to use fime black vegutable mold for this purpose.

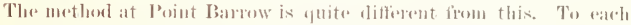

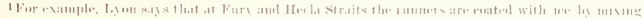

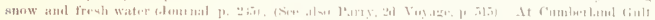

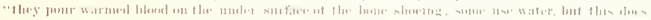

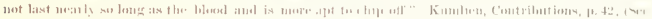

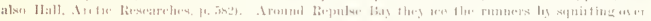

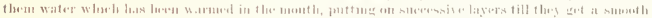

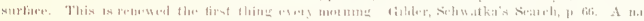

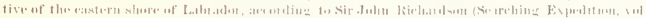

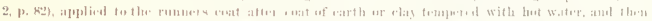

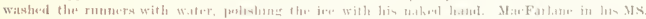

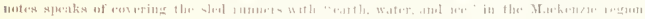

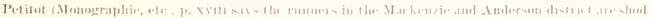
with "

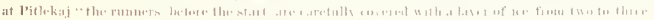

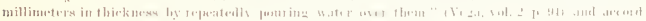

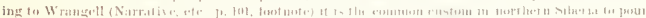

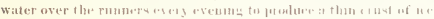

与 ЕТ - 23 
fummer is litted a beary shew of clear iee, as long as the rumer, and Inlly 1 foot high by fi inclues thick. The sledge with these ice rmmers 1. estimated to woigh, even when moarled, upwards of 200 or 360 penmels, but it alpesars that the smoothness of rumning more than connterbalanes the pextra weight. It any rate these slowes are almost

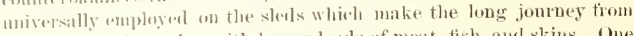
the rivers in the suning with heary loads of meat, fish, and skins. One native, in 1.4.3, shod his sledges with salt-water ice in this way betore starting for the hunting grounts. Is these ice shoes are usually put on at the rivers, I hat wo opjortmuity of seeing the process, thomgh I latwe soren the slediges thus slow atter their return to the village. Litut. lay, who sall the process, destribes it as tollows:

"From the ine on a joud that is free from fracture the cont the pieces the length

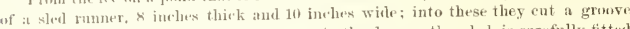

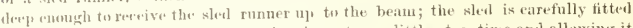
info 1 he ertoove, and sechured hy pouring in water, a little at a time and allowing it fu frep\%. Great are is takes in this part of the operation, for should the workman apply mere than a fow drops at a time the slab ot ioe wombl be split and the work all to de over again; after the ice is firmly seamed the sled is turned bottom up aud

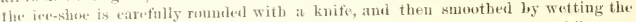
naked batnd and passing it weer the surfare unfil it lecomes perfoctly glazed."
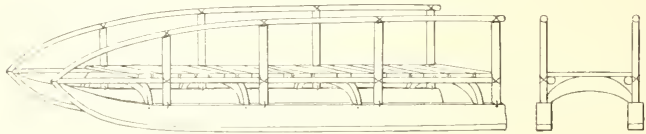

Fut toti.-Roiled sledge, sliartanumatie (from photograph).

In traveling they take great eare of these runers, keeping them sumoth and polished, and mending all eracks by pouring in freslo water. They are also ararotiul to shade them from the noonday sun, which at this seasom of the yoar is warm enough to loosen the shoes, for this purpose hanging a cloth on skin over the smny side of the sled. ${ }^{2}$

Wo ware untiotumately not able to bring home specimens of either style of large sled. Ther rail slets (kámoti) isusnally about 8 or 9 feet long, and $2 \frac{1}{2}$ to 3 tiect wide, and the rail at the batek not wer $2 \frac{1}{2}$ feret high. The

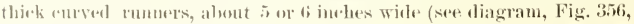

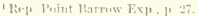

${ }^{2}$ -

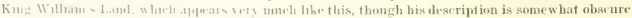

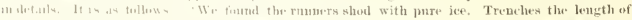

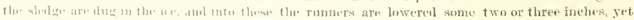

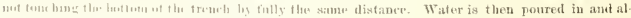

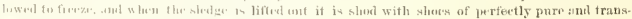

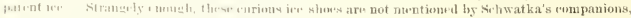

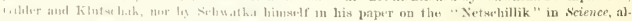

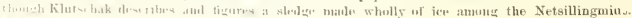

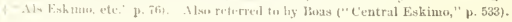




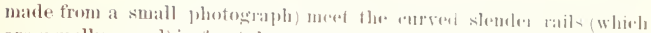

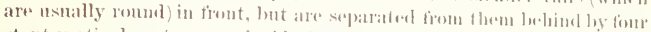

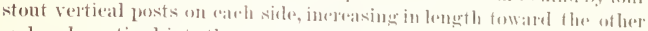
end and mortised into the romers and raik. In ceptal number of stont woulen arehes hatf the levight of the posts are mortised into the lom ners, wath areh a little in front of aatel pair of posts. A longitulimal

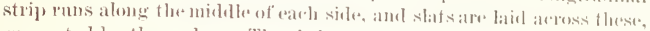

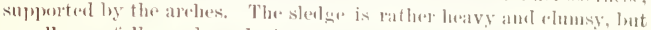
usmally caretinly made and often jainted with red ocher.

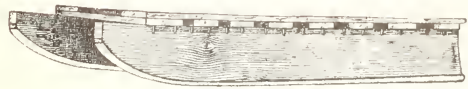

Fit: :57,-Flut - itudere.

of the nuia or that sledge we have, fortunately a geow photograph,

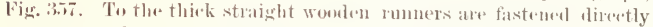

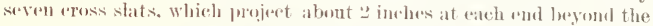

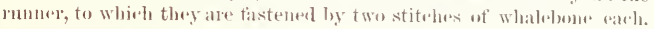

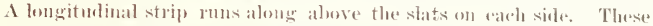
sledges are generally male on the same patterm, varying some wat in

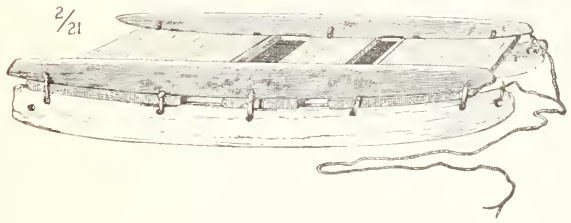

Fu, ask,-small sledge with in ury rmoers.

size. I rommon size is alont b feet longe, alont $2 \frac{1}{3}$ teet wide, and ! or 10 inhes high. Viry small shedges of this pattermare sometimes mate, esperially for the purpese, as we were told, of carying povisions, per.

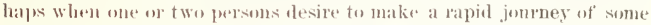
length, or for carrying a small share of meat from eamp to (amp).

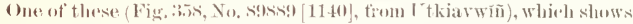
signs of lomg use, was bought home. It is 20.7 inclues long and 133 broal, and has ivory rumers, with there worken slats atross them, held down

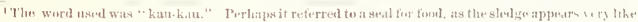

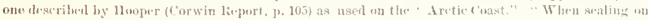

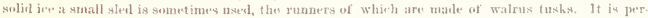

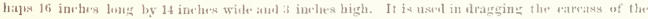
aesil over the jive.

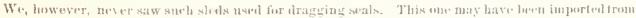

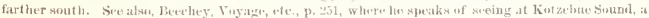
drawiag on ivory of " a send dragged bowe on a small sledge."
} 


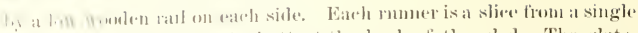
later wahnstusk, with the lnutt at the loak of the sled. The slats,

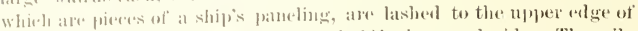

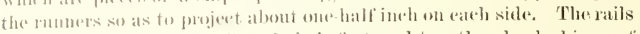

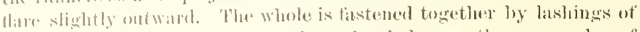

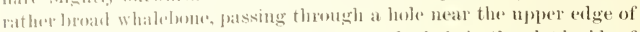
the rumets a moteh in the end of the slat and a hole in the slat inside of the rail. Themearo two bashings at eath end of ear broal slat and one un the millale, at eareh end of the natrow one. The last and the ones

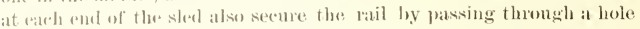

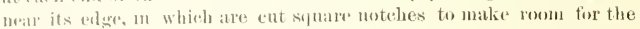
ot her lashings. The traes is a strip ot seral thong about s teet long and one fonth inch wide, split at one (and for aloont 1 foot into two parts. 'The othere end is slit in two for about 3 ineles. This is probably a Groken loop, which server for fastening the trace to a eloges harmess.

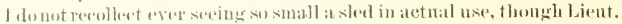

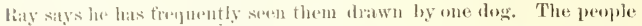
who rime down fiom Ninwalk with a small load of things for trate

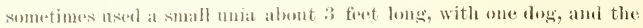

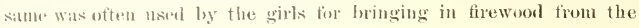
beitu.h.

A rery peruliar sled was formerly used at Point Barrow, hut we have no means ot knowing how eommon it was, It was a sort of toboggan, malde by lashing togrother lengthwise slabs of whalebone, but is now wholly obsuleto, sime whalebont has tor high a market value to per-

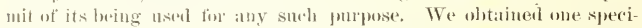
men abunt 10 foret hong, but it was mofortunately in such a dilapielated enmlition that we were unable to hring it home. I tind no presions mention of the use of surh sleds ly any Eskimo. It is uot neessary

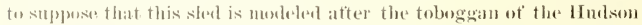
bisy voyagel's, of which these people might have olstained knowledge though the astern nation, sinee that simpla ant of dragging home a "slith" of whalebone: would natmally sugerest this contrivanee.

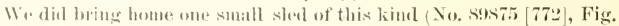

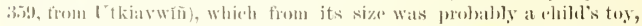

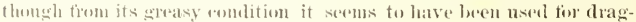

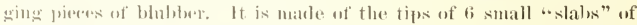

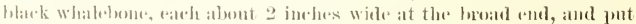

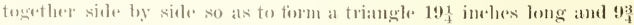

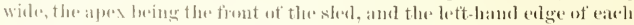

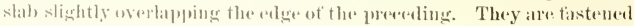

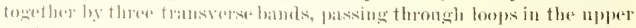

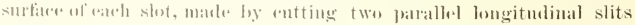
alumt one-hall ineh lomg and one-fourth inch apalt part way through,

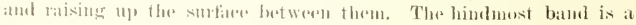

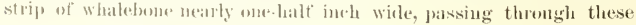




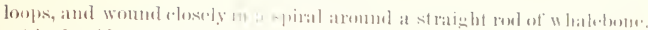

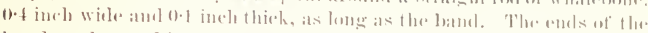

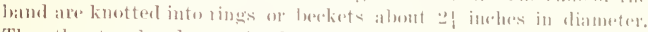

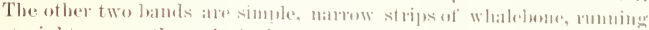
straight aeross thromeh the loope and kuotted at the emels into similar

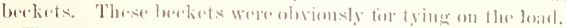

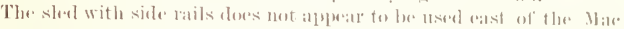

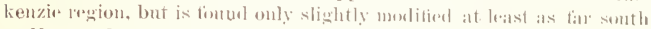

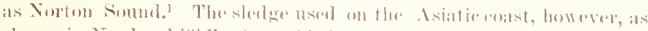

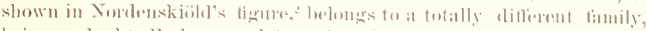

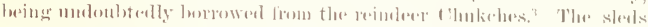
of the rastern Eskimo valy somewhat in pattern and material, hut

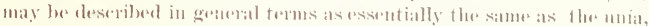
but usmally provided with what is atlled an " upstander, " namely, two

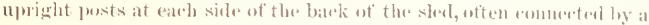

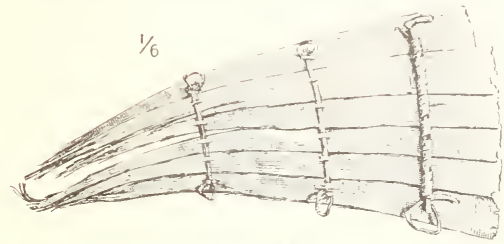

Fie: :599. Sinall toluman af whaldune.

cross rail, which serve to guide the sted from behind. Mang deserip tions and tigures of these sleds will be foum in the rarious leseriptions of the astern Eskino.

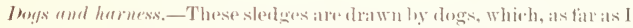

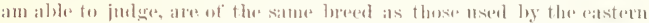
Eskimo. They are, ats a rale, rather large and stent. A number of the

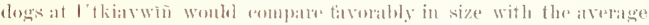

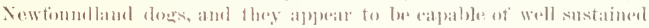
exertion. The commonest color is the regular " lorindle" of the wolf,

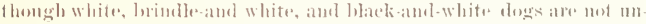
common. There was, however, lont one wholly black dog in the two

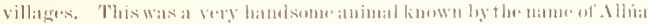

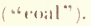

Every dong has his name and knows it. Therir disposition is rather fuarrelsome, esperially among themselves, but they ane wot particu-

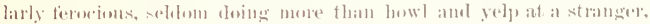
amel it is not diftenlt nsually to make firemels with them. Theme was

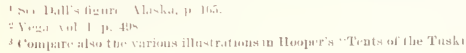


very little diflienlty in petting the half dozen dogs which we had at the station, ame they grew to be very much attached to the laborer who used to ford them. The matives treat their dogs well as a rule, selelom beating them wantonly or severely. Though they do not allow them te cone inte the lomises, the dogs seem to have eomsideralde at tachment to their masters. Comsislomabe eare is bestowed on the purppirs. Those horn in winter are firecpently reared in the igh, and the

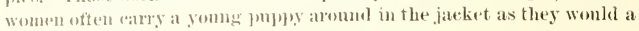
chill.

Wh salw no traces of the disease resembling hydrophobia, which has wrenght suth havor in freentand and Batfin Land. I once, howevel, sitw a puppy applarently suffering from fits of some kind, smuning wildly romed and rouml, yelping furionsty, and ocasionally rolling over and kiuking. The natives said, " Maluku'lirua, asi'rna", "Ile is lowling (? ; ' he is bad"), and some of the loys finally took it ont on the tundra and knocked it on the hearl.

The dog harness, anm (Gr. annt), consists of' a broad strip of stont rawhids (from the bearded seal or walrus), with three parallel loops at one end, trequenfly mate ly simply "ntting long slits siele by side in the thong and bending it into shajes. The head is passed through the middle loop and a foreleg thomgle earh of the side-loops, bringing the main part of the thong over the back. This serves as a trace, and is fornisled at the end with a toggle of bone or wool, by which it is fistened to beekets in a long line of thong, the end of wheh is usually made fast to the midale of the first slat of the sledge. The dogs are attached in a lomg line, alterwately on opposite sides of this trace, just so lar apart that ond dog wan not reach his leader when both are pulling.

The most spirited tog is nsmally put at the head of the line as leader, and the natives sometimes select a bitch in heat for this position, as the dogs are sure to follow lex. The same custom has been observed by Kumlien at Comberland (inlf. ${ }^{2}$ Ten dogs are considered a large team, and tow of the natives ran muster so many. When the sledge is havily loaded men and women fregmently he] to drag it. The dogs are nexer driven, and except over a well known trail, like that between Ithiavwin and the whaling camp in 1 s.83, will not travel unless a Womaln trots along in front, enwomaging them with ories of "Añ! añ? th'lla! th'lla! (Come ! come on!), while the man or woman who runs be. hind the sled to gnide it and keep it from eapsizing, nrges them on with

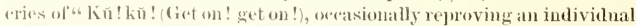
Iog by name. Aftre they are well started, they goon withont wuch urg. ing if nothing distracts their attention. It is uot easy to stople a dog team when the destination is reached. Commands and shonts of "Lie" down!" are seldom sutiticient, and the people generally have to pull

I fitided to get the translition of this word, but it seems to be connected with the Greenlandic indlaw ah, bw howles (a dog ).

xcoutributions, p. 51 . 


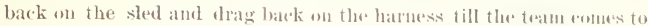
a lialt.

The leader, who is usmally a woman on thild sometimes gaides the team by a line attaeleel to the trace, and lient. Ray says he has sem them, when traveling in the interior, tie a pioce of blublue or meat on the eud of a string and drag it on the suow inst alueal of the leadere. The natives seldom ride on the sledge sarent with a light load on an

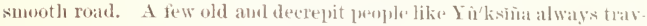
eled $\mathrm{m}$ sledges betwen the villages, and the perple who came down with empty sledges for provisious from the whaling anp. always leurle. on the well beaten trail where the dogs would run without lealing. The dog whip so miversally employed by the eastern liskimo, is not used at Point Barrow, hut when Lient. Ray male at whip for driving his team, the natives called it ijuan'tal, a mame exisntially islontical with that used in the east. They tspecially distingmished ipiram'tat, a whip with a lash, from a endgel, anan'ta. The latter wombl hats also the same meaning in the eastern thalects.

We sal nothing of the eustom of proterting the dogs' feret with sealskin shoes, so prevalent on the Siberian corst.' Curiously enough the only other localities in which the use of this entrivance is mentioned are in the extrene east." During the first warm weather in the spring, helore the dogs have shed their heary winter coats, they suffer a great deal from the beat and an go only a short distance without lying down to rest.

The method of harnessing and driving the dogs raries omsinlemally m different loealities. Anemg the eastron natives the dogs are maally harmessed abreast, each with at separate trace ruming to the sledere. and the driver generally rides, guiling the dogs with a whip. The leader manally has a longer trace than the lest. The hamess used at Fory and Ilecela Straits is predisely the same as that at Point barrow, lout in Greenland, alecordiug to Dr. Kane, it romsists of a "simple breaststralp," with a single trace. The illustration, howerer, in dimlis Tales and Traditions, oplosite p. 230 , which was drawn by a native Cirenlander, shows a pattern of hamess similat to that used in sibrial and deseribed by Xordenskiobl' as 'made of inel-wide strals of skin, torm-

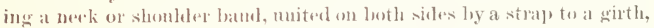
to one sicle of which the draft stratp is tastenesl." It is a curions faut that the two extremes of the liskimo rate (log even it the people of Pitle.

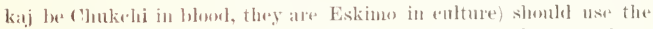
same pattern of latmess, while a different form grevails betwern them. The Siberians also habitually ride upou the sledges, and us* a whip,

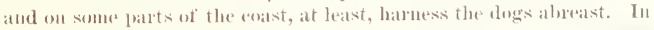

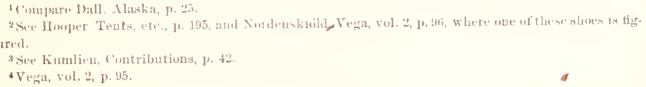




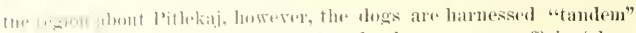

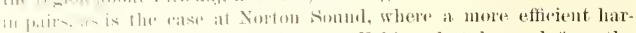
mess is alse nsol, whith is probably not Eskimo, lut leamed from the

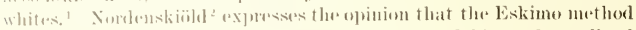

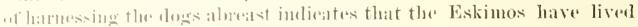

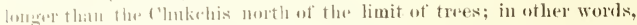

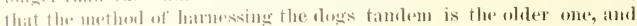

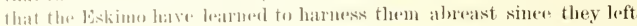
the womblant regions. I "an hardly agere with these comelusions, for it sorms to me that the wasiest and most matnral mothod of attaching

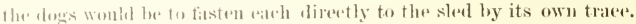
Now, whon many dogs are attachel to the sled in this way, the onter

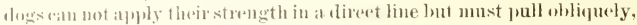
amel, morenor, as we know to be the rase, no many long traces are comstantly beconing antangled, and ench imblividual dog las to be kept stratight by the driver. It, lowerere, the dogs be mate fast to a long

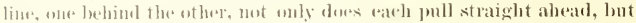
if the bealer lo kept to the track lae pulls the othere dogs after him, re-

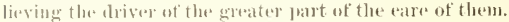

It serms to me therefore, that the tandem method is an improvement in dong harnesing, which has been anlopted only loy the natives of northenstern Siberita aul unthwestern America, and has no connection with the workled or unworled stite of the eomntry. ${ }^{3}$

\section{HINTINA SCORES.}

The only thing that wo saw of the nature of numerical records were the selips of animals engraved npon isory, alreaty alluded to. In most cilses wo were mable to learn whether the figures really represented

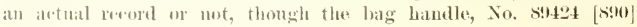
alratly figured, was sitil to montin the actral seore of whales killed ly okl l'uksina. The custom does not appear to be so prevalent als at Norton Somul (sare above, p. 117). Many of these possible seores leing engrated on ivory implements have already been described. Witlo one "xesption they only reoril the "apture of whales or reindeer.

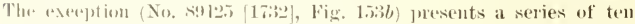

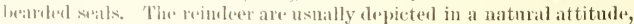
and some of the rimenustaneses of the limut are nsually represented. For instince a man is figned aiming with a bow and allow towald a

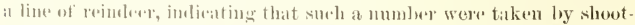
ingr, while it string of deer, representerl without legs as they would ap.

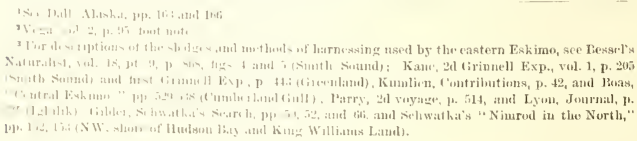




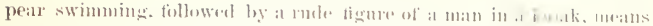

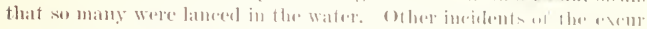

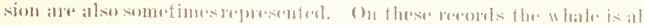

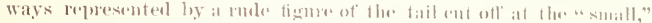

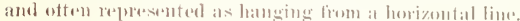

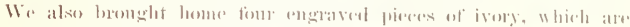
mothinger else than resorits of real ar inatginary seremes. । have figmert all of these. Fig.

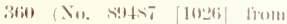
Nuwnilis is narrow that tahlot of ivory, 48 inelus lome and 1 inch wicle, with a strime at (nere "nel to hamer it up by. () earlo fare is an onllamental border inelosing a mumber of incised tigmes, which pobstly: represent actual serents, as the tablet is mot new.

The tigmes on the obserse fare are collowed with mel oxehers. At the mper encl. stambling om at arose line, wibls his heat toward the roul, is a ruclely: drawn man, holding his right hamd upamel his left dewn, with the tiugers ontspmeal. At his lett stamels a boy with both bamls down. These figmes jorbably reperesent the hunter and lise som. Just ledew the reross lime is a man raising a

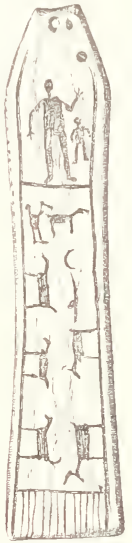

$\alpha$

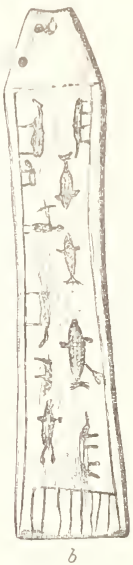

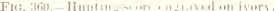

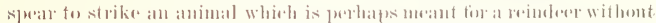

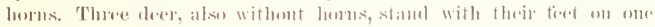

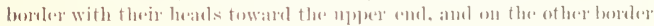

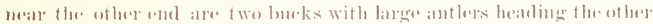

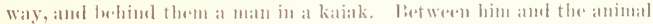

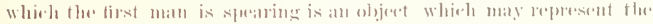
cresent mosu. The story may perhaps lo freely translated as follows: "When the mown was foumg the man and his son killed six reinderes,

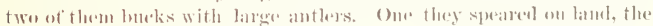
rest they elaseed with the kaiak."

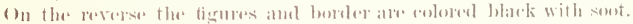

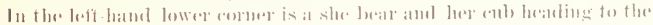

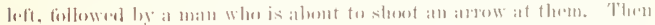

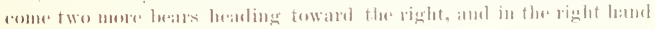




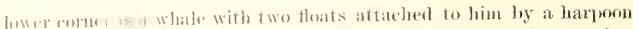

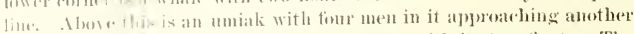

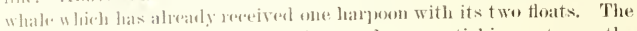

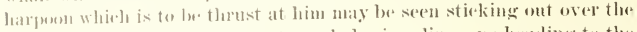
berw of the buat. Then cone two whales in a bine, one heading to the leti and one to the right. In the lefthand mpler corner is a figure

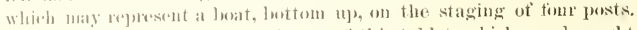
Wir diel not learu the antual history of this tallet, wheh was brought down tor sale with a mumber of other things.

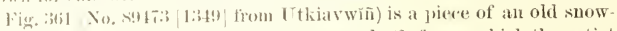
shovel edge with freshly inciserl figures on both faces, which the artist

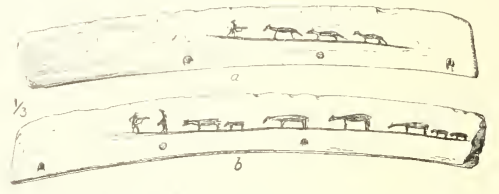

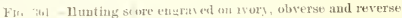

said rejuresentod his own record. The figures are all colored with red ocher. (1) the olverse the figures all stand on a roughly drawn ground line. If the lo ft is a man pointing his rifle at a bear, which stauds on its himl legs taring him. Then comes a she bear walking toward the lat followed by a (nd), then two laree bears also walking to the left, and it she bear in the sane attitude, tollowed by two conbs, one behind the other. This was explained by the artist as follows: "These are all the bears I have killed. This one alone (pointing to the 'rampant'

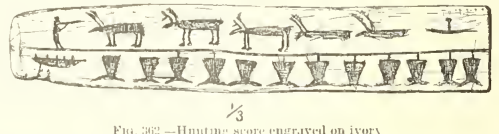

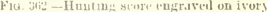

me) was hat. All the others were gomd." We heard at the time of his griving the death shot to the last lowe as it was chargiug his commale, who had wonnderl it with his muzld-loader. On the reverse, the lignes are in the sinne position. The same man points his rifle at a string of thec wolves. His explanation was: "These are the wolves 1 have killecl."

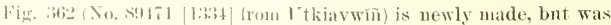

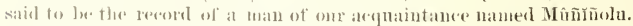
It is at that piece of the outside of a wallus tusk 9. 7 incleses long and 1 's widla at the broater eud. The ligures are incised on one fite only, and 
eolored with red ocher. The lace is divicled lemethwise into two pancls by a horizontal line. In the mpper panel, al the lefl, is at man fareine to

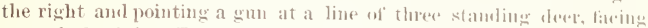
toward the left. Two are lomes ame ane a doe. Tlese comme two bueks, represented withont legs, as if swinning in the waler, followest by a rule figure of a man in a kaiak. 13. low the line at the lett is an umiak with five men, and then a row of twelveronventionalized whales. tails, of which all Int the first. secomel, and tilth ane joined to the hor izontal line by a short straight line. The leesed may be fiesely trans lated as follows: ". I went ont with my gum and killed threse lange remuleer, two bueks and a doe. I also speared two large bueks in the water. My whaling "rew have taken twelve whales." The mumber of whales is open to suspiciou, as they just till up, the lobitul.
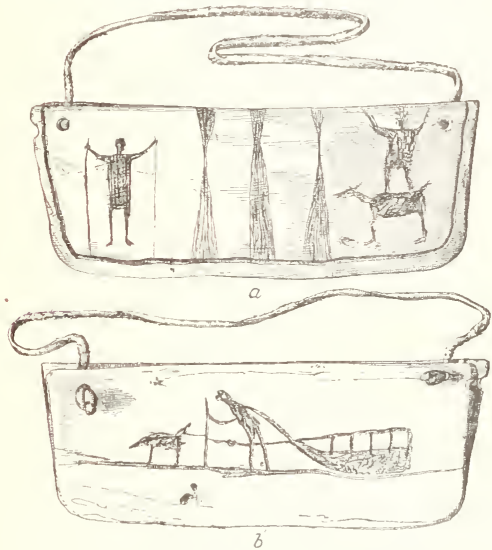

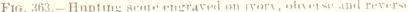

Fig. 36:3 (Xo. 56517 [21] from [thiaywiî) is a piese of an old snow. showel expe f.2 imeles long, with a loop of thoug at the mpler sisle to hamg it mp by. It is eovered on both fares with freshly incised figmes. colored with red orher, representiug some real or inaginary occurrence.

The olverse is botelereal with a single narow line. At the left is a matn standing with arms outstretelest supporting himself by two slen-

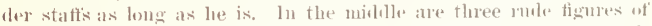

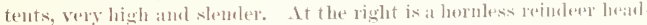
ing to the left, with a man stamcling on its back with his leges straduled 


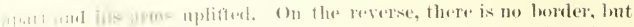

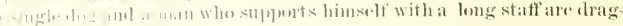

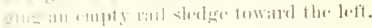

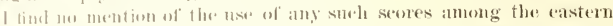
liskimo. Lut they are fory eommon among those of the west, as show

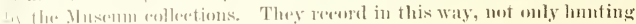

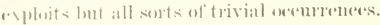

TAMES AND PASTIMES.

Giumbline-These people lave only one game which appeas to be of low nature of gambling. It is plityed with the fwister's and maline spilias masd for batcking the bow, and aldeady deseribed, thomgh Lient. lial saly a lo has seen it played with amy bits of stick or bone. I mever

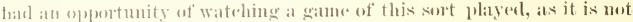
oftem played at the village. It is a very pupular amosement at the

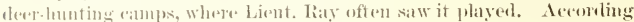
(1) him the players are divided into sildes, who sit on the gromel abont

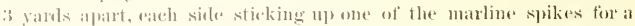
math to thow the twisters at. Six of the latter, he believes, make a fill sot. One kille tosses the whold sot one at a time at the opposite

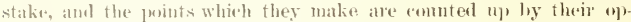
gonents fiom the pesition of the twisters as they fall. II e lis not learn how the points were reckoned, except that twisters with a mark on them comuter differmenty fiom the plain ones, or how loug the game lasted, warh sicle taking its furn of casting at the oppesite stake. He, however, got the imptrasion that the winning side kept the twisters belonging to their oppenents. Mr. Nelson intorms me in a letter that a similar game is playerl with the same implements at Norton somel.

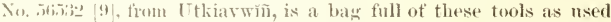
fion playing this game. It contains is twisters, of different patterns, and 7 matine spikes. The hag is of membrame, prerhaps a bladder. It is oxoid in shape, all in one pine, with a long oquening in one side.

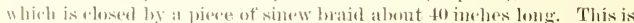
kustad by one end rond a fold of membrane at one end of the month,

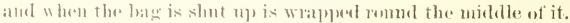

sume of these people have learned what mals are fom the Numatan minn. thomeh they do not know bow to nes them. They described how

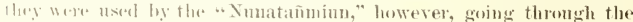

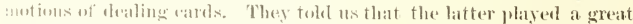

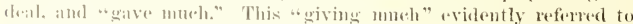
gambling for they told capt. Hexenteren how two of the " Numatan.

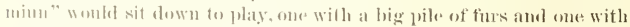
mit any, and when they got mp the firs would all helong to the other man.

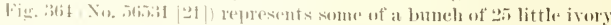

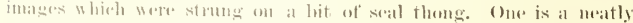

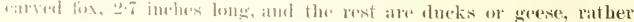




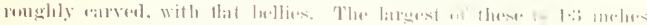

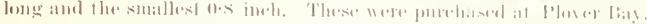

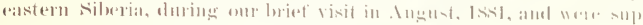

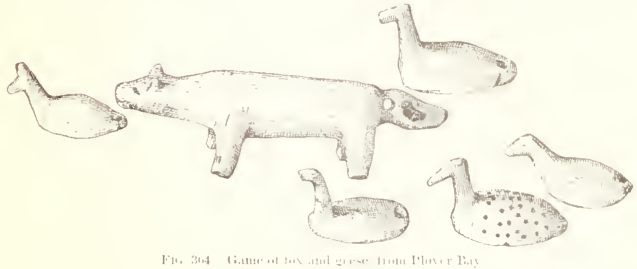

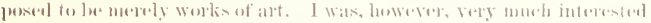

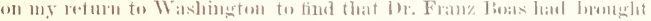

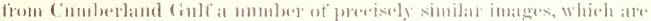

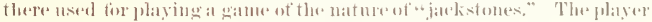
tosies ule a loamelful of these images, and sores points for the numlere that sit up

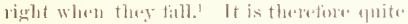
hately that they ane used for a similar pur-

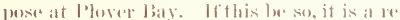
matkable point of similarity between these widlely separated liskimo, lon I an learn mothinge of at similar trutom at any interme. diate puint.

Frstirals.-The most inportant festivals

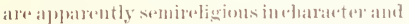
fartake strongly of the nature of dramat ic rejorentations. At these fistivats they make use of many artieles of dhess and adormment, hot worn an oflere oreasions. and exen some "properties" and mestani al contrivinmese to and to the dramatio

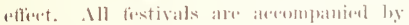
simging, drumbing, and dane.ing.

At the firmal festivals, in the catly winter. the perlormers ane doested in new deerskin rothing, with the snow-white flesh side ontward, and in rertatin parts of the perform

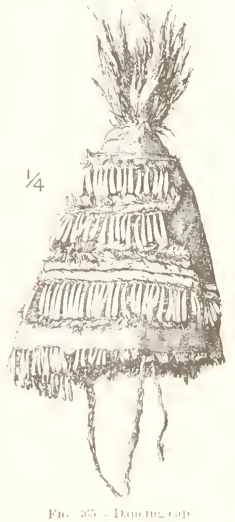

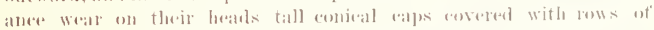

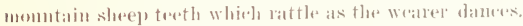

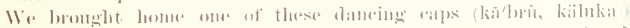

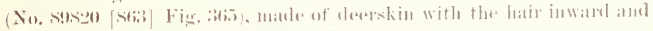




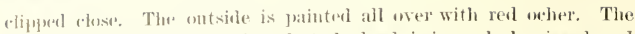
front is notrly all in whe piere, but the bark is irregularly pieced and

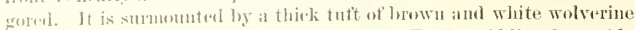

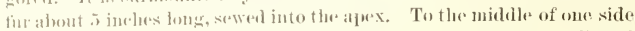

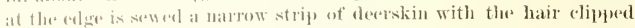

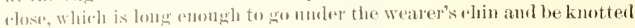
into a slit alose to the adge of the other side of the cap. (On the firent mlere is sererl a row of thirty-five incisor teeth of the mountain sheep for at thrad rumning through a lobe drilled thromgh the root of each.

Tha saries is regularly graduated, having the latgest teeth in the midald and the smallest on the ends. Above this is a narrow strip of

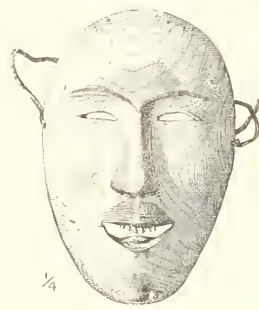

Fis, 366,-Wirolen matsk. brown deerskin rmming two thirds romel the eapl and sewed on flesh side (nit so that the hair projects as a fringe below. Above this are three ornamental bauk about 2 inehes apart rumning twothirds round the eap, each fringed on the lower alge with shepe teeth strung as on the edge of the rap. The lower row contains it treth, the midale 29 , and the nprer 31 . The lowest hand is male of '2 strips of momtain sheepskin with a nartow strip of black sealskin between them, amd a narow strip of hown deerskin with the hair out; the next is of enarse gray deerskin with the hair out: and the upecrmost of brown deerskin with the flesh side out Thr ap is old and dirty, and has been long in use.

The costom of waring this style of cap appears to be peculiar to the nortlowestern Eskino, as I find un mention for it elsewhere. It is ferhalys derived indiresty from the northern Indians, some of whom are represented as wearing a similar headdress.

In cortain parts of tho same remenony as wituessed by Lient. Ray the dancers also wore rattle mittens, which were shaken in time to the musie. A patir of these ware offereel tor salo once, but Lient. Ray did mot consider them sufficiently of pure Eskimo manfanture to be wo:th the price askal for tham. They were mateot sealskin and roveral all

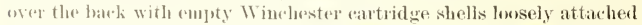
by a string throngly a hole in the bottom, so as to strike against cach otlore when the mithon was shaken. Tho five men who wore these mittrus wore on their leats the stufted skins of various animals, the wolf, hatr, fox, lymx, and doge, which they were supjomed to represent. These

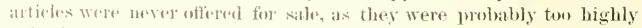
valued.

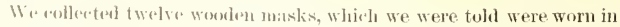

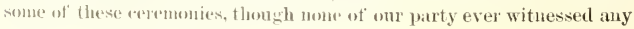


performance in which they were used. Semo of them are of undenthed

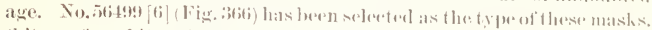
(ki'nam, from ki'na, fare). This is a rather gout wepresentat ion of a male

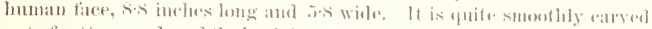

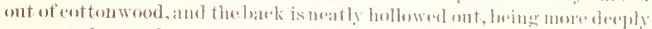
exravater foumd the eyes and month and inside of the mose. The month is represeuter as wide open, showing the fip of the tom and tateberl to the underlip, and has six small treth which look lihe dog's

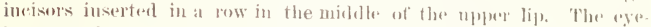
lowws and moustake are marked ont with hlackleat, and there are traves of reel ochere on the cheselis. The holes tior the strings are in the edge about on a level with the "yess. (Mne and of at string of seal theng

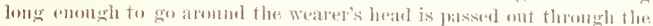
bole on the right sisle, slit elose to the tip, and the other and pasised through this. The other end is passed ont through the hole on the lett

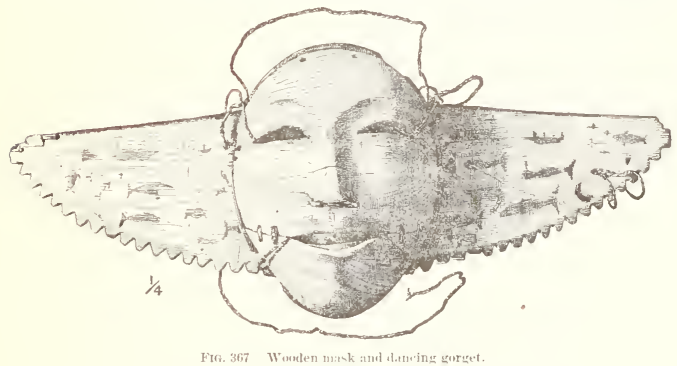

amd mate fast with two halt hitehes. I pow of small holes roumd the edge of the mask shows where a lewol has been tarked on. This mask is rather oll and somm what soilede.

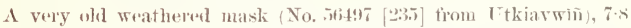
inches loug, and made of soft wood, apparently jone, is similar to the preserling, but has no tongue, and the teeth in both jawk are rep. resented as a contimuons ridge. It has an "imperial" as well as a moustarhe, marked with blacklead likw the pyebrows. The rheeks are rolored with rod wher. The edge is much wappul and brok»n, but slows the remains of a deep narrow groove ruming round on the ontside about $\frac{1}{1}$ inch from the edge, and pireed with small holes for tistening on a hood.

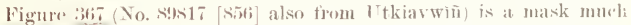
like the preeding, 7.5 inches long, and mate of spruce. It is peruliar 


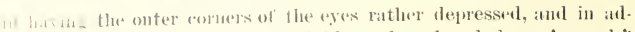
dition th the monstathe and imperial has a brod "whaleman's mark"

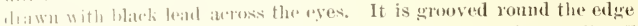
fin lastening on a hood. The lowm part of the face has been split off at the corrers of the menth ant memeled on with two stitches of whale

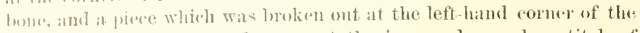
mouth is strmonl by a wooden pege at the inner odge and a stiteh of whalden on the iower side. This mask hats been for a long time

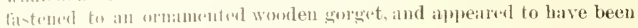
eypuri to the wathere perhalys at the cemetery. The string is male of uns snally stont sinew lnatd.

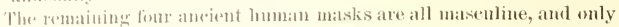
011. hils any imlication of babrets. On this mask, No. s9812 [1063;, there are two small holes in the pusition of the labrets. It is probalue that the waness of these makks am supposed forepresent the ameient Exkimo, whe wore no labrets. I mask which was carelessly mate for

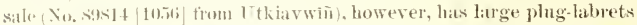

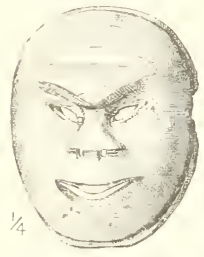

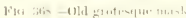
('irved ont. Though roughly e'arved this mask is a very charateristic Eskimo firee, and would almost pass as the portrait of a man of our acruantanes in Ttkiavwrit. The two little romghly earved lomman lawes on the top of this matsk are probalsly merely for ormament. To such things are to bre seen on any of the old maskis which have beren actually used. This mask serms to have been whittled ont of the lottom of an old meat tray, and has a string of whalebone. Host of the gemume makkis are of exollent workmanship, but two are quite romglily arved. Ond of these expe-

vially is suefo a bungling piene of work that it womld be set down as commeral wore it not weathered and evidently okl. The painting Hever wo sitrther than making out the lreard and eyebrows with soot

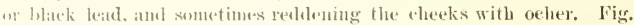

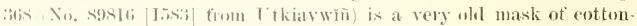
work, blackened with atge and so rudely wared that the work was probaldy done with a stene toul. It is grooved aromed the edge for fastening ma a look and is tis inches long.

The only timald human malsk seren ane nets and mate for sale. One

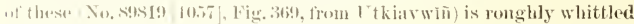
firm the bettom of an ohe meat tray, and has the hatir, eyebrows, and at single line of tattoring on the chin patuted with soot. It is $s \cdot 7$ ine hes long and has strings of whalelwese.

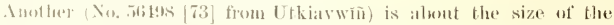

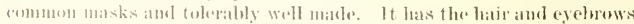
markiol with blatk teat. The last is at foot long, and like the one figr- 


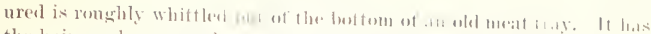

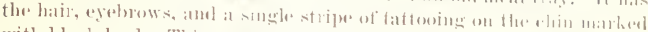

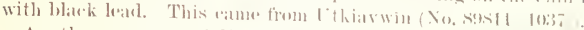

Anothare "ecommereial" mats ( No. s(sit: [107t] from ftliarmiñ is rery haborate, but dombhly and ratre lesisly matle. It is alluost tlat, witl

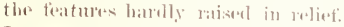
In each comer of the month is in serted a slender irory tusk about 1 inclo long, and besilles the ryctorows, momstaclue, amd imperial, there is a broul "whaleman's mark" ruming obliquely across the right rheek from the bridge of the noxe. Six lomg thathers are sturk in the eflge of tha foreleatl. Curionsly anough these are the foatlers of the sonth Ineriran ostrieh, and camme from the teather duster in use at onr stafion.

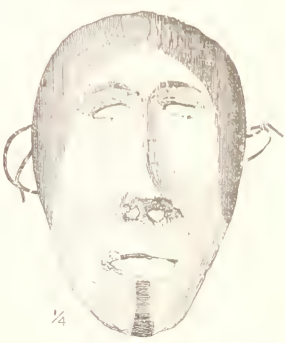

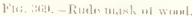

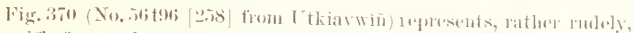
a wolt"s tare and ears, and is the only animal nask we obtained or saw.

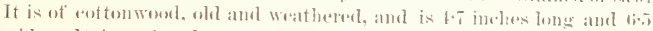
wide. It is prainted on the relge with real owher and hats a streali of the same . 1 lo 1 .

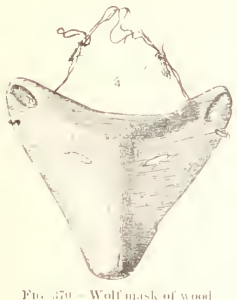

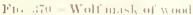
dow the rilge of the" nose. The string is of whalebone and un. bratided sinew pinerel toguther:

Fig. 371 (No, sysis [10.50] firm Itkial. wiii) is a mask that seems almost too smatl to have leen worn, being only $(i \cdot 1$ iuches long and t.7 wisle. It is viry olu, malentiblackened oot-

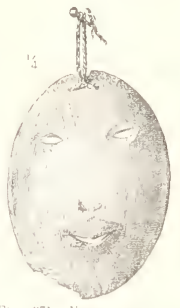

stualt $14,1 \times 2$

tomworl, and is the rudest representation of the human tare which wo saw. It is simply an oval clisk, comearo comsex, with holes ent for the eyes, mostrils, and montl. The gomgh entting abont the chin an-

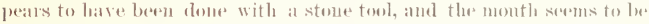

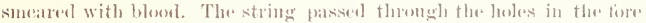

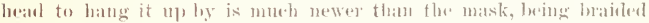
from onten twine and fastened to a common gallyanized boat mail.

9 ENII- 24 
The more southere liskium of Alaska are in the habit of using in their dames very elalwate and highly ormamented and painted masks, of which the National Mnsem positeses a very large collection. The

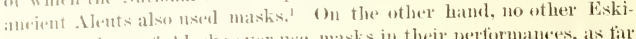
tuo, salle those of daskatever nse masks in their performanees, as far . I I can learn, with the solitary axeeption of the people of Baffin Lasd, where a mask of the hide of the hatheded seal is worn wh rertain owa-

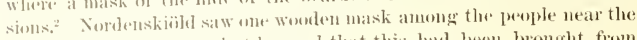
figges winter quarters, hut learmel that this hat been bronght from

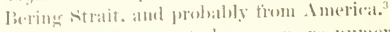

The mats alpleter to become more numeroms and more elaborate the nearer we get to the part of Alaska inlabited be the hadians of the Tolinket stowk, who, as is well known employ, in their reremonies re. mathably daborate wowlen masks and hoduldresses. It may be sng. gresterl that this custem of nsing masks ane from the influence of these Indians, wathe in the simple form alrealy deserileed as far as Point liarrow, but not beyomb.4 With these masks was worn a gorget or lowast-plate, comsisting of a half-mome slateed piece of board abont Is inches long, painted with rude figures of men and animals, and slumer about the nerk. We brought lowe thee of these gorgets. all old and weathered.

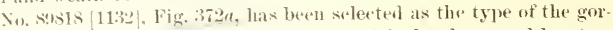
aret (silkmunin). It is mate of spruee, is $18 \cdot 5$ ineles long, and has two berkets of stont simew braiel, whe to so round the nexte and the other lonme the body under the wearer's arms. The figures are all jainted on the front fios. In the midale is a man painted with red wher; all the rest of the fignres are blatk and frobably painted with soot. The man with his arms outstretehed standson a large whale, pepresented as sponting. If hoblels a small whale in eateh hamd. At his right is a small

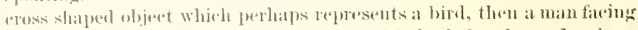
towall the fott and darting a latpoen with both lands, and a bear taring to the lett. On the lett of the red man are two uniaks with five men in eath, a whale nearly eftated, amel thes of the eross-slaped aljerts aldeady mentionul. below them, also, freshly drawn with a hard, blunt leat peneil or the point of a bullet, are a whale, all umiak, and a

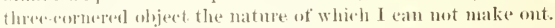

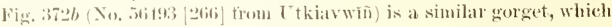

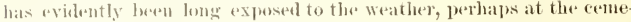
tory, as the tignus are all effared except in the middle, where it was probably corereal by a mask as in Fig. 367 ( same villages. Ther sems to have lowen a red border on the serrated (ntere. In the minldle is the same xed man as before standing on the

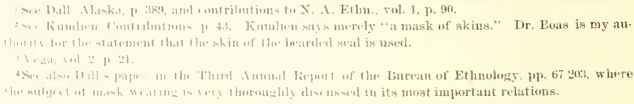


black whale and holding a whale in earh hand. It his right is a blate

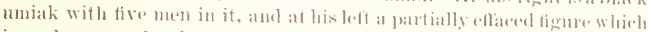
is perhaps anether boat. Thestrings are jut on as hefore, wowpt that

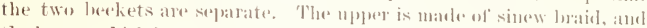

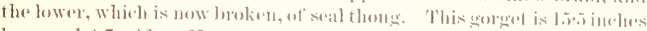

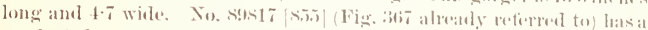
mask tied oser the midelle by means of the bectirets, sol l lat the figures

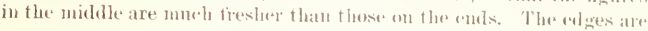

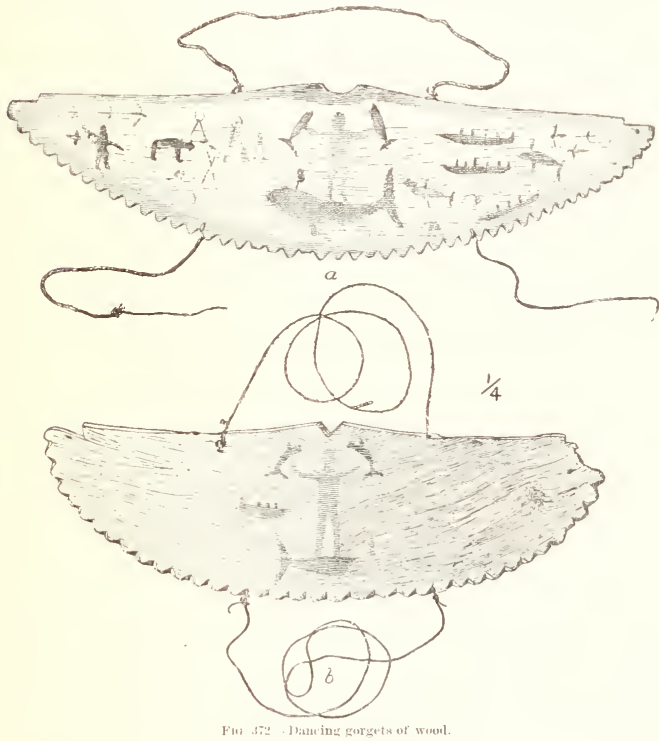

painted red. In the midhle is flue same red man or giant holding the whate. The othere tignes are prainted with sont.

This man or giant, able to hold ont a whale, apluars to loe a leagendary rharater, as we hava his image earved in ivory. We nntortunately

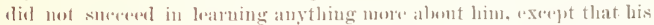

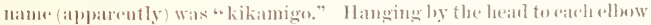
of this tigure is a sal, and opposite its thighst woot the usualconventional 


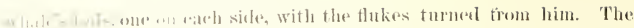

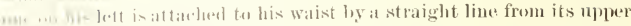

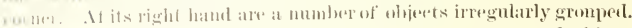

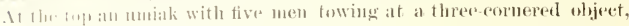

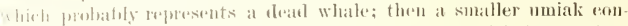
faming tive mont and apporently "fast" tor a whate, which is spouting.

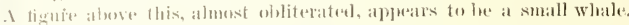

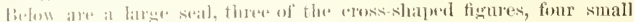

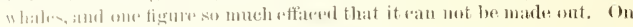
the loft hame of the figure are two numiak, and a whale with a line and

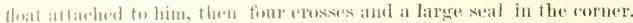

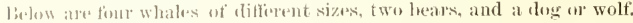

These gorgets alphear to latre gome ont of tashion, as we saw wone which were not very ohd, or whichajperared to have been nsed recently. From the nature of the figures upm them, they were probably used in some of the cremenies conmerted with the whate fisling. Kika migo may le the "divinity" whorentroks the whates and other ses animals. ${ }^{1}$

Theranical contricanes.-1n one of the performances which Capt.

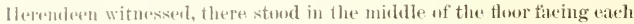
other, the stolful skins of a fox and a raven. These were mounted on whalohome springsand moverl by strings, so that the fox sprang at the ravell and the laven pered at the fox, while the singing and dancing went an. These animals were never offered for sale, but they bronght over a stufted tix very reverdy monnted se as to spring at a lemming, whieh by mouns of strings was male to run in and ont of two holes in 1he boatrl on which the fox was monuterl. (No $5959 \%[137 x]$ from

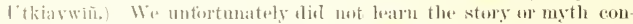
meeterl with this representation.? Tt was the skin of an Aretic fox in the summer pelace, with the paws and all the hones removed, and clum. sily stulind with rope yam, fout filling ont the legs. A stiok was thrust into the tail to within about two imeles of the tip, so that it was curled up ofer the batk. The skin was taken off whole by a single opening that the vent, whieh was loft ojen, and thomeg whieh was thrust into the boxly a strip of whalehone 2 inehes wide and about $\frac{1}{8}$ inch thiek,

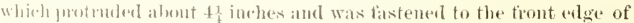
the hole by tying tho tlap of skin to the whalelone with three or fon

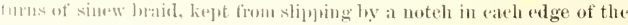
whithelume.

The fox was attareherl to a plece of the paneling of a shipts bulkheat,

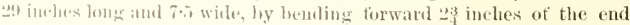
of the whaletwon, and lashing it down parallel to the length of the

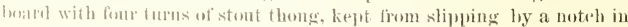

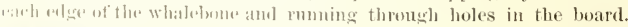


The fox was thes hed up hy the spring parallel (o) the length of the board with its bead and foreleges ratsed. I string of sinew bratel fo feet lomg was pasised themph a bole in the septum of the fox's nose and

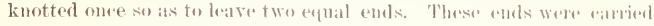

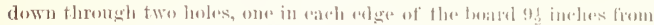

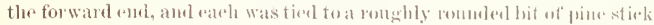

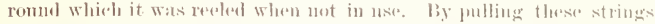
together, the fox was mald to dart down his head, which was mised

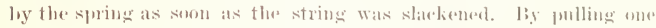
or the oflee string the fox and be mate to dat to whe of the other sicle of the boart.

One man manipulated the fox, prolling at string witlo ate hathe. The

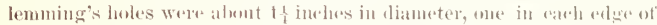
the luard and at sueh a listance from the end that when the string,

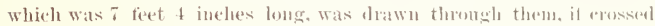
the board just where the fox"s nose struck, when it was pulled down. The ends ot the string were reeled romel bits of stick. The lemming was a narrow strip of wolt"s tur, about 3 ineles lomg, doubled in the middle, with the middle of the string hitehed into the bight. Isy pulling the ends of the string alternately, the lemming was made to jump ont of the lube on one side, run ateross the boat and into the other, very much as a live lemming rams firom one tumel to another on the tumbla. It took two pretsons, one on atels sicle, to hamele the lemming. The foxskin and spring appeared to be older than the rest of the machine. The loand was miginally 10 inches or l timet longer at wall and, but hati to low ent off to pareli it.

Petrotf' mentions a similar eustom among the "Nushegagmute" of bristol Paty, of iutroducing stuffeel animals moverl with hidlem strings

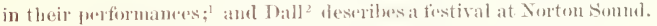
where a lead seal was lorought in and moved about with strings.

Inscription of festirals.- It is greatly to be regretted that we hat not establisher smoli intinate relations with the Hatives, as alterwarls was the ease, in the winter of 1sist-62, sime this was the omly ome of the two seasme that the great winter testival was held at Itkiavwiñ.

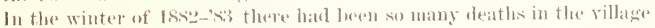
that the natives did not fiel like celebrating any regular festival, and only indulgerl in a fiew impomptu danees late in the seatsom. Thesest were nufortunately held in the evening when the writer's tomr of eluty at the station prevented his wituesing them. Those of the party who tid go over bromght bate only tiagmentary and rather vague aecomts of the performanee. The entining wature of the work at the station prevented our witurssing any of the releblations at Nuwăk al at Pornŷi, when the "Nunatañmin" visitors were entertained.

The best aromuts we lave of any pertormane is giren by Lient.

$$
\text { the port, b, lin }
$$




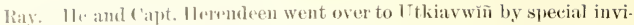

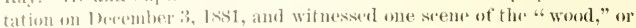

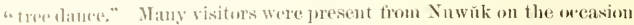
of this dane, which lasterl tor two days and nights. On arriving at

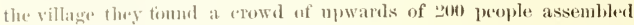
round the enfrance of the kin'dyigi. In front of the entrance were drawn up in line tive: men and two women daneing to the music of a drum : anl two singers.

They ware all drexiod in next dererskin clothes, with the snow-white

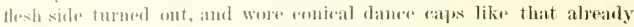
described. They kept time to the music with their teet, moving their lenlies to right and lett with spasmodic jerks. To quote from Lient. laiy's . Mে. motes:

liab daneer in ture sprang to the frout and in extravagant gestures went throngh the motions of kiline stall, wallus, and deer, and the pursuit of the whale. Each,

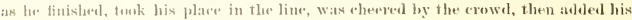
voiec fo the numotomons chant ot the singers.

After all had finislued as many as comld get in entered the "dance hersese" At one encl of this a small spate was partitioned off with a pine of an old satil, and from the loof in the midale hung an object intended to represent a tree. This was mate of two blolong boxes about fi inelhes in diameter, ojeen at both emels, the lower about $2 \frac{1}{2}$ feet long and the uprer about $1 \frac{1}{2}$, hinged together with real thong. At one sidu. hung a woll's skull, and ou the other a dried raven. 'Two performers sat in the middle of the floor with their legs extemlend ome between the ofluer's legs, with his nose tourhing the tree. A row ot old men beat drums and sang, while the performers chatuted a monotemous song, in which rould lo learl the words "rum, tolbacro, seal, deer, and whale."

l'mesently the bottom of the entain was littesl aml ont erawled five mon on all fours, waring on their houds the stufford skins of the heads of diflicht animals-the woll, lwar, fox, lynx, and dog. They swmeg their heads from side to silde in misom, kepping time to the musie, uttring a low growl at earh swing and shaking their rattle mittens. This they kept up, ton lifteen or twenty minutes, while the ehant still went on, and the whet performer, with excited gestures, embraced the tree and rublerl his nose against it from time to time. At last all "sprang to their lewet with a howl, and ended the dance with wild gestures." Similar scenes, with new pertormers, whieh our party did not stay fo witurss, surceeded this, with feasting in the different houses.

('ajpt. Ilerendimall also witnessed at small dance, lasting only one evening, which bores al curtous resemblanep to some of the so-called "favor figures" pertorment in the "tierman cotillon" of civilized dancers. This kind of dance was performed purely for pleasure, and had nothing re- 
ligious or dramatio about it. The musie was firnisherl by the monal medestrat of old mell, who luat drums and sange a monofonons somer. Each person who intemeded to take part in the daner ane povided with some small article to be given away as a "fisor," and lisine in lis tmrn, danesel a few mimtes, and then ralled out the name of the part. ner he wishes to sive it to. The latter then rose, and having reseived the "favor," dances a while with him, and then both lesmumbl their places anomge the speretitors.

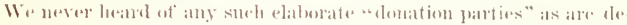
seribed at Norton somed and the Yukm region, whele a mall "salves np lis property for years" to distribute it anomg his guests. I testival,

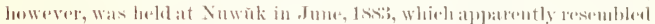

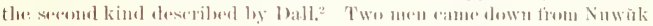

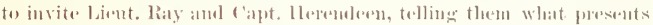

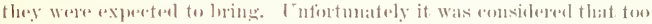
mulel was asked and the invitation was derdined. The messengers anriecl "notrded stieks."

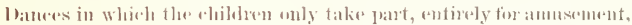

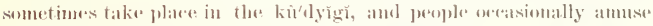
thematves ly dauring in the ieglu. 1 have often seren the natives, esperesally the rhildren and yome feople, dancing in the open air, and the dancing was alwatys of very mule the same char acter. The leet wore hut slightly moved, kere ing time to the musie, while the body swayed gracefinlly and the arms were waved fiom side to sille. Nll the daneing which I saw was rather cuict and graceful, hut they told ns that when they got warmed nu at a great dance they went at it with trementons vigor, thowing ofl thein garments to the waist. The danee which areompanies the song smme by the ehildrem to the amorat, loweror, is more violent. The dimeer clemelues his tists and, luemling his elbows, strikes

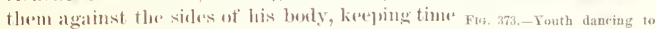
to the song and stamping vigomesty with the

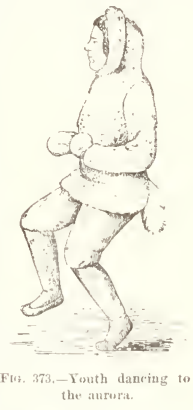

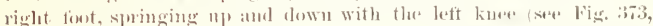
from a sketeh by the writer).

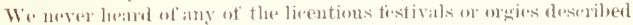
by Egerlet and Kumlien.

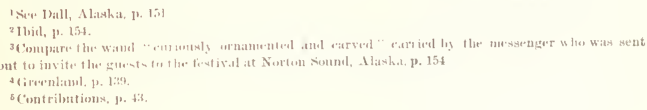


Ihe testrwh of the wistern Eskimo appear to be less formal and

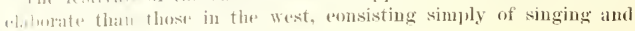
lianting.

TU1: (XU) SPURTY FOR ('HHLDEX AXD OTHERS.

Ihothings.-Thongh the clibluen amuse themselves with a great many sports and plays, we saw very lew togs or playthings in use. We hom hit heme six ohjertis which alprear to have no use except as playthings.

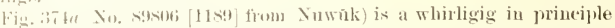

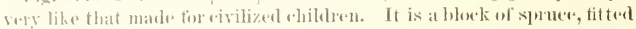
with al shatt of marwhal ivory. This lits loosely in the straglit tubular

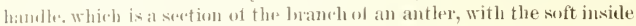
tissue cht out. I string of seal thomg passes thomgh a hole in the milkle of the laturle amol is fastened to the shaft. This string is about s live fong, and abent half of it is tied mp into the hank to make a handle tor pmlling it. It works rery mell like a rivilized child's whirli. gin. The string is womnd aromel the shatt and a smart pull on the handlo. nuwinds if, making the block spin round rapidly. The reartion, spinning it in the opjosite direction, winds up the string again. A "omple of loom hawk's feathers are sturk into the tip of the block, which is patinted with rol ocher for about an incll. Fom equidistant stripes of the sature color rum lewn the sides to a lorter of the same width remul the bake. This was uate for sale and appears to be an unnsnal toy: 1 do not resolhet avp sering the ehildren play with smeh a toy.

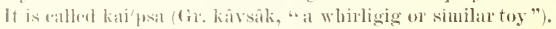

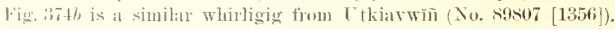
The likek, which is +.2 inclues lome, is mad. of the solid tip of a momutain slowp's lorn, and is raborately ormanented with a eonventional pat. trin of lines and ".rimeles and dots," incised and colored red with ocher. The shatt is of hanel hone, and the line has a little wooden handle at the ent. The bleck is so heavy that it will havdly spin.

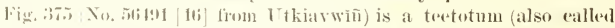
katijkil). The slatt is of pine anel the olisk of spretee and is ormanented with likek lead marks, forming a border abent one fuarter ineh broal

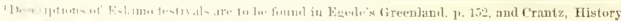

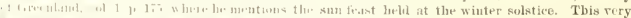

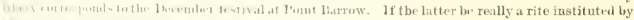

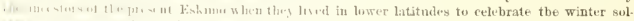

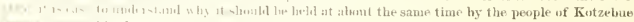

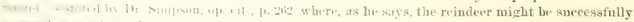

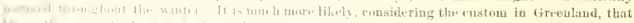

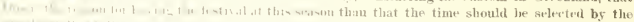

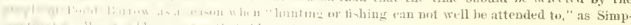

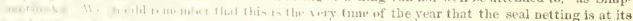

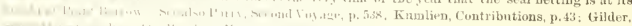

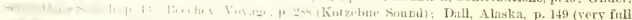

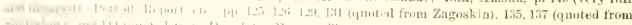

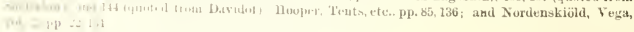


on each face. The mper lase is divided intormatrams by fom namon

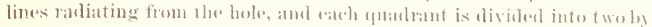

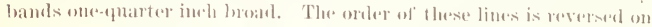

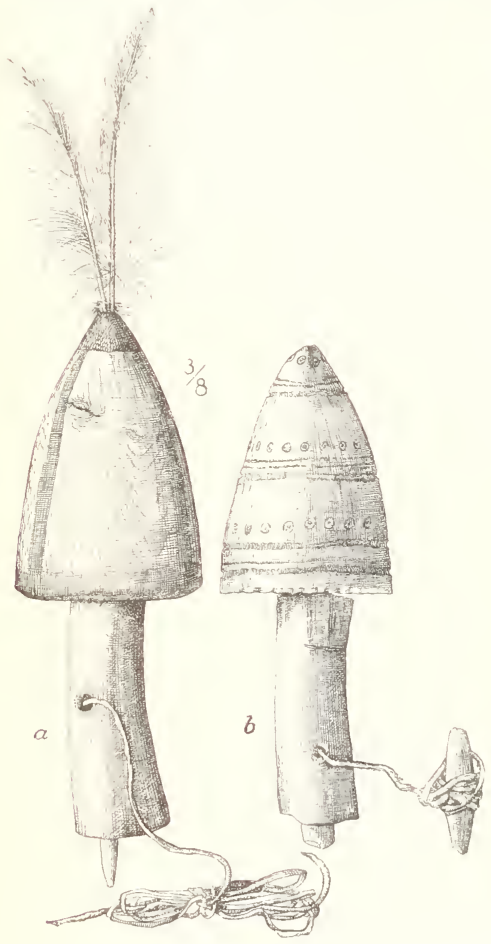

Fig. 374,-Whirlugige.

the molder fare. This is spmen, like a common teetotum, with the fingers, and does not sesm to lo rommon. I do not recollect ever secing any one exeept the maker of this toy spinning one. 


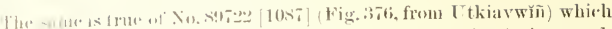

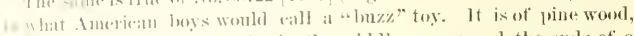

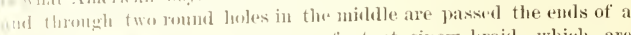

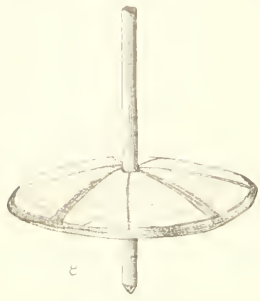

Fin, in-Te+1 int $11+1$ pusere of stont sinew braicl, whish are knoted fogether. When the board is plared in the middle of the string it ean be made to spin round and whiz by alternately pulling and relaxing the ends of tha string. The hoard is rather elabor atedy painterl. One end has a lomer of black leat on both fares, the other a similar bordes of red paint, which appear's to be red lead. Broad red bands form a square 1 inch across around the indes, with lines radiatimg trom earh wor11(6. to the enchers of the board, on hoth laws. (1) the spares between these lines are fignces rudely drawn with black lead.

(1) one fanc, in the first sprace, is a goose; in the seeond, a man with a statif; in the third, the conventional figure of a whale's tail; and in the fourth, a whate with line amb float attalled to him, pursued ly a whal ing muiak. On the ofleer side, the tirst spare contains a dog or wolf watking; the seconsl, two of these animals, sitting on their hauneles, facing wach other; the third, another walking; and the fourth, a reindece in the same attitumle.
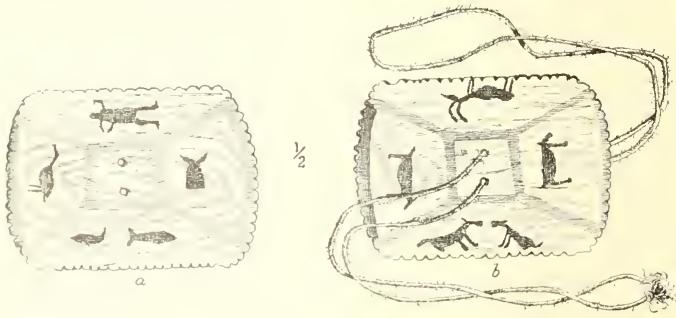

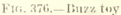

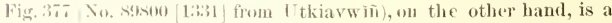
twy which the "hildren often play with. It is the well kuown "whizzing stick" found annong savages in so many widely distant parts of [ He world, and often useal in religions ceremonies. The Eskimoname is imugluta. If consists of a thin board of pine wool, fastened by a string 


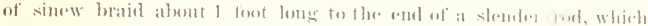
servos as a hamble. When swomes rapidly roumbl by the lamolle it

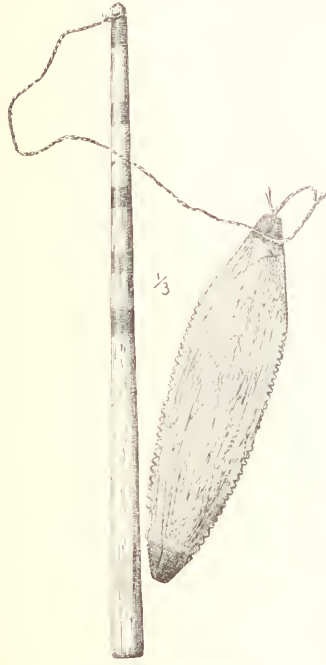

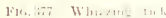
makes a lond, whizring sommul. I1 is very matly matce, and prainterl with blate leat and rod owhers.

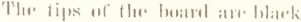
for alrent one half ind and the rest is red, and the upuer halt of the hatmlle markerl with tiverings alont onu.half inch wisle and । inch aprart, altermately black and mel. This appers to be poredy at rhild's toy aud has no mystimal simnitication. I never sal one in the hamds of : an atult. This speeci ment was made and lonought oncer tor sale Iny a lad alome thirteren or fomrtern years old.

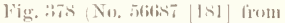
Itkiawwiñ) is motlen plaything lather common with the boys, which takes the plare of the Ameriean boy's "beall snatprer." It is known by the name of miti'. gligam, and is a rod of whalelome, stitt and black, $4 \cdot 6$ inches lomg and $(i \cdot 5$ wide, narrowod and bent sharply up for alout an inch at one and. (11 the npres side uf this end, dost to the tip, is a little follow, farge enomgh to lowd a small pehble, and the other is cut into shan' peeth. This is jurely an instm- $1 / 2$ ment of mischief aud is used for shosting tiny jebblos at peo. ple when they aro looking the other way. Mninialu showed 11s, with great gleo, in ath expressive jantomime. how a boy would hit a frersen in the eyo with a little pellole, and, when

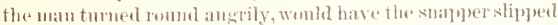
up his sleeve and be ooking earnestly in another therfion. The toothed end, he sibl, was for misthievonsly soratching

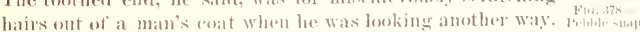
The "sllapprer" is nserl as follows: It is held in the lett hand,

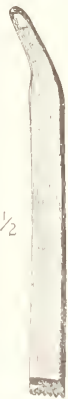
a little perble is set in the sineliet, and the tip of the whalemone bent bak with the right haml. Whan this end is let gon the plastioity of

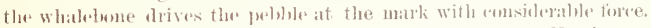
As lar as 1 an learn this misedievous toy is peraliar to the Northwest. 


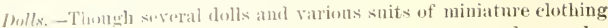
mer-made and hrought orel for sale, they do not appear to be popmlar with the littlo girls. I lo mot recollect ever seeing a child playing with whll. Those in the collewtion, indeed, seem rather less intender for plaything than as, so to speak, works of art to caten the fancy of the

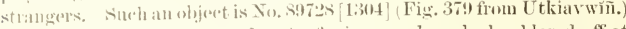

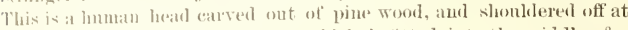
the unels into at stont round pen. which is titted into the middle of a

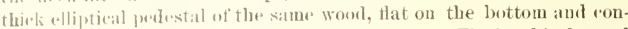
rex on top. The head is dressed in a neatly made hood of thin

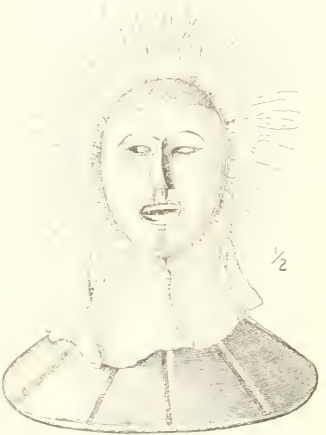

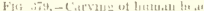
deerskin with the flesh sille cut off round the sloulders and ex. prsing only the fare. The face is very neatly earved, am has hits of green oxidized copper inlaid for the eyes. The eheeks, gnms, and inside of the mouth ate colored with red ocher, and the hair, eyebrows, and beard with black leat. The top of the pedestal is painter red and di vided into eight equal parts by shallow grooves eolored with blawk lead. The height of the whole olject is $4 \frac{1}{2}$ inches, and the workmanslip is remarkably goorl.

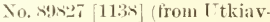
wiii), on the other hand, is very roughly and earelessly made. It is 1.2. inclies long, roughly whit thed ont of a flat piene of red wood hoard into the shape of a man with his legs widn apat and holding "y his hauds on each side of his head. The arms are very short and boarl, with five fingers all nearly ot the same length, and the lews are simply two straight fonr-sided pers rounder on

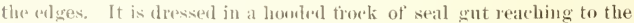
knces and leaving only the face and hands uncovered. and has sealskin kue bosts on the legs. The lace is rud wy in relief, with two narrow bits wf ivory inlaid tor ayes, and a long canine tusk of the sime material inserterl in wath colner of the month. Three small romud bits of wood ar. inlatid in the forched, one in the midlle and one wrer each eve, and

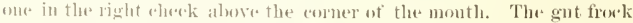

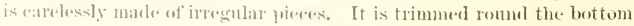
and the wlge of the hood with a strip of dogskin, but is left with a raw 


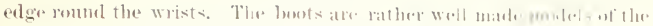
regular waterpuost losts. with soles of white satskin and a batul round the toi] 1 inch wide of the satmu mate-

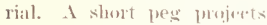

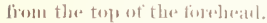
A string of stout sinew bratid

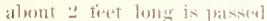
throngha a lasle in the michlle. of the bouly and at kut tiet in the end in front. Thengh the design is elaborate the workmanslip is very mule. and the alothes sem to be matte of odds and tands. The maker perlatps han in miml a fabulons man with tereth like a wallus, aloout whom wa heard some fragmentary tralitions.

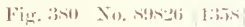
from litkiawint is at enver. thotigli somewhat roughly

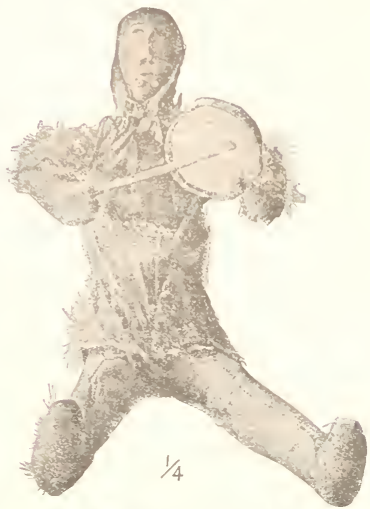

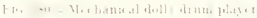

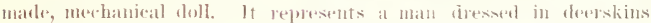
sitting with his legs outstretched and holding in his extended left land a drum and in lis right a stick, as if beating flot drum. The arms alle of whalebone, and by pressing them he eall he mate to beat the drum. The doll is made of a single piesent wored-al knot with

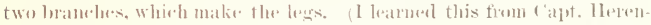
deen, who silw this doll at the village betore it was tinishenl. The height of the sitting tigne is $\mathrm{tl} 1 \mathrm{i}$ inelues.

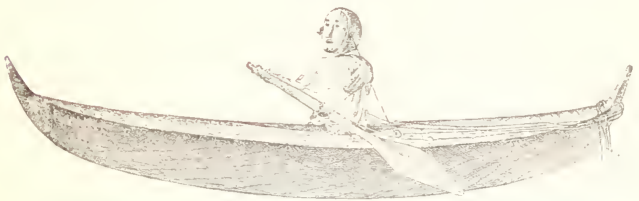

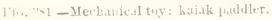

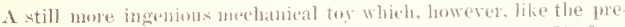

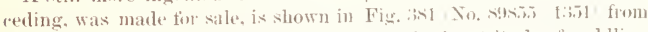
Ctkiavwii). This is a man sitting in a kaiak in the attitute of padelling 


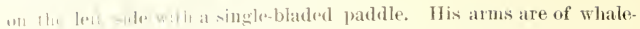
hone, and by meate of strings lie an be made to padille and turn his

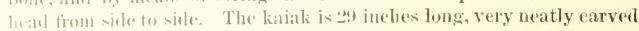

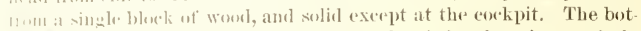
a.cis s lfat, to allow it to stand on the flowr, but it is otherwise previsely of the mocket of the katiaks in the Musenm from the Mackenzie and

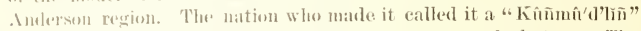

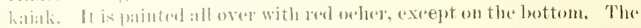
tigme has no legs and tits into the exckpit, which is withont any roam-

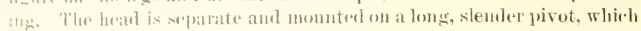
a lithed into a holu in the neek just loosely enongh to allow it to turn mally. It is dressed in a hoorl ot seal gut. The fare is very natural, though rather rouly anverl, and is lightly colored all over with red ocher, with the month printed derply rod, and the eyebows, eyes, nostrils, anf bertrel marlied with blawk feal. The arms are namow strips of whatebone, flue conds of which potrude at the wrists, and are tied to the parlalle by the ends of the strings whieh work it. The body is corroul with at wat shirt.

The padelle is of the common shape, and has the blade and the lower and of the shalt painted red. The strings for working this contrivance are of line sinem braich. (One string is tied into a little hole in the edge of the heol, where the left ear would be, the of her passes round the

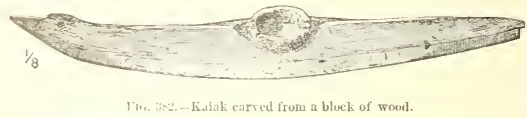

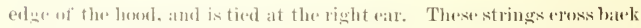
wit the head, and pass through two neat little ivory eyehests inserted

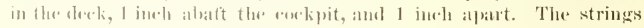

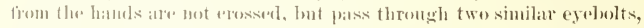

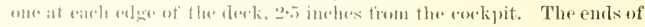
and set of strings are tienl together. When the right pair and left

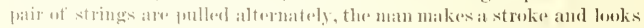

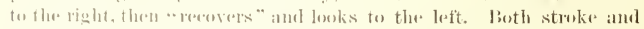
"recovery" ane aided by the elastieity of the arms. This spesimen -hows a grat deal of merebuical ingenuity, and was the only finished aljert of the hind seent.

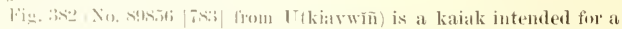

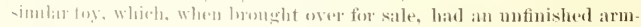

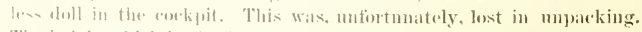

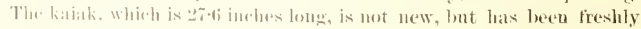
scratued and painted on deck. It is atko a foreign kaiak, being precisely

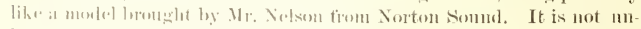

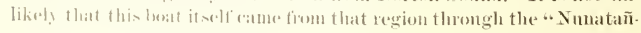




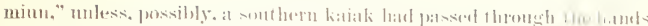

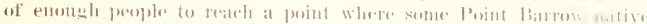

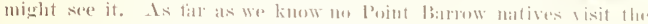

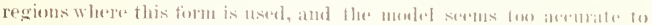
bave been mate fiom a description.

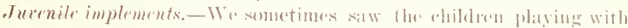
little models of the implements and utensils usol by their piremets. Perhaps the conmmonest thing of this sort is the leos's low. Is som as a boy is able to walli his lather maties him a little low suited to his strength, with blunt anows. with which hu plays with the of hete boys, shooting at marks-for instamed, the fival mindere bromeht home.

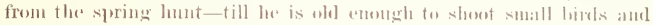
lemmings. We also siow ehikden playing with little trums, and one. man made los little boy an maborate katmoti alunt t teet leng. In the collection are a number of miniature implements, spears, off., some of

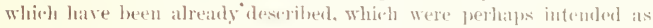
paythings for the childme. As, howerer, they were all newly malle. it is pessible that they ware merely intended to ateh the tansy of the strangers.

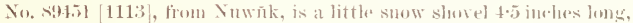

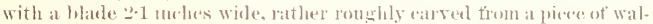
rus ivory:

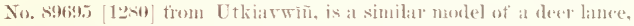
7 inches long, all in one piowe and made of reinteer antler.

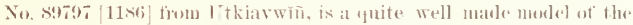

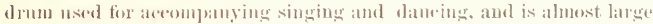
enough to have leeen mod tor a plaything. The stiek is rutirely ont of proportion, beire nerely a ronghly whittled hit of lath, lis inches long.

Games and sports.-The ment have very fow sports, flungh 1 hate sometimes kmown them to amuse themselves by showting at a mallk with their rifles, and 1 one heard of at anmber of them wrestling.

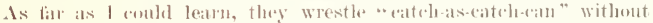
any partienkar system. We never heard of anything like the allaletic

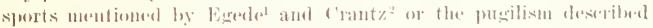
by selowatka anenge the people of King William'x Lanel. When two men

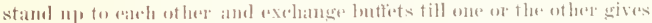

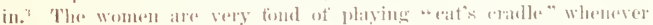
they have lejomre and make a mumber of complieated tignese with the string, matuy of which represent various animals. (he tavorite figme is a very elever representation of a rejuleer, which is male by moving the fingers to run down hill from ome hand to the oflere! Another

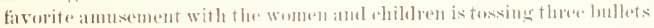
or small pebbles with the right hatud, after the mamer of at juggher,

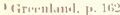

? Yul, 1. 1, 1.

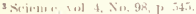

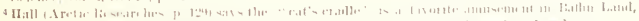

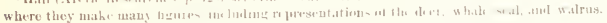


kepping one halt constantly in the air. Shme of the women are very

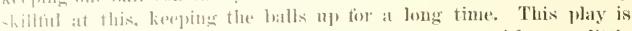
accompaniod ly a rolant sumg to a monotonoms tume with very little ati. but strongly markel time. I never sureeded in eatrhing tlie words of this chant, which are netered with eonsiderable rapidity, and do not

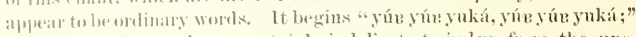
and some of the words are ertainly ind difate to julge from the une-

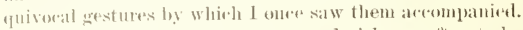

111 the winter the fonng women and girls are often to be seen tossing at suowhall with their feet. A girl wets some snow and makes a ball about as hig as her two fistic, which of eomse immediately beromes a lump of ice. This she hatanes on the toe of me foot and with a kick and a jump tosses it orer to the other fort which catches it and tosses it back. some women will keere this ny, tor a munhere of strokes.

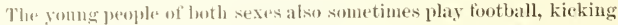
about an old mitten or hoot stuffed with rags or hits of waste skin. I never saw them set u], gorals and play a regular gane as they did in [irentinland. ${ }^{1}$

The little girls also play with the skipping rope. I once watehed three little girls jumping. Two swm the rope and the other stood in the midlule and jumperl. First they swomg the rope unter her feet to tho right, then bats muler lace teet to the leti, and then once or twiee Wholly wound under her fieet and orer ber head, and then began again. ${ }^{2}$ Thuy also play at housekeping, laying stirks romd to represent the sides of the bouse, on ontlining the loonse ly pressing up ridges of sllow betwen their lest. Sometimes they mark ont a complicated labyrintle on the snow in this way, and the game appears to be that one shall fruart this and try to wath the ofleres it they eome in, as in many of the watmes of eivilizesl rhildren.

I hatr aldeaty spoken of the formal chidhen's dances. They often also dane by themselves, beating on old tin eans for drums. One night I saw a party of "Jildren laving futite an elaborate pertormance neal our station. The snow at the time was drifted uj elose under the faves of the house. On the edge of the roof sat three little boys, each bating vigeronsly on an empty tumato ean and singing at the top of his lomgs, while another boy and a litte girl were daneing on the suow waring their arms and singing as nstal, and at the same time trying to avoid another girl about thirteren yars old, who represented a demon. Silu was sfouphes torwarl, and moving slowly romel in time with the musi", tmuing from side to side and rolling her eyes fierely, while she lickinl the blate ot an open dasp knite, drawing it slowly across her lips. They somed intensely in eallest, and were enjoying themselves longely. After dansing a while at the station they went over to the village and as they told we the next day spent the whole night singing in a vatant snow-house. 


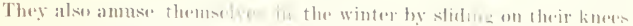

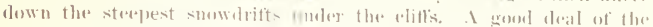

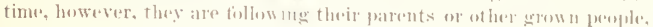

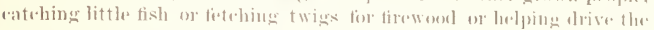
dogs, thomgh as a rnle they ano not mate to do any reanlar work until they are pretty well stown.

\section{IUS:}

Musicul instruments.-Theonly musieal instrument in use : mong the:se. people is the miversal drum or tambonrine (kolyan), ensisting of a

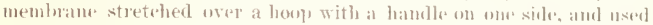

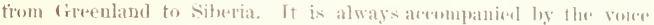
singing or thanting. The player lwhels the hambe in his beft hatud with the membrane away from him, and strikes alternately on wall side of the rim with a short lady pune of ivory, or a long slemler waml, ro. tating the slrum shightly at the same time to meet the stroke. This proclues a boul, resonant, and somewhat musical note. Ther appears, however, to be mo system ut tming these trums, the pitch ot the note alopending entirely on acrident.

We collected four of these drums, of whieh every househuld pusisesses at least one. They are all of essentially the same con struction, but vary in sime. No. riitt [79], Fig.3.3, hats been selected as the type. Thw trame is a tlat strip of willow tit inches long, 1 inch wide, and $0: 3$ inch thick, lent till the two rmils meet, thns making a hoop : $2 * 3$ inches long and $1 !$ incbes wide. The ends are fistened torether by a strap of walrus ivory on the inside of the loon, seemed to

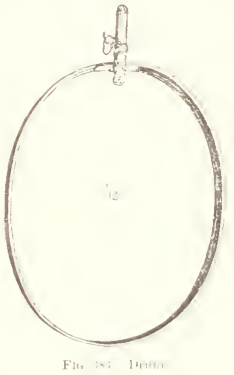
the wood by mat stitehes of hlark whalebone. The handle is of walrus ivory 5.2 inches long. The larger end is rather rubely rarved intu a human fare. liak of this hat amd 1 inch from the large end of the haulle is a sfuare transrerse uoteh, deep and suftieiently wide to fit over both rim and strap at the joint. It is held on hy a lashing of sinew brat passing through hules in rim and strap, one on eath side of the lamdle, and a barge transverse lube in the lattes, below and a little in firont of the noteh. The membraue, which appears to be a showt of the peritonem of a seal, is stretehed ower the other sile of the hool, which is beveled on the outside melev, and its edge is brought down to a dere

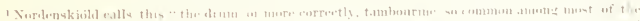

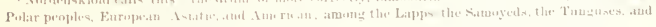

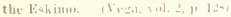

$$
9 \mathrm{ETH}-25
$$




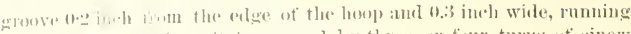

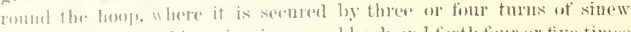

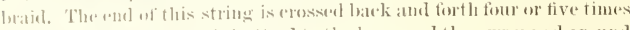

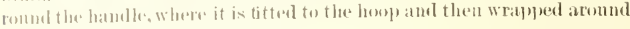
it and tinislund off with a knot.

No.

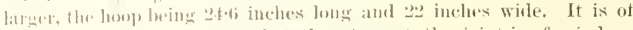
the sane materials, exeept that the strap at the joint is of reindeer antler. Opposite the joint the hoop appears to have shown signs of weilkess, ats it hats ben strengthened with + wo stralps of walrus ivory, (n) on the inside and one on the outside of the loople, fastened together

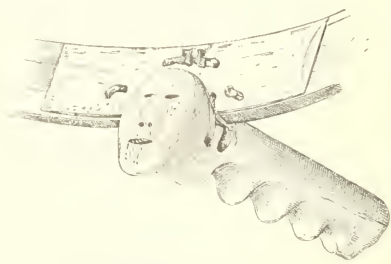

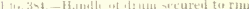
by stitclues of sinew which pass through the word and throngh both straps. The insillestrals is $4 . \bar{t}$ inelues long, the onter 335 inches long, and only hali the width of the rim, and is let into the latter. Thisstrapay, pratrs to have been put (an first, as at each end there is a stited which only rums through the

woorl. The landle is fastened on as leefore, but has two transverst holes instead of one, and las fom derp ronded noteleses for the fingers. (s.e Fig.38t.) The joint is tightened by driving a thin sliver of wood in at the bottom of the wuteh.

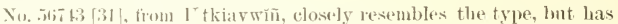
a moth for the thumb as well as for the foretinger on the landle. The

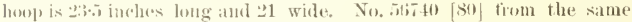

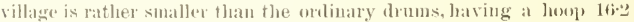
inches long and $14 \cdot 7$ widle. The handle is of antler, but has the usual faren the large end.

IV also fromght lowme cight handles tor these drums, which exhibit lout slight variations. The commonest material tor the handle is walrus ivory. (Inly two out of the twelve are of antler. They are usually

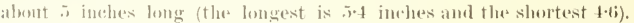
Ilandles with grones tin the fingers and sometimes for the thumb seem to be fuite as common as the plain handles. Fig. 3san represents an ivory hatmlle from Nownk (No. S!) wath finger and it shatlow one on the right side for the thumb. It is 5 inelue lone.

With one exerption ath these handles have the large end more or lexs nuatly carven into al human fate, with the mouth open as it singing, 


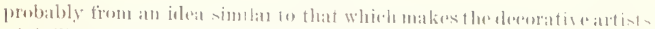
of eivilizal eountries ormament the pipes of a gleat organ witl sineing fares. This face is ustally in the position shown in the speriouens

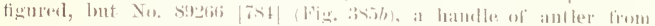

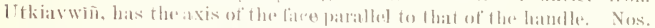

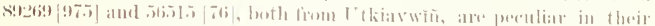
ornamentation. They are hoth of walens ivory. The tormel has a lledl

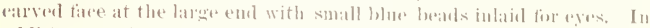

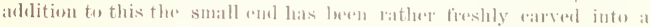
rather ruble seal's heal, and an olmamental pattern lass loeen ineisell

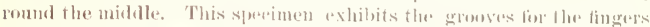
very well. The latter is a plain hamble, lut has a littlo sharp tusk
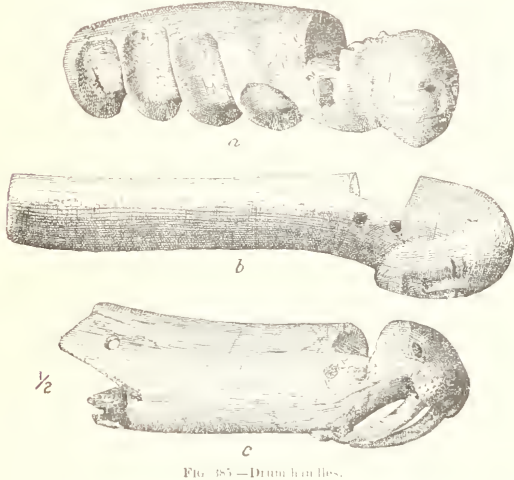

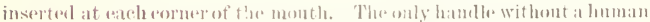

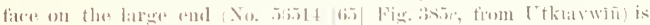
permliar in mamy respeets. It is the lutt end of a small wallus tusk, with a larege pulp eavity, the edges of wheh are muth notelsed and

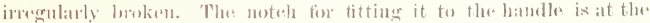
smaller ent, which is matly arored inte a very goos tigure of a wallus head, with the taskis lant bate to the umber side of the hamble. The heaml lats oval bits of woul inlatil for eyes. None of the drums or hamellex in the collection are newly made.

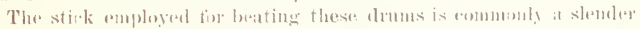
elastie waml abont $20 \frac{1}{2}$ tiect long, lut they alsu sometimes use at short 


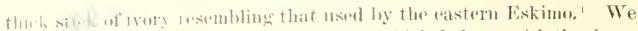
Imanght home two of these stweks, both of which belong with the drum

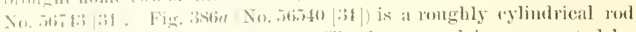
of ivory with a hole for a lanyard. The larere emel is ormanented by rudely incised and darkenel lines which represent the eyes and ontline

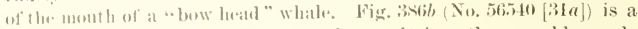

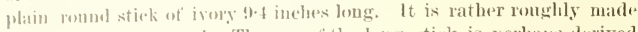
and somewhat warperl. The use of the long stick is perhaps derived from Siberia, where the short thick stirk does not appear to be used.?

Holes in the membant of the drom are sometimes mended with

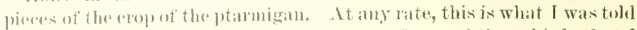
by a lative, who leeggenl from me the crops of two of these lirds that I was skinning, saying that le wanted them to mend his drum. These drums are always heaten as an accompaniment to invorations of spirits or inuntations. This practice is so common that some anthors are in the habit of al ways speaking of them as "shamau drums". As I have
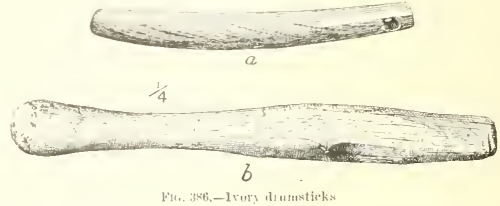

alreacly stated, their unst common use is purely as a musical instru. ment, and they are used not only by the sor-alled "shamaus" lunt by "verybody.

Charecter and frequeney of music.-Their musie consist of monotonous wants, usually with very little pereeptihlo air, and pitehed generally in a minor key. I could not pereive that they had any irlea of "thme" in the musical sense, but when sevaral sing together eath pitehel the tune to suit himself. They, however, keeprexellent time. The ordinary songs are in "rommon" or t time, ${ }^{3}$ The worls are often extemporaneors, and at tolerably regular intervals comes the refraim, "I yiña yaina, a yánia ya," which takes the place of the ". amma aja" of the astorn liskino, Sometimes, when they ar humming or singing to themselves, fhe workls are nothing lout this refrain. Their voiees, at a goneral thing, are musieal.

tike all liskimo, they are very tiond of musie, and are constantly

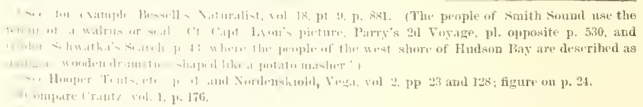


singing and homming to flemselves. somelimes, acombling fo ('apt.

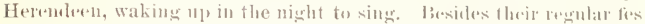
tivals they often amuse themselres in their homses by singing to the drom. They are fond of eivilized muxie, ant, laving usually rery quisk and rather ante ears, realily cateh the dumes, which they sing with

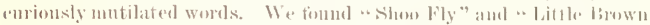
Juge" equat favorites at the time of one arrival, and one old woman

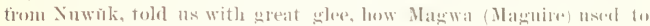
sing "Tolderolderol." Our two violins, the doctur's aul the (onok's, were a ronstant somres of delight to them.

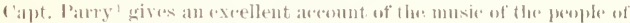
Fury and Herlat straits.

I regret axtremely that I wats not rmongh of a musician to wrifu down

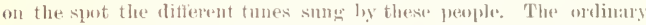
monotomons chant is so devoid ot air that l aan not possibly renollent it, and the same is true of the chant whele areompanes the same of pebble tussing. I was ahle, however, to rateh by ar the song smog by the elitdren when they dance to the anora. I never hat the whole of this song, which we were told had a latge number of stanzas. The tirst three are as tollows:

1. Kioyat ke, kiuyit kw,

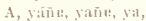

Ilwi, hwi, hwi, hwi!

2. Tridimatlis, tiullimani,

(ดง

llwi, hwi, lwwi, hwi!

3. Kilut:má, kalutanta,

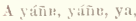

Ifwi, hwi, hwi, hwi!

Wr did not sucreed in learning the meaning of these words, except, of comrse, that the first word, kioya, is aurora. When there is a bright

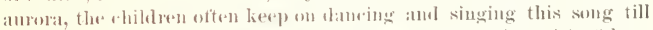
late into the night. I tume was intreduced in the spring of 186, by a party of men firon Kilanwitawni, who came np to take part in the whale-tishing at Itkiarwiñ. It berame at one excectingly popular, and averylosty was singing or humming it. It is peenliar in lowing in waltz or s $^{3}$ time, and has ansiderably more air than the ordinary tmues. I heard uo works smog to it exrept: "O hai hat yaña, 1 hat yiña, $O$ lanja he, ha!ja Ine." Mr. Wall intoms me that lue recognizes this tume as one sung by the Indians on the Yukm.

ART.

The artistie sense alppears to be much more highly developed among the western Eskimo than anomg these of the ast. Among the lattere 


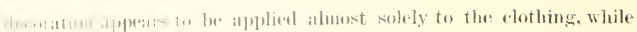

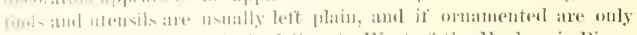

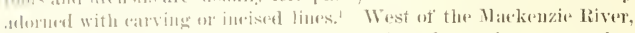

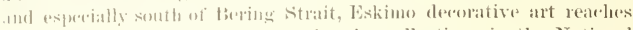
its highest derelopment, as show by the collections in the National

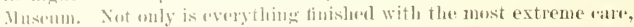
lut all woolen objects alre gaily painted with valroms pigments, amb all

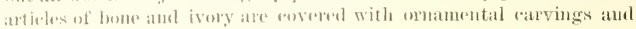
incised lines forming concentional patterus.

There are in the collections also many objects that alpear to have

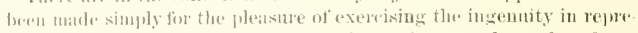
selthing natmal or fancitial objects, amel an thus purely works of art. Wint of spare lortiuls any fimther discussion of these interesting obients. There is in thr. Museun sultionent material for a large momogratple on Eskimo art. Is would naturally le "xpected, art at l'oint thatrow oremples a somewhat intermotiate pusition between the bighly aleveloperl ant of the suntlewest and the simple ant of the east. I have givon suthicient tigures in my description of their clothing and varions inplements to illostrate the condition ot purely decorative art. A few words mat he afdoel by way of resums. It will be motiecel that whenwhe the how or ivory partis of walpons are deroraterl the ornamentation is usually in the firm of ineised lines colored with red ocher or soot. These lines rately reprenent any natural objects, but generally form rather alegant comsentional patterns, most commonly double or single borders, often joined by oblinge cross lines or fringed with short, pointerl parallel lines.

A (xmmon ornament is the incisad "circle and dot," so often referred to in the torreguing deseriptions. This is a circle about one-quarter inch in diameter, described ats aceurately as it done with compasses, with a denply incised dot exactly in the center. This ornament is much more commen south of lopring Strait, where, as Mr. L. M. Tumer informs me, it is a conventionalized meresentation of a tlower. Some of the wher implements in our collection, ormanented with this figmon, may

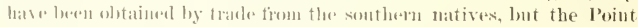

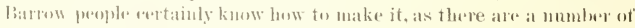

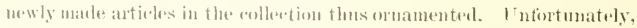

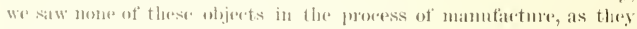
were mate by the natives during ofld moments of leisure, and at the

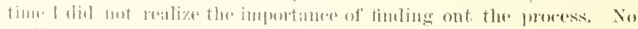

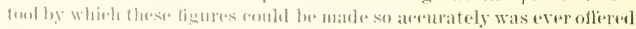
fiil sill:

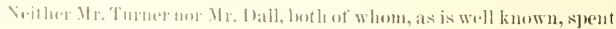

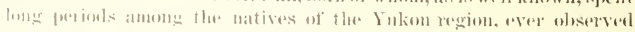

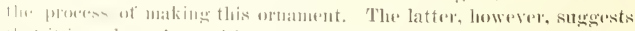

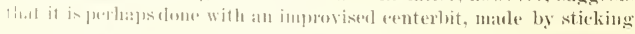




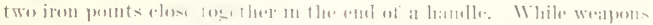

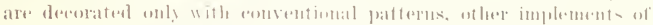

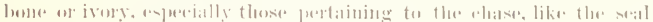

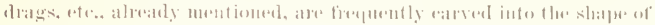

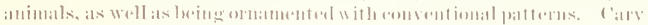

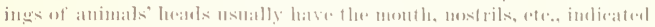

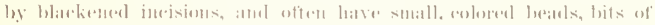

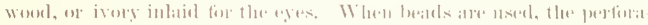

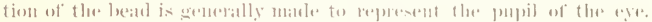

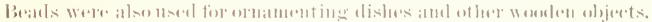

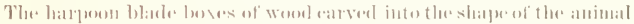

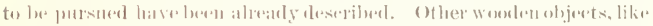

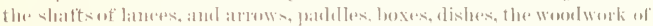

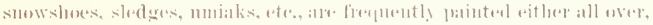

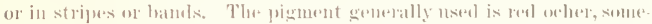

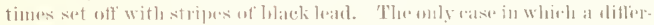

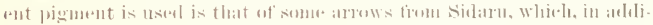

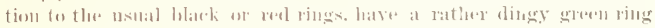

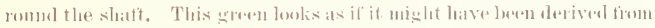

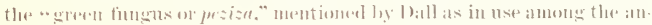

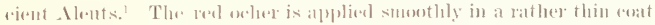

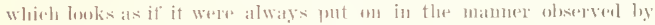
fapt. Ilerendeen, whosaw a man paintinga new slenl at I'tkiarwiñ. He

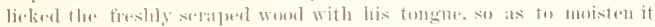

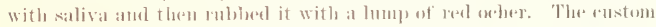

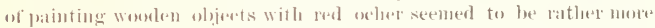

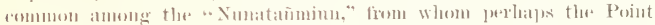

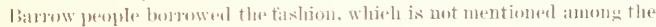
rastem Exkimo. Xombleskiold states that ret is the tavorite color atuong the natives of l'itlekitj."

The painting of the arrow shatts in many eases curiously resimbles

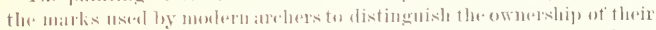

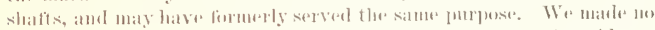

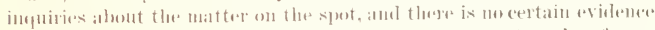

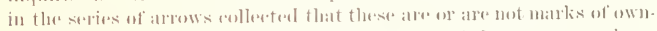

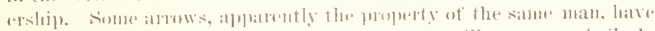

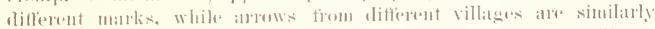

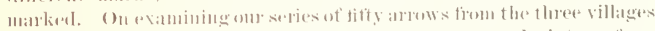

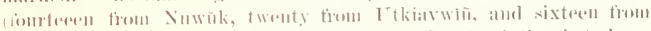

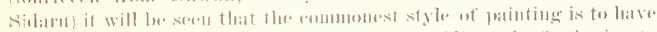

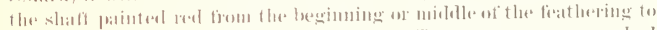

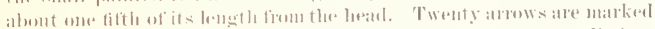

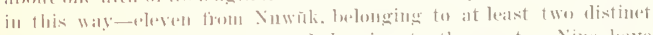

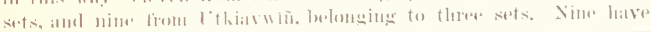




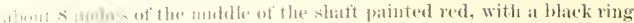

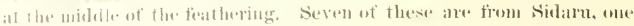

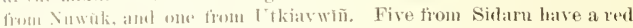
ring renum the midelle, and it gresen one abomt the midelle of the feathering. and thut of the sane set lave also a rest ring in frout of the green ane. Three from I thiarwio, helonging to different sets, have the shat painted rest from the minlele to the beginning of the featlecing, and three rest lings 2 inders from the nork. Seven belonging to these

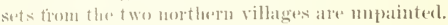

I set of two stmall arrows wheh beloug with the boy's low No.

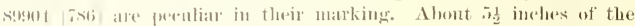
midlle of the shatt is painted led, there is a blaw ring round the middle, and at black spiral rumbing the whole length of the fiathering.

The only deerative work in noetal is to he seen in the pipes amel their acempatnying pirkis and tire steel which have aldeady been alescribed.

In aldition to these illustrations of deeorative art, we lronght home a serius of serenty-nine ol jeets which may be considered as purely works of art without reference to decoration. Some of theolder objects in this sories pertatys also served the purpose of amulets or charms, but a number of the new ones were make simply as works of faney for sale to us. These whects are all rarvings of various materials, sometimes very rude and sometimes very ueatly finished, but in most eases

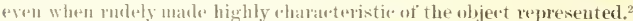
Wialrus ivery, nsmally from the tuskis, hut sometimes from the teeth, is the commonest material for these arviugs. Thirty-six of the series are mate of this material, which is very well suted for the purpose, being worked with tolerable ease, and "apable of reeeiving a bigh finish. Soalpstone, from the fase with whieh it ean be ent, is also rather a favorite material. Seventeen of these carvings are made of soapstone, in miny cases evidently pieces of an old lamp or kettle. Other mineral sulastalless appear to be larely used. Throe inages, all made for sale atul by the same laand, are of solt white gypsum and one tiny image of "t bear is rudely tlaked ont of gray flint. (There are in the collection a mumber of mole images of whales. mate by flaking from flint, jasper, aud ghlass, lant as these lleve ascertained without doubt to be amulets, they will be deseriled muler that head. Eheren are made of wood, nime of bene, one of antere atul one of the teroth of the polat bear. Twenty-thwe of these catrings leperesent human beings, sometimes in-

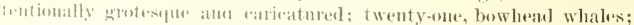

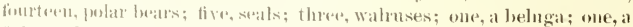
fisth: and severn, finciful monstors. Four are ormanented objects made for sule: not, strietly spe:tling, images,

Six of the representations of the fuman fate or fignue are of wood,

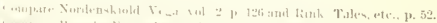

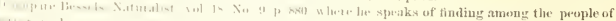

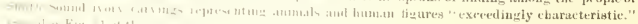
글 


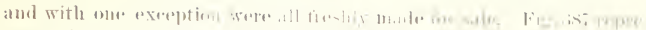

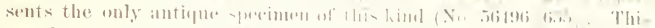

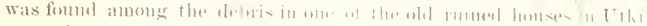

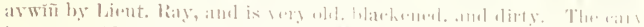

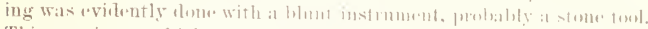

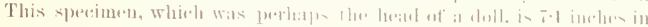

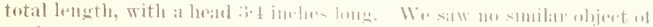
moderm eomstrution.

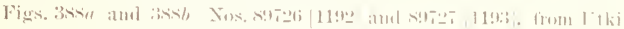

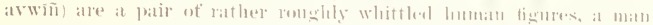

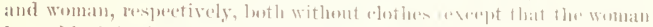

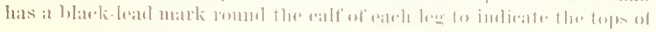

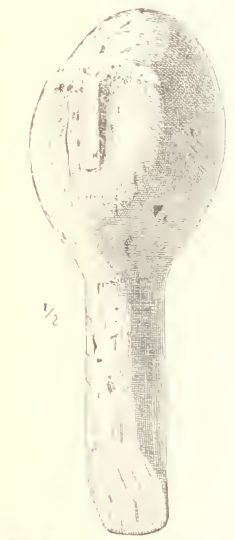

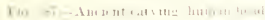
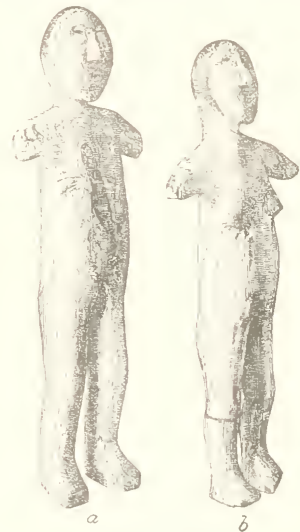

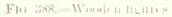

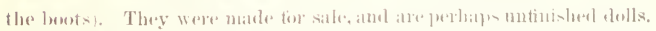

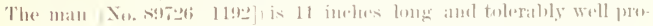

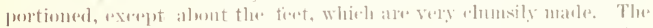

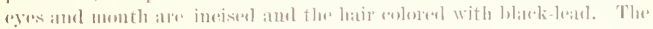

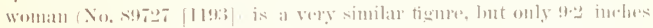

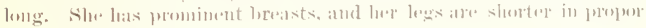
tion than the matus.

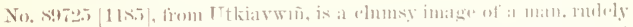

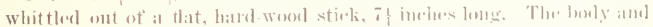

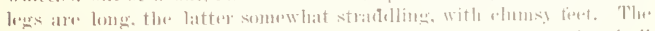

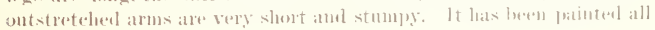




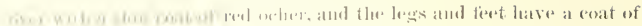

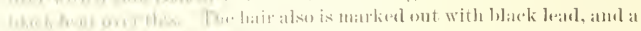

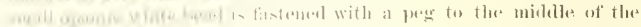

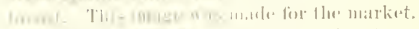

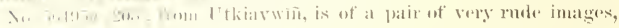

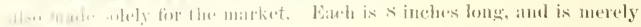

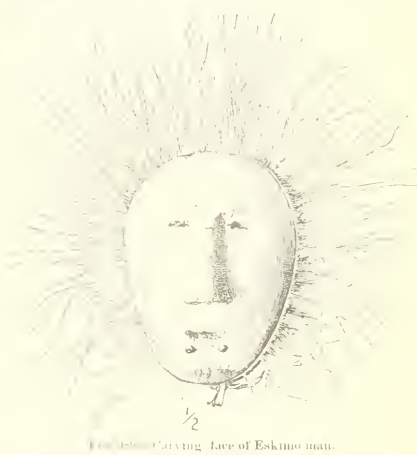
: an oblong piece of loard, that and rough ot the batk, romghly beveled from the mildle to earh side in firont. One ald is surmounted by a rather rutely carred humath hearl, with the fitatures in relief and the eyes and mouth incised. The eyebrows are marked out with blark lead, and there is a longitndinal linest black learldown the mithle of the fiont.

Fig. 359 (No. $897 \pm 4$ [11:3] from Nnwork) is

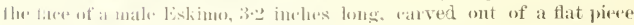

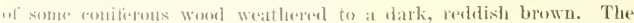

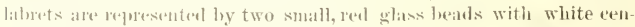
tress, fistemed on in the proper position with

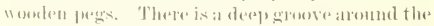

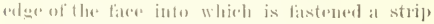
of yollowish wolliskin walh long ful to represent the trimming anomal the hered of tha, jacket. This spereimen wats malde tor sille, and the carving is

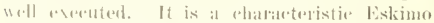
ficer, and wond pass for a jortrait of A paidyaio,

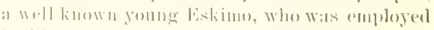
hy lientl. liay as a guthe and hututele.

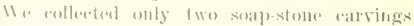

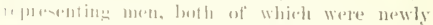

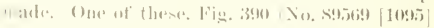

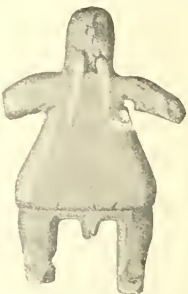

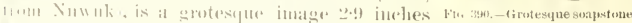

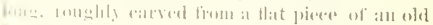
inage, "watrus min." fartap or pot. This is almost exastly the tom in which the Eskimo, coprevally the children, nsually draw a man. The writer's portrait 


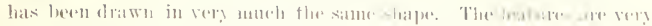

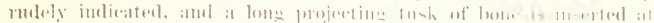

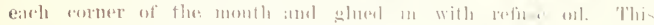

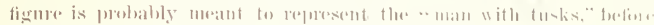

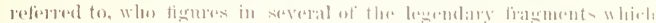
we obtainul.

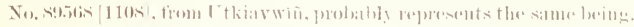

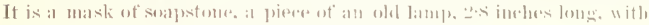

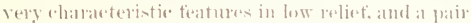

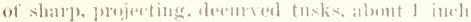

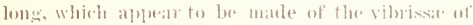
the walrus. The batek ol the mask is romghly hol

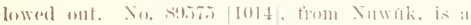
rlumsy and randessly malle image of a man. 3.1

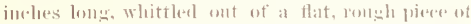
soft, white gypsum. The arms are shest and rlum sy and the lexwistrald ling, and there is a large allipe tiral hole through the midalle of the borly. The features are indirated only by digging little "avit ios (o) the eyes, nostrils, and month. This and two other images of the same material, at hedre explatly

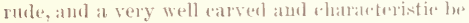
lowa, wore made by the ingentoms young native, Yaksa, previonsly mentioned.

The best bone figure of a man is shown in Fig.3:1

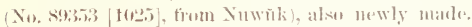
This is an inage, in inelese lome, of the giant "Kikí

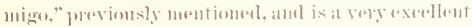
piere of workmamshije. The material is ratlece vas-

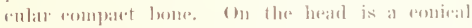

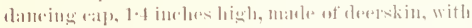
the tlesh side ont, and wolned with red oxeller, with

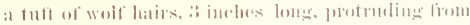

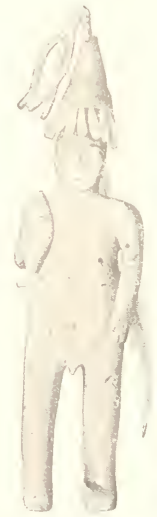

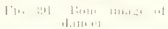

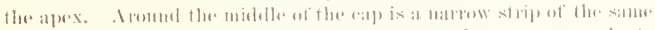

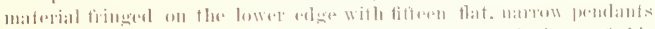

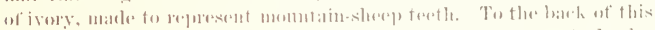

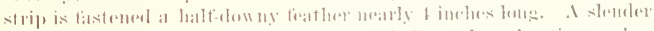
woolen stiels is stuels inte the strip lehime, so that the tip reaches

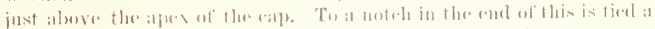

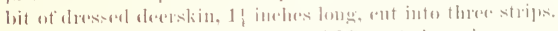

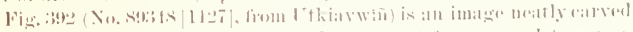

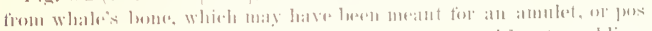

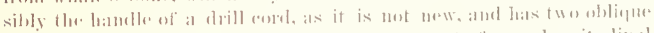

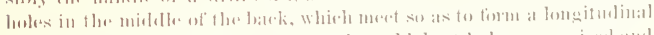

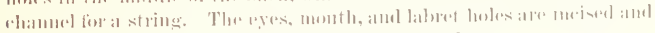
lilled with blark dirt. The total length is 303 inelues. 
1.

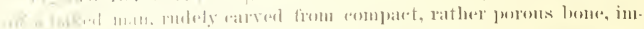

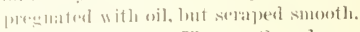

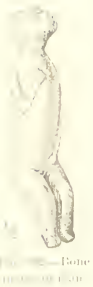

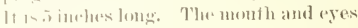

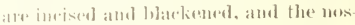
trik simply tored out.

The ivory carvings representiug lu man figmes ate all of r:ather rude workm:1nship. No. scling |1100|, Fig. 3:4, toon Nuwhe, is a tolerably gousl tigne, $3 \because$ inches long, of at silting man lowh ing up Jis hands lwere his fince. This spu+imen is old and is mate of wallows ivory bellow from age amb ail. So.

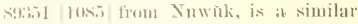

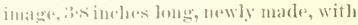

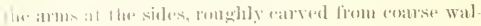
fas isory. Tha eyos and month ane incised and

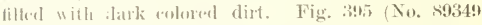
!) 1 , thom Xnwitk is an old inago made of yellow nalous ivery and chosely resembling the bone image

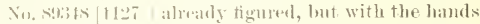
hy the sides. It is $2-7$ inches long and has a string 4

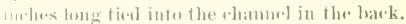

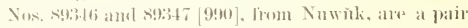

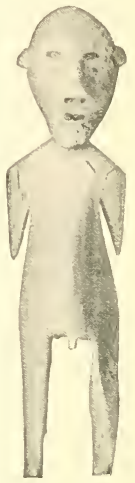

Fin. 393. - Grotesque bone image. of little men, standing erect, abont '2 inches high, rather ronghly arverl, of slightly yellow walrus ivory. Both have

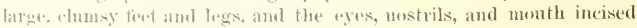

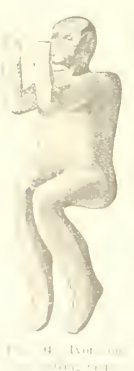
and fillerl in as nsnal with dark colomed lirt. The arms are in high relief. No. s!9:3ti [9906] dhas his hands claspeed in liont of him, while No. S!1347 [990) ] lats

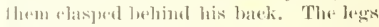
ut the latter are exarated on the inside as it to fit it mow the end of some olyject. It is more probable, however, that this imalge was arroul lirom the foreshatt of a seal dart, and that the exravation is merely the slot in the cond of the latter. These two images are avidently modern, lunt do not apjear lineslily made. No.

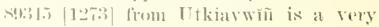
rule intage, 204 ineluse lomg, having at

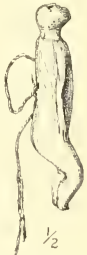

FI0. 395.-Hn man figure cierred from walne ivory. very small heat and no arms. It is somewhat dis.

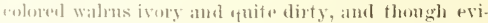

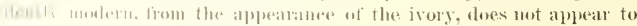




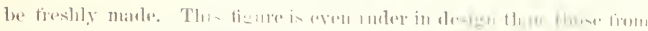

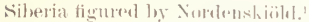

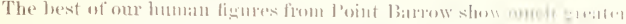

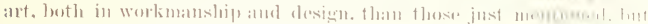
ralu not eompare witli the oleswat tigures in the muxemun limm tha" more soutlerm parts of Aliskis. The four remaining ivory sarvily represent the limman face alome.

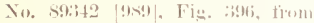
Nuwuke, is a thick plece of wallus

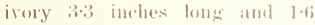
wide, caves into three limman

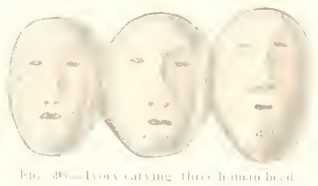

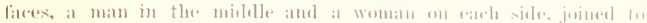

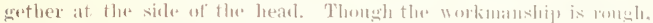

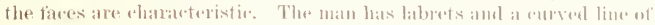

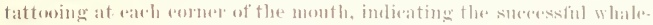

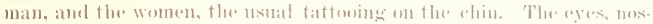

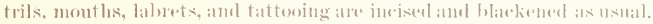

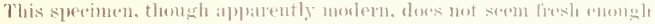
to have bers mate for sale. The seller alled it "a matu and his two wives" withont giving then any names. It may be intended as a jure. trat of some celelorated whaleman.

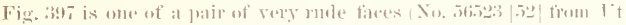

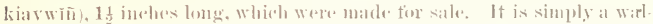

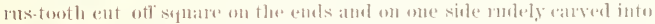

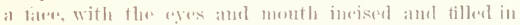

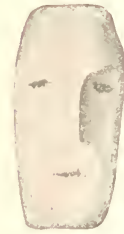

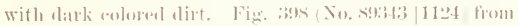

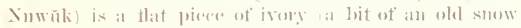

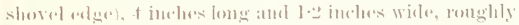

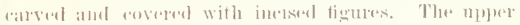
relge is arved into tive hearls: First, a mole luarls

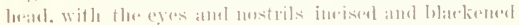

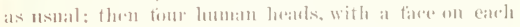
sidle. Tla. lront fieces hare the noses and brows in low reliel and the eyes, mostrils, and montles ineised and blackened: the batek ones are that. with the last throe

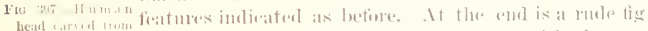

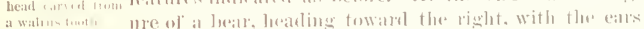

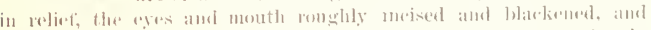

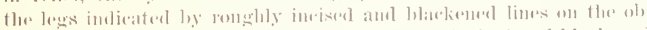

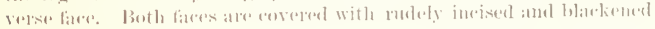
lines.

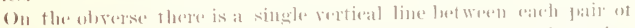

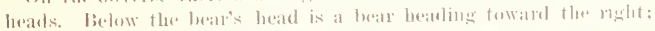

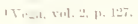




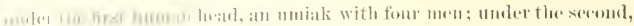

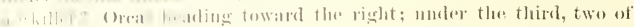
the motal mencentumalized whalese tails suspended from a coss-line;

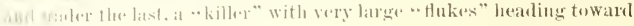
ther lintt.

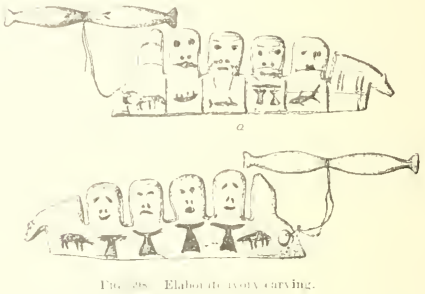

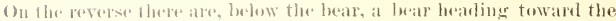
ucht, bolow and of the luman heals a whate's tatil with the flukes mp,

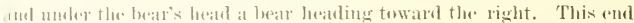
(s pertorater with a large romel hole, into which is knotted a bit of

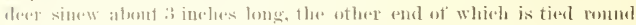
the junction of two little bowhead whales, each alont I ineh long and

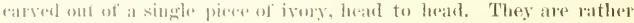

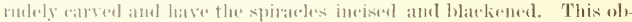
jowt appeats treshly mate, hut perhaps commenorates the exploits of

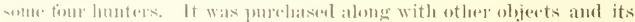
history was net learued at the tine.

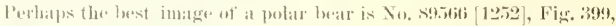

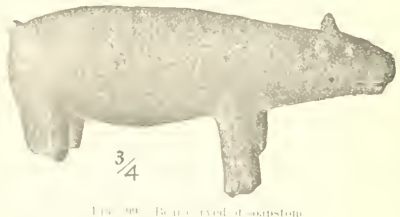
from litklatwiñ, which is quiteranacteristic. It weresents the bear stand. ingamel was earved out of sutt, gray seapsotome with a kuite, and finished on smootluly with a file. It is 4 inches $10 \mathrm{ng}$. No.

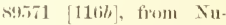
whik, is a rery rude that soapstone bear, $1 \cdot 9 \mathrm{in}$ -

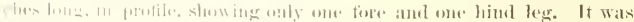

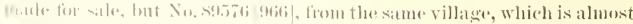

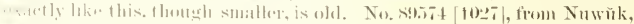

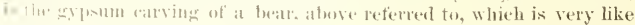




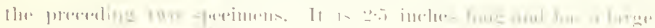

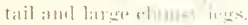

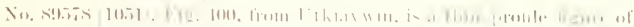

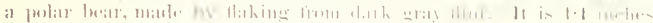

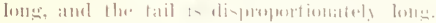

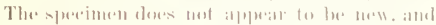

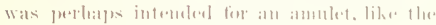
flint whales allomly mentioned.

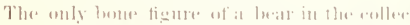

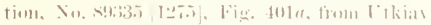
wiï, is very erule. It has a very lomg, slim lexly

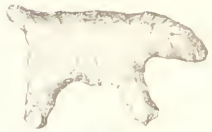

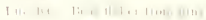

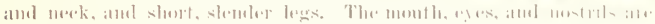

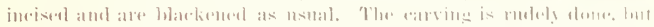

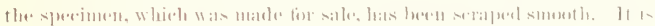

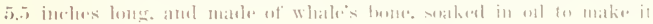

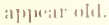

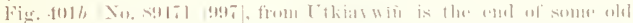

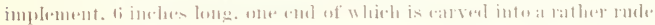

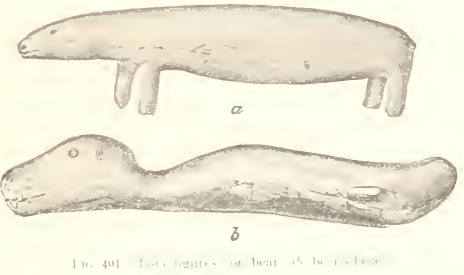

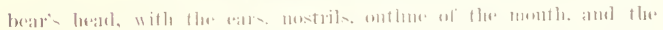

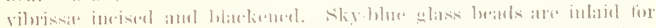

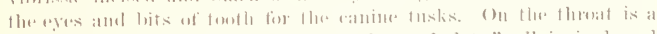

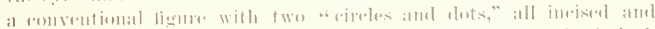

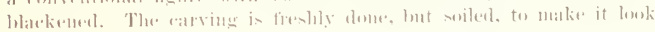
nit.

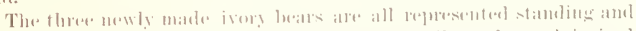

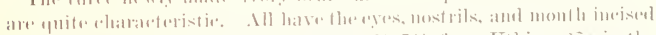

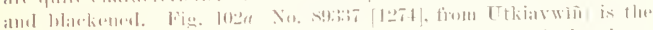

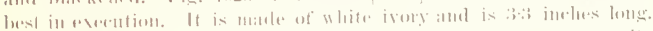

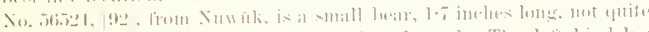

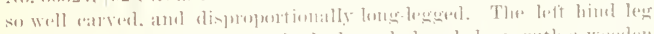

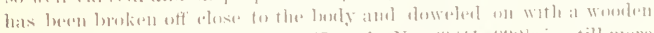

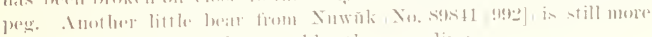

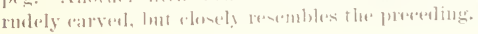




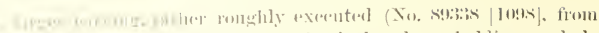

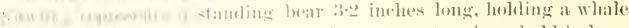

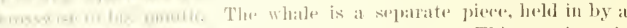

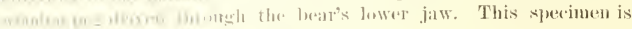

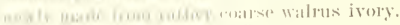

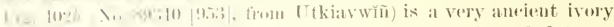

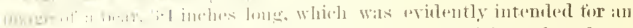

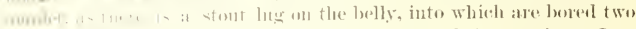

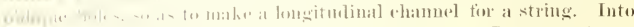

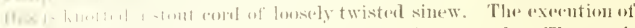

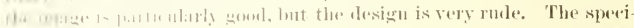

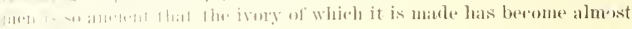
$1,1.11 k$.

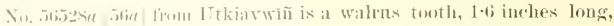

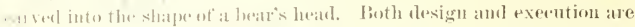
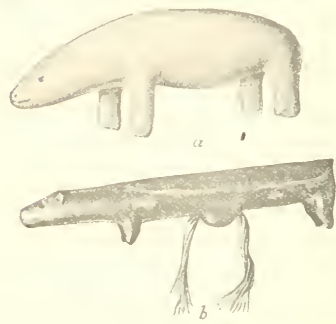
very rute. light blue glasis beads are inlaid fior the eyes, and the nostrils and ontline of the mouth are indived and filleal in with black dirt. It was male for sake. I still mone rnde arving, also marle for sale, is No, insost from ltkiarwin. which is an old and weathered eanime tooth of the polar bear, with the point freshly whitfled sis as to look semething like a bear's head. Two sky-lilue glass beats are inlaid to rapresent the eyes and one for the nose, and the montl is incised and blackened.

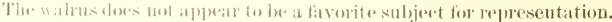

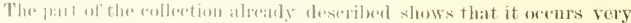

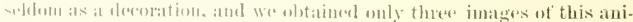
mal, one in soatpstome and two in ivory, all small and rery rucle, both in design and exention. They arwall newly male. The best image

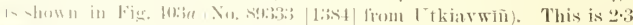

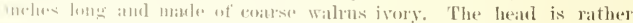

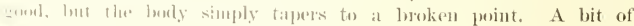

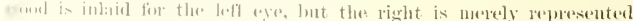
tis a heole.

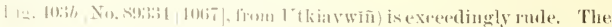

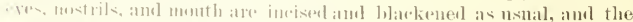

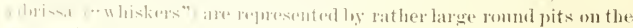

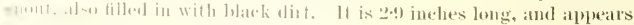




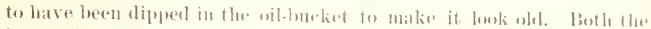
images bear a strong re semblames to the rute. earvings of walrusus from siberiat figmeral by Nordenskïild. No. s!5io $[1271]$ from $\mathrm{Nu}$ whk is of soipstone, "2 inchess long, with tuskis madely earved from wal rus ivory. The hesal is but roughly indicated. while the borly is shapunl like a sluer, and is biticl at the pointed end to represent the hind flippers. The eyes and mo trik are rughly incisted.

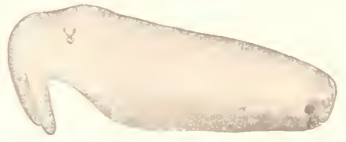

$Q$

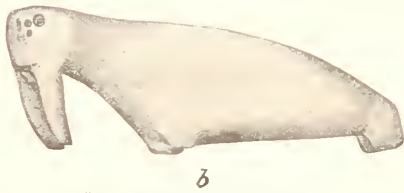

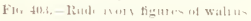

The seal, on the other hand, is a favorite object for antistic represen. tation. It is seen often, as alreally deseribed, as a decoration on various implements, espesially the dray lines, enerally in a very eharacetreristic shape, and the fis seal images in the esllection are excellent in design and execution. Almost all are decidedly superior to those from

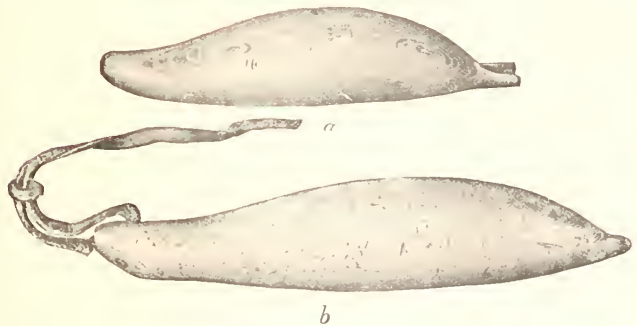

Fifi for Inares of stal-word and loum-

Pitlekaj, figured by Nordenskiöld. All are newly mate axept No.

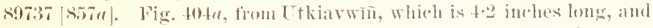
made of spruce, very old, weathered, and discolored with dirt and grease. It is nicely earved and soraped smooth, and is very gond in its gemeral proportions, though the details are not rejresented as in the other images. 
The fan a

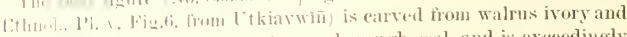

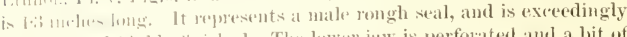
atconsate and highly finsherl. The lower jaw is perforated and a bit of

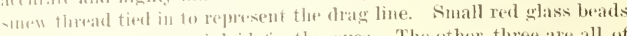
with white renters atre inlaid tor the eyes. The other three are all of

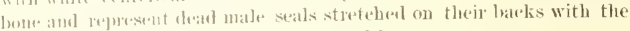
dran line in their jaw as they are dragged home.

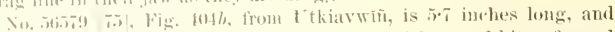

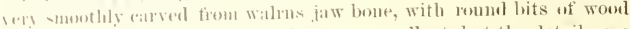
inlaid for the eyes. The juregertions are excellent, but the retails are not strongly hought ont. This sperines is a little older than the rest, and mat have bern an amulet for gowd luek in seal ratehing. The other two are of enupart white bone. jerlatss that of the reindeer.

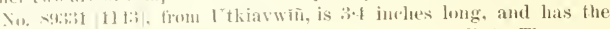
matst and bated flattrued and the flipurers in high relief. The anus,

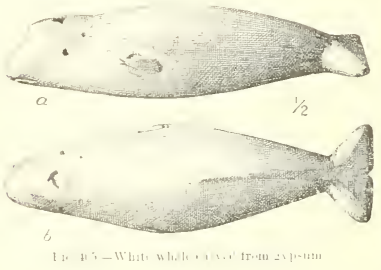
genital opening, and eyes are incised, the latter two fillerl in, as usual, with blark dirt. The drag line is of sinew bricl and has au ivory evlinder slipped over it.

Yo. s!ass $[1167]$, from l'tkiarwiin, is tlac porest in design. It is 5.6inelees fong and has the neek beut up as in dragging. The liuk of a fieshly eaught seal 1. always somewhat thattened by dragring it over the ice, and this lattening is very muld exagereated in this carving by the natural shape of the lome. The fore Hippers are in ligh relief, with thee

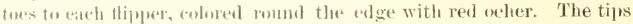
of the limel Hipurers an jeined together, and each has only two toes.

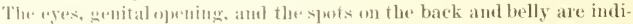
mated hy shallow romed pits colored with ret ercher. The drag line is a douthe lut of sinew braisl, which luas on it two ivory eylinders, one ornatumented witls: 11 incised pattern.

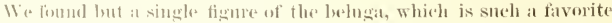
subjeet the liskima antists father south. This is the gypsum carving

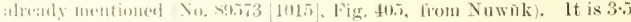
mo-he- long and is very ehatrateristic, thungh rather short in proportion to its girth. It was neatly arred with a kuite.

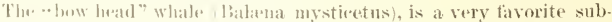

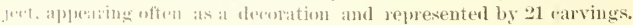
There of these ane of worl, very mued, resembling in desinn and exe-

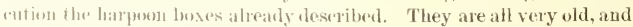




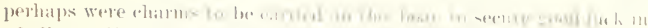

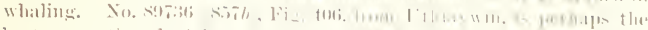

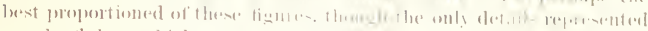

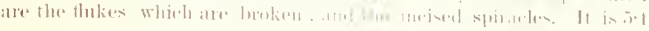

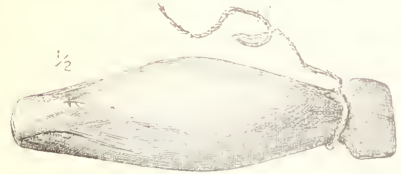

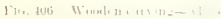

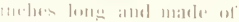
mbuest blach bis dirt. *rease. amol wathering. I long string of sinew liraicl is tienl roumel the...smiall."

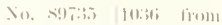
1 thiat 11 in, is alse a ratloer well propertioned tigure. laule in ("Veroltim, with no

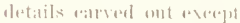

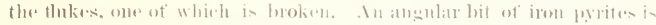

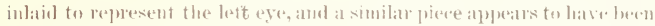
lost from the right eye. The anns is repuesented ly a light bou ghass bead inlaid in the belly. It is s.s inches long and made of sutt wool, probably cottonwond, weathered and stained to a dark torown. It is

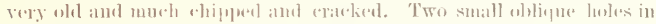
the middle of the batek make al transverse clammel tor a striby. This

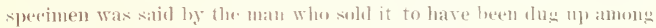

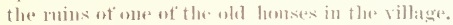

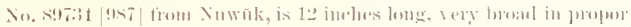

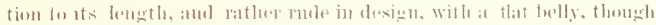

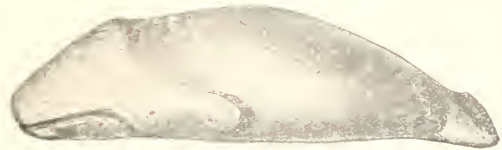

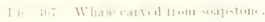

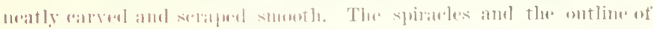

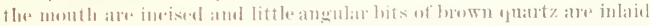

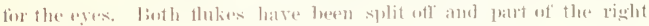
fluke las been fastened on awain with at single wowlen tresmatil. It is of

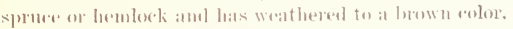

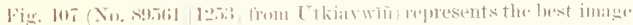

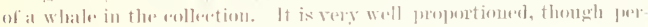

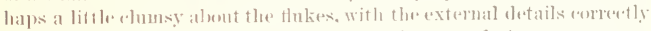

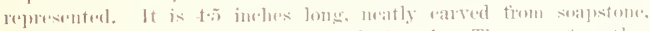

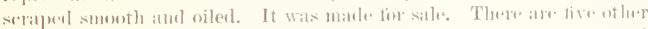

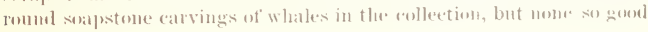


As the cxeept a little one from Xnw Which is almost an enat miniature of the precesling. This sperimen is

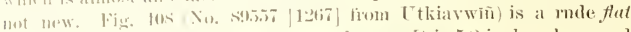

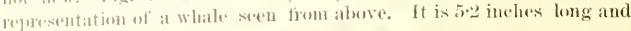

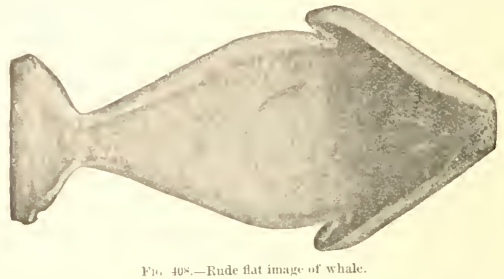

romphly whitted ont of the lootom of an old stone pot. The flippers are large and dumsy, and the spiracles slightly ineised. The speeimen

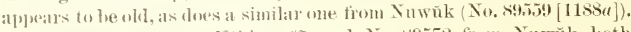

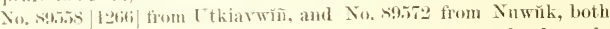

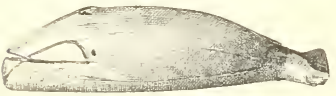

Fis. 409.-Ivory image of whal flat images, are carelessly made for sale, The latter is simply a representation in soapstone uf' the conventional "whate's tail" with the "small" ent off to an angular point. No. \$9325 1160] from Utkiavwhัn is a alumsy, hroul whale with a flat belly, 1-1 inches long, freshly earred from whale's bone, and soaked in oil to make it look old. The eyes, spinates, and ontline of the month are incised and filled in with dark oil leos.

Xone of the ivory carvings of whales lave any special artistic merit.

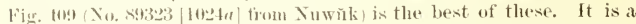
litte better in lesign and exention than the preceding, which it resembles comsilerably. It is the temale of a pair of little whales mate of old brown wallus ivory, which is much ratked. The male differs from the timale only in the shaje of the external sexual orgatus, the male having a littlo romel pit and the temale a longe sulens. This, as well as the eyes, spiractes.s amel ontline of the memth, is ine ised

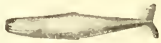
Fifi. 410.-Ivory image of and filled in with dark coloned dirt. The fomale is $3 \cdot 1$ inclues long, the

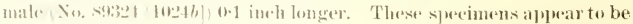
unite ancient.

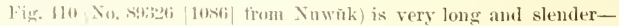
1.3 inches lomg and only 0.7 inch wide-with the belly perfectly flat, 


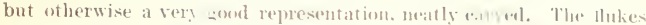
in particular are es[recially well done. and the thiphers are in high reliet. The eyes, the spimales, and the ont line of the mouth are incised and the first blarkened. The materlal is it rather poor quality of walrus ivory. about halt "eore." The spresinen was male for sale, No. \$13:2 9941 from Nuwuk was alsol mate tion sale. It is a little whale $1 \cdot 6$ inches long. rudely carved in willrus irory.

Fig. 411 No. Jifill! bit from Utkiawin represents a pair of little whales, each carved trom a wallums tooth, which probably served fir

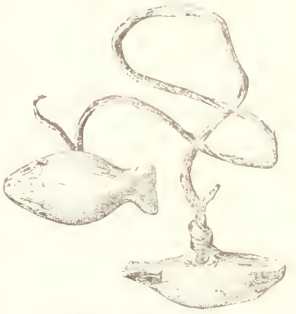

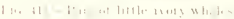
buttons or toggles of some sort, thomgh 1 do not recollect eser sering surh objects in use. The belly of each is that and has in the middle a

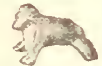

11. 412. - Sio:t stone indige of insterinary ani mall stont lug perforated with a transverae eye. and they are tied together hy a pixe ot thong about 11 inches long. They ane quite well alesigned and exeented, lnt rather "stumpy" in ontline. with the ontline of the moutls and the spinarles inrised and blarkened, and little ronnd bits of teoth inlatid for eres. In the middle of the bate ot' earll was inlaid a small lulue glass bead, which still re mains in one of them. They are old and dirty and somewhat ehipled about the flukes.

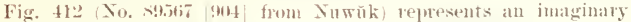
yualruped 2.5 inrhes long. with a short, thiek body and legs, no newh, and a luman heat, with the eyes and mouth incisclel. It is roushly ariod trom liglit gray suapstome, aurl ground liret ty smooth. This figure is not new, and has

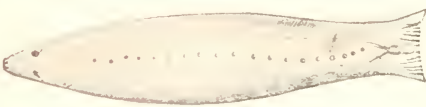

$a$

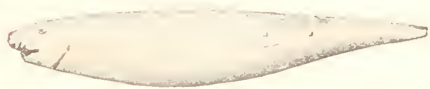

6

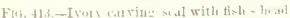
probably ennerted with it some story which we rlid not sureded in lesuruing. The seller

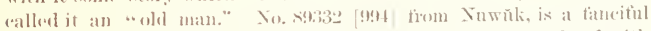
monster, 4. inches lone, carverl in ivory. lt has a human luad with the tuskis of a wallus, the lusly, tail, and Hipleers ot a seal, with lomman ams. The hands, each of which las tom tingers, dasple some round object against the belly. It is not old. lont alyarently was mot made 


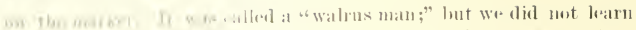

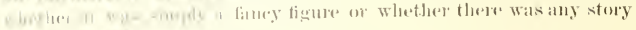

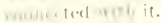

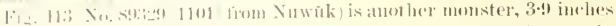

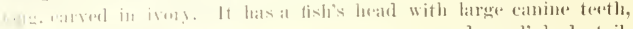

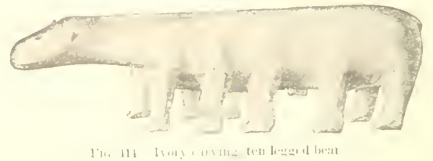
and a seal's lody, tail, and hind flipurers. The eyes, nostrils, yill slits, the outlines of the tail, ant the tors, of which there ar" six on each flip, per, are incised and blackened. A row of wuetan small rouml pits, tilled witlo dark colored dirt rums nearly -traight trom the najes fo the tail.

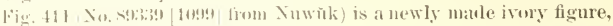
which is interesting fiom its resemblanese to one of the falmolous animals which figure in the (imeonlauml legends. It is 4 inches lomg and repre. snts a bong-necked bear with ten legs, an animal which the maker gave us to uuclerstanel haw onue beren seent at Point barrow. The resemblane of this ani mat to the ". kiliopalk" or * kiliflak" of the firmenland stories, which is deseribed ats "an ani. mal with six or even fen live" is ruite strikimo.

Fig. 41.i (No, s97:2: |lont fom Suwnk, is another repessentation ot the wiant who lockles a whale in tarle lauml. 11. Was ralled in this instamese " Kaibasu," and mot "Kikimi-

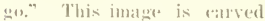
trom very old jalle hown wal. mos ivery, anel is 2:3 inches holl. I transierse incisul

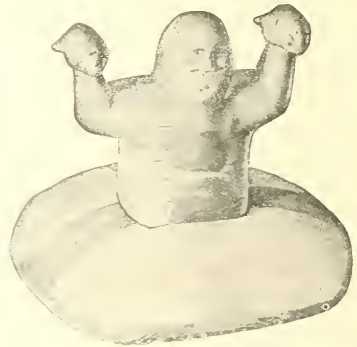

Wh: +15 - trory carving ti.unt holding whaleg.

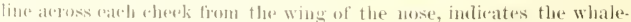

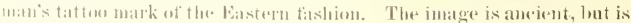

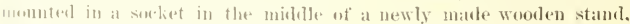

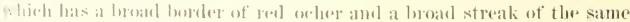
paunt alomg rath dlametrer.

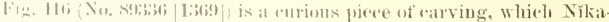

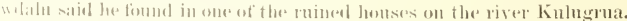




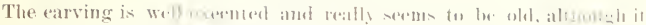

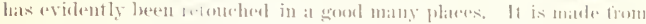

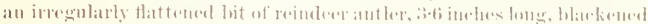
ly the wather on the that surfares. alut represents an andmal w ith foum legs, whith aly

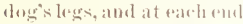
what appears to lo allog's heade. The of these is smaller than the other amb butls lave the airs in re liefi, and the eyes, mostrils. aud outlines of the mouth incisel.

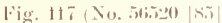
from Nuwink is a fanci fial ubject made solely for

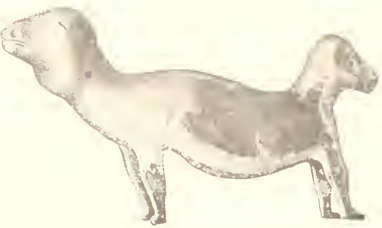

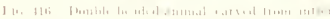

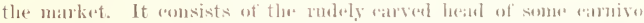
rous animal, mate of irory, and 20 e inches lomg, titted to the broad

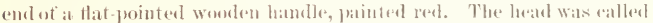

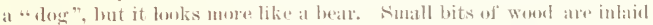
for the eres, and the ontline of the mouth is deeply incised and colored with red aeler, having bits of white ivory inhad to represent the anime tretl. The ears, nostrik, vibristat, and hairs on the muyle are indieated by blackened incisions. There is an erwamented onllat romed
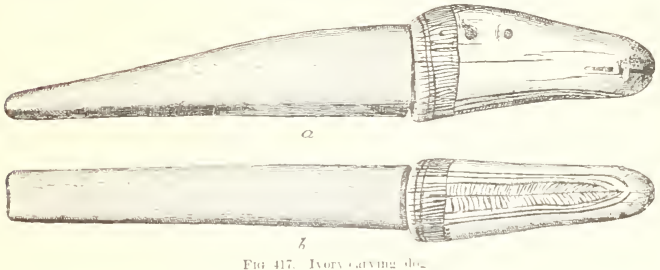

the neek, to which is joined a consentional pattern of triangular form on the throat, and a somewhat similar pattern on the top of the latad betwerll the cars.

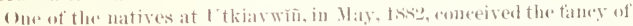
smosthiug otf the tip of a wallus tosk into the shape of a pyamid, surmounted by a little conisal cal and ornamenting it with incisod tignes. which le colored with red oxleer. It appears to base been purely an individnal timey, at it has no utility, nor ame such ohjects made by the Eskimo elsewhere, as far as I know. Having suceeded in timding a sale for this object, either he or one of his tiends, I do not 
mon recollent which, macte another, which was bromght over for sale abmet ton days later. We salw no others afterwards.

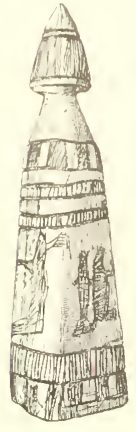

a

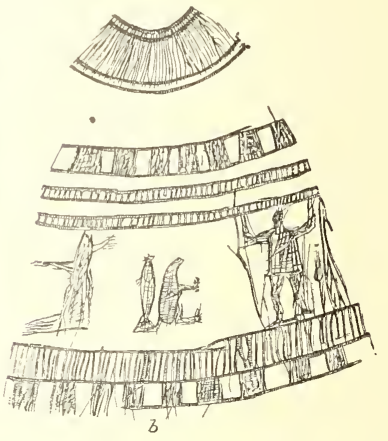

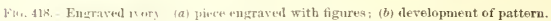

Fig. 41 sis (pattern developed in Fig. $418 b$, No. 56530 [200]) represents the first of these. It is made of solid white walrus ivory. The work-
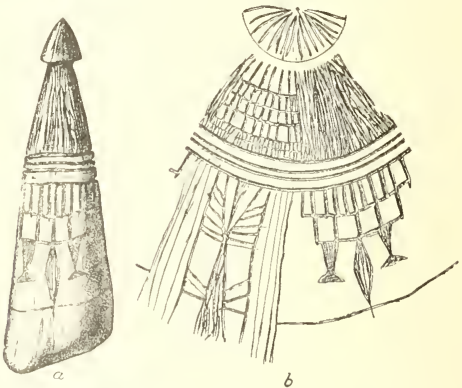

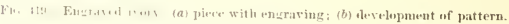

matmship is quite rude, and the eale has been broken oft and neatly fastened on with a worken dowel. The other, Fig. $419 a, 419 b$ (No. 54529 ) 25 ) is $3 \cdot 7$ inelhes long. 


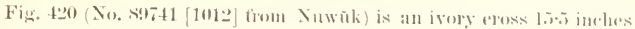
long. The eross is ormamented by incised rings and efols colored

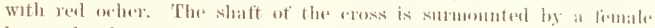

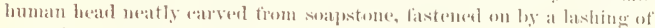
smew lorad, which passes thromgh a transwerse hole in the lawat and

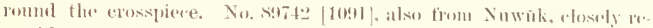
sembles the preceding, but is slightly shorter and has a four-sirled shatt. The heat, more. over, which is marte of hene, represents a man, as is sleow by the little pits, which indirate the labrets. The eheekis and crown of the heat are eolores slightly real with red ocher.

The ingenious Yoiksat, so often mentionsel. marle the tirst image and bought it down for sale. All he conld or would tell us about it was that it wats " -tunat'ktîp kunj'a," ".A kunj'a (jargon for woman) of solustome." The sur. ressful sale of this tirst eross encouraged him to make the serent, lnt we saw no others be fore or atter. (Other natives who siw these objects only langhed. The whole may be simply a faneitil doll, perhaps meant tor a rarieature, the shaft representing the body, and the crosspiece the outstretehed arms. The object is very suggestive of a erucifix, and there is a bare possibility that the maker may have seen something of the sort in the possession of some of the eastern natives who have been visited by a missionary of the Roman Catholic Chureh (Father Petitot).

Ender the bead of works of art may property be includerl No. S9s:3 [11:30], from Utkiaswiñ. This is the skeleton of the jaws of a polar bear, rut off just back of the nose, neatly sewed up in a piere of seatskin with the hair ont, so as to leave uneovered ouly the tips of the jaw. bontes and the canine teetl. This specinem was put up ly the same quirk-witted yome native after his removal from Nuwăk to litki avwion, evidently in initation of the work of peparing spesimens of natural bistory, which he had sean dome at the station. For the same

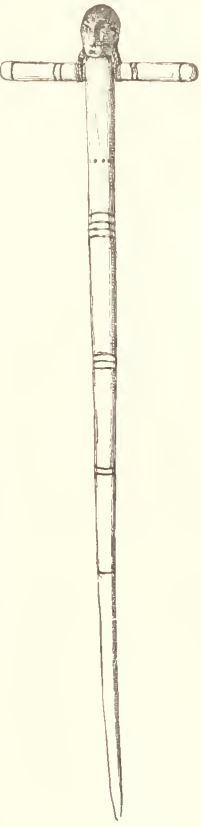

Fui, $420,-1$ vory itill. reasem he thied and earefully preserved in a litfle box whittled ont of a block of woud and tiod up with sinew a littl fires-watel soulpin (cottus puabricornis), whieh he had camght at Kulugrua (No. s95336 $[1145 \mid)$. 


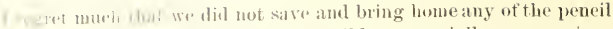

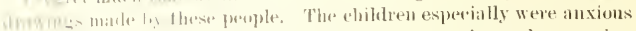

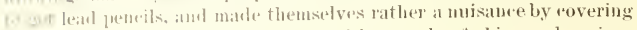
fow a ambel walls of the observatory with serawlis of ships and various

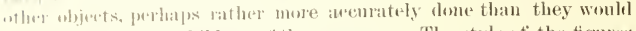

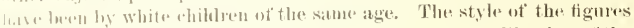

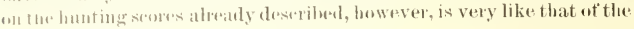
perteil dritwiugs,

DOMEXTI LFE.

Horiage, - Is fat as we could learn, the marriage relation was en-

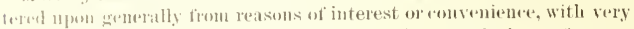

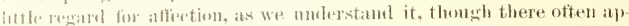

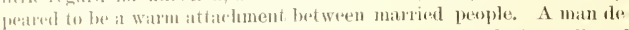
sires (o) obtain at wite who will perform her homsehohl duties well and lithlubly, and will he at the same time an agreable companion, while le ofterl plans to mary inter a rich or influential family. The womam, on the of her hand. appears to desire a hosband who is industrioms and at guod hunter. Thare were, nevertheless, some indieations that real low mate hes sometimes took plax. Marriages are usually arranged by the panents of the contrating parties, sometimes when the principats are mere chilhen. Wo knew of one valse when a young man of about twenty twa offered himself as the prespertive husband of a girl of eight or ton, when she shenld reath a marriageable age. This practice of child leetrothal serms to be prationtly universal among the Eskimo ererywhere:

1). Simpson, in describing the marriage eustoms at Point Barrow, says:

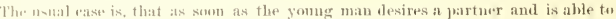

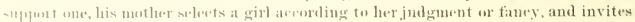
l., I the hat, where she tirst takes the pat of' at "kivgak" or servant, having all

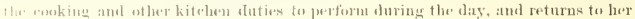

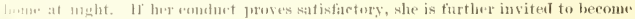
maแlu. of the fimily.

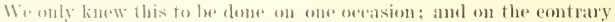

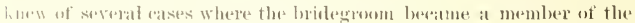
witio tiunily.

()ne fouth, who lawd had his lips pierced tior the labrets just previotsly to on arrival, was, we sum learned, betrothed to a young girl

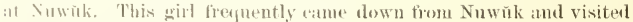
her lover's fimily, staying several days at a time, but we conld uot

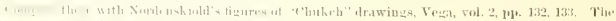

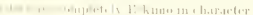

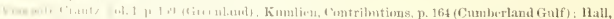

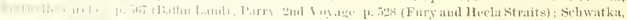

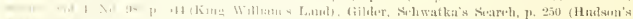

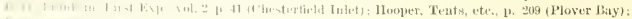

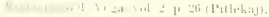




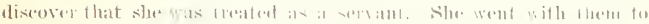

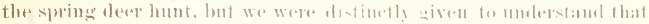

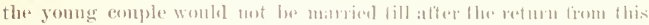

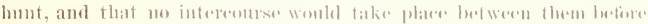

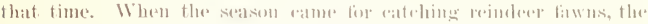

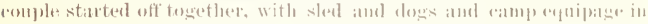

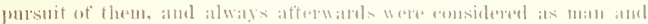
wite.

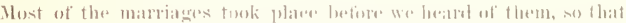

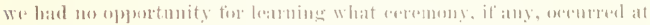

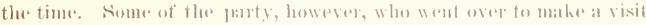

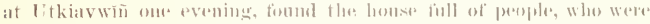
singing and dancing, and were teshl that this was to deletuate the mat

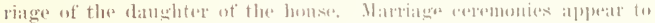

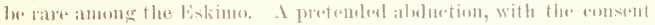

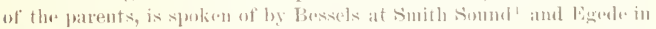

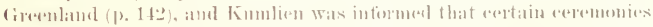

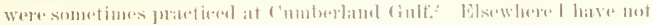

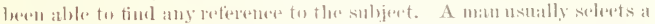

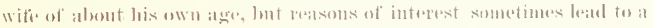

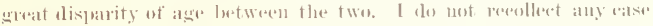
where all old man hat a wite very mueh younger than himself, lut wo knew of several men who had marrienl widews or divoreed women whl

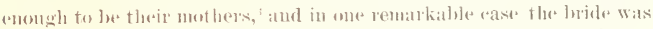
a girl of sixteren of seventern, and the hushand a lad apjearently not

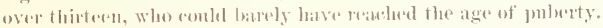

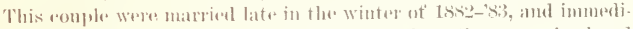
atcly started off to the rivers, deer lout ing, where the young husband

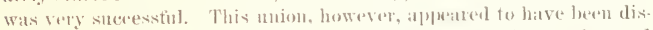

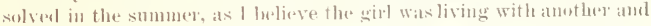

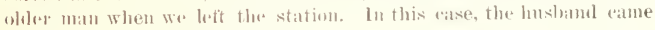
to live with the with's limily.

As is the rase with most liskimm, most of the mone eontent them.

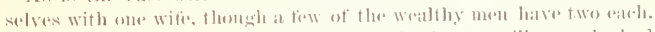

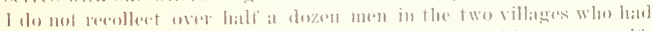

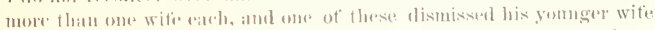
during our staty. W\% never beard of a catse of more than two wives.

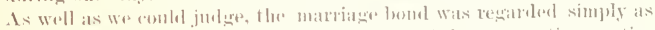

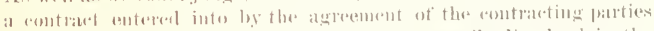
and, withont any fonmal aemenomy of divorer, astily dissolved in the

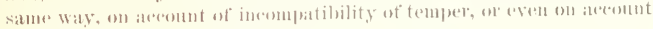
of temporany disagerements.

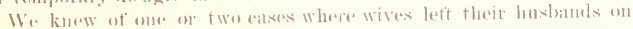

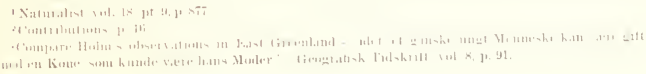




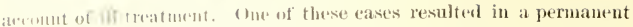

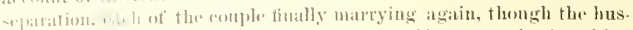
batul tor a long time tried his best to get his wite to come back to him. In another casc, where the wite alter reneiving a beating ran away to Xum nk. amel, as wo wore tohl, namried another man, her first husband tollewal her in a day or two and either by violence or persuasion made het come batk with him. They afterwards appeared to live together on perteretly groud terms.

() the other lamul, we know of several cases where men discarded wise who wore msitistactory or mate themselves disagreable. For instane 1 he youmger Tunazn, when we first made his anduaintance, was matrien to a widow wery much his senior, who seemed to have a disagrombli and qumbloms temper, so that we were not surpised to hear in the spring of listo that they were separated and Tunazu married to a young girl. His serond matrimonial venture was mo more successful thatu his first, tor his yomm wifis proved to be a great talker. As he tohi ns: ". She talked all the time, so that he comblet eat and condel turt sleepe." So he distathed ber, and when we lelt the station he had beral tor some time married to another old widow.

In the atse above mentioned, where the man with two wives diseardwh the youmger of thm, the reasen he assigned was that she was lazy, would not make her own elothes, and was disobedient to the older wile, to whom he Was mueh attathed. Is he saik, Kakasnua (the older wile) fold her, ". (iive me a drink of water," and she said, "No!" so KakaEuna sail, "(io!" and she went. He did not show any partieular eonerin abont it.

1): Simpson says, "A great many "hanges take place before a permathent "hoice is made;" and again, "A union once apparently settled betworn parties growu up is rarely dissolved." And this agrees with om experienes. The same appears to have been the ease in Greenlamb. frante" says, "Sitch quatrels and separations only happen between penple. in their younger years, who have married without due lorethought. Thw wher they grow, the nore they love one anothere"

Fasy and uneremonions divore appears to be the usual custom among bikino generatly, and the divoreal parties are always fiee to matry again. The only writer whe mentions any etremony of divore

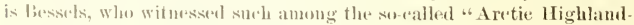
pre" of smith somul (Naturalist, vol. Is, pt. 9, p. sit). 11. Simp.

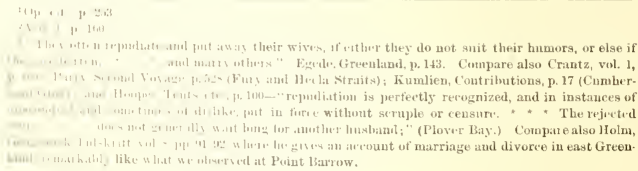


son, in the paragraph refered to alosere, says flat ".I man of mature age chooses a wile for himselt and fertehes her home, fropuently, to all appearance, mueh agabust her will." The only rase of the kind which

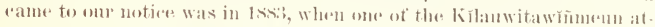
trmpted ly blows to eorere. Adwio'na, an lotkiarwin girl, to live with him, lut was moneressful.

A curions anstom, not peenliar to these peoples, is the habit of ex changing wives temporarily. For instance, one mat of onr arequaintance plamed to go to the rivers dees huntiug in the summer of lss", and borrowed bis romsin's wife for the expedition, as she was a good slot and a grool hand at drer hunting, while his own wif. wont with his cousin on the trading expertition to the rastwand. On their return the wives went back to their respertive hinsbants.

The eomples sometimes timd themselves lutter plasised with their new mates than with the former assoriation, in which ease the raclatenge is made permanent. This happened one in Jtkiavwiñ to mur mertain knowledge. This custom has ben olserved at Fury and Hecla straits, Comberland coult, and in the region aromel liepulse lasy, where it seems to be arriol to an extreme.

Acoording to filder ${ }^{3}$ it is a 11 sual thing amomer friends in that region to exchange wives for a week or two abont exery two montlis. Among the (iverulauler's the only custom of the kimb mentioned is the temporary exehamge of wives at rertain testivals deseribed by Egede.

Ilolm also deseribes "the game of putting out the lamps," or "ahanesing wives," as a common winter sport in East (inrentand. IIr also, however, speaks of the temporary exr hamge of wives among these poples muth as deseribed akewlere. 5

I an informed ly some of the whalemen who winter in the neighborlood of liepulse bay, that at rertain times there is a general exelumge of wives thomghont the village, each woman passing from man to man till she has been thromgle the hamds of all, and finally returns to lor lusband. All these casts seem to me to indicate that the Eskimo have not wholly emerged firom the state ealled communal marriage, in whith each woman is considered as the wite of erery man in the comnumity.

Standing and treatment of women.-The women appear to stand on a foution of perfeet equality with the men both in the family and in the rommmity. The witio is the comstant am trusted comprnion of the man in everything exept the hunt, and her opinion is somght in every bargain or of here inportant unclertaking."

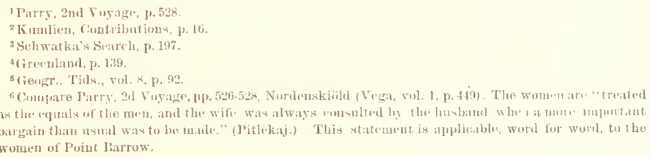


1). Simponats leseription' of the standings of the women at Point

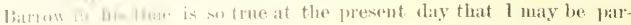
flomel ter youlang the whele of it:

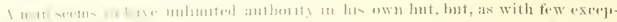

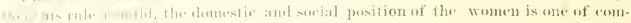

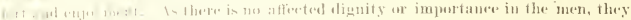

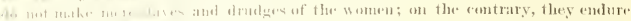

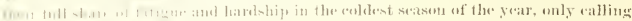

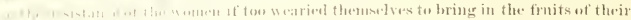

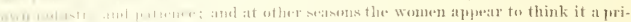

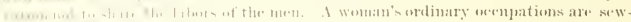

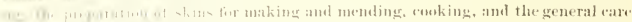

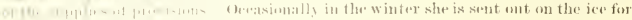

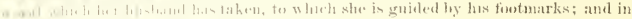

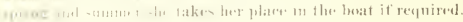

The statement in the lirst sentene that the hoshand's rule is mild is iardly comsistent. with that on the following page that "obedience serems to be the great virtue reguired, and is enfored by blows when neessary, until the man's anthurity is estallished." Aceroding to om experione the tirst statement is marre the truth. We heard of tew ratses of whi-luating, and those ehirfly anong the foumger men. Two l,others, who habitually ill-treated their wives, were looked upen with distirom, by some of om liremls at least. We leard of one rase where a stalwart with lumeal the tables on her hushatud who attempted to ahnse hor, giving hin a thorough beating and then laving his house.

Wite- frating was not nucommon anomg the Grenlanders. ${ }^{2}$ We dicl not leam whother a woman lnomght anything like a dowry,

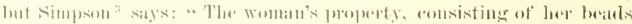

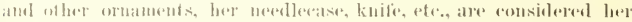
own: and if it separation takes platere the elothes and poresents are retmond and she merely takes away with lier whatever she broughte"

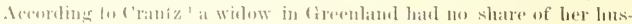
hatad's property, but owns only what she bought with hes, and I am inclined to believe that this is the case at leome barrow.

One whow of my anduantane, who alpleared to have no relatives In the village, was reflued almost fo bergary, though her hushand had been quife wall-to-dlo. All his property and even his boy were faken from low by seme of the oflere natives. Wiulows who have well-to-do relalives, especially grown-up soms, are well taken are of and often marry again. Amording to Captain Parry, mupotonted widows were robbeal at J grlulik.

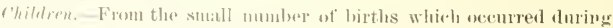
mur sil! al P'oinf Barmow, wo were alole to asertain little in regard to this subject. IThen a womaln is about to be enofined, she is isolated in

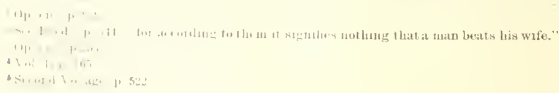


a little snow hut in winter or a little tent in summer, in which she lee mains for some time-just low long we were nuable to learn. C'aptain

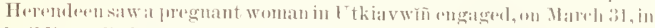
lonilding a little snow house, which she told him was meant for her end finement, but she had evidently somehow miscaldulated her time, as her child was not born till much later, when the people hat moved into the

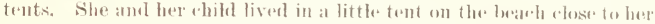
husband's tent, evidently in a sitting position, as the tent was not ladere enough for her to lie down in. Jer husband was dexirous of going oti

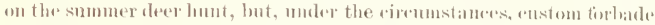
his leaving the neighbordood of the village till the iee at seat lonke ne.

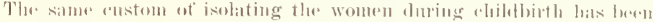

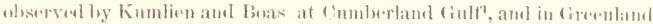
the motleer was not allowed to eat or drink in the ope+ll atr. ${ }^{2}$ lisiansky describes a similar practice in Kadiak in 1sus, and klutselatk also notes it :momgr the Aivillirnint.

The rustom of shutting up the mother and rhilet in a smow lomse m winter must loe very dimgerous to the intant, and, in fiet, the only shild that was born in winter doring our stay liver but a short time. fapt. Iloremberen visitul this tamily at Nownk shortly attere the death of

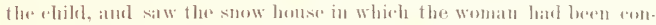
foned. Ile was alout to take at drink of water fom a dipler which he

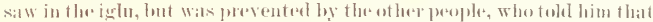
this forelonged to the nother and that it was " barl" for anyoure alse to use it. In Gerenlamel the mother latel a separate water pail. For a

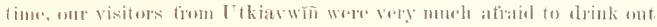

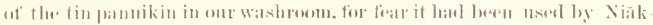
sira, a woman who land lesently sutlered a miscarriage. One man fold us

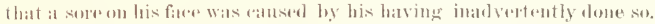
This same womatn was forbislden to go ont among the broken iere of the fand thes, during the spring suceseding her mistarriage, thongh she might go ont on the smooth shore ier. Hor hushand also was forbidelen to work with a hammer or arlz or to go seal-eatrhing for some time atter the mishat).

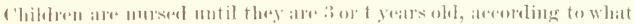
appears to be the nuiversal hal it among lekimo, and whele is prob. ably due, as generally supposed, to the firet that the animal tous on which the parents subsist is not tit for the nomishment of yomg e hil-

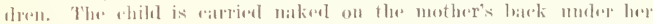

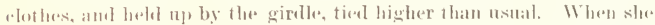
wislus to murse it, she loosens her girdle and ships it round to the breast

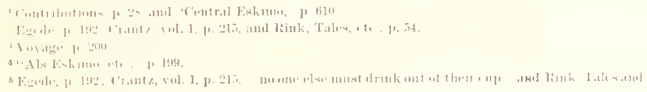


withent hinging 11 ont inte the aid. Ohildren are arried in this way until they are atble to watk and often later.

1 latere chikt sits astricte of his mother's back, with one leg under each of her andes, and hats a littlo suit of elothes in whieh he is dressed when the mother wishes to set lim down. When the rhild is awake, this louml is thrown back and the whihl raised quite high so that he looks orer his mother's shonkler, who then covers her leat with a cloth or something of the sort. The woman alplears to be very little incon-

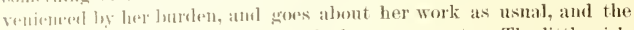

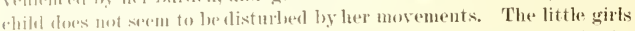
often art as muses and (arry the infants aroumd on their backs, in the same way. If is mo numsal sight to see a little girl of ten or twelve arrying a well gruwn, heary ehild in this way.

This costom an a very similar one seems to prevail among the Eskimo

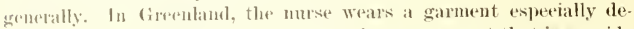
signed tor carrying the child, an amant, i. e., a garment that is so widle in the loak as to lould at ehild, which generally tumbles in it quite naliouland is atromtmodated with no other swadlling clothes or eradle. In last (ireenland, acoording to (atpt. Ifolm, "Siat lienge Bornene ere smati, bates de i det fri paia Moderems liyg."

Potitot's deseription of the methonl of earying the elildren in the Mawkenzie distrint is so naive that it deserves to be ynoted entire."

lans m.res qui allatitent portent me jauputte ample et serrée autour des reins par

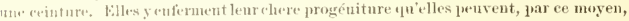
allititur satns J'ixpen.r a mu froid qui lui serait mortel. Ces jeunes enfants sont sans :uemu vitement jusqu it lige d'environ deux ans. Quant aux heongruites que ees petiles orétilures jenvent se permettre sur lo dos de leur mère, qui leur sert de calorifir. l'anum matcrnel, It minte chez tous les peuples, les eudure patiemment et avece imalithéroce.

At Fury and IJ (atried in the how, whith is made specially large on purpose, but sometimes also on the bakk, ats at Point Barrow. The enormous hoods of the Eskimo women in Labrador also served to hold the child. The sitne "ustom prevalis at cinmberland (imlf. ${ }^{5}$ In some loealities, for instance the north shore of Ifulson's straits, where the woman wear very long and loose borts, the children ane said to be earried in these. ${ }^{6}$ Franklin refersto the same ellstom "ast of the Mackenzie River." The Siberian chifhen, however, are dressed in regular swadding clothes of drerskin, with a sort of diaper of dried moss."

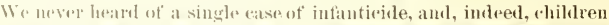

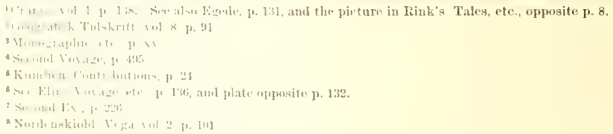




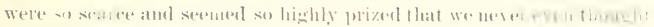

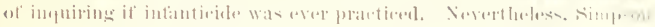

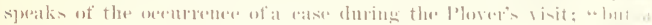

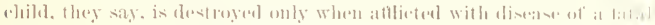

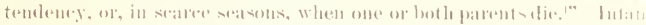

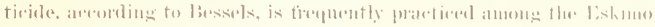

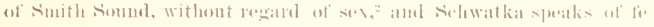

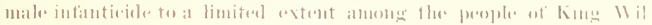
liamis bauml.

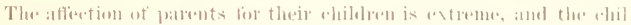

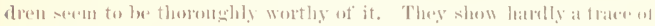
the fretrulness and petulane so rommon among civilized ehilhiren, and though indulges to an extreme extent are remalkably obedient. (orpe

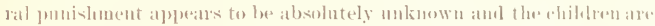

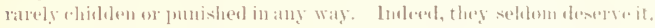

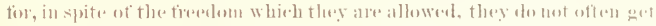

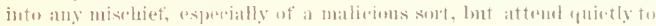
their owe affairs and their own ammsements.

The ofler ehildren take very gend rane of the smaller ones. It is an

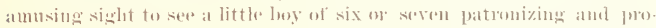

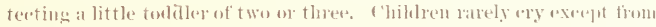
actual pain or teron, and eren then little mes ane remarkalsty fatient

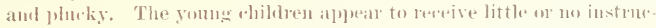

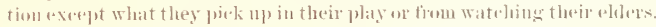

boys of six or seven begin to shoot small bitals and animals aml to lunt for birds' eggs, and when they reard the age of twelve or fourteren ane nsually intrusted with a gom and seal spear and accompany their fithers to the humt. Some of them soon learn to be very skillfinl humters. W. know one boy not over thirteen years old who, during the winter of

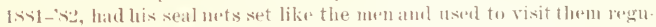

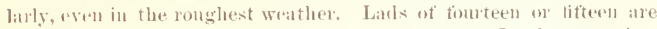
sometimes regulat members of the whaliug creas. In the meantime the little girts are learning to s.w, in imitation of their mothers, and by the time they are twols years old they take their share of the rooking and otleer housework amel assist in making the elothes for the lamily. Thery still, however, have plenty of leisme to play with the ot leer ehit dren until they are old anomgh to be mamide

Athetion tor their rhildren soems a muiversal trait amomg the Eski. mo and there is sancely an anthor who does not sleak in twoms of

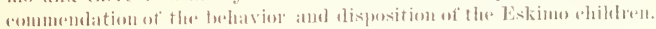

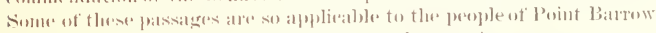

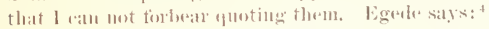

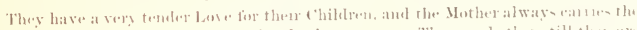
infant ('hild abont with her npom lier latek. They suck them till thes are

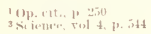$$
\text { (1 ET11- }
$$

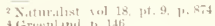$$
+ \text { Gromenlatul. p. } 146
$$ 


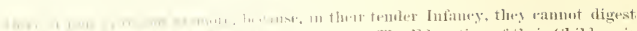

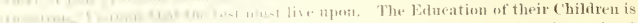

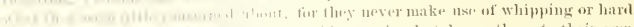

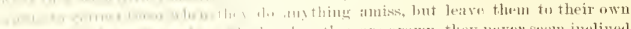

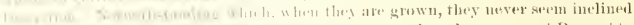

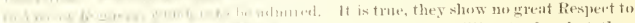

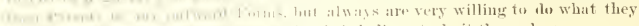

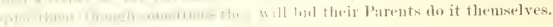

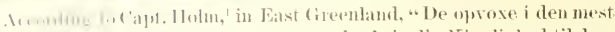

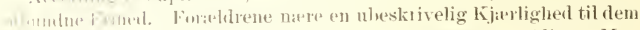
ar- -trath- dem derlor aldrig, selv om de ere nok sala gjenstridige. Man mati imillartid bumdre, hor velopdrague de smata alligevel ere."

J'illy' speaks still more strongly:"

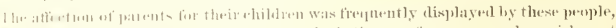

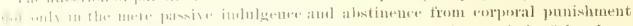

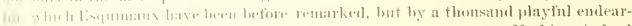

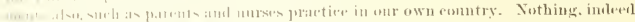

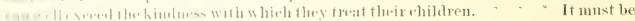

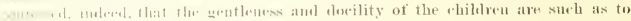

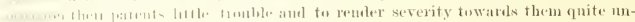

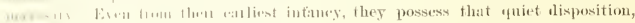

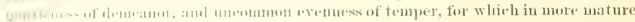

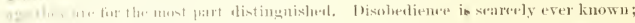

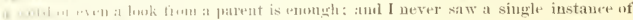

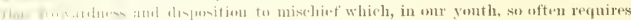

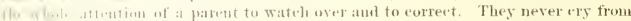

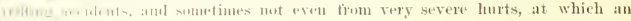

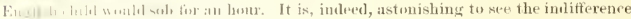

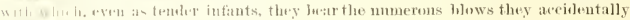

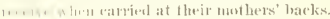

I should be willing to allow this passage to stand as a deseription of the l'oint barme whildren. It is interesting to esmpare with these pas-

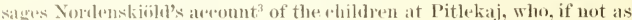

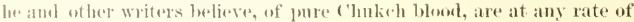
mival ('Jukleh and Bskime deserent:

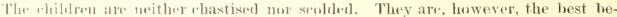

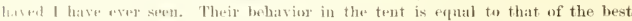

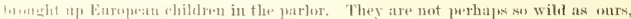

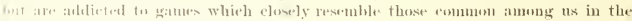

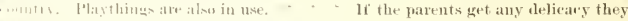

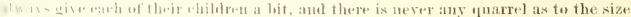

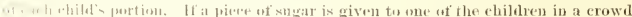

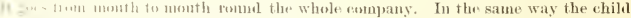

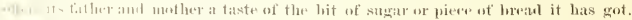

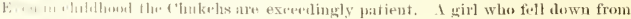

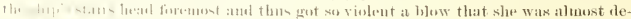

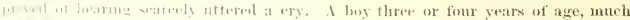

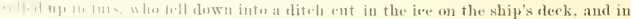

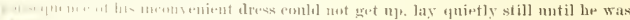

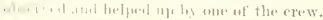

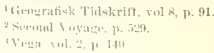


The only extramelinary thing about the chulech fuldem in lhem

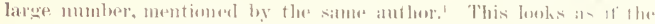
infusion of mew blowe hat imerased the ferfility of the rawe. Ill

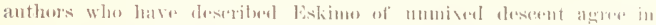

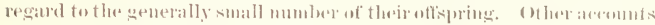

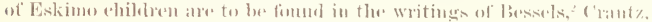

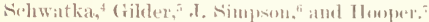

The (eustom of arloption is as moiversal at l'oint barrow as it apperats

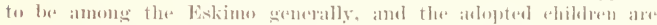
terated ly the parents predisely as if they were their own flesh and blowe. Orphoms ate realily provided for, as there are always phenty of families realy and willing to take fleem, and women who have ses

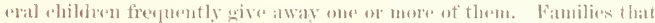

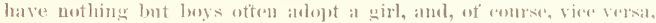
and we know of one case where a woman who had lost a yome intint hat another given her ly one of her timels.

This very general rustom of giving away children, as wall at the habit already mentioned of temporarily "xhanging wives. rendered it quite different to aseertain the parentage of any persom, espowially as it seems to be the enston with them to sfreak of first consins as "milu ataúik" ("ome breast," that is, brother's and sisters). Wloile a loy is resired in the tamily, since he will be the support of his fither when the latter grows too old to hunt, a girl is almost as highly prized, tor not only will she help her mother with the anes of housekeeping when slo grows up, lnt she is likely to obtain a gond husband who may be iuslured to berome a member of his father-in law's family.

\section{JIGIITS AND WRONUS.}

I have aldeaty spoken of the tielings of these people in regatral to otfinses atgainst projerty and erimes of violemes. As to the relations betworl the sexes there serms to be the most romplete absemen of what we consider moral feelings. Promisonous sexmal intereoms botwen

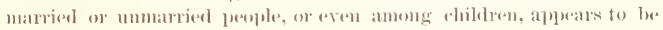
lookel 11 pon simply as at matter for ammsement. As far as wr aonlal learn unchistity in a girl was eonsilered nothing against her. and in finct one girl who was a mest abandoned and shameless prostitute among the salors, and who, we wor told, hat hat improper relations with some of her own race, had uo diffienlty in olotaining an exrellent hustaud.

liematks of the most inderent whareter are freely baudied louk and forth betwen the sexes in public, and are reeeived with shonts of

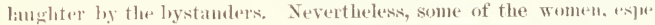

I Teg.t, wol. 1, 1. 449.

${ }^{2}$ Xituralist, vol. 18, pt. 9, p. kit.

zllivtury of Greenland, vol. 1, p. 162.

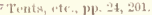

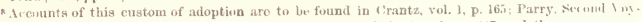
age, p, 31 ; Kumlien, Contributions, p. 17, filder, Sibwatka's Seareh. P. 247, and tlie prasatge concorning ehildren quoted ahove, from Dr. Simpson. 4.ience, vol. 4, No, 98, p. int

skehwatka's Search, D. $2 \times 7$.

60 p. cit., p. 250. 


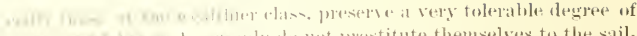

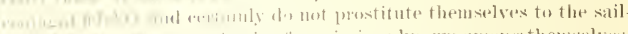

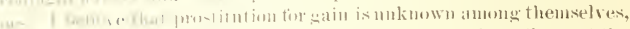

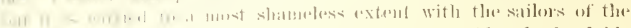

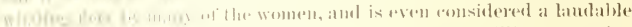

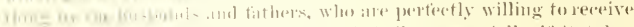

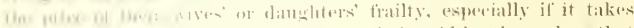

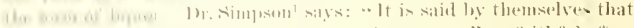

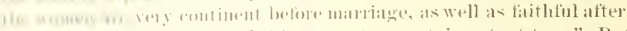

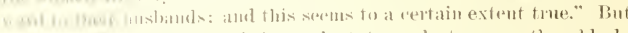

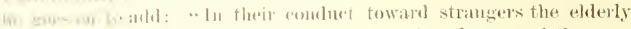

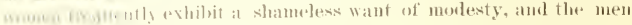

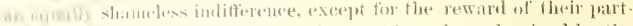

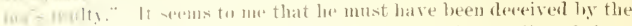

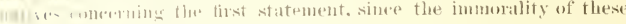

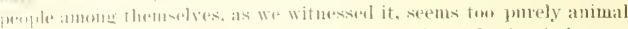

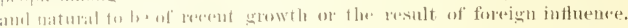

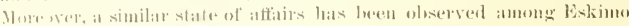

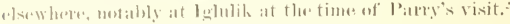

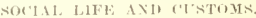

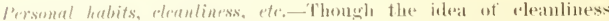

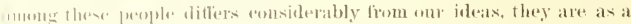

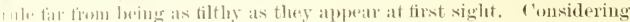
the dithenlty of obtaining water, wan tor purposes of drinking, in the wintor satsm, the iglu, muless dirty work, like the dressing of skins,

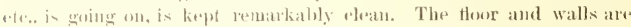
-

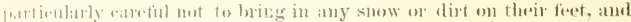

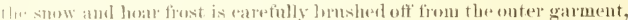
which is often lemevend before entering the reom and lett in the passage.

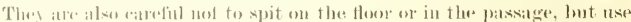

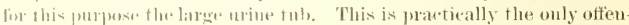

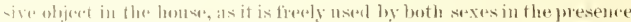

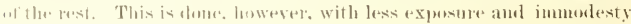

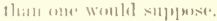




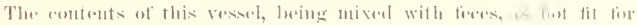

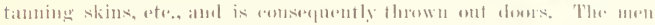
use a small tub (knorwint) as a mrinal, and the eontents of this is care-

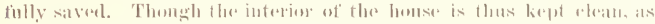

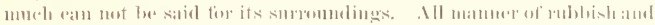

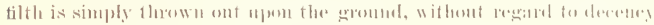

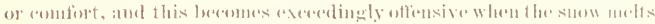

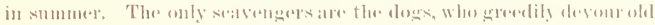

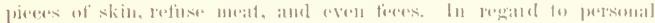

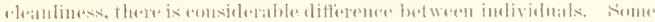

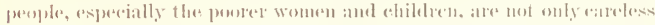

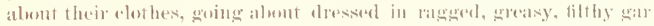
ments, but selelom wath aven their fiares and hamds. numeh less their whole persons. One of these women, indered, was deseribed by lace

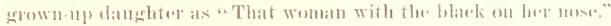

(1) the other hand most of the wealthiel prople appear to fake pride

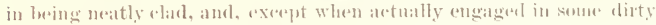

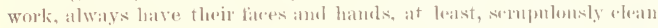
and their hate neatly combed. Even the whote persom is sometimes

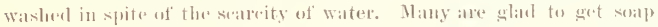
(inkakm!n) and use it firely. Lient. Ray kays that his two guides,

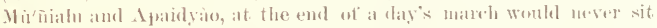
down to suppere withont washing their faces and bands with soap and water, and enmbing their hair, and I recollect that onew. when I went over fo the village to get a youmg man to start with Lient. diay om a lowat

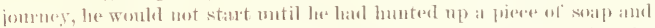
washed his lace and hands. These people, of eomese pratedice the usmal bskimm hahit of washing themselves with theshly passerl mine. Thus anstom arises mot only from the sarreity of water amel the ditiirulty of locating it, but from the faet that the ammonia of the mine is all excellent sulstitute for somp in remosing the grease witl which the

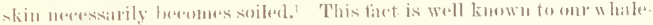
mell, whe are in the laabit of saving their urine to wash the sily elothes

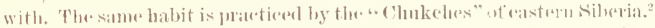
All, Lomever. get more or less shablyy and dirty in the smumer, when they are living in temts ame boats. Alt are more or less infested with liee, and they are in the hal hit of searehing earlo others' hearls for these, which they eat, alter the fashiom of as many other salvages. They

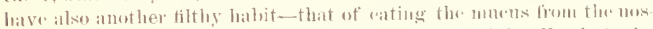

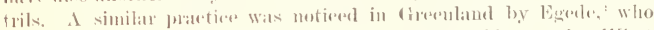

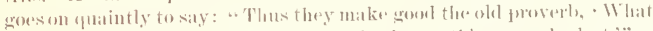

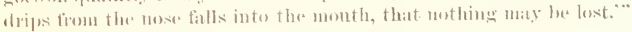

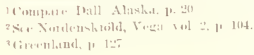




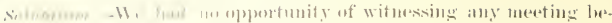

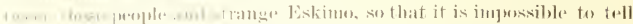

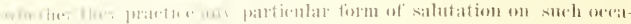

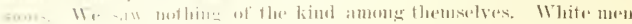

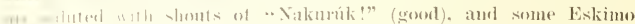

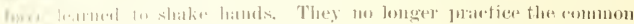

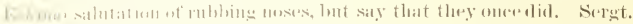

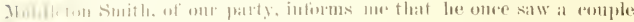

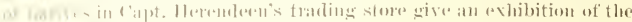

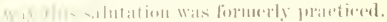

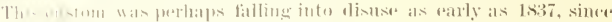

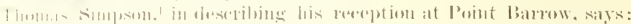

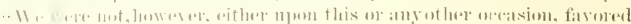

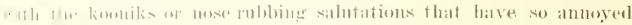

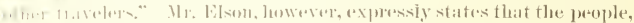

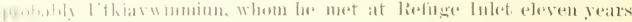

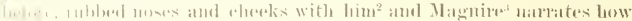

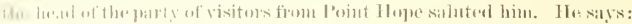

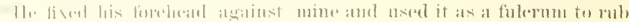

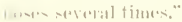

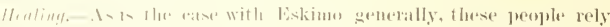

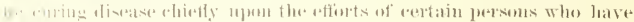

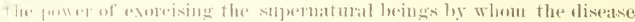

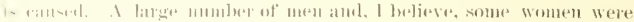

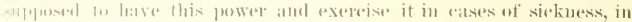

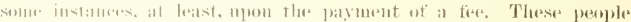

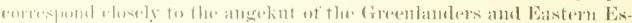

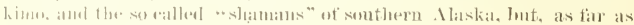

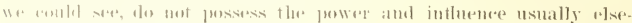

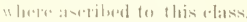

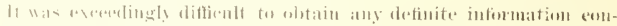

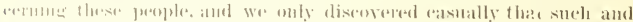

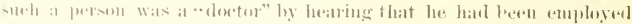

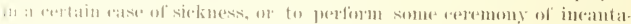

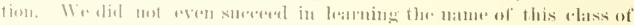

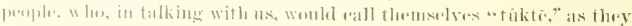

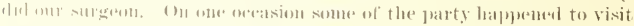

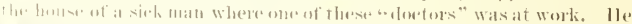

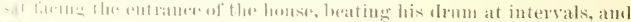

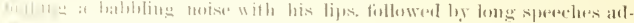

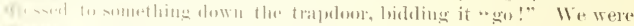

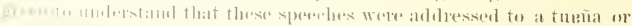

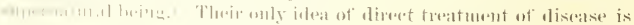


a]parently to :

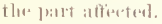

Wr. know of one atse whele a suflerey trom some liver eomplatint hatel

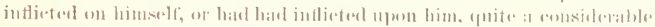
ent on the right sicle with a view of relieving the pain. Wralso hnom

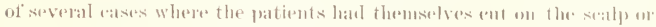

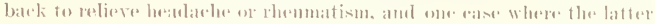

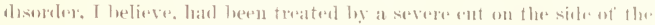

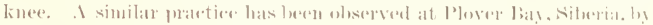
Hoopere' who also mentions the nse of a kind of soton for the relief of he:alathe.

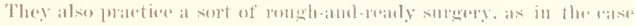

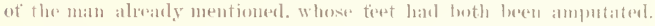

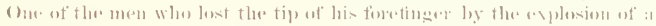

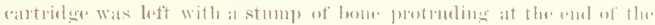

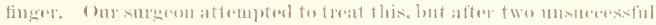

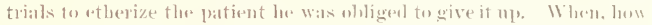

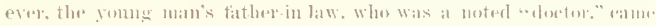

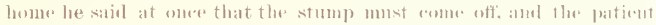

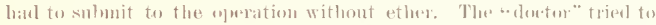

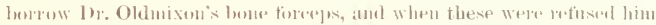

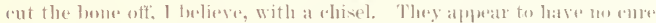

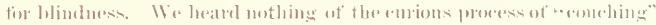

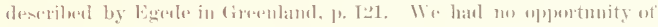

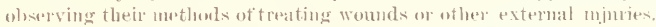

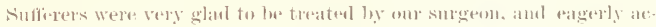
repted his medieines, though he late ronsiderable diftienty in making them olvey his directions alout taking ane of themselye.

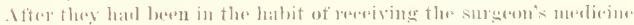

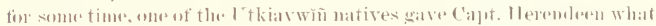
In: said was theig own merlieine. It is a tiny hit of turt which they

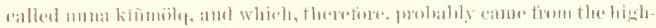

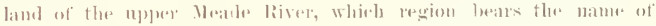

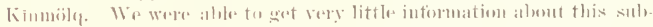

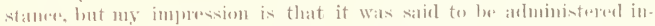

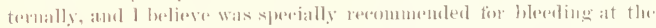
lumgs. Possibly this is the same as " the black moss that germs om the

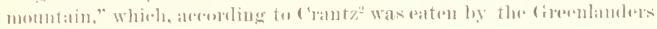
t1) stor) hlond-spitting.

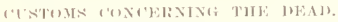

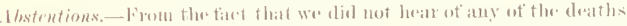

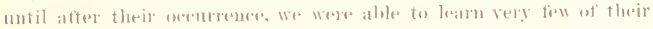

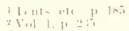




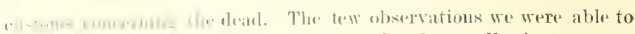

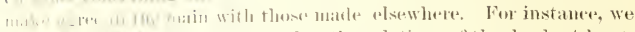

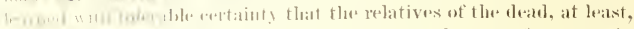

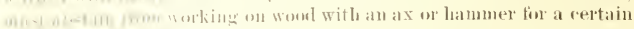

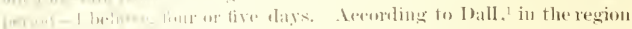

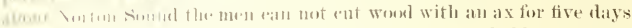

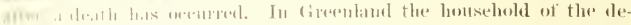

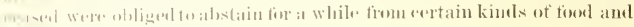
work.

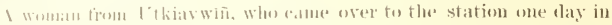

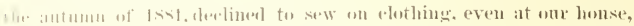

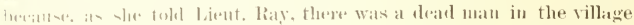
Wh ham not wet hash rarriul ont to the remetery and "he would see

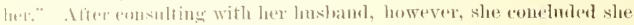

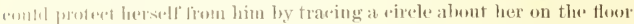
with at sum kulk. In this cirele sle diul the sewing rexpired, and was (atreliul to kerele all leer work inside of it.

(One of the nations informed ne that when a man died his labrets were

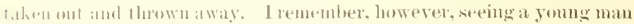

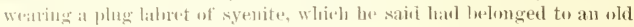

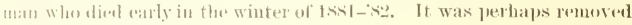
iretione lue atmallydienl.

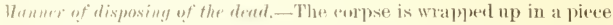
of satefoth (dordskin was tormerly used), laid mpon at that sled, and

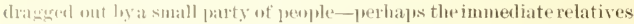

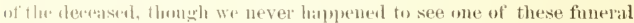

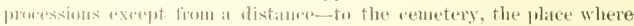

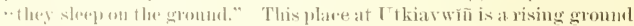

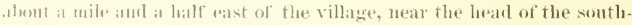

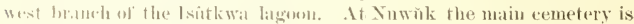

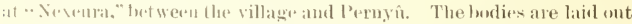

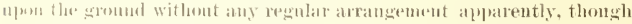
it is dillinult to be sule of this, as must of the remains have been broken

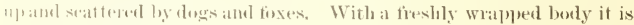
1)ment impussible to tell which is the latal and which the feret. We

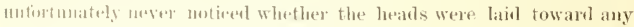

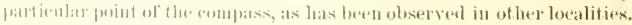

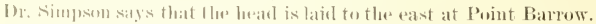

f'arions implements helonging to the dereased are broken and laid ln.

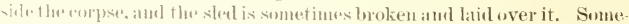
times, howerer, the latter is withlyawn a short distane from the cemetery

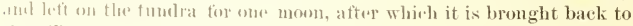
the village. Mon people do wot serem to be tronbled at having the 
bonlies of their relatives distmbel by the dogs or other animals. but we know of one case where the parents of two whilden who diml rely nearly at the sime time, fimling that the dogs were getting at the bodies, raiserl them on stages of driftwoud abont 1 or is liest high.

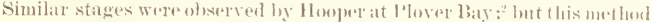
of disposing of the deat appears to have gome ont of nse at the present

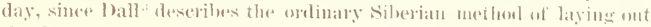
the dead on ovals of stome as in use at Plover Bay at the time of his visit.

The cenetery at Utkiavwin is nut antines to the spot I has men tioned, thongh most of the bodies are paposed there. I few buties

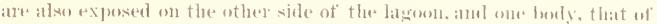
at man, was laid ont at the edge of the bigher tumbra, about a mile due east from the station. The body was anered with ranvas, staked down all round with broken padbles, and over it was baila flat sledee. with one rumer broken. At one end of the body lay a wooken dish,

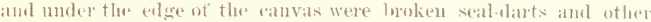
spears. The body lay in an east and west line, but we ronlel fort tall which emol wis the head. All sorts of ohjerets were seattered romet the

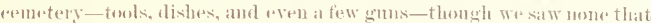

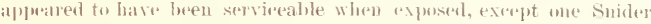
rifle. It, al is the "ase among Eskino in a soul many other plases,

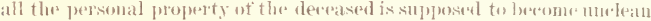
and must be exposed with him, it is probahle that his triends manager

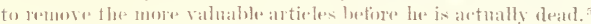

The method of disposing of the deal varies slightly among the Eskimo in different localities, hut the weipons or other implements belonging to the decedsed are always latd beside the corpese. The cons tom at sunth soand, as described by liessels." is remarkably like that

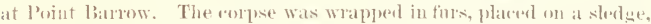
and dragged ont and buried in the snow with the fare to the wext. The sleder was latid over the body and the weatoms of the dereased wore deposited hesidejt. I nlike the Point Barrow natives, howerer. thernsnally aver the body with stomes. In the same passage lor. Bessels desenilus

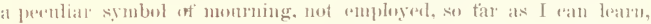
elsewhere. The mate momruers pluged upe the right mostril with hat and the temales the leit, and these plugs were worn tor several days.

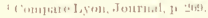

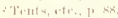

Mlasivit, 1, in:

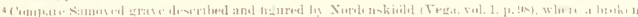

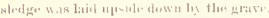

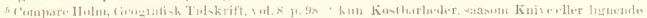

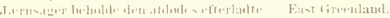

4. Xaturatin-1, yal is, $14,9,12, \times 7 \%$. 


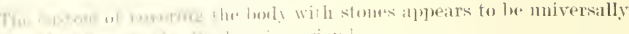

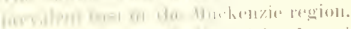

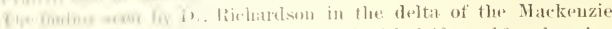

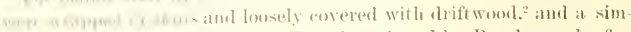

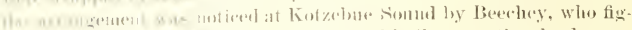

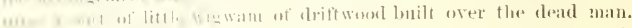

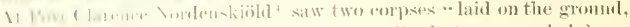

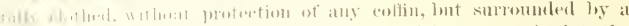

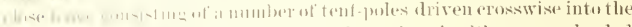

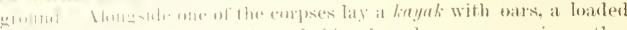

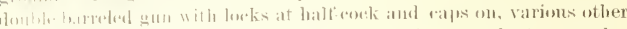

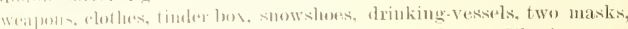

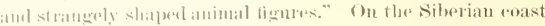

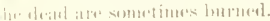

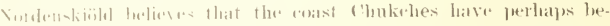

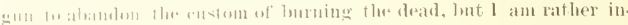

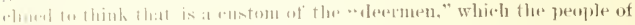

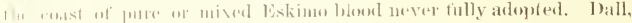

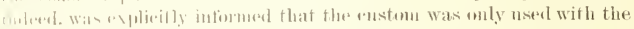

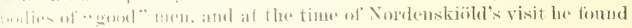

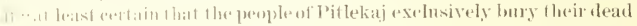

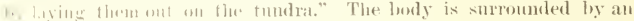

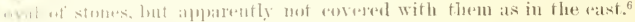

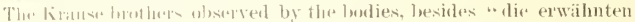

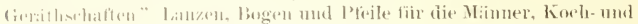

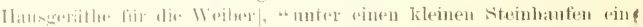

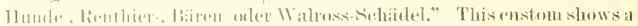

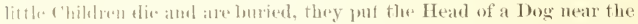

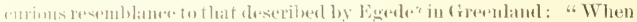

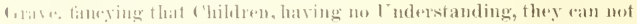

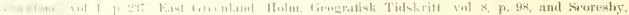

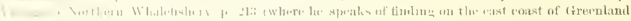

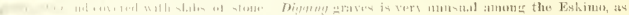

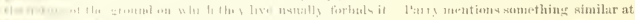

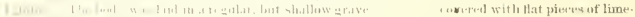

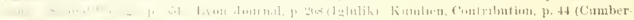

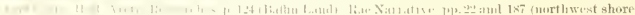

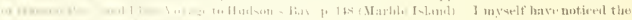

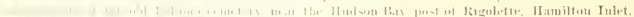

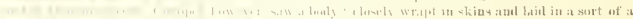

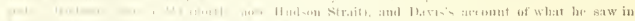

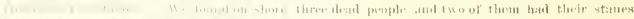

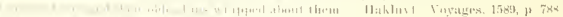

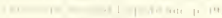

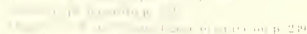

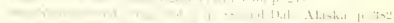

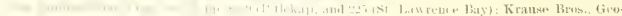

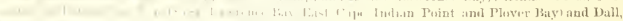


Wy themselves find the Way, but the l loge must guide them to the lanet

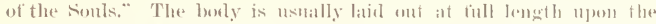

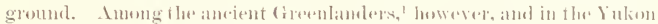

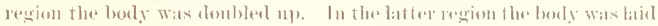
on its sile in a box of planks tome teet long ant raised on fome sup

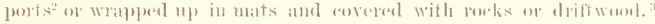

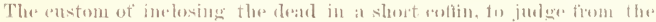

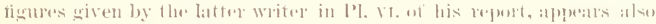

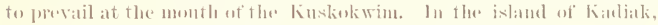
awording to Iball and Lisiansky, the deat wore huried.

\section{(it) FRNMET.}

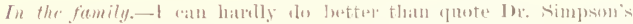

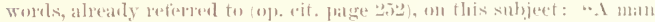

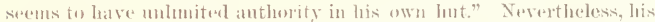

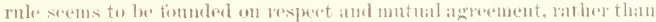

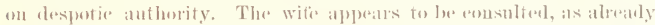
stated. on all important opatsims, :met, to quote Dr. Nimpson again (ibid. : "Seniority gives prerenlene when there ate several women in one hut, and the sway of the clele in the direetion of exerything ans.

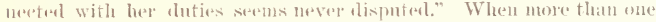

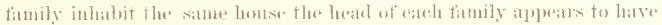
autlority over his own relatives, while the relations between the two are enverned soledy ly mutual agreenent.

In the villegr.-These people have noestablished form of govermment nor any ehiet's in the ordinary sense of the word, lnt appear to be

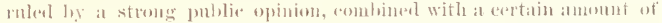
resperet for the opinions of the elder people, louth men and women, and

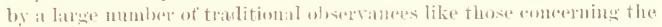
whale fishery, the deseased, ete., already deseribed. In the ordinary relations of lite a person, as a rule, a voids doing anything to his neigh bor which he would not wish to have done to himself, and aftairs which roncern the eommunity ats a whole, as for instance their relations with ns at the station, ale settled by al general and apparenty intormal disenssion, when the optuton of the majority andes the day. The majority aplears to have no meams, short of individual violeme, of en-

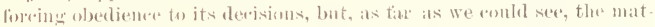

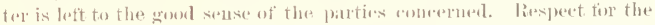

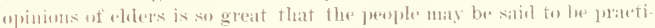
rally muler what is called ".simple alder lule." Public opinion has

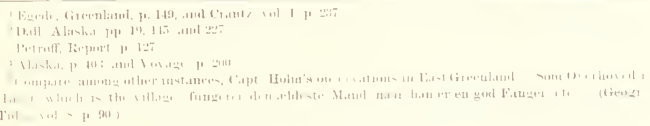




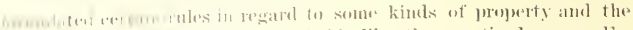

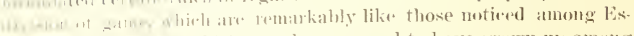

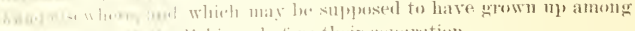

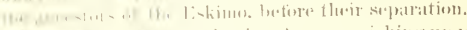

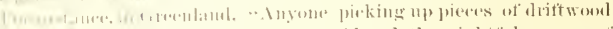

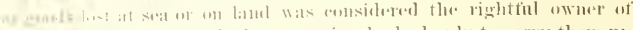

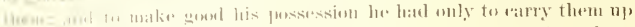

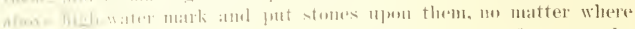

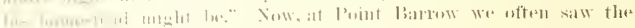

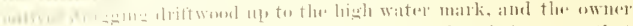

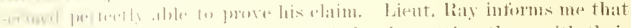

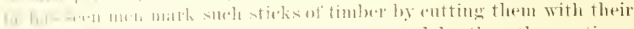

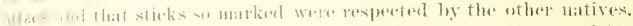

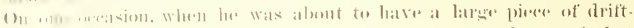

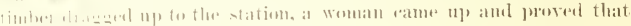

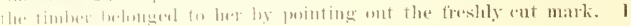

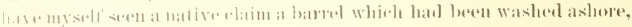

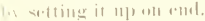

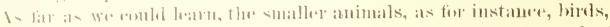

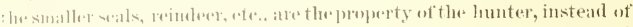

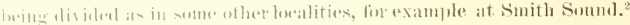
The latrare seals and walruses alperarel to he divided among the boat"s

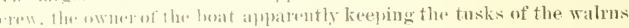
.mul perhalp the skin. A hear, however, both flesh and skin, is einally

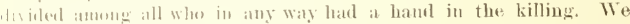

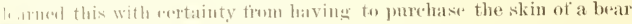

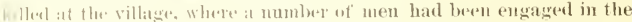
haut. Whena whald is talifn, as 1 have alrealy sairl, the whalebone

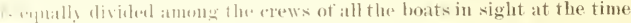

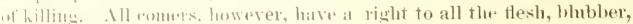

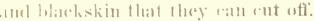

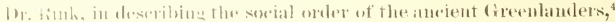

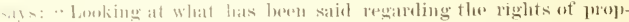

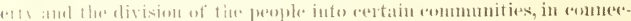

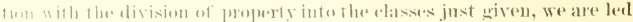

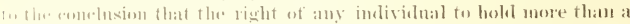

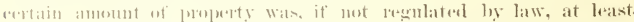

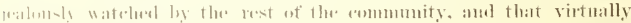

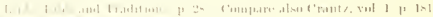

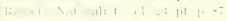

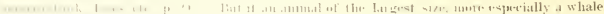

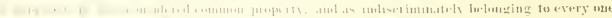
-

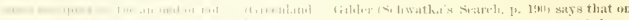

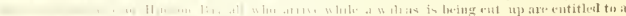

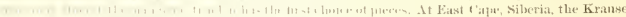

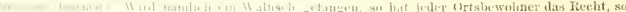

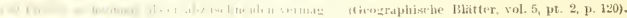




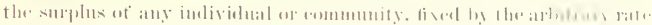

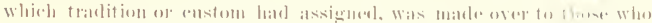

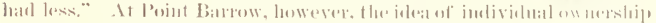

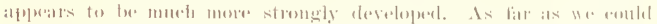

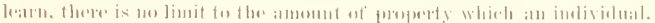

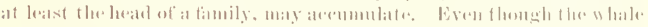

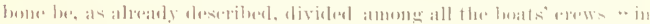

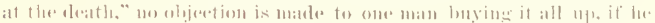
has the matas, fin his ow private 11 s.

This lats given rise to a regulat wealthy and atristowatio elass, 1 low,

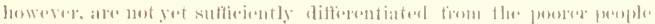

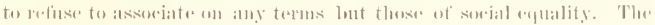

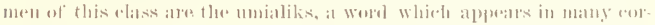
rupteal forms on the roast of Wextern . Imerical and is often suphosal

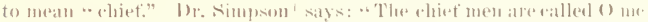

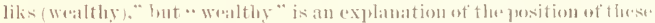
mese, and not a translation of the title, whiche as we olitained it, is fore

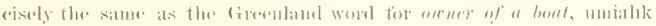

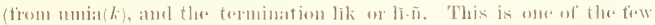

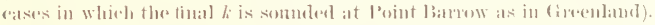

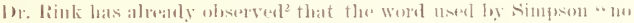
douft must be the same as the (ireenlamelish muialik, signifying awner

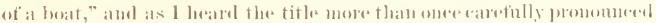
at Point Barmw it was the helentioal word. The unialiks, as simpson

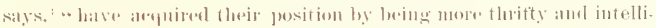

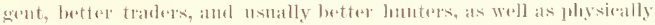

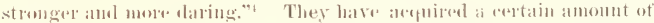

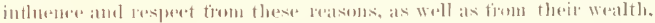
which enables them to purehase the services of others to math theip

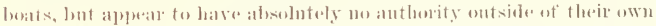

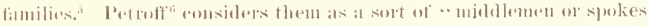
men," who make themsolves " prominent by superintembling all interanuse and traftice witl visitors."

This sort of promineme, however, alphars to hatse been ionfirled npon them ly the traters, who, igumant of the very democratic state of

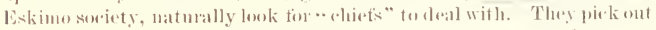

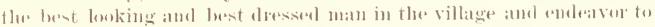
win his filsor by giving him presents, reseiving him into the ablu, and

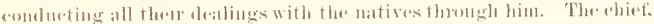




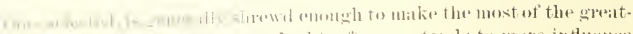

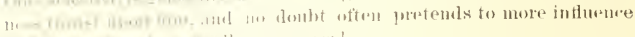

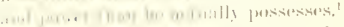

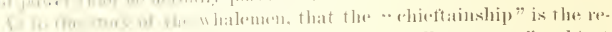

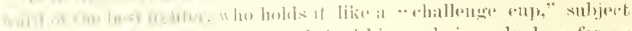

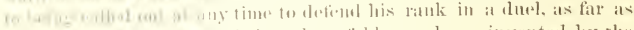

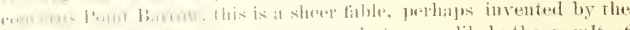

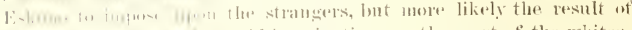

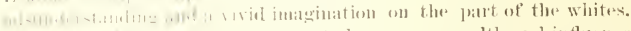

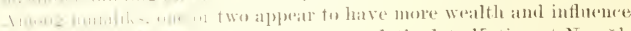

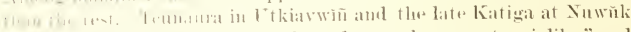

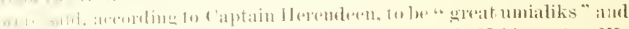

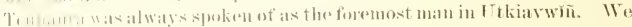

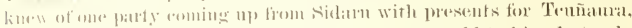

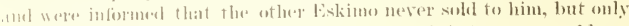

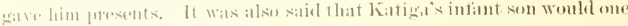
dia! be a

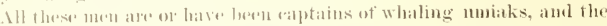

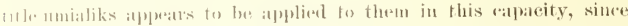
many of the poorer men, who, as tall as we could leam, were not com.

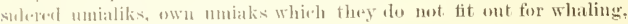
fut 11 -

\section{RELItIIN}

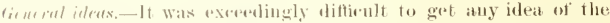
religions belief of the people patrty trom ome inability to make ourselves

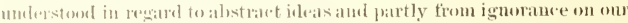

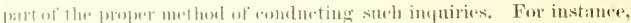
in trying to wet at their illeis of a future life, wo could ouly ask "Where

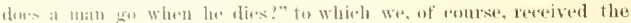
whious atuswer. " Th the malletery!" Moteover, sheh a multitude of other and casiel lines of inpstigation presented themselves for our at-

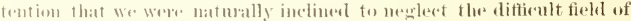

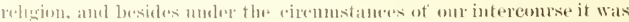
alums impossible to get the attention of the matives when their minds wore net finth of ot lier subjer.ts.

Sicretheless, many of the fragments of superstition and tratition that we were able to collect agres remarkibly with what has been

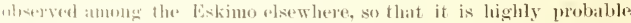
that their seligion is of the same gemeral wasaleter as that of the Green-

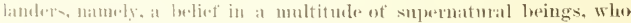

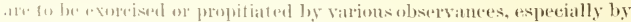

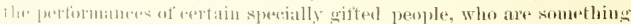

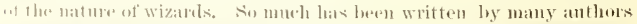

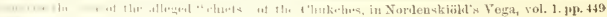




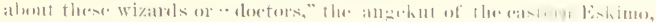

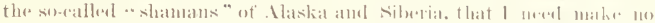

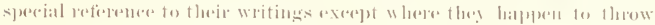

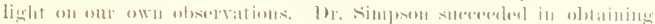

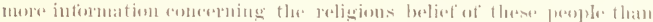

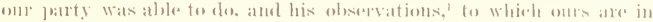

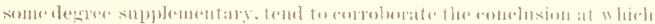
1 have arrived.

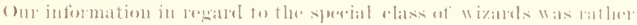

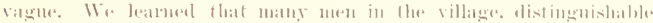

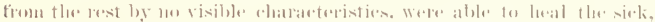

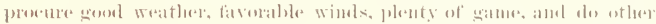

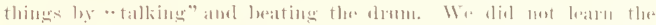

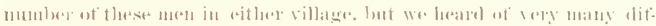

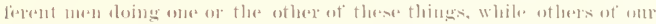

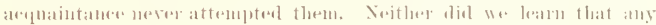

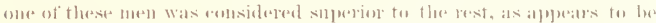

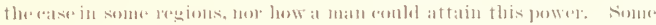

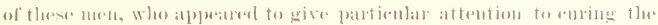

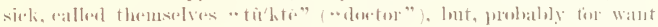

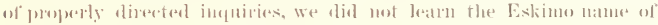

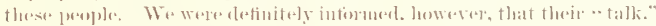

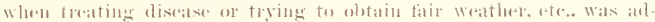

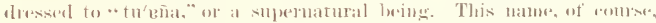

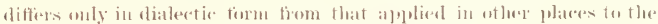
miversal fanniliar spirits ot Eskimo superstition.

We at first sujposal that "tumana" moant some pattiondar individ-

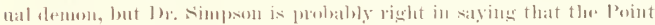

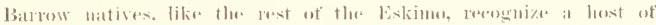

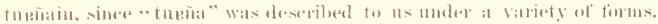

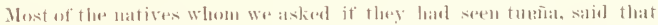

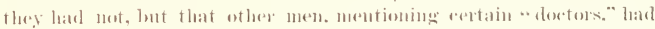

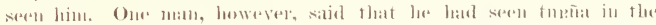
kinlyigl, when t]re people *talked" xitting in the dark, with their

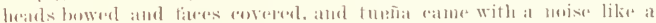

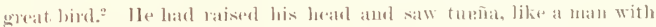

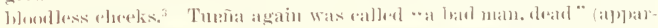

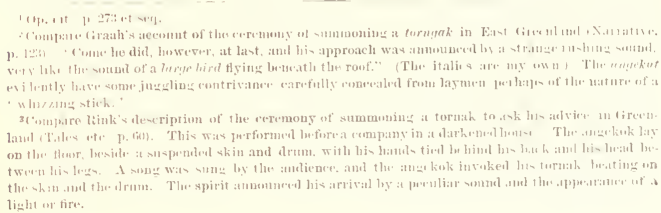

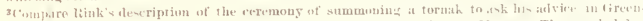

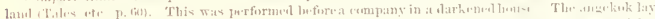

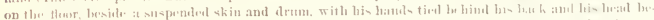

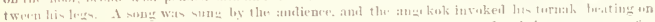
the shate ant the J J lisht of tire. 


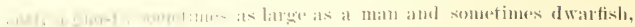

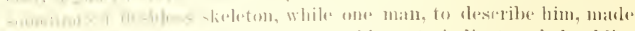

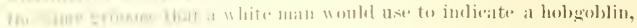

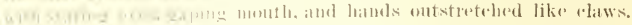

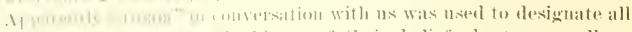

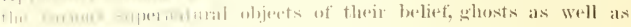

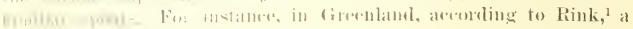

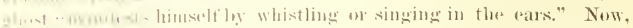

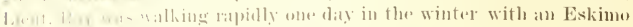

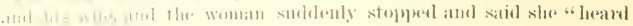

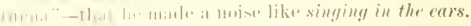

Tin. prople conerally have at great dread of "tueña," who they say womld kill them, and are bery arerse to soing ont alone in the dark.

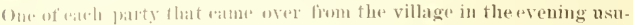

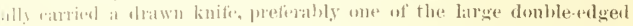

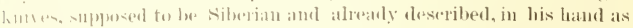

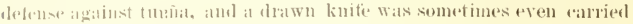

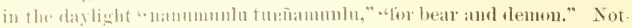

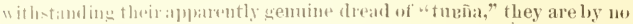
monas antase to talling or even joking about him.

The knifo also sorves als a protertion against the :mrora, which most of them agres is batl, and when bright likely to kill a person by strikinf him in the hatek of the neek. Ifowever, brandishing the knife at

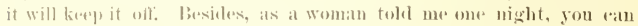

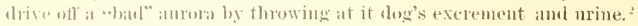

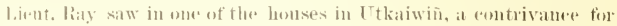

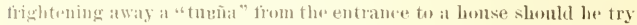

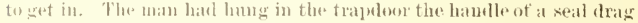
hy means of a thomgespilied to the wall with a karge knile, and told lient.

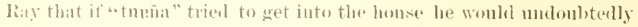

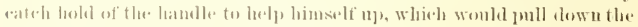

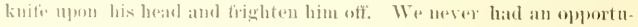

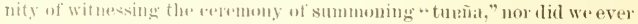

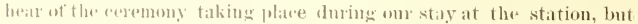

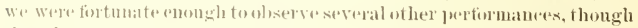
they do not appente to be fremuent. The reremony of healing the sick

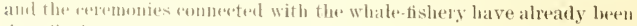

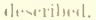

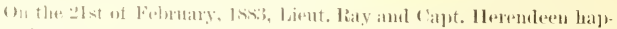

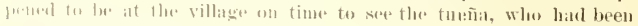

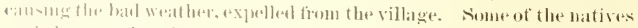

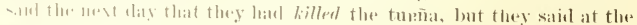

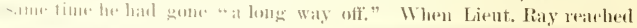


the village, women were standing at the doors of the houses armed with snow-knires and elohe with which they made passes over the ent trane when the people inside ealled out. Ile entered ond house and

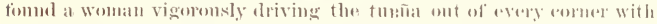
a knife. They then repained to the kindyigi, where there were ten or

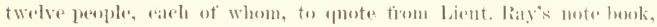
"mate a charge against the evil spirit, tellinge what injuries they hat rexeived fiem it." Then lhey went into the open air, where a tire have

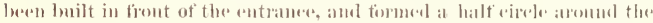
fire. Earh then went uje and made a sperech, bending orer the fire (areording to simpson, who deseribes a similar ceremony at Nowik on p). 274 of his paper, eaxing the tunan to come muler the fire to wam him. self). Then they bronght out a large tuls finll of urine, to which, Ningp-

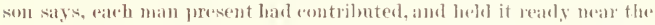
fire, while two men storel with their ritles in vadiness, and a boy storel near the fire with a large stome in his hamds, hareing himselt firmly with his fiest spread apart tor a vigorous thow. Then they rhanted ats tollows (the words of this ehant were obtained afterward by the writer):

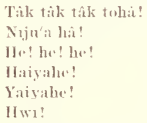

And instantly the contents of the tub were dashed on the fire, the stone thrown into the embers, and both men cliseharged their rifles, whe into the embers, amb one into the cloucl ot steam as it rose. Then all brushed their clothes violently and shouted, and the tueña was killed. liy a fortmate coincideme, the next day was the finest we hat had fir a loug time.

Sarritices are also oreasionally made to these smpernatumal beings as in Geenland "gifts were oftered to the ime of certain rocks, rapes and in firths, principally when travoling and passing those places." t

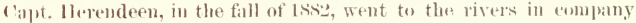
with one of the "doctors." When they arrived at the river Kuarn, where the latter intended to stay tor the fishing, he got ont lis drum and "talked" for a long time, and breaking off very small pinese of tabiceo threw them into the atir, erying out, "Turña, turnia, I giv" you tobacos! grive me plenty of tish." When they passed the deal men at the remetery, he gave them tohaen in the same way, atsking them also for fish. ${ }^{2}$ We notived but few other superstitious observames which have not been abeady deseribed. Is in forendind and elswhere, super-

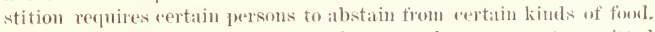
For instaure, Mñ̃ialu, and apparently many others, ware not permit ted

\footnotetext{
think. Titles, tete, 1,. 56.

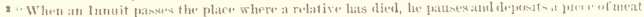
near by," Batfin land, Mall, Artie Researches, p, 574.

9 ЕТН-28
} 
(1) eat the burbet, anotleer man was denied ptarmigan, and a woman' at

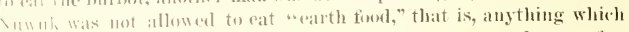

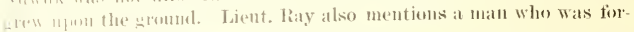
fublen liwats hesh.:

Wh obsertad some traces of the steperstition concerning the heads

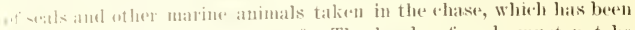

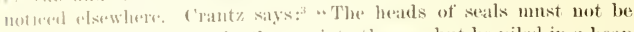
fractureal. nor must they be thrown into the sea, but be pileal in a heap frefore the door. "that the sonds of the seals may not loe enraged and sare their brethen from the coast." And Capt. Parry found that at IInter lstand they mafully jueselved the heads of all the anmals killed shring the winter, exorept two or three of the walrus which he olotained with great dithoulty. The natives told him that they were to be- 1 hrown into the sea in the smmmer, lsut at Iglulik they readily sold tham betione the summer arrived.

l trind very [arr] to get a full series of skulls from the seals taken at I thiaywin in the winter of Ls'- 83 , but thongh I frepuently asked the natives to bring them aver tor sale, they never dia so, till at last one young woman promices to bring me all I wanted at the price of half a jumbl of gurpowcles at skull. Nexertheless, she brought wer only two or there at that pries. We did not observe what was done with the skulls. but fropuently olserved ifnantities of the sualler bones of the

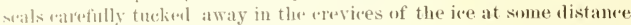
tom the showe. Wr had comparatively little ditlicnlty in obtaining skulls of the Walms, lut 1 olserved that the loottom of Tiserám, the little poud at the colge ot the village, was sovered with old walrus skulls, as if they had berendenosited there for years. The superstition appears to be in hull fores aneng the Chuks hes, who live near the plate where the forfe winterest. Nordenskjöld was unabl. to purchase a pair of fresle walrus learls at the first village he visited, though the tusk were

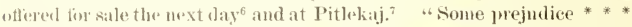
prevonted the (lunkehes from parting with the heads of the seal, thongh * " we officed a high price for them. "Irgatti' (to-morrow) Was the usual answer. But the promise was nerer kept."

Imulets, - Like the firenlanders and other Eskimos, they plate Great reliames on amulets or talismans, which are earriol on the person, in the boat, or "ren inserted in weapons, each alparently with some

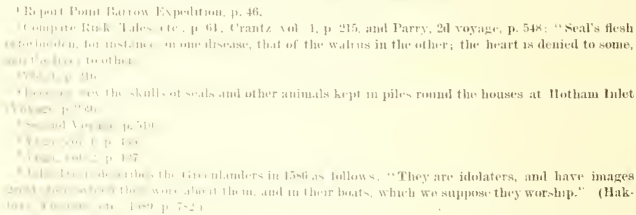


specific purpose, which indeed we learned in the "ase of some of those in the collection. Like the annlots of the (ircenlanlers, they aprear to be " "ertain animals or things which had helongerl to of heen in centart with eertain persons (c. g., the people of an(ient times, or fortunate hunters) or superuatural beings," and "objects which merely by their appearance reealled the offeret expected from the amulet, surh as tigures of various objects." To the lattex class belong the rudely tlaked flint images of whales, already mentioned, and probably many of the other small images of men and animals alrearly deseribed, especially those fitted with holes for strings to lang them up by.

The flint whale is a very common amulet, intented, as we mulerstood, to give goot luck in whating, aud is worn habitually by many of the men and loys muler the elothes, suspended around the neck by a string. The eaptain and harpooner of a whaling crew also wear them as pentants on the fillots already described, Fis, 421.- Whale Hoked frum and on the hreast of the jacket. We obtained

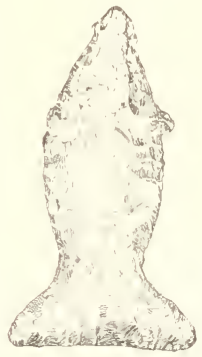
five of these oljoets, all of very nearly the same shape, lut of tiffer ent materials ancl varying somewhat in size. Fig. f21 represents one

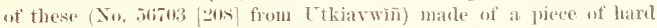
colorless glass, probalbly a fragment ot a ship's "oleallight." It is rather roughly thaket into a figure of a "bowhead" whal , $3 \cdot 4$ inches long, as seen from above and very much flattened with exaggerated flukes. The thippers were rndely indicated in the outline, but the loft one is broken off,

No. Nimis $[771 \mid$ from Utliavwhin is a very similar imagr, $2 \cdot 4$ inehes long, which perhaps is of the same material, though it may be made of

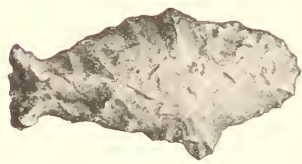

Fic 422, - Whale Haked from red jasper. rock erystal. No, itionf [1,is] from Utkiavwhin is a very small whale $(1 \cdot 4$ incluss long), whipes in latrge flakes out of a water woru pebble of smoky quartz, whilw No. s!15i7 [939] Fig. 12:2, from the same village, which is a trifle larger ( 2 inches long), is made of dark rrimson jasper. The large black thint whale, No, w66s? [61], also trom Itkiavwin, whirh is :39! inches long, is the rudest of all the tigures of the whales. It is precisely the shape of the blade of a skin seraper, exeept for the roughly indieated thukes.

Fig. 42:3 (No, s!5.24 [1399] from [tliavwin) is a rucle woolen image of the same animal, $3 \frac{1}{2}$ inches long, very broal and flat-lellied. It is 


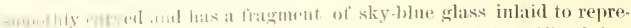
at hit the left .... and a lit of iron prytes tor the right. The Hukes

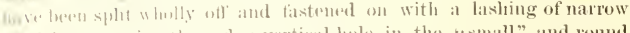

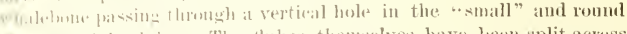

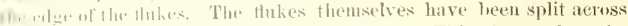
and alpueal to datve been doweled together. This shows that the om ner atfachect considerable value to the object, or he wonld not have

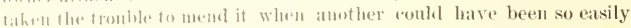
whittled ant. In the milllle of the helly is an ohlong cavity, contain-

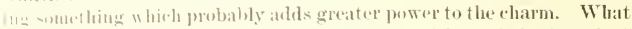
llow is an mot be seen, ats a hand of sealskin with the bair shaved off Thas berfu shmuk on romel the hinder half of the loody and secured by a seam on the jight side. A double turn of sinew braid is knotted

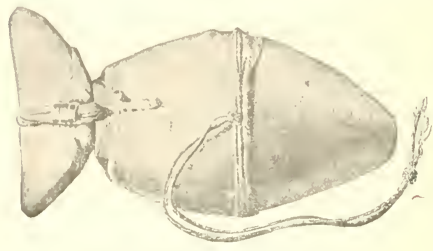

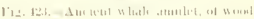
round the middle of the body, leaving two ends which are tiecl together in a los) $)$, showing that this oljeet was meant to beattacher sounewhere about the person.

To this rlass alko probably belenge the skins or pieces of :Ilimals worn as anulets. porbally wh th a view of otstaining the powers of the partieular mimal, as in so many ases in the stories related in link's Tales and Tratitions. We tresuently saw men weange at the belt buneles of

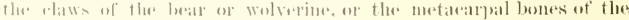

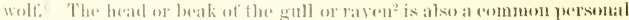

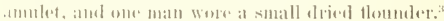

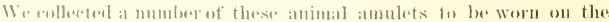

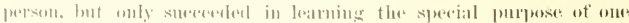

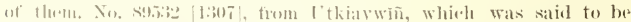

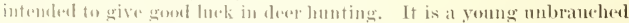

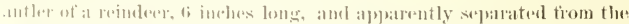
-hull at the ".hur:" with the " velyet" skin still allhorimg, though most

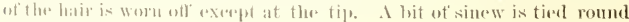
th11. | bisse.

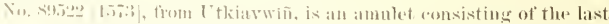

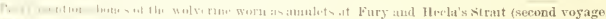

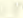

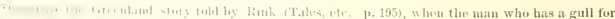

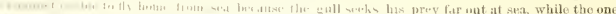

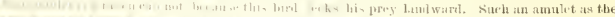

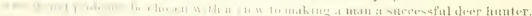

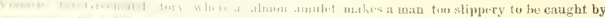

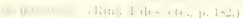


three joints of the foot of a reindere tawn, with the skin and hesf and

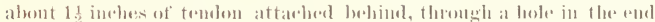

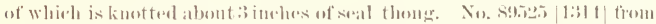

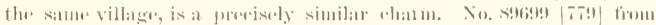
Ttkarwion, is the subtossil incisol tootlo of some ruminame with a lobe

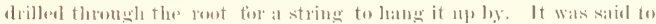

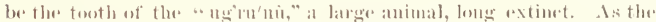

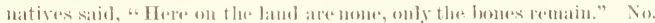

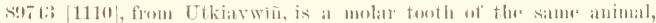
pobably, weathered and old, with a hole tieshly drilled thromgh one

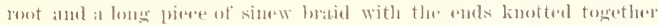
looperl into it. There are also in the collection two very old teeth which probahly were inelosed in little satek of skin and worn as anulits.

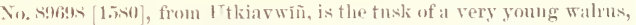

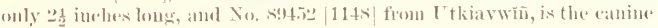
tooth of a polar beas. No. $56547[6,56\}$, trom the salme village, is a simi. lat touth.

The only :molet attahed to a weapon, which we collected, is the terus bill, alrealy alluded to, plated under the whalebone lashing on

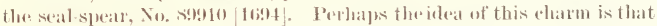
the spear shomld phenge down thwn the seal with as sure an aim as the terlu does now its prey.

A number of anmets of this rlass are always anried in the whaling nuiak. I have aldeaty mentioned the wolf-skulls, stutfod ravens and "algles, fox tails' and hum hes of feathers used for this pmopse. Most of these chams are parts of some raparems aminal or bird, but parts of other animals seem to have some virtue on these oceasions.

For iustance, I notioed the axis vertebra of at seal in one whalingmuiak, and we anllected a rudely stuftiol skin of a godwit (Limosal lapponica haneri), which, we were intormed. Was "for whales." This

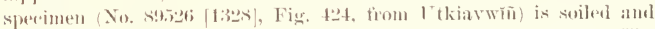
raysed, and hat a stirk thrist through the neck to bohl it ont. The neck is wrapled around with a nalow strije of whalelome and some

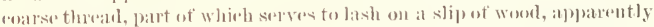
to spliew the stick inside. I hit of white matu's string is passed aromud the buly ant tied in a foup to hange it up by. This wharm is perbaps

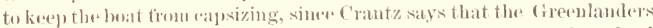
". like to fasten to thej kajak a molel of it * * * or ouly a dead

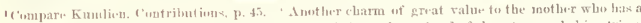

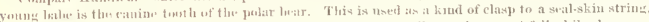
which patses round the buly and herpe the liceats up. Her milk sopply eavust fail while she wears thes, (cinmbertatul (inlf.)

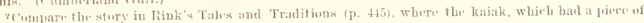

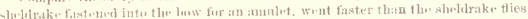

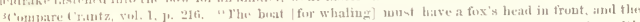
harpon be turnished with an easto's bests. The lattir statement is interesting iucounection with the tera's bill ou the seal harpsou, rrom Point Barrow, alrealy referted to. 


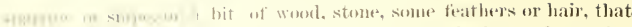

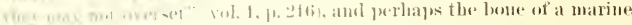

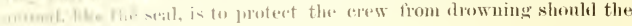

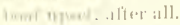

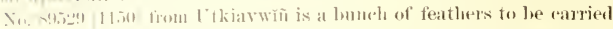

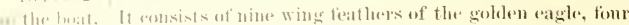

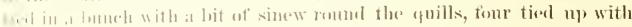

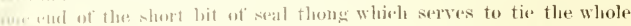

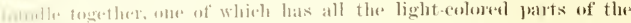

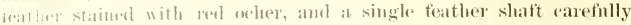

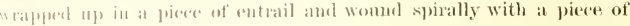
simen liriticl.

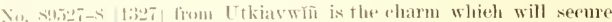

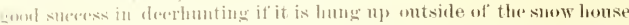

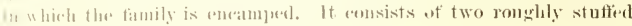

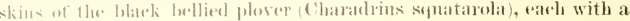

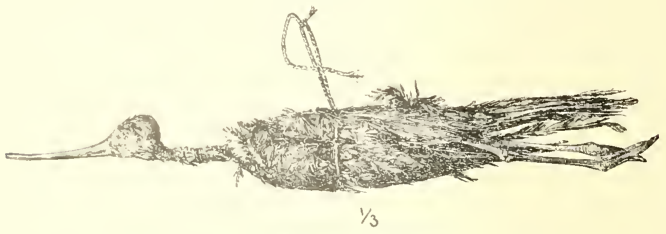

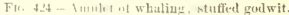

-tiek run fluongh the lowly so that one end supjorts the neek and the

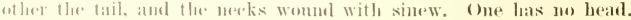
I sling of sinew brath is tied aromol the body of each, so as to leave

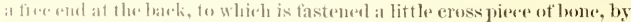
which it may be secolperl to al becket. Like the rest of the ammlets in

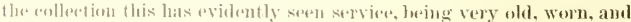
livilud.

The of here alaks at ammlets, latmely objeets which have belonged to or

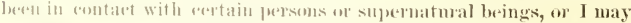

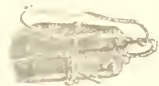

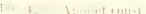

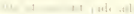
ald aprarently certan lowalities, is represented ly a mumber of sperimens. To the enstom of using such things ats amulets, we moloubtedly owe the preservation of most of the ancient weapons and ot he+p implements, asperially those mate of wool, hour, of other perishable substances, like the an

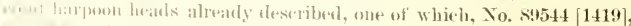

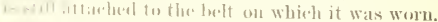

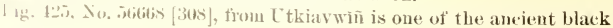


jacle adzes $5+1$ ineloes, slung with thong and whalebour, matking a beeket by which it an lo humy up. We did not learu the history of this ammlet, which at the time of rollecting it was supposed to be a bet sinker. There would, howerer, los no reason for nsing so valualle an

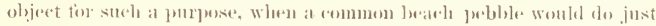
as well, muless it was intemeel as a cham to insme suecess in tishing. It maty even hate been carried as a rlatm on the persom, since we afterwarks saw a still more lualky olject nsed for surh a purpose.

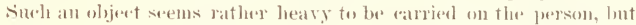
a well known man in Ithiavwîn always carried with him when he went sealing a large peatl-shaped stone, which must have weighed npwarkots two pommls, suspended somewhere about his jerson. It is not mulikely that this stome aropired its virtue as an ammlet from having besen al sinker nserl ly some lucky fisherman in former time or in a distant (omm. try. Mr. H. W: Henshaw has alreaty referrecl to the resimblane of this amulet to the plummet. like ". neelie.ince stmese" of some of onr Indians.'

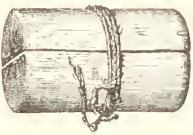

FIG. 426.-Littlitherontaining amulet for w lialuse

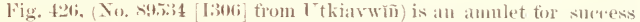
in whaline. It ronsists of three little irregnlar water- worn tiagments of amber carefully wrapped in at bit of parebuent and inclosed in a lit-

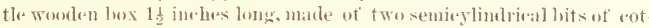
tonword, with the that fares hollowed out and put togetlere and fisstemel up, by three turus of sinew brat romel the mithle, tied in a loese knot. The box is old and brown from age and hambing. Wo leatrol of other pieces of amber and earth ( "nmma") worm as ammlets, wrapled ul in lits of leatler amol loung on the belt.

So. s4.i3:3 [1247], trom ltkiatwin, is simply a nearly sijnare peb. b]te $1 .+$ inches loug, of dark retl jasper, shong in a bit of sinew braid

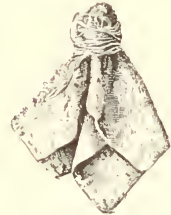

Fis $4: 7,-\mathrm{A} m \mathrm{~m}+\mathrm{I}, \mathrm{t} \mathrm{f}_{10}$ catthus fowl with bulas. so that it ean be lomg on the loelt. Fig. 427 (No. 69525 [130s] from l'thiatriñ) is some small olyeat, plaral in the renter of the grain side of a sefuare lit of white sealskin, the edges of whirh are foldal 11 , around it and tied tightly romul with terer sinew, so as to make a little round knob. I rollected this ammlet, ant was partienlarly informerl low it was to be nsed. It it be fastemel on the right shomler it will insure sneress in takiug durks witl the "loblas." Jig. 4:(No. s4535 [1244] from I thiarwiñ) is an amulet whose history we ditl not learn. It is a little ols. long box $3 \cdot 3$ ineles long, earved from a lolock of cottouwool, witl at flat (o) ver tied on with nine turus of sinew braid, anel rontains twenty one dried humble-lees, which it was said came from the river Kuln- 


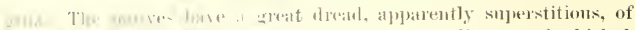

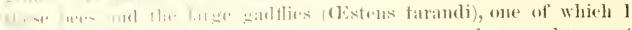

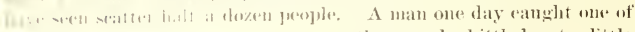

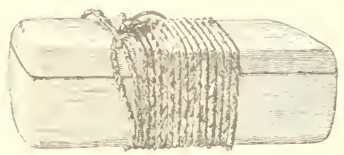

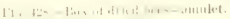
fluese, and whittled out a little lox of wood, in which he shut tha inseret nj, and tied it up' with a shed of sinew, telling capt. Heremoleen that it was

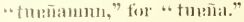

A sumall lump of indurated

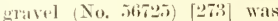
one day bromglit over from

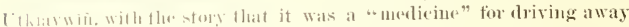
the ioe. The man w low uses this charm stands on the high bank at the village. and hrealking ofl mains of the gravel throws them seaward. This will atuse the in to lanere off from the shere.

Tho asential bulentity of the ammlets of the Point Barow natives with these nsed he the Eskimo alsewhere is slown by the following

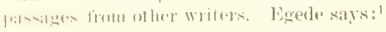

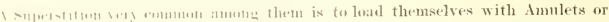

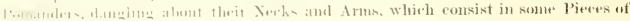

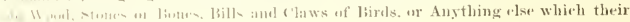

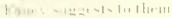

f'131117 - - ily:

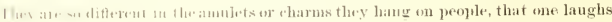

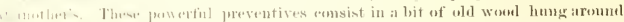

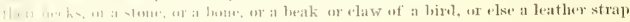

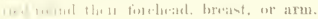

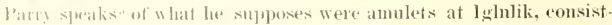
ing of tweth of the fin. wolf, and musk ax, bones of the "liablesarioo" supposed to tre the wolverime), and toxes noses. Kumlien says that

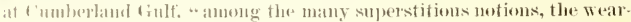
ing of alarms abont the ferson is one of the most cmious. These are callect anymuk of am nxit, and maly he nothing but pieces of bone or worl. himls" bills or elaws, or an animal's teeth or skin." A litfle

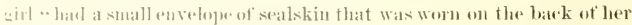

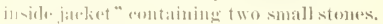

sinch littlo jurkels of skin setwed to tlo imer jacket are very commun at lount barrow, but we diel not snereed in any ase in learning their contents, It lintzolne somul, lieechey saw ravens' skins on which the matives set al high value, while the beaks and claws of these hards wre atlachard to their belts and headbands.5. Petitot describes ${ }^{6}$

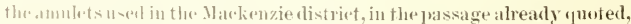

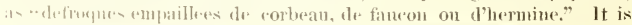

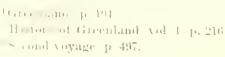

4 C'mitributions. p. 45

5 Toyare, p. 333.

"Nonographie, etc. p. xv. 
not likely that the nese of these is comtined to the women, as his words, "Ellesyportent," would seem to imply. Among the sedentary ('lubelus

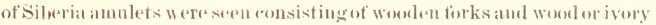
Parvings.' A wolt"sikull, hung up by a thong; theskin, together with the whole rartilaginous portion of a wolt"s nose, and a flat stome, ance also meentioned." Capt. Holm also fount womblerfully similar fllstoms anong

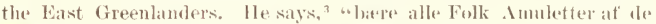
mest forskjelligartede Ting" to gruard against siekmess and to insurr long life, and also for specitio purposes. The men wear them shung round time neele or tied romel the npper arm, the women in their knot of hair or "i Snippen foran pata Pelsen."

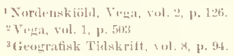




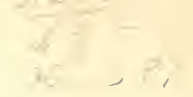








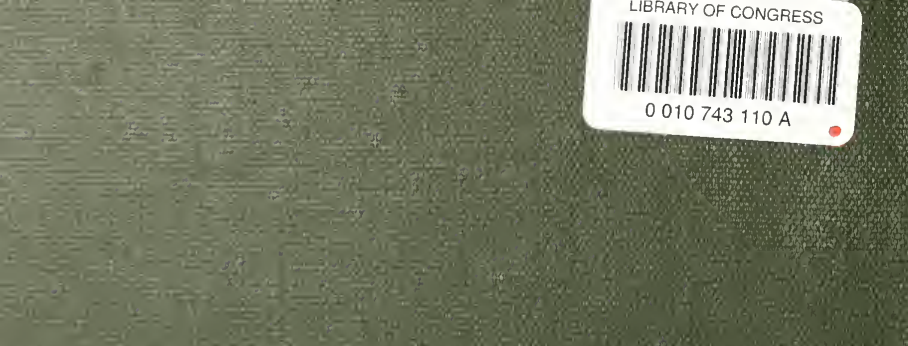